\title{
TRABALHO E TECNOLOGIA NO PROGRAMA MCMV
}

José Eduardo Baravelli

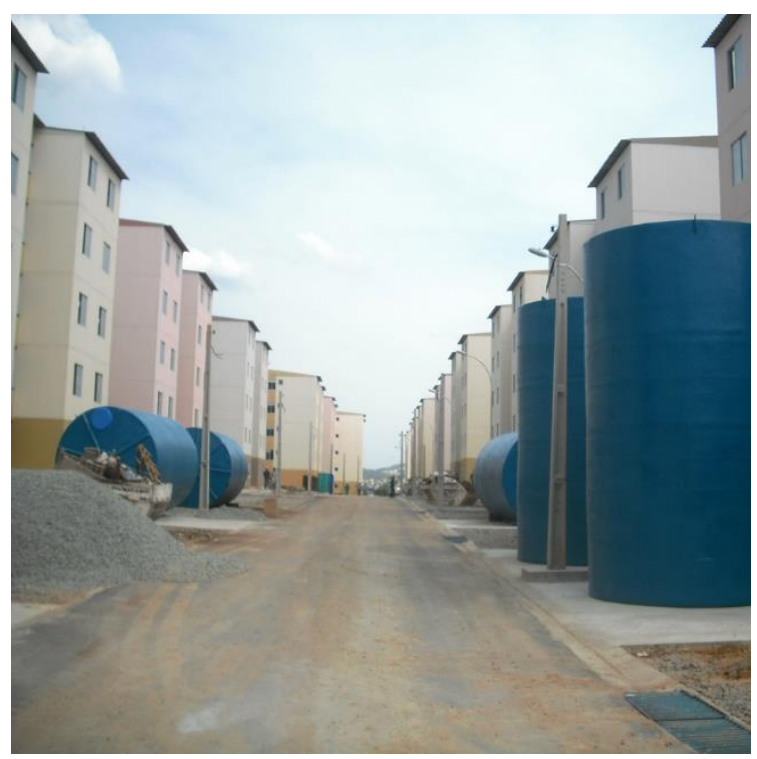

Tese apresentada ao Programa de PósGraduação da FAUUSP como parte dos requisitos para obtenção do título de Doutor em Arquitetura e Urbanismo

Área de concentração: Habitat

Orientador: Ermínia T. M. Maricato

São Paulo - Março de 2014 
AUTORIZO PARA FINS DE ESTUDO E PESQUISA A REPRODUÇÃO E DIVULGAÇÃO DESTA TESE DE DOUTORADO, POR MEIO CONVENCIONAL OU ELETRÔNICO, DESDE QUE CITADA A FONTE

E-MAIL DO AUTOR: JBARAVELLI@GMAIL.COM

Foto da capa: Conjunto MCMV “Guaratinguetá” em OUT13 - empreendimento da Odebrecht OR

|VERSÃO FINAL - CORRIGIDA EM AGOSTO DE 2014|

Baravelli, José Eduardo

B227t Trabalho e tecnologia no programa MCMV / José Eduardo Baravelli. São Paulo, 2014.

226 p. : il.

Tese (Doutorado - Área de concentração: Habitat) - FAUUSP.

Orientadora: Ermínia Terezinha Menon Maricato

1. Habitação popular - Brasil

2. Política habitacional - Brasil

3. Gerenciamento da construção I. Título 
Meu próprio objeto é vulgar. É pequena a distância entre a mão que desenha e a que segura a pá - embora tenham sido gastos séculos de engenhosidade para ampliá-la 


\section{AGRADECIMENTOS}

Esta pesquisa de doutorado contou com o decisivo apoio de duas bolsas de estudos da Coordenação de Aperfeiçoamento de Pessoal de Nível Superior (Capes), uma concedida através do Programa de Excelência Acadêmica (Proex) e outra concedida através do Programa de Estágio de Doutorando nos Estados Unidos, em conjunto com a Comissão Fulbright - Brasil.

Sou o único autor do erro ou imprecisão que houver nesta tese. Para os demais casos, recebi e agradeço as contribuições de Ana Paula Bruno, Ângela Alonso, Ângela Rocha, Beatriz Tone, Bruno Santos, Caio Santo Amore, Carolina Heldt, Flávia Tone, Glécia Vieira, Heloísa Diniz, Isadora Guerreiro, Jean-Benoît Dunckel, João Marcos, José Martella, Juliana Petrarolli, Karina Bertrami, Lúcia Shimbo, Luciana Ferrara, Luciana Royer, Luciana Versiani, Luís Jackson, Luiz Sugahara, Marcelo Versiani, Márcia Haddad, Mariana Fix, Maurício Kamada, Nicolas Godin, Nielsen Irineu, Olavo Faraco, Patrícia Cezário, Paulo Senna, Pedro Arantes, Pedro Torraga, Rejane Alves, Renata Moreira e Taís Tsukumo.

Agradeço em especial quatro professores, cujas contribuições foram tão vastas que ensinaram o próprio significado da pesquisa acadêmica. Estes professores são Gwendolyn Wright, Thomas Angotti, Ermínia Maricato e Jorge Oseki. 


\section{RESUMO}

Lançado em 2009, o programa federal Minha Casa Minha Vida se tornou o mais efetivo programa habitacional brasileiro desde a extinção do BNH, em 1986. Na iminência de acrescentar 3,75 milhões de moradias ao estoque habitacional do país, o programa é um campo de investigação que permite uma análise abrangente do novo papel do governo federal e municipal na política urbana, bem como do setor da construção civil na política econômica. Na produção para famílias de baixa renda na região metropolitana de São Paulo, o programa é um objeto de pesquisa que permite uma análise focada nas alterações que provoca tanto no trabalho e como na tecnologia da construção habitacional.

Quanto ao trabalho, a pesquisa reconstitui tipologicamente os processos de trabalho em canteiros de obras para observar a substituição da manufatura pela industrialização de insumos e pelo treinamento da força de trabalho conforme um novo perfil demográfico e de controle da produtividade.

Quanto à tecnologia, a pesquisa acompanha a introdução de novas tecnologias organizacionais em empreendimentos de construção, que são sistemas de gestão de qualidade e de controle de serviços subempreitados que favorecem a concentração de capital e reforçam a segregação urbana nas cidades brasileiras.

\section{ABSTRACT}

Launched in June 2009, the federal program "My Home, My Life" has led to the construction of nearly 3.75 million homes and it has become the most effective housing program in Brazil since the end of the housing policies introduced under military rule. As a subject of research it allows a broad analysis of the new roles of local and federal government in urban policy and of the building industry in economic policy. In its construction of homes for low-income families in the São Paulo metropolitan area, it allows a more focused analysis of changes promoted by the program in housing construction labor and technology.

Regarding labor, this research offers a typological recreation of labor processes in building sites, in order to observe the substitution of manual work for both industrialized construction materials and workforce training according to new patterns in demographics and productivity controls.

Regarding technology, it follows the implementation of new organizational technologies in building projects, namely, quality management systems and subcontracting controls that impel capital concentration and urban segregation in Brazilian cities. 


\section{LISTA DE GRÁFICOS}

G-1| Argamassa de revestimento - diagrama de manufatura ............................. 29

G-2| Argamassa de revestimento - diagrama de insumo industrializado.......... 29

G-3 | Argamassa de revestimento - diagrama de mecanização ............................ 30

G-4 | Argamassa de revestimento - comparação de custos por $\mathrm{m}^{2}$...................... 42

G-5 | Combinação das Razões Unitárias de Produção (RUP) por 25 dias ............ 66

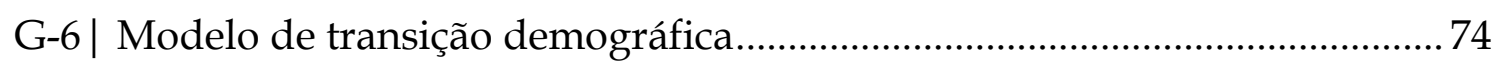

G-7| PEA e População Desocupada na RMSP e em 6 RMs - 2003/2013 .............. 79

G-8 | Taxa de desocupação média na RMSP - 2003/2013 ...................................... 80

G-9| Trabalhadores formais da construção civil em São Paulo - 2006/2012 ...... 81

G-10 | Composição do CUB PIS no Estado de São Paulo - 2007/2013 .................. 86

G-11| PAIC - Receita bruta por porte da construtora - 2007/2010 ...................... 89

G-12| Populações jovem e de baixa escolaridade na PEA da RMSP ................... 94

G-13 | PNDA - Fatores do déficit habitacional no Brasil - 2007/2012 ................ 111

G-14| MCMV 1 e 2 - Evolução dos contratos para baixa renda na RMSP ....... 119

G-15 | ISO - Distribuição das normas internacionais por setor técnico - 2012 .. 124

G-16 | Evolução dos sentidos de qualidade normatizada................................... 125

G-17| Evolução da certificação ISO 9001 no Brasil - 1993 a 2012 ........................ 127

G-18| Esquema de atividades de um empreendimento habitacional ................ 131

G-19| MCMV - Ciclos de investimento na Faixa 2 e 3 ........................................ 182

G-20| MCMV - Ciclos de investimentos para Faixa 1 ....................................... 182

G-21| Distribuição nacional das construtoras no MCMV ................................... 186

G-22| Esquema de promoção pública na política habitacional .......................... 199

G-23| Esquema de promoção privada na política habitacional .......................... 199 


\section{LISTA DE IMAGENS}

I-1 | Consumo e produção no programa Minha Casa Minha Vida ...................... 12

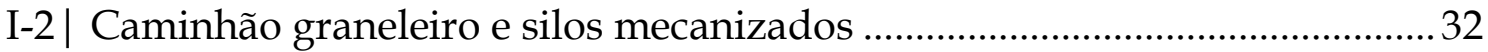

I-3 | Disputa entre pedreiros de argamassa de revestimento ..................................35

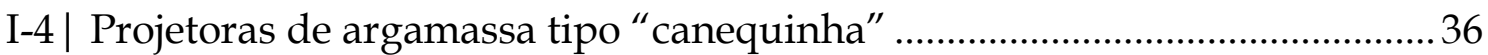

I-5 | Imagens para treinamento de uso de escantilhão e bisnaga..........................59

I-6 | Slides de conferência de Fernando Sabbatini (Sabbatini, 2008a) ..................69

I-7| Notícias da transição demográfica na construção civil ..................................75

I-8 | Skytrak e paletização do canteiro de obras ...................................................... 96

I-9 | Serventes em diferentes configurações de revestimento de argamassa .......98

I-10 | Lançamento mecanizado de CAA em empreendimento MCMV ..............101

I-11 | Ficha de Verificação de Serviço e ensaio de abatimento para CAA ..........102

I-12 | Material publicitário da fase 1 e fase 2 do programa MCMV ....................107

I-13 | Painéis de controle de qualidade observados durante a pesquisa ............143

I-14 | Imagens de treinamentos pelo programa PBQP-H....................................160

I-15 | Inspeção de serviços subempreitados pela construtora Hudson................162

I-16 | Pré-fabricação de lajes da Cury Construtora S/ A ....................................... 166

I-17| Transporte das lajes pré-fabricadas na Cury Construtora S/A .................167

I-18 | Alojamento de empreendimentos da Racional Engenharia Ltda ..............169

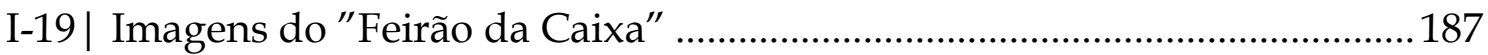

I-20 | Contramarcos pré-fabricados da Cury Construtora S/A ..........................189

I-21 | MCMV 2 - Especificações mínimas de unidade habitacional.....................191

I-22 | MCMV/Faixa 1 - empreendimentos agrupados na RMSP ....................... 201

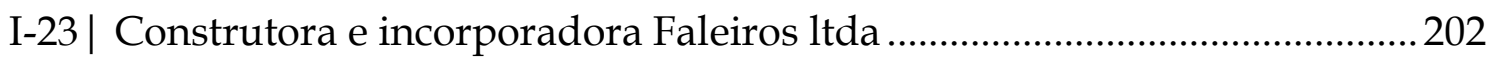

I-24 | Novolar incorporações e construções ltda ...................................................2 203

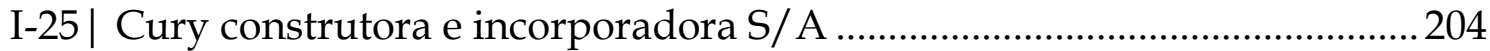

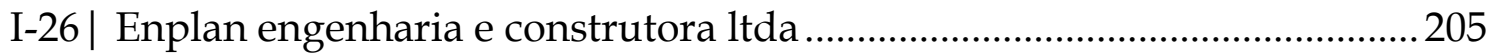

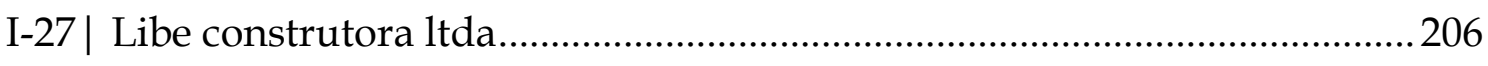

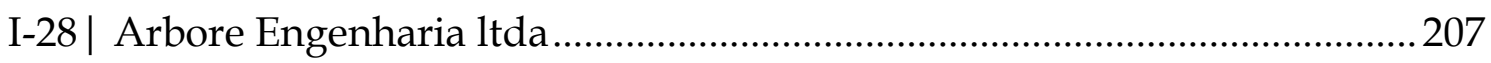

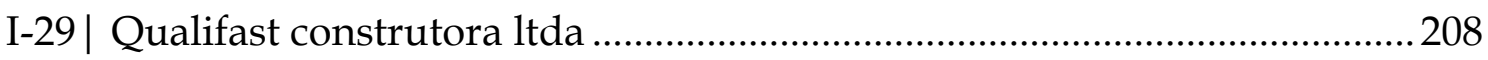

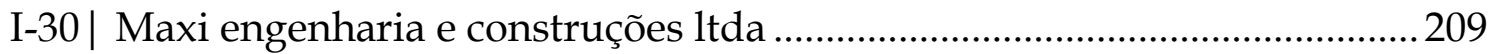

I-31 | Bairro Novo empreendimento imobiliário S/ A ..........................................2210

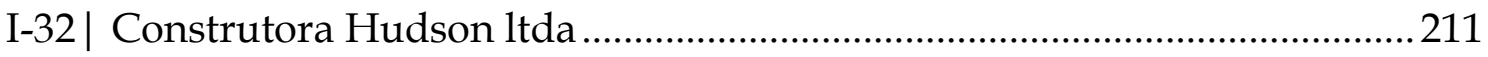




\section{LISTA DE TABELAS}

T-1 | Sinapi - Custo do $\mathrm{m}^{2}$ de massa única com preparo manual .........................39

T-2 | Sinapi - Custo do $\mathrm{m}^{2}$ de massa única com preparo mecânico ....................... 40

T-3 | Argamassa de revestimento - comparação de custos por $\mathrm{m}^{3}$....................... 41

T-4| Relação ajudante/oficial para argamassa de revestimento interno ............. 41

T-5 | Argamassa de revestimento - comparação de tempo dos serventes........... 42

T-6| Tecnologia construtiva da estrutura por HIS e demais segmentos .............. 55

T-7| Material e mão de obra para concreto e alvenaria de vedação ..................... 56

T-8 | Material e mão de obra para alvenaria estrutural .......................................... 57

T-9 | Salário médio de ajudante e profissionais em São Paulo - 2011/2013 ........ 81

T-10 | NBR 12.271:2006 - Quantitativo do projeto-padrão PIS .............................. 83

T-11| CUB - Horas de pedreiro e servente por $\mathrm{m}^{2}$ de projeto-tipo ....................... 85

T-12| Dados gerais da indústria da construção na PAIC 2010 ............................. 88

T-13 | Insumos de concreto em São Paulo, Salvador, Recife, São Luís ................ 99

T-14| MCMV 1 - Contratação por faixa de renda e modalidade......................... 108

T-15 | PNAD - Domicílios e déficit habitacional no Brasil - 2007 a 2012............ 109

T-16| PNDA - Déficit habitacional por faixa de renda familiar - 2007/2012 .... 110

T-17| MCMV 2 - Contratação por faixa de renda e modalidade........................ 114

T-18| MCMV 2 - Subsídio máximo e mínimo para Faixa 1 na RMSP ................ 115

T-19| MCMV - Contratos de baixa renda não iniciados na RMSP - JUN13 ..... 116

T-20 | MCMV - Contratos de baixa renda concluídos na RMSP - JUN13 ........... 117

T-21| MCMV - Contratos de baixa renda em construção na RMSP - JUN13 ... 118

T-22| PBQP-H - Requisitos de qualidade por nível de certificação .................... 139

T-23 | Nível PBQP-H no programa MCMV/ Faixa 1 na RMSP .......................... 144

T-24| Interferências da subcontratação na construção habitacional ................... 152

T-25 | Comparação entre controles de qualidade................................................. 161

T-26| Escolaridade dos trabalhadores em condição análoga à escravidão....... 170

T-27| MCMV2 - Regiões dos 10 maiores valores de aquisição de UH .............. 179 


\section{SUMÁRIO}

INTRODUÇÃO ..............................................................................................................10

PARTE 1 | TRABALHO E O PROGRAMA MCMV ..............................................14

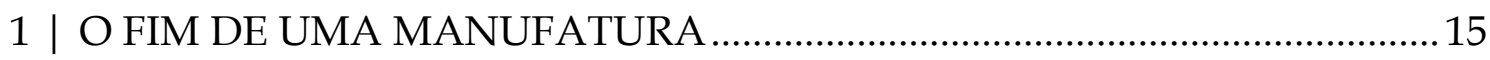

2 | A ARGAMASSA DE REVESTIMENTO COMO TRABALHO-TIPO ............ 24

O processo de trabalho da argamassa de revestimento ..................................24

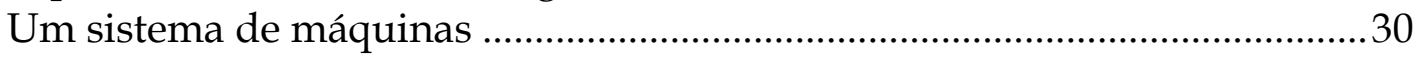

A organização do trabalho como máquina motriz ..........................................38

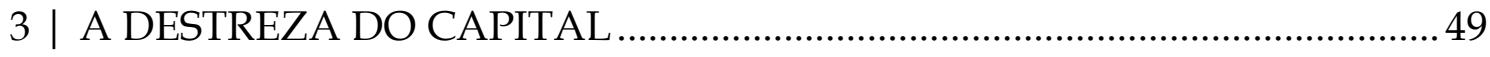

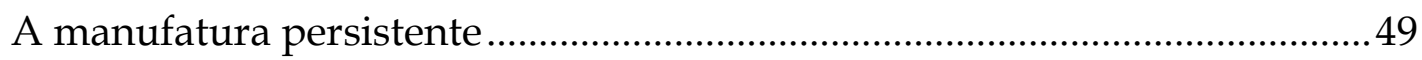

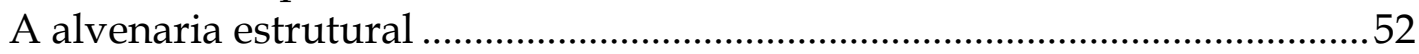

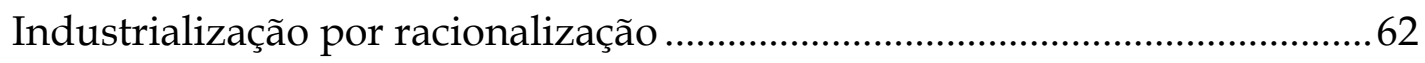

4 | A POPULAÇÃO EXCEDENTE NA CONSTRUÇÃO CIVIL .......................... 73

População e força de trabalho.......................................................................... 73

Índices da nova demografia da construção civil.............................................78

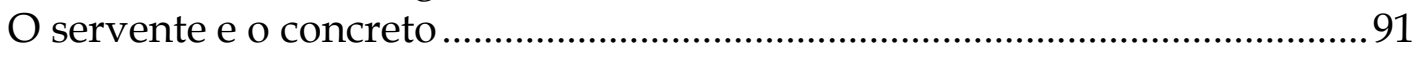

5 | A POPULAÇÃO EXCEDENTE NO PROGRAMA MCMV ............................105

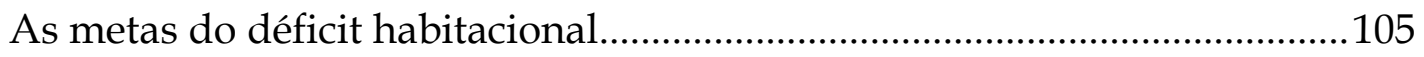

O custo de uma legitimação ........................................................................... 113

PARTE 2 | TECNOLOGIA E CONCENTRAÇÃO DE CAPITAL....................122

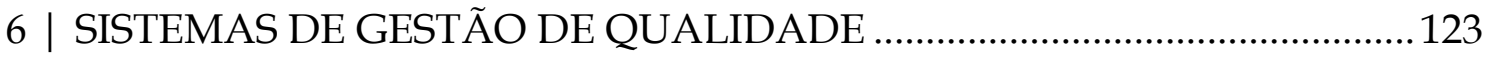

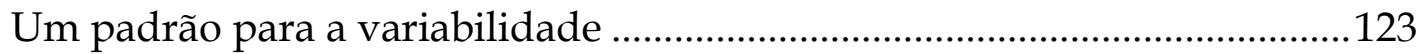

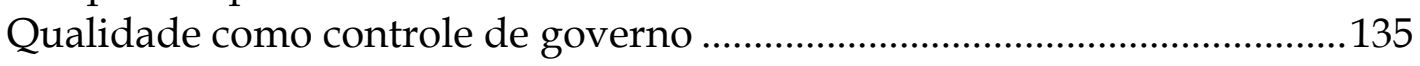

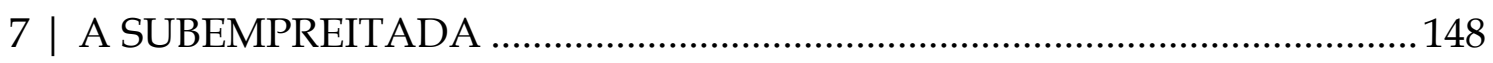

Uma relação de produção.................................................................................148

O treinamento e a Ficha de Verificação de Serviços ........................................156

Concentração de capital..................................................................................163

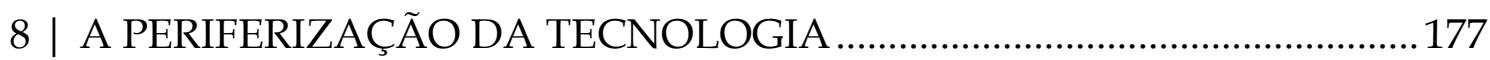

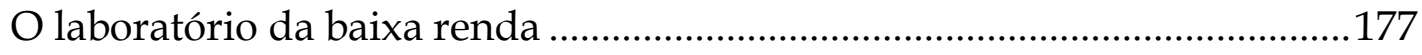

A segregação aperfeiçoada ...............................................................................189

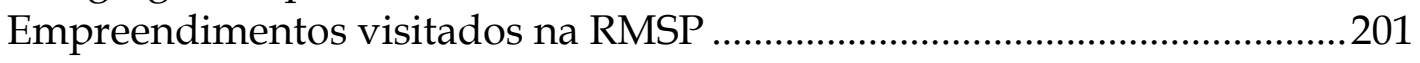

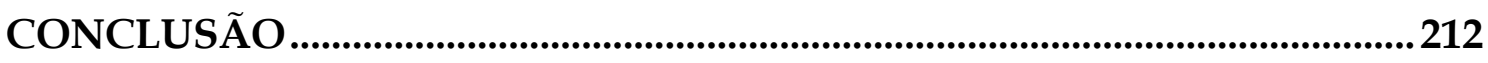

REFERÊNCIAS BIBLIOGRÁFICAS .......................................................217 


\section{INTRODUÇÃO}

Lançado em junho de 2009, ao final da segunda gestão Lula, o programa federal de habitação "Minha Casa Minha Vida" (MCMV) se tornou uma das ações de governo mais efetivas para preservar o Brasil da crise financeira global iniciada no ano anterior com o colapso do sistema hipotecário americano. Ao oferecer diversas linhas de subsídio para as empresas brasileiras construírem 3,75 milhões de moradias até o fim de 2014, o programa colocou a construção civil junto ao complexo exportador agromineral como sustentáculo do desenvolvimento econômico do Brasil. Já ao final de 2010, a taxa de crescimento anual do PIB da construção civil brasileira atingiu $11 \%$ (enquanto a do país chegava a 7,5\%) e a principal idealizadora do programa, a ministra-chefe da Casa Civil Dilma Rousseff, foi eleita Presidente da República.

Do ponto de vista dos estudos urbanos brasileiros, o programa MCMV tem um sentido menos episódico na história do país. Desde o final da ditadura militar em 1985, após o Brasil atingir o pico de seu processo de industrialização e urbanização, apenas a autoconstrução da moradia (com seus diversos graus de precariedade legal e urbana) conseguiu produzir habitação para famílias de baixa renda numa quantidade capaz de alterar a paisagem das periferias brasileiras. $\mathrm{O}$ crescimento do setor da construção civil brasileira encerrava assim mais de duas décadas de estagnação nas políticas públicas em habitação, anos em que até mesmo a classe média permaneceu com acesso mínimo ao financiamento habitacional e a imensa população de baixa renda do país ficou reduzida às alternativas da moradia informal.

Para a análise crítica do programa, há portanto algo de repetitivo na retomada da construção habitacional por empresas privadas subvencionadas por fundos estatais, à medida que adota práticas de segregação urbana de quando esta mesma política foi implantada pela tecnocracia do regime militar. Mais que oferecer uma alternativa de mercado formal à autoconstrução praticada de forma generalizada no Brasil, o programa MCMV reforça práticas clientelistas em governos locais, responsáveis por selecionar famílias para as moradias destinadas à remoção de favelas e ocupações em áreas de risco. A aliança entre construtoras privadas e política de clientela desmonta as iniciativas incipientes de gestão habitacional democrática em municípios que tentam controlar o uso do solo urbano através do Estatuto da Cidade, a progressista legislação federal para planejamento urbano e que permanece inaplicada em nível municipal. Ao invés de confrontar a explosão do preço da terra urbana, os diversos agentes públicos e privados que operam o programa se acomodam a estas fronteiras do mercado imobiliário como uma legitimação para confinar os empreendimentos de baixa renda em áreas periféricas homogeneamente pobres.

O propósito desta tese de doutorado é investigar este aspecto recorrente do programa MCMV sob o viés da produção da habitação social. 
Num texto que foi a primeira orientação desta pesquisa, Ermínia Maricato considera que o "enfoque teórico" que dominou a pesquisa acadêmica sobre a habitação social após a extinção do BNH se afasta da produção da habitação: "os estudos que têm como objeto o urbano, a habitação, o financiamento e a terra raramente incorporam o tema da construção em seu escopo" (Maricato, 2009a: 38). Pelo contrário, são estudos que se orientam para o "consumo da habitação":

A maior parte das pesquisas sobre habitação se dão no contexto da esfera do consumo, dimensionando-o e qualificando-o. O Estado e as politicas públicas ocupam um papel central no conjunto desses trabalhos. Embora eles forneçam um quadro importante sobre a carência de moradias, a segregação territorial, a exclusão social e as políticas institucionais ignoram, frequentemente, a centralidade da produção na determinação do ambiente construído (Maricato, 2009a: 33).

A presente abordagem do programa MCMV pela produção ao invés do consumo da habitação social foi organizada em dois polos temáticos, um relativo ao trabalho e, outro, à tecnologia da construção habitacional. Estes polos evoluíram para as duas partes desta tese de doutorado: Parte 1, "Trabalho e o programa MCMV", com cinco capítulos, e Parte 2, "Tecnologia e concentração de capital", com três capítulos. Esta é uma organização presente desde as primeiras etapas de pesquisa, uma vez que trabalho e tecnologia são temas concebidos como "separação na unidade" e que mantém, a respeito da produção da habitação social, uma evolução paralela. Um breve texto na abertura de cada parte vai introduzir a organização interna de capítulos e assuntos, o que permite limitar esta introdução a uma visão de conjunto deste paralelismo da tese.

Na Parte 1, a análise do trabalho busca situar o trabalhador como sujeito, uma perspectiva em grande parte ausente dos estudos sobre produção e produtividade na construção civil. É um sujeito cuja autonomia tende cada vez mais para a fragmentação da atividade da construção, por isso a primeira abordagem se volta para o declínio da forma de produção da manufatura. $O$ espaço de análise privilegiado é o canteiro de obras, espaço onde a coordenação das especialidades fragmentadas é disputada pela gerência de obra. $\mathrm{O}$ desafio que se coloca ao capital no canteiro de obras é controlar a força de trabalho em função de seus programas de treinamento, desvinculando-a da formação pela manufatura e das novas tendências demográficas que se manifestam no setor produtivo da construção.

Na Parte 2, o sujeito da análise da tecnologia é a empresa construtora, pessoa jurídica que implementa e se transforma através da principal tecnologia em jogo no programa MCMV, a dos sistemas de gestão de qualidade. É uma tecnologia de natureza organizacional, que altera a empresa mais que seus produtos, e que promove a concentração de capital nas construtoras que se capacitam para o gerenciamento da produção e de suas cadeias de suprimentos. O espaço de análise privilegiado é o empreendimento de construção, espaço onde a empresa construtora precisa agenciar a diversidade de operações comerciais envolvidas na produção habitacional. $\mathrm{O}$ desafio que se coloca ao capital no empreendimento de construção é controlar a mais recorrente destas operações, a subempreitada de serviços especializados de obra, através da tecnologia organizacional que se dissemina na construção habitacional. 
Esta dupla construção temática converge para um objeto preciso e que é determinado por circunstâncias institucionais e políticas: o programa MCMV. Por isso, tanto a Parte 1 quanto a Parte 2 desembocam numa análise final de aspectos legais e operacionais do programa federal. Na Parte 1, a população que forma um excedente da força de trabalho é analisada através da noção de déficit habitacional e da legitimação que traz às metas de produção do programa. Na Parte 2, a divisão do programa em faixas de renda e a função do subsídio para baixa renda são analisadas em sua interação com a implantação de tecnologia organizacional nas empresas construtoras.

O confronto entre o programa MCMV e as condições de produção da habitação social que o antecedem e o possibilitam dá origem às duas hipóteses centrais desta tese. A primeira, que o controle e a especialização do trabalho nas empresas em que se concentra o capital da construção habitacional é de matriz industrial e o modelo manufatureiro do canteiro de obras não descreve mais os processos de trabalho mobilizados pelo programa MCMV. A segunda hipótese é que o aspecto socialmente mais ousado do programa federal, o subsídio quase integral da moradia para famílias de baixa renda, se torna igualmente um subsídio para que a empresa construtora possa testar e incorporar a tecnologia organizacional em seus processos produtivos, tecnologia que será posteriormente transferida para outras modalidades do programa, onde reforçará ganhos de incorporação.

\section{I-1|Consumo e produção no programa Minha Casa Minha Vida}
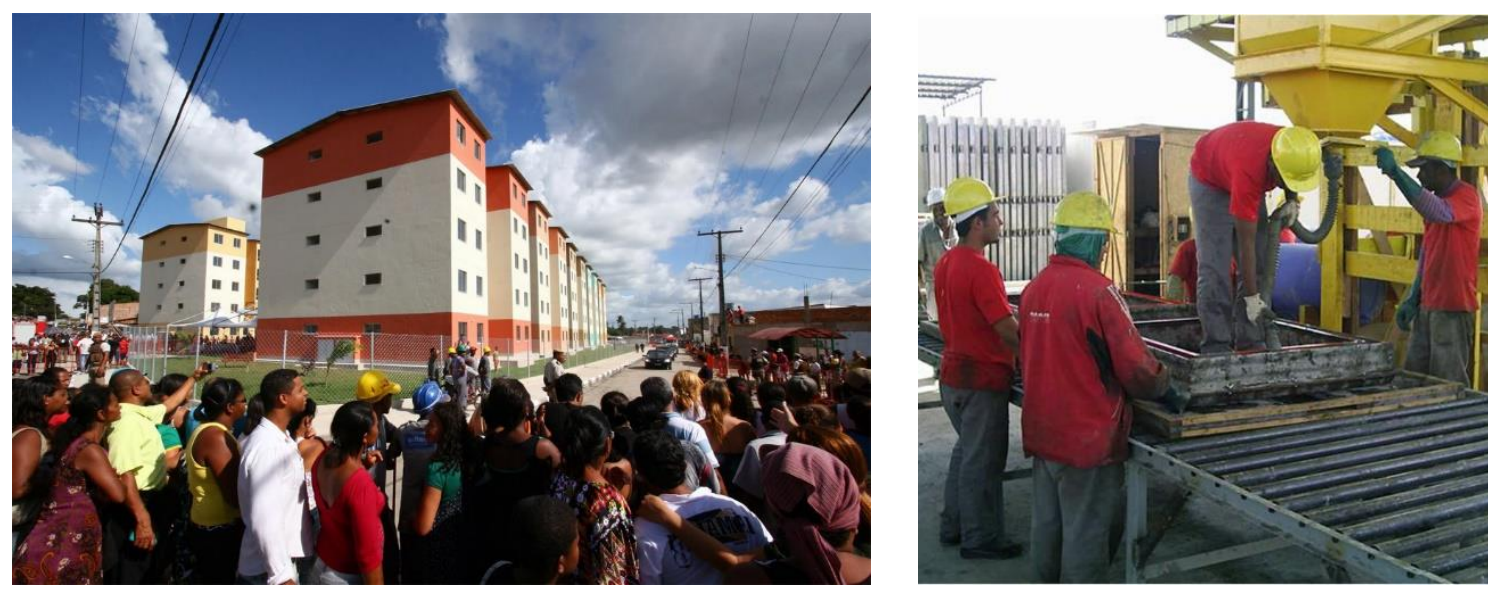

Esquerda: inauguração de empreendimento MCMV, com a má arquitetura que caracteriza o programa (Ricardo Stuckert). Direita: pré-fabricação em canteiro de obras na RMSP (David Nonno).

Por fim, fica evidente na organização da tese e nas suas hipóteses o instrumental teórico de Marx. O primeiro motivo é que este é o instrumental que considera com mais clareza o papel central da produção no estudo de ações e agentes no mercado e no Estado. O segundo motivo é situar esta tese no legado de uma geração de professores do curso de arquitetura e urbanismo da Universidade de São Paulo que estudou em base marxista o espaço urbano após a dissolução do BNH, geração da qual fazem parte Ermínia Maricato, Jorge Oseki, Ângela Rocha, Klara Kaiser, Paulo César Xavier Pereira, Yvonne Mautner e Csaba Déak.

Uma menção especial deve ser feita à obra de Sérgio Ferro, em que o uso de Marx para entendimento da construção habitacional é o mais contundente e sua trajetória na Universidade de São Paulo o levou à condição de formador da geração que foi formadora para esta pesquisa. Só foi possível discordar da 
atualidade de sua compreensão da construção porque o objetivo da tese é conduzir seu marxismo para o entendimento do programa MCMV.

$* * *$

Uma última palavra é necessária sobre os métodos de pesquisa que resultaram na tese que se segue. Embora recorra a fontes bibliográficas e de dados estatísticos pertinentes à construção civil brasileira, o mais central dos procedimentos de pesquisa foi a visita técnica ao canteiro de obras e a observação direta de uma etapa do empreendimento de construção.

O recorte espacial desta tese de doutorado é produto unicamente da capacidade prática de realizar estas visitas, limitada à região metropolitana de São Paulo. Ao todo, 22 empreendimentos de 10 empresas construtoras foram visitados em dois períodos, o segundo semestre de 2011 e o segundo semestre de 2013, em diferentes municípios da RMSP. Para ampliar o contraste da observação, a programação de visitas técnicas incluiu sete construtoras médias e as três únicas empresas de capital aberto com empreendimentos na RMSP: Cury construtora e incorporadora S/A, Bairro Novo empreendimento imobiliário S/A e Novolar incorporações e construções ltda, esta última por manter diversas sociedades de propósito específico com a Tecnisa Engenharia S/ A. Um mapa metropolitano de todos os empreendimentos do programa MCMV para baixa renda, bem como informações sintéticas dos empreendimentos visitados, agrupados segundo as empresas construtoras, estão reunidos na parte final do capítulo 8, no subcapítulo “Empreendimentos visitados na RMSP".

Cada visita técnica gerou uma entrevista com o engenheiro encarregado da gestão do canteiro de obras ou da implantação da política de qualidade da empresa construtora. Em diversas ocasiões foram agendadas entrevistas nas sedes da empresa, onde foi possível obter material adicional em fotos, plantas e planilhas, do qual só foi usado o que se mostrou estritamente relacionado à argumentação da pesquisa. Solicitei permissão para publicar nomes sempre que a informação oral se revelava especialmente importante (o que inclui as falas de quatro pedreiros no capítulo 2 e um marceneiro no capítulo 3 ).

As visitas e as entrevistas se beneficiaram em especial da disciplina de pósgraduação da Escola Politécnica da USP, "Gestão da produção na engenharia civil", ministrada por Francisco Cardoso, Silvio Melhado e Ubiraci de Souza. A perfeita continuidade entre os conceitos e a literatura tratada em aula com práticas reais da construção habitacional foi essencial para a elaboração da tese. Tal continuidade entre pesquisa e canteiro de obras há muito se perdeu na arquitetura e urbanismo. 


\section{PARTE 1 |}

\section{TRABALHO E O PROGRAMA MCMV}

Esta tese vai pesquisar os empreendimentos para baixa renda do programa MCMV como parte integrante de uma indústria da construção civil. Seu primeiro passo, portanto, é comprovar que não se aplica mais a este objeto uma importante chave de leitura da construção da habitação social no Brasil: a da construção como manufatura.

Rever o tema da manufatura na construção habitacional significa também recuperar a literatura fundamental dos estudos da construção entre os anos 1970 e 1990, em que Sérgio Ferro é o guia que liga e contrasta os pesquisadores de uma industrialização incompleta no subdesenvolvimento. Este conjunto, por sua vez, é necessário como base crítica para a literatura que de fato interveio na empresa construtora brasileira - a da Gestão de Produção em engenharia civil - bem como para os instrumentos analíticos que tratam do programa MCMV, não apenas estatísticas e textos legais como também pesquisas técnicas e orçamentárias que medem o valor do trabalho para o capital da construção.

Porque é o trabalho que se transformou na construção da habitação social entre o BNH e o programa MCMV, mais do que as técnicas construtivas e muito mais que a base fundiária dos programas de habitação. A sua atual organização por uma racionalização de matriz industrial é uma evidência no canteiro de obra, mas dificilmente se deixa ver nas estatísticas e, em muitos casos, é contrária a uma importante bibliografia nacional. A solução buscada para comprovar esta transformação é descrever em três capítulos técnicas construtivas reais na forma de processos de trabalho tipológicos. Estes processos de trabalho são a argamassa de revestimento (capítulo 2), a alvenaria estrutural (capítulo 3) e o concreto autoadensável (capítulo 4), este último tipo em complemento à análise de um trabalhador central na tradição construtiva brasileira: o servente de obra.

Nesta primeira parte, depoimentos coletados por mim durante visitas técnicas ou entrevistas não são usados como argumentos para a tese e aparecem, quando muito, em notas de rodapé, restrição que se estende para documentos técnicos e tabelas orçamentárias a que tive acesso exclusivo. Não se trata de preservar algum sigilo em relação a fontes de informação privadas, mas sim o interesse de que, ao debater com obras de grande divulgação como as de Sérgio Ferro, Marta Farah, Nilton Vargas, Ubiraci de Souza e Fernando Sabbatini, fossem utilizados apenas argumentos disponíveis em fontes de acesso público. 


\section{1 \\ O FIM DE UMA MANUFATURA}

Ao publicar em 1976 as notas de aula que resultaram em "O canteiro e o desenho", Sérgio Ferro abre a exposição das relações entre organização do trabalho na construção habitacional e desenho de arquitetura com a seguinte descrição de um canteiro de obras (Ferro, 2006 [1976]: 112):

A areia, a pedra são descarregadas. Um servente as amontoa nos locais previstos do canteiro; um outro leva parte para o ajudante de pedreiro que ajunta água e cal ou cimento, trazidos do depósito por um ajudante diferente; um quarto despeja a argamassa em baldes ou carrinhos e a conduz ao pedreiro que coloca tijolos, faz um revestimento ou enche uma fôrma, seguido do ajudante que segura o vibrador ou recolhe o excesso caído.

Em cima, o carpinteiro prepara outras formas com a madeira empilhada perto dele depois de encaminhamento semelhante ao da argamassa e percorrido por ajudantes e serventes próprios; o armador dobra as barras de ferro assistido do mesmo modo e, por todos os lados, pintores, marceneiros, eletricistas, encanadores etc., sempre rodeados por ajudantes e serventes, constituem equipes numerosas, separadas, especializadas, verticalizadas. Avançada divisão do trabalho e, em cada parcela, hierarquia detalhada.

Pás, enxadas, desempenadeiras, colheres, prumos, esquadros, réguas, fios, serrotes, martelos, alicates, goivas, plainas, rolos, espátulas etc. Instrumentos simples, isolados, adaptados às diversas operações, resultado de lento aperfeiçoamento e diferenciação para um uso preciso. Mais raramente, betoneiras, elevadores, guinchos, vibradores, serras elétricas etc. Sempre, entretanto, máquinas somente auxiliares nas tarefas pesadas; nenhuma operatriz que reúna os instrumentos particularizados. Um mestre transmite as instruções, organiza a cooperação, fiscaliza, impede atrasos: é, também, feitor.

A descrição - de um quadro frequente em país subdesenvolvido como o Brasil -é de típica manufatura serial.

A abertura do livro pela descrição da dependência da construção em relação ao trabalho manual organizado coletivamente - isto é, ao processo produtivo da manufatura - fornece uma situação precisa para a crítica ampliada do desenho de arquitetura como meio de dominação do capital. Esta situação é o subdesenvolvimento no Brasil, cujas características eram claras para um texto elaborado durante os piores anos do regime militar. A manufatura na construção aparece assim como um tema não só de uma fase produtiva ou de um setor econômico, mas também de um período histórico e de um país.

A atribuição de tempo e o espaço não tira a radicalidade da tese central do livro: nas sociedades em que prevalece o modo de produção capitalista, a riqueza reunida sob a forma de edificações se apresenta como uma imensa coleção de mercadorias, condição que liberta o projeto de arquitetura para assumir a forma que quiser, desde que mantenha uma única constante: a de ser instrumento de valorização do capital. Uma tese radical mas também, no dizer de Sérgio Ferro, “quase óbvia" (Ferro, 2006 [1976]: 108) e que, escrevendo trinta anos depois, ele dirá que continua a enfrentar "a indiferença dos profissionais diante de tal evidência, 
que não os afeta. Mais ainda, desviam-se dela entediados, como se se tratasse de uma grosseria deslocada, uma banalidade sem interesse" (Ferro, 2006 [2003]: 379) [1].

O que impede a indiferença é justamente contrapor o desenho de arquitetura às condições da manufatura. Nesta contraposição, ele não é um instrumento que o canteiro usa para produzir para o capital, mas sim um instrumento que o capital usa para dominar o canteiro. A relação entre arquitetura e operário da construção perde a ilusão de complemento e aparece como confronto. Qualquer outra pretensão do desenho é irrelevante: reduzido em sua forma de "tipo-zero" (expressão que Sérgio Ferro retira da antropologia estrutural), ele se revela como condição genérica da produção capitalista à medida que esta é heteronomia e exploração:

Nunca consegui reconhecer qualquer grau de autonomia no desenho de arquitetura. Seu inevitável e essencial papel prescritivo para a produção e que, fora dos projetos imaginários, ele não pode evitar, coloca-o cotidianamente em relação com o conflito de classes (...) Para nós, não há dúvida possível, é porque o canteiro deve ser heterônomo sob o capital que o desenho existe, chega pronto e de fora. O desenho é uma das corporificações da heteronomia do canteiro" (Ferro, 2006 [2003]: 108).

Há uma distância portanto entre a manufatura como forma tradicional de produção de edifícios e a manufatura que é dominada pelo capitalismo com a fundamental participação da arquitetura: a habilidade manual do trabalhador, sempre aprendida em comunidade e muitas vezes passada de geração em geração, é expropriada pelo capital na sua capacidade de se articular como uma habilidade coletiva. Ao trabalhador resta apenas a transferência coagida de sua capacidade profissional, que, presa a seu corpo, é animada ainda por um senso de dignidade de ofício mesmo sob as mais difíceis condições de trabalho [2].

É a leitura da apropriação violenta de uma forma de produção pré-capitalista que converte a descrição de um canteiro de obras dos anos 1970 numa descrição do subdesenvolvimento brasileiro, pois a utilização do trabalho manual como base para a mercantilização do espaço construído corresponde à forma específica da inserção do Brasil no capitalismo mundial. A sobreposição da racionalidade capitalista sobre a tradição da manufatura se encaixa numa leitura crítica de nossa sociedade, em que o clamor por planejamento só persiste enquanto não impedir a desigualdade social e o poder de Estado, que se infla na impessoalidade de códigos e leis, se exerce pela cooptação de clientela ou a violência do puro autoritarismo. Na arquitetura, o resultado é um autoengano

1 A continuação do depoimento de Sérgio Ferro chega ao limite de uma responsabilização moral: “dizer e repetir isso parecem minha inútil obsessão, pois hoje tudo se torna mercadoria, tudo é concebido como mercadoria - ou seja, cristaliza-se em torno do valor. E sair de seu mundo, depois da falência da farsa do socialismo, parece um sonho utópico. Mas esquecer isso, fazer de conta que se trata de uma constante inofensiva, desconsiderá-la porque demasiado universal, é avalizar a usurpação sob o pretexto de que ela existe em toda parte. A prática surda à evidência prolonga-a sem remorsos, mas não evita a corresponsabilidade". O doutorado de Pedro Arantes investiga a atualidade desta linha de pensamento para a arquitetura contemporânea (Arantes, 2012).

2 Primo Levi é um observador atento deste senso de honra no trabalho manual, tema central dos contos sobre o montador de estruturas metálicas Faussone (Levi, 2009 [1978]). Na inimaginável situação do campo de concentração de Auschwitz, ele se lembra de um pedreiro italiano que "detestava a Alemanha, os alemães, sua comida, sua maneira de falar, sua guerra; mas, quando o puseram para erguer muros de proteção contra as bombas, fazia-os corretamente, sólidos, com tijolos bem assentados e com toda a argamassa que era necessária; não em reverência às ordens, mas por dignidade profissional" (Levi, 2004 [1986]: 106). 
bem conhecido dos profissionais de projeto: com exceção dos cínicos, todos precisam crer que a união do edifício à sua função de mercadoria será também a união de seu desenho a um vago ideal de cidade.

Assim, num único lance "O canteiro e o desenho" alinha a crítica de arquitetura com a crítica social exercida durante o regime militar por Francisco de Oliveira (2003 [1972]) e Roberto Schwarz (2000 [1977]) e coloca em definitivo o debate sobre a modernidade entre os pontos cegos do subdesenvolvimento no Brasil. Depois deste livro, estava evidente que a crença no projeto arquitetônico como transição para uma sociedade avançada era inútil diante das relações de produção originadas da migração em massa para as cidades brasileiras e da inserção subalterna do país nos circuitos globais de capital que sustentavam o "milagre econômico brasileiro".

Quase quatro décadas depois, esta pesquisa de doutorado se propõe a ser uma ponta da linha de investigação aberta por "O canteiro e o desenho" ao reunir observações realizadas entre 2010 e 2013 num universo específico de canteiros de obra: o dos empreendimentos do programa MCMV para baixa renda nos municípios da região metropolitana de São Paulo.

A distância entre os canteiros de obras da tecnocracia militar e do programa habitacional implantado nas presidências Lula e Dilma Rousseff pode ser estimada por uma atualização da descrição realizada por Sérgio Ferro nos anos 1970. Esta atualização pode partir da percepção de que, para mostrar num canteiro de obras o subdesenvolvimento de um país, o relato de Sérgio Ferro se aproxima da descrição de um "tipo ideal" da sociologia weberiana: não é a transcrição de uma única observação, mas a síntese das inúmeras que realizou como pesquisador e profissional de arquitetura, cujo amálgama é mais revelador da realidade do que a análise de cada uma de suas partes.

O primeiro ponto de contato com o programa MCMV seria um confronto igualmente tipológico do canteiro de obras descrito nos anos 1970. Reorganizando observações realizadas para a presente pesquisa em diferentes empreendimentos e datas, uma comparação que acompanhasse ponto a ponto o texto de Sérgio Ferro teria a seguinte forma:

Há pouca areia e pedra a granel no canteiro de obras (...) A mistura de agregados, cimento e cal para argamassa só existe na obra como produto ensacado. Os sacos são registrados por leitura óptica pelo almoxarife e, ainda amarrados aos paletes, são levados por Skytrak ao ponto de consumo [Suzano - Novembro de 2011] (...) Nenhum concreto de uso estrutural é produzido dentro do canteiro. A dosagem de [concreto] auto-adensável, com fillers e plastificantes, é impossível de ser feita em obra. O que é comprado da usina, de qualquer forma, é mais o serviço do que o produto: ensaios na entrega (são três), bombeamento mecânico, lançamento por mangotes (operado pelo "mangoteiro"), recolhimento de corpo de prova e relatório de controle tecnológico. $\mathrm{Na}$ obra, já não há mais o pedreiro que desempena e vibra o concreto [Guarulhos - Maio de 2010] (...)". 


\begin{abstract}
"A fôrma de laje tem nervuras com perfis metálicos e foi produzida pela empresa que aluga o cimbramento também metálico. Este conjunto com pouca madeira é montado e nivelado a laser por dois profissionais ainda chamados de carpinteiros, mas que também supervisionam a tela de aço pré-cortada e as armaduras de ancoragem [São Paulo/Itaquera - Novembro de 2011] (...)".
\end{abstract}

"Só existem equipes especializadas quando estão unidas a uma máquina cujo fornecimento, operação e manutenção é de um prestador de serviços igualmente especializado. O pedreiro de argamassa se tornou um operador do sistema misturador-projetor. O grosso do trabalho do armador é conferir a armadura cortada e dobrada em fábrica [Itaquaquecetuba - Fevereiro de 2011] (...) Algumas equipes de instalação [de equipamento hidrossanitário] são uma extensão no canteiro das empresas fornecedoras de insumos industrializados. São treinadas apenas numa tecnologia de termofusão de um único conglomerado [São Paulo/Itaquera - Novembro de 2011] (...)".

“A supervisão do mestre-de-obra está desvinculada de qualquer função de planejamento. Ele instrui, mas não comanda. Quem comanda o acionamento de cada máquina, o transporte de cada insumo e a produtividade de cada trabalhador é quem opera o software de fluxo de serviço e a FVS [Ficha de Verificação de Serviço] preenchida em palmtops. Muitas vezes é um estagiário de engenharia ou um apontador, mas ele é apenas um ponto de conexão on-line com a rede interna de controle de qualidade e de fornecedores da construtora [Guarulhos - Maio de 2010]".

A descrição atualizada do canteiro de obras novamente impulsiona a observação da sociedade brasileira. No entanto, esta observação já não pode mais partir da matriz conceitual marxista da manufatura, isto é, de "um mecanismo de produção cujos órgãos são seres humanos", definição de Marx no primeiro volume do "Capital" que tem o seguinte complemento:

Composta ou simples, a execução permanece artesanal e, portanto, continua a depender da força, da destreza, da rapidez e da segurança do trabalhador individual no manuseio de seu instrumento. O trabalho artesanal permanece sendo a base, e essa base técnica limitada exclui uma análise verdadeiramente científica do processo de produção, pois cada processo parcial que o produto percorre tem de ser executável como trabalho parcial artesanal (Marx, 2013 [1867]: 413).

O que a descrição tipológica dos canteiros do programa MCMV revela não é tanto o fim das operações feitas "à mão", mas sim a ampliação da base técnica da construção civil a ponto de não haver mais nenhuma operação - compra, inspeção, estoque, movimentação, preparo, execução e, principalmente, planejamento e supervisão - que não inclua "uma análise científica do processo de produção": todo trabalho, não importa se mecânico ou manual, está dominado pela racionalização produtiva de matriz industrial. Para compreender estes canteiros de obra, o esquema explicativo da construção civil no Brasil precisa ser invertido: a racionalização industrial da produção não é uma meta ideológica que recobre a natureza manufatureira da construção habitacional, mas sim a base da organização capitalista da produção na construção civil e que, como tal, insere o trabalho manual como parte dominada de sua lógica produtiva.

Esta inversão de perspectivas também comporta uma compensação teórica, pois o predomínio da indústria sobre a manufatura desfaz um dilema da literatura 
sobre a produção habitacional no Brasil entre os anos 1970 e 1980, que precisava identificar uma forma de produção pré-capitalista sem assumir a perspectiva de um setor atrasado na economia nacional. Para isso, a manufatura precisa se distinguir da produção industrial mantendo com ela uma funcionalidade dentro do quadro geral de exploração do trabalho no capitalismo, funcionalidade que em várias situações precisa ser considerada frágil e, em todas, transitória.

Por outro lado, assumir um dualismo entre avanço e atraso impede analisar as diferenças internas ao desenvolvimento econômico como funções coordenadas pelo capital. É contra tal dualismo que Francisco de Oliveira considera a agricultura de subsistência e a autoconstrução da habitação popular como setores integrados na economia nacional, apesar de serem atividades aparentemente précapitalistas, pois desempenham um papel decisivo na composição de valor de sua força de trabalho (Oliveira, 2003 [1977]).

A explicação de uma semelhante integração da construção por manufatura em "O canteiro e o desenho" é breve: na construção civil, a compra de força de trabalho numa proporção elevada em relação à aquisição de máquinas e insumos serviria como compensação para a "queda tendencial da taxa de lucro", tese marxista que aponta como tendência no capitalismo justamente o predomínio cada vez maior do capital imobilizado em estoques e equipamentos sobre a massa salarial. Esta explicação, que Ermínia Maricato dizia ser tanto "atraente" quanto "obscura" (Maricato, 1984: 49), aparece desta forma:

A forma manufatureira de produção do espaço só pode ser explicada como uma das manifestações localizadas da luta de classes na produção, manifestação diversa e necessariamente contraditória. E só pode ser modificada pelo aguçamento da luta de classes generalizada, também, portanto, na produção. Em particular, é reserva contra a queda tendencial da taxa de lucro e fonte privilegiada para a acumulação e reprodução (aumentada) do capital" (Ferro, 1976 [2006]: 139).

É uma linha de pensamento que atravessa os escritos de Sérgio Ferro. Em 2003, ao fazer um comentário a "O canteiro e o desenho" como balanço acadêmico de encerramento da sua docência na Escola de Arquitetura de Grenoble, ele monta um raciocínio sob a afirmação de que "a forma produtiva particular que a hegemonia do valor assumiu no construir é (foi) a da manufatura". O que parece ser uma hesitação de tempos verbais é, na verdade, o reconhecimento de que manufatura atravessa as variações da história como "linha condutora de continuidade" da construção:

Esta forma domina desde o século XV pelo menos (...) A forma manufatureira dá a linha condutora da continuidade. Entretanto, o papel dessa constante desloca-se com o tempo, muda de motivação. Primeira adaptação da produção pelo capitalismo (efetuada nos setores têxtil e da construção), ela serve, primeiro, para a acumulação primitiva: a taxa de mais-valia é aí muito alta. Superada depois pela submissão real do trabalho na indústria, ela serve também (e pode ser mais ainda, segundo as situações) como forma de resistência à queda tendencial da taxa de lucro que a evolução contraditória provoca. A manufatura da construção é, desse modo, fortemente sobredeterminada pelo conjunto da economia política. Nenhuma "natureza", nenhuma especificidade do ato de construir impõe tal forma. (Ferro, 2006 [2003]: 380).

A manufatura na construção é portanto uma condição histórica, mas que se transforma sem jamais desaparecer tanto no pré-capitalismo como capitalismo. 
A permanência da manufatura na construção é um tema tão sensível a Sérgio Ferro que sua própria proposta de avanço político (aqui falando pelo movimento Arquitetura Nova) não deixa de ser apenas uma "mudança de motivação".

A manufatura - destruí-la, conservá-la ou modificá-la? (...) O trabalho de revisão não significará sair da manufatura. É preciso pegar as coisas onde elas estão. E não é evidente que a industrialização da construção seja possivel a curto prazo - ou que seja tão desejável. A única posição realista é assumir a manufatura - orientando-a em favor da autonomia (Ferro, 2006: 402-3).

De qualquer forma, mais complexo que posicionar uma produção por manufatura no interior de uma economia capitalista (subdesenvolvida ou não) é posicioná-la no interior dos próprios canteiros de obras desta economia capitalista, onde materiais, elementos e componentes industrializados já formavam um conjunto relevante desde os primeiros empreendimentos habitacionais financiados pelo Banco Nacional da Habitação - BNH, mesmo quando combinados à exploração extensiva de mão-de-obra (Tavares, 1988). Dentro do canteiro de obras, a continuidade entre atividade e insumos de fabricação externa cria um permanente glissando, em que a manufatura está sempre em transição para a indústria.

A interação entre manufatura e indústria que ocorre no interior de um canteiro de obras é explicitamente tematizada em "O canteiro e o desenho":

Vários produtos industrializados intervêm no canteiro, seja como materiais de base (cimento, aço, isolantes etc.), seja como componentes (equipamento elétrico, hidráulico, caixilharia, paredes ou lajes pré-fabricadas etc.), seja como complemento instrumental (guinchos, betoneiras etc.). O conjunto da produção e cada etapa, porém, são dominados pela estrutura da manufatura. E essa dominante estrutural define a produção do espaço, mesmo se não é a mais avançada técnica ou historicamente. É por isso, aliás, que as diferenças na organização do canteiro em país subdesenvolvido e em país desenvolvido, como a França, fora casos pontuais, podem ser limitadas às que distinguem a manufatura serial (baseada principalmente no trabalho interno e cumulativo) da manufatura heterogênea, baseada principalmente na montagem de elementos pré-fabricados (Ferro, 2006 [1976]: 113).

Tomada apenas neste trecho, a recusa que a industrialização dos insumos implica na industrialização de seu processamento no canteiro de obras se assemelha a uma petitio pricipii. O mais interessante, então, é entender duas consequências da argumentação que Sérgio Ferro assume com coerência. A primeira é tratar "guinchos" e "betoneiras" como "complemento instrumental" da manufatura, máquinas que ampliam o potencial do trabalho humano mas não o subvertem, como acontece com ferramentas como polias ou pás.

É uma opção que impulsiona a segunda consequência, que é estender a dominação da manufatura, uma forma produtiva que "não é a mais avançada técnica e historicamente", para a fase áurea da industrialização da construção na França (que ele viu de perto como refugiado político no início de sua carreira de professor em Grenoble), com a ressalva de que se trata de manufatura heterogênea, de montagem. É preciso então desconsiderar que o operador central desta montagem são complexas máquinas de movimentação de componentes pré-fabricados, diante das quais qualquer habilidade humana é cancelada, e que toda uma literatura técnica diverge apenas em estabelecer o grau de avanço 
industrial que representam. As distinções entre mecanização (por vezes subdividida em "leve" e "pesada"), pré-fabricação e racionalização nunca levaram esta montagem para o campo da manufatura [3].

A intenção de isolar uma produção manufatureira dentro da produção capitalista na construção civil encontrou no fim dos anos 1980 um crítico severo no campo do marxismo, que é Michael Ball. Ao pesquisar a indústria da construção inglesa (que resultou num clássico com o intraduzível título "Rebuilding Construction"), ele se recusa a traçar um limite que separe as atividades "on-site" e "off-site", isto é, entre as atividades realizadas fora do canteiro de obras e que lá chegam como capital fixo através de materiais e instrumentos de trabalho e as atividades que processam os materiais e operam os instrumentos como força de trabalho.

Segundo Michael Ball, a concepção da construção civil como um setor produtivo "atrasado" costuma demandar, numa aproximação com a linguagem médica, "remédios" como a adoção da arquitetura moderna ou o cancelamento da renda fundiária [4]. Quando os supostos remédios se mostram inócuos, a construção civil é considerada inapta, por limites intrínsecos de sua atividade econômica, para se desenvolver como setor plenamente capitalista, ou seja: "no remedy for a permanent affliction". Como o diagnóstico parte de uma "absolute physical constraint", o impedimento para que o canteiro de obras se comporte como uma instalação fabril convencional é igualmente absoluto e "it is concluded that the building industry is doomed to relative technical stagnation".

Contra esta condenação, Michael Ball vai argumentar que as especificidades que podem existir num canteiro de obras não afetam sua continuidade com transformações técnicas gestadas e disseminadas pelo conjunto da sociedade. Se as condições mais gerais da economia induzem a industrialização de setores econômicos não-fabris, como agricultura ou comunicação, então a mesma indução está em aberto para a construção civil, uma linha de raciocínio que, no fundo, é a única coerente com a recusa em abordar a construção habitacional pelo viés do atraso produtivo:

Empirically, it is difficult to say what proportion of construction work is inherently sitebased. Changing techniques over time have considerably altered the sorts of construction work that have to be undertake on-site (...) It would be folly to ignore the special physical characteristics of building production, but to elevate them to a level where they are alldetermining seems both logically and historically false. Technical change has a tendency to transform the physical content of production, making previously seeminglyinsuperable physical barriers either non-existent or easy to overcome (Ball, 1988: 27).

3 Julián Salas (2008) recompõem estas distinções com a vantagem de poder comentá-las com um distanciamento histórico que Sérgio Ferro não contava. Uma trabalhosa discussão conceitual poderia ser feita neste ponto sobre o uso que Sérgio Ferro faz da distinção do capítulo 12 do Volume 1 do "Capital" entre manufatura "serial" e "heterogênea", mas ela não alteraria em nada o interesse das teses de "O canteiro e o desenho", que está ligado a um posicionamento tanto teórico como político.

4 Michael Ball aponta como a construção civil ganha a qualificação de "atrasada" com a conotação médico-popular do "retardamento": "It has, in terms of the backward metaphor, the mental age of an industrial child - living in the age of nineteenth-century handicraft technology (...) Something has either retarded its technological growth or prematurely brought it to a grinding halt, and the purpose of any explanation is to understand what inhibited the industry's development" (Ball, 1988: 23). 
A evidência empírica da falta de barreiras tecnológicas na construção civil desmonta a investigação de um limite manufatureiro, mas não a de que a tecnologia da construção seja um processo socialmente determinado:

Technological advance and physical constraints are mutually influencing process. The question then becomes what determines the form of technological change? Developments in technique are not simply random processes subject to the skills and genius of individual inventors. Instead changes in production methods depend on the economic content of production and the social relations that underlie it. Thus the role played by the physical content of building production can only be understood in context of the contemporary social relations of building production (Ball, 1988: 28).

Michael Ball nota então que o ajuste funcional entre construção e luta de classes antes enfraquece do que reforça a concepção da construção como manufatura. Se esta condição socialmente determinada não pode ser naturalizada, ela também não pode ser mais persistente em uma atividade produtiva do que em outras. Uma vez que as condições da luta de classes se modificam, não há nada no canteiro de obras que possa impedir sua industrialização, ainda que ele continue se organizando de forma diferente de uma típica planta fabril [5].

Por enquanto, a análise da produção habitacional que adota um ponto de vista de continuidade entre força de trabalho e insumos geridos de forma industrial acontece no Brasil unicamente dentro dos limites ideológicos da engenharia civil, em que as pesquisas de Gestão de Produção podem descrever com minúcias a racionalização industrial, mas se limitam a atribuir sua aplicação a sábias decisões de gestores privados ou, secundariamente, de governantes. Ainda assim, se é preciso retomar a literatura acadêmica brasileira sobre os canteiros de construção habitacional, esta retomada precisa ser feita do ponto de vista de uma ruptura, que é a organização do trabalho da construção habitacional sob o programa Minha Casa Minha Vida: nesta organização, a produção industrial não é uma fornecedora marginal de insumos da construção, mas origem e mantenedora central de sua tecnologia de gestão.

E cabe também se manter na temática de Sérgio Ferro que orienta a análise da construção habitacional pela valorização do capital e observar onde o reequilíbrio entre trabalho vivo e trabalho morto resultou na racionalização industrial como forma dominante da extração de valor. Esta racionalização coincide em parte com a mecanização do canteiro de obras, mas é preciso entender que, dentro de um típico canteiro de obras do programa MCMV, a mecanização se fraciona entre dezenas de subempreiteiras de serviços de construção e centenas de fornecedores de insumos, sendo que a única articulação deste conjunto (como em todas as demais indústrias) não é mais uma "máquina-motriz", mas sim um comando do capital que é essencialmente organizacional.

5 A argumentação de Michael Ball neste ponto é certeira: “Why should the future technical development of construction necessarily be towards more and more factory production? An unwarranted idealisation of particular methods of production seems to be elided with a very essentialist view of technical change. Yet, without such a view of the perfect universal technology applicable to the production of everything, how can you compare technologies on a scale of backward and forward? Is the latest generation computer more technically advanced than the most recent piece of genetic engineering? Is an elephant more technically backward than a race horse? Outside riddles in the style of Lewis Carroll, such comparative exercises have no meaning. The backward view of the building industry is asking the wrong question" (Ball, 1988: 32). 
Portanto, se é possível falar no fim de uma manufatura, é preciso deslocar o sentido temporal desta observação: "fim" não como cessação da existência, mas finalidade que orienta a ação do capital. Esta transição não deixa de ressoar um sentido dialético, que faz justiça ao permanente diálogo de Sérgio Ferro com Hegel se pensarmos no uso teleológico que este faz do termo "Zweck", isto é, "fim" como determinação (de terminatio) imanente, manifestação de uma finalidade interna pela qual partes se revelam num todo ao invés de fim imposto do exterior, como uma alternativa entre outros possíveis desenvolvimentos (cf. em especial "Ciência da Lógica”, §1625).

Sob o capital, o fim de toda atividade produtiva é expandir e acelerar a acumulação do próprio capital. No subdesenvolvimento brasileiro, a construção habitacional atingia este fim mantendo uma organização da manufatura. Nos empreendimentos do programa MCMV visitados para esta pesquisa, a racionalidade industrial está no centro da acumulação.

No programa MCMV, a manufatura se torna indústria porque este é o seu fim. 


\section{1}

\section{A ARGAMASSA DE REVESTIMENTO COMO TRABALHO-TIPO}

\section{O processo de trabalho da argamassa de revestimento}

O quadro produtivo que permitiu a industrialização dos empreendimentos do programa MCMV só pode ser diretamente observado pelo trabalho tal como é organizado no interior dos canteiros de obra. Na sua forma mais coerente, esta organização constitui o que Marx trata no "Capital" como um "processo de trabalho", unificação de trabalhos parciais sob orientação de um objetivo preciso e que, na construção habitacional, necessariamente se inicia na recepção de um conjunto de suprimentos e termina na sua transformação em obra acabada. Ao invés de um particularismo, as articulações entre trabalhos parciais revelam estratégias de ação tanto da empresa construtora quanto de seu trabalhador que são partilhadas e generalizáveis para outros empreendimentos habitacionais.

Os métodos estatísticos que são mais usuais para aferir a industrialização da construção civil tomam um rumo contrário: tornam o campo de observação mais amplo e abstrato ao invés de mais concentrado e concreto. É uma perspectiva que opera pela agregação de variáveis e indicadores dos setores econômicos onde se ligam as cadeias produtivas da construção civil, seguindo um modelo de pesquisa já realizado por Victor Prochnik nos anos 1980 para o "macrocomplexo da construção" (Prochnik, 1986). O gigantismo da tarefa é um dado de saída e um exemplo mais recente é o estudo do Serviço Nacional de Aprendizagem Industrial que reuniu indicadores econômicos, análise organizacional e perspectivas tecnológicas referentes ao "segmento edificações" nos anos imediatamente anteriores à presidência Lula (Abiko; Cardoso; Marques; Tigre, 2005).

Tal abordagem estatística, que chega a ser segura para um subsetor produtivo da construção, seria lacunar para um único programa governamental, ainda que do porte do MCMV. Um diagnóstico por indução, que agregasse dados de formação de capital fixo apenas das empresas do MCMV, exigiria, por sua vez, uma complexa modelagem financeira e contábil, mesmo que aplicada à posição singular de uma única empresa na cadeia produtiva da construção habitacional. As quantificações precisariam abrir as composições de custos de cada empresa construtora (que são seu mais valioso segredo comercial) e refazer custos tanto a montante de seu fluxo produtivo, nas aquisições junto a fornecedores, quanto a jusante, na contratação de cada subempreitada.

A alternativa mais imediata para organizar e interpretar o material observado nos empreendimentos visitados do programa MCMV é a tipológica, tal como fez Sérgio Ferro. Trata-se de argumentar com um canteiro de obras reconstituído 
mentalmente mas que sintetiza o que de outra forma só pode ser observado por fragmentos em suas manifestações reais [6].

Várias etapas de obra poderiam ser abordadas, incluindo casos típicos de industrialização por insumos, como a alvenaria estrutural [7]. Recorrer a uma etapa de obra fortemente mecanizada como a de execução de fundações seria pouco esclarecedor, pois as movimentações de terra realizadas por máquinas motorizadas se confundem com a própria tecnologia empregada nas fundações, o que elimina a comparação com a manufatura. Esta comparação é essencial e, portanto, o trabalho-tipo capaz de revelar com mais clareza a industrialização da construção é a argamassa de revestimento, uma vez que ela se desdobra em atividades que são reconhecidas como o ápice da habilidade e autonomia do pedreiro, o profissional onipresente da manufatura no canteiro de obras [8].

As atividades de revestimento de parede se entranham na construção habitacional de forma significativa e progridem dentro do canteiro de obras por etapas de preparação que já estavam presentes na descrição de Sérgio Ferro reproduzida no início do capítulo anterior:

A areia, a pedra são descarregadas. Um servente as amontoa nos locais previstos do canteiro; um outro leva parte para o ajudante de pedreiro que ajunta água e cal ou cimento, trazidos do depósito por um ajudante diferente; um quarto despeja a argamassa em baldes ou carrinhos e a conduz ao pedreiro que coloca tijolos, faz um revestimento.

A forma manufatureira da argamassa de revestimento demanda uma série de etapas obrigatórias e sucessivas, todas anteriores ao seu lançamento sobre a alvenaria. A própria duplicidade dos aglomerantes cal e cimento exige a produção da argamassa intermediária ("massa branca"), mistura de cal hidratada com areia e que precisa ser maturada por um dia. Nos anos em que "O canteiro e o desenho" foi elaborado, existia uma etapa ainda anterior: a preparação da própria cal hidratada: a dissolução em água, sob forte calor de reação, da "cal virgem", isto é, o óxido de cálcio diretamente oriundo de alto-forno e que os pedreiros mais antigos se recordam pelo nome "pedra de cal".

6 “O conceito de tipo ideal propõe-se a formar o juízo de atribuição. Não é uma 'hipótese', mas pretende apontar o caminho para a formação de hipóteses. Embora não constitua uma exposição da realidade, pretende conferir a ela meios expressivos unívocos (...) Obtém-se um tipo ideal mediante a acentuação unilateral de um ou vários pontos de vista, e mediante o encadeamento de grande quantidade de fenômenos isoladamente dados, difusos e discretos, que podem ocorrer em maior ou menor número ou mesmo nunca, e que se ordenam segundo pontos de vista unilateralmente acentuados, formando um quadro homogêneo de pensamento" (Weber, 2006 [1904]:72).

7 A utilidade da alvenaria estrutural, no entanto, está na sua análise como tecnologia produtiva que não mantém compromisso com a forma de produção da manufatura, como se verá no capítulo 3.

8 Antes de elaborar esta pesquisa, a atuação como arquiteto já havia criado o hábito de anotar conversas com profissionais de obra com quem eu trabalhei. Sem pretender que estas falas façam parte de uma metodologia coerente, reproduzo algumas: "Quando o pedreiro sobe uma parede, a obrigação dele é fazer no tempo certo. Quando ele cobre [reveste] a parede, a obrigação dele é fazer bem feito" (Sérgio Moura, o “Serjão"); "O pedreiro de emboço precisa fazer o trabalho dele antes de pegar na colher, precisa ser bom antes de chegar na obra" (José Vicente, o "Mineiro"); “Vá ver uma parede descansando depois do emboço. Na luz que bate na massa você já sabe se o pedreiro é de profissão ou de necessidade" (Ednaldo Bueno, o "Palhano"). O pedreiro Valdeci Matos, o "Lelê", cujo processo de trabalho é descrito no doutorado de Pedro Arantes (Arantes, 2012: 195) valorizava o revestimento através da própria alvenaria estrutural que assentava: "A parede que eu subo já vem aprumada e desempenada. A pessoa olha e diz: ela já está revestida". 
A plasticidade conferida pelo aglomerante cal exige a preparação em paralelo de uma massa de ancoragem com o aglomerante cimento: o chapisco, a camada de areia grossa com "cimento forte" (traço 1:3) que só é efetiva se estiver complemente curada após dois dias do lançamento. Também antes de lançar a argamassa de revestimento, o pedreiro deve assentar as referências de nível, as "mestras", de onde o prumo de parede e linhas de nylon tensionadas servirão de guias para assentar as taliscas [9].

Chegado o momento propriamente de execução do revestimento, mesmo que a argamassa "monocapa" tenha atualmente eliminado a diferença entre emboço e reboco, ela não elimina a "chapada", manifestação maior da habilidade de um pedreiro. A colher de pedreiro (geralmente a de $n^{\circ} 10$, algumas vezes alternada para $n^{\circ} 8$ ) recolhe argamassa dos caixotes ou de masseiras pequenas no volume adequado para cada lançamento e a projeta num acordo permanente entre o ponto de lançamento e a distância em relação à referência de nível. Ao manusear a colher, as articulações de cotovelo e punho se movem com todo o corpo para obter uma combinação ótima de impacto e distribuição de massa.

No tempo certo após o lançamento, quando obteve apenas parte de seu enrijecimento, a massa recebe o "corte" ou "sarrafeamento" entre as referências de nível. Pouco antes de perder por completo sua plasticidade, o revestimento recebe o "desempeno", ciclos de umidificação e raspagem executados com blocos de espuma ou desempenadeira de madeira. Dentro de um canteiro de obras, poucas atividades demonstram tão bem a complementação característica da manufatura entre o corpo humano e os instrumentos de trabalho: a colher é um prolongamento metálico da palma da mão (da qual chega a ter a precisão de um dedo quando porções mínimas de argamassa são lançadas em cantos inacessíveis), a umidade do substrato e da massa é sentida pelo tato, a linha de nylon prolonga, na verdade, a linha de visão do rosto rente à alvenaria.

Sérgio Ferro considerava a parede revestida como uma manifestação de trabalho alienado, em que a camada homogênea de massa impede a identificação do trabalho presente na irregularidade do bloco assentado [10]. É compreensível também do ponto de vista do marxismo que a impressão de um trabalhador profissional da construção civil seja oposta: se o trabalho se humaniza porque, "além do esforço dos órgãos que trabalham, a atividade laboral exige a vontade orientada a um fim, que se manifesta como atenção do trabalhador durante a realização de sua tarefa" (Marx, 1867 [2013]: 256), as diversas etapas de preparação e execução que constroem uma superfície plana são uma habilidade do corpo que é orientada pela ideia necessariamente abstrata e humana do nivelamento de uma camada protetora da parede. Quando este trabalho se insere num mercado que produz e comercializa edificações, o comando do capital não impede o domínio do trabalhador sobre a união hábil de corpo e mente. Para o pedreiro formado na

Outra fala anotada: "Tem serviço que o pedreiro pode fazer até com o pé. A talisca de parede, para ficar boa, o pedreiro não faz nem com a mão, mas com a ponta de dois dedos" (José do Nascimento, o "Japonês").

10 Por apagar as marcas do canteiro de obras, o pedreiro de revestimento seria "o mais trágico dos operários da construção" (Ferro, 2006 [1974]: 130). Esta posição, coerente na sua defesa de uma "poética da economia", algumas vezes é acompanhada do equívoco de afirmar que revestimentos são "dispensáveis do ponto de vista técnico" (Ferro, 2006 [1969]: 77). 
manufatura, quanto mais plana a parede mais visível é a qualidade do trabalho de preparação e execução [11].

O trabalhador está alienado da mercadoria que reveste, mas, nos termos dos "Manuscritos Econômico-Filosóficos", consegue orientar os elementos objetivos e subjetivos de seu trabalho - objeto, instrumentos e a ação que os consome produtivamente - na direção de um resultado que ele antecipa e avalia mentalmente [12].

No entanto, o plano de um revestimento de parede, quando é produto direto da manufatura, contém igualmente tudo o que há de irregular e oscilante de uma atividade humana. A produção por manufatura implica numa variabilidade que, no caso da argamassa, aparece tanto na execução quanto nas suas sucessivas etapas de preparação.

A variabilidade no preparo da argamassa de revestimento sofre um embate cotidiano e antigo com as prescrições da engenharia civil para uma produção normatizada no modelo das atividades industriais. É um embate que aparece concentrado numa recente entrevista com integrantes do Consórcio Setorial para Inovação em Tecnologia de Revestimentos de Argamassa (Consitra), que reúne representantes da indústria de materiais de construção, onde se lê:

Não dá para ter mais atividade do que já temos em canteiro. A construtora fica na mão do operário que está misturando. Isso já foi medido: aquilo que o engenheiro especifica é diferente daquilo que o mestre recomenda para o encarregado, que é diferente também do que o encarregado recomenda para o operador da betoneira. E o operador da betoneira, por sua vez, faz o que lhe dá na cabeça (Faria, 2013: 24).

Não é tanto a variação da dosagem que incomoda a gestão racionalizada do canteiro de obras, mas sim que esta dosagem "fica na mão do operário", de imediato considerado incompetente. Fábio Câmpora, diretor-executivo Associação Brasileira de Argamassas Industrializadas (ABAI), defende que "só é possível ter o controle pleno da operação se ela é industrializada e mão-de-obra não é um processo industrial" (Faria, 2013:24), raciocínio que é a expressão de um lobby apoiado em pesquisas de gestão de produção:

Fizemos um estudo em uma obra no qual medímos o teor de água e a trabalhabilidade da argamassa que saía da argamassadeira. Medíamos também a argamassa do caixote do balancim. Uma era diferente da outra e a especificada era diferente das duas" (Faria, 2013:24).

11 Anotação de uma conversa com o pedreiro José Vicente, que fazia uma confusão recorrente entre meu uso da palavra "revestir" com "vestir": "Você fala que a parede está vestida, mas para mim ela está é pelada. Antes da massa a gente não diz que a parede está "no osso"? [designação popular da alvenaria sem revestimento] Pois é, com a massa ela ganha carne. Você vê uma roupa, mas eu vejo é a pele limpa e lisinha".

12 É na construção habitacional que o sentido marxista do trabalho escapa da crítica de Hannah Arendt contra sua redução a um ciclo metabólico com a natureza, sem o sentido público e único da obra de arte (Arendt, 1998 [1958]). O ciclo de esforço, consumo e repouso é animado por uma finalidade mental que resulta na materialização de um bem social: o edifício. Ao construir tais espaços "o homem tem não só a capacidade de transformar a natureza, mas também de produzir sociedade, formas novas de sociedade que correspondem a novas relações com a natureza e agem por sua vez sobre estas últimas" (Godelier, 1986: 17). 
Ora, por que o teor de água da argamassa variava tanto entre cada caixote? Porque em cada operário, ou melhor, em cada corpo, varia a aptidão para lançar a argamassa, que é umidificada conforme a altura de lançamento, a disposição fisiológica do dia ou mesmo se o trabalhador está trabalhando à sombra ou sob o sol. A busca de um teor de água único a todo e qualquer caixote de argamassa exclui o trabalhador da pesquisa de uma propriedade chamada justamente de... trabalhabilidade. Assim, o que é prescrito por norma técnica e pesquisa tecnológica pela engenharia, na manufatura é subvertida pelo trabalhador que leva para o balancim um estoque próprio de água, que ele acrescenta conforme sua avaliação das condições de produção [13].

Em todos os canteiros de obra do programa MCMV visitados por esta pesquisa está presente o que o mercado da construção civil denomina "argamassa industrializada" [14]. Como insumo, ela é o produto da dosagem e mistura em ambiente industrial de cimento e cal hidratada com areia de granulometria fina e aditivos (plastificantes ou retardadores de pega). A complexidade desta composição pode aumentar para conferir à argamassa propriedades hidrofugantes, para impermeabilizações em ambientes úmidos ou para água sob pressão, ou colantes, para assentamento de pisos e azulejos em diferentes graus de resistência a cisalhamento.

Ao aparecer ensacada num canteiro de obras, mesmo a mais simples das argamassas de revestimento altera a organização manufatureira do canteiro de obras, de imediato porque transforma numa mera administração de sacaria o que no canteiro de obras era antes a elaborada produção da argamassa intermediária, com as diferentes etapas de recebimento, estocagem e mistura. É uma típica industrialização de insumo, mas que afeta diretamente a organização do trabalho no canteiro de obra [15].

Uma comparação por diagramas pode ser encontrada nas pesquisas dos engenheiros Carlos Regattiere e Luciano Silva sobre argamassa de revestimento (Regattiere; Silva, 2003), na qual o ciclo completo de produção da argamassa de revestimento por manufatura aparece no gráfico G-1:

13 Num dos empreendimentos visitados para pesquisa, um pedreiro de argamassa relatou que havia a proibição de levar água para os andaimes "mesmo para matar a sede", numa agressão tanto ao trabalhador quanto à trabalhabilidade da argamassa. A superdosagem de água afeta menos o desempenho mecânico do revestimento do que a superdosagem de cimento e cal, que acontece na convicção errônea de "deixar a massa forte" mas que a torna rígida demais para promover a aderência com a alvenaria.

14 Classificação normatizada na NBR 13529, item 3.2.4.3, em acordo com a Associação Brasileira de Argamassa Industrializada (ABAI). A associação é dominada pelos conglomerados Lafarge, Votorantim e Cimpor, que formam um oligopólio no mercado de cimento e cal no Brasil. A história recente da Cimpor ("Cimentos de Portugal") mostra os interesses compartilhados destes fornecedores: partes significativas de seu controle acionário transitaram da Lafarge para a Votorantim Cimentos, até a empreiteira Camargo Corrêa adquirir 72,9\% do capital social em dezembro de 2012.

15 Marta Farah indicava em 1996 a introdução da "argamassa pré-misturada" nos canteiros como um exemplo de "apropriação de atividades do canteiro de obras pelo segmento produtor de materiais e componentes" (Farah, 1996: 241). Atualmente, a própria cal está desaparecendo como aglomerante adquirido em sacos ou a granel, substituída pelos aditivos com nome comercial de "cal líquida". 


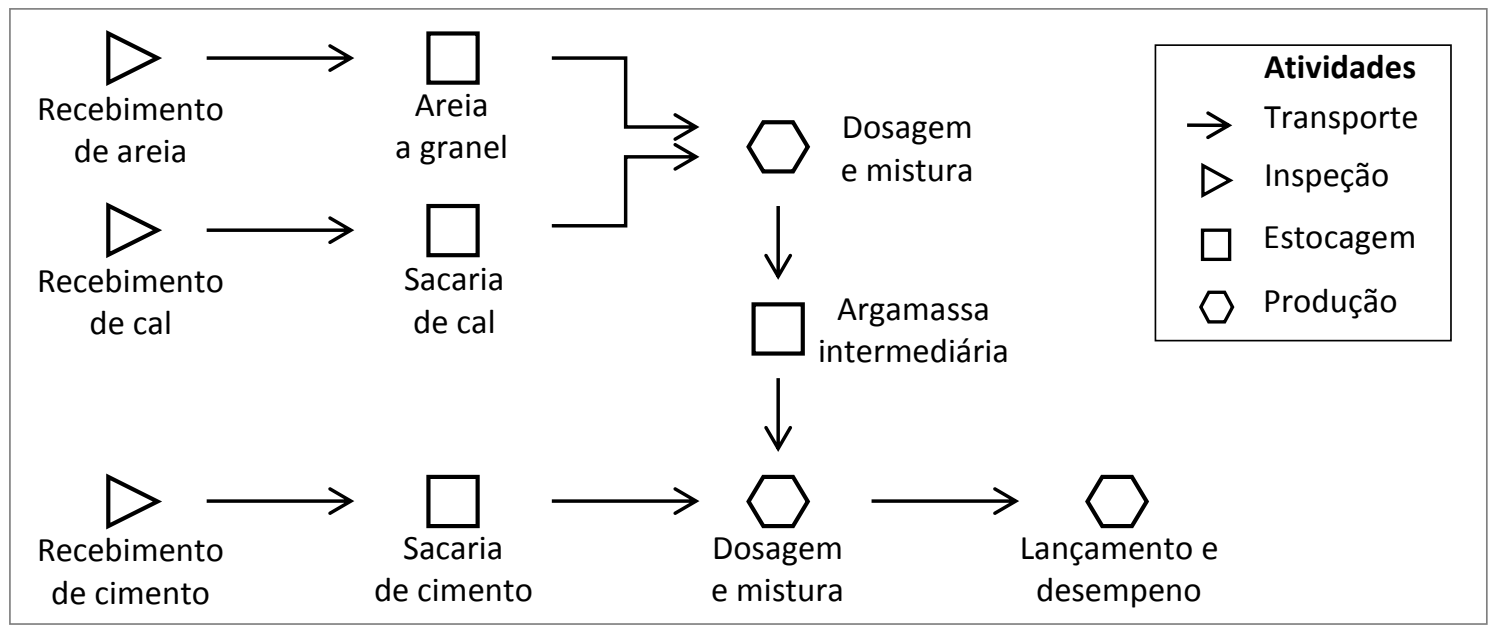

Fonte: adaptado de Regattiere \& Silva (2003)

A introdução da mistura pronta e ensacada de cal, cimento, agregado e aditivos reduz a etapa de preparação de argamassa para apenas três atividades em obra, além de eliminar o dia extra exigido para preparo da argamassa intermediária. Assim, o serviço esquematizado no gráfico G-1 passa a apresentar o diagrama de atividade do gráfico G-2.

G-2|Argamassa de revestimento - diagrama de insumo industrializado

\begin{tabular}{|ccc|c|c|}
\hline $\begin{array}{c}\text { Recebimento } \\
\text { de argamassa } \\
\text { industrializada }\end{array}$ & $\begin{array}{c}\text { Sacaria } \\
\text { de argamassa } \\
\text { industrializada }\end{array}$ & $\begin{array}{c}\text { Mistura } \\
\text { com água }\end{array}$ & $\begin{array}{c}\text { Atividades } \\
\text { Lançamento e } \\
\text { desempeno }\end{array}$ & $\begin{array}{l}\text { Transporte } \\
\square\end{array}$ \\
$\square$ Inspeção \\
$\square$ Produção
\end{tabular}

Fonte: adaptado de Regattiere \& Silva (2003)

O custo unitário de areia, cimento e cal é menor para a compra em separado do que na mistura ensacada, diferença que começa na incidência sobre esta de Imposto sobre Produto Industrializado (IPI) e, consequentemente, um maior valor de referência para cálculo das alíquotas estaduais de Imposto de Circulação de Mercadorias e Serviços (ICMS) [16].

Considerando apenas custos unitários de insumos, a invariabilidade da dosagem industrial é uma vantagem apenas técnica, não econômica. No entanto, o fator que motiva e compensa o aumento de custo da matéria-prima é a diminuição do custo da força de trabalho pela eliminação de processos produtivos. Por afetar atividades de preparação, a diminuição de trabalho retira atribuições do trabalhador mais barato e menos qualificado da construção civil, mas também o mais difuso: o servente de obra, responsável pelo grosso das atividades de transporte eliminadas pela argamassa industrial.

16 Desde Abril de 2009, o Ministério da Fazenda implementou uma política de redução de alíquota de IPI para produtos da construção habitacional. A desoneração coincide com o lançamento do programa MCMV e representa um estímulo para o aumento da fração industrial de seus canteiros de obras. 
No entanto, a última fortaleza da manufatura é o trabalhador manual especializado, o oficial pedreiro, e não o grupo de trabalhadores que lhe é servente. Esta barreira para a industrialização, em que a argamassa deixa de ser industrializada após chegar no caixote do pedreiro, confirmaria a percepção de Sérgio Ferro de que a manufatura é a forma dominante na construção mesmo quando esta se cerca de produtos industrializados nas etapas de preparo.

A ultrapassagem desta barreira foi possível de ser observada em quatro empreendimentos do programa MCMV visitados para esta pesquisa. Com base neles que é possível elaborar um trabalho-tipo em que a fração industrial representada pela argamassa dosada em usina induz a uma diluição da própria atividade do pedreiro de revestimento numa sequência de operações mecanizadas. O que está em preparação também é a industrialização completa da argamassa de revestimento dentro do canteiro de obras, no sentido de unificar o potencial produtivo de equipamentos dispersos e organizá-los na forma de um sistema de máquinas.

\section{Um sistema de máquinas}

A tipologia desta industrialização se baseia nas etapas produtivas da argamassa de revestimento, pelas quais transporte, recebimento, estocagem e aplicação são convertidas em etapas de processamento industrial por meio do emprego de quatro máquinas típicas: o caminhão graneleiro, o silo mecânico, a argamassadeira e o projetor de ar comprimido. A forma desta conversão aparece no gráfico G-3:

G-3|Argamassa de revestimento - diagrama de mecanização

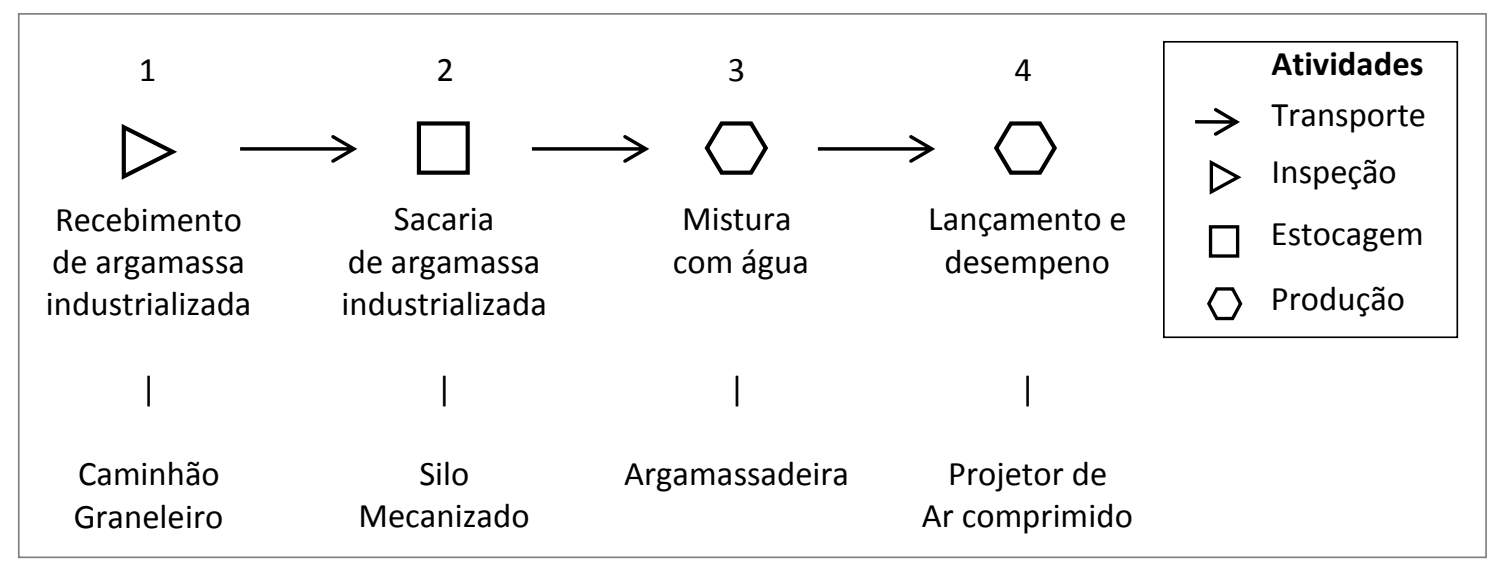

Fonte: adaptado de Regattiere \& Silva (2003)

Uma vez que estas máquinas assumam as atividades numeradas de 1 a 4 , todo o transporte de argamassa industrializada entre elas, acrescida ou não de água, se dará através de bombas mecânicas, de via seca ou via úmida. A descrição dos pontos ligados por tal transporte bombeado é esclarecedora de como desmontam parte por parte o trabalho da manufatura. 


\section{Atividade 1 - Recebimento por caminhão graneleiro}

Tal como o caminhão betoneira, o caminhão graneleiro é uma extensão da mecanização da indústria de insumos, via meio de transporte, para os limites do canteiro de obras. Se ambos promovem um descarregamento mecânico de um insumo produzido industrialmente, o graneleiro avança um passo para dentro da produção do edifício ao exigir como ponto de descarregamento um silo, isto é, um local de estocagem que é início de um processamento industrial implantado em obra.

O verdadeiro sentido do caminhão graneleiro não é, portanto, o transporte de cimento, cal e areia, mas sim a sua estocagem. Ao invés de transportados em sacos dentro de uma caçamba, os componentes secos da argamassa são dosados e pré-misturados em usina e acondicionados no tanque do caminhão graneleiro, com capacidade para transporte de 25 toneladas (com eixos "truck") de argamassa industrializada. $\mathrm{O}$ descarregamento é mecanizado por ar comprimido. $\mathrm{O}$ uso de mangueiras e engates impede que o material seja exposto ao ambiente externo e a própria verificação de quantidades deixa de ser visual: ao invés de estimar volumes, a medição de massa se dá através da pesagem do veículo antes e depois do descarregamento.

O caminhão graneleiro também elimina a estocagem da areia comprada a granel, a "areia solta". Embora seja a forma de aquisição de menor valor unitário, é também a que acarreta mais operações de trabalho no canteiro de obras. Carregada em depósitos ao ar livre e transportada em caçamba aberta, a areia se torna impossível de conferir quanto a granulometria e impurezas. A mistura com terra ou material orgânico embute inevitavelmente o serviço de peneiramento em obra, que não é uma tarefa desprezível, e, se o caminhão descarregar a areia em outro local que não a baia de estocagem (uma calçada ou barranco, por exemplo), surge uma intensa demanda de trabalho de transporte. A entrega em caçamba aberta dificulta a própria conferência de quantidades na recepção da areia. A otimização do custo de frete estimula a adoção do "caminhão" como unidade de compra e, como seu volume em situação normal de transporte e carregamento é impreciso (caçambas menores são constantemente aumentadas por tábuas laterais), a conferência da areia precisa considerar a altura do monte em relação a suas bordas, o chamado "cupim" [17].

\section{Atividade 2 - Estocagem em silo mecanizado}

A areia comprada a granel exige a compra ensacada da cal e do cimento, que exige inspeção por pontos rompidos ou empedrados antes de serem estocados em local fechado e coberto, sobre assoalho e sem contato com paredes. A eventual substituição da cal por aditivos líquidos não altera a complexa estocagem da sacaria de cimento, que demanda uma grande proporção de área de circulação

17 O recebimento de areia é o símbolo maior do descontrole de um canteiro de obras. Algumas vezes, um almoxarife mais cuidadoso monta na caçamba com um vergalhão de aço, que penetra no "cupim" como se isso adicionasse alguma confiabilidade à medição. É significativo que a dificuldade para medir volumes a partir de uma caçamba aberta de caminhão se prolonga na mistura manual de argamassa, baseada em subdivisões do volume da caçamba, que são os carrinhos de mão. 
junto à área de depósito, pois é preciso manter na parte superior das pilhas os sacos recebidos há mais tempo

\section{I-2 | Caminhão graneleiro e silos mecanizados}
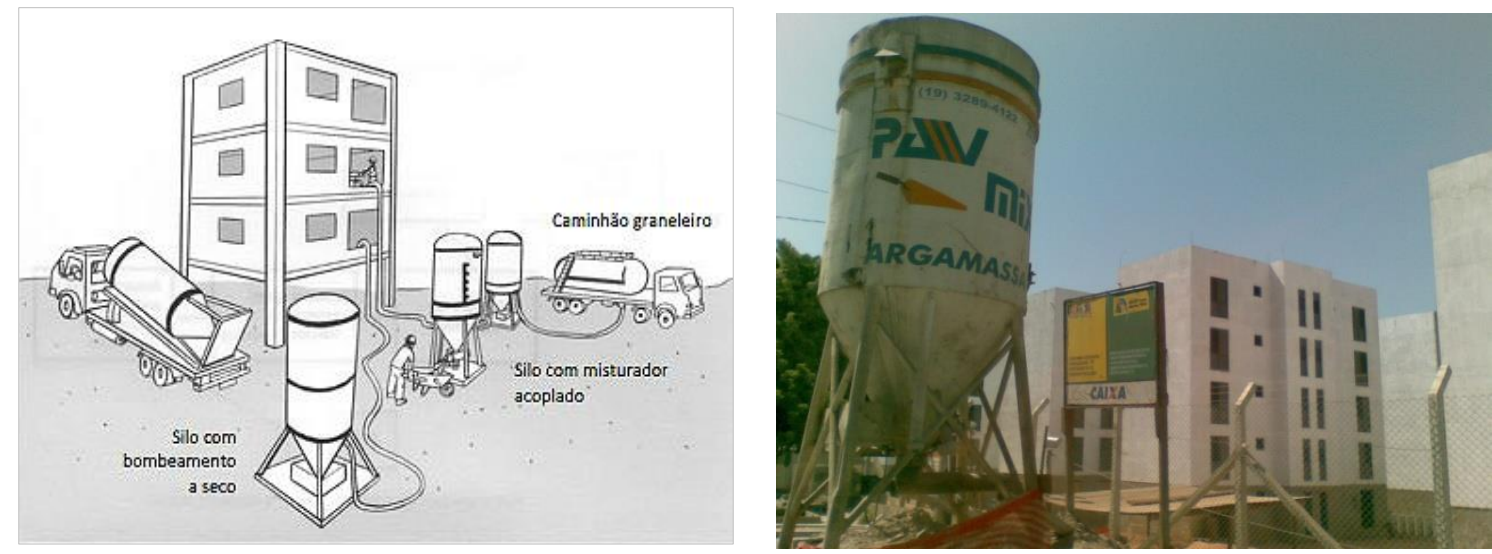

À esquerda, esquema de operação publicado no site da usina de argamassa Pav Mix; À direita, foto de setembro de 2011 do empreendimento "Caraguatatuba", da construtora Hudson (cf. página 211).

O silo estoca até 30 toneladas de argamassa seca numa área de $9 \mathrm{~m}^{2}$, o que elimina a gestão de materiais dispersos no canteiro de obras. Como só pode ser carregado mecanicamente, ele preserva no canteiro de obras o controle que a usina de argamassa exerce sobre seus insumos.

A mecanização do silo se dá por associação a um conjunto de misturador e bomba. Na configuração mais comum, o misturador antecede a bomba e, ligado a um dosador de água, forma uma central de produção de argamassa cuja produção pode ser despejada diretamente no cocho de uma bomba de eixo parafuso e distribuída por mangueiras. Na configuração alternativa, a bomba transfere por ar comprimido a mistura seca para a produção descentralizada da argamassa, feita por misturadores móveis de pequeno porte que adicionam a água próximo ao local de lançamento. Antecedendo o misturador, a bomba é de "via seca", sucedendo ao misturador, é de "via úmida", cujo bombeamento só é possível pela granulometria e plasticidade da argamassa industrial.

Seca ou úmida, a estocagem em silo implica na distribuição mecanizada. A alimentação por bomba e mangueira a partir do caminhão graneleiro corresponde a uma equivalente distribuição por bomba e mangueira da argamassa industrializada. Esta distribuição atinge o ideal das tecnologias de gestão de produção em canteiro de obras que é eliminar o "transporte de material com decomposição de movimento", isto é, transporte em que o equipamento que realiza o deslocamento horizontal não é o mesmo que realiza o deslocamento vertical, situação mais visível no carrinho de mão ou girica que se desloca até um guincho de coluna ou elevador de obra [18].

É possível isolar o aumento de produtividade do sistema caminhão graneleiro e silo mecânico num estudo da Faculdade de Engenharia Civil da Unicamp para o uso de argamassa industrializada em estacas raiz. Após a mistura com água, a

18 Sérgio Ferro trata com escárnio justificado as tentativas de racionalização de movimentos num caso semelhante de associação entre carrinho de mão e elevador (Ferro, 2006 [1976]: 118-9). A generalização do transporte por bombas torna este debate datado. 
argamassa é levada por bombas para estacas de $31 \mathrm{~cm}$ e $40 \mathrm{~cm}$ de diâmetro, A diferença de tempo de preenchimento das estacas é mínima e a de consumo de material, de apenas $5,6 \%$. No entanto,

Na mão de obra para a execução da argamassa, a economia foi de $50 \%$ (...) pôde-se eliminar a etapas de recebimento dos insumos, estocagem e preparo da argamassa (...) A economia de mão-de-obra se deve à substituição de dois serventes por um operador de argamassadeira (Eliezer et alii, 2003: 10)

\section{Atividade 3 - Dosagem e mistura em argamassadeira}

Os aditivos incorporadores de ar que aumentam a plasticidade da argamassa industrializada exigem a exata energia de mistura proporcionada pelo eixo horizontal da argamassadeira, para que a pouca água adicionada fique retida nas microbolhas de ar. Tal energia é impossível de se obter pela mistura "virada em obra", por mais hábil que seja o manuseio da enxada.

A argamassadeira é o misturador mecânico próprio para a adição de água numa mistura de cimento, cal ou aditivo plastificante e agregados miúdos. A mistura se dá ao longo de um eixo tipo parafuso, que tem uma ação mecânica distinta em relação à mistura "por queda", da conhecida família de misturados de concreto, as betoneiras. Nestas, a inclusão de agregados graúdos demanda um tambor relativamente grande, em cujas paredes internas a massa de cimento e areia não adere pela ação gravitacional das próprias pedras britadas [19].

Uma mistura de aglomerantes e agregados em que não há elementos maiores do que grãos de areia demanda uma máquina de menor porte, com pouco mais que um cocho e um tubo alinhado ao motor, caso em que se dispensa até mesmo uma correia de transmissão. A motorização é mais leve e permite combinar num pequeno chassi com rodas um conjunto de bomba e dosador de água. O porte do equipamento resulta adequado não apenas à fluidez da argamassa, mas também da frente de trabalho típica da argamassa de revestimento, que é fragmentada e está em permanente deslocamento. À medida que esta frente se move, a máquina se mantém próxima aos pedreiros e elimina a necessidade de serventes no último estágio de preparo da argamassa, que é a mistura com água e o transporte para os caixotes de cada oficial [20].

De um ponto de vista reverso, a mistura mecanizada com água, que produz a "argamassa úmida", pressupõe a mistura mecanizada de aglomerantes, agregados e plastificantes numa unidade de pré-fabricação, que produz a argamassa seca dosada e ensacada em usina. A mistura por eixo contínuo admite

19 “O ideal é que o preparo da argamassa seja feito com equipamento específico e melhor adaptado para a produção da argamassa. Os fabricantes de argamassadeiras indicam seu uso preferencialmente para argamassas industrializadas" (Regattiere \& Silva, 2001: 9). "Pouco adianta a empresa optar pelo emprego de argamassas ensacadas quando não investe na aquisição ou locação de uma argamassadeira de eixo horizontal, adequada à produção desse tipo de material (...) o que se paga a mais por um material industrializado acaba não retornando" (Barros, 1998: 39).

20 É comum locadores de equipamentos para construção civil anunciarem, como o faz o material publicitário de uma grande empresa de São Paulo, que a argamassadeira "proporciona economia por permitir o trabalho conjunto de até 5 pedreiros, que preparam a sua própria argamassa dispensando a presença do servente" (D-Tec Locações). 
apenas acréscimo de água. Não é possível adicionar em separado cimento, cal e areia e o pequeno porte da argamassadeira é incompatível com os volumes medidos em carrinhos e "virados em obra" com enxadas. Ainda assim, a capacidade produtiva da versão mais comum, em torno de 40 litros de argamassa por minuto, é inatingível para a produção manual.

Um passo mais agressivo na eliminação das atividades de preparação manual é justamente fazer uso da capacidade produtiva da argamassadeira e, ao invés de multiplicá-la pelo canteiro de obras, fixá-la numa “central de produção de argamassa", no ponto inicial de um sistema de transporte por bomba de via úmida. A granulometria fina simplifica o bombeamento e as frentes de obra podem ser alimentadas onde quer que se possa posicionar o extremo final das mangueiras de borracha.

Neste último passo, a argamassadeira pressupõe não apenas a mistura seca industrializada, mas sua estocagem em silos, de onde pode ser alimentada ininterruptamente por acoplagem direta na válvula de fecho.

\section{Atividade 4 - Lançamento por projetora de ar comprimido.}

Mecanizadas todas as etapas de preparação, resta ainda a etapa de lançamento da argamassa de revestimento. Esta é a etapa de máxima especialização da manufatura, exercida unicamente por oficiais pedreiros sobre os quais os estudos ergonômicos da engenharia civil já têm um julgamento preciso:

Nós fizemos um estudo da força com que o operário projeta a argamassa e descobrimos que, com a mesma pessoa, a energia variava $75 \%$. Até nas situações ergonomicamente favoráveis, a resistência de aderência pode ser menor, porque a energia do lançamento é menor. Até se o operário joga com a mesma força mais ou menos argamassa faz diferença (Faria, 2013: 24-5).

A variabilidade da energia humana adquire um viés tão negativo para a Gestão de Produção que, mesmo nas melhores condições para o corpo do operário atuar, isto é, "nas situações ergonomicamente favoráveis", o resultado final pode ser pior do ponto de vista da adesão da massa à alvenaria. Assim, para tornar invariável "a força com que o operário projeta a argamassa" o caminho efetivo é substituir o operário por uma máquina que seja "projetora de argamassa", de forma que a energia de lançamento se desvincule de uma energia que pertença ao corpo do trabalhador. Desincorporada da força de trabalho, esta energia se originará de uma fonte mecânica: o compressor de ar.

O compressor de ar, com motorização elétrica ou a óleo diesel, é uma máquina familiar na construção civil. Em versão mínima, em que pode ser até mesmo carregada pelo trabalhador por cintas, é usado em associação com pistolas de pintura ou grampeadores para drywall. Na maior versão, montado em chassis com rodas e engate ou mesmo em containers estacionários, é usado em associação a rompedores pneumáticos, dos quais as "britadeiras" são o exemplo mais conspícuo.

O fator mecânico decisivo nesta transição de tamanho é a vazão de ar, medida no mercado norte-americano e brasileiro em polegadas cúbicas por minuto (pcm). A densidade e viscosidade da argamassa de revestimento exigem vazão de ar 
regulada num valor entre 300 e 400 pcm. A força de lançamento se estabiliza acima de $10 \mathrm{Kgf} / \mathrm{cm}^{2}$, três vezes maior que a mais oscilante força humana. Tal vazão de ar permite o lançamento de $1 \mathrm{~m}^{3}$ de argamassa em uma hora de utilização de compressor de ar, volume que uma equipe de pedreiro e ajudante dificilmente alcança em um dia de trabalho.

Ainda assim, esta é uma consideração de produtividade empobrecida, pois faz uma relação apenas entre insumo e máquina. Ao se considerar a produtividade como uma relação entre uma variável de tempo do trabalhador por uma unidade de produto acabado (que a técnica de orçamentação da construção civil convencionou ser hora-homem de trabalho por área de parede revestida, ou simplesmente "Hh/ $\mathrm{m}^{2 \prime}$ ), fatores externos, ligados às condições de operação do canteiro de obra, afetam a precisão das informações mecânicas.

Assim, distâncias entre produção e lançamento de argamassa, quantidade de frentes de obra simultâneas ou mesmo condições das instalações elétricas no canteiro de obras se tornam condicionantes da eficiência da projetora de argamassa. No entanto, é certo que em nenhuma destas condições voltará a existir tanto o oficial pedreiro, substituído em definitivo por um meio oficial para executar o "corte da massa", isto é, a retirada de excesso e nivelamento com régua de alumínio da argamassa lançada na parede. A própria granulometria da argamassa projetada torna desnecessário o uso de desempenadeira de madeira e espuma [21].

\section{I-3|Disputa entre pedreiros de argamassa de revestimento}
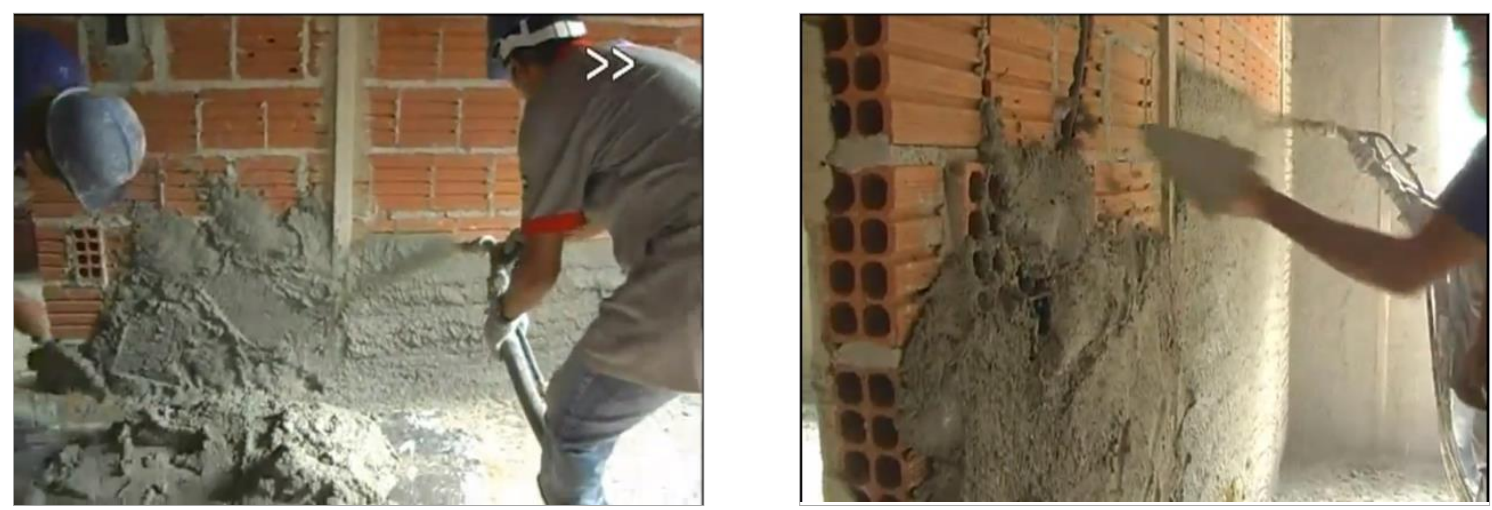

Imagens do programa de TV “Construção Dinâmica". A mestra de nivelamento que separa o pedreiro do operador de projetora deixa o dobro de área para o lançamento a ar comprimido

A máquina projetora ela mesma necessita apenas de um operador que desloque a ponta da lança de projeção enquanto mantém o gatilho da mangueira de ar comprimido travada. Seu treinamento pode ser feito no mesmo dia em que inicia o trabalho [22].

21 Pelo menos uma fabricante que atua no Brasil, a Menegotti Máquinas para Construção, oferece a locação de maquinário com o fornecimento de argamassa industrializada e o serviço de aplicação incluso em contrato. Para tanto, a Menegotti cobra o mesmo que a obra oferece para a subempreiteira de revestimento e se apropria do ganho de produtividade do equipamento que fabrica.

22 Segundo o material publicitário de uma das principais fabricantes nacionais de projetoras de argamassa, “deve-se levar em conta que a BullX JET melhora o nível de qualidade dos profissionais envolvidos. Como ela não precisa de nenhum tipo de especialização, qualquer operário, mesmo em início de carreira, onde supõe-se que seu 
Como final das etapas de recepção, estocagem, mistura e transporte, a mecanização do lançamento da argamassa de revestimento implica em mecanização equivalente proporcionada pelo caminhão graneleiro, o silo mecanizado e a argamassadeira. A projetora é apenas um dos extremos de um conjunto todo ele unido por bombeamentos de via seca e via úmida

Antes de seguir em sua análise, é útil considerar uma variante da projetora de ar comprimido cujo propósito visa justamente quebrar este vínculo entre máquinas. Esta variante é conhecida em São Paulo como "canequinha", pois a mangueira de ar comprimido possui em sua ponta final uma pistola alimentada não por uma mangueira de bombeamento de argamassa, mas sim um "receptáculo de acoplagem" em aço inox. Este receptáculo é chamado pelo diminutivo "canequinha" apesar de dimensionado para acumular até 1,5 litro de argamassa, volume máximo que um operador pode manter estável enquanto aperta o gatilho de projeção. A cada projeção, é preciso recolher material em caixotes que, estes, podem ser abastecidos por argamassa convencional, virada em obra. A acoplagem de uma "canequinha" na ponta de um compressor de ar significa uma acoplagem igualmente monstruosa da mecanização da projeção com as etapas de preparação de argamassa por manufatura.

\section{I-4 | Projetoras de argamassa tipo “canequinha”}
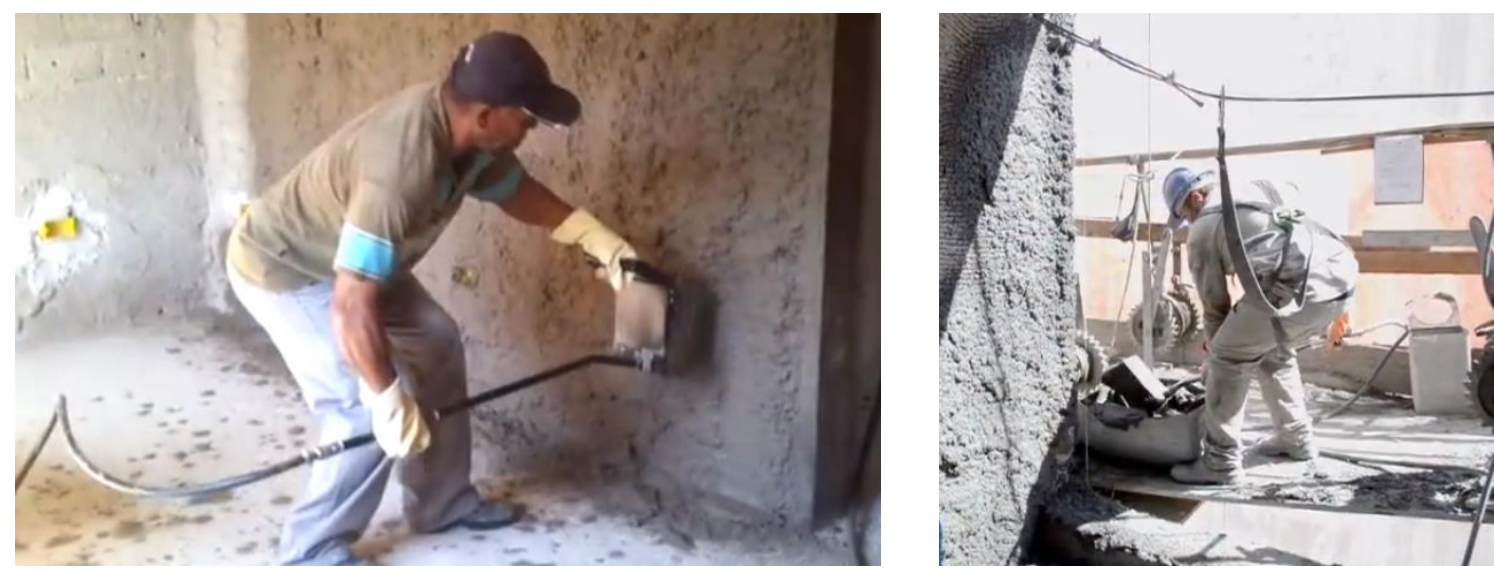

Fonte: imagens de vídeo publicados nos sites dos fabricantes Elthor (esquerda) e Anvi (direita), esta última mostrando o penoso carregamento do receptáculo acoplado num caixote de argamassa.

Apesar de seu hibridismo, a projetora "canequinha" ainda posiciona uma máquina como órgão central da produção de revestimento de panos de alvenaria. Ela substitui o pedreiro de revestimento por um operador de máquina, mas este necessita dos mesmos ajudantes para produzir manualmente a argamassa de revestimento e dos serventes para levá-la até as masseiras e caixotes. Há uma destruição da manufatura, mas na forma incongruente da eliminação apenas de seu trabalhador mais qualificado, o oficial pedreiro [23].

Tal destruição, no entanto, implica na subutilização da compressora de ar, uma vez que sua potência é regulada pelas características materiais da argamassa. Por

rendimento seja inferior aos demais, terá qualidade e versatilidade superiores a qualquer outro operário, já que sua utilização nivela os operários para cima com relação à qualidade dos serviços prestados. Isto traz enorme benefício e economia para o contratante".

23 Assim, os operadores de projetoras "canequinha" preservam o uso da colher de pedreiro, mas apenas como ferramenta de limpeza dos caixotes de argamassa. 
ser uma "projetora descontínua" e exigir pausas frequentes para o operador recolher argamassa em caixotes, a projetora "canequinha" opera abaixo da produtividade potencial da fonte de energia, mas acima da produtividade real de um oficial pedreiro. Sua ociosidade aumenta a cada vez que o ritmo humano de ajudantes e serventes deixar de produzir e transportar argamassa no volume e velocidade que a máquina demanda.

A projetora "canequinha" é, portanto, uma contraprova de que o tipo ideal da industrialização da argamassa não é uma projetora isolada, mas sua integração a um sistema de máquinas. Ao recusar em bloco todos os equipamentos e o próprio insumo transportado por bombeamento, este híbrido entre manufatura e indústria afirma mais do que nega a interdependência destas máquinas. Numa reportagem sobre industrialização da argamassa, a revista Téchne reproduz a declaração de um engenheiro de obras de que "várias empresas de São Paulo usam sistema de canequinha porque não querem comprar a argamassa industrializada exigida para a aplicação via bomba". Esta declaração é comentada da seguinte forma:

Para especialistas, a evolução do mercado é a completa adesão das construtoras ao bombeamento, que representa a industrialização total dessa etapa construtiva (...) é justamente a necessidade de utilização de produtos específicos que torna o método mais eficiente, já que as massas industrializadas facilitam os procedimentos de bombeamento e projeção (Cichinelli, 2010b: 42).

Falta acrescentar que a argamassa industrializada, de forma reversa, dificulta o trabalho tradicional do pedreiro. A dosagem industrial utiliza controle granulométrico mais fino, além de acrescentar de fábrica aditivos plastificantes e, não raro, retardadores de pega. É uma composição que, em estado seco, favorece o transporte por ar comprimido e, em estado úmido, o bombeamento mecânico, mas que provoca pouca aderência nas ferramentas manuais e dificulta recolher e acumular a massa na colher de pedreiro.

A argamassa virada em obra, dosada na exata consistência para se acumular na colher de pedreiro, está adaptada ao corpo humano e é uma referência fundamental para balancear os movimentos do braço e do tronco durante o lançamento manual. A argamassa industrializada está adaptada não apenas ao bombeamento, mas ao conjunto de máquinas unidas pelos mangotes. A industrialização do insumo não pode, assim, ser isolada da dissolução da manufatura no canteiro de obras, pois impõe retroativamente que o processo de trabalho se articule pela projeção, bombeamento, mistura mecânica, estocagem em silo e recebimento por caminhão graneleiro. Os pontos de articulação do sistema de máquinas parecem preservar uma organização interna da cooperação entre trabalhadores da manufatura, mas a suspensão da habilidade humana altera a sua organização para necessidades unicamente do capital [24].

Não foi diferente o que Marx observou na industrialização da lã na Inglaterra do século XIX, quando se organizou através de "uma cadeia de máquinas-ferramentas diversificadas, porém mutuamente complementares":

24 A distinção entre necessidades do trabalho e do capital em cada divisão técnica e social do trabalho em canteiros de obras é uma advertência frequente de Reginaldo Ronconi (Ronconi, 1995). 
Em geral, a própria manufatura fornece ao sistema da maquinaria, nos ramos em que este é primeiramente introduzido, a base natural-espontânea da divisão e, por conseguinte, da organização do processo de produção. Aqui se introduz, no entanto, uma diferença essencial. Na manufatura, os trabalhadores, individualmente ou em grupos, têm de executar cada processo parcial específico com sua ferramenta manual. Se o trabalhador é adaptado ao processo, este último também foi previamente adaptado ao trabalhador. Esse princípio subjetivo da divisão deixa de existir na produção mecanizada. O processo total é aqui considerado objetivamente, por si mesmo, e analisado em suas fases constitutivas. O problema de executar e de combinar os diversos processos parciais é solucionado mediante a aplicação técnica da mecânica, da química etc. (Marx, 2013 [1867]: 453).

Se a manufatura indica o caminho da industrialização, os remansos em que se aglutinavam os ofícios e as especialidades, isto é, a divisão de trabalho formada pela habilidade humana, se transformam em pontos de passagem de um sistema de máquinas que tende a criar um único fluxo produtivo:

\begin{abstract}
A máquina de trabalho combinada num sistema articulado, que reúne tanto máquinas de trabalho individuais de vários tipos quanto diversos grupos dessas máquinas, é tanto mais perfeita quanto mais contínuo for seu processo total, quer dizer, quanto menos interrupções a matéria-prima sofrer ao passar de sua primeira à sua última fase e, portanto, quanto mais essa passagem de uma fase a outra for efetuada não pela mão humana, mas pela própria maquinaria. Se na manufatura o isolamento dos processos particulares é um princípio dado pela própria divisão de trabalho, na fábrica predomina, ao contrário, a continuidade dos processos particulares. (Marx, 2013 [1867]: 454).
\end{abstract}

A percepção de Sérgio Ferro de que a industrialização no canteiro de obras é um fenômeno marginal só pode perdurar quando tal "continuidade dos processos particulares" é desconsiderada da análise. Cabe agora perceber que a verdadeira tecnologia que converte o processo de trabalho da argamassa de revestimento num sistema de máquinas é uma tecnologia de natureza organizacional, concebida em função do domínio não de forças ou matérias físicas, mas sim do trabalho humano.

\title{
A organização do trabalho como máquina motriz
}

Não são as máquinas que cancelam a fragmentação do trabalho manufatureiro, mas sim a organização da produção em torno delas. Uma resistência a esta organização vem tanto de práticas da força de trabalho, quando esta opera sob a forma particular da subempreitada no Brasil, quanto da própria expectativa de um contratante fundamental para a habitação social: a Caixa Econômica Federal (CEF), banco público que é o agente financeiro do programa MCMV.

Com preços atualizados mensalmente para as capitais brasileiras, o Sistema Nacional de Pesquisa de Custos e Índices da Construção Civil (Sinapi) é um banco de dados de insumos da construção habitacional cujo "base de engenharia" - especificação de insumos, composição de serviços e projetos de referência - é elaborada pela CEF. Segundo a Lei de Diretrizes Orçamentárias, o Sinapi é "referência de razoabilidade de preços de obras públicas executadas com recursos federais" e, nesta condição, fornece a base técnica de orçamento para edificação de todos os empreendimentos do MCMV. 
No Sinapi há dois insumos referentes a "argamassa pronta", para revestimento interno e externo (códigos "374" e "375"), mas nenhuma composição de preço inclui a argamassa industrializada como insumo com preparo mecanizado. A tabela pública considera apenas que cada $\mathrm{m}^{2}$ de parede revestida consome meia hora de pedreiro e meia hora de servente, algo semelhante à produtividade esperada nas subcontratações: um dia de 8 horas trabalhadas de pedreiro e servente reveste uma parede externa de 3 metros de altura (um pavimento) por 5 metros lineares, que é a largura do balancim [25].

O processo industrial como serviço associado à argamassa se dá apenas na distinção entre "preparo mecânico" e "preparo manual" no processamento dos insumos isolados da argamassa: cimento, cal e areia, além de pedreiro e servente de obra, os insumos de trabalho vivo. O resultado é um jogo de sucessivas composições de preços que se torna comparável no caso da massa única de revestimento (o "emboço paulista"). Quando especificado com espessura média mínima de 1,5 cm, o "emboço paulista" aparece no Sinapi tanto com "preparo mecânico" (composição “5982") quanto com "preparo manual” (composição “73927/8") [26].

A tabela T-1 abre a composição manual e dá destaque para o tempo de trabalho de servente alocado exclusivamente para a preparo de monocapa em volume suficiente para revestir com argamassa de espessura média de 1,5 cm uma área de $1 \mathrm{~m}^{2}$ de parede, calculado a partir das 10 horas estipulada pela CEF para o lançamento de $1 \mathrm{~m}^{3}$ de argamassa de revestimento.

$\mathrm{T}-1 \mid$ Sinapi - Custo do $\mathrm{m}^{2}$ de massa única com preparo manual

\begin{tabular}{l|l|l|l|l|l} 
Código & Item & Unidade & Quant. & R\$/unid. & R\$/item \\
\hline 4750 & Pedreiro & Hora & 0,5 & $\mathrm{R} \$ 12,88$ & $\mathrm{R} \$ 6,44$ \\
\hline 6111 & Servente [para lançamento] & Hora & 0,5 & $\mathrm{R} \$ 10,58$ & $\mathrm{R} \$ 5,29$ \\
\hline 1379 & Cimento CPII-32 & $\mathrm{Kg}$ & 2,73 & $\mathrm{R} \$ 0,43$ & $\mathrm{R} \$ 1,17$ \\
\hline 1106 & Cal hidratada 1a qualidade & $\mathrm{Kg}$ & 2,73 & $\mathrm{R} \$ 0,41$ & $\mathrm{R} \$ 1,12$ \\
\hline 370 & Areia média - sem frete & $\mathrm{m}^{3}$ & 0,0183 & $\mathrm{R} \$ 53,00$ & $\mathrm{R} \$ 0,97$ \\
\hline 6111 & Servente [para preparo] & Hora & 0,15 & $\mathrm{R} \$ 10,58$ & $\mathrm{R} \$ 1,59$ \\
\hline $73927 / 8$ & Composição final: massa única traço 1:2:8, esp. 1,5 cm - preparo manual & $\mathbf{R \$ ~ 1 6 , 5 8}$
\end{tabular}

Fonte: Sinapi - Valores referentes ao Estado de São Paulo em julho de 2013.

A composição de custo com "preparo mecânico", apresentada na tabela T-2, mostra a substituição do preparo manual por uma combinação entre servente e

25 Os estudos de caso de Sandra Paravisi confirmam em detalhe esta produtividade média da aplicação manual da argamassa de revestimento (Paravisi, 2008:130 - Tabela 21).

26 A composição é montada com a mesma quantidade de cimento e cal para a produção da argamassa, o que é incompatível com o traço do "emboço paulista". Mesmo assim, a quantificação de areia contém o preciosismo de indicar uma redução de volume entre a massa seca e a massa úmida, pela qual a adição de água compacta 1,26 $\mathrm{m}^{3}$ de agregado em de $1 \mathrm{~m}^{3}$ de argamassa. Este efeito de redução de volume é minimizado na argamassa industrializada. 
betoneira, um procedimento que serve apenas como técnica de orçamentação e não como técnica de construção [27].

\begin{tabular}{|c|c|c|c|c|c|}
\hline Código & Item & Unidade & Quant. & R\$/unid. & $\mathrm{R} \$ \mathbf{\text { item }}$ \\
\hline 4750 & Pedreiro & Hora & 0,5 & $R \$ 12,88$ & $R \$ 6,44$ \\
\hline 6111 & Servente [para lançamento] & Hora & 0,5 & $R \$ 10,58$ & $R \$ 5,29$ \\
\hline 1379 & Cimento CPII-32 & $\mathrm{Kg}$ & 2,73 & $R \$ 0,43$ & $R \$ 1,17$ \\
\hline 1106 & Cal hidratada 1a qualidade & Kg & 2,73 & $R \$ 0,41$ & $R \$ 1,12$ \\
\hline 370 & Areia média - sem frete & $m^{3}$ & 0,0183 & $R \$ 53,00$ & $R \$ 0,97$ \\
\hline 6111 & Servente [para preparo] & Hora & 0,09 & $R \$ 10,58$ & $R \$ 0,95$ \\
\hline 10532 & Betoneira 320 litros $3 \mathrm{HP}$ & Hora & 0,01071 & $R \$ 0,99$ & $R \$ 0,01$ \\
\hline 5982 & \multicolumn{4}{|c|}{ Composição final: massa única traço 1:2:8, esp. $1,5 \mathrm{~cm}$ - preparo mecânico } & $R \$ 15,95$ \\
\hline
\end{tabular}

Fonte: elaboração própria a partir da tabela Sinapi com valores para o Estado de São Paulo em julho de 2013. Em destaque, os itens que diferenciam a composição mecanizada e manual.

Assumindo a abstração de medir processos de trabalho para a produção de um único $\mathrm{m}^{2}$ de revestimento, a tabela Sinapi indica que gotejar apenas 1 centavo de custo de betoneira (equivalente ao aluguel do equipamento por um centésimo de hora) sobre o trabalho do servente, reduz o seu custo em salários e encargos de $R \$ 1,59$ para $R \$ 0,95$, como se pode ver pela comparação das linhas em destaque nas tabelas T-1 e T-2. No entanto, tal diferença é pequena porque o grosso do custo se mantém inalterado, quer o preparo da argamassa seja mecânico ou manual, pois é dado pelo valor de $\mathrm{R} \$ 11,73$ formado pela soma de custo de pedreiro e servente para lançamento [28].

Um orçamento que pode ser consultado como parte de uma pesquisa acadêmica é o do engenheiro Flávio Lindner de Oliveira, que calculou em 2006 os custos da adoção da argamassa industrializada num empreendimento em São Paulo, ponderando a mecanização do preparo, do transporte e do lançamento mecânico. O resultado final (Lindner de Oliveira, 2006), apesar de se basear numa adoção ainda incompleta do lançamento por projeção, permitiu comparar manufatura e industrialização sobre a base analítica fornecida pelos estudos sobre argamassa de revestimento de Carlos Regattiere e Luciano Silva (Regattiere; Silva, 2003) [29].

A tabela T-3 indica o custo e a participação por $\mathrm{m}^{3}$ de argamassa de três macroitens: material e equipamentos, mão-de-obra para preparo e mão-de-obra para lançamento da argamassa de revestimento. Todos os valores são referentes a cotações de preço de 2006 na cidade de São Paulo e, no caso de remuneração de mão-de-obra, somam salário e encargos sociais.

27 Um estudo técnico baseado em estudo de caso realizado pelo engenheiro Júlio Shimizu deixa evidente a ineficiência da betoneira para preparo de argamassas (Shimizu, 2002).

28 A diferenciação entre o ajudante de profissional e o servente geral será retomada no capítulo 4.

29 Foram calculados espaços e ciclos para o transporte horizontal e vertical de todos os insumos para revestimento de uma área de $8 \mathrm{mil} \mathrm{m}^{2}$, com emboço de espessura média de $2 \mathrm{~cm}$. 
T-3 |Argamassa de revestimento - comparação de custos por $\mathbf{m}^{3}$

\begin{tabular}{l|c|c|c|c}
\multirow{2}{*}{} & Argamassa manufaturada & \multicolumn{2}{c}{ Argamassa industrializada } \\
\cline { 2 - 5 } & $\mathrm{R} \$$ & $\%$ & $\mathrm{R} \$$ & $\%$ \\
\hline Material e equipamentos & 148,18 & 38,84 & 211,25 & 58,52 \\
\hline Mão-de-obra para lançamento & 142,16 & 37,25 & 123,41 & 34,18 \\
\hline Mão-de-obra para preparo & 92,16 & 23,91 & 26,36 & 7,30 \\
\hline Total & $\mathbf{3 8 1 , 6 0}$ & $\mathbf{1 0 0 , 0 0}$ & $\mathbf{3 6 1 , 0 2}$ & $\mathbf{1 0 0 , 0 0}$
\end{tabular}

Adaptado de Lindner de Oliveira, 2006 - Tabela 8 e 9

O custo de material e equipamento aumenta com a adoção da argamassa industrializada de $\mathrm{R} \$ 148,18 / \mathrm{m}^{3}$ para $211,25 / \mathrm{m}^{3}$, um aumento que não é compensado pela diminuição de $\mathrm{R} \$ 142,16 / \mathrm{m}^{3}$ para $\mathrm{R} \$ 123,41 / \mathrm{m}^{3}$ no custo da mão-de-obra de lançamento da argamassa, em que pode ser isolada a substituição do pedreiro por um operador de projetora a ar comprimido. A alteração de custo mais expressiva, portanto, se dá na mão-de-obra para preparo da argamassa, que implica não só em operações de dosagem e mistura, realizadas pelo ajudante de pedreiro, como também em diversas movimentações de material e produtos no canteiro de obras, realizadas pelos serventes de obra. No estudo de caso, parte da argamassa ensacada foi transportada em carrinhos e guinchos para argamassadeiras distribuídas pela obra, o que se revelou mais eficiente que o transporte de massa fresca por giricas e elevadores.

Quanto à redução das atividades do ajudante de pedreiro, elas confirmam uma pesquisa de Gestão de Produção que "aponta uma redução no uso de ajudantes na execução de revestimentos com argamassa industrializada, ou seja, as obras que utilizaram essa argamassa apresentaram as menores demandas da relação de ajudantes por pedreiros" (Regattiere \& Silva, 2003: 13). A tabela T-4 indica quantos pedreiros oficiais são atendidos por um ajudante de acordo com a organização da produção da argamassa de revestimento. As duas últimas linhas da tabela mostram que, nos casos de completa mecanização de projeção e transporte, a argamassa industrializa necessita apenas do trabalho de oficiais para o "jateamento", convertidos agora em operadores de projetoras de argamassa.

T-4|Relação ajudante/oficial para argamassa de revestimento interno

\begin{tabular}{l|c|c} 
Organização do canteiro de obras & Ajudante & Oficial \\
\hline Produção tradicional em caixotes a partir de sacos de cimento e cal e areia & 1 & 1 \\
\hline Argamassa chegando em jericas pelo elevador & 1 & 2 \\
\hline Misturador de eixo horizontal ou vertical no andar; argamassa industrializada & 1 & 2 \\
\hline Argamassa chegando bombeada ou por gravidade em local distante da execução & 1 & 2,5 \\
\hline Argamassa chegando bombeada ou por gravidade em local próximo da execução & 1 & 3 \\
\hline Jateamento a partir de misturador carregado no andar & 0 & 3 \\
\hline Bombeamento e jateamento da argamassa sem carregamento intermediário & 0 & 4
\end{tabular}

Fonte: Souza, 2013: 84

No estudo de caso mais limitado de Lindner de Oliveira, a principal operação de preparo, que é a dosagem e mistura da argamassa, se reduziu em um terço com o uso de argamassadeiras, enquanto atividades como carregamento de elevador 
e peneiramento de areia se tornaram residuais na contagem de horas trabalhadas, como registrado na tabela $\mathrm{T}-5$ :

T-5|Argamassa de revestimento - comparação de tempo dos serventes

\begin{tabular}{l|c|c|c|c}
\multirow{2}{*}{ Atividades dos serventes } & Argamassa manufaturada & \multicolumn{2}{|c}{ Argamassa industrializada } \\
\cline { 2 - 5 } & Horas & $\%$ & Horas & $\%$ \\
\hline Dosagem e mistura & 978,57 & 49,63 & 327,71 & 47,61 \\
\hline Transporte horizontal & 526,87 & 26,72 & 222,16 & 32,27 \\
\hline Transporte vertical & 176,00 & 8,93 & 117,87 & 17,12 \\
\hline Peneiramento de areia & 152,45 & 7,73 & 7,71 & 1,12 \\
\hline Carregamento de elevador & 128,00 & 6,49 & 7,20 & 1,05 \\
\hline Limpeza de equipamentos & 10,00 & 0,51 & 5,71 & 0,83 \\
\hline Total & $\mathbf{1 . 9 7 1 , 8 9}$ & $\mathbf{1 0 0 , 0 0}$ & $\mathbf{1 . 2 8 3 , 5 3}$ & $\mathbf{1 0 0 , 0 0}$
\end{tabular}

Adaptado de Lindner de Oliveira, 2006

O Gráfico G-4 distribui o valor do orçamento por unidade de área e mostra o predomínio do custo de material e equipamentos no empreendimento estudado, isto é, o predomínio do que o volume 1 do Capital classifica como capital constante ou "trabalho morto". A pequena redução de custo final da argamassa industrializada se deve à redução em maior proporção do custo total de "mãode-obra", isto é, o "capital variável" ou "trabalho vivo". Assim, o menor custo global do serviço de argamassa de revestimento pelo uso de materiais e processos industrializados (de apenas 5,7\%) embute um balanceamento novo entre materiais, instrumentos e força de trabalho [30].

G-4|Argamassa de revestimento - comparação de custos por $\mathrm{m}^{2}$

- Argamassa industrializada

= Argamassa manufaturada

4,23

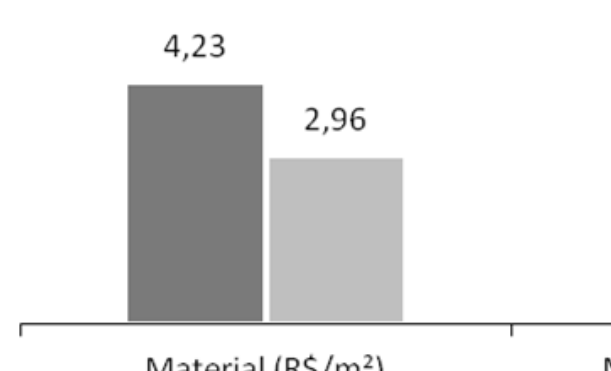

Material $\left(\mathrm{R} \$ / \mathrm{m}^{2}\right)$
4,67

3,00

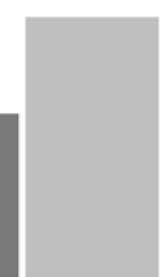

Mão-de-obra $\left(R \$ / m^{2}\right)$
7,63

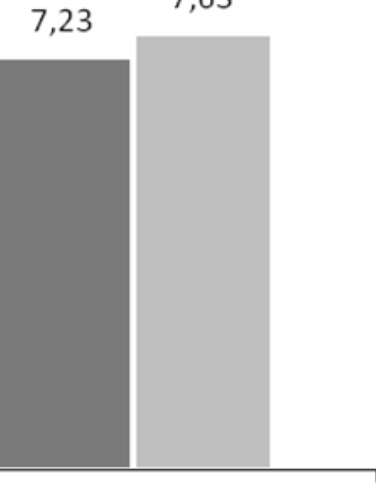

Custo Total $\left(\mathrm{R} \$ / \mathrm{m}^{2}\right)$

Adaptado de Lindner de Oliveira, 2006: 37

30 "Para a produção de mais-valor por meio da transformação do trabalho necessário em mais-trabalho, é absolutamente insuficiente que o capital se apodere do processo de trabalho tal como ele foi historicamente herdado ou tal como ele já existe, limitando-se a prolongar a sua duração. Para aumentar a produtividade do trabalho, reduzir o valor da força de trabalho por meio da elevação da força produtiva do trabalho e, assim, encurtar a parte da jornada de trabalho necessária para a reprodução desse valor, ele tem de revolucionar as condições técnicas e sociais do processo de trabalho" (Marx, 2013 [1867]: 389-390). 
Na nova combinação de tecnologia e valores, cada $\mathrm{R} \$ 1$ investido em material e equipamentos na execução da argamassa de revestimento necessitou de $R \$ 1,58$ para ser processado pela organização da manufatura. Pela organização com insumo industrial, o mesmo $\mathrm{R} \$ 1$ necessitou $\mathrm{R}$ \$ 0,71 em força de trabalho [31].

O estudo de Lindner de Oliveira conclui com uma pergunta pertinente e uma resposta ingênua:

Por que um sistema comprovadamente mais produtivo e de melhor qualidade como o sistema de revestimento com argamassa industrializada possui um pouco menos de $10 \%$ do mercado paulista? (...) A aversão a novas tecnologias, a lentidão dos processos de transformação e a falta de qualificação pessoal são os grandes vilões da indústria da construção no Brasil. A argamassa industrializada será unanimidade no futuro (Lindner de Oliveira, 2006: 40).

Falta um último cálculo para completar o entendimento da argamassa industrializada, que não diz respeito à produtividade nem à composição de custos, mas sim à sua capacidade de dominar o trabalho. Como forma de produção de origem pré-capitalista, a manufatura tende à autopreservação de métodos e hierarquias de trabalho. Seu conservadorismo aparece na forma de remuneração, pois, se o trabalho é do corpo e da habilidade do pedreiro, sua remuneração não pode prever uma alteração substancial de produtividade [32].

Marx reconhece que "na manufatura, o fornecimento de uma dada quantidade de produtos em dado tempo de trabalho torna-se uma lei técnica do próprio processo de produção". Trata-se de uma lei que admite algum desvio, uma vez que não tem domínio das "condições físicas e químicas gerais do processo de produção" (Marx, 2013 [1867]: 420), mas, por ser assentada na própria configuração do trabalho manual coletivo, seu sentido geral é inamovível:

O resultado do trabalho de um é o ponto de partida do trabalho de outro. Assim, um trabalhador ocupa diretamente o outro. O tempo de trabalho necessário para se obter o efeito útil visado em cada processo parcial é fixado conforme a experiência, e o mecanismo inteiro da manufatura repousa sobre o pressuposto de que em dado tempo de trabalho obtém-se um dado resultado (Marx, 2013 [1867]: 419).

O desafio de industrializar a argamassa de revestimento, uma atividade que está no centro da construção por manufatura, aparece por inteiro num debate promovido em fevereiro de 2013 pela editora Pini, que reuniu engenheiros e pesquisadores ligados ao mercado da argamassa industrializada (Giribola, 2013). Como nas demais transformações do capitalismo, as forças produtivas surgem antes que se implementem suas relações de produção. As inovações na fabricação

31 O valor levantado por Lindner de Oliveira relativo à argamassa manufaturada é pouco mais da metade do valor que consta das tabelas Sinapi de meados de 2006 para argamassa monocapa com $2 \mathrm{~cm}$ de espessura e preparo manual (a referência é a composição 73927/9 para "emboço paulista"). Esta discrepância é um indício que a tabela pública não só adota como premia o conservadorismo tecnológico na construção civil e torna economias da ordem de $6 \%$ irrelevantes. Apenas impedimentos ligados à forma de exploração da força de trabalho, que serão abordados no capítulo 4, dão o impulso para o abandono do processo manufatureiro em empreendimentos orçado pela tabela Sinapi.

32 Ou por outra, se a produtividade cai, é porque decai o próprio corpo do pedreiro, o que justifica uma designação popular em canteiro de obras para o trabalhador que envelhece: ele se torna "óleo queimado". A identificação do corpo a um insumo inutilizado do funcionamento do capital é um reconhecimento amargo de submissão do trabalho. 
e processamento mecânico da argamassa de revestimento se defrontam já prontas com a necessidade de alterar a mais conservadora forma de remuneração na construção habitacional: a da subempreitada. No debate, a insubmissão desta organização do trabalho está sintetizada numa fala de Mércia Bottura Barros, pesquisadora especializada em argamassa de revestimento:

Argamassa industrializada potencialmente dá maior produtividade. Só que a construtora contrata o serviço por metro quadrado de uma empresa terceirizada e, muitas vezes, essa subempreiteira não consegue perceber que pode ter ganhos com a argamassa industrializada (...) pode tirar um servente responsável por dosar a areia, por exemplo. Só que a terceirizada não está organizada e estruturada para perceber esses ganhos e oferecer desconto no preço do serviço (Giribola, 2013: 48).

O impedimento para a adoção da argamassa industrializada por parte de uma subempreiteira não é obviamente a possibilidade de "tirar um servente" ou outros ganhos em abandonar o processo de trabalho manufatureiro, mas sim que estas ações implicam em conceder um "desconto no preço do serviço". Como este desconto recai em última instância sobre o valor unitário que remunera a mãode-obra subcontratada, o gerente de produtos da Weber Saint-Gobain, Francisco Lessa, descreveu bem sua consequência:

O problema da projeção é que quando o empreiteiro implanta a mecanização ele acaba reduzindo o valor que ele paga por metro quadrado ao aplicador. O operário consegue fazer mais metros quadrados por dia, mas o valor pago por metro quadrado fica menor. Com isso, o aplicador não se sente motivado para usar a máquina. O benefício vai para a empresa empreiteira, não para o operário (Giribola, 2013: 48).

O gerente de negócios da Votorantim Cimentos, Eduardo Lamana, alega a única vantagem que é possível ofertar ao trabalhador: seu valor socialmente necessário, agora como operador de maquinário, pode ser maior que do operário manual especializado:

Ele diz ao aplicador: com a projeção, você vai ganhar menos por metro quadrado, mas em vez de fazer $30 \mathrm{~m}^{2}$, você vai fazer $90 \mathrm{~m}^{2}$ por dia. Então, o funcionário recebe mais dinheiro no fim da jornada de trabalho, mesmo ganhando menos por metro quadrado (Giribola, 2013: 49).

A racionalização industrial da argamassa de revestimento eleva a remuneração da força de trabalho numa medida abaixo da elevação de produtividade, cumprindo seu primeiro objetivo de alterar a proporcionalidade estrita entre trabalho e produção que é herdada da manufatura. Se o operador de projetora "recebe mais dinheiro no fim da jornada de trabalho", este dinheiro precisa corresponder ainda assim a um valor menor do que ele acresce ao processo produtivo. No final de contas, o gerente da Votorantim não poderia dar melhor explicação do conceito de mais-valor relativo, a forma final que assume a taxa de exploração do trabalho sob o processo industrial [33].

A introdução de maquinário na pequena empresa subempreitada para execução de argamassa de revestimento exige, portanto, o esforço da ideologia além da racionalidade do lucro. Ao comentar uma leva de contratações em São Paulo de

33 Esta tese adota a nova tradução do "Capital", de Rubens Enderle, que estabelece "mais-valor" como versão em Português de "Mehrwert", em substituição à inadequada erudição de "mais-valia". 
aplicadores de argamassa industrializada oriundos de Portugal e Espanha, Francisco Lessa diz:

Quando você faz a conta com o aplicador, no caso da Europa, ele mesmo já se prepara para ser mecanizado. Ele tem andaime, balancim específico, máquina, misturador. Está preparado para aquilo culturalmente. Já no Brasil, temos que fazer um trabalho com o aplicador para mudar a cultura dele (...) Tentamos conscientizar as empresas que vendem as máquinas de que o trabalho tem de ser feito a fundo com os aplicadores. Não adianta dizer quanto custa o equipamento sem dizer qual é o benefício que ele trará. Se o empreiteiro souber que pode triplicar a produtividade, se ensinarmos a fazer os cálculos, ele vai querer a máquina (Giribola, 2013: 49-50).

A discussão sobre a mecanização da argamassa de revestimento necessita da argumentação ideológica sobre remuneração porque, em última instância, é uma discussão a respeito do domínio do capital sobre o trabalho.

Uma vez convertido em operador de projetora, o pedreiro de revestimento não se torna ainda mais subalterno por aceitar um aumento de remuneração que é menor que o aumento da produtividade, mas sim por ceder sua autonomia como trabalhador da manufatura, o que inclui o regime de mando sobre seus ajudantes e a liberdade para controlar a velocidade e a qualidade de sua produção. Ao se inserir dentro de um fluxo de produção industrial, o trabalhador inicia uma dependência em relação às empresas que fornecem e fazem manutenção do sistema de máquinas, além das que fornecem o insumo industrializado segundo especificações de um projeto de revestimento detalhado para cada substrato. Seu campo de ação acaba dominado pelo planejamento de obra e pela alta produtividade das frentes de trabalho de argamassa industrializada, que se baseia no deslocamento acelerado de mangotes, argamassadeiras e projetoras de ar comprimido [34].

Um caso pontual pode ilustrar a resistência do pedreiro em "querer a máquina", levantado num estudo de campo em empreendimentos para baixa renda em Porto Alegre. Ao comparar a produtividade entre equipes de trabalhadores que lançavam argamassa de revestimento com equipamento mecânico e com ferramentas manuais sob organização de manufatura, a pesquisadora Sandra Paravisi observou que a maior resistência e a menor perda de material do lançamento mecanizado com bombas não se convertiam em aumento de produtividade em relação ao lançamento manual:

Os bons indices de produtividade do sistema manual são influenciados pela forma de remuneração dos operários, que recebem por produção. Além disso, os mesmos pareciam estar competindo com o outro sistema [mecanizado]. Por outro lado, a equipe do sistema mecanizado expressou preocupação com a grande produtividade que a mecanização

34 A incorporação do trabalhador a um sistema de máquinas está presente num depoimento do diretor da empresa Tecnisa, Fábio Villas Bôas, em que ele nega a desqualificação que esta incorporação possa causar ao trabalhador, pois "mão-de-obra ruim é quando, teoricamente, qualquer um faz". O depoimento explica esta opinião da seguinte forma: "A vantagem das soluções mais industrializadas, mais elaboradas, é que o próprio fornecedor da solução, obrigatoriamente, tem que treinar mão de obra para viabilizar seu sistema". O exemplo que Fábio Villas Bôas usa é análogo à situação da argamassa de revestimento: "Isso aconteceu com a parte de tubulações: com tubulação normal, qualquer um se dizia ser encanador, e tinha muita gente fazendo bobagem. Já com as soluções eletrossoldadas, se a pessoa não for treinada e não tiver equipamento, não faz" (Villas Bôas, 2011: 28). 
possibilitava. Os operários afirmaram que ficariam sem trabalho antecipadamente em função do uso da bomba de argamassa (Paravisi, 2008: 131).

No estudo de caso, as equipes de lançamento manual pressionaram os ajudantes na entrega da argamassa em caixotes e na montagem/desmontagem de andaimes para chegar na mesma produtividade que a hesitante equipe de operadores do sistema de argamassa industrializada. No entanto, este resultado visível não impediu que a construtora que promoveu a comparação fizesse a opção final pelo sistema mecanizado, pois o foco de sua observação não era o trabalhador, mas sim a máquina:

Apesar de não terem sido obtidos indices de produtividade superiores aos do sistema manual, havia maior potencial de melhoria. Enquanto o sistema manual trabalhava próximo ao seu potencial, no mecanizado havia maiores perdas de mão-de-obra e maior ociosidade dos equipamentos, os quais poderiam ser minimizados. Observou-se que, para isso, era necessário ter visão sistêmica e planejamento de produção, requisitos que muitas empresas não estão preparadas para atender" (Paravisi, 2008:166).

Frente à produção assentada numa associação de máquinas, o trabalhador coletivo da manufatura é comparado não a uma produtividade real, mas sim a uma produtividade potencial, que é técnica e cientificamente objetiva nos insumos e equipamentos industrializados mesmo quando não se realiza no canteiro de obras. Atingir a potencialidade desta produção, no entanto, só é possível quando tanto a subempreiteira quanto seu contratante transformam os processos de trabalho em função complementar ao sistema de máquinas. Retorna ao canteiro de obras, portanto, um desafio básico à gerência do capital, que é reorganizar o trabalho a partir dos instrumentos de produção, desafio descrito da seguinte forma por Marx:

Na manufatura e no artesanato, o trabalhador se serve da ferramenta; na fábrica, ele serve à máquina. Lá, o movimento do meio de trabalho parte dele; aqui, ao contrário, é ele quem tem de acompanhar o movimento. Na manufatura, os trabalhadores constituem membros de um mecanismo vivo. Na fábrica, tem-se um mecanismo morto, independente deles e ao qual são incorporados como apêndices vivos (Marx, 2013 [1867]: 494).

Assim, o mero acréscimo de maquinário sobre a mão-de-obra da manufatura é um indicador ilusório de industrialização da construção, pois a transformação do trabalhador manual em operador de uma máquina não é uma potência da própria máquina. Esta é uma tarefa de gestão e organização do trabalho a ser realizada, no capitalismo, pela gerência empresarial [35].

Se for preciso recuperar o tema marxista da "máquina-motriz", que seria uma pedra-de-toque de um processo industrial por unificar não apenas as máquinas entre si como também trabalho e gerenciamento, então nos empreendimentos do programa MCMV esta máquina é visível apenas como um terminal de computador, uma vez que ela se virtualiza em programas de informática que unificam, controlam e preveem todos os aspectos produtivos do canteiro de

35 Este é um raciocínio que Braverman realiza de forma memorável: "it's essential for the capitalist that the control over the labor process pass from the hands of the worker into his own. This transition presents itself in history as the progressive alienation of the process of production from the worker. To the capitalist, it presents itself as the problem of management" (Braverman, 1998 [1974]: 70). 
obras. São ferramentas de tecnologia de informação que atuam em rede e que afetam os processos de trabalho aqui estudados em pelo menos dois níveis.

O primeiro é permitir o processamento no escritório de obra ou mesmo em smartphones junto às frentes de trabalho de diversos programas de gerenciamento de obras, que unificam o controle de serviços com bases de orçamentação atualizadas pela internet. Existem com este propósito desde programas simples (pouco mais que algoritmos em planilhas eletrônicas) até dispendiosos bancos de dados de composição de preços (comercializados principalmente pelas empresas Pini Sistemas e Multiplus). Não é o caso de aprofundar a descrição deste conjunto de programas além do reconhecimento de que são instrumentos de controle de frentes de trabalho e fluxos de serviço cuja precisão e agilidade ultrapassam em muito o que é possível obter de ferramentas administrativas tradicionais, como os gráficos de barras "Gantt" ou os modelos de caminhos críticos Pert-CPM.

Um segundo nível de utilização da base de informática aprofunda a dominação sobre o canteiro de obras ao radicalizar o gerenciamento nas instâncias mais centrais da empresa construtora. $O$ instrumento essencial desta radicalização é a conexão eletrônica em rede. No empreendimento que foi objeto de sua pesquisa de doutorado, Lúcia Shimbo observou como este sistema de controle baseado na comunicação permanente e instantânea confere poder ao almoxarife, agora administrador de um apontamento on-line sobre trabalhadores e insumos de obra, e vincula cotidianamente o engenheiro de obras ao acompanhamento comercial e produtivo da gerência central da empresa construtora. Tal empoderamento eletrônico, paradoxalmente, apenas reforça a perda de autonomia do canteiro de obras como unidade de produção, pois a comunicação em rede "passou a interferir no diagrama de poder no canteiro ao comprimir o tempo de comunicação e de controle entre trabalhadores e empresa" (Shimbo, 2010: 331).

Quem controla as máquinas parciais através da máquina-motriz eletrônica é a gerência do capital e qualquer análise de um processo de trabalho que se mecaniza precisa convergir a observação para a tecnologia de gestão e organização. Esta é a nota final do debate realizado pela editora Pini sobre argamassa industrializada, na voz de Mércia Bottura Barros:

A projeção dá altíssima produtividade, mas se o resto não tiver equacionado com essa alta produção, a obra trava. Precisamos investir nas equipes especializadas de produção de fachada ou de revestimento interno. Temos que promover a especialização dessas empresas, não só do ponto de vista do saber fazer, mas também da organização da empresa para fazer (Giribola, 2013: 50) [36].

De fato, a mecanização do processo de trabalho unifica "fazer" e "saber fazer" como funções da gerência do capital e, neste sentido, a análise da argamassa de revestimento como tipo ideal traz esta pesquisa para o ponto principal: a tecnologia de gestão e organização do trabalho. Ela, mais que a mecanização, é o ponto sem retorno da industrialização dos canteiros de obras do programa MCMV. Seu ápice é o sistema de gestão de qualidade, tema principal da segunda

36 Esta é a mesma conclusão de artigo que sumariza a pesquisa de Sandra Paravisi: "Para utilizar as bombas de argamassa é fundamental projetar o sistema pensando no todo (...) As melhorias na produção de revestimentos de argamassa não devem se restringir à mecanização da etapa de aplicação. Devem vir acompanhadas de métodos organizacionais que considerem o sistema como um todo" (Paravisi; Masuero; Bonin; Isatto, 2009: 66). 
parte desta pesquisa, mas seu primeiro passo é exercer o maior dos controles sobre a força de trabalho, que é o controle sobre a sua própria formação e que é tema do próximo capítulo.

No entanto, antes de deixar o tópico da argamassa industrializada, reconheça-se também com Marx a dificuldade em criar um processo de trabalho industrial sobre uma base manufatureira:

O sistema mecanizado ergueu-se, portanto, de modo natural e espontâneo, sobre uma base material que lhe era inadequada. Ao atingir certo grau de desenvolvimento, ele teve de revolucionar essa base - encontrada já pronta e, depois, aperfeiçoada de acordo com sua antiga forma - e criar para si uma nova, apropriada a seu próprio modo de produção (Marx, 2013 [1867]: 456). 


\section{$3 \mid$ \\ A DESTREZA DO CAPITAL}

\section{A manufatura persistente}

Uma concepção comum a respeito do processo de trabalho na construção habitacional (particularmente entre arquitetos) é a que faz uma associação estrita entre o "saber-fazer" do trabalhador e a formação prática no canteiro de obras da manufatura. Nesta concepção, a qualificação profissional é fruto de uma experiência antes de tudo vital do trabalhador, sustentada por sua adesão por vínculos familiares ou de comunidade a uma formação da habilidade marcada por antigas identidades de corporação: "peão", "servente", "aprendiz", "ajudante", "meio-oficial", "oficial", "encarregado", "mestre" [37].

Este ponto de vista se torna problemático para os estudos de natureza acadêmica sobre a produção habitacional, onde aparece sob o tema de uma "persistência da manufatura" no conjunto das empresas construtoras. O raciocínio subjacente deste tema é que o emprego de trabalho qualificado no canteiro de obras é um indicador de que a manufatura resiste contra a racionalização da construção como parte inerente de seus processos produtivos.

É neste estágio que as pesquisas sobre a produção da habitação social em São Paulo foram deixadas pelo livro "Processo de trabalho na construção habitacional", de Marta Farah. Elaborado a partir de uma pesquisa de doutorado em sociologia, sua publicação em 1996 fecha o ciclo de estudos urbanos centrados nas relações de produção no canteiro de obras brasileiros que foi aberto vinte anos antes por "O canteiro e o desenho". Desde então, nenhuma pesquisa brasileira sobre o trabalho na construção habitacional ocupou seu papel de referência comum nas áreas da sociologia, arquitetura e engenharia civil.

A repercussão do livro, entretanto, é inversa à sua radicalidade. O subtítulo "Tradição e mudança", por exemplo, se refere a uma justaposição entre a tradição do trabalho na manufatura e a mudança introduzida pela racionalização industrial, justaposição em que nenhum polo domina o outro, antes se anulam ao longo de uma pesquisa extensa e pouco incisiva, como se percebe neste trecho do capítulo de conclusão:

Considerando-se as tendências recentes de mudança em seu conjunto, constata-se um movimento importante de separação entre concepção e execução e de desqualificação do trabalhador (...) No entanto, este movimento não chega a penetrar todo o processo

37 A mobilidade ao longo desta formação é controlada despoticamente por mestres e encarregados através da "classificação" do trabalhador no registro da Carteira de Trabalho, procedimento que envolve no particularismo da manufatura um documento que representa a universalização dos direitos trabalhistas. Ao apontar as retenções irregulares e os registros falsos e omissos, comuns na construção civil dos anos 1990, Alain Morice nota que "o formalismo favorece a informalidade. No caso brasileiro, a instituição da carteira profissional parece fornecer meios adicionais de introduzir uma alta flexibilidade na gestão do trabalho" (Morice, 1992: 40). 
produtivo, a ele se contrapondo uma tendência de preservação do saber operário e mesmo de requalificação do trabalhador (...) As iniciativas recentes que visam reinstaurar a competência do setor incluem, assim, medidas voltadas ao resgate da competência operária, o que denota a centralidade do saber operário e da formação no canteiro para a eficiência do processo produtivo na atividade de construção (Farah, 1996: 278).

Um dos pressupostos da pesquisa de Marta Farah é se distanciar de "um esquema marxista ortodoxo" (Farah, 1996: 38), esquema que teria o potencial de indicar uma contradição ao invés de simples oposição entre trabalho manufatureiro e capital industrial. Sob esta contradição, a funcionalidade que o "saber operário" pode ter para a eficiência do processo produtivo da construção não se estende para "a formação no canteiro" e, esquematicamente, se poderia dizer que o capital expropria o primeiro para eliminar o segundo [38].

Em comum nos vinte anos que separam a publicação de "O canteiro e o desenho" e "Processo de trabalho na construção habitacional" está a visão de que a centralidade da manufatura na construção habitacional é permanentemente constrangida pela economia industrial e pela presença incessante de insumos industrializados nos canteiros de obras. A forma de Marta Farah descrever este panorama produtivo, no entanto, tende a enfatizar mais o anacronismo da manufatura do que sua inserção funcional na construção habitacional, anacronismo que se torna um uso tolerado e conveniente da habilidade do trabalhador tradicional. Daí a consideração repetida de que a manufatura "permanece" e "persiste":

O exercício de boa parte das tarefas que permaneceram no canteiro, mesmo as associadas à absorção dos novos produtos, ainda supunha a preservação de habilidades $e$ conhecimentos tradicionais (...) persistiu no canteiro o saber de ofício, a habilidade tradicional articulando-se a um maior grau de prescrição para as tarefas simplificadas e parcelizadas (...) Persiste, nos ofícios transformados, a necessidade de domínio de um 'saber fazer' de base empírica, não sendo possível sua subordinação integral a uma prescrição padronizada" (Farah, 1996: 201-242).

Para Marta Farah, a industrialização não existe sem a incorporação da manufatura até mesmo nos canteiros de obras caracterizados pela montagem de componentes pré-fabricados.

A estratégia de deslocamento de uma fração das atividades constitutivas dos ofícios tradicionais para a indústria ou para centrais de produção localizadas a montante do canteiro e de substituição, no canteiro, dos oficiais por simples 'montadores' não chega a transformar o processo construtivo como um todo, não eliminando, tampouco, o 'saber fazer' tradicional do canteiro de obras. A própria articulação entre as inúmeras atividades $e$ as várias etapas que caracterizam o processo de construção ainda é em grande parte

38 Ao concluir sua pesquisa, Marta Farah acrescenta a esta tese um caráter transitório: "a consolidação desta tendência [o resgate da competência operária] e o próprio significado deste movimento constituem ainda um processo em aberto. Podem, de um lado, caracterizar um processo de cooptação do trabalho pelo capital numa conjuntura de crise. Podem, por outro lado, vir a se aprofundar como conquista de condições dignas de trabalho por parte dos trabalhadores e de afirmação de sua autonomia e de sua participação no controle do 'fazer'". Ainda que se aceite a ressalva, é preciso reconhecer que a segunda alternativa nunca esteve no horizonte de ação das construtoras brasileiras. É possível reconhecer aqui "a confusão entre dois tipos muito diferentes de propriedade privada, das quais uma se baseia no próprio trabalho do produtor e a outra, na exploração do trabalho alheio. Ela esquece que a última não só constitui a antítese direta da primeira, como cresce unicamente sobre seu túmulo" (Marx, 2013 [1867]: 835). 
dependente da experiência de mestres e encarregados, formados no próprio canteiro (Farah, 1996: 261).

Para Sérgio Ferro, a manufatura é mantida nos canteiros de obras por uma ação deliberada de gestores em aumentar a taxa de lucro ao diminuir o investimento de capital, comprimindo salários e imobilizando o mínimo de valor possível em ferramentas manuais e insumos básicos de construção. Para Marta Farah, a manufatura persiste apenas porque o capital não cria e, portanto, não substitui a habilidade da força de trabalho:

Embora haja conhecimentos científicos embutidos no projeto arquitetônico e nos projetos complementares (estrutura, fundações $e$ instalações) $e$ em alguns componentes industrializados, os trabalhadores intervém com sua experiência prática, de um lado, traduzindo e adaptando os projetos na fase de execução e, de outro, recorrendo a conhecimentos tradicionais na utilização e aplicação dos materiais e componentes. A apropriação do saber fazer pelo capital e seu desdobramento sob a forma de prescrição de modos operatórios é, na verdade, algo pouco desenvolvido na atividade de construção (Farah, 1996: 84).

Neste ponto, mais do que Sérgio Ferro, Marta Farah está em continuidade com as pesquisas de Nilton Vargas realizadas no fim dos anos 1970:

Não obstante a ciência se faça presente na atividade de projeto e os indícios de produtos industrializados marquem os meios de produção, o trabalho é ainda sedimentado sobre uma base estrutural da manufatura. A máquina ainda não incorporou a ferramenta do oficial de forma que se desvencilhe das barreiras orgânicas que o trabalho manual impõe. A maioria do equipamento utilizado (guindastes e gruas) substitui a força muscular do operário, mas não as suas habilidades (Vargas, 1983: 199).

O panorama retratado em "Processo de trabalho na construção habitacional" é a economia brasileira em recessão na passagem das décadas de 1980 e 1990, que no subsetor habitacional da construção civil foi potencializada pela extinção do Banco Nacional de Habitação (BNH) em 1986. Nestas condições, a interrupção de investimentos em usinas de pré-fabricação e em maquinário para transporte e processamento em obra dos insumos industrializado deixava visível justamente práticas produtivas da manufatura.

Assim, a observação de uma construção habitacional em crise cria um segundo grau para a identificação entre habilidade e manufatura, no qual processos produtivos industriais se identificam unicamente com pré-fabricação e maquinário. O que não corresponder a uma operação mecanizada em usina ou canteiro de obras é operação de manufatura, raciocínio que impede Marta Farah, tal como Sérgio Ferro, de reconhecer os processos de racionalização produtiva como processos industriais que alteram a construção unicamente a partir de uma tecnologia gerencial.

Este reconhecimento é essencial para considerar o trabalho submetido à racionalização como uma recriação do capital, pois a habilidade do trabalhador deixa de ser formada entre trabalhadores e passa a ser função de um treinamento implementado por profissionais especializados, direta ou indiretamente ligados à gerência de obras das empresas construtoras.

Novamente, a argumentação desta pesquisa por um novo ponto de vista sobre a habilidade na construção habitacional é a reconstituição de um processo de 
trabalho na forma de um tipo ideal. Desta vez trata-se de um processo de trabalho ligado à tecnologia construtiva dominante nos empreendimentos para baixa renda no programa MCMV: a alvenaria estrutural.

\section{A alvenaria estrutural}

A alvenaria armada com blocos autoportantes - a alvenaria estrutural - começa a se tornar a tecnologia construtiva dominante na habitação social brasileira nos anos finais dos financiamentos para baixa renda operados pelo extinto Banco Nacional da Habitação (BNH). Em "Processo de trabalho na construção habitacional", Marta Farah reconhece que esta tecnologia construtiva afeta a tradição da manufatura ao eliminar atividades de armação e carpintaria de fôrmas, mas acrescenta um equívoco:

Para o desenvolvimento das atividades que permaneceram, houve preservação do saber tradicional, ao qual se acrescentaram prescrições relativas à nova função a ser cumpridas pelas paredes - a função estrutural" (Farah, 1996: 195).

Para dois influentes autores brasileiros do campo de estudos de gestão da produção na engenharia civil, a avaliação é contrária. Segundo Ubiraci de Souza, "os blocos estruturais de concreto, com suas dimensões definidas, são um indutor de industrialização" (Rocha, 2011: 16), enquanto que, para Fernando Sabbatini, a alvenaria estrutural, longe de ser um foco de resistência da manufatura, é " $O$ caminho mais fácil para se ter domínio do processo de industrialização" (Sabbatini, 2008a:40).

Esta discrepância acontece porque, para a engenharia civil, uma análise de processos de trabalho na construção civil não reconhece no assentamento de blocos estruturais qualquer "preservação do saber tradicional", supostamente fornecido pelo pedreiro de alvenaria. Também do ponto de vista do trabalhador da construção civil, o novo profissional formado pela tecnologia da alvenaria estrutural - o "assentador de alvenaria estrutural", mais conhecido como "bloqueiro" - é um profissional notoriamente distinto em relação aos demais ofícios da construção, de imediato porque combina sua atividade com a instalação de tubos e eletrodutos embutidas nos blocos e o corte e colocação de armaduras, mesmo que simplificadas, em vergas, contravergas e respaldos [39].

Não é a combinação de diversos ofícios que situa o bloqueiro como trabalhador da indústria e não da manufatura, mas sim que esta combinação necessariamente esteja submetida a um controle especializado, o do projeto de produção de alvenaria estrutural, sem o qual o jogo entre pilaretes, cintas e respaldos em

39 A denominação "bloqueiro" é de uso corrente na construção civil, embora não corresponda a uma classificação formal para efeitos trabalhistas ou de estatísticas de emprego. Apesar de ser considerado como trabalhador "profissional", sua múltipla capacitação é avaliada negativamente tanto pelos ofícios tradicionais quanto pelo próprio bloqueiro, mesmo quando este diz exercer também a profissão de pedreiro ou ter formação como pedreiro. Uma razão para esta avaliação está ligada ao ambiente da autoconstrução, como me indicaram estas palavras de Valdeci Matos, o Lelê: "o bloqueiro faz obra de empreiteira, a casa da gente quem faz é o pedreiro". O bloqueiro, por ser portador de um treinamento inútil na periferia autoconstruída, é, do ponto de vista da manufatura, um profissional menor da construção. 
concreto grout armado não se coordena com aberturas, amarrações de parede e pontos de água e energia. $\mathrm{O}$ assentamento de cada bloco em cada pano de alvenaria está previsto em projeto conforme uma variação precisa de, no mínimo, três tipos de peças - bloco inteiro, canaleta e meio-bloco (chamado em canteiro pelo expressivo nome "bloco-cabeça") - facilmente multiplicada em peças mais especializados em forma e função: bloco compensador, de amarração, meia canaleta, hidráulico e bloco "jota" (ou "jotão"). Não há qualquer possibilidade de intervenção autônoma do trabalhador que altere o bloco específico a assentar em cada posição de cada fiada, a não ser para causar um erro cuja correção exige complexos retrabalhos para deslocar tubulações e refazer grouteamentos através de fôrmas-cachimbo.

Se uma transformação do ofício da manufatura como esta passa desapercebida, é natural que o segundo passo seja desconsiderar que a racionalização produtiva, por se basear eminentemente na imposição de projeto e planejamento ao canteiro de obras, é promotora de um processo construtivo industrial, uma vez que " $a$ alvenaria estrutural envolve uma racionalização do processo de construção tradicional, mas não implicando na mecanização das operações" (Farah, 1996: 194).

Se não implica em mecanização, Marta Farah segue a opinião corrente dos anos 1980 que a introdução da alvenaria estrutural não altera a composição orgânica do capital, categoria marxista por excelência para avaliar o grau de industrialização de uma atividade produtiva. Ao comentar a crise nos financiamentos do SFH e a interrupção da "construção de conjuntos" por parte do BNH nos anos 1980, ela acrescenta:

Neste novo contexto, as condições favoráveis à introdução de sistema industrializados no
canteiro deixaram de existir. Os sistemas estruturais baseados em fôrmas metálicas e no
uso de grandes elementos pré-moldados em usinas, que pressupunham investimentos
consideráveis em equipamentos, deixaram de ser utilizados à medida que deixou de haver
garantia de produção em escala e de continuidade das obras. Constitui exceção o sistema
de alvenaria estrutural, uma vez que este prescinde de grandes investimentos, mantendo
a composição orgânica do capital. Este sistema acabou por se difundir, ultrapassando os
limites definidos pela promoção estatal" (Farah, 1996: 200).

Esta avaliação reaparece na conclusão de "Processo de Trabalho na Construção Habitacional", que considera a "racionalização do processo de produção" promovida por algumas construtoras nos anos 1990 "uma estratégia que se orienta para o incremento da produtividade, a redução dos custos e a garantia da qualidade, sem alterações significativas da composição orgânica do capital" (Farah, 1996: 250).

A "composição orgânica do capital" é o tema com que Marx, ao final do primeiro volume do "Capital", inicia a exposição da "lei geral da acumulação capitalista", segundo a qual, "uma massa cada vez maior de meios de produção, graças ao progresso da produtividade do trabalho social, pode ser posta em movimento com um dispêndio progressivamente decrescente de força humana" (Marx, 2013 [1867]: 720). Trata-se de uma tese que vincula a expressão "acúmulo de capital" não a um processo histórico linear, em que o processo de valorização deposita sobre camadas mais antigas novos valores de uma mesma natureza, produzidos por uma exploração do trabalho que se expande mas não se modifica. A acumulação de capital é por essência "acumulação ampliada", em que o valor se converte em capital de forma exponencial e cada múltiplo multiplica a si mesmo. O resultado é uma aceleração 
do processo histórico, em que o capital regula não apenas sua base técnica como também as condições materiais e sociais que o sustentam, incluindo aí a própria população trabalhadora.

A acumulação de capital, portanto, é um fenômeno que se explica não pela expansão da produção, mas pela elevação da produtividade, isto é, pelo permanente aumento dos meios de produção (em matéria-prima e instrumentos de trabalho) que são transformados e utilizados pela força de trabalho:

O volume crescente dos meios de produção em comparação com a força de trabalho neles incorporada expressa a produtividade crescente do trabalho. O aumento desta última aparece, portanto, na diminuição da massa de trabalho proporcionalmente à massa de meios de produção que ela movimenta ou na diminuição do fator subjetivo do processo de trabalho em comparação com seus fatores objetivos. Essa alteração na composição técnica do capital, o aumento da massa dos meios de produção, comparada à massa da força de trabalho que a põe em atividade, reflete-se na composição de valor do capital, no aumento do componente constante do valor do capital à custa de seu componente variável (Marx, 2013 [1867]: 699)

Esta mútua determinação entre composição técnica e composição de valor do capital na determinação da produtividade de um setor econômico é a composição orgânica do capital [40]. A lei geral da acumulação capitalista simplesmente afirma que o capital se acumula alterando esta composição no sentido do aumento da produtividade, isto é, pelo dispêndio cada vez menor de força de trabalho no processamento de cada vez mais matéria-prima e instrumentos de trabalho.

Imaginar, como faz Marta Farah, que a passagem da alvenaria convencional para a alvenaria estrutural mantém a composição orgânica do capital conduz a atenção justamente para o aspecto conservador da manufatura na construção. Por ser uma forma de produção "cujos órgãos são seres humanos", o limite de energia e habilidade a que podem chegar estes órgãos condiciona a acumulação de capital pela expansão da produção, nunca da produtividade. Para obter mais produto, a empresa construtora manufatureira pode apenas empregar mais trabalhadores ou, como é mais comum, estender a sua jornada de trabalho (com serões ou viradas). Em termos propriamente de Marx, a manufatura opera pela extração de mais-valor absoluto ao invés do mais-valor relativo.

Entre o fim do BNH e o início do programa MCMV, o sistema construtivo predominante para empreendimentos habitacionais para baixa renda migrou da estrutura em sistema reticulado de viga e pilar em concreto armado moldado in situ - que o mercado da construção civil ainda nomeia como "estrutura convencional" - para a tecnologia construtiva com blocos autoportantes. As poucas exceções adotam a tecnologia, esta sim inovadora, da moldagem integral de parede e laje em concreto auto-adensável [41].

Em 2012, uma pesquisa de mercado comparou a tecnologia construtiva entre uma amostra de 36 empresas especializadas na produção de HIS e Habitação

40 "Chamo a composição de valor do capital, porquanto é determinada pela composição técnica do capital e reflete suas modificações, de composição orgânica do capital" (Marx, 2013 [1867]: 689).

41 O capítulo 4 aborda algumas implicações do concreto auto-adensável para o trabalho na construção. 
Econômica para o programa MCMV com informações cadastradas de 4.200 construtoras que atuam nos segmentos de médio e alto padrão em todo o país. $O$ resultado, reproduzido na Tabela T-6, mostra a preponderância da adoção da alvenaria estrutural pelas empresas atuantes no programa MCMV, proporção que difere das empresas que atuam fora do programa federal.

T-6|Tecnologia construtiva da estrutura por HIS e demais segmentos

\begin{tabular}{l|c|c} 
Tecnologia construtiva da estrutura & HIS e Hab. Econômica (\%) & Demais segmentos (\%) \\
\hline Alvenaria estrutural & 73,22 & 24,46 \\
\hline Parede de concreto & 20,30 & 2,67 \\
\hline Painel pré-fabricado & 4,08 & 2,16 \\
\hline Concreto armado & 2,37 & 69,12 \\
\hline Steel framing & 0,03 & 0,19 \\
\hline Estrutura metálica & 0,00 & 1,41
\end{tabular}

Fonte: Della Penna; Souza; Melo, 2012: 23

Diversas notícias da construção habitacional reforçam a proporção indicada pela pesquisa, como esta, relativa a uma construtora especializada em empreendimentos de padrão popular:

O diretor da construtora Carrara, Rodrigo de Castro Morais aposta cada vez mais no método construtivo da alvenaria estrutural (...) apenas seis empreendimentos seguem o sistema convencional, mas só porque já haviam sido planejados dessa maneira. Outras unidades em fase de projeto serão de alvenaria estrutural: "pelo rigor que é necessário ter e pelo número de fabricantes bem reduzido, considero a qualidade melhor. Não se compram os blocos em depósito de bairro, só direto na indústria", comenta (Aquino, 2011: B4).

É uma migração para um novo material, o bloco estrutural (que só pode ser adquirido "direto na indústria") e a um novo profissional - o bloqueiro responsável por seu assentamento. São portanto meios de produção e força de trabalho na composição da alvenaria estrutural inexistentes na alvenaria erguida por processo tradicional.

A adoção da alvenaria estrutural não demanda a alteração da maioria dos subsistemas da edificação com estrutura de concreto armado, como fundações (a carga estática não se altera substancialmente), revestimentos, coberturas, esquadrias etc. e contém ela mesma um volume semelhante de concreto armado em cintas e pilaretes. No entanto, estas são peças de concreto armado moldadas in loco que dispensam a complexa armação e carpintaria de fôrma para vigas e seus encontros e amarrações com pilares e são executadas por ajudantes de bloqueiros como serviços inclusos na contratação de alvenaria estrutural junto a subempreiteiras. Seria possível também incluir neste serviço parte considerável do trabalho das equipes de instalação elétrica e hidráulica na execução de ramais verticais de água, esgoto e eletrodutos [42].

42 "A alvenaria estrutural permite que diversas etapas da obra sejam feitas simultaneamente, além de dispensar as fôrmas, utilizar menos aço, acumular menos entulho e necessitar de menos mão-de-obra para a execução. $\mathrm{Na}$ estrutura reticulada em concreto armado, cada etapa, como a colocação dos blocos de vedação e a instalação da rede elétrica do empreendimento, depende da outra para começar a ser feita, o que aumenta o prazo de execução do serviço e, consequentemente, os gastos com a mão-de-obra" (Rocha, 2009: 4). 
Assim, uma comparação reduzida a valores unitários de material e mão-de-obra para alvenaria de vedação e alvenaria estrutural não esclarece a cadeia de efeitos mais amplos da adoção de uma ou outra tecnologia. Seria preciso realizar uma comparação entre orçamentos de edificação completos, em que um mesmo empreendimento é orçado em todos os serviços de construção variando apenas a alvenaria de vedação e a alvenaria estrutural. Tal comparação é que impulsiona as construtoras do segmento da habitação econômica a migrar entre sistemas construtivos, mas raramente é publicada com itens de serviço abertos de material e mão-de-obra que revelem as composições de valores de capital.

A tabela T-7 é uma exceção a esta regra, na forma de um orçamento de edificação publicado pela editora Pini para prédio residencial de 12 pavimentos servidos por elevadores e com área construída total de $4.660 \mathrm{~m}^{2}$. Os apartamentos têm 50 $\mathrm{m}^{2}$ e foram especificados para a faixa de renda familiar intermediária (Faixa 2) no programa MCMV.

\begin{tabular}{|c|c|c|c|c|c|}
\hline \multirow{2}{*}{ Descrição de serviço } & \multirow{2}{*}{ Un. } & \multirow{2}{*}{ Qt. } & \multicolumn{2}{|c|}{ Valor Unitário (R\$) } & \multirow{2}{*}{ Total (R\$) } \\
\hline & & & Material & M/Obra & \\
\hline Fôrma em chapa compensada resinada $12 \mathrm{~mm}$ & $\mathrm{~m}^{2}$ & 6.864 & 22,48 & 9,43 & 219.030 \\
\hline Cimbramento tubular desmontável - locação mensal & $\mathrm{m}^{3}$ & 287 & 12,90 & 22,45 & 10.145 \\
\hline Armadura em vergalhões de aço & $\mathrm{kg}$ & 93.392 & 5,63 & 1,05 & 623.859 \\
\hline Concreto usinado com lançamento e adensamento & $\mathrm{m}^{3}$ & 711 & 255,29 & 76,71 & 236.052 \\
\hline Verga $10 \times 15 \mathrm{~cm}$ em concreto armado & $\mathrm{m}^{3}$ & 12 & 812,20 & 451,02 & 15.159 \\
\hline \multicolumn{3}{|l|}{ Subtotal dos serviços de concreto armado } & 875.060 & 229.185 & 1.104 .245 \\
\hline Alvenaria de vedação: bloco cerâmico $10 \times 20 \times 20$ cm & $m^{2}$ & 9.164 & 9,47 & 18,58 & \\
\hline \multicolumn{3}{|l|}{ Subtotal dos serviços de alvenaria de vedação } & 86.783 & 170.267 & 257.050 \\
\hline \multicolumn{3}{|l|}{ Total dos serviços de concreto armado e alvenaria } & 961.843 & 399.452 & 1.361 .295 \\
\hline
\end{tabular}

Edifício de 12 pavimentos, padrão econômico. Preços TCPO 13, com data-base de outubro de 2009. Fonte: Guia da Construção, 2010: 10-11.

A tabela T-7 apresenta valores unitários e totais de material e mão-de-obra (que são equivalentes ao uso que Marx faz de "massa de meios de produção" e "massa de força de trabalho) referentes aos serviços de construção em concreto armado (pilares, vigas e lajes) complementados pelo serviço relativo à alvenaria de vedação (destacado em fundo cinza).

Nos serviços em concreto armado, o valor dos materiais supera em muito o valor da mão de obra (R\$ 875 mil em material são processados por uma mão-de-obra de valor equivalente a $\mathrm{R} \$ 229 \mathrm{mil}$ ). Esta proporção contrasta com a alvenaria de vedação, em que R $\$ 87$ mil gastos na aquisição do bloco cerâmico 10x20x20 cm (o popular bloco " 8 furos") demandam um valor equivalente a $\mathrm{R} \$ 170$ mil em mãode-obra para seu assentamento. Portanto, o valor dos materiais para concreto armado é 10 vezes mais elevado do que o valor do bloco cerâmico para vedação, mas o conjunto de armadores, carpinteiros, ajudantes e serventes utilizados nos serviços de concreto armado tem valor apenas 1,35 maior que o valor do pedreiro e ajudantes que assentam a alvenaria convencional. 
A tabela T-8 reapresenta os serviços para a hipótese do edifício adotar a alvenaria com blocos estruturais (destacado em fundo cinza) em combinação com serviços de concreto convencional e concreto grout para construir os mesmos $9.164 \mathrm{~m}^{2} \mathrm{de}$ panos verticais de parede. A laje maciça, mais comum em estruturas com vigas de concreto armado, foi substituída por laje pré-fabricada, mais comum em estruturas de alvenaria autoportante [43].

T-8| Material e mão de obra para alvenaria estrutural

\begin{tabular}{|c|c|c|c|c|c|}
\hline \multirow{2}{*}{ Descrição de serviço } & \multirow{2}{*}{ Un. } & \multirow{2}{*}{ Qt. } & \multicolumn{2}{|c|}{ Valor Unitário (R\$) } & \multirow{2}{*}{ Total (R\$) } \\
\hline & & & Material & M/Obra & \\
\hline Fôrma em chapa compensada resinada $12 \mathrm{~mm}$ & $\mathrm{~m}^{2}$ & 395 & 22,48 & 9,43 & 12.620 \\
\hline Cimbramento tubular desmontável - locação mensal & $\mathrm{m}^{3}$ & 287 & 12,90 & 22,45 & 10.145 \\
\hline Armadura em vergalhões de aço & $\mathrm{kg}$ & 10.998 & 5,63 & 1,05 & 73.469 \\
\hline Concreto usinado com lançamento e adensamento & $\mathrm{m}^{3}$ & 46 & 255,29 & 76,71 & 15.229 \\
\hline Concreto Grout com preparo e lançamento & $\mathrm{m}^{3}$ & 642 & 267,86 & 44,58 & 200.736 \\
\hline Laje pré-fabricada $12 \mathrm{~cm}$ (para piso ou cobertura) & $\mathrm{m}^{2}$ & 4.229 & 47,70 & 27,77 & 319.163 \\
\hline Verga $10 \times 15 \mathrm{~cm}$ em concreto armado & $\mathrm{m}^{3}$ & 12 & 812,20 & 451,02 & 15.158 \\
\hline \multicolumn{3}{|l|}{ Subtotal dos serviços de concreto armado } & 469.787 & 176.732 & 646.520 \\
\hline Alvenaria estrutural: bloco de concreto $14 \times 19 \times 39 \mathrm{~cm}$ & $\mathrm{~m}^{2}$ & 9.164 & 20,37 & 12,20 & \\
\hline \multicolumn{3}{|l|}{ Subtotal dos serviços de alvenaria } & 186.671 & 111.801 & 298.472 \\
\hline \multicolumn{3}{|l|}{ Total dos serviços de concreto armado e alvenaria } & 656.459 & 288.533 & 944.992 \\
\hline
\end{tabular}

Edifício de 12 pavimentos, padrão econômico. Preços TCPO 13, com data-base de outubro de 2009. Fonte: Guia da Construção, 2010: 10-11.

O valor da mão de obra para lançamento de concreto grout em pilaretes e cintas é menor que o valor para lançamento de concreto usinado em fôrmas (de fato, a manipulação do concreto grout se dá unicamente por ajudantes de pedreiro ou mesmo por um servente geral), mas a transferência de boa parte das armaduras para as lajes pré-fabricadas diminui o processamento em canteiro de obra de vergalhões de aço, cujo valor como meio de produção é mais de cinco vezes o valor da sua força de trabalho, o armador. O resultado final é uma diminuição, na alvenaria estrutural, da proporção de valor entre material e mão de obra para os serviços de concreto armado. No edifício com estrutura convencional, esta proporção é 3,82 (resultado de R $\$ 875$ mil de material dividido por R $\$ 229$ mil de mão-de-obra), enquanto que no edifício em alvenaria estrutural, é 2,65 (resultado de $\mathrm{R} \$ 470$ mil de material dividido por $\mathrm{R} \$ 177$ mil de mão-de-obra). O valor total dos serviços em concreto armado, no entanto, se reduz em 41,3\% (de R\$1.104 mil para $\mathrm{R} \$ 647 \mathrm{mil})$.

Este resultado se explica por outra alteração da composição de valor de capital, desta vez invertida, que acontece na passagem da alvenaria de vedação para a alvenaria estrutural. Enquanto o assentamento de $1 \mathrm{~m}^{2}$ do simplório bloco "8 furos" utiliza um material cujo valor é metade do valor do pedreiro, o assentamento de $1 \mathrm{~m}^{2}$ do industrializado bloco de concreto estrutural utiliza um

43 Esta diferenciação nos orçamentos reflete práticas de mercado, pelas quais os serviços de carpintaria de fôrma e armação necessários para construção de vigas e pilares moldados in loco são prolongados para fôrma e armadura de lajes maciças. 
material cujo valor é 1,67 maior que o valor do bloqueiro. A tecnologia e o projeto de produção incorporado no bloco autoportante, com seu correspondente aumento de custo, dispensam assim grande parte da massa de valor empregada na estrutura convencional de concreto armado. Na comparação entre as tabelas T-7 e T-8, o valor dos serviços de concreto armado, quando se combina a concretagem de lajes com a alvenaria estrutural, se reduz de $\mathrm{R} \$ 875$ mil para $\mathrm{R} \$$ 470 mil em material e de R\$ 229 mil para R\$ 112 mil em mão de obra.

Para o conjunto de serviços de concreto armado e de alvenaria (que são os únicos que variam no orçamento publicado), fica visível apenas uma pequena variação de $6 \%$ na composição de valor entre material e mão de obra (de 2,41 para 2,26), mas que recobre duas expressivas alterações na composição técnica na passagem da estrutura convencional para a alvenaria estrutural. A primeira é a inversão da relação de valor entre meios de produção e força de trabalho nos serviços de alvenaria, que passa de 0,51 para 1,67. A segunda é que o bloco estrutural provoca na verdade uma elevação de custo dos serviços de alvenaria, mas o encarecimento em 16\% deste item reduziu o custo global de edificação porque reduziu em 30,5\% o valor dos serviços de concreto armado [44].

Reduções semelhantes de valor global disseminaram a alvenaria estrutural para todo o mercado brasileiro da construção habitacional. Elas são resultado de alterações produtivas na composição orgânica do capital devido à combinação de um novo meio de produção, o bloco estrutural, com uma nova força de trabalho, o bloqueiro. Se o bloco estrutural difere do bloco baiano porque ele " $n \tilde{a} o$ se compra em depósito de bairro, só direto na indústria", o bloqueiro igualmente não se forma nos canteiros de obras da manufatura, mas por treinamento em processo industrial.

Para abordar este treinamento, é útil perceber seu contraste com a formação de outro profissional, o carpinteiro, tal como aparece na declaração de um gestor executivo de planejamento da construtora MRV: "Uma grande vantagem da alvenaria estrutural é a menor mão de obra necessária. Não há quase nenhum carpinteiro" (Tamaki; Rocha, 2010: 40). Esta declaração ecoa outra, de um consultor da Associação Brasileira da Indústria de Blocos de Concreto (BlocoBrasil):

No cenário de falta de mão de obras generalizada, mesmo quando é necessário um treinamento, ele é simples (...) é mais fácil formar um pedreiro [assentador de blocos estruturais] que um carpinteiro. O pedreiro, em menos de uma semana, pode assentar os blocos corretamente (Tamaki; Rocha, 2010: 40).

Tal eficiência do treinamento no assentamento de blocos só e possível porque não se treina uma habilidade corporal e mental, que será potencializada pelo uso de ferramentas manuais, mas a interação ergonômica com instrumentos de trabalho que controlam, independentemente de decisão do trabalhador, o alinhamento dos panos de alvenaria, o nivelamento das fiadas e a espessura das juntas. Os gabaritos e escantilhões eliminam ferramentas imemoriais como o prumo de parede, que é inútil sem a complexa habilidade para controlar o espaçamento do

$44 \mathrm{O}$ orçamento global de custos de edificação, de $\mathrm{R} \$$ 5,505 milhões para o edifício em estrutural convencional de concreto, se reduz para $\mathrm{R} \$ 5,089$ milhões para o edifício em alvenaria estrutural. $\mathrm{O}$ valor de venda considera um terreno de $2.700,00 \mathrm{~m}^{2}$, que comportar uma vaga de estacionamento ao ar livre por apartamento, em terreno a ser comprado - em 2010 - por $\mathrm{R} \$ 250,00 / \mathrm{m}^{2}$. 
peso de metal e avaliar sua distância em relação a diversos planos de parede. A própria colher de pedreiro desaparece, substituída por régua meia-cana e bisnagas, cuja adequação ao assentamento da alvenaria estrutural pode ser avaliada no seguinte depoimento do diretor técnico da construtora Rôgga, que atua no programa MCMV na região sul do país:

O treinamento serviu para que os operários aprendessem a usar escantilhão e bisnagas para aplicar argamassa no assentamento de blocos, já que ambos não eram utilizados pela construtora. A única ferramenta, diz o diretor, era a colher de pedreiro (...) usando a colher, o operário gasta mais que o dobro de argamassa que precisa (...) a execução das instalações elétricas nas paredes também ficava prejudicada, já que a argamassa ficava dentro do bloco, impossibilitando que a tubulação passasse (Ferreira, 2013a: 6).

O trabalhador que assenta o bloco estrutural não é mais o pedreiro de alvenaria, formado no canteiro de obras e hábil no uso de instrumentos de trabalho adaptados a seu corpo, de sua propriedade e muitas vezes até mesmo de sua fabricação, mas sim o bloqueiro, treinado no uso de instrumentos cuja concepção e propriedade é da empresa construtora. A bisnaga de napa, em particular, aparta o trabalhador da tradicional colher de pedreiro e impõe um instrumento que, ao invés de ampliar a força de todo o braço, utiliza apenas as articulações dos dedos. O sentido deste esforço lesivo para mão e antebraço não é sequer a irrelevante economia de argamassa, mas sim a limpeza ao redor dos espaços vazados dos blocos, o que facilita a passagem de conduítes e tubos das instalações elétricas e hidráulicas nos alvéolos dos blocos.

O treinamento ganha assim um sentido mais impositivo ao trabalhador, pois, como afirma a respeito das doenças do trabalho associadas à bisnaga o gerente de um dos principais fornecedores de equipamentos de construção civil de São Paulo, "este problema pode ser controlado a partir do treinamento adequado da mão-deobra. Hoje ensinamos o operário a manter uma mão na frente para direcionar o bico enquanto a outra torce suavemente a bisnaga para liberar o material" (Prisma, 2003).

\section{I-5| Imagens para treinamento de uso de escantilhão e bisnaga}
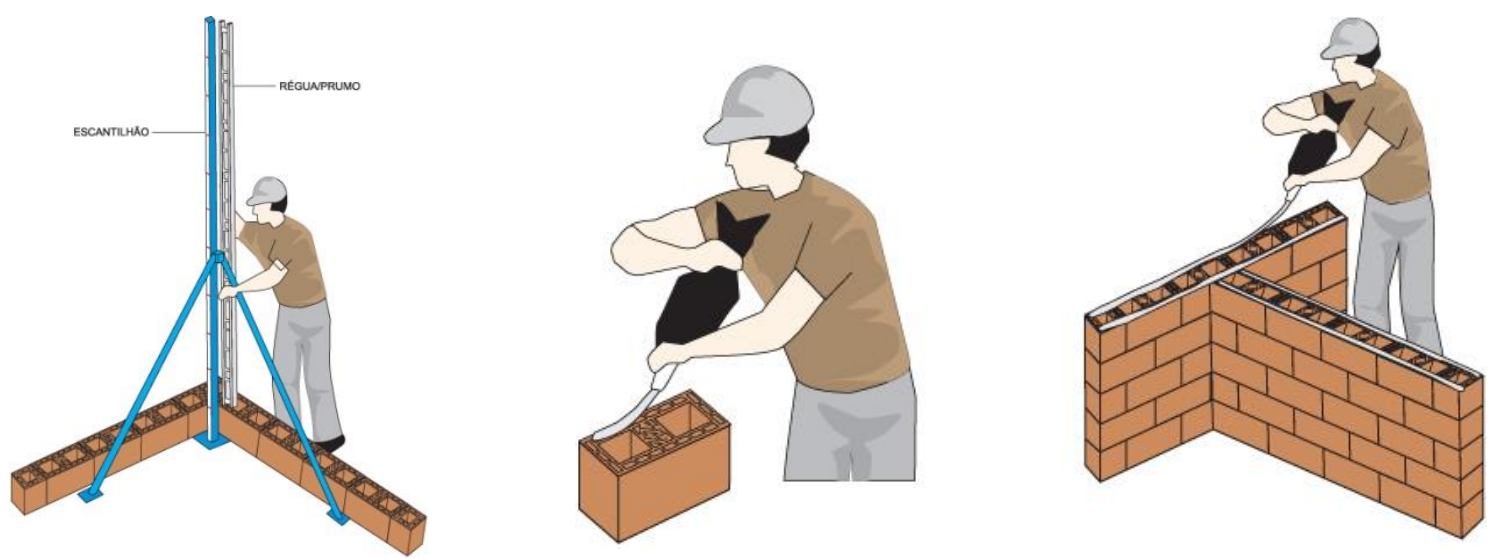

Fonte: manual de treinamento da empresa Selecta Blocos (“www.selectablocos.com.br/ae_dc_01")

Mais significativa que a substituição de profissionais contida na relação entre pedreiro de alvenaria e bloqueiro é a eliminação de um profissional: o carpinteiro. Com a generalização do cimbramento de lajes com escoras metálicas, ele pode ser empregado no manuseio de chapas vinílicas para fôrmas de laje, como parte das equipes terceirizadas de fornecedores de lajes pré-fabricadas ou 
mesmo de escoramento, mas não voltará a realizar o especializado trabalho com fôrmas para vigas e pilares, eliminadas na construção com alvenaria estrutural.

O desaparecimento do carpinteiro tem repercussões maiores para a organização do canteiro de obras, pois sua flexibilidade para atuar em diversas etapas e frentes de construção o torna um ponto de referência comum a todos os trabalhadores, do servente ao mestre de obras, algo que a fragmentação das atividades do pedreiro não pode realizar [45].

Uma pesquisa de Eliete Franco sobre a formação do mestre-de-obra na construção civil em Santa Catarina aponta esta centralidade da carpintaria:

De um total de 20 mestres, aproximadamente $80 \%$ deles tiveram como profissão anterior a carpintaria. Como o aprendizado se dá no próprio canteiro e a ascensão de postos dentro da organização se dá em função das habilidades, o carpinteiro, com uma habilidade mais especial de interpretar projetos, galga mais facilmente os postos dentro desta hierarquia (Franco, 1995: 75).

Neste contexto, a eliminação do carpinteiro na construção com alvenaria estrutural representa mais que uma diminuição da mão-de-obra (com a consequente alteração da composição orgânica do capital), pois é a dispensa de um trabalho especializado cuja formação está sob domínio da relação manufatureira entre aprendiz-oficial e não do treinamento do capital.

Tal formação no e pelo canteiro é uma observação central para Marta Farah:

A habilidade do trabalhador, o saber de que é detentor, é adquirido no próprio canteiro de obras, o que equivale a dizer que sua formação se dá no interior da própria força de trabalho (...) predomina ainda o aprendizado estabelecido na relação direta entre oficial e ajudantes (Farah, 1996: 87).

Alain Morice acrescenta que a formação no canteiro de obras está longe de representar uma autonomia criativa para o trabalhador, pois se integra no conjunto de regras informais estabelecidas pelo poder despótico dos mestres de obras, mestres também na troca de favor por obediência:

A aprendizagem é feita no local da produção. Por isso, o reconhecimento estatutário das aptidões passa por mecanismos internos ao ramo. Além do mais, nem o ramo, nem o poder público geraram, em termos práticos, qualquer sistema formal de reconhecimento baseado em regras objetivas e únicas, o que resulta numa grande disparidade da qualificações segundo o local e a época (...) Essa desordem aparente tem uma ocorrência política: a formação e a promoção dependem da submissão à boa vontade dos mestres, enquanto a seleção é fundamentada num conjunto de relações preferenciais e garante estabilidade ao corpo social nas obras" (Morice, 1992: 36-7)

A formação do trabalhador "no interior da própria força de trabalho" representa, na manufatura, uma resistência do trabalho dentro do processo produtivo,

45 Uma vez concluída a construção de uma edificação por técnicas tradicionais, é a obra do pedreiro que fica mais visível em suas diversas especialidades: revestimentos, alvenarias, pisos. No entanto, durante a construção, a obra que se faz onipresente é a do carpinteiro, não apenas na regularidade das fôrmas e escoras, mas nas inúmeras construções de apoio, como tapumes, escadas, masseiras, caixotes, andaimes, bancos, mesas e barracões, sempre moventes e demandando a engenhosidade de soluções construtivas ad hoc. "Onde o trabalhador encosta, está um trabalho que eu fiz", me dizia o carpinteiro Ivanildo Souza, o Mistura. 
resistência que é antes uma astúcia contra o controle do capital e que se manifesta no "corpo mole", o "soldiering" tão combatido por Taylor. Diante deste quadro, o controle da gerência do capital sobre o canteiro de obras recua para um plano de compromisso, de onde o capital pode se apropriar de resultados de um processo de produção que, entretanto, não conduz integralmente:

O capital depende da qualificação do trabalhador, de sua habilidade, para viabilizar a produção. A definição de programação e alocação de tempos, o estabelecimento do ritmo de trabalho e o próprio controle da produção se dão no interior da força de trabalho, sob a liderança do mestre e do encarregado de ofício (...) A obra é 'tocada' pelo mestre e pelos encarregados, cabendo ao engenheiro um controle meramente administrativo da produção (...) não há por parte da engenharia um controle do 'como fazer', restringindo-se o controle aos produtos das atividades parciais da obra, mantendo-se, mesmo este, dentro de certos limites" (Farah, 1996: 84-91).

Antes de comentar como se alterou este quadro na construção habitacional, principalmente no que diz respeito ao controle que a engenharia civil passou a exercer sobre o canteiro de obras, é preciso fechar o raciocínio sobre a alvenaria estrutural e a formação do trabalho na manufatura lembrando seu inimigo de mais de um século: Frederick Taylor. Toda sua argumentação por uma racionalização produtiva está mergulhada no combate sem trégua que ele exerceu, como engenheiro e ideólogo, contra as diferentes dimensões em que a gerência empresarial deixa de exercer controle integral sobre o processo produtivo, limitando-se à imposição apenas de metas e condições de trabalho que decorrem de sua condição de representante do capital.

O próprio Taylor aplicou ao assentamento de alvenaria os quatro princípios da Administração Científica - domínio da gerência, seleção e treinamento do trabalho, controle da execução e constância da supervisão - justamente como prova de superioridade da racionalização industrial num campo de resistência da manufatura. No segundo capítulo de "The principles of scientific management" há a seguinte análise dos estudos de tempo e movimento realizados pelo casal Gilbreth para o "bricklaying", o assentamento de tijolos maciços:

First: the development (by the management, not the workman) of the science of bricklaying, with rigid rules for each motion of every man, and the perfection and standardization of all implements and working conditions.

Second: the careful selection and subsequent training of the bricklayers into first-class men, and the elimination of all men who refuse to or are unable to adopt the best methods. Third: bringing the first-class bricklayer and the science of bricklaying together, through the constant help and watchfulness of the management, paying each man a large daily bonus for working fast and doing what he is told to do.

Fourth: an almost equal division of the work and responsibility between the workman and the management. All day long the management work almost side by side with the men, helping, encouraging, and smoothing the way for them, while in the past they stood one side, gave the men but little help, and threw on to them almost the entire responsibility as to methods, implements, speed, and harmonious cooperation (Taylor, 1967 [1911]: 85).

Cem anos depois, esta descrição de um processo de racionalização industrial se aplica melhor ao assentamento do bloco estrutural do que do tijolo maciço. As pesquisas científicas alteraram a técnica construtiva da alvenaria (no completo sentido da palavra "tecnologia") e instituíram procedimentos de cálculo e 
normas de execução com bloco estrutural que estenderam o controle do capital da produção fabril para toda a organização de seu assentamento em canteiro de obras. Esta organização tem pelo menos quatro instâncias de controle por parte da gerência empresarial que são coincidentes com as quatro aplicações de princípios da administração científica na atividade de "bricklaying" mencionadas por Taylor.

A primeira instância - domínio da gerência - é representada pelas empresas projetistas ou departamentos especializados no projeto de produção da alvenaria estrutural. A segunda - seleção e treinamento do trabalho - pelos instrutores de treinamento de mão-de-obra e demais profissionais de recursos humanos, encarregados da gestão de mão-de-obra. A terceira - controle da execução - pela equipe de engenharia e estagiários responsáveis pela fiscalização de projeto e do uso do equipamento específico para alvenaria estrutural. A quarta - constância da supervisão - pela integração da subempreitada nos sistemas de gestão de qualidade, pela qual pagamento e verificação de conformidade técnica são unificados por uma única tecnologia de gestão [46].

É um controle do trabalho por parte do capital cuja mecanização acontece apenas na logística de canteiro de obras, não sendo ela condição necessária para que as instâncias de projeto, treinamento, acompanhamento e verificação de qualidade exerçam seu domínio sobre o assentamento da alvenaria estrutural. A destruição do ordenamento manufatureiro dos ofícios de pedreiro - sem que nenhum "saber tradicional" seja preservado - deriva essencialmente da implantação de tecnologias de racionalização do processo de trabalho. Cabe então analisar como tal racionalização não mecanizada é constitutiva de um processo de industrialização da construção habitacional.

\section{Industrialização por racionalização}

Maurice Godelier escreve no volume da Enciclopédia Einaudi dedicado à noção de trabalho que a conexão entre valorização do capital e exploração do trabalhador pela apropriação de uma parte excedente da sua jornada de trabalho tem uma estranha sutileza. A acumulação de capital através de um trabalho considerado excedente exige estabelecer um limite para além do qual a valorização da mercadoria alimenta o capital ao invés do trabalhador, e este limite não é fornecido pela relação concreta de trabalho, mas sim por um valor que o trabalho adquire por ser apenas mais uma entre as inúmeras mercadorias em circulação numa sociedade capitalista. A descoberta de que o próprio mercado regula a medida da exploração do trabalho é, nas palavras de Engels lembradas por Godelier, "a descoberta fundamental sobre a lógica interna do modo de produção capitalista":

46 O quarto aspecto, referente aos sistemas de gestão de qualidade, é abordado na Parte 2 desta tese. A aproximação da atual tecnologia organizacional na construção habitacional com a velha Administração Científica de Taylor é indicativa apenas de um alinhamento histórico e ideológico. Uma análise da construção sob uma estrita ótica taylorista, admissível quando Nilton Vargas publicava sua pesquisa neste sentido (Vargas, 1979), nos dias de hoje dificilmente deixaria de ser um anacronismo. 
Esta descoberta pode se resumir numa fórmula que, à primeira vista, parece tornar mais impenetrável a origem e a natureza desta exploração. O trabalho, medida do valor, não é por ele mesmo valor; o que possui valor é a força de trabalho quando se torna mercadoria, e o valor desta mercadoria, como de qualquer outra, é calculado na base do seu custo de produção e de reprodução. (Godelier, 1986: 41).

Como qualquer outra mercadoria, o valor de troca da força de trabalho é uma somatória de custos de produção, que, no caso, são todos os custos implicados na transformação, a cada jornada, do trabalhador em força de trabalho: são "custos de vida" mas também custos trabalhistas e de legislação social. É apenas sobre esta base comum de formação de valor que a força de trabalho adquire um uso que é, ele sim, único e excepcional: o de transmitir valor no processo de produção numa proporção que é maior que seu próprio valor [47].

Para adquirir a capacidade de produzir mais-valor, a força de trabalho perde sua identidade com cada trabalho concreto e adquire uma nova, como mercadoria, cuja abstração decorre de estudos ergonômicos, indicadores sociais, negociações sindicais e imposições da concorrência não apenas entre empresas, como também entre trabalhadores. Sem esta diluição pelas condições sociais de produção a força de trabalho não pode ser consumida de forma produtiva pelo capital como o "trabalho socialmente necessário" que está na base da teoria do valor de Marx.

Tal solvente geral que reduz os trabalhos concretos à produtividade média é um tema constante nos estudos de gestão da produção na construção civil e atende por nomes que ocupam um campo semântico coerente: formação, capacitação, treinamento, competência, destreza e habilidade.

É a formação da habilidade que torna o tema da manufatura especialmente crítico na construção civil. Nesta forma de produção, mesmo o trabalhador no grau de qualificação inicial, o ajudante, necessita de uma formação prévia cujo desafio ao capital está em sua origem no canteiro de obras, através de um processo que está fora do controle da empresa construtora [48].

A impossibilidade de controlar a formação da força de trabalho no canteiro de obras da manufatura teria gerado, segundo Marta Farah, uma "crise de competência" no setor da construção habitacional ao final do BNH. Na base da crise, está a introdução de inovações tecnológicas que não produzem por si a capacitação do trabalho que o capital necessita, mas que ainda assim tornam obsoleta e destroem a habilidade tradicional da construção habitacional.

Há uma perda de saber por parte do trabalhador sem que tal saber seja apropriado pelo capital (...) a obsolescência do conhecimento tradicional não foi acompanhada pela

47 Nunca é demais lembrar com o primeiro capítulo do "Capital" que "as mercadorias possuem objetividade de valor apenas na medida em que são expressões da mesma unidade social, do trabalho humano, pois sua objetividade de valor é puramente social e, por isso, é evidente que ela só pode se manifestar numa relação social entre mercadorias" (Marx, 2013 [1867]: 124-5).

48 O carpinteiro volta a ilustrar a formação na manufatura, desta vez pelo comentário de Harry Braverman a respeito de seu ajudante: "The carpenter's helper (or other craft helpers classified as 'unskilled labor' because they fall neither into the craft nor into the machine-operative categories) is of little use to the carpenter until he learns a great variety of tools and materials in their various sizes and dimensions, and until he gains a familiarity with the craftsman's operations; it is unquestionable that this large section of the "laborers" grouping requires a longer training period than most operatives. Even pick and shovel work takes more learning before it can be done to required standards than many assembly or machine-feeding jobs" (Braverman, 1998 [1974]: 328). 
consolidação de uma estrutura alternativa de transmissão do saber relativo à construção" (Farah, 1996: 246-8).

Esta tensão entre criação e destruição observada nos anos 1980 não deixa de revelar um deslocamento moderno do conflito entre capital e trabalho. O objeto do conflito deixa de ser o valor com que remunera a habilidade da força de trabalho e passa a ser uma disputa sobre quem vai produzir esta habilidade. A linhagem marxista desta disputa é reconstituída por David Harvey, em "Limits to Capital", nos termos de um rompimento de monopólio da habilidade:
One the one hand, there is the traditional craft and artisan skill which confers a certain power upon whoever possesses it because it is, to some degree, monopolizable. Such skills are anathema to capital. They can act as a barrier to the accumulation of capital (wage rates are sensitive to their scarcity) and prevent the penetration of capitalist social relations of domination and subordination within production. These are the skills that have to be eliminated if capitalism is to survive. On the other hand, it is important for capital that new skills emerge: skills which allow for flexibility and adaptability and, above all, for substitutability - that are non monopolizable. The 'de-skilling' of which Marx writes often entails a direct transformation from monopolizable to non-monopolizable skills (Harvey, 2006 [1982]: 109).

No campo da construção civil, há um permanente esforço para que deixe de ser um monopólio do trabalhador a mercadoria que ele vende às empresas construtoras: a sua força de trabalho devidamente capacitada para a produção. Este esforço é parte do processo histórico de concentração dos meios de produção sob domínio do capital e busca fornecer ao trabalhador tanto quanto extrair dele a habilidade que a empresa construtora vai alugar mediante salário ou remuneração por produção. $\mathrm{O}$ fornecimento da habilidade ao trabalhador, por sua vez, se torna responsabilidade de diversas instâncias sociais, que se multiplicam com a própria expansão produtiva da construção civil: treinamento por empresas consumidoras ou fornecedoras de mão-de-obra, treinamento para prestação de serviços de instalação e operação vinculados a fabricantes de elementos e componentes construtivos, cursos técnicos ou escolas profissionalizantes mantidos por entidades patronais, além dos cursos de extensão e capacitação em universidades e centros de pesquisa.

Em todas estas instâncias de formação da força de trabalho opera a condição histórica de que nenhuma habilidade útil ao capital seja produzida mediante relações sociais dominadas unicamente por trabalhadores. A qualificação que antes era domínio único do trabalhador (domínio que, refugiado nos artistas, ainda torna suas obras materialmente incomensuráveis) é agora uma especialização flexível do próprio capital, que se multiplica em tantas qualificações quanto se abrem novos mercados. Segundo o comentário de Harvey a respeito das especializações produzidas pelo capital, "they could reasonably be accounted for as so many multiples of simple abstract labor" (Harvey, 2006 [1982]: 118).

A literatura de administração de empresas em língua inglesa difere "skill" / habilidade, que é o resultado de uma formação abrangente, que tem múltiplas condicionantes e pode envolver toda a vida do trabalhador, de "dexterity" / destreza, que está associada mais estritamente a um programa de treinamento ou a condicionamentos comportamentais (de onde se diz "animal 
adestrado" em Português). Enquanto a manufatura produz habilidade através de formação pessoal, a indústria produz destreza através de treinamentos padronizados. O embate descrito por Marta Farah ao final da política habitacional ancorada no $\mathrm{BNH}$ diz respeito à destruição do primeiro sem a constituição do segundo, quando a transição da manufatura à indústria só se completa quando e onde toda habilidade da força de trabalho se converte numa destreza do capital. É esta transição que aparece de forma exemplar numa declaração de Giorgio Vanossi, diretor técnico da empresa construtora Living, subsidiária de capital aberto da Cyrela Brazil Realty, em que ele faz referência ao programa MCMV, então recém-lançado:

Na construção o brasileiro tem que parar com a mania de ser criativo. Temos que ter mais humildade e olhar para os japoneses que fazem simplesmente o que é para ser feito - nem mais nem menos. Nas obras brasileiras todo operário tem uma maneira de fazer melhor, mais barato e mais rápido o mesmo serviço, mas os procedimentos devem ser padronizados para não atrapalhar o processo (...) A palavra-chave éo treinamento de mão-de-obra. Todos buscam isso porque agora temos a oportunidade, a renda e o agente financeiro (Vanossi, 2009, p. 24-26).

A consolidação da tecnologia da alvenaria estrutural na construção habitacional segue exatamente a peroração acima. Ela não é uma persistência da habilidade do pedreiro, mas sim sua transformação em destreza por meio de procedimentos padrão e programas de treinamento de bloqueiros [49].

Uma comprovação da integração do bloqueiro como especialização do trabalho abstrato acontece pelos diversos estudos de produtividade que esta tecnologia recebeu no Brasil pelo método da "análise de fatores", consolidado na construção civil americana (Thomas; Yakoumis, 1987). São estudos que abandonam a análise de base financeira da construção habitacional, em que o "custo de mão-de-obra" é simplesmente distribuído pela área construída de alvenaria. Enquanto a programação de custos afeta o planejamento comercial de um empreendimento habitacional, a análise de fatores de produção estabelece uma composição propriamente técnica do capital. Aplicada à execução da alvenaria estrutural, busca ponderar fatores intervenientes no seu processo de trabalho, que podem ser tanto quantitativos (como a distância ou tempo de deslocamento entre recepção de blocos e bloqueiro) quanto qualitativos, aferidas apenas como "presente" ou "ausente", como o transporte mecânico de blocos.

O tempo de trabalho é decomposto sucessivamente em horas e em trabalhadores (a "hora-homem" ou "Hh"), para se tornar uma variável de cada unidade de produção de alvenaria. O valor resultante, "Hh/ $\mathrm{m}^{2}$ ", revela as condicionantes coletivas da produção previstas por Marx através do "grau social de

49 "A escassez de mão de obra qualificada em todos os níveis, assunto recorrente no setor, é apontada pelos entrevistados como uma das principais causas nos atrasos das obras (...) O problema não se concentra tanto na falta de trabalhadores, mas, principalmente, na baixa qualificação dessas equipes" (Reis, 2010: 32). Segundo um dirigente do Sinduscon-SP, "a tarefa mais dramática da economia brasileira consiste em aumentar drasticamente a produtividade dos fatores de produção, e a mão de obra é apenas um deles (...) afora isso, a resposta é treinamento, treinamento e treinamento" (Moura Fé, 2013: 43). Já uma pesquisa da Fundação Getúlio Vargas (mais comentada no próximo capítulo) constata que "a oferta de mão de obra é limitante até mesmo para a adoção de novos métodos construtivos e para o uso mais intensivo de máquinas e equipamentos. Portanto, o treinamento é um fator que condiciona dois componentes da produtividade: a própria mão de obra e também o capital" (FGV, 2012: 48). 
produtividade do trabalho", embora inverta dividendo e divisor de uma produtividade que "se expressa no volume relativo dos meios de produção que um trabalhador transforma em produ to durante um tempo dado, com a mesma tensão da força de trabalho" (Marx, 2013 [1867]: 698). O que a análise de fatores busca determinar é a quantidade relativa de tempo durante o qual o trabalhador transforma em produto um meio de produção dado, com a mesma tensão da força de trabalho.

Este modelo apresenta como característica o fato de analisar a produtividade da mão-deobra quanto às equipes de trabalho, sendo que o trabalho desta equipe é afetado por uma quantidade de fatores que pode levar a perturbações de caráter aleatório ou sistêmico ao desempenho (...) O efeito cumulativo das perturbações pode gerar uma irregularidade quanto à forma da curva de produtividade real que dificultaria sua interpretação. Caso as perturbações sejam matematicamente descontadas, obter-se-á uma curva de produtividade de referência para o serviço estudado (Librais; Souza, 2002: 7).

Esta "curva de produtividade de referência", isolada de perturbações anômalas ou sistêmicas do canteiro de obras, é a Razão Unitária de Produção (RUP), capaz de se impor a qualquer aspecto da construção justamente por seu caráter abstrato. Sua depuração final se dá por um recurso estatístico, pois é formada unicamente pela mediana das aferições diárias de produtividade (RUP diárias) cujos valores sejam inferiores à variação cumulativa da produtividade ao longo de períodos de tempo mais longos, acima de 20 dias.

A depuração de variações diárias e cumulativas resulta num índice de produtividade que é chamada de "potencial" pelo principal divulgador da análise de fatores na construção civil brasileira, o engenheiro Ubiraci de Souza [50]. A "potencialidade" tem o sentido de uma virtualidade, pois indica um valor que pode ser atingido por qualquer equipe de obra nas condições em que foi feita a aferição de produtividade, ou seja, é " a produtividade considerada representativa de um bom desempenho e passível de ser repetida muitas vezes na obra avaliada" (Souza, 1998: 8). Uma representação gráfica da combinação das diferentes Razões Unitárias de Produção aparece no Gráfico G-5.

G-5|Combinação das Razões Unitárias de Produção (RUP) por 25 dias

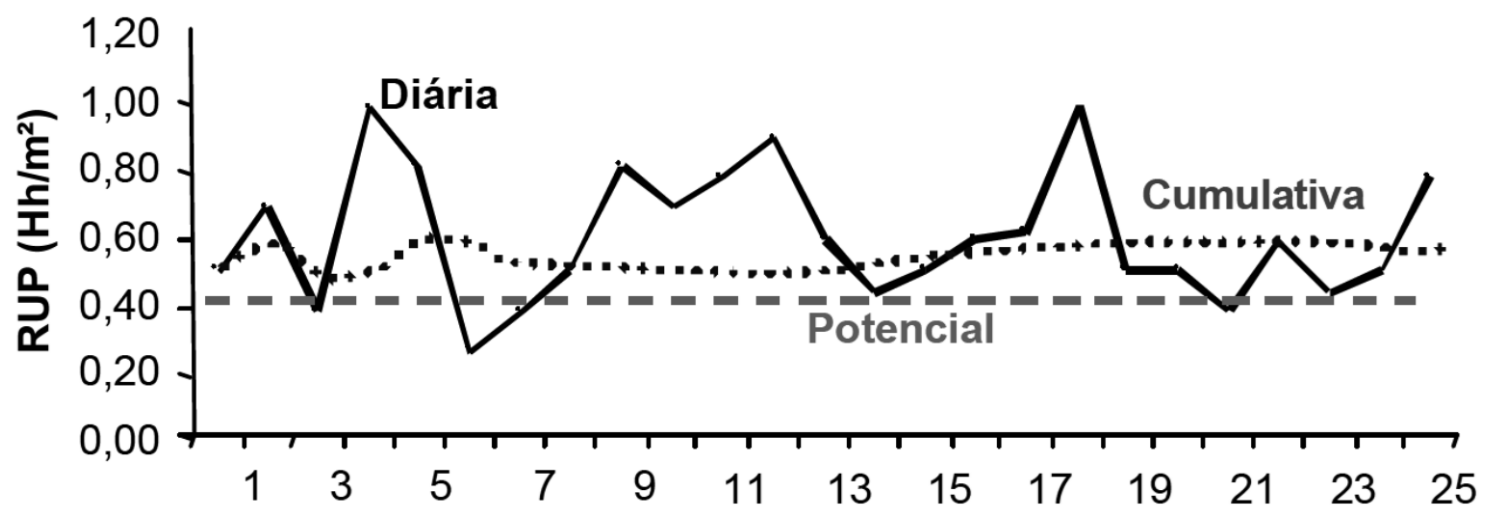

Fonte: reproduzida de Librais; Souza, 2002: 12

50 Além de diretor da consultoria Produtime, é professor de gestão de produção no curso de Engenharia Civil da EP/USP, onde coordena, durante a finalização desta pesquisa em 2013/2014, a revisão das composições de custo do Sistema Nacional de Pesquisa de Custos e Índices da Construção Civil (Sinapi), a referência básica de orçamentos para empreendimentos do programa MCMV. 
A redução dos trabalhos concretos a um trabalho abstrato através de índices de produtividade indica também uma distinção no controle do trabalhador pela gerência empresarial que é tratada no capítulo do Capital "Resultados do processo imediato de produção" (dito "inédito") como "submissão formal" e "submissão real" do trabalho ao capital. Sem promover a alteração da produtividade, o capital submete o trabalhador apenas formalmente, pois consegue constranger e regular a quantidade de trabalho, mas não sua produtividade. O treinamento busca a submissão do trabalho no interior do processo produtivo e, mais ainda, a transformação dos trabalhadores numa única e homogênea força de trabalho. Qualquer resistência do trabalhador a esta submissão apenas fornece novos meios para fazê-lo aderir aos indicadores de produtividade [51].

A variação da produtividade que leva em consideração unicamente o tempo de trabalho de cada unidade produzida é, em essência, uma medição da extração de mais-valor relativo, uma vez que apenas fatores técnicos intervêm nesta variação. Esta é uma medição apropriada ao processo industrial, diferentemente de uma análise da produção com ênfase em custo de mão-de-obra, que é uma medição de mais-valor absoluto por induzir ao barateamento do trabalho pela redução de salários ou, o que é a mesma coisa, a ampliação da jornada de trabalho.

Diferentemente, a análise de produtividade aplicada à alvenaria estrutural considera que são fixos tanto a jornada dos trabalhadores envolvidos no assentamento do bloco estrutural quanto seu valor. Para Ubiraci de Souza, a estabilização da remuneração do trabalho na construção civil é um dado de saída:

Hoje a produtividade física é muito mais importante, porque o custo horário de trabalho é, na maior parte dos lugares, pré-definido por legislação, piso salarial etc. (...) O que precisa ser trabalhado é justamente a eficiência da mão-de-obra" (Corsini, 2012a: 22).

A mesma imobilidade da jornada de trabalho é assumida em outro estudo de produtividade, desta vez de revestimento cerâmico:

A quantidade de "horas" (h) é obtida em função do tempo disponível dos oficiais e ajudantes para a execução do serviço a cada dia. Estes valores são, basicamente, os especificados nas leis trabalhistas brasileiras (Librais; Souza, 2002: 13).

Os levantamentos coordenados por Ubiraci de Souza em empreendimentos em São Paulo indicam variações de produtividade para a alvenaria estrutural entre 0,51 Hh/ $\mathrm{m}^{2}$ a 0,98 Hh/m² (Rocha, 2011: 16). A diferença existente é função muito mais do projeto e gestão do processo do que da produtividade individual da mão de obra empregada, com destaque para cadeias de insumos e logística geral do canteiro de obras:

Observamos em trabalhos que realizamos construtoras terem perdas de até $40 \%$ na execução da alvenaria, em geral por enorme falta de gestão: compras de blocos da pior qualidade, de fornecedores sem compromisso também com prazos de entrega, que era feita de qualquer jeito. O resultado era perda de material, retrabalho, qualidade final ruim etc.

51 O historiador Edward Thompson observa que cada avanço do capital corresponde a um avanço da resistência do trabalhador na própria produção; "No worker known to historians ever had surplus-value taken out of his hide without finding some way of fighting back (there are plenty of ways of going slow); and, paradoxically, by his fighting back the tendencies were diverted and the 'forms of development' were themselves developed in unexpected ways" (Thompson, 1978: 345). 
Já outras construtoras, com boa gestão, fornecedores de qualidade e obras racionalizadas conseguiram indices de perda na alvenaria de 1\%, por exemplo. Esses são os polos opostos, mas reais, do mercado da construção (Rocha, 2011: 16).

Num estudo em que duas construtoras obtiveram produtividades aproximadas para alvenaria estrutural $\left(0,62 \mathrm{Hh} / \mathrm{m}^{2}\right.$ e $\left.0,66 \mathrm{Hh} / \mathrm{m}^{2}\right)$, Ubiraci de Souza e Luís Cocito de Araújo perceberam a participação crítica que tem um fator frequentemente negligenciado no planejamento de canteiro de obras, que é o deslocamento do bloco em paletes: as $0,08 \mathrm{Hh} / \mathrm{m}^{2}$ consumidas com o transporte por grua se elevariam para $0,39 \mathrm{Hh} / \mathrm{m}^{2}$ caso fosse usado o carrinho manual (adaptado para mini-paletes e operado por serventes) e elevador de obra (Cocito de Araújo \& Souza, 2001: 23).

O resultado recorrente destas medições tem algo de paradoxal: a produtividade já não é do trabalhador, mas da organização da produção. O treinamento não fornece um novo limiar de produtividade, apenas insere o trabalho num processo de racionalização da produção que, por sua vez, é objeto da tecnologia organizacional e só pode alterar o trabalho à medida que altera a empresa.

Assim que a produtividade obtém referências por condições abstratas do canteiro de obras, não apenas a rigidez da jornada de trabalho é um dado de saída, mas também sua condição de submissão à indústria. Não existe mais uma produção específica, qualitativa, da manufatura, mas sim uma variação quantitativa da eficiência no interior da indústria. A diferença entre ambas as perspectivas é propriamente dialética: do ponto de vista da manufatura, que é de quem se submete, há uma alteridade em relação à indústria, alteridade que se revela na negação do saber operário em ser transferido ao capital, enquanto que do ponto de vista da indústria, a submissão do trabalho coloca todas as formas de produção está sob uma única racionalidade [52].

Eis porque, entre o impasse sugerido por Marta Farah e a própria literatura em engenharia civil produzida a partir dos anos 1990, para a qual "Processo de trabalho na construção habitacional" é referência teórica, há antes o esvaziamento de um problema: a manufatura na construção civil já não tem mais estatuto próprio, quanto mais um significado profundo do ato de construir que aparece nas pesquisas de Sérgio Ferro.

Tal unicidade do capital é lugar comum nos estudos de Gestão de Produção da construção civil. Em 2008, a consultoria Centro de Tecnologia de Edificações (CTE) promoveu um seminário - intitulado "Encontro sobre habitação econômica e industrialização da construção" - que se tornou importante no mercado da construção habitacional por ter estabelecido consensos a respeito da produtividade na construção habitacional que, no mesmo ano, seriam

52 Lúcia Shimbo (Shimbo, 2010) observou nos empreendimentos habitacionais do "segmento econômico" que um profissional como o almoxarife assume parte do controle das atividades no canteiro que antes eram exclusivas do mestre-de-obras. Mas este profissional o faz apenas porque passou a ser treinado como ponto de ligação privilegiado com os manuais de procedimento da empresa, isto é, como integrante da racionalização produtiva: "o mestre de obras traz uma autoridade reconhecida pelo seu 'saber fazer' tão caro à construção civil, enquanto o almoxarife se impõe pelo conhecimento 'novo', por assim dizer, a respeito dos instrumentos de prescrição, de padronização e de controle do trabalho elaborados pela empresa" (Shimbo, 2010: 283). No reforço da capacidade de prescrição do almoxarife, o que se vê é mais uma etapa na ampliação do controle do capital sobre o canteiro de obras da manufatura. 
apresentados aos formuladores do programa MCMV como requisitos de desempenho das empresas. Uma das apresentações neste seminário é de uma autoridade da Gestão de Produção no Brasil, o engenheiro Fernando Sabbatini, com dois de seus "slides" reproduzidos na Imagem I-6.

I-6|Slides de conferência de Fernando Sabbatini (Sabbatini, 2008a)
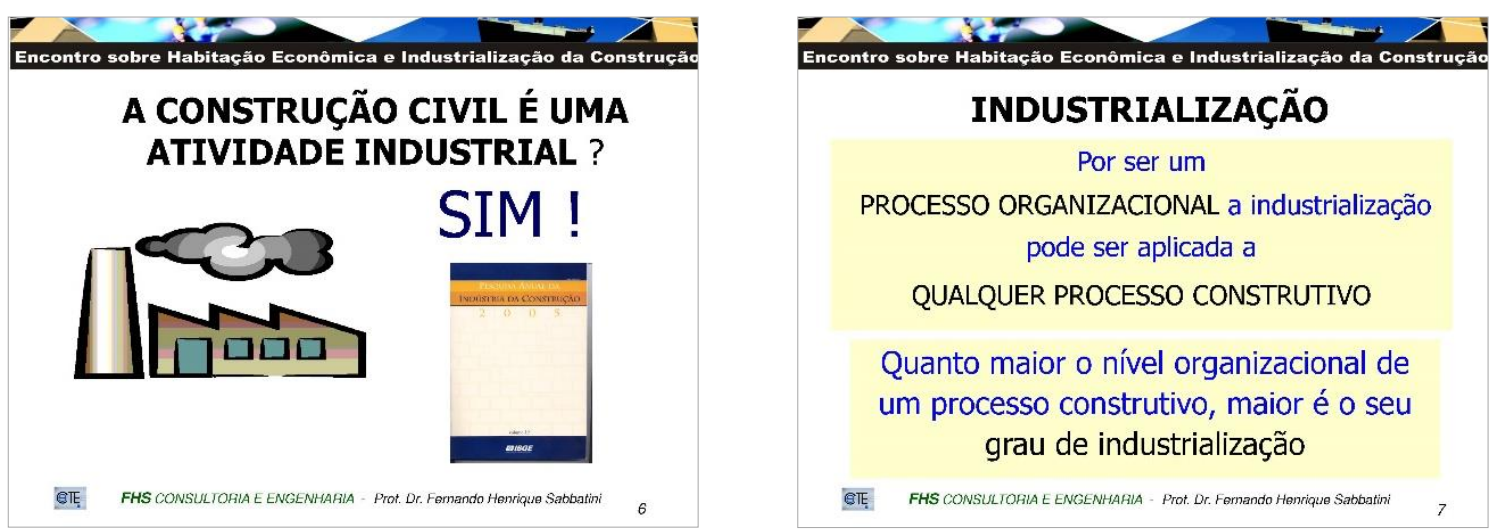

Fonte: consultável em “http://www.cte.com.br/eventos/eventos2008/economica/palestras.asp”

Em um dos slides, sob o "Sim!" que afirma a integração da construção à atividade industrial, aparece uma edição da "Pesquisa Anual da Indústria da Construção" (PAIC). Trata-se de uma das mais importantes pesquisas econômicas do Instituto Brasileiro de Geografia e Estatística, cujo vigésimo volume, referente ao ano de 2010, foi publicado durante a elaboração desta pesquisa (IBGE, 2012) [53].

O objetivo do "slide" é enfatizar a cadeia produtiva e não a planta fabril como signo de industrialização. A construção civil é indústria já pela classificação censitária das atividades econômicas, algo presente desde o título da pesquisa. Embora a metodologia internacional seguida pela Classificação Nacional de Atividades Econômicas (CNAE - versão 2.0) mantenha a construção de edifícios num grupo de atividades separado da indústria de transformação ("Seção F" e "Seção C", respectivamente), sua inserção no sistema de contas nacionais e cadastros fiscais (IBGE, 2007: 14) se dá em conjunto com empresas que constituem a indústria de bens de consumo duráveis [54].

O que pode haver de trivial em reduzir a industrialização da construção a uma classificação estatística desaparece nas ideias expressas no "slide" à direita na Imagem I-6. O seu tema é o "processo organizacional" como unificador técnico das atividades da construção, pelo qual todas elas são parte de uma atividade industrial, cabendo apenas uma distinção de grau. $O$ indicador que operacionaliza esta gradação "está relacionado com um indice que mede a eficiência potencial do processo. Um indicador muito utilizado na construção de edifícios é o de consumo de mão-de-obra no canteiro" (Sabbatini, 2008a: 8), indicador que relaciona tempo de uso da força de trabalho por diferentes unidades de medição de um produto da construção: pontos de instalações, metro lineares de tubulações, áreas de piso ou volumes de concreto e fôrma. A sofisticação já discutida das medições

53 As principais informações do PAIC 2010 são comentadas no capítulo 4.

54 A revisão do CNAE 2.0 decorre da revisão 4 da "International Standard Industrial Classification of all Economic Activities" - ISIC, aprovada em resolução da Comissão Nacional de Classificação - Concla. 
da Razão Unitária de Produção (RUP) põe em relevo precisamente a "produtividade potencial" de qualquer operação em canteiro de obras, em relação à qual uma obra com alto ou baixo grau de industrialização apenas agrega ou deixa de agregar os "fatores de produção" ligados à organização da construção e que alteram sua produtividade.

Os instrumentos de análise da engenharia não se contrapõem mais à manufatura, em relação à qual demarcariam um salto qualitativo estritamente associado à adoção de máquinas e pré-fabricação. Pelo contrário, ao adotar o diapasão do processo organizacional, as pesquisas de Gestão de Produção cancelam os limites à expansão do processo industrial: o que antes era uma generalização estatística se converte num campo tecnológico único e contínuo. O extremo desta ideia aparece num comentário de Ubiraci de Souza sobre "uma obra em realização na periferia da cidade de São Paulo":

Existe uma distância muito grande entre situações encontradas nas empresas líderes do mercado formal e aquelas encontradas na construção informal (...) O despreparo da mãode-obra é um problema, principalmente quando esse despreparo chega nos níveis do existente na construção informal. Uma gestão profissional consistente (varrendo as várias etapas do empreendimento, contemplando da concepção à produção) pode ter resultados extremamente satisfatórios quanto à melhoria da produtividade (Souza, 2006: 18-19).

Assim, a redução de todos os canteiros de obras ao processo industrial é, antes de tudo, uma operação analítica da Gestão de Produção da engenharia civil [55].

Ao contrário das poucas e marcantes obras que procuram identificar a manufatura na construção como alteridade ao processo produtivo da indústria, a hegemonia da tecnologia organizacional como base de compreensão da construção civil brasileira se revela na produção ininterrupta e com poucos destaques de artigos técnicos, atas de eventos, pesquisas para entidades patronais ou governamentais e revistas segmentadas por subsetores de atividade, uma produção que é multiplicada por grupos de pesquisa, entidades de classe, órgão de governo e organismos internacionais [56].

A atualidade desta visão no Brasil tem ao menos um ponto de partida de consenso no campo da Gestão de Produção na engenharia civil em São Paulo, que são as definições contidas na tese de doutorado de Fernando Sabbatini, defendida no final dos anos 1980 (Sabbatini, 1989). Ela parte da concepção de Carlo Testa (Testa, 1972) de que "a essência da industrialização na construção de edifícios é a organização" para estabelecer a seguinte definição:

Industrialização da construção é um processo evolutivo que, através de ações organizacionais e da implementação de inovações tecnológicas, métodos de trabalho e

55 Em outro texto, Ubiraci de Souza volta a tratar a moradia autoconstruída (que ele chama de "habitação de mercado de autogestão") como campo de oportunidade para aplicação dos princípios de racionalização da construção (Souza; Deana; Faria, 2005).

56 Apesar de editada por uma entidade de classe nacional, a American Society of Civil Engineers (ASCE), o "Journal of Construction Engineering and Management" é a publicação periódica que forma o eixo central de divulgação acadêmica da tecnologia organizacional por divulgar regularmente a replicação de suas pesquisas em diversos países e âmbitos econômicos. 
técnicas de planejamento e controle, objetiva incrementar a produtividade e o nível de produção e aprimorar o desempenho da atividade construtiva (Sabbatini, 1989: 52).

O centro da definição é a produtividade, cujo aprimoramento só se relaciona ao maquinário se este é parte de uma tecnologia organizacional [57].

Mais adiante, quem dá concretude a esta definição são os "processos construtivos de alvenaria estrutural":

Fundamentalmente estes processos se diferenciam dos tradicionais pelo seu nível organizacional, traduzido por uma centralização e planejamento das decisões. As decisões não são tomadas pelo operário, que é simplesmente o executor, mas sim em níveis gerenciais que dominam todo o processo e podem identificar as interferências de uma decisão isolada no conjunto (Sabbatini, 1989: 79).

A ênfase de Sabbatini na organização do canteiro de obras e não em sua mecanização o leva à seguinte ressalva:

Esta noção contraria o conceito que muitos técnicos, no Brasil, têm sobre a industrialização. Imagina-se que para industrializar ter-se-ia necessariamente que adotar sofisticados processos de produção, verdadeiros sistemas construtivos, totalmente préfabricados, denominados 'sistemas industrializados' (...) Esta concepção equivocada do que seja industrialização tem conduzido, geralmente, a atitudes de imobilismo (porque a introdução de sistemas industrializados depende da garantia de continuidade de produção e esta depende de ações governamentais, que não se consubstanciam) ou, em total oposição, tem conduzido a atitudes apressadas e irrefletidas de se criar da noite para o dia novos 'sistemas'. Sistemas estes que, como em um passe de mágica, iriam retirar a construção civil de um estado caracterizado por uma caótica desorganização produtiva e elevá-la a uma posição consentânea com o atual desenvolvimento tecnológico dos outros ramos industriais. Cabe destacar que estamos aqui nos referindo à industrialização na construção de edificações habitacionais, que tem sido objeto de debate pelo menos nos últimos vinte anos no país (Sabbatini, 1989: 50).

Ao comentar sobre os 20 anos que antecedem a tese defendida em 1989, Sabbatini preenche a periodização que esta recuperação bibliográfica necessita. O livro de Marta Farah que indica uma "crise de competência" na construção habitacional brasileira em meados dos anos 1990 pode ser acurado para os anos de recessão econômica no país, mas o embate que tematiza entre manufatura versus mecanização já estava teoricamente morto. A construção habitacional que Sérgio Ferro concebia em apenas duas diferentes condições da manufatura heterogênea ou serial - estava confinada pela engenharia civil entre as gradações de uma única organização industrial.

Talvez em nenhum momento o contraste seja mais forte do que na avaliação que "O canteiro e o desenho" faz das situações em que, na construção habitacional, "a mesma massa de salários manipula uma massa maior de materiais". Para Sérgio Ferro, há um "absurdo" quando "a diminuição do índice é apresentada como sinal de industrialização" pela simples razão que ela ocorre sem o concurso de máquinas:

57 Entre outras referências teóricas desta definição, aparece a advertência da tese de doutorado de Paulo Bruna, realizado no mesmo ano em que foi publicado "O canteiro e o desenho": "a industrialização está essencialmente associada aos conceitos de organização e de produção em série, os quais deverão ser entendidos, analisando de forma mais ampla as relações de produção envolvidas e a mecanização dos meios de produção" (Bruna 1976: 19) 
Como a mecanização do canteiro é precária e não atinge o essencial (trata-se de uma manufatura de modelo bastante tosco), a melhoria do rendimento vem, em geral, do aumento da exploração do trabalho, o que encontra disfarce na referência deslocada à industrialização (Ferro 2006 [1976]: 122).

Levando as palavras de Sérgio Ferro para a perspectiva da Gestão de Produção, não há processo de trabalho que seja "tosco o bastante" para deixar de ser submetido a uma tecnologia de gestão de matriz industrial, pois esta tecnologia não reconhece alteridade numa manufatura. Há apenas extremos de eficiência e ineficiência, cuja distância relativa a qualquer canteiro de obras pode ser medida numa mesma escala [58].

A industrialização atinge assim uma universalidade abstrata porque está ancorada não mais em maquinário, mas em gestão do processo de trabalho. Seu aspecto mais importante é a formação da destreza do trabalhador como uma destreza do capital, pela qual a força de trabalho se submete à dominação real da gerência de produção.

Este é o momento de deixar a análise do trabalho no canteiro de obras e observar as condições de sua industrialização em âmbito externo, em que o controle da gerência sobre o trabalho aparece não mais como impulso interno do processo capitalista, mas como reação a novas condições de reprodução social do próprio trabalhador.

58 Ubiraci de Souza e Carlos Librais vão ressaltar que "os serviços que compõem o processo construtivo ainda apresentam uma organização bastante primitiva", mas eles não impedem de reconhecer que "a construção civil tem características industriais ao se estudar os níveis gerenciais e de planejamento do empreendimento" (Librais; Souza, 2002:5). 


\section{$4 \mid$ \\ A POPULAÇÃO EXCEDENTE NA CONSTRUÇÃO CIVIL}

\section{População e força de trabalho}

Em fevereiro de 2013, o economista Samuel Pessôa, ligado ao Instituto Brasileiro de Economia (IBRE/FGV), publicou um artigo sobre o mercado de trabalho brasileiro que se iniciava com a seguinte advertência:

É natural que as pessoas atribuam características excepcionais à época que vivem. Em geral pensamos que grandes transformações únicas na história da humanidade estão ocorrendo (...) vou correr o risco de cair nessa armadilha e atribuir um papel excepcional na história da sociedade brasileira ao desenvolvimento que tem ocorrido na última década e meia no mercado de trabalho" (Pessôa, 2013: B16).

O desenvolvimento ao qual Samuel Pessôa se refere é a aquisição pelo mercado de trabalho de propriedades econômicas de "inelasticidade", isto é, ele não mais conseguiria suprir de força de trabalho as demandas recentes do capital brasileiro, o que "explica boa parcela da elevação dos salários, principalmente dos trabalhadores mais desqualificados". Com aplomb característico dos economistas, esta perda de flexibilidade da oferta de força de trabalho é analisada à luz de um evento histórico cuja malignidade é formadora da sociedade brasileira:

Durante séculos fomos um país escravista. O escravismo torna a oferta de trabalho no longo prazo muito elástica (...) No longo prazo, a rentabilidade do escravo tem que ser igual ao custo de compra do escravo no porto da África adicionado ao custo do transporte. Ou seja, independentemente da melhora técnica no escravismo, a rentabilidade de um escravo está fixada. Qualquer melhora técnica que eleva a rentabilidade de um escravo redunda na elevação das importações. É nesse sentido que no escravismo a oferta de trabalho é elástica: a rentabilidade do escravo no longo prazo está fixada independentemente da tecnologia (Pessôa, 2013: B16).

A oferta elástica de trabalho no Brasil se estende do tráfico negreiro até os fluxos imigratórios do início do século passado, a partir do qual se inicia no país uma sequência de eventos típica do "modelo de transição demográfica", cuja organização por "estágios" é recorrente para análises populacionais de diversos países ou regiões do globo [59].

O modelo é geralmente apresentado através de um gráfico de variação no tempo do contingente populacional e as taxas de mortalidade e natalidade que implicam no aumento ou diminuição deste contingente. A variação temporal das três linhas caracteriza uma sucessão de quatro estágios demográficos, representados no Gráfico G-6. 


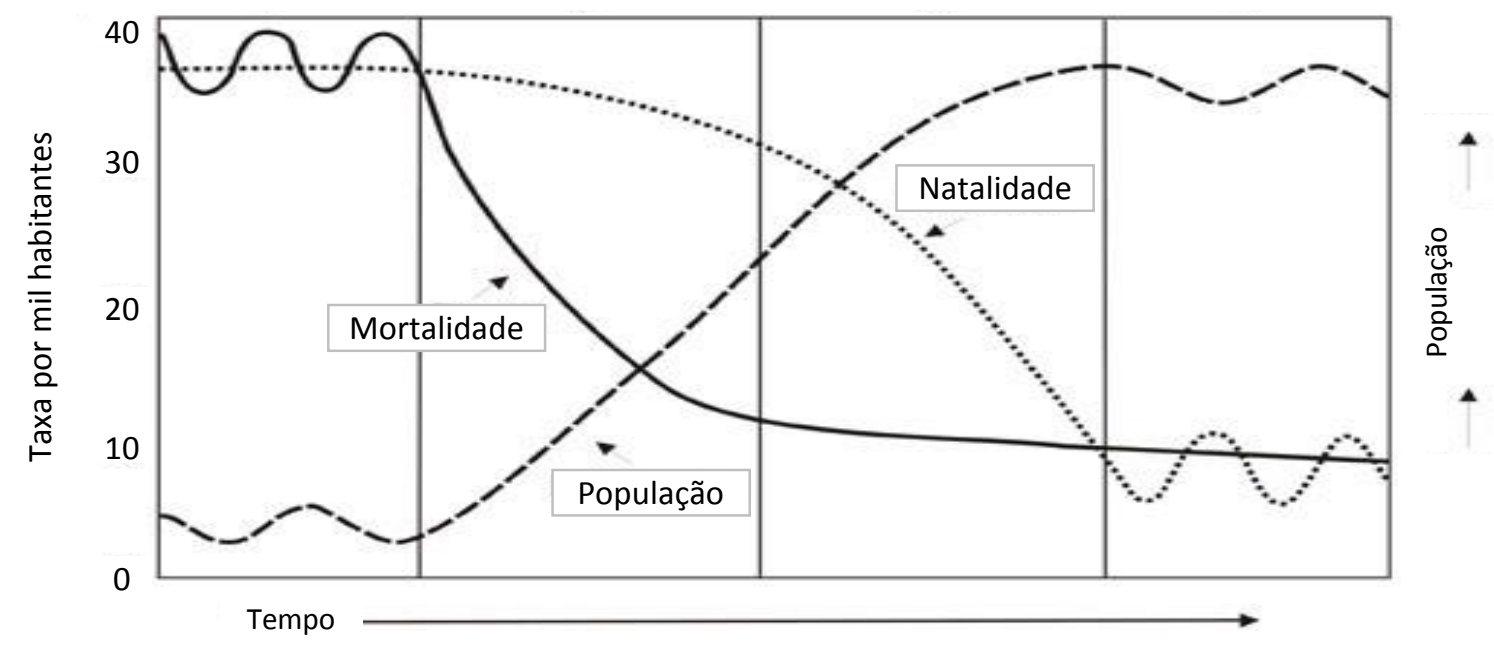

Fonte: adaptado de "http: //www.ibge.gov.br/home/estatística/população"

Comprimidos entre estrapolações para o passado e o futuro, que são o primeiro e o quarto estágio, os estágios que apresentam propriamente uma transição são o segundo e o terceiro. Neles, se alteram em tempos diferentes as taxas de mortalidade e natalidade de uma população, alteração cuja explicação mais geral está ligada ao desenvolvimento de forças produtivas. No segundo estágio, são serviços sanitários e de medicina que reduzem a taxa de mortalidade, ainda sem alterar a taxa de natalidade advinda de um estágio anterior. A redução desta no terceiro estágio tem causalidade mais difusa mas não menos ligada a condições econômicas, pois é correlata aos efeitos da urbanização sobre o comportamento familiar, principalmente da incorporação das mulheres como força de trabalho.

$\mathrm{O}$ efeito do descompasso entre mortalidade e natalidade é, num primeiro momento, acelerar e, depois, desacelerar o crescimento populacional do século 20. Altera um padrão pré-capitalista, em que uma pequena e jovem população era mantida com altas taxas de nascimento e mortes, e o conduz a um hipotético futuro em que estas taxas voltam a se anular, mas desta vez para estabilizar uma população grande e envelhecida.

A sucessão temporal não impede que diferentes estágios ocorram simultaneamente em diferentes territórios, sejam eles regiões, países ou continentes. A elaboração de um modelo de transição demográfica se torna então uma classificação econômica não só de tempos como de espaços, com o estágio 2 coincidindo com países de economias subdesenvolvidas e o estágio 3, com países de economias em desenvolvimento. Neste modelo demográfico, o Brasil estaria no final de seu processo de desenvolvimento econômico, pois as taxas de mortalidade e natalidade aferidas no censo demográfico de 2010 apontaram pela primeira vez uma fecundidade inferior à necessária para a simples reposição populacional. O fim do aumento populacional vegetativo no país corrobora assim a opinião de Samuel Pessôa:

Os cinco séculos de oferta elástica de trabalho estão ficando no passado. Para nós, o século 21 já pode ser chamado do século da restrição de mão-de-obra. Não será a solução para todos os nossos problemas e, em particular, não resolverá o problema da baixa 
produtividade da mão de obra, em grande medida fruto da baixa qualidade de nosso sistema educacional. (Pessôa, 2013: B16).

Uma economia que se depara com um quadro de inelasticidade da oferta de trabalho só pode aumentar a riqueza se este trabalho se torna mais produtivo: a quantidade da produção, portanto, precisa ser desvinculada da quantidade de trabalhadores. Assim, sob as incessantes notícias que anunciam uma crise de mão-de-obra na construção civil desde o lançamento do programa MCMV não há apenas um temor pela escassez de trabalhadores, mas sim pela dificuldade em aumentar sua produtividade [60].

Um editorial da revista "Construção e Mercado", um dos principais periódicos de divulgação da construção civil no Brasil, fazia a seguinte previsão para o ano de 2010:

A escassez de mão de obra qualificada nos canteiros de obra ganhou posição de destaque entre os gargalos do setor. Na época do boom imobiliário (2007-2008), foi um dos principais desafios enfrentados pelas construtoras. Com a retomada da economia e o iminente pico de produção, o problema está de volta e preocupa empresários para o decorrer de 2010. E há, agora, um agravante: o programa habitacional Minha Casa, Minha Vida (Mendes, 2010).

\section{I-7|Notícias da transição demográfica na construção civil}
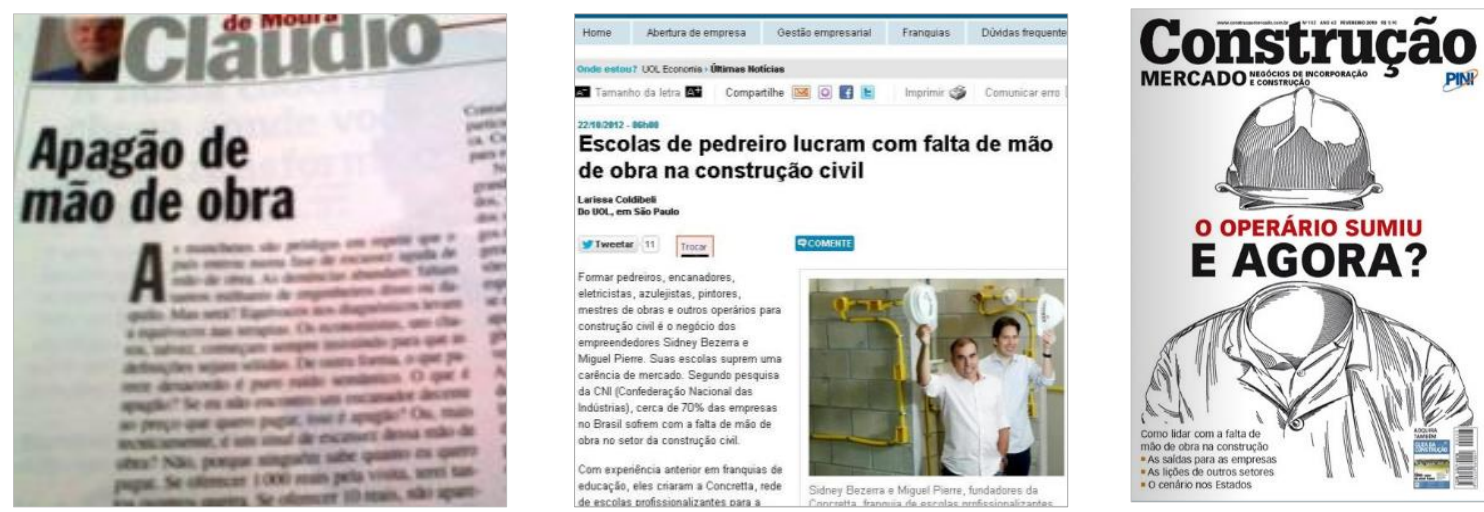

À esquerda, colunista da revista Veja. No centro, notícia no site UOL. À direita, revista da editora Pini

A divulgação de novas condições para arregimentar trabalho na sociedade brasileira, de toda forma, tende a naturalizar o modelo de transição demográfica e transformá-lo numa espécie de tábua das marés da população mundial. Do ponto de vista de uma análise do trabalho, é preciso seguir também a advertência de um artigo pouco recordado de Francisco de Oliveira, "A produção dos homens" (Oliveira, 1976): "partindo exatamente da população como um todo, a demografia não trabalha sobre relações sociais, quaisquer que elas sejam", uma vez que “a população não é natural em nenhum sentido, a não ser remotamente no sentido biológico" (Oliveira, 1976: 8-9). É um raciocínio que estende à moderna demografia a permanente confronto de Marx contra o malthusianismo:

60 Ainda no campo da opinião pública, poucos debates atravessaram tantos aspectos históricos da sociedade brasileira quanto a aprovação, em março de 2013, do Projeto de Emenda Constitucional $n^{\circ} 66$, que estendeu direitos trabalhistas comuns a empregadas domésticas. Às vésperas da aprovação, a proprietária de uma agência de trabalho declarava: "há pessoas que parecem viver em outro planeta. Ainda hoje chegou um pedido para contratar uma profissional que trabalhe direto por 15 dias sem folga" (Rolli; Roman, 2013). 
Cada modo de produção particular na história tem suas leis de população particulares, historicamente válidas. Uma lei abstrata de população só é válida para as plantas e os animais e, ainda assim, apenas enquanto o ser humano não interfere historicamente nesses dominios" (Marx, 2013 \{1867]: 707).

A particularidade histórica do capitalismo é transformar trabalho, este ato definidor da humanidade, numa mercadoria padronizada, mensurável e livremente produzida: a "força de trabalho". É esta particularidade que leva os últimos capítulos do primeiro volume do "Capital" a tratar o trabalho como um fenômeno coletivo, que se transforma em eras e territórios. Como a força de trabalho é uma mercadoria, a regulação de seu preço e valor se dará num mercado que tem a escala da população de um país ou, contando com fluxos migratórios, de continentes e todo o planeta [61].

Daí a ideia reforçada no artigo de Francisco de Oliveira: é a sociedade que produz a população, pois, de uma perspectiva marxista, esta população é uma abstração, enquanto as classes sociais e suas relações de produção são uma concretude. Ao longo das transformações demográficas do século XX, é o capital que produz para si uma população, ou melhor, uma população que dê suporte a uma força de trabalho que seja, esta sim, elástica em relação às demandas da produção.

Força de trabalho não é população, mas a capacidade de trabalho de uma população. Essa capacidade de trabalho pode ter um limite mínimo, assimilado à pura força muscular do homem, mas seu limite máximo é completamente elástico em relação ao estoque de população: essa elasticidade quem dá é o capital (...) esta é a dificuldade basilar que responde pela impossibilidade de desvendar a relação entre população e modo de produção demograficamente (Oliveira, 1976: 16).

No modo de produção capitalista, há uma lei de população historicamente determinada, pela qual a produção não busca o uso integral da força de trabalho de uma população. Pelo contrário, procura manter permanentemente desempregada uma parte para torná-la uma "superpopulação relativa", que Marx denominou em outros momentos "exército industrial de reserva". Uma denominação mais simples é "população excedente", entendendo que é uma população que excede a população empregada pelo capital ainda que não possa ser empregada de nenhuma outra forma produtiva [62]:

A acumulação capitalista produz constantemente, e na proporção de sua energia e seu volume, uma população trabalhadora adicional relativamente excedente, isto é, excessiva para as necessidades médias de valorização do capital e, portanto, supérflua (...) A superpopulação relativa é, assim, o pano de fundo sobre o qual se move a lei da oferta e da demanda de trabalho. Ela reduz o campo de ação dessa lei a limites absolutamente condizentes com a avidez de exploração e a mania de dominação próprias do capital" (Marx, 2013 [1867]: 705-714).

61 "A acumulação de capital é, portanto, multiplicação do proletariado" (Marx, 2013 [1867]: 690). Nos dias de hoje, China e sudeste asiático comprovam a importância da transformação de populações em força de trabalho.

62 A terminologia bélica do "exército de reserva" poderia ter alguma contemporaneidade com a atual composição da guerra, que depende cada vez menos da ação de massas de soldados em campo e cada vez mais de máquinas automatizadas, como aviões não-tripulados e programas computacionais. 
Para a literatura crítica da construção civil brasileira dos anos 1970 e 1980, a percepção de uma população excedente era a chave de leitura de um padrão de exploração de trabalho que Ermínia Maricato classifica em um dos capítulos de sua tese de doutorado como "massacre dissimulado" (Maricato: 1984).

É um padrão de exploração que prolonga outras violências da formação social brasileira, mas cada aspecto da precarização trabalhista e da submissão despótica do canteiro de obras se integra a uma organização produtiva adaptada à massa migratória de origem rural daquelas décadas, cuja relação com a construção civil se dava como mão-de-obra transitória e informal. Sobrecarregar esta força de trabalho com viradas, serões, salários insuficientes e privação de direitos corresponde, por um cálculo compensatório, a uma opção por negligenciar a tecnologia já disponível no Brasil em componentes, logística e gestão. Na tese de doutorado de Ermínia Maricato, esta economia fechada entre expansão da força de trabalho e compressão da tecnologia construtiva aparece pelos estudos do economista Cézar Manoel de Medeiros sobre o desenvolvimentismo dos anos 1970:

A oferta de mão-de-obra é mais elástica que a oferta de materiais de construção, o que impede, segundo o autor, de adotar processos tecnológicos mais modernos (...) A oferta de mão-de-obra farta e barata entre nós funciona como desestimulante aos avanços permitidos ou possíveis à indústria da construção (Maricato, 1984: 169).

É uma visão compartilhada por vários autores e aberta na construção civil por Sérgio Ferro já ao final dos anos 1960. Em “A produção da casa no Brasil" ele anota que "a força de trabalho, meio de produção mais barato, é abundante, cria a massa uniforme de moradias com técnica retrógrada" (Ferro, 2006 [1969]: 83), observação que ele complementa com sarcasmo em relação à tecnocracia do regime militar:

Há excesso de mão-de-obra, sempre houve: candango não falta. Principalmente hoje: um dos cuidados maiores do nosso governo, sabemos, é manter exércitos e, com especial carinho e silencioso pudor, o exército de reserva de mão-de-obra - desarmado, lógico. $O$ combustível básico da manufatura está garantido numa quantidade e a um tal preço que dispensa quaisquer preocupações quanto à sua substituição (Ferro, 2006 [1969]: 87) [63].

Nos anos finais do regime militar e do $\mathrm{BNH}$, a organização do trabalho na construção habitacional brasileira tinha assumido, segundo Nilton Vargas, caráter de "depredação da força de trabalho" (Vargas, 1983: 206). Apenas a extensão da jornada e a extenuação do operário repunham o valor de sua manutenção e reprodução. Nilton Vargas apresenta um quadro puro de extração de mais-valia absoluta, que novamente não é justificado pelo pouco desenvolvimento das forças produtivas, mas sim pelo excedente populacional:

Estas condições de trabalho têm permanecido porque há sempre um contingente de trabalhadores do campo, prontos a assumir as novas vagas criadas no setor (...) A construção civil tem-se mostrado, onde quer que esteja, como a opção para a fuga do campo. Assim, em virtude dessa abundância da mão-de-obra, entende-se o porquê dos altos níveis de acidentes de trabalho (...) O contingente de reserva e a desmobilização e

63 Esta pesquisa se beneficiou da reedição dos textos de Sérgio Ferro pela editora Cosac Naify, sob coordenação de Pedro Arantes. 
desorganização operária dão condições para que a estrutura manufatureira da produção subsista (Vargas, 1983: 211 - 219).

Como estes diferentes raciocínios deixam claro, a brutalidade da exploração do trabalho na construção habitacional está ligada ao excesso tanto da população empregada em combinação com técnicas construtivas da manufatura quanto da população que, mesmo desempregada, continua a exercer concorrência pelo emprego, pois está confinada à construção civil como um dos polos da oscilação campo-cidade. A incorporação de trabalhadores à produção capitalista destrói seus vínculos com o trabalho quase servil do mundo rural, mas à custa de manter uma parte dela permanentemente fora do trabalho produtivo. Como Marx analisa, o capital age sobre a população "em dois lados ao mesmo tempo":

Por um lado, sua acumulação aumenta a demanda de trabalho, por outro, sua 'liberação' aumenta a oferta de trabalhadores ao mesmo tempo que a pressão dos desocupados obriga os ocupados a pôr mais trabalho em movimento, fazendo, até certo ponto, que a oferta de trabalho seja independente da oferta de trabalhadores (Marx, 2013 [1867]: 715).

O descolamento entre a quantidade de trabalhadores e a quantidade de trabalho que deles pode ser extraída é o eixo das análises populacionais do marxismo. Facilmente aplicado para interpretar a contenção dos salários em épocas de expansão populacional, também dá conta das sucessivas quedas da natalidade nas economias em que é a produtividade que se expande: tudo se passa como se o trabalhador, quando aumenta sua capacidade de produzir, deixa de ter a necessidade de se reproduzir e, "dialeticamente, o aumento da fertilidade da força de trabalho determina uma diminuição da fertilidade da população operária" (Oliveira, 1976: 20).

As análises do modelo de transição demográfica aceitam facilmente que a evolução produtiva afete a fertilidade e mortalidade das populações. A abordagem de Marx apenas acrescenta que a população excedente sempre existirá e, se ela não for mais criada por homens e mulheres, será criada pelas tecnologias que aumentam a produtividade.

\section{Índices da nova demografia da construção civil}

A relação não linear entre população e força de trabalho abre novas interpretações para os termos da demografia contidos na Pesquisa Mensal de Emprego (PME), uma das mais antigas pesquisas econômicas realizadas pelo Instituto Brasileiro de Geografia e Estatística (IBGE) [64].

A População em Idade Ativa (PIA), hoje definida por um único corte etário acima dos dez anos de idade, está presa às variações descritas pelo modelo de transição demográfica e condiciona a formação de força de trabalho apenas como estoque

64 Pesquisa iniciada em 1980 e que passou por diversas revisões metodológicas, sendo a última e mais abrangente realizada em 2001 (IBGE, 2007b), o que permite analisar as gestões Lula e Dilma no governo federal pela mesma metodologia de coleta de dados em áreas metropolitanas. Está prevista para $2015 \mathrm{o}$ cancelamento e definitiva substituição da PME pela Pesquisa Nacional por Amostra de Domicílios Contínua (PNAD Contínua), com nova metodologia, abrangência e periodicidade. 
de contingente populacional. No interior deste contingente, critérios metodológicos recomendados em 2003 pela Organização Mundial do Trabalho deram novos contornos a um subgrupo que é mais importante ao funcionamento do capitalismo, a População Economicamente Ativa (PEA), por definição formada pela soma de duas populações, uma "ocupada" e outra "desocupada". Enquanto o trabalho como "ocupação econômica" tem uma caracterização mínima (pelo menos uma hora diária, mesmo que dedicada a uma produção doméstica sem remuneração), a "população desocupada" é considerada como economicamente ativa quando é composta de "pessoas sem trabalho na semana de referência, mas que estavam disponíveis para assumir um trabalho nessa semana e que tomaram alguma providência efetiva para conseguir trabalho no período de referência de 30 dias" (IBGE, 2002: 4).

A atividade econômica desta população desocupada é justamente, através de "providência efetiva", regular os preços do mercado de trabalho [65].

O Gráfico G-7 contém a evolução destas duas populações economicamente ativas numa retrospectiva da PME tanto na região metropolitana de São Paulo quanto na soma com as demais metrópoles em que há coleta de dados: Rio de Janeiro, Belo Horizonte, Salvador, Recife e Porto Alegre.

G-7|PEA e População Desocupada na RMSP e em 6 RMs - 2003/2013

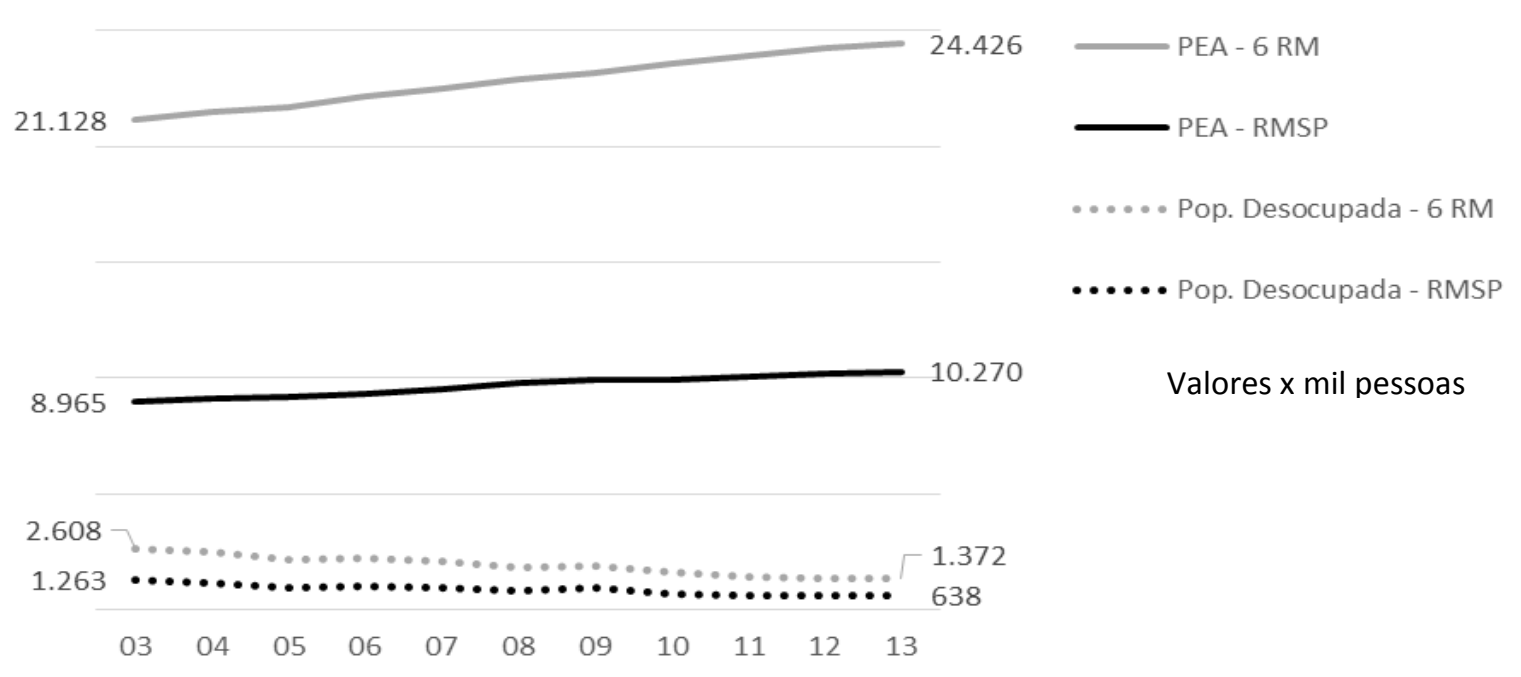

Fonte: elaboração própria com dados da PME/IBGE; a média anual de 2013 usa dados até Agosto.

Mais decisivo que o aumento da PEA (que manteve no período 2003/2013 uma proporção de $60 \%$ em relação à população acima de 10 anos de idade) é a diminuição consistente da sua parcela desocupada, isto é, da massa de trabalhadores cujo desemprego tem a função de impedir a elevação do preço e do valor da força de trabalho. Nas médias anuais verificadas na região metropolitana de São Paulo, os 1,263 milhão de desempregados em 2003 representavam 14,08\% da população economicamente ativa de então, composta

65 Esta população excedente não se confunde portanto com as pessoas em "idade ativa" que se excluem da força de trabalho de forma voluntária ou pelo que IBGE denomina "desalento" na busca de "contato estabelecido com empregadores; a prestação de concurso; a inscrição em concurso; a consulta à agência de emprego, sindicato ou órgão similar; a resposta a anúncio de emprego; a solicitação de trabalho a parente, amigo, colega ou por meio de anúncio; a tomada de medida para iniciar negócio etc." (IBGE, 2012: 295). 
por 8,965 milhões de pessoas. Dez anos depois, além da quantidade absoluta de desempregados ter caído para 638 mil pessoas, o crescimento da PEA na metrópole paulistana, que atingiu o patamar de 10,270 milhões de pessoas, reduziu a taxa de desocupação para $6,21 \%$, uma das mais baixas médias anuais medidas pelo IBGE.

Depois da revisão do CNAE (IBGE, 2007a), a "Pesquisa Mensal de Emprego" passou a decompor seus dados por "grupamentos de atividade econômica". O Gráfico G-8 mostra que, na metrópole de São Paulo, as taxas de desemprego medidos para o grupamento de atividades denominada "construção" foram significativamente menores do que as taxas médias ponderadas para a totalidade da PEA [66].

\section{G-8|Taxa de desocupação média na RMSP - 2003/2013}

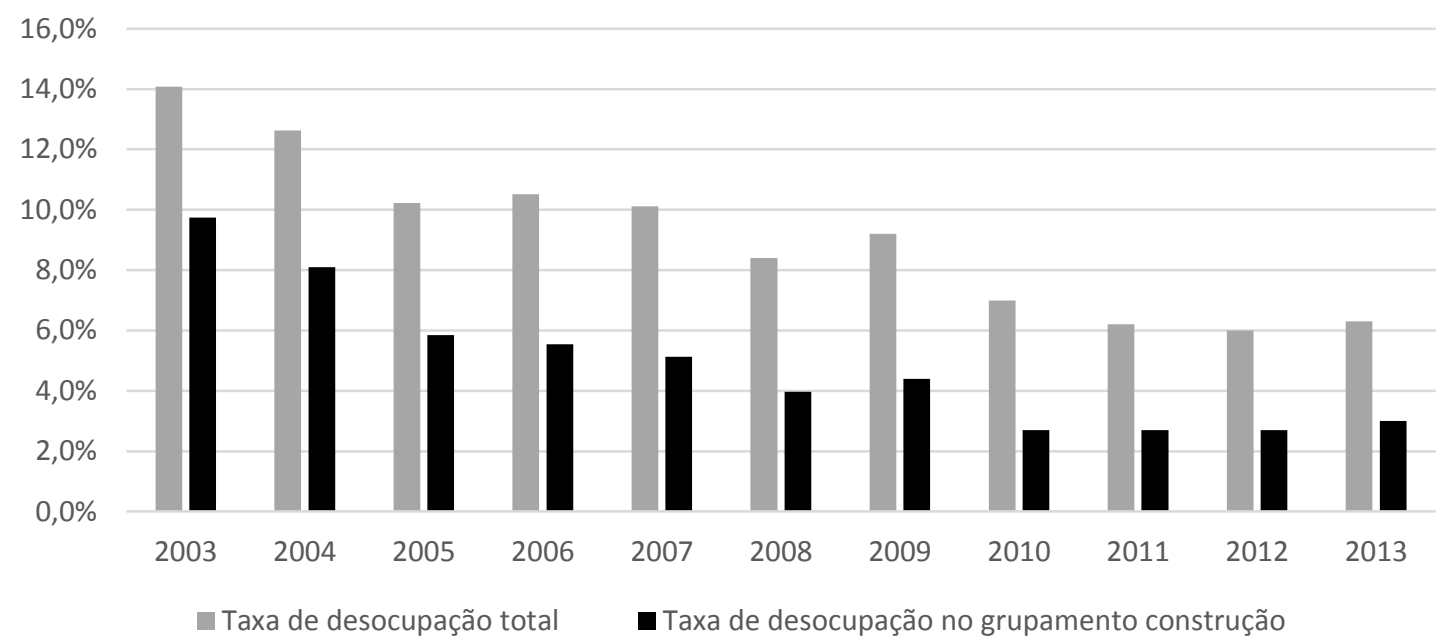

Fonte: elaboração própria com dados da PME/IBGE; a média anual de 2013 usa dados até Agosto.

Ainda no grupamento de atividades da construção, o levantamento da PME de "empregados com carteira de trabalho assinada" indica um crescimento de $86 \%$ na RMSP entre 2003 e 2012. Os números absolutos, que variaram de 132 mil trabalhadores formais para 246 mil, são no entanto extrapolações da amostragem de entrevistas com pessoas residentes na metrópole de São Paulo.

Uma fonte de informações alternativa, a Relação Anual de Informações Sociais (RAIS/MTE), cuja base de coleta de dados são empresas agrupadas conforme sua sede comercial, traz números mais elevados, que aparecem no Gráfico G-9:

66 Por variações metodológicas (entre as quais o conceito de "desemprego oculto"), uma outra tradicional pesquisa sobre a PEA em regiões metropolitanas, a da Fundação Seade (atualizada mensalmente em "http:/ / www.seade.gov.br"), chega a porcentagens mais elevadas de taxa de desemprego, mesmo que mantenha evolução semelhante à da pesquisa mensal do IBGE: queda de 42,6\% no decênio 2002/2012. No entanto, a possibilidade de analisar a PEA por "grupamentos de atividades" torna o uso da pesquisa do IBGE mais interessante que a da Fundação Seade, que incorporou a classificação CNAE 2.0 apenas a partir de 2011. Portanto, seria impossível verificar através desta pesquisa que uma das menores taxas de desocupação média anual da construção - de apenas 1,68\% - aconteceu em 2010, na região metropolitana do Rio de Janeiro. 


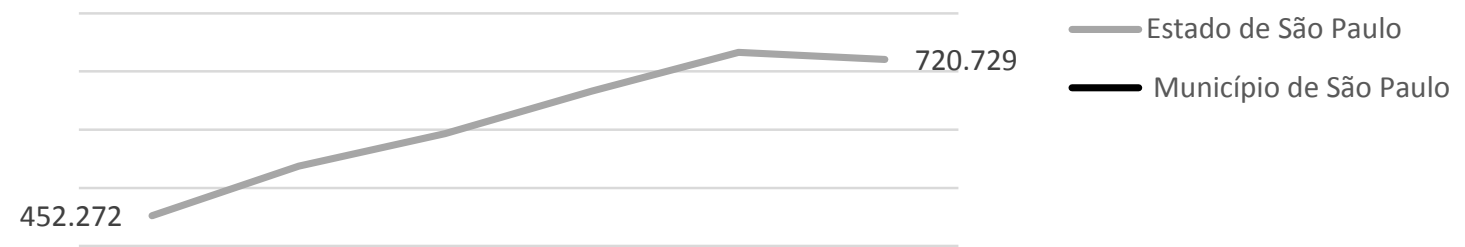

199.094

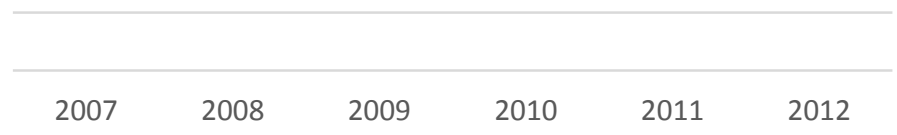

Fonte: RAIS - Ministério do Trabalho e Emprego

As tendências invertidas de desemprego e assalariamento na construção civil resultam em elevações de salário acima de índices de custo de vida ou mesmo de custo de construção. A Tabela T-9 registra a evolução dos salários por hora para os meses de Maio de 2011, 2012 e 2013, data dos dissídios coletivos negociados para todo o Estado de São Paulo, além do salário mensal, calculado para uma carga horária básica de 220 horas, com e sem encargos sociais [67].

T-9|Salário médio de ajudante e profissionais em São Paulo - 2011/2013

\begin{tabular}{l|c|c|c|c|c|c|c}
\multirow{2}{*}{} & \multicolumn{2}{|c|}{ Valor da hora trabalhada } & Salário mensal em MAI13 & \multicolumn{2}{c}{ Variação } \\
\cline { 2 - 8 } & MAI11 & MAI12 & MAl13 & Base & Com encargos & 1 Ano & 2 Anos \\
\hline Ajudante & $\mathrm{R} \$ 3,97$ & $\mathrm{R} \$ 4,26$ & $\mathrm{R} \$ 4,76$ & $\mathrm{R} \$ 1.047,20$ & $\mathrm{R} \$ 1.838,15$ & $10,50 \%$ & $16,60 \%$ \\
\hline Pedreiro & $\mathrm{R} \$ 4,80$ & $\mathrm{R} \$ 5,13$ & $\mathrm{R} \$ 5,80$ & $\mathrm{R} \$ 1.276,00$ & $\mathrm{R} \$ 2.239,76$ & $11,55 \%$ & $17,24 \%$ \\
\hline Carpinteiro & $\mathrm{R} \$ 4,78$ & $\mathrm{R} \$ 5,12$ & $\mathrm{R} \$ 5,76$ & $\mathrm{R} \$ 1.267,20$ & $\mathrm{R} \$ 2.224,32$ & $11,11 \%$ & $17,01 \%$ \\
\hline Armador & $\mathrm{R} \$ 4,73$ & $\mathrm{R} \$ 5,11$ & $\mathrm{R} \$ 5,80$ & $\mathrm{R} \$ 1.276,00$ & $\mathrm{R} \$ 2.239,76$ & $11,90 \%$ & $18,45 \%$ \\
\hline Eletricista & $\mathrm{R} \$ 5,04$ & $\mathrm{R} \$ 5,37$ & $\mathrm{R} \$ 6,06$ & $\mathrm{R} \$ 1.333,20$ & $\mathrm{R} \$ 2.340,17$ & $11,39 \%$ & $16,83 \%$ \\
\hline Encanador & $\mathrm{R} \$ 4,93$ & $\mathrm{R} \$ 5,25$ & $\mathrm{R} \$ 5,95$ & $\mathrm{R} \$ 1.309,00$ & $\mathrm{R} \$ 2.297,69$ & $11,76 \%$ & $17,14 \%$ \\
\hline Pintor & $\mathrm{R} \$ 4,93$ & $\mathrm{R} \$ 5,30$ & $\mathrm{R} \$ 6,05$ & $\mathrm{R} \$ 1.331,00$ & $\mathrm{R} \$ 2.336,30$ & $12,40 \%$ & $18,51 \%$
\end{tabular}

Fonte: elaboração própria com dados do Sinduscon/SP

É preciso considerar ainda que as elevações salariais podem ser majoradas com as remunerações informais da construção habitacional, onde é comum haver prêmios por produtividade que não são regulados por acordos sindicais. De qualquer forma, para a crescente massa de assalariados da construção civil em São Paulo indicada pela RAIS/MTE, os acordos coletivos entre Maio de 2011 e Maio de 2013 proporcionaram aumentos salariais entre 16,60\% e 18,51\%, que ultrapassam em $68 \%$ e $88 \%$ a taxa de inflação de $9,85 \%$ medida no mesmo período

67 Em agosto de 2013 os encargos sociais do setor da construção em São Paulo foram calculados em $175,53 \%$ sobre o salário base. O cálculo realizado pelo Sinduscon/SP se baseia na incidência sobreposta de encargos classificados como "básicos" (com destaque para contribuições ao INSS de 20\% e ao FGTS, de $8 \%$ ), majorados por direitos trabalhistas e acordos coletivos (o de maior peso sendo o almoço fornecido pela empresa). Os informes são publicados mensalmente em www.sindusconsp.com.br. 
pelo Índice de Preços ao Consumidor (IPC-Fipe), tradicionalmente usado em campanhas salariais em São Paulo.

Um índice criado e mantido pelas entidades patronais da construção civil capta esta elevação salarial de uma forma propícia para expor os dilemas em extrair força de trabalho da nova composição populacional brasileira: o Custo Unitário Básico $\left(\mathrm{CUB} / \mathrm{m}^{2}\right)$, calculado mensalmente pelo Sindicato da Indústria da Construção Civil (Sinduscon) desde sua instituição em Dezembro de 1964 pela Lei Federal 4.591. Nesta lei, que regulariza condomínios e incorporações imobiliárias, a tecnocracia militar inseriu dois artigos que obrigaram os departamentos estaduais do Sinduscon a fornecer parâmetros de custo para os diferentes empreendimentos então financiados através do $\mathrm{BNH}$ :
Art. 53. O Poder Executivo, através do Banco Nacional da Habitação, promoverá a celebração de contratos com a Associação Brasileira de Normas Técnicas (ABNT), no sentido de que esta (...) prepare, no prazo máximo de 120 dias, normas que estabeleçam, para cada tipo de prédio que padronizar: I - critérios e normas para cálculo de custos unitários de construção, para uso dos sindicatos (...) Art. 54. Os sindicatos estaduais da indústria da construção civil ficam obrigados a divulgar mensalmente, até o dia 5 de cada mês, os custos unitários de construção a serem adotados nas respectivas regiões jurisdicionais (Lei Federal 4591, de 16DEZ64).

A norma técnica demandada no texto legal à ABNT é representada hoje pela NBR 12.721:2006, que foi reeditada em 2006 após uma revisão que "buscou a modernização do $\mathrm{CUB} / \mathrm{m}^{2}$ e a melhor adaptação à atual realidade (...) uma vez que a antiga norma baseava-se nos processos construtivos de 1964" (Sinduscon/MG, 2007: 17). Trata-se de uma adaptação muito abstrata, a começar pela própria necessidade de adotar projetos padronizados, derivados de doze combinações de área, pavimentos e padrão construtivo para uso residencial (que vão da "residência popular RP1Q" à "Residência Multifamiliar Padrão Alto R16-A"), além de quatro combinações para edifícios comerciais e uma tipologia genérica de galpão industrial, com mil $\mathrm{m}^{2}$ de área.

A adoção do projeto-padrão não deixa de ser funcional diante da pouca diversidade já praticada no mercado imobiliário brasileiro. A maior abstração, portanto, é a estipulação de um mesmo procedimento de cálculo do índice $\mathrm{CUB} / \mathrm{m}^{2}$ para todos os projetos-padrão, que consiste em variar quantidades de um único "lote básico de insumos". Este lote é composto de 25 itens listados como "materiais", 1 item como "equipamento", outro item como "administração" e apenas 2 itens como "mão-de-obra", um referente a horas-trabalho de pedreiro, outro a horas-trabalho de servente. A justificativa para calcular índices de custo de 17 projetos-padrão pela quantificação de um mínimo lote de insumos está numa suposta comensurabilidade com outros itens de orçamento. Na linguagem da NBR 12.721:2006, "as quantidades dos insumos foram extraídas do agrupamento de todos os insumos em famílias cujos itens são correlatos" (ABNT, 2007: 38).

Um projeto-padrão específico interessa de perto esta pesquisa: o "Projeto de Interesse Social - PIS", que é a tipologia de edifício de apartamentos usada em todos os empreendimentos do programa MCMV destinados a famílias de baixa renda na RMSP. A tabela T-10 mostra a quantificação do "lote básico de insumos" desta tipologia-padrão na habitação social em São Paulo: 
T-10|NBR 12.271:2006 - Quantitativo do projeto-padrão PIS

L. $\mid$ LOTE BÁSICO POR M² DE CONSTRUÇÃO

QUANT.

\begin{tabular}{|c|c|c|c|}
\hline A & Mão-de-obra & & \\
\hline 1 & Pedreiro & $\bar{h}$ & 18,07540 \\
\hline 2 & Servente & $\mathrm{h}$ & 6,53232 \\
\hline B & \multicolumn{3}{|l|}{ Material de construção } \\
\hline 3 & Chapa compensado plastificado $18 \mathrm{~mm} \times 2,20 \mathrm{~m} \times 1,10 \mathrm{~m}$ & $m^{2}$ & 0,69418 \\
\hline 4 & Aço CA-50 Ø $10 \mathrm{~mm}$ & $\mathrm{Kg}$ & 7,68513 \\
\hline 5 & Concreto fck= $25 \mathrm{MPa}$ convencional com brita 1 e 2 pré-dosado & $\mathrm{m}^{3}$ & 0,09129 \\
\hline 6 & Cimento CP-32 II & $\mathrm{Kg}$ & 40,90577 \\
\hline 7 & Areia média & $\mathrm{m}^{3}$ & 0,12619 \\
\hline 8 & Brita $n \circ 2$ & $\mathrm{~m}^{3}$ & - \\
\hline 9 & Bloco cerâmico para alvenaria de vedação $9 \mathrm{~cm} \times 19 \mathrm{~cm} \times 19 \mathrm{~cm}$ & un. & - \\
\hline 10 & Bloco de concreto sem função estrutural $19 \mathrm{~cm} \times 19 \mathrm{~cm} \times 39 \mathrm{~cm}$ & un. & 14,39994 \\
\hline 11 & Telha fibrocimento ondulada $6 \mathrm{~mm} \times 2,44 \mathrm{~m} \times 1,10 \mathrm{~m}$ & $m^{2}$ & 0,20309 \\
\hline 12 & Porta interna semi-oca para pintura $0,60 \mathrm{~m} \times 2,10 \mathrm{~m}$ & un. & 0,16744 \\
\hline 13 & Esquadrias de correr de alumínio anodizado natural & $m^{2}$ & - \\
\hline 14 & Janela de correr de chapa dobrada & $\mathrm{m}^{2}$ & 0,18303 \\
\hline 15 & Fechadura interna média cromada & un. & 0,08541 \\
\hline 16 & Azulejo branco $15 \mathrm{~cm} \times 15 \mathrm{~cm}$ & $m^{2}$ & 0,19836 \\
\hline 17 & Tampo (bancada) de mármore branco 2,00 m x 0,60 m & un. & 0,03345 \\
\hline 18 & Placa de gesso liso $60 \mathrm{~cm} \times 60 \mathrm{~cm}$ & $m^{2}$ & 2,13677 \\
\hline 19 & Vidro liso transparente $4 \mathrm{~mm}$ colocado com massa & $\mathrm{m}^{2}$ & 0,10633 \\
\hline 21 & Tinta látex PVA & L & 2,57219 \\
\hline 22 & Emulsão asfáltica impermeabilizante & $\mathrm{Kg}$ & 0,72716 \\
\hline 23 & Fio de cobre anti-chama, isolamento $750 \mathrm{~V}$, \# 2,5 mm² & $\mathrm{m}$ & 35,19608 \\
\hline 24 & Disjuntor tripolar $70 \mathrm{~A}$ & un. & 0,43300 \\
\hline 25 & Bacia sanitária branca com caixa acoplada & un. & 0,03687 \\
\hline 26 & Registro de pressão cromado $\varnothing 1 / 2 "$ & un. & 0,19898 \\
\hline 27 & Tubo de ferro galvanizado com costura $\varnothing 21 / 2 "$ & $\mathrm{~m}$ & 0,24006 \\
\hline 28 & Tubo de PVC-R rígido reforçado para esgoto $\varnothing 150 \mathrm{~mm}$ & $\mathrm{~m}$ & 0,54821 \\
\hline $\mathrm{C}$ & Equipamento & & \\
\hline 29 & Betoneira de 320 litros - locação & Dia & 0,14045 \\
\hline $\mathrm{D}$ & Administração & & \\
\hline 30 & Engenheiro & $\mathrm{H}$ & 0,41008 \\
\hline
\end{tabular}

Fonte: reprodução com adaptações de ABNT, 2007: 28 (Tabela 4).

A norma técnica não publica desenhos de arquitetura, mas a descrição é a da conhecida "tipologia $\mathrm{H}^{\prime}$, edifício de apartamentos em que a escada coletiva, sempre servindo ao máximo de cinco pavimentos, separa unidades habitacionais de $45 \mathrm{~m}^{2}$ em pares dispostos nos extremos de seu patamar de giro:

Composição do edifício: pavimento térreo e quatro pavimentos-tipo. Pavimento térreo: hall, escada, 4 apartamentos por andar, com 2 dormitórios, sala, banheiro, cozinha e área de serviço. Na área externa estão localizados o cômodo da guarita, com banheiro e central de medição. Pavimento-tipo: hall, escada, 4 apartamentos por andar, com 2 dormitórios, sala, banheiro, cozinha e área de serviço. Área real: 991,45 m² (ABNT, 2006: 19).

As primeiras linhas da tabela T-10 mostram certa razoabilidade no uso da "correlação de materiais" para representar custos complexos através de poucos itens. O jogo de fôrma, aço e concreto indica com clareza uma estrutura 
convencional de concreto armado moldado in situ, confirmada pela escolha de uma betoneira de 320 litros para indicar o custo de equipamentos. Ainda assim, a opção por esta técnica construtiva não impede que as quantidades relativas apareçam distorcidas: para cada metro quadrado de área construída há $0,7 \mathrm{~m}^{2} \mathrm{de}$ chapa para forma (linha "3"), 7,7 kg de aço (linha "4") e 90 litros de concreto de média resistência (linha " 5 "). A linha " 6 " registra um consumo de quatro sacos de aglomerante a cada $5 \mathrm{~m}^{2}$ de área construída, que é uma indicação exagerada de técnicas de revestimentos e contrapiso tradicionais [68].

Já a especificação na linha "10" de que o bloco de concreto é um bloco "sem função estrutural" leva a NBR 12.721:2006 a adotar tecnologia convencional lá onde ela é menos empregada, na tipologia "Projeto de Interesse Social". Apesar de ter dimensões da "família 40" (19 x 39 × 39 × cm), o bloco de concreto aparece na norma técnica com a mesma função de vedação que o tem o bloco cerâmico de dimensão $9 \times 19 \times 19 \times \mathrm{cm}$ (o conhecido "bloco baiano de 8 furos"), com quantidade zerada para a tipologia PIS. Desta forma, todas as possibilidades de reorganização do processo de trabalho vistos anteriormente a respeito da alvenaria de blocos estruturais, bem como seus rearranjos orçamentários, deixam de ser representadas no índice $\mathrm{CUB} / \mathrm{m}^{2}$.

Questionar as opções tecnológicas dos materiais listados no "lote básico de insumos" pode ser injustificado, pois o procedimento de intercambiar "itens correlatos" permite ao menos uma concepção dinâmico daquilo que num canteiro de obras pode ser entendido como seu capital constante: os macro-itens "material", "equipamento" e até mesmo "administração", caso em que, segundo a cartilha "Custo Unitário Básico", a carga horário do engenheiro-civil pode representar também custos de combustíveis, lubrificantes, cópias xerográficas e sondagens de solo (Sinduscon/MG, 2007: 51).

O mesmo não pode ser dito do macro-item "mão-de-obra", porque a hora trabalhada de pedreiro só serve para intercambiar horas de outros profissionais da construção civil, enquanto que a hora trabalhada de servente é um dos poucos itens de CUB sem correlato (Sinduscon/MG, 2007: 45).

Mais injustificado, no entanto, é o estabelecimento por norma técnica de uma quantidade fixa destas horas para as unidades de área de cada projeto-tipo. Isto significa a imobilização do capital variável do canteiro de obras e o impedimento que os custos de edificação incorporem alterações na relação entre trabalho vivo e trabalho morto, que equivalem à relação entre "horas-homem" e " $\mathrm{m}^{2}$ " tão estudada pelas pesquisas de Gestão da Produção na engenharia civil.

A tabela T-11 traz estas quantidades fixas de horas trabalhadas na NBR 12.721:2006 para os seis projetos-tipos residenciais de acabamento considerado "Padrão Baixo":

68 A representação dos custos de administração (linha “ $\mathrm{D}$ ”) através da carga horária de um engenheiro civil é esclarecedora por sua carga ideológica, pois reforça uma divisão do trabalho que é antes social do que técnica ao apartar o engenheiro da mão-de-obra do canteiro para que ele a confronte unicamente como represente do capital. 
T-11|CUB - Horas de pedreiro e servente por $\mathrm{m}^{2}$ de projeto-tipo

\begin{tabular}{|c|c|c|c|}
\hline \multirow{2}{*}{ Projeto Padrão de Padrão Baixo para cálculo de CUB } & \multicolumn{2}{|c|}{ Horas $/ m^{2}$ constr. } & \multirow{2}{*}{$\begin{array}{c}\text { Área Real } \\
\left(\mathrm{m}^{2}\right)\end{array}$} \\
\hline & Pedreiro & Servente & \\
\hline PIS: Projeto de Interesse Social (Térreo + 4 pav., 20 apt. de 2 dorm.) & 18,08 & 6,53 & 991,45 \\
\hline RP1Q: Residência Popular (unifamiliar, 1 dorm.) & 28,14 & 22,59 & 39,56 \\
\hline R1-B: Residência Padrão Baixo (unifamiliar, 2 dorm.) & 26,43 & 9,72 & 58,64 \\
\hline PP-B: Prédio Popular Padrão Baixo (Térreo + 3 pav., 16 apt. de 2 dorm.) & 21,74 & 8,85 & $1.415,07$ \\
\hline R8-B: Residência Multifamiliar Padrão Baixo (Térreo + 7 pav., 32 apt.) & 20,52 & 8,20 & $2.801,64$ \\
\hline GI - Galpão Industrial (com administração, 2 banheiros e vestiário) & 13,97 & 9,26 & $1.000,00$ \\
\hline
\end{tabular}

Fonte: NBR 12.271: 2006: (Tabela 9)

Na NBR 12.721:2006, o tempo de trabalho de pedreiro e servente por unidade de área é menor no projeto-padrão PIS do que nos demais projetos-tipo residenciais (principalmente em relação à térrea, minúscula e arcaica "Residência Popular RP1Q"). A pouca demanda de mão-de-obra traz as marcas da origem do projetopadrão PIS na compra pública da habitação social sob a imposição de um programa de qualidade na construção civil (assunto principal da Parte 2). Pelo menos é o que se pode deduzir da seguinte observação presente na Tabela 4 da NBR 12.712:2006: “a orçamentação e as especificações deste padrão [PIS] foram baseadas nos projetos do Programa de Arrendamento Residencial - PAR, da Caixa Econômica Federal" (ABNT, 2006: 40).

A menção ao Programa de Arrendamento Residencial como referência para estabelecer o custo básico da tipologia padrão da habitação social cria uma ligação direta com o programa MCMV, pois a gestão do PAR pela Caixa Econômica Federal, baseado na contratação direta da unidade habitacional junto a empresas construtoras, que a repassam ao banco antes do arrendamento/leasing para a família moradora, serviu como modelo para formatar o grosso das operações para a baixa renda do programa MCMV [69].

Como o orçamento de referência do projeto-tipo PIS foi transplantado do setor de engenharia da Caixa Econômica Federal ao invés de elaborado pelos comitês técnicos da $\mathrm{ABNT}$, ele possui o mais baixo índice de utilização de mão-de-obra por unidade de área construída entre as tipologias residenciais da NBR 12.721:2006. Apenas um projeto-tipo comercial, justamente qualificado como "Galpão Industrial - GI" (com índices reproduzidos no pé da tabela T-11), possui uma proporção menor de capital variável em relação ao capital constante.

Ainda que a composição orgânica do capital no projeto-tipo PIS seja singular, sua menor demanda de trabalho está congelada como nas composições de custo das demais tipologias-padrão. Ora, num quadro de elevação de salários acima da inflação, se a quantidade de horas trabalhadas por unidade de área está fixada

69 Daí o apelido que o programa MCMV recebeu dos técnicos da Caixa Econômica Federal logo após seu lançamento: "PAR-ecido". Para além do trocadilho, esta referência está registrada no próprio Plano Nacional de Habitação, quando precisou reconhecer no programa MCMV uma origem externa ao Sistema Nacional de Habitação de Interesse Social: "o programa Minha Casa Minha Vida utiliza o mesmo arcabouço jurídico e financeiro de um programa, já existente: o Programa de Arrendamento Residencial (PAR) " (MCidades, 2009: 193). Estas diferentes linhagens institucionais são detalhadas no capítulo 5. 
em norma, o resultado inevitável é a participação cada vez maior deste item no seu custo estimado, tal como aparece no gráfico G-10:

\section{G-10|Composição do CUB PIS no Estado de São Paulo - 2007/2013}

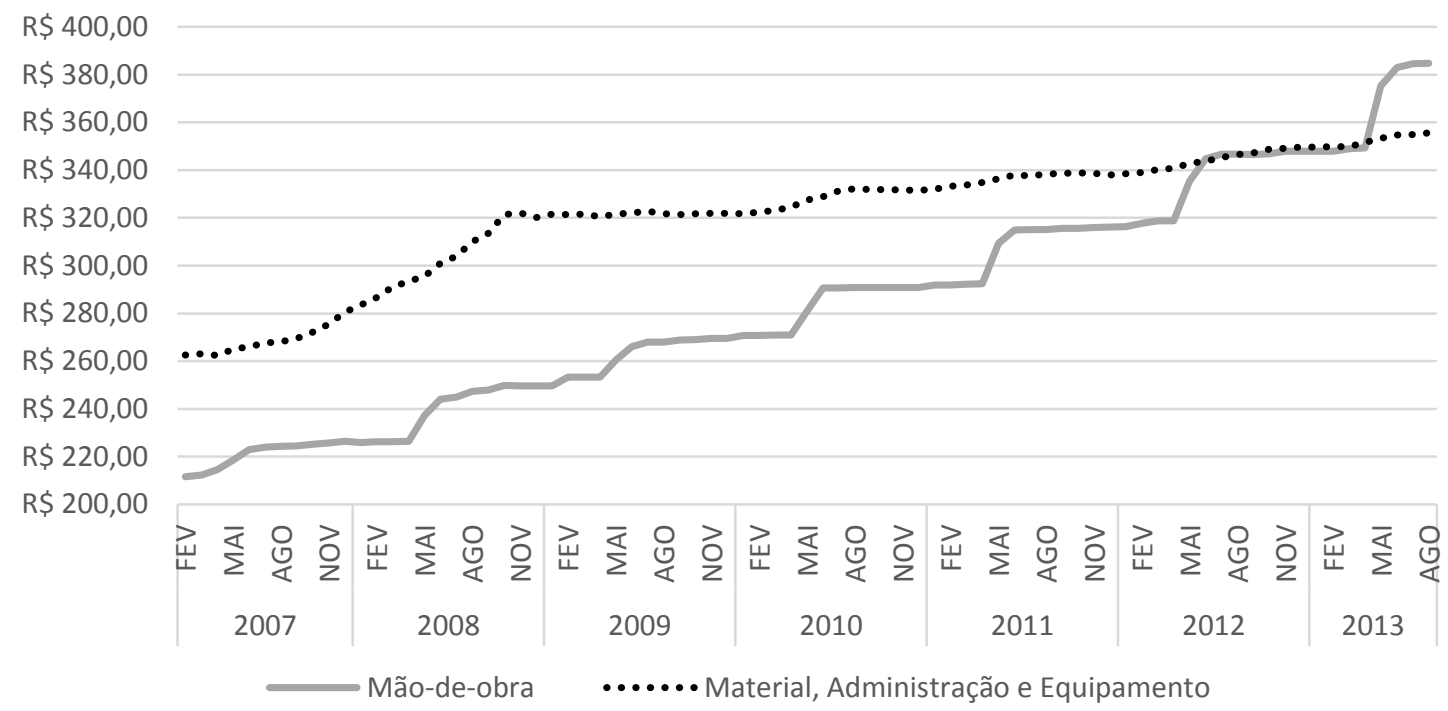

Fonte: elaboração própria com dados do Sinduscon/SP

Nos meses que antecedem a crise financeira internacionalizada pelo colapso do sistema hipotecário americano em Setembro de 2008, a curva referente aos macroitens de material, administração e equipamentos apresentou uma alta acentuada no cálculo do CUB/m²: passou do patamar de $\mathrm{R} \$ 260$ para $\mathrm{R} \$ 320$ em pouco mais de um ano e meio. Após a eclosão da crise financeira, a alta se interrompe por período semelhante até retomar uma trajetória pari passu com a inflação monetária brasileira. A evolução de valores na curva referente ao macro-item "mão-de-obra" é diferente: a cada mês de dissídio coletivo na construção civil em São Paulo, em Maio, aparecem saltos de valores, que são unidos por elevações semelhantes às dos demais custos. É, portanto, uma curva invertida em relação à curva de participação da população desocupada na PEA. Em Maio de 2013, o custo da mão-de-obra se tornou majoritário no cálculo do CUB da tipologiapadrão PIS, fato até então inédito na história do índice [70].

A dificuldade em incorporar alterações de produtividade pelo índice CUB $/ \mathrm{m}^{2}$ deixa evidente ao próprio setor da construção habitacional que, frente à escassez de população excedente e aos aumentos de salário acima da inflação, a construção por manufatura tornou-se inviável, se não do ponto de vista de

70 Na mesma época, um outro índice ligado à construção civil, o Índice Nacional de Custo da Construção (INCC), passou a ser criticado por empresas construtoras por subestimar a elevação da mão de obra. Calculado pela Fundação Getúlio Vargas a partir de uma coleta de preços de 51 itens de materiais e 16 itens de mão-de-obra em sete capitais brasileiras, o INCC é adotado há décadas pelo mercado imobiliário, onde é utilizado por acordo entre partes em contratos de compra e venda de imóveis, principalmente para a comercialização em fase de projeto. O INCC não tem, portanto, a vinculação legal que caracteriza o $\mathrm{CUB} / \mathrm{m}^{2}$, que é uma moeda escritural obrigatória no registro da incorporação, mas, por reajustar uma realização de valor, o seu descompasso com preços de mercado produz reações mais rápidas das empresas imobiliárias, como aparece nesta declaração do presidente da construtora de porte médio Bianchini Arquitetura e Construção: "atuamos no estado de São Paulo, onde o custo de mão-de-obra está entre os mais altos do país, e sofremos a concorrência das grandes incorporadoras, que atraem nossos trabalhadores com diversos benefícios (...) O INCC só reflete a correção monetária do piso salarial, quando na prática não se consegue mais contratar trabalhadores pelo piso" (Moura Fé, 2013: 42). 
demografia, pelo menos do ponto de vista comercial. Sua alteração técnica desde então é uma necessidade não apenas ideológica como também material.

O impasse do $\mathrm{CUB} / \mathrm{m}^{2}$ diante das transformações no mercado de trabalho brasileiro serve também para ressaltar a diferença entre "composição de valor" e "composição orgânica" do capital, introduzidas por Marx apenas na terceira edição do "Capital" e com margens para diferentes interpretações. A composição de valor registra alterações no balanceamento entre capital constante e capital variável que são determinadas por forças sociais que a empresa capitalista isoladamente não pode controlar, tais como monopólios de fornecimento, preços internacionais, custos tributários, infraestrutura urbana ou, como é o caso, uma elevação salarial diretamente provocada pela redução da população excedente na construção civil. A alteração de ordem técnica que a empresa capitalista impõem sobre sua produção com o preciso objetivo de reagir contra tais forças sociais é o que dá sentido para uma outra composição de seu capital, desta vez dita "orgânica". Segundo David Harvey, esta categoria permite interpretar a transformação do capital através do domínio tecnológico que ele procura exercer sobre sua própria produção:

Marx apparently intended to reserve the term 'organic composition' to indicate those shifts in technology within an enterprise that affect the value composition of capital. It is a label that identifies a particular source of shifts in value composition. The significance of such an identification lies in this: technological mix within the enterprise is broadly under the control of individual capitalist, who can and do (as far as they are able) alter it in their restless pursuit of surplus value, either in response to competition or out of concern for the state of class struggle. The dynamics of such a process can be understood regardless of the fluctuation costs of inputs into production (Harvey, 2006 [1982]: 127).

Um índice que se propusesse a captar uma alteração tecnológica contra o aumento salarial e a queda do desemprego precisaria mostrar as variações relativas na construção civil entre a quantidade de trabalhadores (a população ocupada do setor econômico) e o valor que ela produz nas empresas construtoras. A "Pesquisa Anual da Indústria da Construção" - PAIC, realizada desde 2002 pelo IBGE, possibilita aproximar estas variações no Brasil, ainda que de forma limitada aos dados agregados para todo o país e conforme a nova classificação das atividades econômicas no Brasil em 2007 (CNAE 2.0). O mais recente volume editado reúne informações até o ano de 2010 (IBGE, 2012) e permite comparar dados econômicos da "indústria da construção" imediatamente anteriores e posteriores à crise financeira internacional iniciada em Setembro de 2008 e ao lançamento do programa MCMV em abril de 2009.

A unidade de análise da PAIC é a "empresa de construção" e seu universo é obtido pelo cruzamento dos dados de CNPJ com atividades classificadas como "construção" (item "F" do CNAE 2.0) no Cadastro Central de Empresas Cempre. São coletados dados por questionário padrão da totalidade das empresas que empregam mais de 30 pessoas e, por amostragem, das demais empresas, até o limite de 5 empregados. A pesquisa integra o Sistema de Contas Nacionais e, portanto, o cálculo do Produto Interno Bruto (IBGE, 2013: 11).

Os principais dados agregados para o Brasil estão na tabela T-12, com valores em Reais deflacionados para o período entre 2007 e 2010. Na tabela, é possível 
comparar altas expressivas tanto de receitas e despesas das empresas construtoras quanto no número de pessoas físicas e jurídicas:

T-12|Dados gerais da indústria da construção na PAIC 2010

\begin{tabular}{l|c|c|c|c|c} 
& 2007 & 2008 & 2009 & 2010 & Variação \\
\hline Empresas ativas (milhares) & 52,9 & 57,1 & 63,7 & 79,4 & $\mathbf{4 9 \%}$ \\
\hline Pessoal ocupado (milhões) & 1,576 & 1,806 & 2,044 & $\mathbf{2 , 4 7 9}$ & $\mathbf{5 7 \%}$ \\
\hline Receita operacional líquida (R\$ bilhões) & 124,46 & 154,58 & 186,29 & $\mathbf{2 4 5 , 1 6}$ & $\mathbf{9 7 \%}$ \\
\hline Valor das obras e serviços (R\$ bilhões) & 123,80 & 158,69 & 190,84 & $\mathbf{2 5 0 , 0 4}$ & $\mathbf{1 0 2} \%$ \\
\hline Gastos com pessoal (R\$ bilhões) & $\mathbf{2 8 , 9 7 9}$ & $\mathbf{3 8 , 7 2 5}$ & $\mathbf{4 8 , 1 6 6}$ & $\mathbf{6 3 , 1 2 8}$ & $\mathbf{1 1 8 \%}$
\end{tabular}

Fonte: adaptado de IBGE, 2013: 27. Os valores estão deflacionados para o período entre 2007 e 2010.

No curto período entre 2007 e 2010, as empresas ativas no setor da construção civil (cujo número aumentou em quase 50\%) passaram a empregar $57 \%$ mais trabalhadores, para os quais destinaram um montante por sua vez maior em $118 \%$ na rubrica "gastos com pessoal". Este montante inclui, além de salários diretos, "contribuições para previdência social; FGTS; contribuições para previdência privada; indenizações trabalhistas e por dispensas incentivadas; e benefícios concedidos aos empregados" (IBGE, 2012: 15), itens incorporados pelos Sinduscon estaduais como encargos sociais [71].

Há portanto uma desproporção entre aumento de "pessoal ocupado" e "gastos com pessoal". A informação mais importante na tabela T-12 é que o valor dos itens "Receita operacional líquida" e "Valor das obras e serviços", que são medidas diretas do valor da produção, cresceram acompanhando mais de perto o valor destinado à massa salarial e não o acréscimo de população trabalhadora. Isto indica que as empresas construtoras brasileiras investiram e extraíram valor da força de trabalho entre 2007 e 2010 numa proporção muito maior do que o aumento de trabalhadores. Assim, o aumento relativo da massa salarial sobre a valorização do capital, isto é, o aumento de capital variável sobre capital constante, não resultou da manutenção de formas convencionais de exploração do trabalho, mas sim da introdução de novas e mais produtivas formas de extrair valor da força de trabalho. Esta circunstância, em que diminui a quantidade de trabalhadores mas não o montante de seus salários em relação à quantidade produzida, é bem descrita por Marx:

Exercendo o comando de um número igual ou até decrescente de trabalhadores, o capital variável cresce, no entanto, se o trabalhador individual fornece mais trabalho e, com isso, aumenta seu salário, ainda que o preço do trabalho se mantenha igual ou caia, só que num ritmo mais lento do que o do aumento da massa de trabalho. O crescimento do capital variável torna-se, então, o indice de mais trabalho, mas não de mais trabalhadores ocupados. Todo capitalista tem interesse absoluto em extrair uma determinada quantidade de trabalho de um número menor de trabalhadores, em vez de extraí-lo por um preço igual

71 Sobre os salários indiretos na construção civil, ver nota 67. Os valores registrados como "gastos com pessoal" são circunscritos à massa de salários e benefícios de todas as empresas do setor da construção, chegando às subcontratadas. Isto evita o equívoco de outra rubrica do PAIC/IBGE, sob a denominação "salários, retiradas e outras remunerações", que mistura "salários fixos, pró-labore, retiradas de sócios e proprietários, honorários, comissões, ajudas de custo, $13^{\circ}$ salário, férias, gratificações e participações nos lucros dos empregados e administradores", que são pagos sem distinção "ao pessoal ocupado assalariado ligado ou não à construção e ao pessoal ocupado não assalariado (proprietários e sócios) " (IBGE, 2012: 19). 
ou até mesmo mais barato de um número maior de trabalhadores. No último caso, o dispêndio de capital constante aumenta na proporção da massa de trabalho posta em movimento. No primeiro caso, ele aumenta mais lentamente. Quanto maior a escala de produção, tanto mais decisivo é esse motivo e seu peso aumenta com a acumulação do capital (Marx, 2013 [1867]: 711).

Portanto, a última Pesquisa Anual da Indústria da Construção registra no intervalo entre 2007 e 2010 que, para obter uma elevação de 102\% no valor em obras e serviços (e $97 \%$ na receita líquida), as empresas de construção elevaram seus "gastos com pessoal" numa proporção um pouco maior, em $118 \%$, mas para captar a força de trabalho de um contingente de trabalhadores que cresceu em $57 \%$. Há, desta forma, uma elevação da produtividade que não se dá pela compressão da massa salarial, como era comum nos relatos dos anos 1970-80. Tais aumentos de salário a serviço de um aumento de produtividade não podem ser observados isoladamente quer na demografia das taxas de emprego e desemprego, quer em índices de custo que imobilizam as variações da composição orgânica do capital.

Outra informação importante da PAIC é que a valorização do capital, se ultrapassa o aumento de trabalhadores, ultrapassa também e em maior grau o aumento do número de empresas. Esta informação, combinada ao aumento da produtividade do trabalho, indica que está em curso no Brasil um significativo processo de centralização de capital.

Entre os dados que a PAIC distribui por "porte de empresa", que é medida unicamente pela quantidade de empregados, está uma comparação da elevação da receita operacional entre 2007 e 2010. Em 2007, as empresas com mais de 250 empregados detinham $47,8 \%$ do total de $\mathrm{R} \$ 125$ bilhões de receita operacional da construção civil, enquanto que, em 2010 , detinham $52,8 \%$ da receita total de $\mathrm{R} \$$ 245 bilhões (IBGE: 2012: 30). Os valores absolutos e a variação percentual aparecem no gráfico G-11 [72].

G-11|PAIC - Receita bruta por porte da construtora - 2007/2010

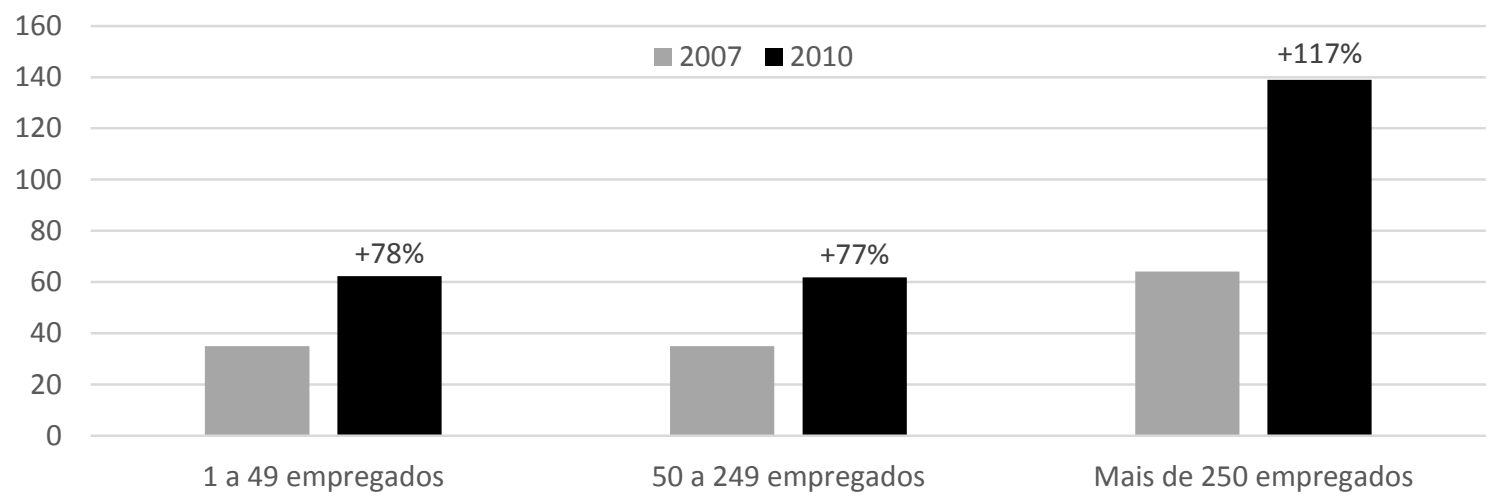

Fonte: IBGE: 2012: 30. No eixo "Y", valores deflacionados em bilhões de reais.

Uma pesquisa encomendada pela Câmara Brasileira da Indústria da Construção - CBIC (FGV, 2012) faz uma análise de salário médio e produtividade por porte de empresa a partir da base de dados da PAIC para o período entre 2003 e 2009.

72 A definição de "grande empresa" para a empregadora de mais de 250 pessoas segue a Recomendação 2003/361/CE da Comunidade Europeia. 
Pelo conceito de "produtividade total dos fatores", que combina a relação entre produto não apenas com a quantidade de trabalhadores como também com a quantidade de equipamentos e instalações, o estudo realizado pela Fundação Getúlio Vargas conclui que:

De 2003 a 2009 a produtividade total dos fatores (PTF) cresceu à taxa média de 1,2\% ao ano, esse resultado positivo se deve ao crescimento de 3,1\% ao ano da PTF no período mais recente, de 2006 a 2009. O resultado favorável de evolução da produtividade deve ser atribuído exclusivamente ao desempenho das maiores empresas (com 30 ou mais pessoas ocupadas) no período de 2006 a 2009. Isso significa que, nos três últimos anos da pesquisa, o grupo das maiores empresas expandiu o produto (valor adicionado) em um ritmo superior ao do aumento do estoque de capital e de mão-de-obra (FGV, 2012: 10).

A alta salarial se revela então um derradeiro fator a contribuir com a centralização de capital, à medida que penaliza unicamente a produtividade das empresas construtoras de menor porte, que a pesquisa da FGV delimita no patamar de 30 empregados. Em relação a estas, as grandes construtoras pagam um salário médio $65 \%$ maior, mas os ganhos de produtividade que acumularam até 2009 foram consistentemente superiores ao aumento salarial:

Quanto ao comportamento dos salários, de 2003 a 2009 o grupo das menores empresas concedeu reajuste médio real de 2,3\% ao ano. Essa taxa é pouco superior ao crescimento médio de $1,8 \%$ ao ano da produtividade do trabalhador dessas construtoras. Além de pagar salários maiores, o grupo das maiores empresas elevou o salário ao ritmo de 4,5\% ao ano e, ainda assim, essa taxa foi superada pelo crescimento de 6,7\% ao ano da produtividade do trabalhador. A julgar por esses resultados, a tarefa das menores construtoras de atrair e reter mão-de-obra especializada tem se tornado cada vez mais difícil, sobretudo em um contexto em que a produtividade do trabalhador das menores empresas cresce a uma taxa três vezes menor que a das maiores empresas (FGV, 2012: 45).

A combinação entre centralização de capital e aumento da produtividade do trabalho é um fenômeno observado desde o início do capital monopolista:
É evidente que a acumulação, o aumento gradual do capital por meio da reprodução que passa da forma circular para a espiral, é um procedimento extremamente lento se comparado com a centralização, que só precisa alterar o agrupamento quantitativo dos componentes do capital social. O mundo ainda careceria de ferrovias se tivesse de ter esperado até que a acumulação possibilitasse a alguns capitais individuais a construção de uma estrada de ferro. Mas a centralização, por meios das sociedades por ações, concluiu essas construções num piscar de olhos. E enquanto reforça e acelera desse modo os efeitos da acumulação, a centralização amplia e acelera, ao mesmo tempo, as revoluções na composição técnica do capital, que aumentam a parte constante deste último à custa de sua parte variável, reduzindo, como isso, a demanda relativa de trabalho (Marx, 2013 [1867]: 703).

Combinada com a centralização de capitais, a "redução da demanda relativa de trabalho" reduz não a população ocupada, mas seu crescimento em relação ao valor das empresas. Este é exatamente o processo de acumulação de capital em curso na construção civil brasileira e, para conduzir as estatísticas de volta para o canteiro de obras, é oportuno observar como ele afeta uma forma de trabalho em especial: o trabalho maximamente desqualificado do "servente de obra". 


\section{O servente e o concreto}

No quadro teórico em que a construção habitacional brasileira era descrita pela forma de produção da manufatura, o trabalhador que a caracterizava com mais precisão não era o profissional formado na habilidade manual ou organizado à semelhança de uma corporação, mas sim o "servente de obra", tão desprovido de especialização que também admite a denominação "servente-geral". É sobre este trabalhador - e não sobre os profissionais qualificados, sejam eles oficiais, meio-oficiais, encarregados ou mestres - que verdadeiramente recai o massacre, a degradação e a superexploração denunciada pela literatura acadêmica a respeito da construção como manufatura sob domínio do capital [73].

Ao investigar uma outra e mais ambígua denominação do servente - o "peão de obra" - Alain Morice percebe que estas violências se alinham numa ideologia que desqualifica em conjunto as relações de produção no canteiro de obras:

Na prática, esse vocábulo reflete uma reveladora confusão entre o todo e a parte. Com efeito, ele é usado, segundo cada caso (inclusive pelos próprios interessados), para apontar apenas os serventes - fala-se também de 'peãozada' - ou o conjunto dos operários da obra. Essa confusão reflete uma desvalorização indistinta, onde a parte a mais aniquilada desses operários serve de referência semântica para todos, como se os profissionais qualificados não tivessem muito mais valor do que os serventes. Por outro lado, mesmo que, frente às humilhações e ao sofrimento amplamente compartilhados, os profissionais dizem 'nós, os peões...' quando falam de si, dificilmente aceitam ser chamados de 'peões' pelos serventes" (Morice, 1992:35).

A ideologia está em impor uma identidade negativa (o "peão" como migrante do campo, inconstante, desprovido de vontade e ambição de se aperfeiçoar numa profissão) para justificar o arcaísmo das relações de produção e limitar a generalização da relação salarial contratual [74].

O brilho da análise de Morice se estende a uma análise da autoconsciência do trabalhador envolvida na aceitação deste papel social:

A recusa mental em encarar a humilhação, os riscos e todos os sofrimentos levados pela condição de peão corresponde a um mecanismo de sobrevivência, no qual o desafio é a simples possibilidade de aguentar a permanência nesse meio hostil (...) Uma consciência geral muito aguda do esmagamento ligado à condição de peão é mascarada pela negação das modalidades particulares do mesmo. Quer nas questões de salário, quer nas de contratação, ou ainda nas de formação, a reação é sempre a mesma: 'eu sei que eles estão me enrolando, mas nem quero saber como'. Fechar os olhos para suportar, tal é o conteúdo da suposta inconsciência (Morice, 1996: 45).

A resignação política do trabalho e o esforço ideológico do capital envolvidos na conversão do "peão" em trabalhador universal da manufatura possui uma

73 É comum que a violência da relação de produção a que se submete o servente de obra seja associada a condições de seu trabalho: salário, escalas de horário, alojamento, arbítrio de mestre e encarregados. No entanto, a primeira violência é o próprio trabalho, marcado pelo incessante deslocamento de carga sobre ombros, diretamente no caso de latas e sacos, ou através da musculatura dos braços, no caso de carrinhos de mão e giricas. As lesões musculares no abdómen e as ósseas no dorso são inevitáveis.

74 O documentário "Peões", realizado por Eduardo Coutinho em 2004, explora o embate entre modernidade e atraso envolvida nesta designação do trabalhador na mais combativa geração do sindicalismo brasileiro, a dos metalúrgicos liderados por Lula. 
justificativa material na "lei de população" do capitalismo: é através do servente que se estabelece a conexão entre canteiro de obras e a população excedente na construção civil entre os anos 1960 e 1980, as décadas de migração campo-cidade no Brasil. Como observador privilegiado deste período, Sérgio Ferro anota o seguinte sobre o servente de obra:

Sua posição é disputadíssima: constitui ponto privilegiado de pressão do exército de reserva de força de trabalho. A manufatura particular, seguindo seus gráficos Pert, contrata e descontrata initerruptamente os operários desta área sem preocupações, pois sabe que a oferta é maciça a qualquer momento (Ferro, 2006 [1969]: 89-90).

Segundo Sérgio Ferro, o que se transmite através deste ponto de pressão (por onde se faz presente no canteiro de obras a força demográfica da fase mais aguda de urbanização do Brasil) é a "pura energia física auto-movente" do servente (Ferro, 2006 [1969]: 89-90), um estoque de energia social tão disponível à construção civil quanto a qualquer outro setor carente de trabalho não especializado:

A mobilidade é reforçada pelo comportamento do próprio servente: restrito às tarefas primárias para as quais nenhum aprendizado é necessário, mas sempre se vendendo como "ser em transição", impossibilitado, portanto, de aumentar o valor de sua força de trabalho pela aquisição de maior qualificação no próprio trabalho, procura realizar um valor maior para sua força de trabalho desqualificada deslocando-se entre setores e ramos de produção. Ora, objetiva e subjetivamente instável, sem nenhum laço forte ou interesse específico na construção, na qual só permanece enquanto serve sua animalidade, sua força. A radical negação de sua humanidade no trabalho impede qualquer vinculação não contratual com ela ou o ramo (Ferro, 2006 [1969]: 90).

Ainda assim, um caminho tortuoso (mapeado por Morice) permite que um ou outro servente geral se engaje numa especialidade da construção civil e se torne um "ajudante", ocupação agora particularizada pelo complemento "de pedreiro", "de armador", "de carpinteiro" [75]. No entanto, um pressuposto permanece: o ponto de partida é uma população de origem rural, que transita sem pouso entre a construção e outros setores econômicos (e mesmo entre campo e cidade).

Já entre 1990 e 1991, uma pesquisa realizada por Nilton Vargas em 30 canteiros de obras em nove cidades brasileiras indicava uma mudança de perfil do trabalhador da construção civil que afetava em especial "a visão de que o 'peão' não tinha nenhuma preocupação em se fixar, seja na empresa, seja na cidade onde trabalhava, pois ainda estava vinculado à terra natal" (Vargas, 1992: 47). A pesquisa, publicada justamente com o título "tendências de mudança na indústria da construção", alterava a visão do mesmo autor de uma "degradação do trabalho" na construção, uma vez que:

O fluxo migratório campo/cidade vem perdendo sua intensidade e a taxa de natalidade vem sofrendo declínios constantes. Para o setor [da construção habitacional] significa uma diminuição do contingente que tradicionalmente procura os canteiros de obras. Além

75 Ao tratar das "brechas" pelas quais é possível "passar progressivamente dos serviços gerais da obra para um serviço particular de profissional", Alain Morice comenta que "reflete essa evolução a antiga terminologia, hoje meio esquecida, que estabelecia a diferença entre o 'servente' e o 'ajudante'. Passar de servente a ajudante é entrar num processo de formação" (Morice, 1992: 39). 
dessa transformação quantitativa uma outra, de ordem qualitativa, vem tendo um forte impacto sobre o setor. Até a década de 1970 era normal encontrar imigrantes expulsos o meio rural que procuravam o setor como forma de sobrevivência às péssimas condições de trabalho no campo. No entanto, hoje o quadro é outro (...) O trabalhador tem atualmente procurado o setor como um atrativo para o seu desenvolvimento profissional (Vargas, 1992: 49). [76]

Por não exigir treinamento e qualificação, o servente de obra provém de uma massa populacional que de fato mantém uma conexão direta com as taxas de natalidade em meio urbano e rural e os fluxos migratórios que as equilibram. É um trabalhador que está pronto para ser empregado assim que ingressa, pela mera necessidade de renda, nas fileiras da população economicamente ativa. No entanto, o servente de obra não precisa obrigatoriamente ser um recém-chegado a esta população. A baixa idade só é desejável para este trabalhador porque indica que há pouco comprometimento do corpo com as sequelas do trabalho pesado, mas nunca foi incomum haver serventes com 40 e até 50 anos de idade nos canteiros de obras de grandes cidades brasileiras [77].

Mais importante para discriminar uma população que fornece uma força de trabalho puramente física é a baixa escolaridade, fator social que exclui pessoas de qualquer idade do mercado de trabalho que exija uma mínima qualificação no domínio da linguagem e na execução de operações lógicas, que atualmente se concentra no setor de serviços [78].

Uma forma indireta, portanto, de perceber através de estatísticas a diminuição da presença do servente de obra na metrópole de São Paulo é acompanhar a diminuição da participação do trabalhador jovem e do trabalhador de baixa escolaridade na PEA da RMSP, apresentada no gráfico G-12.

76 Lúcia Shimbo relaciona este texto de Nilton com a experiência empírica de sua pesquisa de doutorado e conclui que "das trajetórias ocupacionais que recuperei em entrevistas e das observações que realizei durante minhas permanências no canteiro de obras, não dá para classificar, hoje, o trabalhador da construção civil dentro de uma categoria homogênea, que pudesse reforçar a figura do 'peão de obras' presente no senso comum" (Shimbo, 2010: 276).

77 Recentemente, uma (e apenas uma) das inúmeras execuções policiais de homens negros e pobres no Brasil ganhou repercussão na imprensa: a de Amarildo de Souza, morador na favela da Rocinha assassinado no interior de uma Unidade de Polícia Pacificadora (UPP) em Julho de 2013. Nas semanas que se seguiram, jornais e televisão divulgaram sempre os mesmos detalhes da vida de Amarildo: apesar de ter 42 anos, ele fazia justiça ao apelido de "Boi" por carregar o dobro de sacos de cimento e areia que seus companheiros em obras na zona sul do Rio de Janeiro, trabalho de onde obtinha meio salário mínimo mensal. Ainda assim, Amarildo é sempre referido como "pedreiro" (com poucas exceções para "ajudante de pedreiro"), o que acrescenta à violência de sua morte uma segunda violência, desta vez simbólica: a invisibilidade da condição de servente de obra.

78 Segundo a PME/IBGE, entre 2003 e 2012 o "grupamento de atividades" que mais aumentou sua população ocupada foi o de "serviços prestados a empresas" (onde se inclui, por exemplo, os serviços de "telemarketing" ou "teleatendimento", ocupação codificada como "8220-2" na CNAE 2.0). O crescimento da quantidade de trabalhadores em 49,2\% em pouco menos de uma década tornou este setor econômico o segundo que mais emprega nas sete maiores metrópoles brasileiras após o setor de comércio $(16,2 \%$ e $18,7 \%$ da população ocupada, respectivamente). Neste mesmo período, o grupamento de atividades "construção" manteve participação estável, empregando 7,6\% da população ocupada em 2003 e 7,8\% da população ocupada em 2012 (IBGE, 2012: 168). 

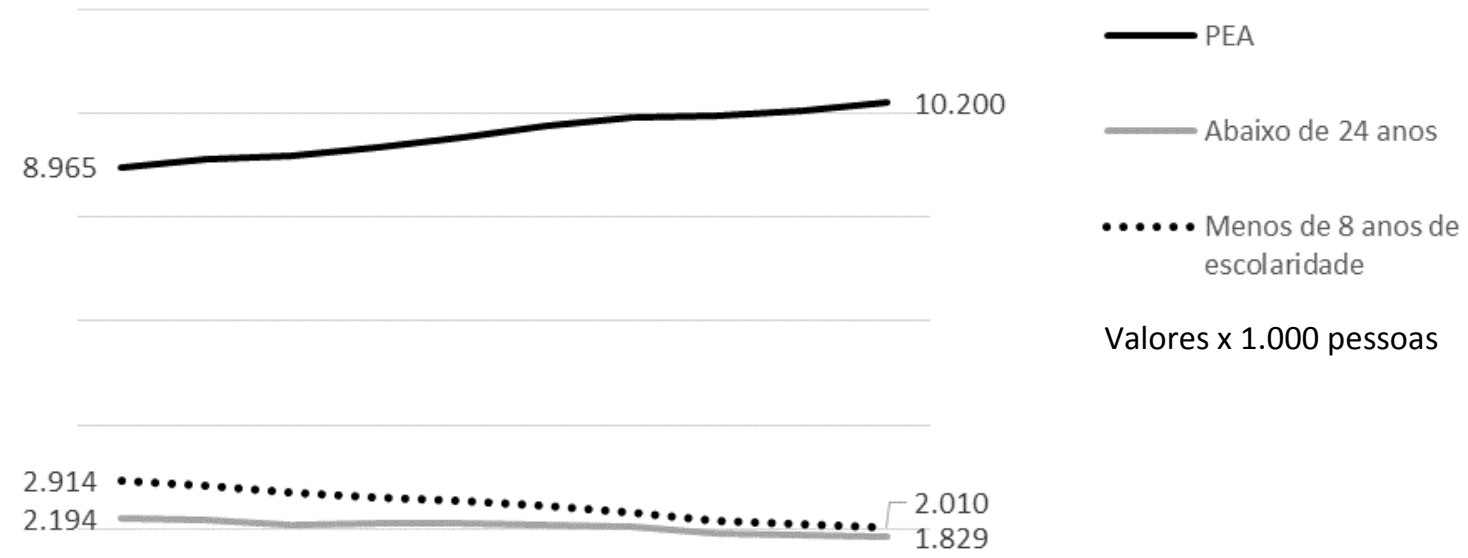

$\begin{array}{llllllllll}03 & 04 & 05 & 06 & 07 & 08 & 09 & 10 & 11 & 12\end{array}$

Fonte: IBGE: 2012

Como "pura energia física auto-movente", o servente de obra não é produto de formação ou treinamento: ou esta energia é extraída diretamente de um contingente populacional ou precisa buscar novas fontes caso este contingente passe do regime de abundância para o de escassez. A alternativa mais simples para esta substituição é utilizar energia física auto-movente concentrada em máquinas, mais especificamente máquinas de movimentação de carga.

De fato, a função básica do servente de obra é a movimentação de carga tanto interna ao canteiro de obras quanto na recepção de insumos provindo do exterior. Seja dentro ou adentrando o canteiro de obras, todos os materiais, elementos e componentes da construção precisam ser então subdivididos num limite superior de volume e peso suportável para o ser humano, sendo a lata metálica de 18 litros e o saco de cimento de $50 \mathrm{Kg}$ uma referência unitária universal, não por acaso dominante nas especificações de traço para o "concreto virado em obra" [79].

Como a manufatura é uma cooperação entre trabalhos especializados, ela necessita de uma contraparte de trabalho genérico que é a movimentação entre as etapas de produção, já antevista por Marx:

Estabelecer e manter a conexão entre as funções isoladas exige o transporte constante do artigo de uma mão para outra e de um processo para outro. Do ponto de vista da grande indústria, isso se revela uma limitação característica, dispendiosa e imanente ao princípio da manufatura (Marx, 2013 \{1867]: 418).

A conexão material entre os trabalhos especializados da manufatura exige "operações simples, que qualquer ser humano é normalmente capaz de executar", mas que "são agora destacadas de sua conexão fluida com os momentos mais plenos de conteúdo da atividade e ossificadas em funções exclusivas", de onde Marx conclui:

79 Por lidar cotidianamente com a movimentação de sacos de cimento, o servente de obra ganha sua mais depreciativa denominação: "orelha seca". O contato da embalagem de cimento com o rosto, uma vez apoiada sobre os ombros do servente, resseca e abre feridas na pele, deixando no corpo uma marca permanente e visível da humilhação do trabalho. 
Em todo ofício de que se apodera, a manufatura cria, portanto, uma classe dos chamados trabalhadores não qualificados, antes rigorosamente excluídos pelo artesanato. Ao mesmo tempo que desenvolve, à custa da capacidade total de trabalho, a especialidade totalmente unilateralizada, que chega ao ponto da virtuosidade, ela já começa a transformar numa especialidade a falta absoluta de desenvolvimento (Marx, 2013 [1867]: 424).

Cada etapa de trabalho tem tempos específicos para receber insumos e deslocar produtos, que se multiplicam por outras etapas tanto sucessivas quanto simultâneas. Portanto, num canteiro de obras com torres de apartamentos baixas como nos empreendimentos do programa MCMV, a pouca capacidade de carga do servente de obra importa menos que sua adaptabilidade para alcançar a qualquer tempo todos os seus espaços. Máquinas de movimentação presas a bases ou trilhos, como pórticos rolantes e gruas, substituem com facilidade a força de centenas de serventes, mas demandam atividades de obra concentradas no espaço e são viáveis economicamente apenas pelo posicionamento de componentes pré-fabricados, deslocados uma única vez, do veículo do fornecedor externo ao local de montagem final.

Um processo de industrialização com ênfase na tecnologia de gestão, como é o caso dos empreendimentos do programa MCMV, opta por outra família de máquinas de movimentação de carga, em que a mecanização visa deliberadamente substituir a mobilidade e flexibilidade de deslocamentos do servente de obra. As máquinas que comumente operam esta substituição são de tipo "Skytrak", marca comercial que designa por metonímia a família dos veículos com manipulador telescópico e que são onipresentes nos empreendimentos em alvenaria estrutural. Como esta é a tecnologia construtiva dominante no programa MCMV na região metropolitana de São Paulo, em todos os empreendimentos visitados para esta pesquisa foi constatada a presença de máquinas Skytrak [80].

Na configuração padrão, são veículos com apenas 2,5 metros de largura e que podem realizar giros externos reduzidos, de 4 metros quando esterçam os dois eixos de rodas, enquanto o braço pneumático entrega cargas de até 2,7 tonelada a 13 metros de altura. Em empreendimentos habitacionais com torres de 5 pavimentos, todas as frentes de trabalho podem ser servidas por uma máquina com estas especificações, mesmo numa densa implantação de edifícios.

Na extremidade livre do manipulador telescópico é possível acoplar diferentes acessórios de carga (pá-carregadeira, ganchos, porta-concreto, carregador de giro ou com inclinação), nenhum tão utilizado como o garfo padrão de empilhadeira. Através dele, a unidade mínima de movimentação de carga da indústria, o palete (geralmente na dimensão PBR), se universaliza também no canteiro de obras. Como mostrado na imagem I-8, a inumanidade de peso e volume dos blocos de

80 Apenas 3\% das empresas construtoras que participaram da pesquisa "Tendências no setor de habitação econômica e de interesse social" declararam não ter mecanizado a movimentação de carga em canteiro de obra (Della Penna, 2013: 28). 
concreto paletizados exige por si só que a movimentação deixe de ser feita por servente e se torne exclusivamente mecânica [81].

\section{I-8|Skytrak e paletização do canteiro de obras}
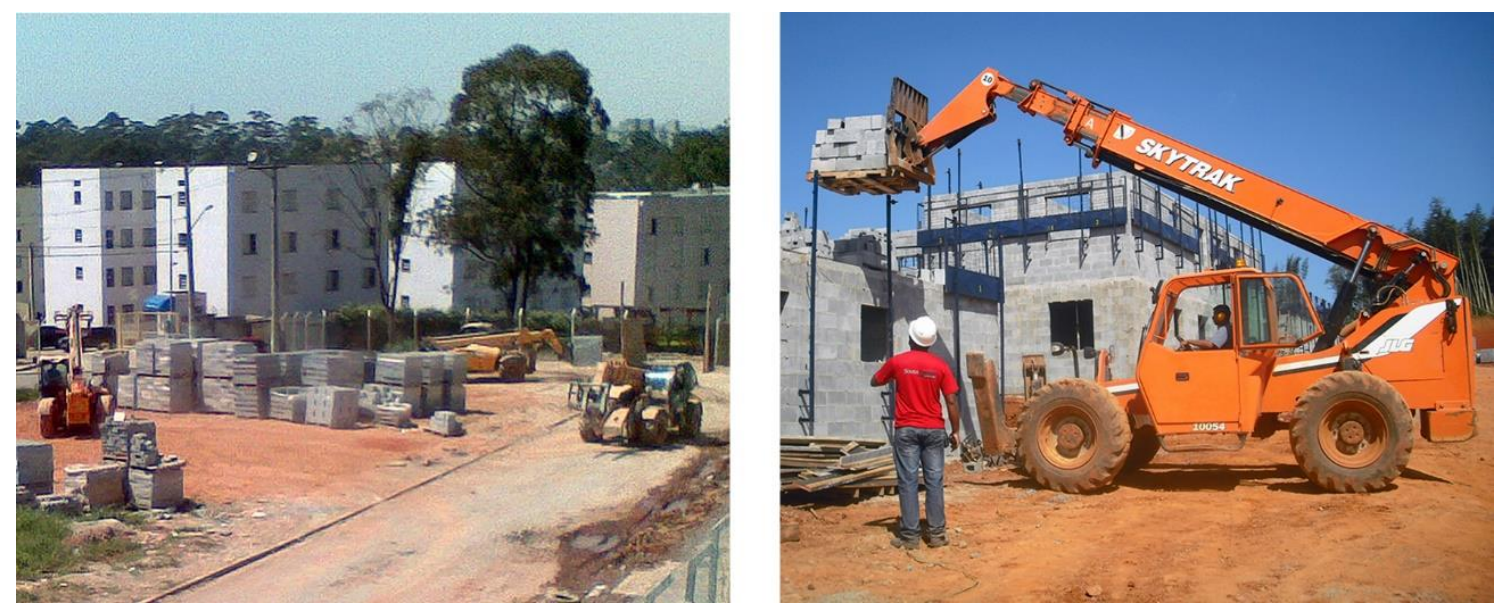

À esquerda, máquinas em estoque de bloco de empreendimento da construtora Hudson; à direita, deslocamento em altura de palete em empreendimento da construtora Cury.

No final de 2012, um dos vice-presidentes da Associação Brasileira de Tecnologia para Equipamentos e Manutenção (Sobratema), que reúne revendedores de máquinas e equipamentos para construção civil, declarou que "houve venda de 100 mil equipamentos nos últimos cinco anos no país. Do sexto ao décimo anos anteriores, a venda foi de 40 mil equipamentos" (Corsini, 2012b: 46). A enumeração deste explosivo aumento de vendas, que se refere apenas à "linha amarela" (para movimentação de terra e carga), tinha o objetivo de negar um futuro desabastecimento no Brasil, pois "com os canais de importação e com a facilidade do crédito, vejo pouca possiblidade de não se atender o mercado" (Corsini, 2012b: 47). Em outras palavras: com a oferta apoiada por capital financeiro de maquinário produzido na China, o fornecimento de equipamentos se tornou, de fato, um fornecimento elástico, capaz de atender qualquer elevação da demanda. $O$ mesmo não aconteceria em relação ao fornecimento da mão-de-obra necessária para operar estes equipamentos, o que estaria provocando um "apagão de operadores" no Brasil (Corsini, 2012b) [82].

Segundo dados da Sobratema, em 2012 entraram em operação no Brasil 32 mil equipamentos da "linha amarela". Somados aos equipamentos utilizados em "construção pesada e mineração", são 88 mil novos equipamentos, o que provocou a seguinte preocupação de um dos diretores da associação:

81 Ao comentar o processo de racionalização da alvenaria estrutural nos empreendimentos da construtora Rôgga, seu diretor técnico deu destaque para a mecanização do transporte: "antes, chegavam os paletes e tínhamos que desmontá-los para levar os blocos pelo elevador" (Ferreira, 2013a: 6). Entenda-se no plural "nós" que cabe ao servente o carregamento e descarregamento do carrinho de mão, em que os blocos precisam ser manipulados de par em par, além da penosa movimentação. Segundo um dos gerentes de tecnologia da construtora Gafisa, "com a paletização, a mão-de-obra de descarga - que custa muito dinheiro - é retirada (...) Todos os contratos de mão-de-obra também passam a custar mais barato. Começamos assim a atrair as melhores empresas para trabalhar conosco (Cichinelli, 2010a: 59-60).

82 O Brasil ainda não reinventou "canais de importação" de trabalhadores para construção civil, função que foi da escravidão (como lembrou o economista Samuel Pessôa) e que reaparece na imigração clandestina e patrocinada para países de economia solvente, com contornos de escravidão moderna em casos notórios, como o da construção civil nos Emirados Árabes (Hari, 2009). 
Isso significa, automaticamente, 88 mil novos operadores, considerando um turno de trabalho; se forem dois turnos, o número dobra. Sem contar o pessoal de apoio, como mecânicos. Quem está formando essa turma?" (Corsini, 2012b: 47).

A escassez de profissionais operadores de máquina é um problema cuja solução está internalizada no mercado da construção civil, pois é uma força de trabalho que a empresa construtora pode criar por si ou por entidades de classe através de programas de treinamento. Não é incomum que os principais locadores de máquinas estacionárias ou móveis forneçam também os operadores como um serviço associado (como será analisado adiante para o caso do fornecimento de concreto auto-adensável).

O custo salarial deste profissional operador é certamente maior que o de um servente de obra, mas seu cálculo só faz sentido quando agregado a outros custos do próprio capital: o valor da locação de uma máquina precisa ser amortizado pela diminuição de prazo da obra, que pode se beneficiar da aquisição de produtos paletizados, que por sua vez são fornecidos por empresas com capacidade para faturar pagamentos em prazos mais alongados etc. Trata-se então de uma decisão empresarial de caráter puramente gerencial a respeito da composição orgânica das frações de capital sob seu controle [83].

Já a escassez de serventes de obra se apresenta como um limite histórico e social à forma de produção da manufatura, cuja solução não se encontra no campo de ação da empresa construtora a não ser pela racionalização industrial do canteiro de obras. Um índice de que esta racionalização ultrapassou o limiar de autopropaganda do setor da construção civil é a proliferação de estudos com alternativas para movimentação de materiais no canteiro de obras, a chamada "logística de obra". Nela, toda iniciativa de mecanização e gestão de estoques só atinge o patamar de eficiência quando a movimentação de carga deixa de ser realizada através do servente de obra.

Para as diversas movimentações de insumos e produtos envolvidas no lançamento da argamassa de revestimento (vistas em detalhe no capítulo 2), o mais importante trabalho de divulgação de Ubiraci de Souza - justamente intitulado "Como aumentar a eficiência da mão-de-obra" - ensaia oito "situações" em que a quantidade de serventes "varia em função da forma de fornecimento e transporte interno de argamassa" (Souza, 2006: 84). As ilustrações referentes às quatro destas situações de obra mais significativas e contrastantes estão reproduzidas na imagem I-9.

83 Os operadores de máquinas Skytrak nos empreendimentos visitados para esta pesquisa foram formados entre ajudantes do próprio canteiro de obras e desmentem a estimativa da associação Sobratema de que é preciso no mínimo 240 horas para treinar o operador de um veículo banal, com um braço comandado apenas por uma alavanca de ângulo e o botão de acionamento do movimento telescópico. 

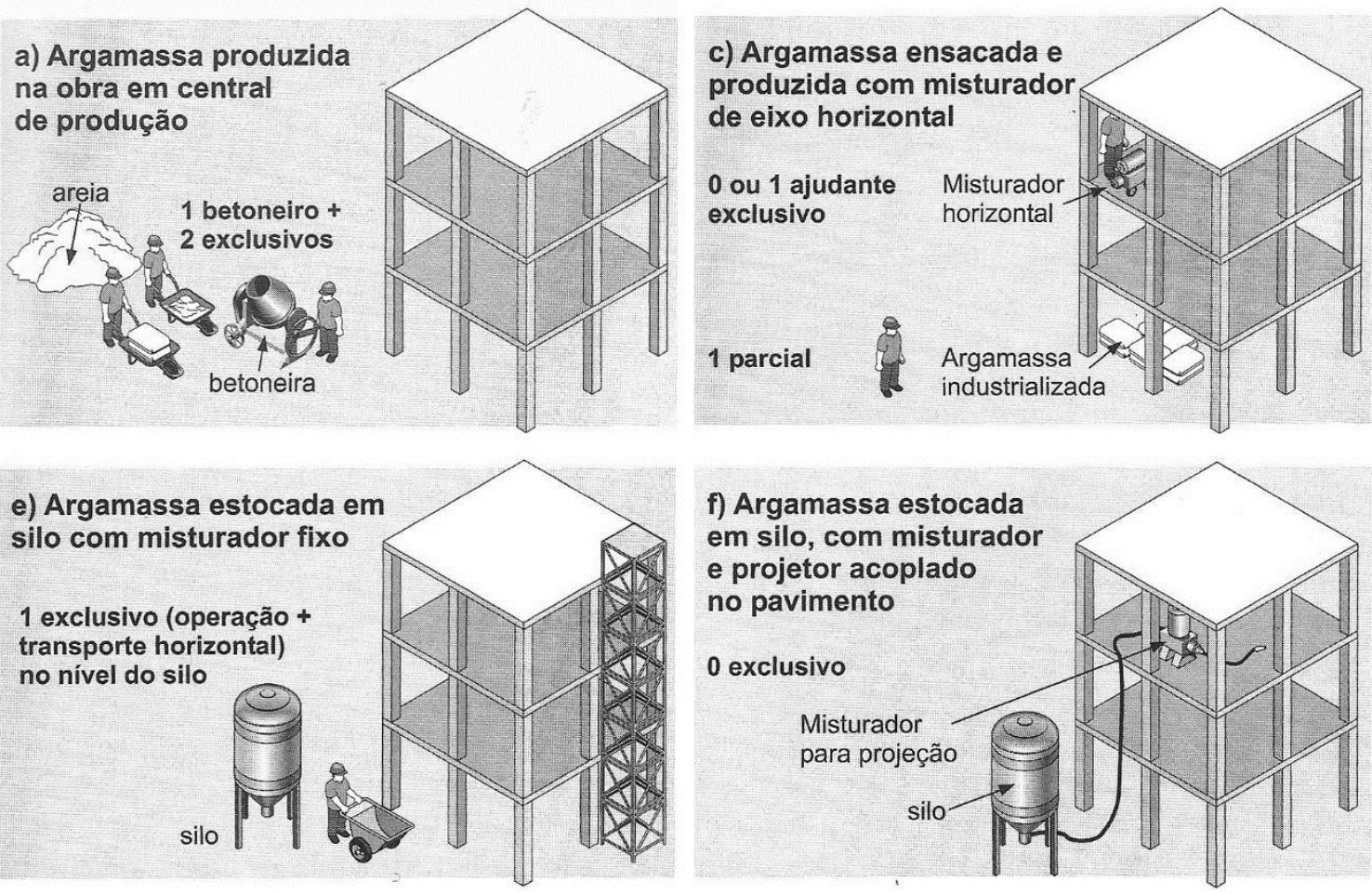

Fonte: Souza, 2006: 85

Ubiraci de Souza agrupa os serventes de obra como uma "equipe de apoio", que trabalha "em atividades-meio (por exemplo, transportando tijolos)" e é composta por "operários que dão apoio à distância com relação ao grupo direto" (Souza, 2006: 34). Já "grupo direto", por contraste, é a equipe de trabalhadores que executa atividades-fim, composta tanto por oficiais quanto por ajudantes de oficial [84].

Na imagem I-9, a situação identificada pela letra "a" (no canto superior esquerdo) mostra que, mesmo no grau menos industrializado da produção de argamassa, a "equipe de apoio" já está organizada em função de uma máquina: a betoneira. Ainda que seja uma máquina inadequada para produção de argamassa (como abordado no capítulo 2), ela fixa um operador (o "betoneiro") e demanda de forma "exclusiva" ser alimentada por dois serventes de obra, que movimentam e manuseiam aglomerantes ensacados e agregados soltos.

Na situação " $c$ " (canto superior direito), a argamassa é industrializada como insumo ensacado e a máquina que vai prepará-la é o misturador de eixo horizontal, equipamento leve, móvel e mecanicamente adequado ao preparo de argamassa. Com a máquina próxima à frente de trabalho, um servente pode dedicar uma jornada "parcial" para movimentar os sacos de argamassa industrializada entre o local de estocagem e o de preparo. A máquina misturadora (que opera com dosador mecânico de água) é acionada apenas por um comando liga/desliga e, assim, é operada pelo ajudante ou mesmo pelo próprio oficial que executa o revestimento.

Na situação " $\mathrm{e}$ " (canto inferior esquerdo), a argamassa industrializada não é estocada em sacos, mas num silo mecânico. Como o misturador está acoplado ao

84 Uma variação na proporção entre oficiais e ajudantes de oficial em função da "logística de obra" está reproduzida na tabela $\mathrm{T}-4$. 
silo, um servente deve se ocupar com exclusividade em acionar o equipamento, encher a girica e transportá-la até o elevador de carga. Na situação "f" (canto inferior direito), silo, misturador e projetora de argamassa estão ligados por mangueiras pressurizadas. A movimentação de argamassa, da estocagem ao lançamento na parede, elimina integralmente o servente de obra.

Manuais como o de Ubiraci de Souza, de qualquer forma, exploram alternativas de racionalização e mecanização nas argamassas que já aconteceram em larga escala no fornecimento de concreto dosado em usina e lançado por bombeamento. O caso que mais altera o trabalho em canteiro de obras é o do concreto auto-adensável (CAA), uma tecnologia construtiva (mais que um simples insumo) que só pode ser compreendida quando colocada contra o pano de fundo que é a generalização do uso de concreto usinado nas grandes cidades brasileiras. Na região metropolitana de São Paulo, a distribuição territorial das usinas de concreto torna questionável a produção de concreto em canteiro de obra até mesmo quando é necessário pouco volume ou baixa resistência, percepção confirmada no seguinte depoimento de Hugo Marques da Rosa, diretor-presidente da construtora Método Engenharia:

Algumas coisas se tornam irreversíveis. Na década de 1970, por exemplo, grande parte das obras em São Paulo fazia concreto na betoneira na própria obra. Até recentemente, em algumas capitais do Nordeste fazia-se concreto em betoneira porque era mais barato que o usinado. Mas o fato é que os prazos de construção também estão cada vez mais apertados. Para atender a estes cronogramas, é preciso usar sistemas construtivos mais industrializados. Hoje é impensável em São Paulo fazer concreto em betoneira. Antigamente se fazia esta conta, hoje ninguém faz. (Tamaki, 2011b: 28) [85].

Que conta é essa, que tornava até recentemente a fabricação do concreto em canteiro de obra mais barata "em algumas capitais do Nordeste" do que em São Paulo? Certamente não é a que considera o custo unitário dos insumos do concreto, todos mais elevados nas capitais nordestinas Salvador, Recife e São Luís do que na capital de São Paulo, como mostra a tabela T-13, com preços levantados pelo IBGE para as tabelas Sinapi de Outubro de 2013.

T-13 | Insumos de concreto em São Paulo, Salvador, Recife, São Luís

\begin{tabular}{l|c|c|c|c|c|c} 
Insumo na tabela Sinapi & cód. & un. & São Paulo & Salvador & Recife & São Luís \\
\hline Cimento CPII-32 & 10511 & saco & $\mathrm{R} \$ 20,80$ & $\mathrm{R} \$ 24,00$ & $\mathrm{R} \$ 25,00$ & $\mathrm{R} \$ 27,00$ \\
\hline Areia média - sem frete & 370 & $\mathrm{~m}^{3}$ & $\mathrm{R} \$ 53,00$ & $\mathrm{R} \$ 55,00$ & $\mathrm{R} \$ 70,00$ & $\mathrm{R} \$ 60,00$ \\
\hline Pedra britada n.1 - sem frete & 4721 & $\mathrm{~m}^{3}$ & $\mathrm{R} \$ 51,25$ & $\mathrm{R} \$ 51,25$ & $\mathrm{R} \$ 67,29$ & $\mathrm{R} \$ 93,18$ \\
\hline Pedra britada n.2 - sem frete & 4718 & $\mathrm{~m}^{3}$ & $\mathrm{R} \$ 49,50$ & $\mathrm{R} \$ 49,50$ & $\mathrm{R} \$ 65,00$ & $\mathrm{R} \$ 90,00$
\end{tabular}

Fonte: Sinapi/IBGE - Outubro 2013

Apenas o custo da força de trabalho dos serventes pode favorecer o uso em canteiro de obras de uma central de produção de concreto com betoneira, pois

85 O adjetivo "irreversível" também é usado pelo diretor técnico da Tecnum Construtora a respeito da adoção de armaduras pré-fabricadas para peças convencionais da estrutura de concreto: "comprar as barras e fazer corte e dobra dentro do canteiro sai mais caro do que comprar pronto (...) é uma tendência irreversível" (Faria, 2007: 12). Na metrópole de São Paulo, apenas custos de transporte precisam ser levados em conta para a encomenda da armadura pré-fabricada e não é incomum encontra-las mesmo em obras de autoconstrução informal em favelas e loteamentos clandestinos. 
são eles os responsáveis por descarregar, peneirar e dosar em caixotes os agregados, descarregar e movimentar a sacaria de cimento, carregar e deslocar giricas com concreto, além de realizar a limpeza e manutenção de ferramentas, caçambas, eixos, rodas e tambores.

Um sinal de que o chamado "concreto convencional" se tornou o concreto préfabricado em usina é que uma variante desta pré-fabricação, o concreto autoadensável (CAA), agora se apresenta como inovação tecnológica que sofre resistência para substituir as práticas da construção formadas em torno do fornecimento de concreto usinado [86].

O custo do CAA, sempre em torno de $10 \%$ mais elevado em relação a outros concretos de mesma resistência, é a barreira contra a qual os estudos de Gestão de Produção alegam nova economia compensatória na eliminação de mão-deobra, pois a fluidez e plasticidade deste concreto pressupõem não apenas a sua produção em usina como também o seu enrijecimento em fôrmas metálicas ou em PVC, onde não há brechas e descontinuidades que são comuns em fôrmas em chapas vinílicas produzidas por manufatura. O trabalhador que produz estas fôrmas não é, portanto, o carpinteiro e seus ajudantes, mas o "montador de fôrma", inexistente na construção civil antes da introdução da tecnologia do CAA e que, em 2010, provocava uma polêmica que apareceu na seguinte nota da mais antiga revista do mercado brasileiro voltada para a construção civil:

\begin{abstract}
A formação de montadores de fôrma para execução de paredes de concerto tem provocado impasses trabalhistas entre construtoras e sindicatos. Em algumas obras, como a função desses operários é, de acordo com as empresas, muito simples e sem necessidade de qualificação especializada - como a exigida de um carpinteiro, por exemplo - eles são registrados como serventes. Os sindicatos reivindicam o registro em cargos com maiores desembolsos salariais, como pedreiros (Construção e Mercado, 2010: 80).
\end{abstract}

O título da nota continha uma pergunta - "Servente ou montador? " - que desde então foi respondida pelas empresas construtoras pela segunda opção, como fica claro numa notícia, esta mais recente, sobre o emprego de fôrmas de alumínio nos empreendimentos de uma empresa média de Minas Gerais, a Passos Construções e Empreendimentos:

Para a mão de obra, a construtora montou uma equipe própria com salário em torno de $15 \%$ acima do que se paga no mercado, por ser um serviço mais especializado. Os trabalhadores, no início, são treinados no próprio canteiro pela empresa fornecedora das fôrmas, e até um consultor em paredes de concreto foi contratado para acompanhar os operários (Guia da Construção, 2013).

A interdependência entre o CAA e a fôrma produzida com peças e materiais próprios para a completa selagem dos espaços cria de fato uma nova profissão de montagem, pois não se trata de uma única e simplificada montagem de painéis

86 Segundo a NBR 15.823-1: 2010, o CAA deve ter propriedade de autoadensabilidade apenas em função da sua constituição e deve preencher os espaços de fôrma e armadura sem auxílio de vibradores ou compactação externa, criando uma superfície superior autonivelada. Só é possível obter estas propriedades pela completa automação do preparo, dosagem e mistura em usina, que não deixa ser apenas a replicação da automação de produção do próprio clínquer/cimento. O único complemento da indústria mecânica é o transporte e lançamento por caminhão betoneira-bomba, máquina especializada que necessita de seu próprio operador-motorista. 
metálicos ou plásticos, mas de um permanente ciclo de desmontagem, limpeza, movimentação, marcação, nivelamento e montagem sem o qual a tecnologia e, consequentemente, o capital embutido na fôrma deixa de ser reaproveitado.

No entanto, as implicações do CAA para o trabalho em canteiro não estão apenas no tipo de fôrma que exige, mas no seu próprio lançamento até esta fôrma: ele só pode ocorrer por bombeamento mecânico, sendo inútil seu descarregamento numa masseira ou numa "bica" de onde serventes tivessem que carregar as giricas com pá e enxadas.

Assim, por ser vendido apenas "posto em fôrma", este concreto torna indistinta a industrialização da fabricação e do canteiro de obras, pois não é possível separar a produção do insumo do seu processamento final e, não por acaso, o lançamento do concreto é executado por profissionais vinculados diretamente ou por terceirização à usina e não à empresa construtora. Estes profissionais são o operador de mangote ("mangoteiro"), que monta os dutos de borracha, conduz o bico de lançamento e faz a limpeza e manutenção do conjunto, geralmente com ajudante próprio, e o operador de bomba de pistões hidráulicos, equipamento que é montado em caminhão próprio (em que ele é o condutor) quando complementado pela "lança" ou mastro de distribuição [87].

\section{I-10| Lançamento mecanizado de CAA em empreendimento MCMV}
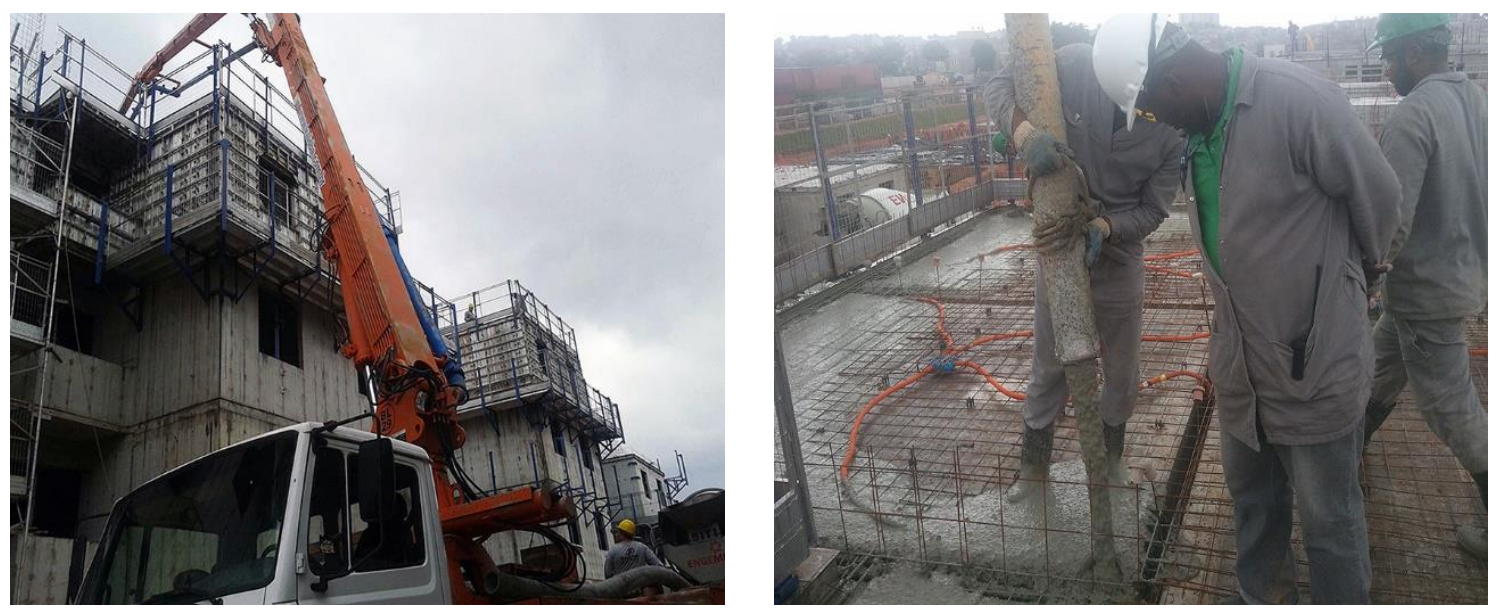

Fonte: acervo do controle de qualidade da Odebrecht OR: à esquerda, bombeamento operado por funcionário da concreteira Engemix; à direita, mangoteiro inspecionado por mestre de obras.

O mangoteiro e o operador de bomba estão incorporados como parte viva do capital constituído pela máquina. Quando se introduzem no canteiro de obras, cada um modifica à sua maneira a organização que o trabalho assumia em regime de manufatura. A ação do mangoteiro afeta diretamente os trabalhadores profissionais, não para eliminá-los, mas para transferir suas atividades para as funções de inspeção e reparo. Deixa de existir o pedreiro oficial que "puxa a massa", isto é, coordena o tombamento dos carrinhos e latas, nivelando seu

87 A passagem da industrialização do insumo para o processo de trabalho no fundo acontece na passagem do concreto do caminhão betoneira para a bomba instalada em reboque ou em caminhão-bomba. É uma passagem prevista por Marx quando considera, no sistema de máquinas, que "cada máquina parcial fornece à máquina seguinte sua matéria-prima, e uma vez que todas atuam simultaneamente, o produto encontrase tanto nos diversos estágios de seu processo de formação como na transição de uma fase da produção a outra" (Marx, 2013 [1867]: 454). 
conteúdo com a régua de madeira ou alumínio, bem como o pedreiro meiooficial, que distribui o concreto com enxada e faz o adensamento com vibradoragulha (sua maior habilidade sendo o deslocamento de dançarino sobre formas e vigotas). $\mathrm{Na}$ concretagem com CAA, a hierarquia de oficial e meio-oficial adquire função de acompanhamento ao invés de execução, pois é necessário apenas um encarregado para preenchimento da planilha de controle de qualidade e um profissional de prontidão para correção do que este controle indicar como "não-conformidade" ao padrão de serviço [88].

\section{I-11|Ficha de Verificação de Serviço e ensaio de abatimento para CAA}
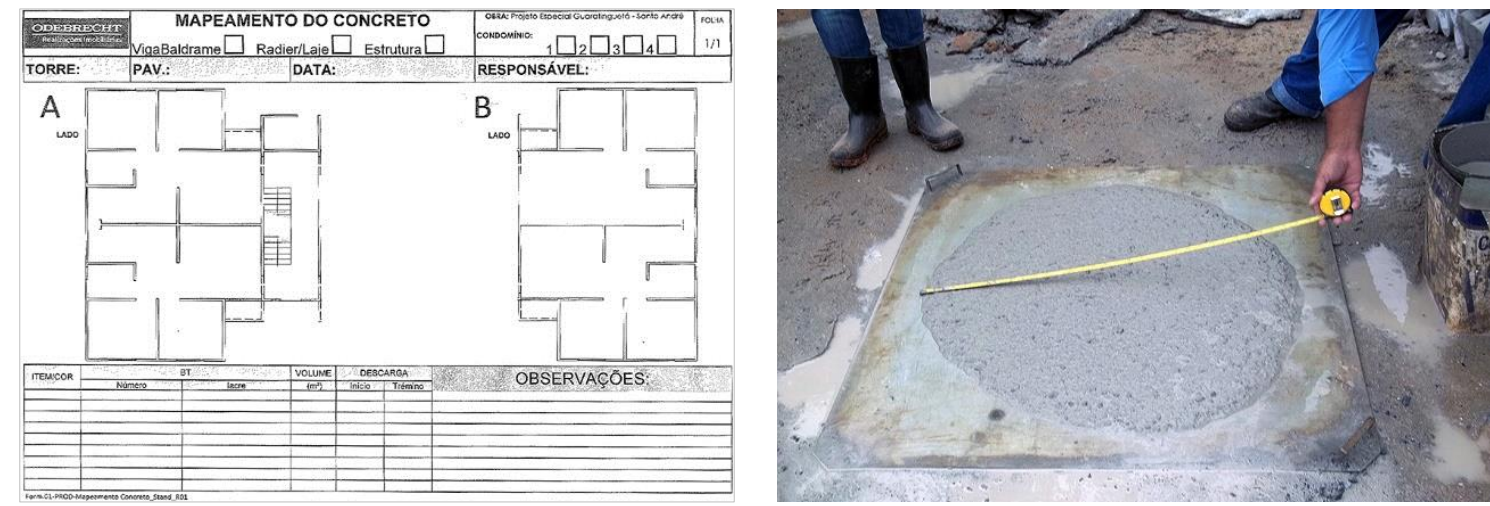

Fonte: acervo do controle de qualidade da Odebrecht OR

O operador de bomba, por sua vez, provoca uma modificação mais radical do processo de trabalho da concretagem, uma vez que este profissional elimina de fato todo o contingente de serventes de obra que movimentam o concreto convencional em giricas e latas, geralmente na proporção de 3 a 4 trabalhadores para cada meio-oficial (contando entre eles o operador de betoneira).

Acompanhar uma concretagem com CAA impressiona, então, pelo relativo silêncio da operação, marcada apenas pelo ritmo lento dos pistões de bombeamento. O que faz falta não é o ruído incessante dos vibradores-agulha, mas sim a fala alta, feita de interjeições e gritos dos serventes de obra, sobre as quais se acumulam as ordens e deboches dos meio-oficiais. Toda esta tensão humana acontece porque a concretagem é uma convergência no tempo e espaço de inúmeros esforços parciais, acumulados em dias e até semanas de trabalhos prévios. Numa obra tradicional, se apresentam simultaneamente na concretagem todos os profissionais especializados e não especializados: mestre, encarregados, pedreiros, instaladores, carpinteiro, armador, ajudantes e serventes. $\mathrm{O}$ trabalhador coletivo da manufatura aparece por inteiro, nas suas precisas proporções e identidades. O nervosismo deste momento crítico se extravasa em instruções e incentivos ao trabalho em que a apreensão não consegue se dissociar, estranhamente, de certo entusiasmo [89].

Segundo um dos diretores da construtora Tecnisa, "as tecnologias ligadas a paredes de concreto têm utilização menor de mão-de-obra, e a mão-de-obra é mais específica, qualificada e mais produtiva" (Villas Bôas, 2011: 26). Falta esclarecer que ela realiza atividades diferentes que as ligadas ao concreto convencional.

89 Para quem nunca acompanhou uma grande concretagem, uma surpreendente aproximação pode ser encontrada nas narrativas da caça à baleia em "Moby Dick", quando, num momento curto e decisivo, todas as patentes de uma embarcação se lançam em botes coordenados numa caçada em mar aberto. 
Já em 2008, Denise Dal Molin, pesquisadora do Núcleo Orientado para a Inovação da Edificação (Norie/UFRGS) e uma das primeiras divulgadoras do CAA no Brasil, antevia que a substituição do servente pela bomba mecânica sofreria resistência por parte das subempreiteiras de concretagem (que são essencialmente agenciadoras de trabalho humano) e que esta resistência só poderia ser levantada pela escassez de mão-de-obra:

Há uma particularidade no Brasil, que é a de trabalharmos muito com empreiteiro de mãode-obra. E ele nos cobra por metro cúbico de concreto, pacote que abrange montagem das fôrmas, lançamento, adensamento, acabamento etc. Ele não consegue - ou não quer quantificar o aumento de produtividade proporcionado pelo uso de um concreto autoadensável para reduzir o custo de seu metro cúbico. Mas, com a escassez de mão-de-obra, isto está mudando. Ele pode não encontrar homens para realizar esses serviços. Considerando isso, pode contratar menos trabalhadores e reduzir os custos do metro cúbico se essas tecnologias forem utilizadas (Loturco; Faria, 2008: 26).

Apenas parte do problema aparece na advertência de que o subempreiteiro de concretagem "pode não encontrar homens para realizar esses serviços", pois ao encontrá-los será preciso adquirir a preço mais caro a mercadoria força de trabalho, valendo aqui outra advertência, a do consultor e empresário em préfabricação de concreto Francisco Oggi:

O Nordeste está se desenvolvendo e não nos manda mais mão-de-obra. Do Sul já não vem operário há muito tempo. Outros setores da economia são muito mais atraentes. A última opção é a construção civil. E, tendo que carregar saco de cimento, aí que não vem mesmo. Se souber que vai operar um equipamento, sem fazer força, vem, pois o salário é um pouco melhor e a condição é humana (Loturco, 2008: 29-30).

Em qualquer hipótese, há elevação do valor socialmente necessário não apenas do trabalhador qualificado da construção habitacional, cuja especialização pode ser deslocada para montagem de fôrma, operação de maquinário ou mesmo a inspeção destas atividades, mas sim do trabalhador que a organização da manufatura exige que ocupe o polo produtivo da mais completa desqualificação.

Indicadores tecnologicamente conservadores, como o $\mathrm{CUB} / \mathrm{m}^{2}$, são acurados ao menos neste ponto: não mecanizar a movimentação de carga passou a ter um custo que já não pode mais ser controlado pela população excedente brasileira. O próprio apelo ideológico de fornecer emprego à população trabalhadora desqualificada fica esvaziado, bem como sua ancoragem na manutenção ativa de técnicas construtivas da manufatura, tal como expressa numa conhecida declaração de Rubens Vaz da Costa, quando diretor do extinto BNH:

\footnotetext{
Arpoadores, oficiais, meio-oficiais, remadores e marinheiros do leme trocam entre si falas cuja tensão é, em essência, idêntica à de uma concretagem manual (ver em particular os capítulos 48 e 81). A aproximação faz algum sentido quando se considera uma obra em que as forças da natureza são confrontadas tanto por um homem trágico quanto pela elaborada unidade de produção manufatureira que ele lidera, que é o navio baleeiro Pequod.
} 
No setor da construção civil, os meios tradicionais de produção devem ter a preferência no momento atual, dada a necessidade de criar empregos para mão-de-obra não qualificada (Costa, 1972: 12) [90].

No programa MCMV, são poucas as menções em documentos oficiais ou mesmo promocionais a uma "necessidade de criar empregos" através do programa MCMV e, quando surgem, nunca vêm acompanhadas de maior ênfase. A razão é que a necessidade de empregar muitos trabalhadores nos empreendimentos do programa, ao invés de solução política, se tornou um problema tecnológico para o capital da construção civil. É um fenômeno histórico que reverte a expectativa levantada por Alain Morice entre proprietários de empresas construtoras no início dos anos 1990, quando estes lamentavam a extinção do BNH e exigiam que o governo federal voltasse a implantar um programa de habitação popular:

Curiosamente, o marasmo que se segue a esse acontecimento [a extinção dos programas habitacionais] reativou, entre os construtores, o discurso voluntarista dos primeiro anos do BNH: 'Nós temos uma reponsabilidade histórica na resolução dos problemas do país' (...) Dizem eles: 'nós somos duas vezes responsáveis diante da sociedade: primeiro para acabar com o déficit habitacional, segundo para dar emprego a todos esses migrantes oriundos do campo, que não têm outra qualificação que servir na construção civil (...) $\mathrm{Na}$ barganha com as autoridades politicas e financeiras da nação isso se traduz nestes termos: 'Queremos a reativação dos programas habitacionais públicos e a liberação do dinheiro. Em troca providenciaremos muitos empregos” (Morice, 1992: 46).

Em âmbito federal, a reativação dos programas habitacionais públicos acontece em 2009, com o programa MCMV, pouco mais de vinte anos após a extinção do BNH em 1986. Neste meio tempo, a formação de um operariado treinado na construção civil brasileira dispensa a responsabilidade das empresas construtoras em oferecer empregos para uma massa desqualificada da população. Como Alain Morice registra que os empresários da construção se veem como "duas vezes responsáveis diante da sociedade", então sua tarefa nos dias de hoje se reduziu à metade e a única justificativa ideológica que resta para um novo programa habitacional é a de eliminar o déficit de moradias. Afinal, se não há mais uma população excedente para produzir a habitação social, há ainda uma população excedente para consumi-la.

90 Compare-se a declaração com esta entrevista sobre o programa MCMV, realizada em 2012 com o diretor financeiro de uma incorporadora de capital aberto. O entrevistador, o engenheiro Gabriel Andrade, pergunta: "como a empresa lida com o avanço dos custos? A inflação da mão de obra em conjunto com a menor produtividade não faz com que haja estouro de orçamentos? ". A resposta é: "a empresa só se dispõe a entrar em obras do MCMV com o preço de venda fechado, e não indexado aos custos, pois tem perfeito domínio do seu método produtivo. Utilizamos fôrmas de alumínio para a construção, o que a torna mais ágil e menos intensiva em mão de obra" (Andrade, 2012: 73-4). 


\section{$5 \mid$}

\section{A POPULAÇÃO EXCEDENTE NO PROGRAMA MCMV}

\section{As metas do déficit habitacional}

Um traço comum dos textos que abordam o programa MCMV do ponto de vista do mercado imobiliário é começarem a exposição pela quantificação do "déficit habitacional brasileiro". Ao adotar este ponto de partida, eles espelham por uma expectativa empresarial a legitimação que as instâncias de poder governamental procuram para sua própria ação, uma vez que "o foco nas carências habitacionais e nos déficits de moradia tem sido a forma predominante dos órgãos públicos tratarem a questão da habitação" (Maricato 2009a: 34).

O objetivo deste capítulo é investigar a pertinência desta associação entre déficit e política habitacional, tanto no confronto direto entre metas de produção e estimativas de demanda quanto entre as estratégias desta produção e seus beneficiários. O começo da investigação, no entanto, se dá pela análise da política pública e não do déficit habitacional, pois a gestão de um programa de governo é ao mesmo tempo a gestão de sua legitimação, seja em termos da mais rasa publicidade quanto do mais rigoroso estudo acadêmico.

Como se verá no caso do programa MCMV, é a ação de governo que provoca a pesquisa de uma demanda social. Pensar que o déficit de moradias no Brasil se comporta como um primeiro motor que põe em movimento o programa federal é investigar um "falso problema", semelhante ao que Gabriel Bolaffi descreveu para a política habitacional baseada no antigo BNH, que "é formulada não a partir das características intrínsecas ao problema, mas a partir das necessidades da estratégia do poder" (Bolaffi, 1982: 40).

Um princípio bem assente da administração pública estipula que a implantação de um programa, último limiar de gestão antes da ação efetiva de governo, deve se prender a uma hierarquia de planejamento, em que o programa integra um plano de caráter setorial e, daí, uma política pública de longo prazo. É uma hierarquia pela qual toda atuação de órgão de governo, que é pontual e específica, se articulada a uma visão de Estado, que é ampla e abrangente.

O programa MCMV, no entanto, embaralha este princípio por ser, desde sua instituição, um "programa-plano", na expressão dos economistas Cleandro Krause, Renato Balbim e Vicente Lima Neto: ele concentra tantos recursos e resultados que acaba por esvaziar, pela ponta final da ação de governo, seu próprio pressuposto de planejamento: o Plano Nacional de Habitação (PlanHab), marco legal para onde confluem um arranjo institucional e orçamentário composto, respectivamente, pelo "Sistema Nacional" e pelo "Fundo Nacional" que dão suporte à "Habitação de Interesse Social":

Desde seu lançamento, o MCMV passou a encabeçar a atuação do governo federal na provisão habitacional, promovendo, em sua esteira, mudanças no próprio marco do 
Sistema Nacional de Habitação de Interesse Social (SNHIS). Uma das mudanças mais importantes foi que o Fundo Nacional de Habitação de Interesse Social (FNHIS), o principal instrumento de efetivação do SNHIS, mantido com recursos do Orçamento Geral da União (OGU), praticamente deixou de apoiar a provisão pública de habitação de interesse social (...) o MCMV, que define uma estratégia de ação e apresenta os mecanismos para tanto, parece ter sido alçado à esfera de política de provisão habitacional. (Krause; Balbim; Lima Neto (2013): 7-8) [91].

Se o que deve ser entregue pela política habitacional é uma acelerada provisão de novas unidades habitacionais, então o melhor ponto de partida de fato não parece ser o Sistema Nacional de Habitação de Interesse Social. Sua instituição pelo lei federal 11.124/2005 (que previa a elaboração do PlanHab e a reunião de recursos orçamentários no Fundo Nacional de Habitação de Interesse Social) exige um processo prévio de descentralização federativa, para o qual municípios e Estados devem aderir voluntariamente e criar Planos Locais de Habitação de Interesse Social (PLHIS) e instâncias locais de planejamento e gestão, entre eles conselhos de habitação com pelo menos um quarto de representantes desvinculados de órgãos de governo [92].

Em comparação com o SNHIS, a gestão do programa MCMV se dá através de um enxuto "Comitê de Acompanhamento" coordenado pela Casa Civil e constituído por representantes de apenas três ministérios federais: Cidades, Fazenda e Planejamento. Esta organização, tão eficiente quanto desprovido de controle social, contrasta com a composição do Conselho Gestor do FNHIS, que conta com 24 representantes igualmente divididos entre órgãos do governo federal e diversos movimentos populares, entidades empresariais, órgãos de classe, instituições acadêmicas e organizações não-governamentais [93].

A diversidade de representantes de governo e sociedade na gestão do FNHIS encontra no PlanHab uma equivalente diversidade de "linhas programáticas" na produção da habitação de interesse social, linhas que buscam se diferenciar por adequação a dinâmicas econômicas e sociais regionalizadas no país. Assim, numa cidade pequena e de economia rural, a prefeitura poderia obter recursos federais em gestão compartilhada com um conselho local para abrir lotes com ligações a redes de transporte e saneamento, para os quais seria possível fornecer cestas de materiais para construção ou ampliação de casas térreas. Já na área central de uma grande metrópole, o governo e o conselho de habitação estadual poderiam licitar a reabilitação de edificações abandonadas ou a produção por

91 “Mesmo sendo formalmente um único programa, com espectro de atendimento bastante amplo, (...) o programa MCMV na prática pode ser visto como uma política com diferentes estratégias de atendimento conforme a faixa de renda da população" (Ferreira, 2012: 40-1).

92 A dificuldade em implantar este processo de descentralização e participação social pode ser seguida através dos diversos Relatórios de Gestão do FNHIS disponíveis no site do Ministério das Cidades.

93 A composição do Comitê de Acompanhamento do MCMV é regulada pelo decreto federal 6.962/2009. A do Conselho Gestor do FNHIS, pelo decreto federal 5.796/2006. Ermínia Maricato percebe que, nos canais de participação abertos aos movimentos sociais de moradia, "ocorre uma atração muito forte pelo espaço institucional ou pela institucionalização de práticas participativas, como se isso constituísse um fim em si" (Maricato, 2011: 93). A percepção é parte de uma crítica mais ampla, direcionada ao esgotamento de força política do ideário da Reforma Urbana no Brasil. 
autogestão de conjuntos habitacionais adensados, mediante assessoramento técnico especializado a movimentos de moradia [94].

Já o programa MCMV é impulsionado por uma única meta: a construção de novas unidades habitacionais, na forma de conjuntos condominiais implantados em glebas vazias ou que tenham edificações demolidas já na etapa de limpeza do terreno. Quando foi lançado em Março de 2009 através da Medida Provisória 459 era esta "meta física" que estava no centro de sua divulgação pública, no número exato de 1 milhão de moradias [95].

Em Dezembro de 2010, outra Medida Provisória (de número 514), preparada pela equipe de transição da então Presidente da República eleita Dilma Rousseff, fazia modificações relevantes na operação do programa, que passou a receber a designação "MCMV 2". No entanto, ao ser promulgada como Lei Federal 12.424 em Julho de 2011, a modificação enfatizada foi a duplicação da meta física para dois milhões de novas unidades habitacionais [96].

\section{I-12 | Material publicitário da fase 1 e fase 2 do programa MCMV}
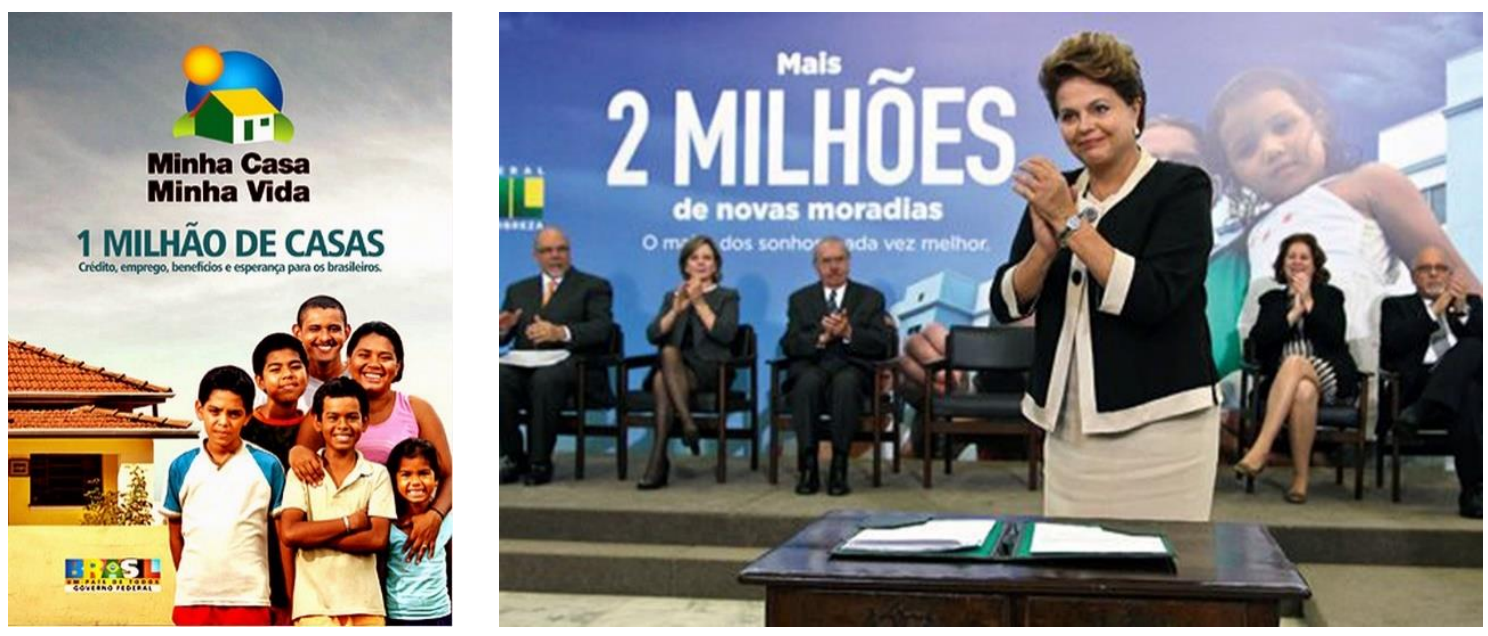

À esquerda, capa da primeira cartilha do programa MCMV, editada pela Casa Civil e distribuída pela CEF; à direita, foto oficial da promulgação do MCMV 2 (blog.planalto.gov.br).

A transição entre as duas etapas do programa MCMV é um ponto de observação natural para avaliar a pertinência destas metas milionárias, pois conta com os resultados oficiais da primeira prestação de contas pública do programa, datada

94 A listagem desta diversidade de linhas programáticas nunca realizada preenche todo o capítulo 6 do PlanHab (MCidades, 2009: 145 a 164). Como integrante de uma assessoria técnica, a Usina CTAH, pude observar diretamente a migração dos movimentos de moradia de São Paulo para os financiamentos operados pelo programa MCMV ao invés do FNHIS.

95 A Medida Provisória foi convertida na Lei Federal 11.977 em 7 de Julho de 2009. Num artigo publicado na mesma época, o coordenador técnico da equipe que elaborou o PlanHab, Nabil Bonduki, classificou tal exatidão numérica como "uma meta cabalística" (Bonduki, 2009: 8).

96 Mesmo assim, o Artigo $1^{\circ}$ de ambas as leis federais inclui entre as finalidades do programa MCMV a "requalificação de imóveis urbanos", o que mostra a insuficiência da análise de uma ação de governo apenas por leis e regulamentos. Em Abril de 2012, Dilma Rousseff anunciou a elevação de meta do programa em mais 400 mil unidades habitacionais destinadas a pequenos municípios, cedendo da seguinte forma a uma exigência do clientelismo difuso praticado por sua base de sustentação no legislativo federal: "a primeira condição é o déficit habitacional, por esse critério a concentração seria nos grandes municípios. Mas leva em conta também a desigualdade social, a existência de pobreza nos municípios e nas regiões. A combinação desses dois critérios permitiu que a gente pudesse enfrentar com muita determinação a concentração de pobreza em algumas regiões" (Damé, 2012: 22). 
de 31 de Dezembro de 2009, último dia em que funcionou como "marca de gestão" da presidência Lula. Esta prestação de contas subdivide a meta segundo o aspecto socialmente mais progressivo do programa MCMV, que é uma clara diferenciação de faixas de subsídios e benefícios por faixas de renda familiar mensal. Medidas em salários mínimos (sm), as faixas de renda da primeira etapa do programa eram 0 a $3 \mathrm{sm}, 3$ a $6 \mathrm{sm}$ e 6 a $10 \mathrm{sm}$. Mesmo os críticos mais atentos a tamanha amplitude de renda familiar não deixaram de perceber que, de forma inédita, estava aberta a possibilidade para subsidiar, a partir de verbas orçamentárias da União, moradias para famílias de baixa renda ou mesmo para famílias sem renda alguma:

O volume de subsídios que [o programa MCMV] mobiliza, 34 bilhões de reais (o equivalente a três anos de Bolsa-Família), para atender a população de 0 a 10 salários minimos de rendimento familiar, é, de fato, inédito na história do país - nem mesmo o antigo BNH dirigiu tantos recursos à baixa renda em uma única operação (Arantes; Fix, 2009: 1) [97].

Na primeira prestação de contas do programa MCMV, estavam contratadas pelo operador financeiro do programa, a CEF, até Dezembro de 2009, a construção de 1.005.128 unidades habitacionais. Na tabela T-14, esta soma aparece dividida entre as três faixas de renda estipuladas pela primeira etapa do programa MCMV, bem como as modalidades de contratação:

T-14|MCMV 1 - Contratação por faixa de renda e modalidade

\begin{tabular}{|c|c|c|c|c|}
\hline Renda (sm) & Meta (UH) & Modalidade de contratação & Contratos (UH) & $\%$ \\
\hline \multirow{6}{*}{0 a 3} & \multirow{6}{*}{400.000} & Repasse para construtoras (FAR) & 404.407 & 40,23 \\
\hline & & Subsídio pelo FGTS & 88.580 & 8,81 \\
\hline & & Oferta pública em cidades até 50 mil hab. & 63.772 & 6,34 \\
\hline & & Repasse para entidades organizadoras (FDS) & 9.395 & 0,93 \\
\hline & & Repasse para habitação rural (PNHR) & 5.167 & 0,51 \\
\hline & & Subtotal & 571.321 & 56,84 \\
\hline 3 a 6 & 400.000 & Financiamento pelo FGTS & 284.772 & 28,33 \\
\hline 6 a 10 & 200.000 & Financiamento pelo FGTS & 149.035 & 14,83 \\
\hline & & Total & 1.005 .128 & 100,00 \\
\hline
\end{tabular}

Fonte: elaboração própria a partir da Lei Federal 11.977 e Ministério das Cidades.

O cálculo de déficit habitacional a ser confrontado com a meta superada em $0,5 \%$ segue a metodologia estabelecida pela Fundação João Pinheiro (FJP) para realizar a "Pesquisa de Necessidades Habitacionais", pesquisa contratada pelo próprio Ministério das Cidades em apoio à elaboração do PlanHab (FJP, 2011). A metodologia parte de variáveis da Pesquisa Nacional por Amostra de Domicílios (PNAD) que permitem identificar como características dos "domicílios particulares permanentes" quatro fatores de déficit habitacional: despesa

97 Publicado num jornal de circulação restrita apenas três meses depois de lançado o programa MCMV, a força crítica do artigo "Como o governo Lula pretende resolver o problema da habitação", de Pedro Arantes e Mariana Fix, resiste até hoje, mesmo com todas as nuances que uma segunda etapa do programa e quatro anos de empreendimentos construídos poderiam exigir. Editado de forma apressada pelo jornal "Correio da Cidadania" e desde então circulando em cópias ainda mais truncadas pela internet, ele é citado aqui conforme versão mimeo, fornecida pelos próprios autores. 
excessivo com aluguel, coabitação involuntárias entre famílias, precariedade construtiva e adensamento excessivo dos dormitórios. Como a PNAD é realizada pelo Instituto Brasileiro de Geografia e Estatística em todos os anos não censitários, as variáveis selecionadas pela FJP puderam ser agrupadas numa série histórica entre 2007 e 2012 pela “Nota Técnica 5" do Instituto de Pesquisa Econômica (Lima Neto; Furtado; Krause, 2013). Esta série histórica fornece um panorama recente do total de domicílios e do déficit habitacional brasileiro tanto em meio urbano quanto em meio rural, tal como aparece na tabela T-15:

T-15|PNAD - Domicílios e déficit habitacional no Brasil - 2007 a 2012

\begin{tabular}{l|c|c|c|c|c|c} 
Domicílios e Déficit & $\mathbf{2 0 0 7}$ & $\mathbf{2 0 0 8}$ & $\mathbf{2 0 0 9}$ & $\mathbf{2 0 1 1}$ & $\mathbf{2 0 1 2}$ & Variação \\
\hline Domicílios urbanos & $\mathbf{4 7 . 5 3 6 . 3 4 9}$ & $\mathbf{4 9 . 0 9 7 . 5 6 9}$ & 50.044 .074 & 53.219 .429 & 54.446 .869 & $14,54 \%$ \\
\hline Déficit urbano & 4.607 .176 & 4.278 .033 & 4.791 .825 & 4.548 .545 & 4.502 .572 & $-2,27 \%$ \\
\hline Domicílios rurais & 8.381 .689 & 8.605 .592 & 8.640 .529 & 8.250 .625 & 8.549 .663 & $2,00 \%$ \\
\hline Déficit rural & 986.015 & 913.532 & 911.178 & 860.665 & 741.953 & $-24,75 \%$ \\
\hline Total domicílios & $\mathbf{5 5 . 9 1 8 . 0 3 8}$ & $\mathbf{5 7 . 7 0 3 . 1 6 1}$ & $\mathbf{5 8 . 6 8 4 . 6 0 3}$ & $\mathbf{6 1 . 4 7 0 . 0 5 4}$ & $\mathbf{6 2 . 9 9 6 . 5 3 2}$ & $\mathbf{1 2 , 6 6 \%}$ \\
\hline Total déficit & $\mathbf{5 . 5 9 3 . 1 9 1}$ & $\mathbf{5 . 1 9 1 . 5 6 5}$ & $\mathbf{5 . 7 0 3 . 0 0 3}$ & $\mathbf{5 . 4 0 9 . 2 1 0}$ & $\mathbf{5 . 2 4 4 . 5 2 5}$ & $\mathbf{- 6 , 2 3 \%}$
\end{tabular}

Fonte: adaptado de Lima Neto; Furtado; Krause, 2013: 4 e 6

Vista de forma abrangente, a série histórica indica que o primeiro milhão de moradias do programa MCMV, contratado em 2009 e construído ao longo de 2010 e 2011, se incorporou ao crescimento do número de domicílios particulares permanentes no país - que foi de 12,66\% entre 2007 e 2012 - sem ter um efeito que possa ser isolado na queda de $6,23 \%$ do déficit habitacional no mesmo período, queda que segue uma tendência observável antes de 2009.

A impressão de que a lenta queda do déficit habitacional tem um curso independente do programa MCMV se reforça quando os números agregados para meio rural e meio urbano mostram que ela se concentra no minoritário grupo de domicílios rurais, onde havia em 2012 um quarto a menos de domićlios com fatores de déficit habitacional do que em 2007. Neste mesmo intervalo e no grupo largamente majoritário de domicílios urbanos, o déficit habitacional se reduziu muito menos $-2,27 \%$. Como se pode ver na tabela T-14, a primeira etapa do programa MCMV teve um desempenho modesto fora das cidades, com apenas 5.167 moradias contratadas pelo subprograma de habitação rural [98].

Mesmo o papel que o programa MCMV poderia ter na pequena queda do déficit habitacional nas cidades adquire um caráter problemático quando se observa como ele evoluiu pelas diferentes faixas de renda familiar.

Tomando os números absolutos levantados pela Fundação João Pinheiro com dados da PNAD de 2008 (FJP, 2013), fica clara a imensa concentração do déficit habitacional na faixa de renda familiar entre 0 e 3 salários mínimos, que em meio

98 Não é possível converter este confronto entre metas e amostras censitárias num juízo definitivo sobre o desempenho do programa MCMV, mas ao menos ele não cede ao gesto fácil de submergir a noção de déficit habitacional numa crítica em bloco da segregação urbana brasileira: " a noção de déficit habitacional como número a ser quantitativamente superado cai por terra na medida em que há no país um estoque de seis milhões de domicílios vagos. Essa estatística revela não só a má distribuição das moradias, em razão da atuação dos agentes do mercado privado, mas também o baixo poder aquisitivo dos pobres no acesso ao estoque habitacional adequado" (Nascimento; Tostes, 2011). 
urbano era de 4.113.659 domicílios. Diante deste contingente, o programa MCMV contratou em sua primeira etapa a construção ou o financiamento de 571.321 novas unidades habitacionais para famílias com renda mensal entre 0 e 3 salários mínimos, o que representa $142,8 \%$ da sua meta física inicial, mas apenas 13,8\% do déficit do ano anterior entre os domicílios de baixa renda. No entanto, as 433.807 unidades habitacionais contratadas na mesma etapa do programa MCMV para as faixas de renda entre 3 e 10 salários mínimos, embora representem 3/4 da meta inicial, correspondem à quase a totalidade do déficit habitacional levantado pela FJP para esta ampla faixa de renda, estimado em 2008 em 448.565 domicílios. A disparidade entre meta e déficit que se verifica nos domicílios da população de baixa renda não existe, portanto, nos domicílios da população de renda mais elevada.

Assim, era de se esperar já no lançamento do programa MCMV que o déficit habitacional brasileiro, caso se reduzisse, se reduziria de forma desigual, apenas pelo atendimento dos extratos de maior renda. A série histórica 2007/2012 realizada pelo Ipea confirma esta expectativa ao distribuir os dados da PNAD por faixas de renda familiar. Esta distribuição é reproduzida na tabela T-16, com destaque para a evolução do déficit habitacional entre domicílios de baixa renda:

T-16|PNDA - Déficit habitacional por faixa de renda familiar - 2007/2012

\begin{tabular}{l|c|c|c|c|c} 
Renda familiar mensal & $\mathbf{2 0 0 7}$ & $\mathbf{2 0 0 8}$ & $\mathbf{2 0 0 9}$ & $\mathbf{2 0 1 1}$ & $\mathbf{2 0 1 2}$ \\
\hline Até 3 SM & $70,7 \%$ & $70,2 \%$ & $71,2 \%$ & $73,0 \%$ & $73,6 \%$ \\
\hline Entre 3 e 5 SM & $13,1 \%$ & $14,0 \%$ & $13,5 \%$ & $11,7 \%$ & $11,6 \%$ \\
\hline Entre 5 e 10 SM & $10,4 \%$ & $10,3 \%$ & $9,6 \%$ & $9,1 \%$ & $9,4 \%$ \\
\hline Acima de 10 SM & $4,1 \%$ & $3,9 \%$ & $3,8 \%$ & $3,2 \%$ & $2,9 \%$ \\
\hline Sem declaração de renda & $1,7 \%$ & $1,7 \%$ & $1,9 \%$ & $3,0 \%$ & $2,4 \%$
\end{tabular}

Fonte: Lima Neto; Furtado; Krause, 2013: 5

Os levantamentos estatísticos ainda deixam várias questões em aberto sobre os efeitos do programa MCMV na pequena diminuição do déficit habitacional total nas cidades brasileiras, pois permitem pensar que o programa, se não reduziu o déficit, evitou que ele se ampliasse. No entanto, uma questão já pode ser fechada: o programa MCMV tornou este déficit socialmente mais regressivo: a partir de uma inflexão em 2009, ele tem participação cada vez maior de domicílios pobres e, como o cumprimento das metas físicas são significativas apenas para o déficit habitacional medido nas faixas de renda de 3 a 10 salários mínimos, é o programa MCMV que retira prioritariamente as faixas de renda média deste cálculo.

Uma confirmação indireta do empobrecimento do déficit habitacional brasileiro está em outra decomposição possível deste índice, desta vez não por faixa de renda mas por fator domiciliar de déficit.

Dos quatro fatores cuja presença no levantamento PNAD é suficiente para indicar déficit habitacional, três deles têm distribuição variada entre meio rural e urbano: a coabitação (quando famílias ocupam apenas cômodos ou dividem de maneira involuntária um mesmo domicílio) é preponderante no déficit habitacional nas cidades, principalmente em áreas de cortiços, mas pouco significativo no ambiente rural. O inverso ocorre com a precariedade construtiva (definida principalmente pelo uso de materiais rústicos como taipa e cobertura 
de palha), que tem presença mais relevante no déficit no campo do que nas cidades. O terceiro fator, que é o adensamento domiciliar, em que há mais de 3 pessoas por qualquer dependência que seja usada como dormitório, é o de menor participação tanto em meio rural quanto urbano, o que se deve provavelmente à queda das taxas de natalidade no Brasil, isto é, à diminuição de tamanho das famílias mais do que ao aumento de tamanho dos domicílios.

Diferentemente dos três fatores acima, a metodologia da Fundação João Pinheiro aplica unicamente em meio urbano o quarto fator que determina a contagem de um domicílio como déficit habitacional: o "ônus excessivo de aluguel", em que a locação do domicílio consome mais de $30 \%$ da renda familiar média mensal. Mais ainda, este fator também só é considerado como fator de déficit quando a renda domiciliar é igual ou inferior a 3 salários mínimos, pois uma despesa elevada com aluguel que onera uma renda domiciliar igualmente elevada não compromete obrigatoriamente outras necessidades vitais de uma família.

Pois este quarto fator, exclusivamente urbano e de baixa renda, é o único cuja contagem entre os domicílios brasileiros se elevou de forma consistente desde 2007, tanto em termos absolutos quanto relativos, como se vê no gráfico G-13:

\section{G-13 |PNDA - Fatores do déficit habitacional no Brasil - 2007/2012}
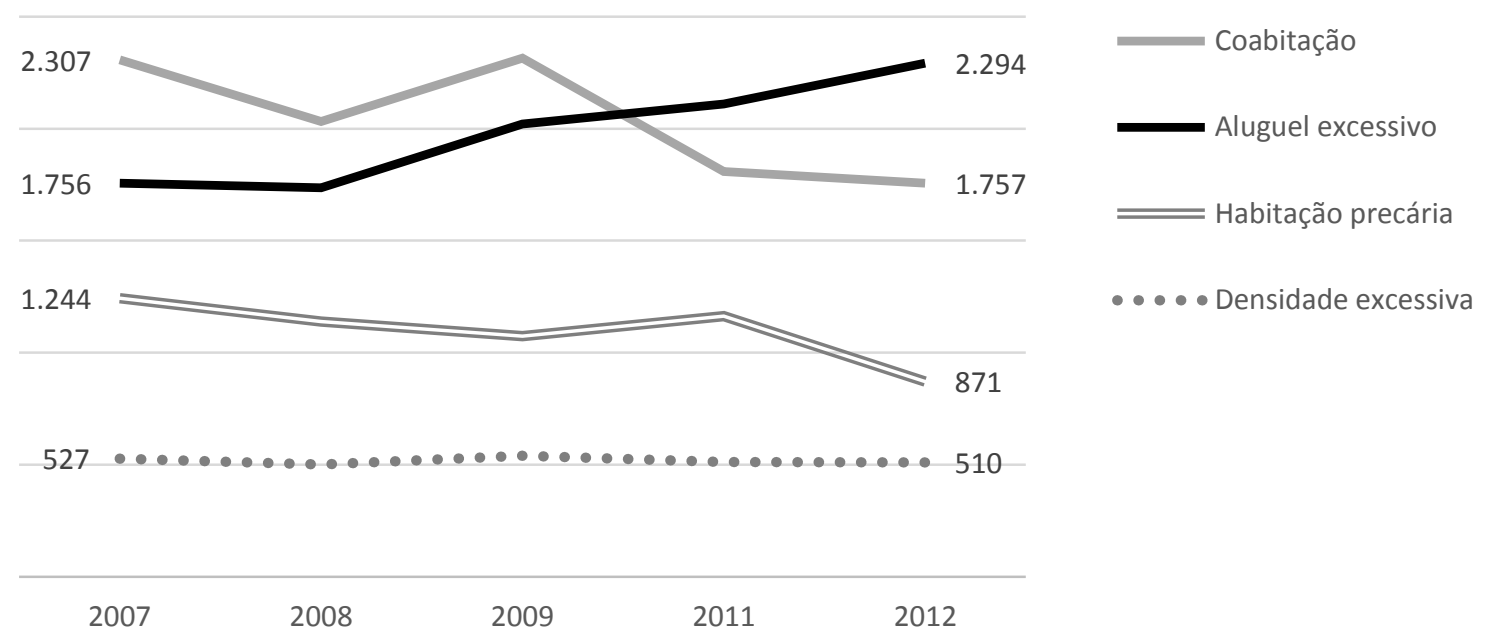

Fonte: elaboração própria a partir de Lima Neto; Furtado; Krause, 2013: 6.

Obs.: Valores em milhares de domicílios. Como um domicílio pode apresentar mais de um fator de déficit, as somas são superiores às quantidades apresentadas na tabela T-15.

A informação a extrair do gráfico G-13 é que as famílias de baixa renda nas cidades estão ingressando cada vez mais no déficit habitacional não por uma condição construtiva ou espacial do domicílio (a rusticidade dos materiais, o compartilhamento da moradia ou dos dormitórios), mas por uma condição eminentemente social do domicílio - o aluguel - cujo valor é regulado, em última instância, pela abstração do mercado de localizações urbanas.

De fato, um valor de aluguel que compromete as despesas básicas de uma família é uma condição integralmente urbana, que não faz sentido ser levantada em meio rural, pois ele mede uma disputa por localização como estratégia de vida nas cidades: paga-se mais aluguel, até mesmo por uma moradia mais precária ou em coabitação, porque este é o preço da proximidade com equipamentos coletivos ou ofertas de emprego e também é o preço da distância que uma família pobre 
tenta manter em relação a áreas impróprias para habitação, seja no sentido geotécnico do termo ou outros ainda mais profundos, como a carência de dinamismo econômico e a exposição à violência urbana.

É um limite intrínseco dos levantamentos estatísticos que, em tais espaços urbanos degradados e violentos, não conte como parte do déficit habitacional uma família que vive isolada numa moradia autoconstruída, dentro da qual seus membros podem dormir em pares pelas dependências erguidas com uma mínima estrutura de concreto armado com fechamentos cerâmicos tipo "bloco baiano", insumos da pobreza mas que não são "rústicos" como palha ou taipa. Quando a recusa de uma família de baixa renda em viver nesta condição periférica acarreta um "ônus excessivo do aluguel", ao menos um subproduto desta segregação urbana aparece nas estimativas de demanda de moradia [99].

Se é o valor dos aluguéis que está impedindo a queda do déficit habitacional entre a população de baixa renda, então que papel nele pode desempenhar as metas físicas do programa MCMV? Embora possa aumentar em parte a oferta de imóveis para aluguel (contrariando regras de arrendamento da unidade habitacional da Caixa Econômica Federal), a construção das novas moradias pelo programa implica muito mais num aumento de demanda por terra urbana que, em última instância, sustenta a dinâmica imobiliária recente nas grandes e médias cidades brasileiras, de incessantes elevações de valor para compra e também aluguel de moradia.

A associação entre o ônus excessivo do aluguel e o período de alta de preços no mercado imobiliário coincidente com a vigência do programa MCMV é feita com cuidado pelos autores do Nota Técnica $\mathrm{n}^{\circ} 5$ do Ipea:

O aumento do gasto das famílias pode ser decorrente de acréscimos nos valores de aluguel, em alguma medida, atrelados à valorização imobiliária pela qual passam as cidades brasileiras no período estudado (Lima Neto; Furtado; Krause, 2013: 12).

Há menos hesitação do ponto de vista do movimento de moradia de São Paulo. Segundo Guilherme Boulos, dirigente do Movimento dos Trabalhadores SemTeto (MTST), "O valor dos imóveis subiu mais de cinco vezes e o dos aluguéis duas vezes e meia acima da inflação" entre 2009 e 2013:

O mercado passou a capitalizar regiões antes periféricas. É o caso do Campo Limpo, distrito com maior concentração d favelas da capital de São Paulo, em que o valor do metro quadrado dobrou desde 2008. O mesmo ocorreu em Itaquera, na zona leste. A consequência é que milhares de famílias que viviam nessas regiões não conseguem mais arcar com o valor do aluguel (Boulos, 2013: A3).

Este é o preço final das sucessivas metas de construção do programa MCMV estarem desvinculadas de uma política habitacional abrangente e controlada por forças sociais outras que o mercado da construção e o mercado imobiliário: as respostas que o PlanHab poderia oferecer para o controle do valor da localização

99 Segundo o atual presidente do IAB, Sérgio Magalhães, a elevação da quantidade de domicílios fora do déficit habitacional não implica por si mesmo numa elevação de qualidade urbanística no Brasil: "o MCMV é um esforço importante, mas é mais do mesmo. Atingindo as metas, construirá 3,4 milhões de moradias em 8 anos, enquanto no período o país terá construído 12 milhões. Como? Tal como antes, na dificuldade, na precariedade, na irregularidade" (Magalhães, 2013: 21). 
urbana não podem ser oferecidas isoladamente por um programa de provisão habitacional, mesmo um "programa-plano" como o MCMV. Desta forma, o efeito de suas metas físicas sobre o déficit habitacional brasileiro se limita a um único ponto: concentrar e isolar seu núcleo de pobreza numa segregação urbana que, esta, permanece intocada.

\section{O custo de uma legitimação}

As análises sobre déficit habitacional não interessam de imediato às empresas construtoras que atuam no programa MCMV, pois a concentração cada vez maior do déficit na população pobre das grandes cidades brasileiras apenas reforça sua caracterização como "demanda não solvente" para a construção habitacional, cuja renda familiar não permite consumir a habitação que as estimativas domiciliares indicam que ela carece.

Mais importante para as construtoras, portanto é a legitimação que o déficit habitacional dá ao eixo central do programa MCMV, que é formado pelas diversas escalas de subsídio oriundos de aportes do Orçamento Geral da União ao programa, que chegaram no triênio 2011-2013 a R\$ 176 bilhões (PAC, 2014: 160). São estes subsídios que dão capacidade consumidora a uma população que, de outra forma, continuaria a ser uma demanda por habitação sem valor de mercado. André Singer trata a racionalidade desta política como parte do "sonho rooseveltiano" do segundo mandato Lula (Singer, 2012: 125), sonho que admite a seguinte interpretação de Pedro Arantes e Mariana Fix, mais focada na provisão habitacional:
A história do subsídio habitacional no Brasil é conhecida pela constante captura da subvenção pelas classes médias e agentes privados da produção imobiliária, ao invés de atender, na escala necessária, os trabalhadores que mais precisam. Embora essa tendência deva novamente prevalecer, há que se considerar o interesse político e eleitoral do governo em atingir a base da pirâmide. Ao contrário do regime militar, no qual a sustentação era dada sobretudo pelas classes médias, o governo Lula precisa fazer chegar a casa a uma parcela do seu eleitorado (Arantes; Fix, 2009: 4) [100].

Na forma final que o programa MCMV recebeu através da Lei Federal 12.424, os subsídios aparecem tanto nas dotações orçamentárias para o seu principal fundo, o FAR, quanto nas diversas disposições legais que concedem isenções fiscais e de custos de registro imobiliário, além dos novos dispositivos legais para regularização fundiária em terrenos a serem doados como contrapartidas municipais aos empreendimentos financiados pelo programa, principalmente através do "auto de demarcação urbanística".

A lei também cria um instrumento de segurança para os recursos onerosos, através do "Fundo Garantidor da Habitação Popular" (FGHab), que refinancia

100 O contraste com o BNH é relevante, como atesta uma análise da época: “O Banco Nacional da Habitação atuando essencialmente como um banco comercial, sem uma clara política de distribuição dos financiamentos pelo espectro social, permitiu distorções na alocação dos recursos, provocadas, sem dúvida, pela especulação imobiliária, que prefere as garantias oferecidas pela classe média às dificuldades e incertezas das classes de menor poder aquisitivo" (Bruna 1976: 109). 
as prestações mensais de arrendamento em caso de inadimplência e confere segurança tanto para as operações financeiras da Caixa Econômica Federal quanto aos empréstimos subsidiados para construção de infraestrutura urbana oriundos do Banco Nacional de Desenvolvimento Social (BNDES).

Na ponta do consumo final da unidade habitacional, o subsídio mais impactante é o que incide para a faixa de renda familiar mais baixa do programa MCMV. Na segunda fase do programa, esta faixa de renda está desvinculada dos aumentos do salário mínimo pelo valor-teto de $\mathrm{R} \$ 1.600$ e recebe a denominação pouco descritiva de "Faixa 1". O quadro completo das faixas de renda e das correspondentes metas e modalidades de contratação aparece na tabela T-17:

T-17|MCMV 2 - Contratação por faixa de renda e modalidade

\begin{tabular}{c|l|c|c}
\multicolumn{1}{c}{ Faixa de renda } & Modalidade de contratação & Meta física (UH) & $\%$ \\
\hline \multirow{3}{*}{ Até R\$ 1.600 } & Repasse para construtoras (FAR) & 860.000 & 43 \\
\cline { 2 - 4 } & Oferta pública em cidades até 50 mil hab. & 220.000 & 11 \\
\cline { 2 - 4 } & Repasse para entidades organizadoras (FDS) & 60.000 & 3 \\
\cline { 2 - 4 } & Repasse para habitação rural (PNHR) & 60.000 & 3 \\
\hline $\mathrm{R} \$ 1,600$ a $\mathrm{R} \$ 3.275$ & Financiamento subvencionado pelo FGTS & 600.000 & 30 \\
\hline $\mathrm{R} \$ 3.275$ a $\mathrm{R} \$ 5.000$ & Financiamento subvencionado pelo FGTS & 200.000 & 10 \\
\hline & Total & $\mathbf{2}$ milhões & $\mathbf{1 0 0}$
\end{tabular}

Fonte: elaboração própria a partir da Lei Federal 12.424/2011 e Resolução 702 do CCFGTS.

A maior meta parcial do programa MCMV 2 está concentrada no Fundo de Arrendamento Residencial (FAR): 43\% da meta total de dois milhões de moradias estabelecida em Julho de 2011. Este fundo financia exclusivamente projetos habitacionais para baixa renda elaborados e apresentados à CEF por empresas construtoras privadas [101].

São também empresas privadas que produzem os imóveis ofertados com juros subsidiados para as faixas de renda entre R\$ 1.600 e $\mathrm{R} \$ 3.275$ ("Faixa 2") e entre $\mathrm{R} \$ 3.275$ e R\$ 5.000 (“Faixa 3"), desta vez com recursos do quase cinquentenário Fundo de Garantia por Tempo de Serviço (FGTS) [102].

O FAR, segundo Pedro Arantes e Mariana Fix, é “um fundo público secundário e sem conselho (...), mais maleável e desregulado, capaz de atender ao interesse do capital da construção" (Arantes; Fix, 2009: 13). Herdado de um antigo programa habitacional operado pela CEF (ver nota 69), seu estrito controle governamental se desdobra num controle tanto da produção do imóvel, pelo instrumento do repasse, quanto do seu consumo, pelo instrumento do arrendamento. Pelo repasse, a empresa construtora é remunerada (e bonificada em 18\%) unicamente

101 Além da oferta pública de recursos para pequenas cidades, aparece com pouca expressividade como modalidade de contratação o repasse a empreendimentos organizados por movimentos de moradia, com recursos do Fundo de Desenvolvimento Social (FDS). O encolhimento desta forma socialmente mais progressista de provisão habitacional, indicativa de uma inflexão conservadora do Partido dos Trabalhadores, é tema de uma recente pesquisa de Evaniza Rodrigues (Rodrigues, 2013).

102 Faixas de renda atualizadas conforme Decreto Federal 7.825 de 15 de Outubro de 2012 e Resolução 702 do Conselho Gestor do FGTS. O capítulo 8 analisa a interação entre a altamente subsidiada "Faixa 1", exclusiva da habitação de baixa renda, e as faixas de renda média "Faixa 2" e "Faixa 3", uma vez que as mesmas empresas construtoras gerenciam empreendimentos muito semelhantes entre estas modalidades do programa MCMV. 
por custos construtivos e recebe a última parcela apenas após a transferência de todo o empreendimento à CEF. Pelo arrendamento, a CEF prolonga a regulação de uso da edificação e de sua fração ideal pelos dez primeiros anos de ocupação do imóvel pela família moradora, prazo durante o qual o financiamento é considerado uma locação com opção de compra após quitação de todos os pagamentos. As 120 parcelas mensais de arrendamento, no entanto, são altamente subsidiadas. A tabela T-18 indica a porcentagem assumida pelo FAR para os limites de renda familiar superior e inferior da "Faixa 1" quando se considera o máximo valor de repasse da unidade habitacionais na RMSP, atualmente em R\$ 76 mil.

T-18|MCMV 2 - Subsídio máximo e mínimo para Faixa 1 na RMSP

\begin{tabular}{c|c|c|c|c} 
Renda familiar & Prestação mensal & $\mathbf{1 2 0}$ prestações & Subsídio pelo FAR & \% subsídio \\
\hline Menor que R\$ 500,00 & $\mathrm{R} \$ 25,00$ & $\mathrm{R} \$ 3.000,00$ & $\mathrm{R} \$ 73.000,00$ & $96,05 \%$ \\
\hline $\mathrm{R} \$ 1.600,00$ & $\mathrm{R} \$ 80,00$ & $\mathrm{R} \$ 9.600,00$ & $\mathrm{R} \$ 66.400,00$ & $87,37 \%$
\end{tabular}

Fonte: Elaboração própria a partir da Portaria Interministerial 477 de 14 de Outubro de 2013

Na linguagem do agente financeiro do programa, a Caixa Econômica Federal, o MCMV concede às famílias da "Faixa 1" o "subsídio integral do valor da moradia", uma vez que autoriza o FAR "a absorver o saldo residual" de um plano de pagamentos por um prazo de 10 anos, com prestação mínima de R\$ 25 e que não pode exceder o limite de $5 \%$ da renda familiar. Por dispensar qualquer investigação cadastral, uma família cadastrada pelo governo municipal se integra ao programa MCMV assim que possa assumir o simbólico pagamento mensal de $\mathrm{R} \$ 25$, sem que seja preciso considerar seu grau de integração aos circuitos de crédito ou consumo no Brasil.

A porcentagem de subsídio, que oscila em torno de $90 \%$ do valor total da moradia, decorre tanto do baixo valor a ser dispendido pelas famílias moradoras durante o arrendamento quanto do alto valor que o programa MCMV repassa à empresa construtora. $\mathrm{O}$ atual valor de $\mathrm{R} \$ 76.000$ na região metropolitana de São Paulo, fixado pelas Portaria 168/2013 do Ministério das Cidades, é o maior do Brasil e pode ainda obter um "Apoio Financeiro Complementar" do Fundo Paulista de Habitação de Interesse Social, no valor de R \$ 20 mil por unidade [103]

A construção de um apartamento de padrão popular na RMSP, caso seja repassado à CEF pelo valor máximo de $\mathrm{R} \$ 96$ mil, teria um custo por unidade de área construída em torno de $\mathrm{R} \$ 2 \mathrm{mil} / \mathrm{m}^{2}$, quando o correspondente indicador de custo de construção CUB $/ \mathrm{m}^{2}$ (do projeto-padrão PIS) é R \$ 740,42/ $\mathrm{m}^{2}$ em Agosto de 2013 . A diferença de $\mathrm{R} \$ 1.260 / \mathrm{m}^{2}$ se torna então uma remuneração movediça para a compra do terreno e a bonificação da empresa construtora, que é difícil de ser comprovada através do orçamento do empreendimento.

Um levantamento junto às Gerências de Desenvolvimento Urbano da CEF, que realizam a análise e acompanhamento dos contratos do programa MCMV, revela que existe pouca variação no valor de repasse nos empreendimentos para baixa

103 O Fundo Paulista de Habitação de Interesse Social - FPHIS - foi instituído em Janeiro de 2008 pela Lei Estadual 12.801. O seu conselho gestor aprovou a complementação de recursos do programa MCMV através da Deliberação Normativa 6 e 8 de 20 de Março de 2012. 
renda na RMSP. As tabelas T-19, T-20 e T-21 a seguir dividem este levantamento em três grupos de contratos, respectivamente: contratos aprovados e assinados, cujas obras ainda não iniciaram; contratos de obras concluídas e integralmente repassadas à CEF; contratos com obras em execução, com diferentes porcentagens de repasses já realizados. Todas as informações foram atualizadas para Junho de 2013, data limite em que esta pesquisa busca agrupar as informações estatísticas sobre o programa MCMV e a força de trabalho na construção habitacional no Brasil e na RMSP.

T-19|MCMV - Contratos de baixa renda não iniciados na RMSP - JUN13

\begin{tabular}{l|l|l|l|l|l|l} 
CONTRATO & EMPRESA CONSTRUTORA & MUNIĆPIO RMSP & BAIRRO & UH & VALOR TOTAL & VALOR/UH \\
\hline $01 / 10 / 2010$ & CONSTRUTORA CRONACON LTDA & SÃO PAULO & CIDADE LÍDER/ITAQUERA & 300 & $\mathrm{R} \$ 15.600 .000,00$ & $\mathrm{R} \$ 52.000,00$ \\
\hline $14 / 12 / 2010$ & SIMETRICA ENGENHARIA LTDA & SÃO PAULO & GUAIANAZES & 56 & $\mathrm{R} \$ 2.912 .000,00$ & $\mathrm{R} \$ 52.000,00$ \\
\hline $14 / 12 / 2010$ & SIMETRICA ENGENHARIA LTDA & SÃO PAULO & GUAIANAZES & 60 & $\mathrm{R} \$ 3.120 .000,00$ & $\mathrm{R} \$ 52.000,00$ \\
\hline $31 / 12 / 2012$ & CURY CONSTRUTORA E INCORPORADORA S/A & SUZANO & JARDIM MONTE CRISTO & 300 & $\mathrm{R} \$ 22.800 .000,00$ & $\mathrm{R} \$ 76.000,00$ \\
\hline $31 / 12 / 2012$ & CURY CONSTRUTORA E INCORPORADORA S/A & SUZANO & JARDIM MONTE CRISTO & 300 & $\mathrm{R} \$ 22.800 .000,00$ & $\mathrm{R} \$ 76.000,00$ \\
\hline $20 / 06 / 2013$ & EMCCAMP RESIDENCIAL S/A & GUARULHOS & TIJUCO PRETO & 1.408 & $\mathrm{R} \$ 107.008 .000,00$ & $\mathrm{R} \$ 76.000,00$ \\
\hline $24 / 06 / 2013$ & SFERA ENGENHARIA LTDA & SÃO PAULO & CENTRO & 72 & $\mathrm{R} \$ 5.441 .824,55$ & $\mathrm{R} \$ 75.580,90$ \\
\hline $28 / 06 / 2013$ & CONSTRUCENTRO LTDA & EMBU & CHÁCARA SÃO MARCOS 1 & 120 & $\mathrm{R} \$ 9.120 .000,00$ & $\mathrm{R} \$ 76.000,00$ \\
\hline $28 / 06 / 2013$ & EMCCAMP RESIDENCIAL S/A & SÃO PAULO & JARDIM SHANGRILÁ & 1.188 & $\mathrm{R} \$ 90.288 .000,00$ & $\mathrm{R} \$ 76.000,00$ \\
\hline $28 / 06 / 2013$ & CURY CONSTRUTORA E INCORPORADORA S/A & SUZANO & JARDIM EUROPA & 500 & $\mathrm{R} \$ 38.000 .000,00$ & $\mathrm{R} \$ 76.000,00$ \\
\hline $28 / 06 / 2013$ & CURY CONSTRUTORA E INCORPORADORA S/A & SÃO PAULO & PARQUE SAO RAFAEL & 980 & $\mathrm{R} \$ 74.480 .000,00$ & $\mathrm{R} \$ 76.000,00$ \\
\hline $28 / 06 / 2013$ & PREDIAL SUZANENSE CONSTRUCOES E INCORP. LTDA & MOGI DAS CRUZES & CAPUTERA & 300 & $\mathrm{R} \$ 22.800 .000,00$ & $\mathrm{R} \$ 76.000,00$ \\
\hline $28 / 06 / 2013$ & PREDIAL SUZANENSE CONSTRUCOESE INCORP. LTDA & MOGI DAS CRUZES & CAPUTERA & 300 & $\mathrm{R} \$ 22.800 .000,00$ & $\mathrm{R} \$ 76.000,00$ \\
\hline & TOTAL & & & $\mathbf{5 . 8 8 4}$ & $\mathrm{R} \$ \mathbf{4 3 7 . 1 6 9 . 8 2 4 , 5 5}$
\end{tabular}

Fonte: elaboração própria com dados da CEF/GIDUR/SP

A tabela T-19 mostra dois grupos distintos de contratos assinados mas sem obras iniciadas, divididos pelos empreendimentos contratados junto à Cury Construtora e Incorporadora S/A no último dia de 2012. Antes deste evento, havia três contratos assinados em 2010 cuja perspectiva de início de obra é remota, uma vez que carregam ainda o valor de $\mathrm{R} \$ 52$ mil por unidade habitacional vigente durante a primeira etapa do programa MCMV. Nos demais contratos, a perspectiva comercial se altera através do novo valor do repasse da unidade habitacional de R\$ 76 mil, 46\% mais elevado. Estavam aprovados e assinados em Junho de 2013 contratos de grande escopo, em que aparece uma tendência de concentração de produção em duas grandes empresas construtoras, a própria Cury Construtora e Incorporadora S/A e a Emccamp Residencial S/A, as únicas de capital aberto da listagem. Seus empreendimentos somam $80 \%$ do total de 5.884 unidades habitacionais com obras ainda por iniciar na RMSP.

Um destaque por contraste é a pequena construtora Sfera Engenharia Ltda, que assinou contrato em 24 de Junho de 2013 para requalificar 78 apartamentos situados na área central da cidade de São Paulo (mais precisamente, em três números na rua Conselheiro Crispiniano: 119, 125, 131). Do ponto de vista do planejamento urbano, cada apartamento deste pequeno contrato tem efeitos urbanos mais abrangentes do que os 1.408 apartamentos a serem construídos pela construtora Emccamp no bairro de Jardim Shangrilá (no extremo sul da região de Interlagos) ou os 980 apartamentos a serem construídos pela construtora Cury no bairro Parque São Rafael, cujo endereço cadastrado na GIDUR/CEF não tem CEP e consta apenas como "Estrada da Servidão 7, s/n".

Para produzir habitação para baixa renda numa região consolidada e significativa como a do centro da cidade de São Paulo, a construtora Sfera orçou seus serviços no valor algo pudico de $\mathrm{R} \$ 75.580,90 / \mathrm{UH}$, enquanto que todas as 
demais construtoras, nos diferentes bairros periféricos da metrópole, chegam ao valor exato de $\mathrm{R} \$ 76 \mathrm{mil} / \mathrm{UH}$, o que é mais um sinal de que contratos em regiões centrais não seguem uma tendência generalizada no programa MCMV.

\begin{tabular}{|c|c|c|c|c|c|c|}
\hline CONTRATO & EMPRESA CONSTRUTORA & MUNICÍPIO RMSP & BAIRRO & UH & VALOR TOTAL & VALOR/UH \\
\hline $30 / 09 / 2009$ & CONSTRUTORA E INCORPORADORA FALEIROS LTDA & MOGI DAS CRUZES & BAIRRO CAPUTERA & 140 & $R \$ 7.279 .650,02$ & $R \$ 51.997,50$ \\
\hline $30 / 09 / 2009$ & CONSTRUTORA E INCORPORADORA FALEIROS LTDA & MOGI DAS CRUZES & BAIRRO CAPUTERA & 140 & $R \$ 7.238 .560,00$ & $\mathrm{R} \$ 51.704,00$ \\
\hline $10 / 12 / 2009$ & CURY CONSTRUTORA E INCORPORADORA S/A & MOGI DAS CRUZES & VILA JUNDIAPEBA & 140 & $R \$ 7.279 .993,28$ & $R \$ 51.999,95$ \\
\hline $10 / 12 / 2009$ & CURY CONSTRUTORA E INCORPORADORA S/A & MOGI DAS CRUZES & VILA JUNDIAPEBA & 140 & $R \$ 7.279 .993,28$ & $R \$ 51.999,95$ \\
\hline $10 / 12 / 2009$ & CURY CONSTRUTORA E INCORPORADORA S/A & MOGI DAS CRUZES & VILA JUNDIAPEBA & 280 & $R \$ 14.559 .993,26$ & $\mathrm{R} \$ 51.999,98$ \\
\hline $10 / 12 / 2009$ & CURY CONSTRUTORA E INCORPORADORA S/A & MOGI DAS CRUZES & VILA JUNDIAPEBA & 380 & R\$ 19.759.915,95 & $\mathrm{R} \$ 51.999,78$ \\
\hline $10 / 12 / 2009$ & CURY CONSTRUTORA E INCORPORADORA S/A & MOGI DAS CRUZES & VILA JUNDIAPEBA & 280 & $R \$ 14.559 .993,26$ & $R \$ 51.999,98$ \\
\hline $10 / 12 / 2009$ & CURY CONSTRUTORA E INCORPORADORA S/A & MOGI DAS CRUZES & VILA JUNDIAPEBA & 280 & $R \$ 14.559 .993,26$ & $R \$ 51.999,98$ \\
\hline $10 / 12 / 2009$ & CURY CONSTRUTORA E INCORPORADORA S/A & MOGI DAS CRUZES & VILA JUNDIAPEBA & 280 & $R \$ 14.559 .993,26$ & $\mathrm{R} \$ 51.999,98$ \\
\hline $10 / 12 / 2009$ & CURY CONSTRUTORA E INCORPORADORA S/A & MOGI DAS CRUZES & VILA JUNDIAPEBA & 280 & $R \$ 14.559 .993,26$ & $R \$ 51.999,98$ \\
\hline $11 / 12 / 2009$ & CONSTRUTORA MENIN LTDA & SÃO PAULO & JARDIM SAPOPEMBA & 300 & $R \$ 15.600 .000,00$ & $R \$ 52.000,00$ \\
\hline $11 / 12 / 2009$ & CONSTRUTORA MENIN LTDA & SÃO PAULO & JARDIM SAPOPEMBA & 180 & $R \$ 9.360 .000,00$ & $R \$ 52.000,00$ \\
\hline $23 / 12 / 2009$ & CONSTRUTORA E INCORPORADORA FALEIROS LTDA & MOGI DAS CRUZES & SITIO UNA / OROPO & 180 & $R \$ 9.358 .200,00$ & $\mathrm{R} \$ 51.990,00$ \\
\hline $23 / 12 / 2009$ & CONSTRUTORA E INCORPORADORA FALEIROS LTDA & MOGI DAS CRUZES & SITIO UNA / OROPO & 200 & $\mathrm{R} \$ 10.383 .776,77$ & $R \$ 51.918,88$ \\
\hline $28 / 12 / 2009$ & H.E.ENG. COMERCIO E REPRES.LTDA & SÃO PAULO & SAO MATEUS & 200 & $R \$ 10.399 .400,00$ & $R \$ 51.997,00$ \\
\hline $12 / 02 / 2010$ & CONVIVA EMPREENDIMENTOS IMOBILIARIOS LTDA & GUARULHOS & BONSUCESSO & 200 & $\mathrm{R} \$ 10.400 .000,00$ & $R \$ 52.000,00$ \\
\hline $04 / 03 / 2010$ & CONSTRUTORA E INCORPORADORA FALEIROS LTDA & MOGI DAS CRUZES & VILA SUISSA & 280 & $R \$ 14.533 .593,00$ & $\mathrm{R} \$ 51.905,69$ \\
\hline $01 / 07 / 2010$ & YPS CONSTRUCOES E INCORPORACOES LTDA & SUZANO & VILA CLIMATERIA & 378 & $R \$ 19.653 .269,17$ & $R \$ 51.992,78$ \\
\hline $17 / 09 / 2010$ & HZR CONSTRUTORA LTDA & OSASCO & JARDIM BELMONTE & 420 & $R \$ 21.840 .000,00$ & $R \$ 52.000,00$ \\
\hline $01 / 10 / 2010$ & CONSTRUTORA CRONACON LTDA & SÃO PAULO & CIDADE LIDER & 300 & $R \$ 15.600 .000,00$ & $R \$ 52.000,00$ \\
\hline $01 / 10 / 2010$ & CONSTRUTORA HUDSON LTDA & SÃO PAULO & ITAQUERA & 160 & $\mathrm{R} \$ 8.320 .000,00$ & $R \$ 52.000,00$ \\
\hline $01 / 10 / 2010$ & CONSTRUTORA HUDSON LTDA & SÃO PAULO & ITAQUERA & 140 & $R \$ 7.280 .000,00$ & $R \$ 52.000,00$ \\
\hline $01 / 10 / 2010$ & SIMETRICA ENGENHARIA LTDA & SÃO PAULO & CIDADE TIRADENTES & 260 & $R \$ 13.520 .000,00$ & $R \$ 52.000,00$ \\
\hline $06 / 12 / 2010$ & SANED ENGENHARIA E EMPREENDIMENTOS LTDA & SÃO PAULO & RAPOSO TAVARES & 30 & R\$ $1.560 .000,00$ & $R \$ 52.000,00$ \\
\hline $14 / 12 / 2010$ & SIMETRICA ENGENHARIA LTDA & SÃO PAULO & JOSE BONIFACIO & 40 & $R \$ 2.080 .000,00$ & $R \$ 52.000,00$ \\
\hline $14 / 12 / 2010$ & SIMETRICA ENGENHARIA LTDA & SÃO PAULO & CIDADE TIRADENTES & 32 & $\mathrm{R} \$ 1.664 .000,00$ & $R \$ 52.000,00$ \\
\hline $14 / 12 / 2010$ & SIMETRICA ENGENHARIA LTDA & SÃO PAULO & CIDADE TIRADENTES & 60 & $R \$ 3.120 .000,00$ & $\mathrm{R} \$ 52.000,00$ \\
\hline $15 / 12 / 2010$ & EDIVIA EDIFICACOES E INCORPORACOES LTDA & SÃO PAULO & ITAQUERA & 118 & $\mathrm{R} \$ 6.136 .000,00$ & $R \$ 52.000,00$ \\
\hline $28 / 12 / 2010$ & GECCOM - CONSTRUTORA LTDA & TABOÃO DA SERRA & JARDIM NOVO RECORD & 80 & R\$ 4.160.000,00 & $\mathrm{R} \$ 52.000,00$ \\
\hline $28 / 12 / 2010$ & GECCOM - CONSTRUTORA LTDA & TABOÃO DA SERRA & JARDIM NOVO RECORD & 80 & $\mathrm{R} \$ 4.160 .000,00$ & $R \$ 52.000,00$ \\
\hline $01 / 02 / 2012$ & CONSTRUTORA CRONACON LTDA & SÃO PAULO & ARTUR ALVIN & 40 & $\mathrm{R} \$ 2.478 .403,20$ & $\mathrm{R} \$ 61.960,08$ \\
\hline \multirow[t]{2}{*}{$30 / 03 / 2012$} & ESECON CONSTRUTORA E INCORPORADORA LTDA & EMBU & PARQUE DAS CHACARAS & 224 & $\mathrm{R} \$ 14.560 .000,00$ & $R \$ 65.000,00$ \\
\hline & |TOTAL & & & 6.242 & $\mathrm{R} \$ \mathbf{3 2 7 . 8 0 4 . 7 2 0 , 9}$ & \\
\hline
\end{tabular}

Fonte: elaboração própria com dados da CEF/GIDUR/SP

A tabela T-20 agrupa os 32 contratos na Faixa 1 de renda do programa MCMV já concluídos na região metropolitana de São Paulo entre meados de 2009 e meados de 2013, quando 6.242 unidades habitacionais foram repassadas para a CEF mitigar o déficit habitacional desta porção do país. A quantidade de contratos tem algo de ilusória, pois vários deles correspondem a empreendimentos contíguos, organizados como um único canteiro de obras e que resultaram numa única espacialidade urbana. Este é o caso de todos os empreendimentos de mesma construtora e bairro, com destaque para os da construtora Cury em Mogi das Cruzes (nomeados de "Jundiapeba 1" a "Jundiapeba 8"), que serão objeto de estudado mais detalhado no capítulo 7 desta pesquisa.

Todos os empreendimentos da listagem foram contratados na fase 1 do programa MCMV e orçaram o valor da unidade em R\$ 52 mil, com alguns centavos de desconto, com exceção dos dois empreendimentos de assinatura mais recente, da Construtora Cronacron Ltda e da Esecon Construtora e Incorporadora, que foram contratados na fase 2 do programa. Esta diferença de etapas aumentou para $\mathrm{R} \$$ $61.960,08$ o valor de cada uma das 40 unidades habitacionais do pequeno empreendimento da construtora Cronacron (valor que segue uma regra de transição entre as fases 1 e 2 do programa MCMV) e para exatos R 65 mil, no caso do empreendimento de 224 unidades habitacionais da construtora Esecon. 


\section{T-21|MCMV - Contratos de baixa renda em construção na RMSP - JUN13}

\section{CONTRATO EMPRESA CONSTRUTORA}

\begin{tabular}{|l|l} 
MUNICÍPIO RMSP & BAIRRO \\
\hline
\end{tabular}

\begin{tabular}{|c|c|c|c|c|c|c|}
\hline & & & & & & \\
\hline $08 / 02 / 2010$ & WWGI EIVIPREEINDIIVIENIUS E IINCURPURACUES LIDA & GUARULHUS & AGUA CHAIA & 500 & R> $25.999 .802,16$ & $\mathrm{R}>51.999,60$ \\
\hline $01 / 07 / 2010$ & YPS CONSTRUCOES E INCORPORACOES LTDA & SUZANO & VILA CLIMATÉRIA & 378 & $R \$ 19.655 .323,62$ & $R \$ 51.998,21$ \\
\hline $31 / 08 / 2010$ & DIB ARQUITETURA INCOPORADORA LTDA & GUARULHOS & BAIRRO DOS PIMENTAS & 580 & $R \$ 30.123 .555,19$ & $R \$ 51.937,16$ \\
\hline $31 / 08 / 2010$ & DIB ARQUITETURA INCOPORADORA LTDA & GUARULHOS & BAIRRO DOS PIMENTAS & 500 & $R \$ 26.000 .000,00$ & $R \$ 52.000,00$ \\
\hline $24 / 09 / 2010$ & RGA CONSTRUTORA LTDA & SANTO ANDRÉ & JD SANTA CRISTINA & 132 & $R \$ 6.836 .300,30$ & $R \$ 51.790,15$ \\
\hline $24 / 09 / 2010$ & RGA CONSTRUTORA LTDA & SANTO ANDRÉ & VILA ALZIRA & 220 & $\mathrm{R} \$ 11.433 .912,88$ & $R \$ 51.972,33$ \\
\hline $01 / 10 / 2010$ & CONSTRUTORA HUDSON LTDA & SÃO PAULO & ITAQUERA & 300 & $\mathrm{R} \$ 15.600 .000,00$ & $\mathrm{R} \$ 52.000,00$ \\
\hline $01 / 10 / 2010$ & CONSTRUTORA HUDSON LTDA & SÃO PAULO & ITAQUERA & 160 & $\mathrm{R} \$ 8.320 .000,00$ & $R \$ 52.000,00$ \\
\hline $01 / 10 / 2010$ & CONSTRUTORA HUDSON LTDA & SÃO PAULO & ITAQUERA & 180 & $\mathrm{R} \$ 9.360 .000,00$ & $R \$ 52.000,00$ \\
\hline $06 / 12 / 2010$ & SANED ENGENHARIA E EMPREENDIMENTOS LTDA & SÃO PAULO & JARDIM ESMERALDA & 240 & $\mathrm{R} \$ 12.480 .000,00$ & $R \$ 52.000,00$ \\
\hline $29 / 12 / 2010$ & CONSTRUTORA CROMA LTDA & SÃO PAULO & ITAQUERA & 120 & $R \$ 6.240 .000,00$ & $\mathrm{R} \$ 52.000,00$ \\
\hline $29 / 12 / 2010$ & CONSTRUTORA CROMA LTDA & SÃO PAULO & ITAQUERA & 100 & $\mathrm{R} \$ 5.200 .000,00$ & $\mathrm{R} \$ 52.000,00$ \\
\hline $29 / 12 / 2010$ & CONSTRUTORA CROMA LTDA & SÃO PAULO & CAPAO REDONDO & 180 & $R \$ 9.360 .000,00$ & $R \$ 52.000,00$ \\
\hline $29 / 12 / 2010$ & CONSTRUTORA CROMA LTDA & SÃO PAULO & ARTUR ALVIM & 80 & $R \$ 4.160 .000,00$ & $R \$ 52.000,00$ \\
\hline $31 / 08 / 2011$ & SOUEN \& NAHAS CONSTRUTORA E INCORPORADORA & DIADEMA & TABOÃO & 232 & $\mathrm{R} \$ 13.688 .000,00$ & $R \$ 59.000,00$ \\
\hline $30 / 09 / 2011$ & DIB ARQUITETURA INCOPORADORA LTDA & GUARULHOS & BAIRROS DAS LAVRAS & 1.460 & $\mathrm{R} \$ 94.898 .518,71$ & $R \$ 64.998,99$ \\
\hline $29 / 12 / 2011$ & SANED ENGENHARIA E EMPREENDIMENTOS LTDA & SÃO PAULO & SAPOPEMBA & 300 & $\mathrm{R} \$ 15.600 .000,00$ & $\mathrm{R} \$ 52.000,00$ \\
\hline $29 / 12 / 2011$ & SANED ENGENHARIA E EMPREENDIMENTOS LTDA & SÃO PAULO & SAPOPEMBA & 140 & $\mathrm{R} \$ 8.679 .999,97$ & $R \$ 62.000,00$ \\
\hline $29 / 12 / 2011$ & SANED ENGENHARIA E EMPREENDIMENTOS LTDA & SÃO PAULO & SAPOPEMBA & 20 & $\mathrm{R} \$ 1.239 .999,98$ & $R \$ 62.000,00$ \\
\hline $10 / 02 / 2012$ & TERRA NOVA ENGENHARIA E CONSTRUCOES LTDA & OSASCO & JARDIM PIRATININGA & 86 & R\$ 5.331.177,94 & $\mathrm{R} \$ 61.990,44$ \\
\hline $10 / 02 / 2012$ & TERRA NOVA ENGENHARIA E CONSTRUCOES LTDA & OSASCO & JARDIM PIRATININGA & 48 & $\mathrm{R} \$ 2.973 .340,83$ & $\mathrm{R} \$ 61.944,60$ \\
\hline $10 / 02 / 2012$ & TERRA NOVA ENGENHARIA E CONSTRUCOES LTDA & OSASCO & JARDIM PIRATININGA & 76 & $\mathrm{R} \$ 4.710 .422,07$ & $R \$ 61.979,24$ \\
\hline $10 / 02 / 2012$ & TERRA NOVA ENGENHARIA E CONSTRUCOES LTDA & OSASCO & JARDIM PIRATININGA & 66 & $R \$ 4.087 .388,82$ & $R \$ 61.930,13$ \\
\hline $10 / 02 / 2012$ & TERRA NOVA ENGENHARIA E CONSTRUCOES LTDA & OSASCO & JARDIM PIRATININGA & 126 & $R \$ 7.809 .484,24$ & $\mathrm{R} \$ 61.980,03$ \\
\hline $19 / 03 / 2012$ & YPS CONSTRUCOES E INCORPORACOES LTDA & SUZANO & GOIABEIRA & 200 & $\mathrm{R} \$ 12.734 .103,81$ & $R \$ 63.670,52$ \\
\hline $19 / 03 / 2012$ & YPS CONSTRUCOES E INCORPORACOES LTDA & SUZANO & GOIABEIRA & 80 & $R \$ 5.158 .651,53$ & $\mathrm{R} \$ 64.483,14$ \\
\hline $30 / 03 / 2012$ & RGA CONSTRUTORA LTDA & SANTO ANDRÉ & VILA CAMILÓPOLIS & 132 & $\mathrm{R} \$ 8.356 .211,42$ & $R \$ 63.304,63$ \\
\hline $30 / 03 / 2012$ & RGA CONSTRUTORA LTDA & SANTO ANDRÉ & VILA CAMILÓPOLIS & 176 & $\mathrm{R} \$ 9.152 .000,00$ & $R \$ 52.000,00$ \\
\hline $25 / 05 / 2012$ & SIMETRICA ENGENHARIA LTDA & SÃO PAULO & CIDADE TIRADENTES & 200 & $\mathrm{R} \$ 12.400 .000,00$ & $R \$ 62.000,00$ \\
\hline $28 / 05 / 2012$ & GMP ENGENHEIROS ASSOCIADOS S/C LTDA & SUZANO & VL. CLIMATÉRICA & 280 & $\mathrm{R} \$ 18.199 .521,27$ & $\mathrm{R} \$ 64.998,29$ \\
\hline $30 / 05 / 2012$ & SOUEN \& NAHAS CONSTRUTORA E INCORPORADORA & DIADEMA & JD PORTINARI & 200 & $\mathrm{R} \$ 13.000 .000,01$ & $\mathrm{R} \$ 65.000,00$ \\
\hline $31 / 05 / 2012$ & B \& B - ENGENHARIA E CONSTRUCOES LTDA & SÃO PAULO & CAPAO REDONDO & 160 & $\mathrm{R} \$ 10.400 .000,00$ & $\mathrm{R} \$ 65.000,00$ \\
\hline $31 / 05 / 2012$ & B \& B - ENGENHARIA E CONSTRUCOES LTDA & SÃO PAULO & CAPAO REDONDO & 40 & $\mathrm{R} \$ 2.600 .000,00$ & $R \$ 65.000,00$ \\
\hline $31 / 05 / 2012$ & B \& B - ENGENHARIA E CONSTRUCOES LTDA & SÃO PAULO & CAPAO REDONDO & 60 & $R \$ 3.900 .000,00$ & $R \$ 65.000,00$ \\
\hline $31 / 05 / 2012$ & B \& B - ENGENHARIA E CONSTRUCOES LTDA & SÃO PAULO & CAPAO REDONDO & 40 & $\mathrm{R} \$ 2.600 .000,00$ & $\mathrm{R} \$ 65.000,00$ \\
\hline $15 / 06 / 2012$ & EDIVIA EDIFICACOES E INCORPORACOES LTDA & SÃO PAULO & JOSE BONIFÁCIO & 50 & $R \$ 3.250 .000,00$ & $R \$ 65.000,00$ \\
\hline $18 / 06 / 2012$ & EDIVIA EDIFICACOES E INCORPORACOES LTDA & GUARULHOS & JOSE BONIFÁCIO & 156 & $\mathrm{R} \$ 10.140 .000,00$ & $\mathrm{R} \$ 65.000,00$ \\
\hline $29 / 06 / 2012$ & BAIRRO NOVO EMPREENDIMENTO IMOBILIARIO S/A & SANTO ANDRÉ & JD. ALZIRA FRANCO & 200 & $\mathrm{R} \$ 13.000 .000,00$ & $R \$ 65.000,00$ \\
\hline $29 / 06 / 2012$ & BAIRRO NOVO EMPREENDIMENTO IMOBILIARIO S/A & SANTO ANDRÉ & JD. ALZIRA FRANCO & 200 & $\mathrm{R} \$ 13.000 .000,00$ & $\mathrm{R} \$ 65.000,00$ \\
\hline $29 / 06 / 2012$ & BAIRRO NOVO EMPREENDIMENTO IMOBILIARIO S/A & SANTO ANDRÉ & JD. ALZIRA FRANCO & 180 & $\mathrm{R} \$ 11.700 .000,00$ & $R \$ 65.000,00$ \\
\hline $29 / 06 / 2012$ & MAXI ENGENHARIA E CONSTRUCOES LTDA & MOGI DAS CRUZES & JUNDIAÍ & 200 & $\mathrm{R} \$ 12.399 .800,00$ & $\mathrm{R} \$ 61.999,00$ \\
\hline $29 / 06 / 2012$ & BAIRRO NOVO EMPREENDIMENTO IMOBILIARIO S/A & SANTO ANDRÉ & JD. ALZIRA FRANCO & 300 & $\mathrm{R} \$ 19.500 .000,00$ & $\mathrm{R} \$ 65.000,00$ \\
\hline $29 / 06 / 2012$ & MAXI ENGENHARIA E CONSTRUCOES LTDA & MOGI DAS CRUZES & JUNDIAÍ & 200 & $\mathrm{R} \$ 12.399 .800,00$ & $\mathrm{R} \$ 61.999,00$ \\
\hline $31 / 07 / 2012$ & CONSTRUTORA E INCORPORADORA FALEIROS LTDA & GUARULHOS & BANANAL & 380 & $\mathrm{R} \$ 23.560 .000,00$ & $\mathrm{R} \$ 62.000,00$ \\
\hline $31 / 07 / 2012$ & CONSTRUTORA E INCORPORADORA FALEIROS LTDA & GUARULHOS & BANANAL & 360 & $\mathrm{R} \$ 22.320 .000,00$ & $R \$ 62.000,00$ \\
\hline $31 / 08 / 2012$ & QUALYFAST CONSTRUTORA LTDA & GUARULHOS & BONSUCESSO & 1.500 & $\mathrm{R} \$ 97.500 .000,00$ & $R \$ 65.000,00$ \\
\hline $28 / 09 / 2012$ & ENPLAN ENGENHARIA E CONSTRUTORA LTDA & CAJAMAR & CENTRO & 311 & $\mathrm{R} \$ 19.441 .348,82$ & $R \$ 62.512,38$ \\
\hline $28 / 09 / 2012$ & ARBORE ENGENHARIA LTDA & EMBU-GUAÇU & ITARARÉ & 360 & $\mathrm{R} \$ 28.896 .437,73$ & $\mathrm{R} \$ 80.267,88$ \\
\hline $02 / 10 / 2012$ & WGT EMPREENDIMENTOS E INCORPORACOES LTDA & GUARULHOS & ÁGUA CHATA & 240 & $\mathrm{R} \$ 18.240 .000,00$ & $R \$ 76.000,00$ \\
\hline $22 / 11 / 2012$ & ENPLAN ENGENHARIA E CONSTRUTORA LTDA & GUARAREMA & NOGUEIRA & 80 & $\mathrm{R} \$ 5.200 .000,00$ & $\mathrm{R} \$ 65.000,00$ \\
\hline $22 / 11 / 2012$ & ENPLAN ENGENHARIA E CONSTRUTORA LTDA & GUARAREMA & NOGUEIRA & 64 & $\mathrm{R} \$ 4.160 .000,00$ & $R \$ 65.000,00$ \\
\hline $22 / 11 / 2012$ & ENPLAN ENGENHARIA E CONSTRUTORA LTDA & GUARAREMA & NOGUEIRA & 72 & $\mathrm{R} \$ 4.680 .000,00$ & $\mathrm{R} \$ 65.000,00$ \\
\hline $22 / 11 / 2012$ & ENPLAN ENGENHARIA E CONSTRUTORA LTDA & GUARAREMA & NOGUEIRA & 88 & $R \$ 5.720 .000,00$ & $R \$ 65.000,00$ \\
\hline $22 / 11 / 2012$ & ENPLAN ENGENHARIA E CONSTRUTORA LTDA & GUARAREMA & NOGUEIRA & 104 & $\mathrm{R} \$ 6.760 .000,00$ & $R \$ 65.000,00$ \\
\hline $22 / 11 / 2012$ & ENPLAN ENGENHARIA E CONSTRUTORA LTDA & GUARAREMA & ITAPEMA & 52 & $\mathrm{R} \$ 3.063 .895,43$ & $\mathrm{R} \$ 58.921,07$ \\
\hline $27 / 11 / 2012$ & AVITA CONSTRUCOES E INCORPORACOES LTDA & DIADEMA & CONCEIÇÃO & 40 & $\mathrm{R} \$ 3.040 .000,00$ & $R \$ 76.000,00$ \\
\hline $27 / 12 / 2012$ & NOVOLAR INCORPORACOES E CONSTRUCOES LTDA & CARAPICUÍBA & VILA HELENA & 216 & $\mathrm{R} \$ 18.360 .000,00$ & $\mathrm{R} \$ 85.000,00$ \\
\hline $27 / 12 / 2012$ & NOVOLAR INCORPORACOES E CONSTRUCOES LTDA & CARAPICUÍBA & VILA HELENA & 300 & $R \$ 25.500 .000,00$ & $R \$ 85.000,00$ \\
\hline $27 / 12 / 2012$ & NOVOLAR INCORPORACOES E CONSTRUCOES LTDA & CARAPICUÍBA & VILA HELENA & 300 & $\mathrm{R} \$ 25.500 .000,00$ & $\mathrm{R} \$ 85.000,00$ \\
\hline $28 / 12 / 2012$ & RGA CONSTRUTORA LTDA & DIADEMA & CASA GRANDE & 240 & $\mathrm{R} \$ 16.555 .260,00$ & $\mathrm{R} \$ 68.980,25$ \\
\hline $28 / 12 / 2012$ & RGA CONSTRUTORA LTDA & DIADEMA & CASA GRANDE & 120 & $\mathrm{R} \$ 8.401 .184,40$ & $\mathrm{R} \$ 70.009,87$ \\
\hline $31 / 12 / 2012$ & CURY CONSTRUTORA E INCORPORADORA S/A & MOGI DAS CRUZES & JD. AEROPORTO & 1.240 & $\mathrm{R} \$ 94.240 .000,00$ & $\mathrm{R} \$ 76.000,00$ \\
\hline $21 / 01 / 2013$ & WGT EMPREENDIMENTOS E INCORPORACOES LTDA & GUARULHOS & ÁGUA CHATA & 440 & $\mathrm{R} \$ 33.440 .000,00$ & $R \$ 76.000,00$ \\
\hline $28 / 03 / 2013$ & HZR CONSTRUTORA LTDA DIMENTOS IMOBILIARIOS & OSASCO & JARDIM BELMONTE & 300 & $\mathrm{R} \$ 22.800 .000,00$ & $R \$ 76.000,00$ \\
\hline $28 / 03 / 2013$ & WGT EMPREENDIMENTOS E INCORPORACOES LTDA & GUARULHOS & ÁGUA CHATA & 280 & $\mathrm{R} \$ 21.280 .000,00$ & $R \$ 76.000,00$ \\
\hline $11 / 04 / 2013$ & METACONS ENGENHARIA LTDA & POÁ & JD DÉBORA & 256 & $\mathrm{R} \$ 19.238 .712,45$ & $\mathrm{R} \$ 75.151,22$ \\
\hline
\end{tabular}

\section{Fonte: elaboração própria com dados da CEF/GIDUR/SP}


A tabela T-21 reúne todos os contratos da Faixa 1 de renda do programa MCMV com obras em andamento em Junho de 2013 nos diferentes municípios da RMSP. São 16.621 unidades habitacionais, contratadas a um custo total de mais de um bilhão de reais. A disposição por ordem cronológica de assinatura de contrato mostra a progressão do valor de repasse ao longo do programa, desde o valor de $\mathrm{R} \$ 51.999,60$ do mais antigo empreendimento ainda em obra naquele mês, da construtora WGT Empreendimentos e Incorporações Ltda, até os três empreendimentos contratados em 27 de Dezembro de 2012 junto à construtora Novolar Incorporações e Participações (braço empresarial de outra grande construtora de capital aberto, a Tecnisa S/ A) e que são os primeiros na metrópole de São Paulo a atingir valor de repasse de R\$ 85 mil por unidade habitacional.

Tal dispersão de valores tem uma cronologia precisa, mais atrelada à evolução institucional do "programa-plano" MCMV do que a alterações das condições urbanas em que os empreendimentos são executados. O gráfico G-14 dispõem numa única linha do tempo os valores tanto de contratos concluídos quanto em execução para a baixa renda na RMSP:

G-14| MCMV 1 e 2 - Evolução dos contratos para baixa renda na RMSP

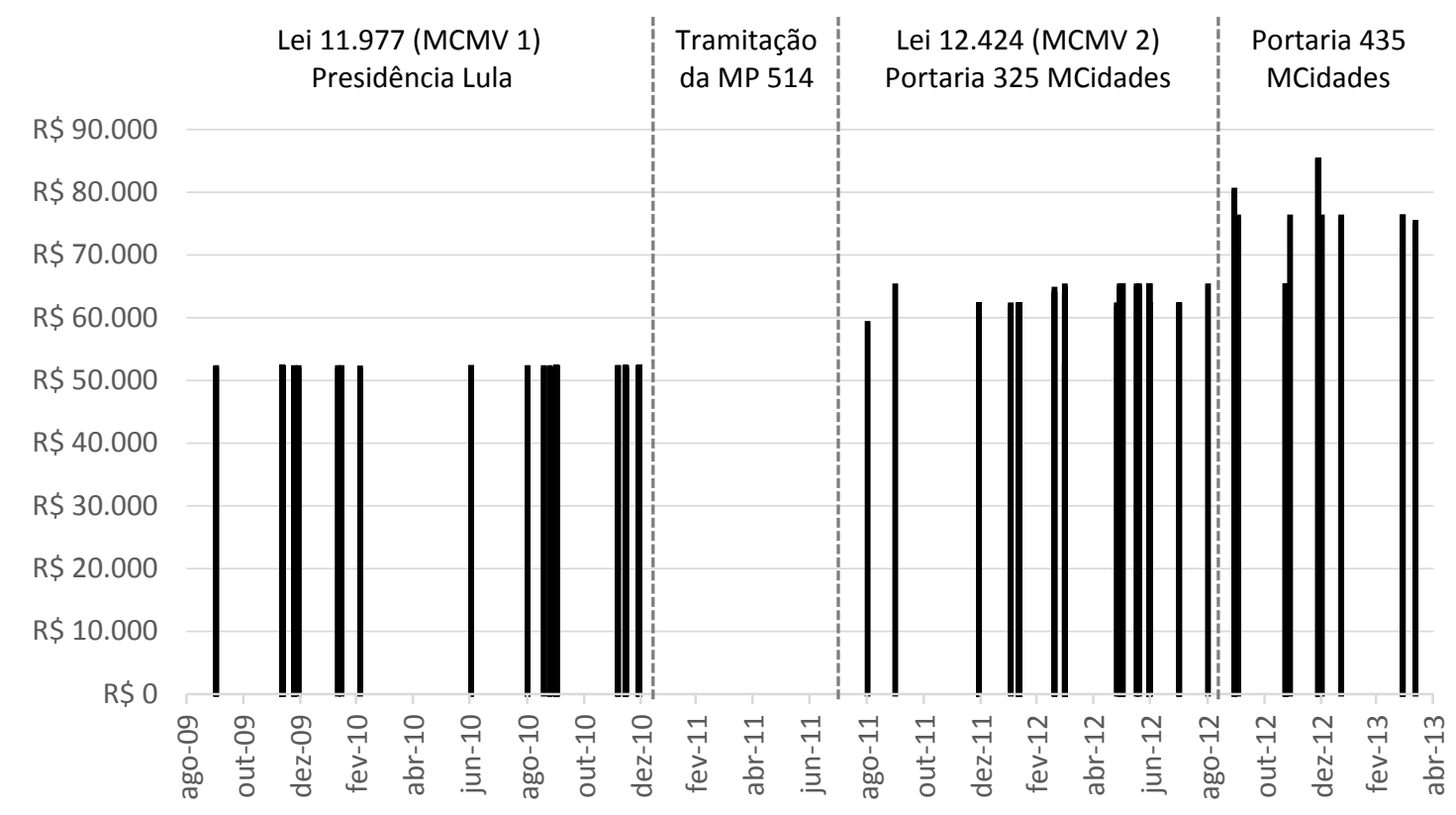

Elaboração própria com dados da CEF/GIDUR/SP e Ministério das Cidades (MCidades)

Nenhum empreendimentos foi contratado no intervalo de tramitação no Congresso Nacional da Medida Provisória 514, que instituiu os atuais parâmetros de atendimento e repasse para o programa MCMV, uma vez que o debate (e a correspondente atividade de lobby) sobre as emendas parlamentares durante os primeiros meses da presidência de Dilma Rousseff tornava insegura para as construtoras a assinatura de contratos pelo programa. Uma vez instituída em lei federal a dotação orçamentária do Fundo de Arrendamento Residencial e os valores de repasse nas Portarias do Ministério das Cidades, o intervalo entre meados de 2011 a meados de 2012 se mostrou um dos mais intensos em contratação na metrópole de São Paulo, região em que a CEF adquiria as unidades habitacionais pelo maior preço no Brasil. A Portaria 435 do Ministério das Cidades, de 29 de Agosto de 2012 empurrou novamente os valores orçados 
de unidades habitacionais para o patamar de $\mathrm{R} \$ 76$ mil, com picos acima de $\mathrm{R} \$$ 80 mil com o complemento do Fundo Paulista de Habitação de Interesse Social.

A soma dos valores nominais e não reajustados de todos os contratos pelo FAR para a região metropolitana de São Paulo, que aparecem nas tabelas T-19, T-20 e $\mathrm{T}-21$, resulta na cifra bilionária de $\mathrm{R} \$ 1.836 .548 .699,10$. Por este valor, a CEF vai adquirir 28.747 unidades habitacionais, a um custo médio por $\mathrm{m}^{2}$ de área construída em torno de $\mathrm{R} \$ 1.400,00$.

No entanto, este elevado investimento público é minimizado pela própria meta física por Estados, adotada pelo Ministério das Cidades segundo a ordem de grandeza do déficit habitacional (cf. Portaria 465 MCidades). Nesta gestão mínima do programa MCMV, a meta física no Estado de São Paulo seria a maior do Brasil, de 181.043 novas moradias para a Faixa 1 de renda até o fim de 2014, que significa pouco diante do déficit habitacional estadual estimado pela FJP em 1,113 milhões de domicílios em 2012, sendo 561.307 domicílios na região metropolitana da capital (Lima Neto; Furtado; Krause, 2013: 9-10) [104]

Portanto, as 28.747 unidades habitacionais referentes à soma das moradias em contrato, em construção e já entregues pelo FAR na região metropolitana de São Paulo representam 15,8\% da meta regional do programa MCMV, que por sua vez é $16,2 \%$ do déficit estadual que norteou a elaboração da mesma meta. Nenhum conceito de déficit - seja ele científico ou ideológico - justifica uma produção ao mesmo tempo tão dispendiosa e tão reduzida.

Por outro lado, o que está assegurado ao mercado da construção habitacional é que as metas do programa MCMV não vão gerar uma crise de superprodução, um risco das expansões produtivas que é mais perigoso para o mercado da construção do que a existência de déficits habitacionais.

A rigor, uma crise habitacional se torna uma crise do capital da construção civil apenas quando há ciclos de superprodução. Manter um regime de escassez por habitações, isto é, manter elevada sua demanda junto a um mercado consumidor, é o objetivo mais amplo dos agentes imobiliários que produzem e comercializam residências. Quando o estoque habitacional de um país ou mesmo de uma região é elevado, este objetivo se converte na ampliação da capacidade de endividamento das famílias, ampliação que está na base de todas as crises de superprodução na construção civil. Acontece nestes momentos uma "superprodução de financiamentos", para usar a expressão de Peter Marcuse, um fenômeno que ficou evidente no colapso do sistema hipotecário americano em Setembro de 2008 (Marcuse, 2009). Poucos meses após a internacionalização deste colapso, o déficit habitacional brasileiro, que antes foi estudado como uma crise social, se torna, através do programa MCMV, uma solução para transferir recursos públicos para empresas privadas e mobilizar o capital da construção civil brasileira em tempos de crise financeira mundial.

Para as faixas de renda médias, o programa MCMV de fato promove uma ampliação da quantidade de consumidores pelas modalidades "Faixa 2" e "Faixa

104 Utilizando dados da Pesquisa de Condições de Vida de 2006, a Fundação Seade chegou a 1,217 milhões de moradias no Estado de São Paulo consideradas como "déficit ampliado", que incorpora parte de fatores que a Fundação João Pinheiro usa para caracterizar "inadequação da moradia” (Seade, 2010). 
3", em que recursos do Fundo de Garantia por Tempo de Serviço (FGTS) são utilizados para subvencionar o comprador do imóvel. Este tem direito ao seguro das mensalidades pelo Fundo Garantidor da Habitação Popular (FGHab) e, dependendo do perfil de renda, a juros menores e isenção de taxas cartoriais, o que aumenta seu acesso ao mercado residencial formal.

No entanto, para os domicílios de baixa ou nenhuma renda, que compõem o centro e as margens do déficit habitacional brasileiro, o subsídio oferecido pelo MCMV não amplia o mercado consumidor de habitação, pois está vinculado ao arrendamento de uma unidade habitacional sem ampliar a capacidade de endividamento das famílias junto ao mercado imobiliário. Estas famílias se tornam antes uma demanda fechada, oferecida à construção civil formal através dos cadastros sociais das prefeituras municipais. O Fundo de Arrendamento Residencial fornece, portanto, um subsídio que dá às construtoras acesso às famílias de baixa renda, e não o contrário.

No programa MCMV, a produção habitacional é remunerada por fundos públicos, sem os riscos da criação de um mercado consumidor ou de crédito imobiliário. O déficit habitacional, neste caso, assume unicamente a função de legitimação política: assim como o capital precisa de uma população excedente que regule o preço da força de trabalho, a condução política do programa MCMV precisa de uma população excedente que legitime como um programa habitacional o que na realidade é uma política de desenvolvimento econômico dedicada à ampliação da capacidade produtiva das empresas de construção habitacional.

Esta é uma tese a ser argumentada numa nova parte desta pesquisa, em que é preciso transitar o foco do campo do trabalho para a campo da tecnologia na construção habitacional e investigar os instrumentos e o interesse das empresas construtoras em aderir a um programa habitacional que, se é generoso na aquisição por repasse da moradia de baixa renda, retira o risco e também o lucro de converter novas populações para o mercado imobiliário.

O primeiro instrumento e interesse, vimos, é adaptar o capital a uma nova força de trabalho na construção habitacional, força de trabalho que fornece valor à indústria e não à manufatura. No capitalismo, o conjunto desta adaptação do trabalho ao valor se chama tecnologia. 


\section{PARTE 2 |}

\section{TECNOLOGIA E CONCENTRAÇÃO DE CAPITAL}

O interesse em estudar a tecnologia associada ao programa MCMV é que ela não pode ser isolada em iniciativas exemplares de uma ou outra empresa construtora, mesmo que sejam as de maior capital. Ela é uma iniciativa de âmbito setorial, implantada por uma coerção de governo sobre toda a promoção privada da habitação social e, no limite, é a aplicação na construção habitacional brasileira de uma tendência global de padronização produtiva. Esta tendência é o sistema gestão de qualidade, tema central desta parte da pesquisa.

O sistema de gestão de qualidade, tema do capítulo 6, é uma tecnologia organizacional e, portanto, altera a empresa mais do que a mercadoria que produz. Ele confirma a identificação feita na primeira parte desta pesquisa entre industrialização e organização da produção e desloca o foco de análise do canteiro de obras para o empreendimento de construção, âmbito em que as operações de obra se multiplicam numa variabilidade incontornável de relações comerciais e contratuais com fornecedores de bens e serviços, os mais importantes sendo os subempreiteiros.

A subempreitada, tema do capítulo 7, é a relação de produção da construção habitacional que melhor caracteriza a concentração de capital em curso no programa MCMV, pois a certificação do sistema de gestão de qualidade coloca grandes e pequenas empresas construtoras em posições complementares mas que tendem a se distanciar: de um lado, a empresa com capacidade gerencial para integrar e controlar múltiplos serviços, de outro, a empresa cuja sobrevivência demanda o ingresso por especialização numa cadeia de suprimentos. São condições inéditas de competição e a menção que será feita adiante ao uso de trabalho análogo à escravidão no programa MCMV não é a denúncia de velhas práticas, mas sinal perturbador dos novos poderes da tecnologia organizacional.

Ao final da pesquisa, no capítulo 8, a tecnologia organizacional encontra o espaço urbano - ao menos tal como ele é concebido nas modalidades do programa MCMV: segregado por faixas de renda. Numa delas, a da baixa renda, vai encontrar condições ideais para ser absorvida pelas empresas construtoras e, posteriormente, irradiada para os empreendimentos de renda mais elevada e localização de maior valor. É, portanto, um avanço tecnológico que reforça o mercado das localizações urbanas, mercado que os gestores do programa aceitam e, indiretamente, subsidiam.

Um dos relatos para esta pesquisa forneceu um nome: "o laboratório da baixa renda". Neste laboratório, o que de fato se aperfeiçoa é a segregação urbana. 


\section{$6 \mid$ \\ SISTEMAS DE GESTÃO DE QUALIDADE}

\section{Um padrão para a variabilidade}

A expansão das atividades das empresas construtoras através das metas do programa MCMV significa uma inédita expansão para a moradia de baixa renda de um fator de industrialização que é irreversível na construção habitacional: os sistemas de gestão de qualidade. A irreversibilidade não se deve tanto à imposição de uma padronização de produtos (em que a busca de qualidade não pode ser separada da restrição à concorrência comercial), mas sim no deliberado caráter sistêmico que esta tecnologia de gestão e organização adquire ao se autonomizar por meio de normas técnicas, auditorias independentes, consensos de mercado e, no caso das empresas que atuam no programa MVMC, órgãos de regulação estatal associados ao financiamento público da habitação de interesse social. Ao submeter a tal sistemática de gestão a construção de mais de 3 milhões de unidades habitacionais (sendo pelo menos 2 milhões para famílias de baixa ou nenhuma renda) o programa MCMV abre a possibilidade das empresas construtoras obterem mais controle não apenas sobre sua produção como também sobre o próprio mercado da construção habitacional: é possível agora padronizar tanto os empreendimentos habitacionais quanto o desenvolvimento tecnológico de empresas gestoras de obras e empresas prestadoras de serviços especializados de construção.

Ao contrário das investigações sobre processos de trabalho na Parte 1 desta pesquisa, a abordagem deste raciocínio sobre a tecnologia organizacional precisa começar longe dos canteiros de obras e partir da base institucional global de onde se disseminam pelos mercados regionais os sistemas de gestão de qualidade: a "International Organization for Standardization", associação cujo acrônimo - ISO - altera a sequência das iniciais para fazê-las coincidir com o prefixo grego que expressa regularidade e equivalência. A ISO congrega atualmente 164 entidades nacionais especializadas em normatização técnica. Desde sua fundação em 1947 (entre as 25 entidades fundadoras estava a Associação Brasileira de Normas Técnicas - ABNT), ela mantém a base de padronização e normatividade industrial sem a qual não seria possível a expansão comercial e tecnológica após a $2^{\mathrm{a}}$ Guerra Mundial [105].

105 Os interesses comerciais presentes no período pós-Guerra foram soterrados pelas transformações do capitalismo. A pressão exercida pelo bloco soviético que então se formava está presente até hoje com a equiparação do russo ao inglês e francês nos documentos oficiais da ISO, mas as normas regionais mais influentes foram desenvolvidas na Alemanha (pela Deutsches Institut for Nörmung - DIN) e Japão (Nippon Kōgyō Kikaku - JIS). Todas adotam o sistema métrico e unidades S.I., mas não impediram a internacionalização das séries especiais com gradação em polegadas para diversos produtos industriais normatizadas pela American Society for Testing and Materials - ASTM. 
Assim como cada uma das entidades normativas nacionais representa um consenso de mercado para padrões produtivos implementados por empresas privadas, o consenso em bases internacionais agenciado através da ISO dá suporte a atividades de comércio e prestação de serviços em escala global através da produção de "international standards". Em 2012, a ISO mantinha em vigor 19.573 normas internacionais, produzidas e revisados por dezenas de câmaras técnicas e centenas de grupos de trabalho. A distribuição desta cifra em nove setores técnicos mais abrangentes aparece no gráfico G-15 [106].

G-15|ISO - Distribuição das normas internacionais por setor técnico - 2012

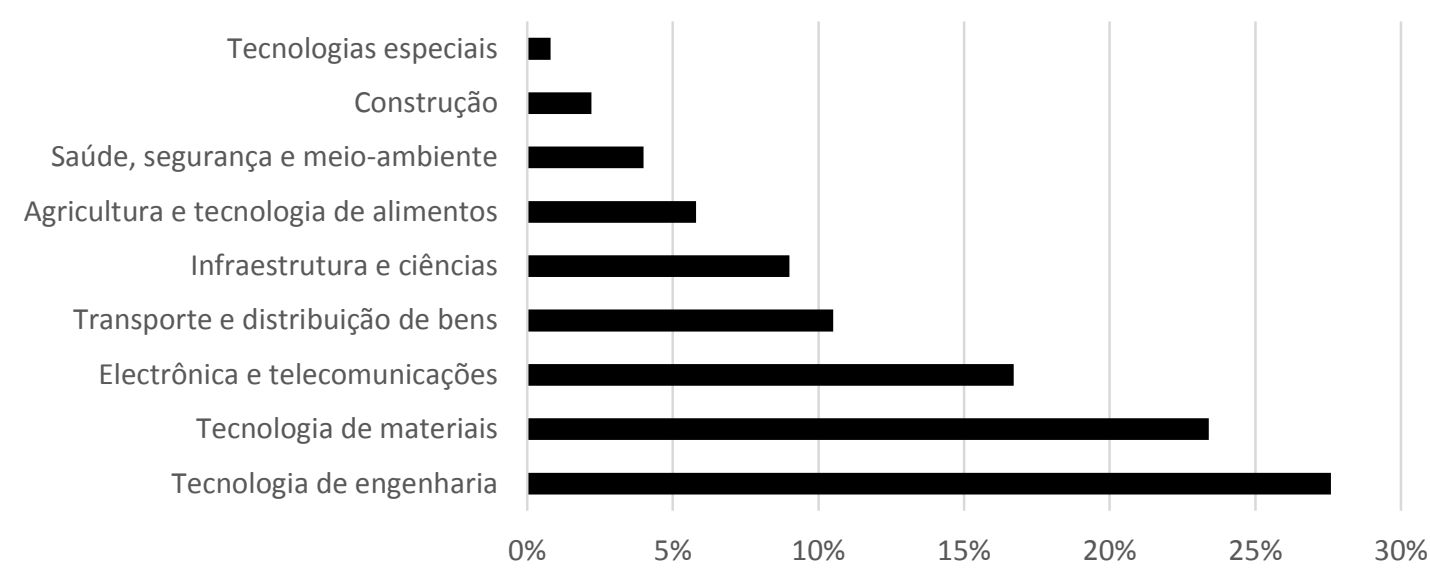

Fonte: adaptado de ISO, 2013a

As minoritárias normas internacionais voltadas para indústria da construção civil (2,2\% do total em vigor em 2012) têm uma presença mediada na construção civil brasileira. São normas referentes a especificações, desempenho e ensaios de insumos e serviços de construção que têm equivalentes nas normas que a ABNT emite no Brasil em condições institucionais similares às emitidas pela ISO: elaboração por câmaras técnicas e consultas públicas, aprovação por consenso de mercado e adoção voluntária por parte das empresas construtoras.

A normatização internacional que atinge mais diretamente a construção civil brasileira são os padrões da "Família 9000", elaboradas pela ISO como uma "tecnologia especial" dedicada à gestão de qualidade na produção de bens e na prestação de serviços. Esta família “contains some of ISO's best known standards" e sua disseminação mundial e para empresas de diversos setores econômicos justifica sua classificação de "global status standards" (ISO, 2013b) [107].

Como a maioria das normas de "gestão e liderança" da ISO, as normas da família 9000 estabelecem terminologia e definições que constituem um campo especializado da administração empresarial. É o caso de normas como a ISO

106 Um exemplo sempre citado do processo de normatização internacional são as dimensões dos containers "Série 1", símbolo maior do comércio global. No entanto, é útil perceber que toda a sua carga de produção industrial - aço, parafusos, componentes eletrônicos, medicamentos - é igualmente padronizado em escala planetária, incluindo os protocolos bancários e de telecomunicações que dão suporte a estas transações.

107 Há outras famílias ISO de normas de gestão e qualidade, estas mais especializadas: ISO 50001, focada em gestão de energia; ISO/TS 16949:2009, que adapta a gestão de qualidade a requisitos específicos da indústria automotiva; ISO 13485:2012, que é a norma de qualidade voltada para serviços médicos. 
9000:2005, sobre "fundamentos e vocabulário", ou a ISO 9004:2009, com orientações genéricas sobre "eficiência e eficácia" da gestão de qualidade.

A transição da generalidade de terminologia para a produção efetiva acontece na norma “ISO 9001:2008 - Sistemas de gestão de qualidade - requisitos", que demanda nas três primeiras de suas oito seções justamente a elaboração de uma política de qualidade própria e adaptada a cada empresa, expressa em documentos (com destaque para o "manual de qualidade") e numa cadeia de responsabilidade entre direção e demais departamentos. Uma vez feita esta vinculação particular (ainda que formal) da atividade empresarial a uma política de qualidade, esta passa a se materializar em diversos requisitos mensuráveis, descritos nas seções 4 a 8 da norma: controle de documentos e registros (item 4.2); gestão de recursos (incluindo infraestrutura produtiva - item 6 - e ambiente de trabalho - item 5); atividades associadas à "realização de produto", do planejamento de produção (item 7.1) aos equipamentos de controle de qualidade (item 7.6). O próprio sistema de gestão de qualidade é monitorado através de "medição, análise e melhoria", que incluem auditorias internas (subitem 8.2.2), controle de produtos e serviços considerados não-conformes ao padrão de qualidade (8.3), para os quais a empresa deve prever ações corretivas (8.5.2) e preventivas (8.5.3).

A mobilização de tal massa de informações para produzir uma mercadoria ou serviço é indicativa das sucessivas ampliações de sentido do termo "qualidade" quando aplicado a um processo produtivo. $\mathrm{O}$ "controle de qualidade" nascido com a linha de montagem fordista, que apenas prolongava as atividades de inspeção em fábrica para o produto acabado, passou ao longo do século XX a incorporar interpretações cada vez mais abrangentes ao conectar "qualidade" a diferentes graus de "satisfação dos clientes". Na ISO 9001:2008, tal satisfação é uma referência efetiva (tratada nos itens 5.2, 7.2 e nos subitens 7.2.3, 7.5.4 e 8.2.1) mas uma meta nunca atingida em definitivo, pois lida com "necessidades $e$ expectativas, expressas de forma explícita ou obrigatória" (ISO, 2012), mas numa escala de sentidos dinâmica tal como aparece no gráfico G-16.

G-16|Evolução dos sentidos de qualidade normatizada

G) QUALIDADE É UMA CARACTERÍSTICA RELATIVA E DINÂMICA

F) QUALIDADE INCLUI OS SERVIÇOS AGREGADOS AO PRODUTO

E) AS NECESSIDADES DO CLIENTE SÃO ATENDIDAS COM ECONOMIA

D) AS NECESSIDADES DO CLIENTE PODEM SER EXPLICITAS OU IMPLICITAS

C) CLIENTE PODE SER INTERNO OU EXTERNO OU TODA A SOCIEDADE

B) ATENDIMENTO DE NECESSIDADES DO CLIENTE

A) CONFORMIDADE COM REQUISITOS

Fonte: adaptado de Picchi, 1993: 53 [108].

108 Em seu estudo pioneiro sobre a aplicação das normas ISO 9000 à construção habitacional brasileira, Flávio Picchi adverte que "as ampliações mais recentes do conceito da qualidade completam o processo de tirar 
O ponto de inflexão que extravasou o sentido de qualidade do campo das técnicas de engenharia para as técnicas de marketing aconteceu em meados do século passado, nas pesquisas em gestão de Edwards Deming e Joseph Juran, especialistas em controle estatístico de qualidade e que participaram da reconstrução da indústria japonesa após a $2^{a}$ Guerra Mundial. Suas propostas de melhorias cíclicas e contínuas de qualidade, em que a correção de um produto realimenta novas fases de projeto, produção e aferição, estão na base dos atuais sistemas TQM (Total Quality Management): a gestão de qualidade deixa de ser "parcial", função de um departamento especializado, e se torna compromisso permanente de todos os cargos de uma empresa, no modelo empresarial do toyotismo [109].

A extensão dos sentidos de qualidade pela esfera do consumo implicou numa similar extensão de seu controle pela esfera da produção, que já não se exerce na mercadoria acabada, mas por toda a organização produtiva. Normatizar este controle significa então normatizar a própria empresa, como observa John Seddon, pesquisador que exerce uma visão crítica da norma ISO 9001 de dentro do campo a administração de empresas:

Quality assurance, according to the Standard, is a way of managing that prevents nonconformance and thus "assures quality". This is what makes ISO 9000 different from other standards: it is a management standard, not a product standard. It goes beyond product standardisation: it is standardising not what is made but how it is made. To use standards to dictate and control how organisations work was to extend the role of standards to new territory (Seddon, 2000a: 45).

Neste "novo território", em que a qualidade de um produto se origina de uma tecnologia de gestão e organização, aparece o requisito mais custoso e invasivo para as empresas que pretendem adotar a ISO 9001:2008: o processo de certificação de atendimento da norma ("compliance") por meio de empresas de auditorias externas, chamadas "certificadoras de terceira parte". Ao invés de uma certificação a respeito de um produto ou serviço que é emitida pelo próprio fabricante ou fornecedor ("primeira parte") ou por seu consumidor, quando este é uma empresa com grande poder de compra ("segunda parte"), a certificação de atendimento da ISO 9001:2008 deve ser emitida por uma empresa independente, contratada e remunerada pelo produtor, mas que realiza atividades de auditoria com a autonomia do consumidor [110].

a primazia no assunto da engenharia e da área da produção e enfatizam cada vez mais aspectos familiares a ciências como a psicologia e sociologia e setores da empresa como propaganda e marketing" (Picchi, 1993: 58)

109 Uma apresentação consagrada na administração de empresas sobre a evolução histórica das tecnologias de gestão entre fordismo e toyotismo pode ser encontrado em Garvin, 1992, além do trabalho clássico de Womack; Jones; Ross, 1991. O guia para elaboração deste capítulo são as pesquisas de Josephine Yong e Adrian Wilkinson que tratam da passagem entre inspeção e gerenciamento para a definição de qualidade produtiva (Yong; Wilkinson, 2002).

110 A "certificadora de terceira parte", por sua vez, segue normas próprias (ISO/IEC 17.021) e passa por um processo de acreditação nos países em que atuam. No Brasil, o reconhecimento das empresas que atuam como organismo certificador é realizado pelo Instituto de Normalização, Metrologia e Qualidade Industrial - INMETRO. Este não é um mercado para auditorias de pequeno porte. As duas maiores empresas certificadoras da NBR ISO 9001:2008 no Brasil são filiais de gigantes do mercado europeu Lloyd's Register e Det Norske - com atuação centenária nos setores correlatos de seguros e classificação de riscos. Uma certificadora de destaque entre empresas construtoras no Brasil é o Instituto Falcão Bauer 
A empresa de auditoria externa faz visitas técnicas regulares tanto nos departamentos administrativos da empresa postulante da certificação como nos seus locais de produção. Os auditores podem recolher documentos, entrevistar funcionários, inspecionar diretamente processos de produção ou execução de serviços. A certificação ISO 9001:2008 é concedida apenas em caráter temporário (geralmente por três anos) após compromissos da empresa com o que for listado como "oportunidades de melhoria" e correção do que for levantado como "nãoconformidade" com requisitos da norma [111].

Em 2012, as auditorias de terceira parte certificaram o cumprimento da ISO 9001:2008 em 1,101 milhões de empresas em todo o mundo. No mesmo ano, a versão brasileira da norma, NBR ISO 9001:2008 teve cumprimento certificado em 25.791 empresas, seguindo a evolução histórica mostrada no gráfico G-17:

\section{G-17|Evolução da certificação ISO 9001 no Brasil - 1993 a 2012}

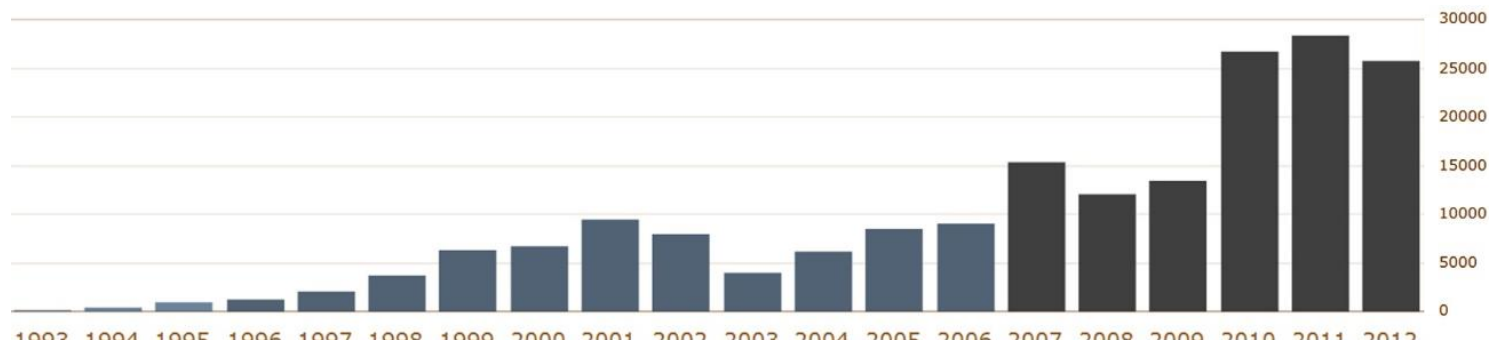

19931994199519961997199819992000200120022003200420052006200720082009201020112012

Fonte: ISO, 2013b

A disseminação mundial da ISO 9001:2008, principalmente entre empresas de médio porte, atingiu dimensão suficiente para gerar críticas de que sua adoção está se tornando uma burocracia autossuficiente e desvinculada do ideal de qualidade produtiva. Em termos mais materiais, a certificação se limita a ser uma imposição de mercado para empresas menores permanecerem como fornecedoras de organizações com grande poder de compra, como redes de varejo ou setores de governo [112].

John Seddon comentava já no início do século que a normatização de qualidade tinha se transformado em "coerção de mercado" ("market-place coercion", que ele comenta em termos simples: "you comply or we won't buy") e que era sustentada menos por inovação tecnológica ou saltos produtivos e mais pela manutenção do

de Qualidade (IFBQ), que tem origem como prestadora de serviços de controle tecnológico para concreto e de ensaios de campo e laboratoriais para componentes da construção civil.

111 Esta dimensão administrativa passa longe da formação acadêmica do arquiteto e do círculo privilegiado em que ele atua profissionalmente. Meu primeiro contato com o sistema de gestão de qualidade se deu ao perceber a permanente apreensão de engenheiros e administradores das empresas construtoras que atuam no programa MCMV a respeito da "auditoria de qualidade", mesmo as internas e que cumpriam apenas um requisito parcial para a certificação de qualidade. Tal competição interna é uma técnica comum de gestão de empresas e, nas construtoras de capital aberto, se alinham com as demais exigências de "corporate governance".

112 "Getting an ISO certification is expensive and time-consuming. What's more, doing so requires codifying nearly every aspect of business operations (...) But if you don't go through the process, you often can't work for the big guys" (Clifford, 2005: 54). "Companies either care about quality and benefit from that approach, or they do not care about quality and suffer from that approach. An expensive and time-consuming ISO 9000 certificate just does not play into it. So why register? How did we get to this state where the quality profession flocked to support a valueless, expensive program? I think there are several reasons. Part of it is herd mentality. The train of thought is, 'If I have to get registered, then all my suppliers should too' (Dalgleish, 2005: 45). 
arranjo organizacional responsável pela gestão do próprio sistema: diretores de qualidade, auditorias internas e externas, empresas de consultoria e todo o mercado de certificação e acreditação das normas baseadas na família ISO 9000:

The infrastructure of consultants, assessors and quality managers now pervades organisational life on an international scale. Managers point to the excessive bureaucracy and work whose only purpose is to satisfy the ISO 9000 assessor (Seddon, 2000b: 9).

Num documento de divulgação das normas de gestão de qualidade elaborado pela própria ISO, a certificação é apresentada numa perspectiva mais básica do que qualquer um dos sentidos de qualidade produtiva: "the certification verify that the organization is managing its processes effectively - or, to put it another way, to check that it is fully in control of its activities" (ISO, 2012). A desconfiança de que este objetivo seja apenas um entrave burocrático para pequenos prestadores de serviços pode ser coerente, mas para o setor construtivo que é objeto desta pesquisa - as empresas de construção habitacional que atuam junto ao programa MCMV - obter controle integral sobre o processo produtivo é em si e de imediato uma inovação tecnológica relevante.

Antes de tratar das normas de qualidade que interagem especificamente com estas empresas, é preciso retomar um tema recorrente nos estudos de gestão de produção da construção: a distinção de fundo entre os processos produtivos da construção civil e os dos demais setores da indústria de transformação, que afeta diretamente a aplicação de normas técnicas de gestão. Os autores que tratam desta distinção enfatizam que a ausência de uma planta fixa de fabricação é causa de uma variabilidade que é constitutiva dos processos de produção da construção civil tanto numa dimensão espacial quanto temporal.

A observação da variação espacial conduz a uma análise focada no canteiro de obras, um espaço de produção que varia com a localização do edifício ou obra de infraestrutura a ser construído. Na terminologia da Gestão de Produção, o canteiro de obras é uma "produção posicional", na qual a planta de fabricação é absorvida na construção acabada e o processo de construção é justamente o processo de transformação deste canteiro no produto final.

A variação de caráter posicional abre a possibilidade de conceber cada canteiro de obras como uma singularidade espacial, caso em que é comum enfatizar diferenças no próprio suporte geotécnico da construção, que demandaria soluções únicas para distribuição de carga no terreno ou para controle de empuxos de solo e água. Embora esta opinião seja comum entre arquitetos, elas só são válidas para obras de infraestrutura sob responsabilidade primária da engenharia civil, que as denomina "obras de arte" porque as condições geotécnicas exigem especialização de projeto e obra para produzir estruturas de fato singulares: geralmente são trechos de obras viárias, como túneis ou pontes (mas não estradas), ou obras que exigem a interação entre fundações e controle estático e dinâmico de corpos d’água, como barragens e eclusas (mas não canais). 
Nilton Vargas afirma que em tais obras de infraestrutura, qualquer produto final é, para a engenharia civil, um "protótipo de si mesmo" [113].

Diferentemente das obras de infraestrutura, na construção habitacional nenhum canteiro de obras se torna singular por aspectos geotécnicos. Com exceção do que for deliberadamente extravagante, as obras de fundação, contenção e impermeabilização de um edifício residencial demandam unicamente soluções construtivas convencionais, variações quantitativas de insumos e serviços de fundação cuja especificação, procedimentos de execução e desempenho são padronizados. Por serem soluções compartilhadas com outros edifícios, elas não isolam os edifícios, mas sim fornecem uma base técnica comum.

A observação da variedade temporal na construção civil, por sua vez, produz resultados teóricos mais coerentes. Neste caso, seu foco de análise é o empreendimento de construção civil, cuja variabilidade está ligada mais à sucessão de etapas construtivas num canteiro de obras do que à diferença espacial que possa haver de um canteiro para outro [114].

Enquanto a incorporação imobiliária de uma edificação representa um agenciamento de capitais, o empreendimento de construção representa, em última instância, um agenciamento de força de trabalho. A força de trabalho de um empreendimento, no entanto, nunca se confronta com o capital com a clareza que aparece na fábrica de planta fixa, mas sim fracionada numa grande dispersão de qualificações profissionais (com as diferentes alianças com o capital que esta dispersão provoca) e ao mesmo tempo agrupada e mediada por uma rede de empresas prestadoras de serviços e departamentos empresariais em permanente associação e competição. A combinação das diferentes qualificações e empresas forma um conjunto heterogêneo, em que se destacam pelo menos oito núcleos:

1) Arquitetos e engenheiros empregados de empresas de projeto ou autônomos prestando serviço eventual de consultoria;

2) Topógrafos e tecnólogos, cujas empresas prestam serviços regulares de levantamentos planialtimétricos e ensaios de controle tecnológico;

3) Supervisores e inspetores de diversas especialidades (suprimentos, contratos, segurança do trabalho), que fazem visitas a partir de departamentos centrais da empresa responsável pelo empreendimento;

113 A afirmação aconteceu durante a aula "Marxismo e construção civil", parte de curso organizado pelo Laboratório de Habitação e Assentamentos Humanos da FAU/USP em Abril de 2007. Na mesma ocasião, Nilton Vargas associou esta característica de imprevisibilidade não a um suposto atraso produtivo ("uma categoria inexistente em Marx"), mas a uma expertise das grandes empresas construtoras brasileiras que as tornaram modelos internacionais em "lidar com o caos e situações adversas ao capital", principalmente com "projetos capazes de integrar os diversos produtores da construção".

114 Esta precedência das condições produtivas do empreendimento sobre as condições supostamente naturais do canteiro de obras me foi alertada pelo engenheiro de qualidade da construtora Cury, Fabiano Souza: "Você fala em variabilidade de solo, de condição climática. Para mim, que sou engenheiro de qualidade, tudo isso já vem equacionado no planejamento e no projeto, não é um assunto para ser resolvido na obra. A variabilidade que me afeta mesmo é de suprimentos e dos subempreiteiros: fornecedor que não é de confiança, que atrasa a entrega ou entrega material fora de padrão, empresa que não garante conformidade de serviço dos empregados. Este tipo de variação é o que mais me afeta, mas também é a que posso controlar com os instrumentos de gestão de qualidade". 
4) Engenheiro-residente, estagiários de engenharia, mestre-de-obras, almoxarife e técnico de compras, que representam a empresa (ou subsidiária) responsável pelo empreendimento como seu núcleo de comando e administração;

5) Trabalhadores terceirizados em serviços de apoio, como vigilância e cozinha;

6) Operadores, montadores e mecânicos ligados a empresas de locação de máquinas e equipamentos;

7) Profissionais instaladores e ajudantes treinados, homologados e contratados pelos fornecedores de sistemas prediais;

8) Finalmente, levas de oficiais, meio-oficiais e ajudantes empregados por diferentes subempreiteiras especializadas, muitas vezes duplicadas e triplicadas para competirem entre si em macros-serviços como fundação, alvenaria estrutural, concretagem de lajes, esquadrias e pintura.

Desta massa variada de força de trabalho, se observa que o empreendimento de construção civil não é apenas uma fábrica efêmera, mas sim uma reunião intermitente de vários núcleos de trabalhadores, muitos deles mobilizados em tempos e espaços diferentes em relação ao tempo e espaço dos serviços de edificação realizados no canteiro de obras. Este é caso quando se inclui no empreendimento atividades relacionadas a escritórios de projeto, usinas de préfabricação e centrais de produção que ocupam terrenos alugados, laboratórios para ensaios de materiais de construção, empresas locadoras de máquinas e equipamentos de obras, além de departamentos da própria construtora localizados em diferentes sedes [115].

Flávio Picchi propôs em 1993 um gráfico simplificado de um empreendimento de construção civil, que, com poucas atualizações, pode representar todos os serviços que reúne em cinco curvas temporais de "nível de atividade" (gráfico G18). Três destas curvas se sobrepõem pouco e têm uma intensidade de atividades que cresce lentamente até uma interrupção relativamente rápida: são as fases de estudo de viabilidade, de aprovações/projeto e de execução de obra. Duas outras curvas - planejamento de obra e administração de contratos e suprimentos atingem rapidamente um pico de intensidade das atividades, que é seguido de um longo ritmo decrescente que faz com que elas se sobreponham à demais atividades durante todo o empreendimento [116]:

115 Os arquitetos com vivência em canteiro de obras compreendem de imediato a discordância de Randolph Thomas e Sunil Sinha em relação à tradicional descrição inglesa do canteiro de obras como um "desfile de profissões" ("a parade of trades"): "This phrase applies to sequential operations. Sequential operations occur in construction operations at a macro level, but usually do not occur when a more detailed analysis is made. Thus, construction operations at the activity level are more like modeling a riot than a parade" (Thomas; Sinha, 2002: 1354).

116 "A construção de edifícios é uma atividade de grande complexidade, envolvendo um grande número de insumos, fornecedores e intervenientes; diversas etapas do processo (projeto, planejamento, execução etc.) ocorrem simultaneamente, o mesmo acontecendo com vários serviços. Os sistemas da qualidade são instrumentos que facilitam a cooperação, coordenação, visão de conjunto, integração de setores. Na construção de edifícios estes fatores são fundamentais, não só internamente na empresa (entre departamentos) como também entre esta e os demais intervenientes" (Picchi, 1993: 121). 


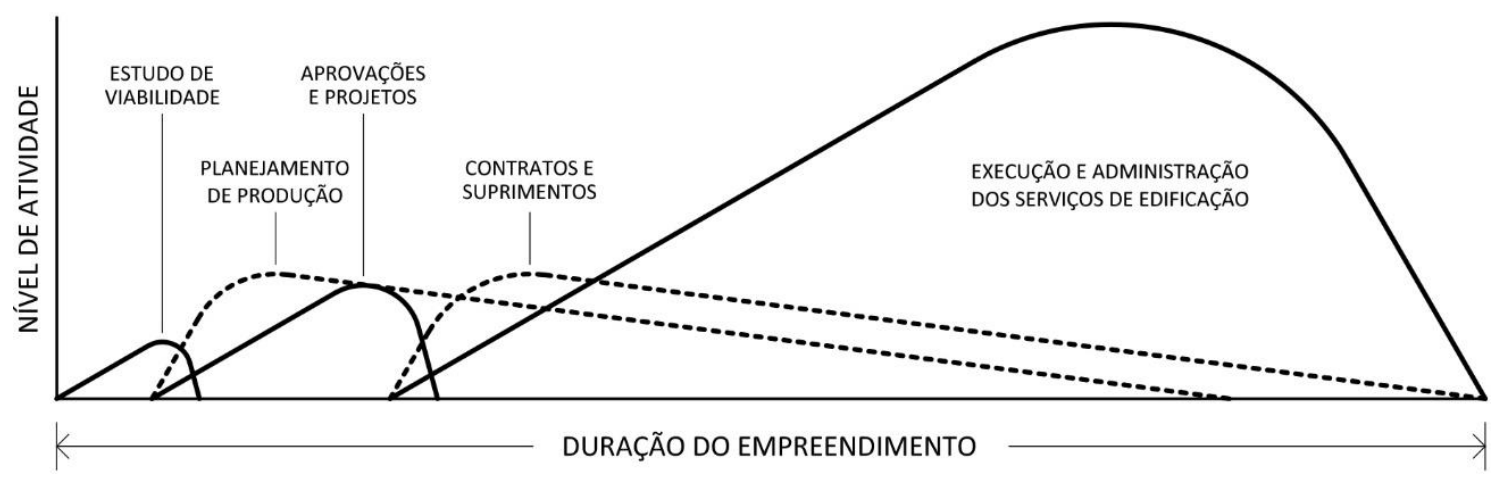

Fonte: adaptado de Picchi, 1993: 121.

A ênfase na variabilidade temporal do empreendimento é dominante na literatura técnica de língua inglesa sobre gestão da construção civil e aparece na distinção entre "design" e "Project", o primeiro denotando a atividade técnica que envolve concepção mental e expressão gráfica, enquanto o segundo o esforço de natureza empresarial para produzir num tempo delimitado um bem ou serviço igualmente delimitado, esforço que é objeto de um campo especializado da administração de empresas: o "Project-management". No caso da construção civil, a noção de uma "Project-base production" serve para reforçar a distinção com as indústrias de planta de fabricação fixa ("Factory-based production"), uma vez que o empreendimento de construção civil é conduzido por "an ad hoc 'team' comprising designers, builders and specialist contractors who have frequently not worked together before and who will probably not do so again" (Franks, 1984: 2). A produção "ad hoc", que se organizado apenas "para esse" empreendimento, é um agenciamento de trabalho que varia por não poder se fixar no espaço e nem se repetir no tempo.

No Brasil, as pesquisas de Gestão de Produção reproduzem esta concepção da variabilidade da construção civil pelo empreendimento. Luiz Augusto dos Santos, em pesquisa sob orientação de um especialista em "Project management", Silvio Melhado, utiliza o sistema de gestão de qualidade para ressaltar a diferença entre indústria seriada e construção civil:

A implantação de sistemas de gestão de qualidade baseados na estrutura da norma ISO 9000 também tem sido aplicada à indústria da construção civil, na qual, em analogia à indústria seriada, cada empreendimento de construção de edifícios representa o mesmo que o projeto [no sentido de "Project"] de um novo produto. Contudo, as particularidades entre um produto e outro são bem marcantes e os caminhos para implantação de sistemas de gestão da qualidade também devem considerar situações particulares deste tipo de ambiente [da construção civil]. A tipologia para a qual a norma de qualidade foi concebida prevê uma relação biunívoca e estável entre cliente e fornecedor, onde os processos e as atividades de produção são repetitivos, a demanda pode ser analisada mais detalhadamente e os custos advindos são pulverizados ao longo do processo. $O$ formato da construção civil é diferente do observado na indústria de produção em série, pois possui uma sucessão de fases caracterizadas por terem coordenações distintas e múltiplos relacionamentos limitados a dois intervenientes, ou seja, bilaterais. Há grande dispersão de responsabilidades e baixo grau de integração entre agentes, que pouco se conhecem (Santos; Melhado, 2003: 3). 
Outra tendência da literatura brasileira é tornar absoluta a descontinuidade entre a fabricação fixa e o empreendimento de construção, descontinuidade necessária, por exemplo, para o tema da "persistência da manufatura" apartar a operação de construção em relação aos processos industriais da fabricação de insumos, elementos terminados e componentes:

As atividades de fabricação, que eliminam ou substituem as tradicionais do canteiro, tendem a ser desenvolvidas segundo uma organização do trabalho 'taylorizada', sobretudo no caso dos produtos industrializados (...) Nas atividades que permanecem no canteiro tende a prevalecer o 'saber fazer' tradicional, ainda que articulado à incorporação das inovações. Este saber fazer de base empírica, em que se articulam concepção e execução dificilmente pode ser eliminado totalmente da atividade de construção, pela margem incompressivel de variabilidade que persiste no processo de trabalho no setor (Farah, 1996: 276).

Nesta interpretação, a imanência da variabilidade na construção civil é transferida para a manufatura e, desta forma, a "margem incompressível de variabilidade" implica necessariamente que sua gestão se dê através de um "saber fazer de base empírica". A mesma variabilidade, no entanto, está na base do mais recente paradigma de gestão da construção em países do capitalismo avançado, a "Lean Construction", que utiliza complexos modelos matemáticos para transferir para a construção civil a tecnologia gerencial toyotista e, assim, obter "an active management of variability, starting with the structuring of the Project (temporary production system) and continuing through its operation and improvement" (Ballard; Howell, 2003: 8) [117].

Um ponto de equilíbrio entre estes tratamentos extremos da variabilidade na construção é a corrente francesa de análise da construção liderada pelo economista Benjamin Coriat, que afasta o uso de modelos da indústria serial (principalmente derivados do controle de tempos e movimentos) e concebe a variabilidade como determinação positiva da construção civil (no sentido de uma busca de sentido pelo que a construção é, ao invés do que não é). O equilíbrio proposto por Coriat identifica a variação temporal do empreendimento à uma forma produtiva específica do canteiro de obras:

As pesquisas e os estudos sobre a construção conduzem a distinguir entre as indústrias com processo de trabalho baseado na grande produção em série de produtos padronizados - a forma fábrica regida por princípios dominantes rígidos tayloristas e fordistas de parcelamento e repetição do trabalho - $e$ as indústrias com processo de trabalho baseados na reunião-montagem de componentes sob o regime da variabilidade: a forma canteiro prevalece neste caso (Coriat, 1984: 6).

Tanto a "forma-fábrica" quanto a "forma-canteiro" são parte de uma "indústria de formas", em que há "uma relação direta entre o ritmo de trabalho e a quantidade de produção obtida por unidade de tempo", mas o canteiro de obras opera sob "regime de variabilidade":

Por causa mesmo da extrema variabilidade essencial que é parte constituinte do processo de trabalho, sua base principal, o canteiro se constitui em um laboratório privilegiado de

117 O principal propositor da "Lean Construction", Lauri Koskela, defende que "the contribution of the quality movement lies, firstly, in the recognition of variability as a part of industrial life and the development of related methods" (Koskela, 2000: 78). 
experimentação e de estudo de possibilidades e limites de adaptação ao caráter aleatório que se tornou uma característica da demanda. Talvez mais do que outros setores ele reúne condições internas favoráveis para a passagem a formas flexíveis de produção necessárias para satisfazer à demanda quando esta assume formas variáveis e aleatórias. Esta proposição é bastante especulativa, mas ela deriva de numerosos estudos de caso de empresas do setor. E mesmo que ela deva ser verificada em pesquisas posteriores, e reformulada se necessário, me parece que a Construção não será mais analisada como um setor "atrasado", "insuficientemente taylorizado" para ser apreendida sob categorias novas, próprias e adequadas, e se abrir para uma pesquisa mais ampla, do estudo das formas flexíveis de produção de espaços (Coriat, 1984: 12) [118].

O entendimento da variabilidade na construção habitacional pode se dar na própria evolução histórica deste subsetor produtivo, o que dispensa, no limite, a comparação com a indústria estacionária. Trata-se da passagem da tecnologia construtiva de "ciclo fechado" para "ciclo aberto". Uma autoridade na pesquisa da industrialização da construção - Julián Salas - disseminou mundialmente a expressão "industrialização sutil" como termo final desta passagem.

La producción por lotes de productos estandarizados es la forma de producir del momento. En ella concurren los mayores esfuerzos para hacer realidad el binomio producto industrial-variedad. La meta es la producción rentable de lotes de elementos aparentemente idénticos aunque con ciertas características diferenciadoras, aplicando los principios de la producción continua a la fabricación de grupos de componentes similares (...) En el campo de la producción industrial, las recientes aportaciones de los sistemas organizativos, la progresiva utilización de máquinas complejas (robotización) y la masiva utilización de equipos para el tratamiento de datos (informática), han modificado substancialmente las técnicas de producción (Salas, 2008: 32-3).

Luiz Ceotto, diretor da incorporadora Tishman Speyer e idealizador dos processos de racionalização construtiva da antiga construtora Encol, utiliza igualmente a expressão "industrialização sutil" para descrever a evolução tecnológica da construção habitacional brasileira após o conglomerado Lafarge iniciar a produção no país dos componentes de forro e parede em gesso acartonado e perfil de aço galvanizado:

Industrialização "sutil" pelo fato dela ser pouco percebida pelas pessoas e de ser aberta a todo novo tipo de componente, não necessitando de equipamentos pesados nem de grandes investimentos na sua adoção. Assim, a partir de 1997 a parte sul e sudeste do Brasil entrava finalmente na tão esperada industrialização. Grande parte dos produtos feitos nos canteiros centrais de obras passaram a ser produzidos pelas indústrias que anteriormente só produziam os materiais de construção (Ceotto, 2005: 96) [119].

Industrialização sutil é a transferência de processos construtivos de empresas construtoras isoladas para a amplitude do mercado de insumos da construção. Nas palavras de Julián Salas, "la estrategia sectorial se clarificó: los prefabricadores

118 Para Coriat, pesquisas como a que Nilton Vargas realizou no Brasil sobre a construção habitacional durante o regime militar (Vargas, 1979) seriam "vítimas de um modelo de referência exterior à construção e que revelou progressivamente não ser adequado. Este "modelo" exterior que serviu de referência implícita ou explícita é o taylorismo" (Coriat, 1984: 1).

119 Ceotto atribui a expressão “industrialização sutil” ao engenheiro Álvaro Meseguer, embora os textos de Julián Salas, um dos principais pesquisadores do Instituto Eduardo Torroja, tenham uma grande divulgação nos estudos de racionalização e pré-fabricação em construção civil. 
dejaron de ser constructores y pasaron a ser industriales" (Salas, 2008: 22). O que antes era concebido num ciclo fechado, em que projeto e construção se concentravam numa única empresa, agora se abre como solução tecnológica do mercado de insumos, acessível e, mais importante, adaptável a qualquer empreendimento através de projeto de produção [120].

Assim, por sobre os grandes conglomerados produtores de insumos básicos surge uma camada de produtores de materiais intermediários, que são igualmente fabricados por automação, mas de forma inovadora justamente por tender menos à cartelização. Assim, ao redor da grande indústria de aglomerantes, aparecem fabricantes de argamassas ensacadas; da indústria de aço, fornecedores de armaduras cortadas e dobradas; da indústria de chapas de madeira, fôrmas pré-fabricadas e portas prontas e montadas [121].

A variabilidade da força de trabalho que produzia em canteiro de obras os materiais intermediários específicos de cada empreendimento se transfere para um mercado intermediário de fornecedores de insumos, com planta fixa mas produção diversificada. Este novo panorama produtivo leva Ceotto a reproduzir a identificação popular entre democracia e acesso a bens de consumo para afirmar que "a grande evolução que a industrialização sutil trouxe foi a democratização da tecnologia para todas as empresas e profissionais do setor, com baixíssimos investimentos" (Ceotto, 2005: 97).

Na diversificação produtiva das cadeias fornecedoras de material de construção acontece a industrialização da própria variabilidade dos empreendimentos de construção, não no sentido de que estes possam produzir em massa produtos idênticos, mas sim de que as suas fábricas efêmeras e sua força de trabalho reunida de forma "ad hoc" vão lidar apenas com produtos padronizados, que serão empregados ao longo de um empreendimento de construção segundo uma processo industrial articulado pelo sistema de gestão de qualidade.

Antes de levar este raciocínio para dentro dos empreendimentos de construção, é ilustrativo fechar esta abordagem abstrata da especificidade de uma indústria da construção com a opinião de um profissional de mercado. Segundo Fábio Villas Bôas, diretor de engenharia da construtora Tecnisa, a descrição paradoxal da construção habitacional como "uma indústria que faz peças diferentes o tempo inteiro" precisa ser entendida com o seguinte complemento:

Isso não é industrializar, é só usar processo industrializado. Creio que a solução que o mercado adotou como carro-chefe, e que faz mais sentido, é a industrialização do processo produtivo, mesmo que sem industrializar o produto (Villas Bôas, 2011: 26).

120 Na pesquisa que realizou nos anos 1970, Paulo Bruna já percebia o esgotamento da industrialização de ciclo fechado na Europa quando empresas construtoras fizeram uma demanda ao governo francês pela "manutenção de um mercado de escala que permitisse planejar os investimentos a longo prazo". A contraproposta da política de inovação tecnológica criada pela gestão de Giscard d'Estaing foi a seguinte: "as construtoras seriam obrigadas a respeitar certas condiçôes como, por exemplo, a coordenação modular, ou utilizar elementos pré-fabricados dentro do sistema aberto" (Bruna, 1976: 97).

121 "Production is transferred to off-site production where unit costs can be reduced by repetitive production techniques using sophisticated plant in a controlled environment. These factory conditions also raise productivity of labour engaged in the production of buildings and structures. Although some construction workers may be transferred to factory production from site assembly, most site-based skills become redundant in the process, to be replaced by fewer people fixing building components" (Gruneberg, 2002: 67). 
Industrializar o processo produtivo ao invés do produto significa normatizar tecnicamente a qualidade do processo produtivo ao invés do produto. Este é o "novo território" em que a normatização técnica avançou através do sistema de gestão de qualidade e é também "a solução que o mercado adotou" para conferir um padrão para a variabilidade dos empreendimentos habitacionais.

\section{Qualidade como controle de governo}

Não foi uma coerção de mercado que, no final dos anos 1990, conduziu a adaptação para a construção civil brasileira das normas de gestão de qualidade que se disseminavam mundialmente na indústria seriada. Foi uma coerção de governo, exercida para assegurar uma qualidade uniforme para a habitação social que era encomendada através de duas empresas públicas - a Companhia de Desenvolvimento Habitacional e Urbano do Estado de São Paulo (CDHU) e a Caixa Econômica Federal (CEF). São empresas com setores de engenharia que têm capacidade gerencial suficiente para demandar e aplicar parâmetros técnicos à construção habitacional.

No interregno entre a provisão habitacional do BNH e o programa MCMV, o poder de compra destes clientes governamentais da construção habitacional era relativamente grande. Em 1999, a CDHU construía 50 mil unidades habitacionais contratadas em 300 operações financeiras, enquanto a CEF, no mesmo ano, financiava 280 mil novas unidades habitacionais (ainda que uma minoria delas para baixa renda) a partir de um orçamento anual, calculado em dólares, de US\$ 2,2 bilhões (Cardoso; Vivancos; Jesus 2001: 2-9).

Em 1996, o governo estadual de São Paulo lança o Programa da Qualidade da Construção - QualiHab. O Artigo $6^{\circ}$ do Decreto Estadual 41.337, que institui o programa, prevê que "a CDHU inserirá em suas licitações de obras, projetos e serviços de engenharia exigências relativas a demonstração da qualidade de produtos e serviços, conforme as metas e prazos estabelecidos em programas setoriais da qualidade". Tais programas setoriais estabelecem em comum acordo com órgãos de representação empresarial (à frente deles, o departamento paulista do Sindicato da Indústria da Construção Civil - Sinduscon) os requisitos técnicos que constituem um padrão de qualidade construtiva, cujas "metas e prazos" de cumprimento se tornariam barreiras de entrada para as licitações de habitação popular da CDHU [122].

O padrão de qualidade, de qualquer forma, estava longe de constituir uma barreira intransponível para o setor da construção habitacional que atuava em São Paulo, pois adotava apenas 11 requisitos técnicos da norma ISO (muitos deles combinados) e selecionava um conjunto restrito de 34 insumos e 25 processos

122 Em 1998, a empresa “MC Construções Ltda" pediu na 4a Vara de Fazenda Pública (processo 1.504/98) um Mandado de Segurança contra a obrigatoriedade de "apresentação de certificado de participação no Programa Setorial de Qualidade, como requisito de habilitação e também a assinatura dos contratos". Como o Artigo 30 da Lei Federal 8.666/93, que regula licitações públicas, é ambíguo sobre a discricionariedade do poder público em impor condições a respeito da "capacidade técnico-operacional" para uma construtora participar de licitação, o Tribunal de Contas Estadual de São Paulo restringiu o atendimento ao QualiHab para a fase de classificação e não de habilitação nas licitações da CDHU. 
produtivos considerados críticos para produção e para os quais seria obrigatório adotar a rastreabilidade de insumos e o controle de operações.

Em 2004, um convênio técnico entre CDHU e a Escola Politécnica da Universidade de São Paulo realiza uma checagem do programa QualiHab, num procedimento de pesquisa que emula os ciclos de melhoria contínua "Plan-DoCheck-Act" (PDCA) preconizados pelos sistemas de gestão de qualidade. Num dos artigos originados deste convênio, Cláudia Nascimento de Jesus e Francisco Cardoso constatam a pouca eficácia do programa estadual de 10 anos atrás:

Pela análise da implementação nas obras dos sistemas de gestão da qualidade das empresas construtoras e gerenciadoras, ficou claro que o resultado final do programa ainda estava aquém do possível e do desejável; os sistemas de gestão da qualidade não haviam ainda contribuído significativamente para a melhoria do produto como um todo ou mesmo de suas partes (Jesus; Cardoso, 2004: 6).

Seguem-se encontros entre representantes setoriais e as consultorias da USP e IPT, além de uma participação pioneira de empresas certificadoras acreditas pelo Inmetro para aplicação das normas ISO 9000. A primeira ação após a checagem, no entanto, é um retorno à coerção de governo sobre empresas individuais, mesmo que depois se traduzam em consensos negociados com representantes setoriais da construção habitacional de São Paulo:

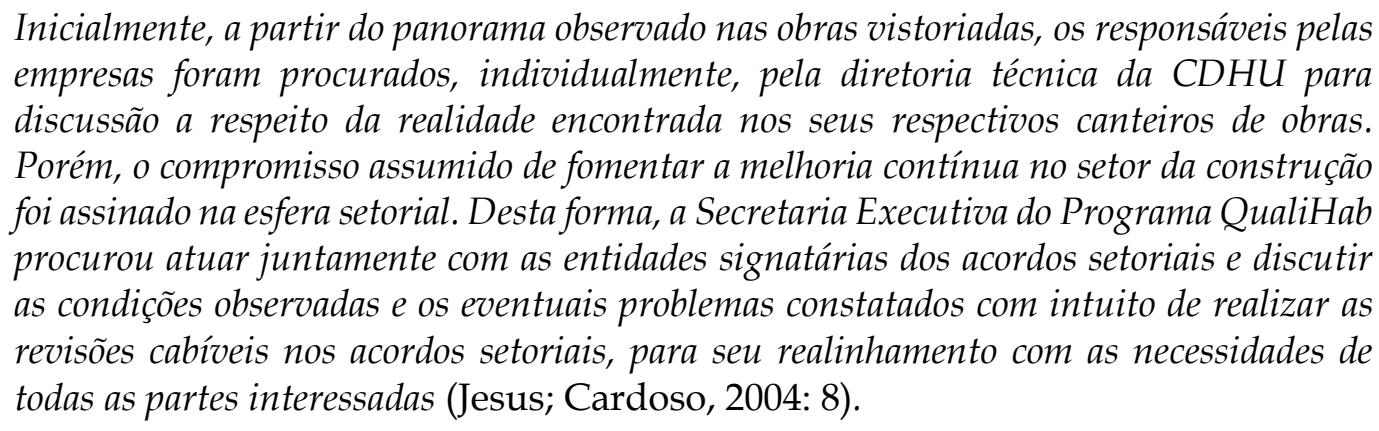

Em 1998, a Secretaria Nacional de Desenvolvimento Urbano, ligada ao gabinete da presidência Fernando Henrique Cardoso, utiliza o QualiHab como modelo para o Programa Brasileiro da Qualidade e Produtividade na Construção Habitacional - PBQP-H. Atualmente inserido no Plano Plurianual do Ministério das Cidades e sob gestão da Secretaria Nacional de Habitação, o PBQP-H passou a englobar requisitos setoriais para obras de saneamento e infraestrutura urbana em conjunto com os de construção habitacional [123].

O PBQP-H é um programa que partiu da experiência do Programa QualiHab e o adotou como modelo, sobretudo no que se diz respeito ao sistema de qualificação de empresas de serviços e obras da construção civil (...) com o passar dos anos, o programa nacional tomou um rumo próprio (Jesus; Cardoso, 2004: 17).

O "sistema de qualificação" mencionado por Cláudia Nascimento de Jesus e Francisco Cardoso está hoje consolidado no Sistema de Avaliação de Conformidade de Empresas de Serviços e Obras da Construção Civil (SiAC), um sistema único de referenciais normativos mantido por uma Comissão Nacional

123 A extensão do referencial normativo para além das obras habitacionais levou à alteração do sufixo " $\mathrm{H}^{\prime}$ do programa federal, que de "Habitação" passou a significar "Habitat". 
composta por entidades da construção civil, clientes contratantes e órgãos técnicos (MCidades, 2012: 9). O controle que o PBQP-H exerce sobre o padrão de qualidade de obras licitadas com recursos do governo federal se baseia nos referenciais normativos gerais e os requisitos complementares do SiAC para edificações, saneamento básico e sistema viário. Por se apoiar em legislação federal, tanto os referenciais normativos gerais quanto os requisitos complementares têm caráter nacional e podem ser aplicados a contratos e obras civis em todo país [124].

Na passagem dos acordos setoriais do governo paulista para o programa e o sistema de qualidade do governo federal houve uma vinculação definitiva dos requisitos técnicos aplicáveis à habitação social do Brasil em relação ao padrão normativo internacional da ISO, o que une vigência nacional com legitimação global. As distâncias que se abrem entre a referência internacional e as empresas construtoras brasileiras passou a ser medida por um padrão compartilhado com empresas de todos setores econômicos e em escala mundial.

O conjunto dos requisitos técnicos que forma o referencial normativo do PBQP$\mathrm{H}$ tem a mesma organização temática e sequência de seção, requisito e subitens da norma ISO 9001:2008. Mesmo quando a terminologia é modificada para indicar com mais clareza sua aplicação ao empreendimento de construção, ela mantém coerência de sentido com a generalidade da norma internacional [125].

A diferença maior entre o referencial normativo do PBQP-H e da ISO não está na terminologia ou na organização dos requisitos, mas sim que a sua certificação de cumprimento se dê através de uma gradação composta de "Nível de Adesão", “Nível B" e "Nível A". Enquanto o "Nível de Adesão" é simplesmente um compromisso formal com a implantação dos requisitos de qualidade do SiAC, o "Nível B" demanda uma certificação em grau considerado "evolutivo", pois se restringe ao cumprimente de um conjunto parcial de requisitos, que é cumprido integralmente apenas nas empresas certificadas em "Nível A". Na norma ISO 9001:2008 não há graus de implantação do sistema de gestão de qualidade e sua certificação só pode acontecer por conformidade completa [126].

Ainda assim, o topo do processo de certificação promove a completa fusão entre a normatividade ISO e SiAC. As empresas construtoras que cumprirem integralmente os requisitos do PBQP-H podem receber das auditorias externas tanto o "Nível A" no programa federal quanto o certificado referente ao padrão internacional ISO 9001:2008. Um elemento estratégico do PBQP-H, portanto, é adotar na certificação evolutiva um "Organismo de Avaliação de Conformidade"

124 “Os princípios subjacentes do poder de compra do Estado e da parceria com os principais agentes do setor da construção também foram adotados no PBQP-H. No entanto, nele não há apenas um único cliente, que seria a CDHU, mas um conjunto deles e nas três esferas de ação do governo: municipal, estadual e federal" (Cardoso; Vivancos; Jesus, 2001: 9).

125 A seção 7 da norma ISO 9001:2008, por exemplo, reúne os requisitos de "realização do produto", enquanto a seção 7 do referencial normativo do PBQP-H reúne os requisitos de "execução de obra".

126 "Novamente, o setor da construção foi bastante criativo e desenvolveu o conceito de qualidade evolutiva, com etapas prévias para se obter a certificação mais completa. Essa ideia foi adotada no país pelo programa QualiHab da CDHU de São Paulo e pelo PBQP-H e ampliou consideravelmente o número de produtos e empresas certificadas" (Agopyan, 2005: 74). Antes da revisão regimental de Dezembro de 2012, o SiAC previa uma terceira certificação intermediária de "Nível C" após o nível de adesão. 
(OAC), reconhecido pelo Instituto Nacional de Metrologia, Qualidade e Tecnologia (Inmetro) como apto a realizar a certificação da norma internacional ISO. O efeito institucional desta decisão é significativo, pois coloca a favor do programa federal o peso do mercado de certificação industrial.

Por outro lado, o acesso ao PBQP-H dispensa auditoria e ocorre através de uma "Declaração de Adesão ao SiAC", um "documento pelo qual a alta direção da empresa declara a sua adesão ao PBQP-H e o seu comprometimento com a mobilização dos recursos para implantar o seu sistema de gestão da qualidade" (MCidades, 2012, Anexo 1: 4). Trata-se antes de uma carência de prazo para obtenção da classificação de "Nível $\mathrm{B}^{\prime \prime}$, que deve ocorrer por meio de auditoria de terceira parte em no máximo doze meses e evoluir para "Nível A" em até 36 meses, o que significa que toda construtora com quatro anos de adesão ao PBQP-H (senão menos) possui um sistema de gestão de qualidade compatível com a norma ISO 9001:2008.

A diferença mais marcante entre "Nível B" e "Nível A" não aparece na listagem de requisitos exigidos de um ou outro nível de certificação, mas sim em dois requisitos técnicos considerados complementares para "execução de obras de edificação" e que são aplicáveis a empresas de ambos os níveis de certificação, mas em graus diferentes (MCidades, 2012, Anexo IV). O primeiro destes requisitos complementares é o controle de serviços "que afetem a qualidade do produto exigido pelo cliente", que segue uma lista mínima de 25 serviços, de "compactação de terreno" a "pintura externa" (MCidades, 2012, Anexo IV: 2). Controlar estes serviços exige documentar os procedimentos de execução e os equipamentos necessários, bem como listar os instrumentos de monitoramento e os critérios de liberação e aprovação após a conclusão. A construtora certificada em "Nível A" no PBQP-H deve controlar 100\% destes serviços, enquanto a de "Nível B", 40\%. O segundo requisito complementar é o controle de pelo menos 20 materiais de construção que a construtora organizará através de uma lista que "deve ser representativa dos sistemas construtivos por ela utilizados" (MCidades, 2012, Anexo IV: 3). O controle destes materiais implica em documentar a especificação técnica, registrar origem, fornecedor e local de utilização, além dos ensaios pertinentes de recepção e desempenho. A construtora certificada em "Nível A" no PBQP-H deve controlar $100 \%$ dos materiais listados, enquanto a de "Nível B", $50 \%$ [127].

É uma diferença relativa entre os níveis da certificação PBQP-H, pela qual requisitos compartilhados são executados de forma desigual, o que difere dos requisitos cujo cumprimento é obrigatório para o "Nível A" e dispensável para o "Nível B", tal como aparecem na tabela T-22.

127 O “Nível C" previsto nos regimentos do SiAC antes de Dezembro de 2012 precisava cumprir uma porcentagem menor de controles, de $15 \%$ dos serviços e $20 \%$ dos materiais. 
T-22|PBQP-H - Requisitos de qualidade por nível de certificação

SEÇÃO REQUISITO

ITEM

\begin{tabular}{|c|c|c|}
\hline \multirow{5}{*}{$\begin{array}{l}\text { 4. Sistema de Gestão } \\
\text { da Qualidade }\end{array}$} & \multicolumn{2}{|l|}{ 4.1 Requisitos Gerais } \\
\hline & \multirow{4}{*}{$\begin{array}{l}4.2 \text { Requisitos de } \\
\text { Documentação }\end{array}$} & 4.2.1 Generalidades \\
\hline & & 4.2.2 Manual da Qualidade \\
\hline & & 4.2.3 Controle de Documentos \\
\hline & & 4.2.4 Controle de Registros \\
\hline \multirow{11}{*}{$\begin{array}{l}\text { 5. Responsabilidade } \\
\text { da Direção da } \\
\text { empresa }\end{array}$} & \multicolumn{2}{|c|}{ 5.1 Comprometimento da Direção da Empresa } \\
\hline & \multicolumn{2}{|l|}{ 5.2 Foco no Cliente } \\
\hline & \multicolumn{2}{|l|}{ 5.3 Política da Qualidade } \\
\hline & \multirow{2}{*}{ 5.4 Planejamento } & 5.4.1 Objetivos da Qualidade \\
\hline & & 5.4.2 Planejamento do Sistema de Gestão da Qualidade \\
\hline & \multirow{3}{*}{$\begin{array}{l}5.5 \text { Responsabilidade, } \\
\text { autoridade e } \\
\text { comunicação }\end{array}$} & 5.5.1 Responsabilidade e Autoridade \\
\hline & & 5.5.2 Representante da Direção da empresa \\
\hline & & 5.5.3 Comunicação interna \\
\hline & \multirow{3}{*}{$\begin{array}{l}\text { 5.6 Análise Crítica pela } \\
\text { direção }\end{array}$} & 5.6.1 Generalidades \\
\hline & & 5.6.2 Entradas para análise crítica \\
\hline & & 5.6.3 Saídas da análise crítica \\
\hline \multirow{5}{*}{$\begin{array}{l}\text { 6. Gestão de } \\
\text { Recursos }\end{array}$} & \multicolumn{2}{|l|}{ 6.1 Provisão de Recursos } \\
\hline & \multirow{2}{*}{ 6.2 Recursos Humanos } & 6.2.1 Designação de Pessoal \\
\hline & & 6.2.2 Treinamento, conscientização e competência \\
\hline & \multicolumn{2}{|l|}{6.3 Infraestrutura } \\
\hline & \multicolumn{2}{|l|}{ 6.4 Ambiente de Trabalho } \\
\hline \multirow{22}{*}{ 7. Execução da obra } & \multirow{2}{*}{ 7.1 Planejamento da Obra } & 7.1.1 Plano da Qualidade da Obra \\
\hline & & 7.1.2 Planejamento da Execução da Obra \\
\hline & \multirow{3}{*}{$\begin{array}{l}\text { 7.2 Processos Relacionados } \\
\text { ao Cliente }\end{array}$} & 7.2.1 Identificação de Requisitos Relacionados a Obra \\
\hline & & 7.2.2 Análise Crítica dos Requisitos Relacionados a Obra \\
\hline & & 7.2.3 Comunicação com o cliente \\
\hline & \multirow{8}{*}{ 7.3 Projeto } & 7.3.1 Planejamento da Elaboração do Projeto \\
\hline & & 7.3.2 Entradas de Projeto \\
\hline & & 7.3.3 Saídas de Projeto \\
\hline & & 7.3.4 Análise Crítica de Projeto \\
\hline & & 7.3.5 Verificação de Projeto \\
\hline & & 7.3.6 Validação de Projeto \\
\hline & & \begin{tabular}{|l|} 
7.3.7 Controle de Alterações de Projeto \\
\end{tabular} \\
\hline & & 7.3.8 Análise Crítica de Projetos Fornecidos pelo Cliente \\
\hline & \multirow{3}{*}{ 7.4 Aquisição } & 7.4.1 Processo de Aquisição \\
\hline & & 7.4.2 Informações para Aquisição \\
\hline & & 7.4.3 Verificação do Produto Adquirido \\
\hline & \multirow{5}{*}{$\begin{array}{l}\text { 7.5 Operações de Produção } \\
\text { e Fornecimento de } \\
\text { Serviços }\end{array}$} & 7.5.1 Controle de Operações \\
\hline & & 7.5.2 Validação de Processos \\
\hline & & 7.5.3 Identificação e Rastreabilidade \\
\hline & & 7.5.4 Propriedade do Cliente \\
\hline & & 7.5.5 Preservação do Produto \\
\hline & 7.6 Controle de Dispositivos & le Medição e Monitoramento \\
\hline & 8.1 Generalidades & \\
\hline & & 8.2.1 Satisfação do Cliente \\
\hline & & 8.2.2 Auditoria Interna \\
\hline & 8.2 Medição e & 8.2.3 Medição e Monitoramento de Processos \\
\hline 8. Medição, análise & & $\begin{array}{l}\text { 8.2.4 Inspeção e Monitoramento de materiais e serviços de } \\
\text { execução controlados e da obra }\end{array}$ \\
\hline & 8.3 Controle de Materiais e $\mathrm{d}$ & serviços de execução controlados e da obra não-conformes \\
\hline & 8.4 Análise de Dados & \\
\hline & & 8.5.1 Melhoria Continua \\
\hline & 8.5 Melhoria & 8.5.2 Ação Corretiva \\
\hline & & 8.5.3 Ação Preventiva \\
\hline
\end{tabular}

Fonte: MCidades, 2012, Anexo IV

Para indicar os desafios que a tabela T-22 impõe aos empreendimentos de construção, a descrição vai se prender aos requisitos exigidos unicamente para obtenção de "Nível A" e que distinguem, portanto, a completa integração ao 
sistema de gestão de qualidade da ISO em relação a um grau evolutivo que o SiAC entende ser moderado para a construção civil no Brasil [128].

O requisito 5.5 .3 - "Comunicação interna" - exige a abertura de canais de comunicação permanentes e acessíveis entre diretores, gerentes e subordinados em geral, principalmente em sentido ascendente na escala empresarial (meios de divulgação como murais ou informativos internos, portanto, não atendem esta definição). O modelo mais avançado deste requisito é o grupo de discussão "Kaizen" do sistema de produção toyotista, que suspende hierarquias de trabalho na implementação de melhorias de produção e, assim, são de difícil adoção em empresas construtoras menores e de organização familiar.

As exigências do requisito 6.4 - "Ambiente de trabalho" - são auditadas nos termos difusos de conforto quanto a poluição, poeira, umidade e iluminação. Neste caso, o mais importante é que ele não desobriga a construtora de "Nível B" de "identificar, prover e manter a infraestrutura necessária para a obtenção da conformidade do produ to", que é o requisito 6.3. O campo de aplicação deste último requisito, específico de infraestrutura de trabalho, são "canteiros de obras, escritórios da empresa, demais locais de trabalho, ferramentas e equipamentos relacionados ao processo de produção e serviços de apoio tais como abastecimentos em geral, áreas de vivência, transporte e meios de comunicação" (MCidades, 2005, Anexo III: 10) e coincidem genericamente com as disposições da conhecida Norma Regulamentadora 18 (NR-18) do Ministério do Trabalho e Emprego, que regula "condições e meio ambiente de trabalho na indústria da construção". Como a NR 18 tem adoção obrigatória para todo empreendimento de construção no Brasil, seu conteúdo não pode ser uma opção apenas das construtoras de "Nível A" no PBQP-H.

Na norma ISO 9001:2008, o subitem 7.2.3 - "Comunicação com o cliente" demanda a publicação de "informações do produto", na forma de manual de operação ou catálogo on-line, além de canais exclusivos de atendimento a clientes (como os links "fale conosco") e meios específicos para registrar e encaminhar reclamações. No caso dos empreendimentos do programa MCMV, o único cliente das empresas construtoras a ser atendido por esta comunicação é a Caixa Econômica Federal, agente financeiro do programa para quem é repassada a unidade habitacional após a conclusão do empreendimento realizado com recursos do Fundo de Arrendamento Residencial - FAR.

Os subitens 7.3.1 a 7.3.7 exigem "planejamento da elaboração de projeto", com definição de "entradas" e "saídas" de projeto para construção e posterior "análise crítica", "verificação" e "validação", mantendo "controle de alterações". Na norma ISO 9001:2008, estes subitens se referem ao requisito de "Projeto e desenvolvimento", em que "desenvolvimento" se aplica mais propriamente à produção seriada ou da prestação contínua de serviços, pois indica variações de categoria, sazonalidade, tamanho, partes opcionais etc. Como estas propriedades não fazem sentido na variabilidade da construção civil, o PBQP-H reúne os mesmos subitens sob o requisito de "projeto". "Entrada" e "saída" são uma

128 A descrição integral dos requisitos pode ser acessada na página eletrônica do Ministério das Cidades, onde está hospedada o regimento e anexos normativos do SiAC instituídos pela Portaria 582, de Dezembro de 2012 (MCidades, 2012). 
tradução de "input" / "output", expressões utilizadas na norma ISO 9001:2008 e equivalentes na terminologia em inglês de gestão de empresas a "recursos/insumos" e "resultados/produtos". Quando aplicadas à atividade de projeto para construção civil descrevem o conjunto de informações e documentos que devem ser considerados para elaboração do projeto bem como os produtos decorrentes, na forma de desenhos, memoriais e orçamentos. As informações de "entrada" devem ser documentadas e anexadas a controles de trabalho, enquanto que as informações de "saída" devem deixar evidente que as primeiras foram consideradas e atendidas em conjunto com projetos anteriores (subitens 7.3.2 e 7.3.3). É um processo mais cumulativo do que de transformação, o que é confirmado pela exigência de "controle de alterações" (subitem 7.3.7).

A "análise crítica" determina que a elaboração de projeto tenha pontos de verificação ("decision reviews") que assegurem qualidade e adequação entre fases e especialidades (subitem 7.3.4). Uma vez concluído o projeto, a exigência de "verificação" leva à checagem da relação entre "entrada" e "saída" (memórias de cálculo, condições técnicas e orçamentárias, compatibilização), enquanto a exigência de "validação" leva a ensaios e laudos dos elementos projetados na edificação ou de protótipos (subitens 7.3.5 e 7.3.6).

A distinção entre "verificação" e "validação" é recorrente em sistemas de gestão de qualidade e reaparece no subitem 7.5.2 - "Validação de processo construtivo". Aplicado a um processo construtivo, a "verificação" é a checagem de que a construção se deu conforme o projeto, enquanto a "validação" é a checagem de que a construção cumpre o objetivo do projeto em termos de estabilidade, desempenho, conforto, custo etc. A validação de uma prumada de instalações hidráulicas, por exemplo, demanda não apenas o confronto com o projeto e orçamento como também a inspeção de vazamentos e a realização de testes de carga/estanqueidade [129].

Diferentemente do subitem de "Comunicação com cliente", em que o foco da gestão de qualidade é o "cliente externo" da empresa construtora, que passa a gerir o edifício quando acaba o empreendimento, o foco do subitem 7.5.4 "Propriedade do cliente" - é o "cliente interno", empresas especializadas que se relacionam com a empresa construtora enquanto ela gere o empreendimento: fornecedores de materiais, locadores de equipamentos e prestadores de serviços especializados. A empresa construtora precisa identificar as propriedades destes clientes internos - terrenos alugados, andaimes ou veículos locados, ferramentas e máquinas de subempreiteiros - e os procedimentos de uso e salvaguarda específicos [130].

129 Há situações impossíveis de validar antes de concluída uma construção. É o caso, para seguir com o exemplo das instalações hidráulicas, de uma estação de tratamento de esgoto condominial, com tanques anaeróbicos e de decantação. Nestas situações, um sistema de gestão de qualidade exige a previsão de checagens intermediárias para substituir os requisitos de validação.

130 A relação que as normas de qualidade estabelecem entre "clientes internos" assume a forma de controle da subempreitada, que será analisada mais detidamente no capítulo 7. Tanto o SiAC quanto a ISO 9001:2008 anotam que a propriedade de um cliente sob responsabilidade de uma empresa pode ser intelectual. No caso de uma construtora, a primeira referência deste tipo de propriedade são os documentos técnicos e o conjunto de projetos especializados de engenharia. 
O subitem 8.2.3 - "Medição e monitoramento de processos" - direciona a gestão de qualidade para seus próprios processos de controle, uma vez que o manual de qualidade da empresa construtora deve especificar "os métodos adequados para monitoramento e, quando aplicável, para medição dos processos do sistema de gestão da qualidade. Esses métodos devem demonstrar a capacidade dos processos em alcançar os resultados planejados" (MCidades, 2005, Anexo III: 21)

Por fim, o reverso da qualidade industrial no seu sentido mais nuclear é a "nãoconformidade" de um produto em relação aos requisitos técnicos ou demandados por clientes. O objetivo do subitem 8.5.3 - "Ação preventiva" - é levar o sistema de gestão de qualidade a seu ponto mais avançado, que é o combate à não-conformidade que é virtual ou potencial e que, portanto, não é passível de correção, mas sim de prevenção. Mesmo assim, há um bom senso em documentar procedimentos em torno de uma não ocorrência, pois "as ações preventivas devem ser proporcionais aos efeitos dos problemas potenciais" (MCidades, 2005, Anexo 3: 23). Assim, num empreendimento habitacional a especificação das ações de prevenção decorre principalmente da retroalimentação de informações advindas do monitoramento de falhas e reclamações da etapa de pós-obra, monitoramento que é regulado pelo próprio sistema de gestão de qualidade.

Numa reportagem focada em habitações de renda média e alta, onde a "satisfação do cliente" estabelece um contato direto entre construtora e morador, Luciana Tamaki pergunta a um engenheiro de assistência técnica se ele " $f a z a$ retroalimentação dos problemas à empresa". A resposta que recebe é um condensado de procedimentos padrões da gestão de qualidade:

Sim, quando há algum problema, elaboro um plano de ação apontando o que não deu certo, por um documento formal da ISO. Isso vai para o pessoal do departamento de qualidade, eles retroalimentam o sistema, que volta a todas as obras. Há reuniões semanais de análise crítica, quando discutimos todos os problemas com a diretoria (Tamaki, 2011a: 14).

A "análise crítica" mencionada pelo engenheiro de assistência técnica é a mesma exigida pelo requisito 7.3.4 do PBQP-H e da ISO 9001:2008, o que fecha o ciclo dos instrumentos de controle que são exclusivos das empresas construtoras que atingem o nível "A" do SiAC. Nada caracteriza melhor os sistemas de gestão de qualidade do que as atividades que se fecham em ciclos, em que as operações produtivas, todas minuciosamente registradas e documentadas, passam a prevenir uma não-conformidade no futuro mediante retroalimentação de informações do passado. Do ponto de vista de um empreendimento habitacional, a prevenção como parte de um processo contínuo e infinito de gestão implica na diminuição progressiva nos processos construtivos de qualquer atividade que não tenha sido antes projetada ou planejada, o que inclui até mesmo o erro e o desvio. Apenas quando a gestão de qualidade realiza esta passagem da correção para a prevenção os processos produtivos de um empreendimento habitacional se tornam, no plano da tecnologia organizacional, equiparáveis aos dos demais setores da indústria seriada [131].

131 Esta é a diferença em relação ao observado por Luiz Augusto dos Santos e Silvio Melhado em 2003, quando pesquisaram políticas de qualidade de oito empreendimentos privados de médio e alto padrão na região metropolitana de São Paulo: “Todas as empresas demonstraram dificuldades para retroalimentar as 
Num sentido mais amplo, o ciclo incessante pelo qual toda ação presente é lançada para o futuro como aperfeiçoamento produtivo reproduz nas condições de mercado do século 21 a dinâmica fundamental do capital como valor em processo de valorização. Assim como esta dinâmica necessita de um valor de uso apenas como passagem intermediária a novos ciclos de acumulação de capital, o foco ideológico na necessidade do cliente, que é sempre insaciável, impulsiona um ciclo perpétuo de melhoria de qualidade produtiva que coincide com a própria autonomização do capital [132].

\section{I-13 | Painéis de controle de qualidade observados durante a pesquisa}
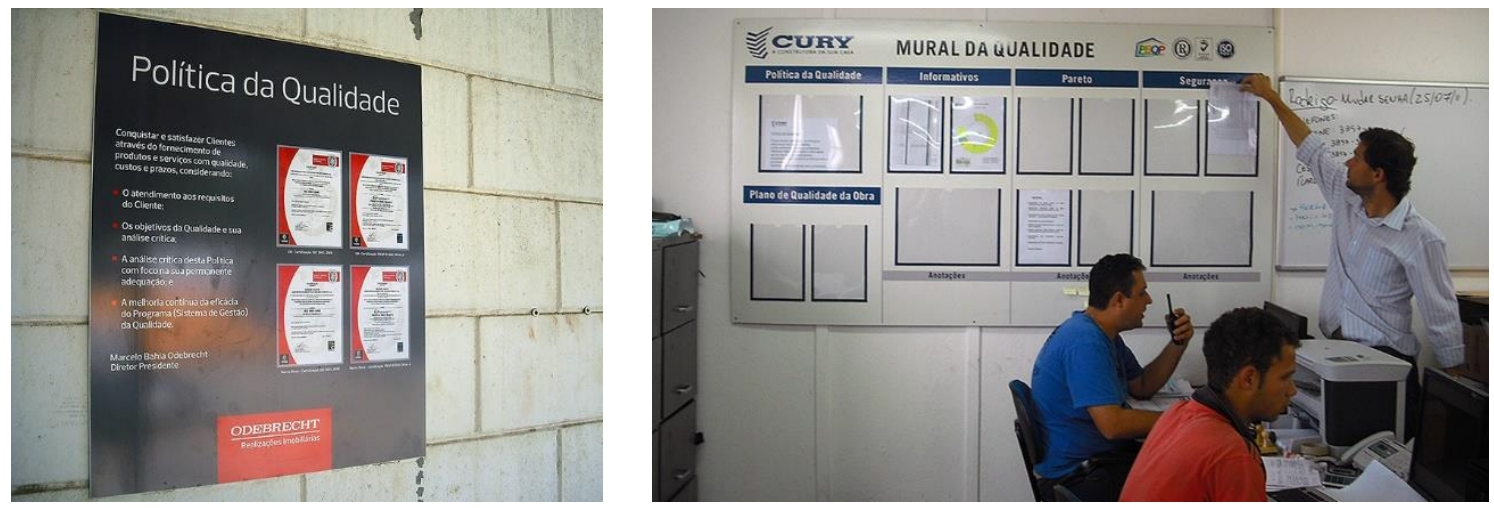

À direita, painel de divulgação da política de qualidade da construtora Odebrecht OR. À esquerda painel de comunicação interna do sistema de gestão de qualidade da construtora Cury.

A implantação desta lógica autônoma do capital no interior do processo de gestão empresarial quebra qualquer resistência de uma organização própria da construção habitacional, mesmo quando esta atinge um estágio de inspeção de produto. A existência do "Nível de Adesão" e do "Nível B" poderia sugerir uma solução de compromisso entre a tecnologia organizacional do sistema de gestão de qualidade e um conjunto de operações produtivas de menor qualidade das empresas construtoras brasileiras. Se este compromisso existe, ele não se dá no plano das construtoras capazes de propor e aprovar empreendimentos para Faixa 1 do programa MCMV, pois os prazos para cumprimento do nível " $A$ " de fato conduzem as empresas construtoras para a completa adesão aos sistemas de gestão de qualidade em padrão internacional, tal como indica a tabela T-23.

informações de empreendimentos anteriores. O sistema de gestão era compreendido apenas como uma tarefa fiscalizadora, rotineira e burocrática para realização das atividades. Também associou-se o sistema a um mecanismo de avaliação e controle, ou seja, um identificador de erros para ações corretivas, com atribuições semelhantes às de uma fiscalização, não como meio de planejamento e prevenção" (Santos; Melhado: 11).

132 "Ao assumir incessantemente a forma tanto de dinheiro quanto de mercadoria, o valor é o sujeito de um processo independente em que muda sua própria magnitude, retira mais valor de si mesmo enquanto valor originário e, assim, valoriza a si mesmo. Pois o movimento pelo qual adiciona mais valor é seu próprio movimento, sua valorização é portanto autovalorização" (Marx, 1990 [1867]: 255). 


\section{T-23 | Nível PBQP-H no programa MCMV/ Faixa 1 na RMSP}

\begin{tabular}{|c|c|c|c|}
\hline EMPRESA CONSTRUTORA & TOTAL UH & NÍVEL SiAC & EMPRESA CERTIFICADORA DE TERCEIRA PARTE \\
\hline DIB ARQUITETURA INCOPORADORA LTDA & 2540 & A & Instituto Falcão Bauer da Qualidade \\
\hline QUALYFAST CONSTRUTORA LTDA & 1500 & A & Associação Brasileira de Normas Técnicas \\
\hline WGT EMPREENDIMENTOS E INCORPORACOES LTDA & 1460 & A & TÜV Rheinland do Brasil Ltda \\
\hline CURY CONSTRUTORA E INCORPORADORA S/A & 1240 & A & Lloyd's Register Quality Assurance \\
\hline RGA CONSTRUTORA LTDA & 1020 & A & DNV Germanischer Lloyd \\
\hline BAIRRO NOVO EMPREENDIMENTO IMOBILIARIO S/A & 880 & A & Bureau Veritas Certificação \\
\hline NOVOLAR INCORPORACOES E CONSTRUCOES LTDA & 816 & A & TÜV Rheinland do Brasil Ltda \\
\hline ENPLAN ENGENHARIA E CONSTRUTORA LTDA & 771 & A & DNV Germanischer Lloyd \\
\hline CONSTRUTORA E INCORPORADORA FALEIROS LTDA & 740 & A & TÜV Rheinland do Brasil Ltda \\
\hline SANED ENGENHARIA E EMPREENDIMENTOS LTDA & 700 & A & Fundação Carlos Alberto Vanzolini \\
\hline YPS CONSTRUCOES E INCORPORACOES LTDA & 658 & A & Instituto Falcão Bauer da Qualidade \\
\hline CONSTRUTORA HUDSON LTDA & 640 & A & TÜV Rheinland do Brasil Ltda \\
\hline CONSTRUTORA CROMA LTDA & 480 & A & Instituto Falcão Bauer da Qualidade \\
\hline SOUEN \& NAHAS CONSTRUTORA E INCORPORADORA LTDA & 432 & A & British Standard Institute do Brasil \\
\hline TERRA NOVA ENGENHARIA E CONSTRUCOES LTDA & 402 & A & Instituto Tecnológico de Avaliação e Certificação \\
\hline MAXI ENGENHARIA E CONSTRUCOES LTDA & 400 & A & TÜV Rheinland do Brasil Ltda \\
\hline ARBORE ENGENHARIA LTDA & 360 & A & SAS Certificadora \\
\hline B \& B - ENGENHARIA E CONSTRUCOES LTDA & 300 & A & TÜV Rheinland do Brasil Ltda \\
\hline HZR CONSTRUTORA LTDA DIMENTOS IMOBILIARIOS LTDA & 300 & A & TÜV Rheinland do Brasil Ltda \\
\hline GMP ENGENHEIROS ASSOCIADOS S/C LTDA & 280 & C & Associação Brasileira de Normas Técnicas \\
\hline METACONS ENGENHARIA LTDA & 256 & A & Associação Brasileira de Normas Técnicas \\
\hline EDIVIA EDIFICACOES E INCORPORACOES LTDA & 206 & A & TÜV Rheinland do Brasil Ltda \\
\hline SIMETRICA ENGENHARIA LTDA & 200 & A & Instituto Falcão Bauer da Qualidade \\
\hline AVITA CONSTRUCOES E INCORPORACOES LTDA & 40 & A & TÜV Rheinland do Brasil Ltda \\
\hline
\end{tabular}

Fonte: elaboração própria com dados da CEF/GIDUR/SP e Inmetro. Atualizados para Agosto de 2013

A tabela relaciona a classificação de nível SiAC e as empresas de auditoria de terceira parte de cada uma das 24 empresas construtoras que, em Agosto de 2013, eram responsáveis pela totalidade dos empreendimentos do programa MCMV para baixa renda na região metropolitana de São Paulo. Apenas a empresa GMP Engenheiros Associados Ltda, recém-ingressada no PBQP-H e responsável por um empreendimento de 280 unidades habitacionais no município de Suzano, tem classificação de nível diferente de " $\mathrm{A}$ ". O predomínio do nível máximo é certificado por uma maioria de empresas de auditoria com tradição de mercado. Nove construtoras são auditadas pela TÜV Rheinland do Brasil Ltda, de origem centenária na indústria pesada alemã (onde é "Technische Überwachungsvereine", isto é, "Sociedade de inspeções técnicas") e que, no Brasil, assumiu em 2007 o controle acionário da Ductor Implantação de Projetos S.A., uma das maiores gerenciadoras de projetos do país.

O sistema de gestão de qualidade não substitui um controle sobre o empreendimento que anteriormente se daria de forma não padronizado, mas ainda assim exercido por engenheiros. Ele substitui um controle que era exercido pela força de trabalho da construção através de suas instâncias de mando internas ao canteiro de obras - oficiais, encarregados e mestre. O domínio dos empreendimentos habitacionais pela tecnologia de gestão da engenharia só se torna integral - criando ciclos que partem da rastreabilidade dos insumos à retroalimentação de pós-obra e vice-versa - após os referenciais normativos de qualidade se instalarem em todos os aspectos do canteiro de obras, numa transformação antecipado da seguinte forma por Fernando Sabbatini:

Em um processo de produção como o adotado tradicionalmente pela indústria da construção civil, no qual grande parte das decisões que importa para qualidade do produto são tomadas pelos próprios executores, a qualidade não pode ser garantida, pode ser apenas constatada. O domínio do processo está na mão dos executores e a responsabilidade pela qualidade do produto é do próprio executor. No passado esta responsabilidade era clara e a qualidade poderia ser conseguida através da seleção dos executores. Hoje, isso não mais 
ocorre, e em qualquer setor industrial a qualidade é resultante de um processo cujo dominio está centrado na engenharia, de projeto e produção (...) Somente disporemos de todas as informações necessárias para conduzir com eficácia o processo de produção se, em sua organização estiverem perfeitamente estabelecidos: os procedimentos de controle; a sistemática de coleta de informações; as metodologias de análise das informações; os procedimentos para correção de não-conformidades etc. (Sabbatini, 1998: 4-12).

Uma década depois de implantado como programa de qualidade adaptado aos setores produtivos envolvidos na provisão habitacional, a aplicação pelo PBQP$\mathrm{H}$ das normas consolidadas no SiAC sofreu uma expansão significativa ao se tornar obrigatória para as empresas construtoras que vão propor projetos junto aos fundos públicos utilizados no programa MCMV. Desde seu lançamento, todos os empreendimentos do maior programa de habitação federal operam um sistema de gestão de qualidade [133].

Neste ponto, cabe uma última comparação com o panorama tecnológico legado pelo BNH para a construção habitacional na passagem dos anos 1980-1990:

As iniciativas de inovação são assistemáticas, propostas de fora para dentro pelo contratante - o Estado - e de forma episódica, não chegando a constituir uma nova 'cultura' nas empresas. Assim, na construção da habitação popular, incorpora-se à produção um novo sistema construtivo, sem que esta incorporação seja acompanhada por uma reorganização da empresa" (Farah, 1996: 116).

No programa MCMV, a inovação tecnológica ainda é "proposta de fora para dentro pelo contratante - o Estado", mas através de sistemas de controle produtivo permanentes e de âmbito nacional, à frente deles o SiAC. Em sua última reforma regimental, em 2012, o SiAC se consolida institucionalmente ao operar em conjunto com um sistema de avaliações técnica (SiNAT) e um sistema de certificação de materiais e componentes na construção civil (SiMaC). Entre os limites que tal institucionalidade pode ter para de fato intervir na construção civil brasileira não está “a forma episódica”. A pretensão do SiAC de "constituir uma nova cultura nas empresas" seria de outra forma ilusória e o resultado no programa MCMV é o inverso termo a termo do observado por Marta Farah como legado do BNH: incorpora-se à produção uma reorganização da empresa, sem que esta incorporação seja acompanhada por novos sistemas construtivos. $\mathrm{O}$ controle da variabilidade do empreendimento de construção pelos sistemas de gestão da qualidade altera irreversivelmente seus processos produtivos pela organização e não pela construção [134].

A questão final para este capítulo, no entanto, é que esta alteração não se estende para todo um setor da construção civil, mas apenas para uma parte com grande concentração de capital e que é definida pelas condições em que as empresas

133 Segundo o vice-presidente de habitação econômica do Secovi-SP, Flávio Prando, "quem está no mercado é consciente de que a qualidade é fundamental para permanecer. É simplesmente uma necessidade, e ninguém quer perder uma oportunidade como a que a gente está vivendo". O programa MCMV é tanto a "necessidade" quanto a "oportunidade" a que se refere Flávio Prando (Prates, 2010: 28).

134 Mais uma vez, Fernando Sabbatini é preciso ao vincular industrialização e organização produtiva: "Não existe embutido no conceito de industrialização, a exigência de que para evoluir obrigatoriamente uma empresa tenha de alterar os seus processos construtivos. Tem, sim que organizá-los. Em outras palavras: a industrialização não é um processo associado a saltos tecnológicos ou a mudanças operacionais radicais. Ela é essencialmente um processo contínuo de organização da atividade produtiva" (Sabbatini, 1998: 3). 
podem acessar fundos públicos de gestão governamental. Posto na realidade do mercado da construção civil, a homogeneidade obtida na produção por meio do referencial normativo de qualidade não altera a heterogeneidade do controle de mercado entre as empresas construtoras. Um pesquisador da organização setorial da construção civil e membro da Comissão Nacional do SiAC, Francisco Cardoso, reconhece esta disparidade entre normatividade técnica e forças de mercado:

Quanto aos padrões de competição, além das ações articuladas por programas como o Qualihab e o PBQP-H e pelas empresas e suas entidades (em especial a normalização técnica), cabe dizer que em certas relações há ainda forte iniquidade de forças, quer por mecanismos de mercado (cartel, quase-monopólio, commodities cotadas em dólar etc.), quer em termos de diferença de porte e de disponibilidade de recursos em geral (Cardoso, 2005: 96).

Do ponto de vista dos programas de gestão de qualidade, a primeira "iniquidade de forças" se dá pela sua baixa adesão entre empresas construtoras brasileiras, mesmo sendo uma porta de entrada única para ter projetos aprovados junto ao programa MCMV. Segundo a página eletrônica do PBQP-H mantida pelo Ministério das Cidades, "são aproximadamente 3.000 construtoras ativas nos três níveis de avaliação do Programa", o que representa apenas 3,78\% das 79.408 "empresas ativas" do setor da construção levantadas pelo IBGE na mais recente Pesquisa Anual da Indústria da Construção (IBGE, 2012) [135].

O diretor da construtora Tecnisa, Fábio Villas Bôas, é mais otimista em relação à porcentagem de empresas capazes de controlar seus processos produtivos:

Há algo em torno de dezenas de milhares de empresas do setor de construção civil. As que efetivamente têm condição de tecnologia são algo em torno de 5\%. Elas têm condições de trabalho adequadas, segurança no trabalho, metodologias construtivas muito bem estabelecidas, canteiros organizados, logística, parte ambiental, tudo incorporado em seus processos (Villas Bôas, 2011: 34).

O corte bruto que separa esta minoria de empresas das restantes é a capacidade financeira e de gestão para suportar o custo inerente da implantação do sistema de gestão de qualidade, não apenas para comprar serviços de consultoria e auditoria, como também em horas-homem para novos cargos, treinamentos e administração. São custos que afastam as micro e pequenas construtoras e concentram as médias e grandes construtoras no reduzido grupo das empresas com certificação pelo PBQP-H [136].

Em outra página eletrônica do Ministério das Cidades, o PBQP-H é apresentado numa perspectiva de concorrência empresarial para o provimento de habitação

135 Estimativa sobre o PBQP-H disponível em “www.cidades.gov.br/pbqp-h/resultados.php". Na mesma página se lê que o número de 3 mil empresas "demonstra o alto grau de aceitação e a credibilidade que o Programa conquistou no segmento de obras e serviços de construção".

136 Numa pesquisa circunscrita às construtoras com sede na cidade de Curitiba, os engenheiros Cláudio Ferreira e Martinho Giacomitti perceberam em 2007 que apenas empresas de grande porte estavam certificadas pelo PBQP-H, uma vez que "a elaboração, bem como a implementação, manutenção e melhoria do sistema de gestão da qualidade, exigem grande investimento de tempo e recursos financeiros, além de profissionais suficientemente qualificados, o que acaba se tornando um complicador para as pequenas organizações" (Ferreira; Giacomitti Jr, 2007: 45). 
social: "o objetivo, a longo prazo, é criar um ambiente de isonomia competitiva, que propicie soluções mais baratas e de melhor qualidade para redução do déficit habitacional no país, atendendo, em especial, a produção habitacional de interesse social" [137].

No entanto, a igualdade de condições competitivas que o sistema de gestão de qualidade pode proporcionar para a "a redução do déficit habitacional" não implica em generalizar o avanço tecnológico e produtivo para a maioria dos agentes da construção civil no país (incluindo aqui organizações sem fins lucrativos e movimentos de moradia), mas sim criar um conjunto restrito de empresas construtoras que tem exclusividade na apresentação de projetos habitacionais para as linhas de financiamento operadas pela Caixa Econômica Federal, o que inclui o programa MCMV.

Quando Luiz Augusto dos Santos e Sílvio Melhado reconhecem que "a certificação de qualidade deixou de ser vantagem competitiva e tornou-se um critério selecionador de empresas" (Santos; Melhado, 2003: 2), descrevem, no caso do programa MCMV, uma seletividade que não é de consumidores finais, mas sim de clientes governamentais com imenso poder de compra ao administrarem fundos públicos do programa federal. Sob a coerção deste poder de compra governamental, a adesão ao sistema de gestão de qualidade cria uma vantagem competitiva que não é de uma ou outra empresa construtora, mas de um bloco minoritário com capacidade financeira para obter a certificação e, desta forma, controlar a concorrência com a grande maioria das empresas construtoras brasileiras.

A isonomia competitiva pretendida pelo Ministério das Cidades se assenta, portanto, sobre uma desigualdade radical. Ainda assim, ao criar uma clivagem no mercado da construção civil brasileiro através do PBQP-H, o sistema de gestão de qualidade não impede que pequenas construtoras atuem no maior programa habitacional do país, mas deixa claro qual o papel que elas vão exercer em seu interior: serão subempreiteiras.

137 “www4.cidades.gov.br/pbqp-h/pbqp_apresentacao.php" 


\section{$7 \mid$}

\section{A SUBEMPREITADA}

\section{Uma relação de produção}

Antes dos sistemas de gestão de qualidade se universalizaram entre os canteiros de obras para baixa renda por uma coerção de governo, já era universal outra característica organizacional nestes empreendimentos, desta vez imposta por uma lógica unicamente empresarial: a subempreitada de serviços de execução de obra. Este capítulo investiga como a lógica coercitiva da gestão de qualidade altera a prática da subempreitada disseminada pelo mercado.

A base empírica para discutir esta alteração são as visitas técnicas realizadas no segundo semestre de 2011 e no segundo semestre de 2013 e que abrangeram um total de 22 empreendimentos de baixa renda do programa MCMV vinculados a 10 empresas construtoras na região metropolitana de São Paulo [138]. Diferentemente da discussão sobre processos de trabalho na primeira parte desta tese, não é necessário recriar tipologicamente a subempreitada para clarificar as suas características nos empreendimentos visitados: eram subempreitados para empresas dotadas de equipes especializadas de trabalho todos os serviços de "execução de obras" que correspondiam a itens orçados e medidos nos repasses da Caixa Econômica Federal através das Planilhas de Levantamento de Serviços (PLS). As exceções a esta observação recorrente nas visitas e depoimentos (fornecidos durante as visitas ou em contatos posteriores) eram apenas pontuais e sempre contingentes.

Esta constante também aparece em reverso e a única força de trabalho que era possível observar como vinculada à empresa contratante das subempreiteiras não ultrapassava o mestre-de-obras (com um ou mais encarregados, principalmente para supervisão de alvenaria estrutural), técnicos administrativos para compras e contratos, almoxarife e apontador de obra, uma equipe de manutenção de canteiro de obras (pedreiro, carpinteiro e ajudante, eventualmente acompanhados de armador ou mecânico/operador de máquina) e, finalmente, uma equipe de engenharia cuja quantidade e cargos variava durante o empreendimento, mas sempre contava com o extremo superior, que é a função de chefia e representante da empresa, e o inferior, que são os estagiários em engenharia civil, principais responsáveis por levantamentos de campo e inspeção cotidiana de serviços.

A universalidade da subempreitada nos empreendimentos visitados é de tal ordem que, do ponto de vista marxista, ela pode ser considerada como relação de produção básica da construção habitacional no MCMV. Isto significa dizer que, no programa federal, a contradição entre capital e trabalho só pode ser

138 As fichas e o mapa de distribuição espacial dos empreendimentos (e sua discussão) aparecem no capítulo 8 desta pesquisa. 
entendida com a mediação destas micro e pequenas empresas de construção, todas elas não aderentes aos programas setoriais de qualidade e às correspondentes vantagens competitivas e de reserva de mercado. A extração de mais valor se transfere para uma relação entre empresas, em que uma apenas revende a força de trabalho que controla enquanto outra controla as condições financeiras em que esta força de trabalho pode ter uso produtivo.

As linhas gerais que permitem tratar a subempreitada como relação social de produção estão presentes no prefácio de "Para a crítica da economia política":

Na produção social da sua vida os homens entram em determinadas relações, necessárias, independentes da sua vontade, relações de produção que correspondem a uma determinada etapa de desenvolvimento das suas forças produtivas materiais (Marx, (1982 [1859]: 25).

Não é preciso perseguir a célebre consequência deste raciocínio, em que as relações de produção formam uma "base real" para a vida social e política (de modo que "não é a consciência dos homens que determina o seu ser, mas, inversamente, o seu ser social que determina a sua consciência"), basta verificar dois aspectos do trecho citado. O primeiro é o caráter necessário que deve assumir uma relação de produção, presente na subempreitada como uma relação na qual os homens entram "independentes da sua vontade". Nos empreendimentos do programa MCMV em São Paulo, a alternativa de uma empresa construtora executar a obra sem utilizar subempreiteiros é apenas imaginária: enquanto não houver pelo menos a pré-contratação das principais etapas da obra, o empreendimento não é sequer levado para aprovação junto à CEF. Do ponto de vista da força de trabalho, nenhum trabalhador vai ser utilizado na execução de obras nos empreendimentos do programa MCMV se não estiver empregado numa subempreiteira. $\mathrm{O}$ mínimo contingente de operários profissionais e ajudantes empregados pelas médias e grandes construtoras é utilizado apenas para serviços de manutenção e apoio no canteiro de obras [139].

O segundo aspecto, e que vai ser mais detalhado a seguir, é a adequação da relação de produção a novas "forças produtivas materiais". A subempreitada se tornou preponderante nos canteiros de obras quando se formou uma força de trabalho baseada na massa rural que migrou para as metrópoles brasileiras nos anos 1970 e 1980. Neste caso as forças produtivas já presentes na forma de máquinas e equipamentos foram descartadas para constituição da "subempreitada de mão de obra", que maximiza a exploração da força de trabalho abundante e destreinada através da burla a proteções trabalhistas.

Atualmente, a subempreitada observada nos canteiros de obras do programa MCMV na metrópole de São Paulo realiza serviços especializados, delimitados em contrato e executados por força de trabalho treinada e igualmente especializada. Como relação de produção, ela corresponde à diminuição do

139 Talvez a limitação do operário da construção assalariado das grandes empresas de construção habitacional explique esta inversão observada por Sérgio Pereira, Giancarlo de Filippi e Francisco Cardoso: "As micro e pequenas empresas são caracterizadas por serem um local de treinamento da força de trabalho inexperiente. Quando esta não consegue mais evoluir dentro da pequena empresa, procura uma grande empresa, onde possivelmente disporá de maiores oportunidades de crescimento. Ao analisar os subempreiteiros, verificou-se que isto não acontece. Muitas vezes ocorre até o contrário: quando o empregado sai de uma grande construtora, ele prefere trabalhar em uma subempreiteira, onde poderá ter melhores oportunidades" (Pereira; de Filippi; Cardoso, 2000: 9). 
contingente de trabalhadores e à ampliação no Brasil do mercado de locação de máquinas e equipamentos, além de fornecedores de componentes em que a comercialização inclui a instalação em obra. Nesta nova configuração de forças produtivas, não é possível dividir indiferentemente a execução de um serviço de construção entre força de trabalho subempreitada e não subempreitada (com o pressuposto que ambas são destreinadas) e, ao longo da década de 1990, a porcentagem de serviços subempreitados na construção habitacional começou a caminhar rapidamente para 100\% [140].

O sentido material da subempreitada de serviços especializados é diminuir o tempo que o capital permanece na etapa produtiva da construção civil, aproximando os momentos da "fórmula geral do capital" em que o capital é investido na produção de uma mercadoria (Dinheiro-Mercadoria) e outro posterior, em que a mercadoria é vendida e se torna mais capital (Mercadoria Mais Dinheiro). Apesar da edificação resultante ser um bem tão associado ao entesouramento de valor, a empresa construtora depende da rapidez da produção para competir em regime de concorrência de mercado num grau mais elevado que a empresa incorporadora, cujos ativos se valorizam muitas vezes por um controle de tempo oposto, de retardamento e espera.

Acelerar o tempo de retorno do capital ("turnover") é mais adequado em ambientes de concorrência do que a verticalização produtiva, isto é, o controle monopolístico de diversas fases da cadeia produtiva e de suas massas de valorização. David Harvey é um dos poucos intérpretes de Marx a observar que o controle sobre o tempo do trabalho mantém uma coerência interna com a própria ideia de acúmulo de capital:

How long should capital remain within production before testing its value in the sphere of exchange? Marx's answer to that question is: as short a time as possible, since capital is value only when it is in motion, i.e., in the act of being transformed from money into productive activity into commodities into money, and so on. There is a strong incentive, therefore, to accelerate the turnover of capital as much as possible. This militates against vertical integration of production, since the latter requires that capital remain for a longer period in production before entering the sphere of exchange. The splitting of a production process into many different phases and firms linked through market exchange appears to be highly desirable, since it diminishes the turnover time of capital. For this reason, even large corporations prefer to sub-contract a lot of production to small firms with shorter turnover times (Harvey, 2006 [1982]: 132)

Assim, o ponto mais sensível de qualquer contrato de subempreitada são os prazos para execução dos serviços. A interconexão entre tempo e dinheiro acontece explicitamente nas cláusulas que estipulam multas financeiras por atrasos em etapas de obra, que são um item de negociação intensa com

140 "Em entrevistas realizadas na presente pesquisa" diz Marta Farah se referindo à pesquisa que realizou no início da década de 1990, "observou-se uma tendência a uma participação mais elevada da subcontratação, chegando a mais de 80\%, em empresas com um perfil 'tradicional'" (Farah, 1996: 118). Daniel Ohnuma identifica um ponto de inflexão para a subcontratação total dos empreendimentos habitacionais no próprio ano de publicação de "Processo de trabalho na construção habitacional": "verifica-se que é expressiva a utilização, a partir de 1996, de 80\% a 100\% de mão-de-obra subempreitada para a execução dos serviços (...) Este movimento pela subcontratação ocorreu simultaneamente ao momento em que as empresas buscavam reduzir os seus custos de produção" (Ohnuma, 2003: 99). 
subempreiteiras especializadas. É raro se estipular multas em dinheiro por falta de qualidade de um serviço, pois esta multa aparece na forma de punição ao atraso que eventualmente decorrer de sua não-aprovação [141].

A estratégia de acumulação de capital que divide o orçamento de obra entre várias empresas ainda gera periodicamente manifestações contrárias no mercado da construção civil brasileira. Nestas manifestações, a opção pela verticalização das atividades produtivas retorna pela defesa de que a força de trabalho das subempreiteiras seja transferida para a empresa que as contrata:

Ao contratar um empreiteiro, estou pagando pelo serviço e pela margem de lucro com que ele trabalha. Ora, o lucro dele é o lucro que eu deixo de ter, porque o valor que receberei no final da obra é fixo! Então, é mais interessante ter minha própria mão de obra e meu corpo técnico (Leal, 2010: 21).

No entanto, nos depoimentos de administradores de obra obtidos durante esta pesquisa os poucos serviços realizados por mão-de-obra não subempreitada sempre aparecem como solução de contingência (a mais frequente sendo a absorção de mão-de-obra oriunda de uma quebra de contrato de subempreitada), não como estratégia de produção, hipótese tratada como impensável pela grande maioria de engenheiros de obra que abordaram o assunto [142].

De fato, a verticalização produtiva decai no ritmo em que aumenta a oferta de mercado para fornecimento de materiais semiacabados e componentes para construção habitacional, oferta que retira sentido econômico em produzir argamassa, lançar concreto ou cortar e dobrar armaduras com mão-de-obra agenciada no canteiro de obras. Substituir a força de trabalho especializada dos subempreiteiros, cujo treino e experiência permitem a execução rápida de uma etapa de obra e sua posterior desmobilização sem custo, por uma força de trabalho permanente é um contrassenso econômico de mesma ordem: neste caso, a formação da força de trabalho exigiria um treinamento oposto, de polivalência, para evitar a ociosidade na sucessão de etapas construtivas:

A subempreitada tende para a utilização de trabalhadores especializados. Logo a polivalência não parece ter lugar aqui. A propósito uma das grandes vantagens da subempreitada reside justamente no fato de se empregar mão-de-obra mais especializada, que consegue alcançar maior eficiência na execução dos serviços. A polivalência, por sua vez, parece ser mais adequada àqueles casos em que se opta por empregar mão-de-obra própria, uma vez que ela funciona como um instrumento de combate à rotatividade (Pereira, 2003: 111).

O autor da citação acima, Sérgio Rodovalho Pereira, realizou em conjunto com Daniel Ohnuma estudos de caso de subempreitada de obras em São Paulo entre

141 O sentido do contrato de "preço fechado" está em garantir antes o tempo de execução do que o seu valor, pois o preço fixo funciona de imediato como punição ao serviço excessivamente prolongado. Em alguns empreendimentos visitados havia bonificações não-financeiras para prazos cumpridos: transporte para estação de metrô, cesta de natal, sorteio de bens como eletrodomésticos. No entanto, sempre havia multas expressivas para prazos descumpridos.

142 Uma conversa com uma engenheira da Construtora e Incorporadora Faleiros foi esclarecedora neste ponto: "não sei se alguma construtora do MCMV está assumindo serviço com mão-de-obra própria. O que eu sei com certeza é que, neste serviço, ela está perdendo dinheiro". 
os anos 2000 e 2003, um período de aplicação ainda incipiente do sistema de gestão de qualidade do PBQP-H e pelo menos seis anos antes de sua expansão na habitação social pelo programa MCMV. Ainda assim, os resultados refletem a estratégia de retorno de capital bem implantada neste período [143].

O gráfico T-24 adapta tabelas presentes nas dissertações de mestrado de ambos os pesquisadores e distribui em três grupos as avaliações ponderadas de gestores de obras habitacionais a respeito da interferência causada pela subcontratação em aspectos dos empreendimentos que foram analisados como estudo de caso.

T-24| Interferências da subcontratação na construção habitacional

\begin{tabular}{l|l|l|l} 
Aspectos da subcontratação & \multicolumn{1}{c}{ Interferência da subempreitada } \\
\hline Produtividade & Positiva & Indiferente & Negativa \\
\hline Controle dos custos & & & \\
\hline Custo de produção & & & \\
\hline Manutenção de equipamentos e mão-de-obra & & & \\
\hline Desperdício de recursos físicos & & & \\
\hline Processo de inovação tecnológico & & & \\
\hline Domínio dos aspectos técnicos & & & \\
\hline Reclamações trabalhistas & & & \\
\hline Encargos sociais & & & \\
\hline Segurança do trabalho & & & \\
\hline Operacionalizar planejamento e programação & & & \\
\hline Controle do processo produtivo & & & \\
\hline Qualidade dos serviços & & & \\
\hline Cumprimento de prazos & & & \\
\hline Flexibilidade do volume de produção & & & \\
\hline Motivação dos operários & & & \\
\hline
\end{tabular}

Fonte: Adaptado de Ohnuma, 2003: 101 e Pereira, 2003: 152

As duas principais interferências que favorecem a decisão em subempreitar um empreendimento habitacional aparecem nas primeiras linhas da tabela T-24, que indicam efeitos positivos na produtividade dos serviços de execução de obra e no controle de seus custos. O benefício sobre a produtividade se dá na eficácia da força de trabalho, não se trata propriamente de uma diminuição de prazo na execução da obra (o que explica que, mais abaixo na tabela, a subempreitada seja considerada "indiferente" no que diz respeito ao "cumprimento de prazos"). Há, assim, manutenção de prazos definidos em contrato, mas com o menor uso e menor gestão de força de trabalho [144].

143 O pressuposto destas pesquisas é difícil de questionar: "os subempreiteiros participam cada vez mais das atividades de construção. Por consequência, o seu poder de influência na evolução da tecnologia aumentou. Em decorrência disto é anacrônico pensar na implantação de qualquer tecnologia construtiva sem que se leve em conta o papel a ser desempenhado por estes agentes" (Pereira, 2003: 76).

144 Grandes obras de infraestrutura, em que o processo construtivo admite alterações de projeto e escopo, estimulam empresas construtoras a antecipar a conclusão contratada de empreendimentos. Este 
A subempreitada favorece o controle dos custos simplesmente por fixar seus valores nos contratos de prestação de serviço, através de cláusulas de "preço fechado". Este preço é fixado por um jogo de força entre contratante e contratada que, longe de ser igualitário, tende a favorecer os capitais maiores.

Outros três efeitos positivos estão relacionados entre si para manter sob controle os custos de obra. A subempreitada diminui "custos de produção" (material e força de trabalho), que são convertidos no custo mínimo de gerenciar sua transferência para valores dos contratos de prestação de serviços. Ela diminui igualmente os serviços de "manutenção de equipamentos e mão-de-obra", pois máquinas, andaimes, instalações de apoio e boa parte dos custos de alimentação e alojamento são transferidos para outras empresas. Quanto à diminuição de "desperdício de recursos físicos", o maior deles não se mede pela redução de resíduos de obra mas sim pela diminuição da ociosidade de força de trabalho, uma mercadoria vital para o canteiro de obra.

Já a avaliação positiva da subempreitada sobre os aspectos de domínio e inovação de tecnologia construtiva é assim explicada por Daniel Ohnuma:

A prática da subcontratação aponta para evidências de se elevar a especialização dos serviços e isto facilita a implantação de novas tecnologias ou de tecnologias construtivas racionalizadas. O processo de inovação tecnológica deve estar condicionado à uma gestão eficiente da tecnologia e da mão-de-obra, ou seja, às atividades de planejamento/controle e de treinamento ou capacitação da mão-de-obra (Ohnuma, 203: 102).

A última avaliação positiva da subempreitada, quanto a "reclamações trabalhistas", é, por sua vez, de compreensão imediata, pois a imensa maioria dos trabalhadores em canteiro de obras são empregados unicamente das empresas subempreitadas. O único esforço que esta situação demanda da empresa que as contrata é conferir os registros referentes à legislação trabalhista, uma vez que ela tem responsabilidade subsidiária no pagamento de seus encargos [145].

Quanto às interferências da subempreitada que gestores de obras entrevistados por Daniel Ohnuma e Sérgio Pereira consideram ser "indiferentes", é possível dividi-las em dois grupos. O primeiro grupo diz respeito a obrigações legais derivadas da responsabilidade jurídica e financeira sobre o empreendimento e seu canteiro de obras. Desta forma, a presença de subempreiteiras não altera a obrigatoriedade de atender acordos sindicais, realizar os recolhimentos da legislação previdenciária (que devem constar, a partir da Lei Federal 9.711/98, na emissão de nota fiscal) e atender aos requisitos de segurança de trabalho exigidas pela NR 18 do Ministério do Trabalho e Emprego.

estímulo é notório nas obras de geração de energia no Brasil, em que consórcios constroem a infraestrutura e posteriormente vendem a energia que ela produz. Vantagens desta ordem não existem na construção habitacional e o objetivo principal de seu planejamento se limita a evitar o atraso.

145 A responsabilidade subsidiária pelo pagamento de encargos trabalhistas decorre do Art. 455 da CLT: "Nos contratos de subempreitada responderá o subempreiteiro pelas obrigações derivadas do contrato de trabalho que celebrar, cabendo, todavia, aos empregados, o direito de reclamação contra o empreiteiro principal pelo inadimplemento daquelas obrigações por parte do primeiro". Interpretações jurídicas recentes levam à responsabilidade solidária, que é reconhecida mesmo quando a empresa subempreitada não é questionada na Justiça do Trabalho. 
Um segundo grupo de aspectos em que o efeito da subempreitada é considerado indiferente são as atividades de "planejamento e programação", "controle do processo produtivo" e de "qualidade de serviços", atividades que não são terceirizadas justamente por se converterem no cerne da estratégia comercial da empresa construtora e, como tal, principais instrumentos de controle sobre as empresas subempreitadas, como será detalhado adiante.

As interferências da subempreitada consideradas "negativas" estão ligadas à falta de vinculação direta entre força de trabalho e gerenciamento central do canteiro de obras. Este distanciamento eleva custos de treinamento, que precisam se repetir a cada nova contratação de subempreitada, e aparta os trabalhadores das políticas de bônus e prêmios de produtividade, ações de motivação que praticamente não existem nas pequenas empresas subempreitadas. Do ponto de vista das médias e grandes empresas que contratam serviços subempreitados, flexibilizar a programação ou escopo de serviços é uma tarefa impossível de ser realizada com agilidade, pois passam a lidar com uma força de trabalho sobre a qual perderam comando direto.

Este quadro de interferências da subempreitada é igualmente válido para a forma dominante de subempreitada nos empreendimentos do programa MCMV, que a terminologia da construção civil chama de "subempreitada global". Nela, todos os serviços medidos e remunerados pela CEF, das fundações à cobertura e paisagismo são executados por subempreiteiras sob especificações de projeto definidas em contrato, o que inclui responsabilidades específica sobre qualidade, segurança de trabalho e, eventualmente, fornecimento de materiais, projeto de produção e responsabilidade técnica. A empresa responsável pelo financiamento junto ao programa federal e contratante da subempreitada global assume tarefas de planejamento e gerenciamento, cuja remuneração decorre não apenas da verba de bonificação, mas da diferença que criar entre o valor do repasse recebido pela CEF e o valor de contratação do serviço especializado.

Esta forma de subempreitada predominante no programa MCMV não é a mesma, portanto, da que predominava no Brasil até o fim do século passado, em que uma "subempreiteira de mão-de-obra" alocava trabalhadores no canteiro de obras do começo ao fim do empreendimento e em diferentes frentes de obras, uma vez que elas não requeriam especialização. É uma organização do canteiro de obras que depende primordialmente de oferta abundante de trabalhadores e que Luiz Ceotto descreve da seguinte forma:

As empresas "empreiteiras de serviços" eram na verdade "empreiteiros de mão-de-obra", deixando a tecnologia de produção, a definição do processo de trabalho e o gerenciamento dos serviços sob responsabilidade da construtora contratante. As equipes administrativas das contratantes comandavam o pessoal das empreiteiras e esses por sua vez, faziam exatamente aquilo que lhes eram mandado fazer. As "empreiteiras de serviço" praticamente locavam sua mão de obra, colocando-a sob comando da empresa contratante sem interferir muito no processo de trabalho ou no planejamento da execução dos serviços. Este tipo de organização era de certo modo reflexo da tecnologia construtiva disponível, onde a não especialização dos operários, exceto nos serviços de instalações prediais, era característica da mão-de-obra necessária, uma vez que a tecnologia construtora disponível era muito mais dependente do uso intensivo da mão-de-obra do que da sua especialização (Ceotto, 2005: 98). 
Para Luiz Ceotto, o que conduziu a construção civil brasileira para a subempreitada global foi a formação de um mercado fornecedor de serviços de construção externos ao canteiro de obras (a "industrialização sutil" discutida no capítulo 6) e o primeiro polo da relação de produção que este mercado transformou não foi o da empresa subempreitada, mas sim o da empresa que a contrata: ela se torna gestora de serviços em que projeto e produção estão integrados na execução.

Os componentes sendo fabricados por empresas do mercado, os equipamentos de transporte e de içamento facilmente alugados por períodos definidos, a montagem dos componentes feita por equipes terceirizadas qualificadas faz com que o único investimento que uma construtoras precise realmente fazer é no domínio dos processos gerenciais por parte de suas equipes tecno-administrativas (...) As construtoras seriam muito mais gerenciadoras e integradoras de sistemas construtivos do que "fazedoras" de obras. Seriam muito mais "cérebro" do que "braço". Poderiam ter poucos profissionais, pois grande parte dos serviços poderia ser terceirizada. Seriam especializados em integração de sistemas, em projeto, em planejamento, na aplicação e gerenciamento de sistemas de qualidade e na administração de contratos (Ceotto, 2005: 97-100).

Uma empresa que é "mais cérebro do que braço" ilustra bem um paradigma estabelecido por Fernando Sabbatini no campo da Gestão da Produção, o da empresa construtora como "integradora de sistemas complexos".

Acreditamos que a vocação das empresas construtoras seja a de integradora de sistemas complexos. Neste contexto, idealmente, a construtora irá produzir edifícios integrando os seus diversos subsistemas (estruturas, vedações, instalações etc.) através de projeto e planejamento sistêmicos e de processos de gestão e controle específicos no canteiro. A construtora seria uma compradora de subsistemas projetados por ela, mas construídos ou montados no seu canteiro por parceiros especialistas na produção dos mesmos. Na terminologia específica compraria subempreitadas globais (Sabbatini, 1998: 7).

É uma concepção que reflete condições das cadeias fornecedoras de materiais e serviços para a construção civil, mas que também se insere entre as teorias de gestão estratégica de empresas, baseadas na noção de "core-business", que não é apenas uma redução de atividades produtivas, mas sim sua concentração baseada numa análise de competição de mercado, no correto sentido empresarial de "desverticalização" [146].

Ainda assim, a concepção empresarial de Sabbatini se refere a uma situação ideal, que ele opõe contra a realidade brasileira que separa a subempreitada de todo um empreendimento da subempreitada propriamente global.

Muitas construtoras pensam estar agindo como integradoras, subempreitando praticamente todos os serviços pertinentes ao produto edifício (...) Ocorre que estas construtoras não dispõem de nenhum dos pré-requisitos necessários para atuar com integradora de forma eficaz: projetos e planejamentos sistêmicos; organização de produção adequada, sistemas de controle eficientes etc. (Sabbatini 1998: 7).

146 O sentido de estratégia de mercado é mais definido na noção de "core-competence", divulgada nos anos 1990 por Gary Hamel e Coimbetore Prahalad, para quem "any company that wants to capture a disproportionate share of profits from tomorrow's markets must build the competencies that will make a disproportionate contribution to future costumer value" (Hamel; Prahalad, 1994: 217). 
De qualquer forma, o sujeito da transformação das empresas subempreiteiras no Brasil é a empresa que contrata a subempreitada. A direção que esta toma nas condições atuais de mercado busca o ideal da integração de "subsistemas construtivos complexos", que exige não apenas força de trabalho especializada e treinada como também sua combinação com equipamentos e projetos de produção. O caminho que leva a este ideal é o sistema de gestão de qualidade.

\title{
O treinamento e a Ficha de Verificação de Serviços
}

Os estudos que tratam da subempreiteira no Brasil abordam de vários ângulos a sua dependência técnica e comercial em relação às empresas contratantes, que decorre da sua própria condição micro ou pequena empresa de construção inserida num ambiente de mercado fragmentado, em que precisa competir com todas suas congêneres de forma desorganizada e desprotegida:

\begin{abstract}
Estas empresas não têm uma representação forte junto às instâncias de poder, na medida em que não são filiadas a nenhum sindicato, grupo financeiro ou cooperativa. Seus interesses, portanto, não são defendidos de maneira adequada (...) Apesar de uma evolução nas estruturas dos subempreiteiros, estes ainda se encontram subordinados às construtoras, principalmente pelas condições impostas pelo mercado atual (Pereira, De Filippi; Cardoso, 2000: 9).
\end{abstract}

O vasto predomínio numérico das subempreiteiras no mercado brasileiro se converte assim em sua maior fraqueza. Ainda que a demanda por subempreitar seja crescente, ela é sempre satisfeita por uma oferta incessante e principalmente desarticulada de serviços subempreitados. A venda de seus serviços, portanto, é regulada por uma população excedente de pessoas jurídicas, que comprime os preços da subempreitada à semelhança de um exército industrial de reserva:

Os subempreiteiros, que usualmente não dispõem de poder representativo no momento das negociações, são obrigados a se submeter às condições impostas pelas construtoras, ainda que desvantajosas, a fim de garantirem a sua sobrevivência. Este baixo poder de negociação decorre da grande concorrência a que está submetida a maior parte dos subempreiteiros - o número de construtoras é relativamente pequeno quando comparado ao número de subempreiteiros encontrados no mercado -, do baixo nível tecnológico e até mesmo do visível despreparo comercial detido por estes empresários (Pereira, 2003: 57).

Não é incomum nas grandes metrópoles brasileiras que a própria criação da subempreiteira decorra da imposição de uma grande empresa construtora, que desverticaliza suas atividades coagindo ex-encarregados ou profissionais instaladores a abrirem uma pessoa jurídica apenas para executar uma encomenda específica. Após impor esta iniciativa de empreendedorismo, a grande construtora pode fidelizar esta subempreiteira com novas encomendas a baixo preço ou abandoná-la no mercado de serviços de construção [147].

147 Esta era uma prática da empresa construtora Dib Arquitetura e Incorporadora Ltda, antes de abandonar dois empreendimentos no programa MCMV na cidade de Guarulhos. Um de seus diretores declarou para esta pesquisa que procurava manter as subempreiteiras como "empresas sem maiores anseios", pois assim "elas não vão bater asas". 
O quadro final é equivalente a uma proletarização da subempreiteira, como se ela apenas reproduzisse no plano empresarial a prévia condição social de seus fundadores, em geral profissionais da construção formados em canteiro de obras. Esta estreita ligação com o mundo do trabalho acaba organizando a subempreiteira conforme os mesmos vínculos de dominação pessoal formados no canteiro de obras entre encarregado, profissional e ajudante, muitas vezes reforçados por uma proximidade de comunidade e parentesco. Foi o que observou Luciana Brandli em pesquisas que realizou em Florianópolis:

As subempreiteiras têm origem em uma ou duas pessoas, geralmente iniciadas na construção civil como operários (serventes, pedreiros, carpinteiros), que tiveram uma carreira de ascensão dentro dos mais variados ofícios da obra (...) Aparece muito a ligação parental nestas organizações: empresas subcontratantes que se originaram da união de irmãos, cunhados e primos. A maioria deles não tem o primeiro grau completo, aprenderam tudo que sabem no dia-a-dia (Brandli; Jügles; Heineck, 1998: 4).

Sérgio Pereira chega a questionar a posição da subempreitada em relação ao acúmulo de capital, uma vez que se comportam como uma organização voltada apenas para obtenção de renda para proprietário e funcionários.

Como a grande parte das micro e pequenas empresas no Brasil, os subempreiteiros da construção civil são empresas que surgiram para acúmulo de capital, mas que representam na verdade instrumentos de sobrevivência, tanto para seus proprietários, quanto para seus funcionários (Pereira; De Filippi; Cardoso, 2000).

O que impede a ascensão econômica de uma subempreiteira de fato é semelhante às barreiras que impedem o trabalho de se apropriar de meios de produção: a baixa remuneração dos contratos não permite que as empresas adquiram tecnologia ou capacidade gerencial. A guerra de preços entre subempreiteiras, cuja condição limítrofe é a ampla oferta, é descrita da seguinte forma por um consultor de produtividade na construção civil:

Para as construtoras [contratantes], a produtividade não é tão importante. Elas se preocupam mais em forçar preços baixos no momento do fechamento do contrato com os subempreiteiros. Se houver a necessidade de acelerar a obra, contrata-se mais um subempreiteiro. Muitas vezes o subempreiteiro quebra. Então contrata-se outro (apud Pereira, 2003: 61).

A disputa entre subempreiteiras regida apenas por preço de serviços embute, por fim, um risco que é o mesmo do pagamento "por tarefa", tão comum na construção habitacional: com o serviço, os contratos transferem também os riscos de retrabalhos, atrasos e estimativas erradas de produção e produtividade [148].

Este era o quadro geral da relação de produção da subempreitada que a literatura de Gestão de Produção levanta no Brasil antes da implantação do programa MCMV. A observação dos empreendimentos na região metropolitana de São Paulo indica uma alteração deste quadro que é mais acentuada quanto mais

148 Estes riscos assumem escalas maiores quando grandes incorporadoras repassam o comando de um empreendimento a uma pequena construtora local sob contratos de "preço máximo garantido": "as empresas nacionais, ao priorizar o "preço máximo garantido" em suas parcerias com as construtoras locais, acreditavam que esse mecanismo garantiria o custo e a qualidade do produto imobiliário que deveriam entregar ao mercado, o que de fato não aconteceu, porque elas realmente nunca foram parceiras efetivas de seus subordinados regionais" (Feller, 2013: 17). 
consolidado é o sistema de gestão de qualidade das empresas construtoras que atuam no programa federal. Qualidade produtiva se torna custo e, portanto, um novo critério de contratação de subempreitada para além de preço e prazo de execução de obra. Como os requisitos de qualidade só podem ser cumpridos quando a empresa submete seus serviços à tecnologia organizacional e gerencial embutida no programa PBQP-H, se estabelece de imediato uma continuidade entre a gestão da média e grande empresa construtora atuante no programa MCMV com a de micro e pequenas empresas subempreitadas.

A comparação com a relação assalariada pode avançar: assim como as atuais políticas de "enriquecimento de cargos" só fazem sentido quando aumentam o desempenho dos empregados (que neste processo passam a ser denominados colaboradores), a introdução de critérios de qualidade na remuneração das subempreiteiras só acontece quando elevam o controle sobre a sua produção (e daí as subempreiteiras passam a ser denominadas "parceiras"). Como previsto por Ubiraci de Souza, pelo menos parte do ganho de produtividade subsequente pode ser temporariamente apropriada pelas subempreiteiras.

\begin{abstract}
Alguns construtores já perceberam que o modelo de simples pressão sobre os preços não é mais exequível. Como em vários desses casos se pretende manter a política de subcontratação, a postura relativa à produtividade tem sido a de monitorá-la, para entendê-la melhor e para tomar decisões em conjunto com o subempreiteiro, para melhorar sua atuação e fazê-lo aumentar seus lucros, na expectativa de que tal melhoria possa, agora sim, ter retorno futuro em termos de redução de preços (Souza, 2006: 54).
\end{abstract}

O alinhamento produtivo pelos critérios de qualidade e controle de operações do PBQP-H insere a subempreitada numa cadeia de relações comerciais centrada nas médias e grandes empresas construtoras. Contratante e contratada passam a fazer parte do que a Logística e a Engenharia de Produção denominam "Cadeia de Suprimentos Integrada", que são "series of integrated enterprises that must share information and coordinate physical execution to ensure a smooth, integrated flow of goods, services, information and cash" (Coyle; Bardi; Langley, 2003: 18). A própria relação social de produção da subempreitada pode se alterar neste fluxo integrado de interesses, pois a contradição entre capital e trabalho deixa de ser mediada pelo subempreiteiro que, no canteiro de obras, além de patrão era também parente e companheiro de trabalho (de "cum panis", que divide o pão). A contradição se torna ao mesmo tempo mais direta e mais abstrata, pois, à medida que o trabalho se fragmenta em especializações coordenadas pelo mercado, o capital se funde em cadeias de suprimentos que só podem ser apreendidas contra uma intrincada rede de fornecedores e distribuidores [149].

A confirmação desta tendência no programa MCMV está substituindo uma massa depauperada de fornecedores de serviços genéricos de execução de obras por subempreiteiras especializadas, capazes de vender serviços para empresas maiores e "integradoras de subsistemas complexos". Há dez anos atrás, os estudos de caso realizados por Sérgio Pereira indicavam que as subempreiteiras especializadas "dispõem de melhores argumentos no momento das negociações", mas

149 Martin Christofer, um dos principais teóricos da Logística, descobriu mais de um século depois de Marx que "real competition is not company against company but rather supply chain against supply chain" (Christopher, 1998: 18). 
que "ainda nesses casos é comum que a construtora continue sendo o agente mais forte, fixando exigências desvantajosas para os subempreiteiros". A continuidade de seu raciocínio, no entanto, aponta os sistemas de gestão de qualidade como fator capaz de modificar a submissão da subempreitada:

Esta é uma realidade que tende a se modificar. Com o estabelecimento de sistemas de gestão da qualidade, passou-se a exigir dos fornecedores níveis elevados de excelência. Frente à nova prática é provável que os subempreiteiros que apresentarem maior qualidade e controle sobre os seus processos, mesmo atuando em atividades mais básicas, passem a deter algum poder nas negociações (Pereira, 2003: 58).

De fato, um aumento de poder de negociação dos subempreiteiros foi relatado diversas vezes durante esta pesquisa, tanto por encarregados das equipes subempreitadas quanto por engenheiros residentes. No entanto, o maior poder que a especialização confere às subempreiteiras significa também a aceitação do controle pelos sistemas de gestão de qualidade. No Sistema de Avaliação da Conformidade de Empresas de Serviços e Obras da Construção Civil (SiAC), a subempreitada global é explicitamente tratada no Art. $14^{\circ}$ do regimento específico para execução de obras:

A empresa construtora que pede a certificação somente pode ser certificada com base em auditoria numa obra onde pratique a subempreitada global de obra desde que nela tenha implantado o seu sistema de gestão da qualidade e que disponha de equipe técnica própria presente na obra, contando obrigatoriamente com um engenheiro, arquiteto ou tecnólogo de nível superior, que assegure o correto funcionamento de tal sistema, e independente da disponibilizada pela empresa à qual subempreitada a obra.

Os requisitos do SiAC mantêm a obrigação de submeter os serviços subempreitados a procedimentos documentados de inspeção da conformidade com padrões de qualidade. O subitem 7.5.1 do referencial normativo do PBQP-H exige das empresas construtoras tanto no "Nível B" quanto no "Nível A" que elas exerçam "controle de operações" de construção, com duas importantes ressalvas para "quando a empresa construtora optar por adquirir externamente algum serviço controlado" (subitem 7.5.1.1). A primeira ressalva é que a empresa construtora com certificação PBQP-H deve "definir o procedimento documentado de realização do processo, garantir que o fornecedor o implemente e assegurar o controle de inspeção desse processo". A segunda ressalva para serviços subempreitados é que a empresa contratante promova "qualificação do pessoal que realiza o serviço".

O requerimento de "qualificação do pessoal que realiza o serviço" traz para dentro do canteiro de obras parte do monopólio sobre a formação do trabalho conquistado pelo capital, monopólio discutido no capítulo 3 desta pesquisa. Em geral esta qualificação toma a forma de um curso expositivo e prático, que raramente excede 5 horas (o que permite organizá-lo em 1 hora por dia útil ou meio período no sábado). O conteúdo é inteiramente voltado para as especificações técnicas determinadas pela empresa construtora contratante dos serviços e que são documentadas como parte de sua política de qualidade. Os elementos desta documentação são as conhecidas fichas de "procedimentos de execução de serviço" - PES (algumas vezes reunidos em "manuais de procedimentos") e se tornam referência básica dos cursos e das inspeções subsequentes, uma vez que contém para cada serviço especializado a relação de materiais, ferramentas, projeto e método executivo. É um conjunto que exerce 
sobre os serviços da subempreiteira o controle da formação da força de trabalho que acontece apenas de forma fragmentada por programas setoriais do Sinduscon/SP e entidades de classe, como Sesi (cf. Oliveira, 2008).

\section{I-14| Imagens de treinamentos pelo programa PBQP-H}
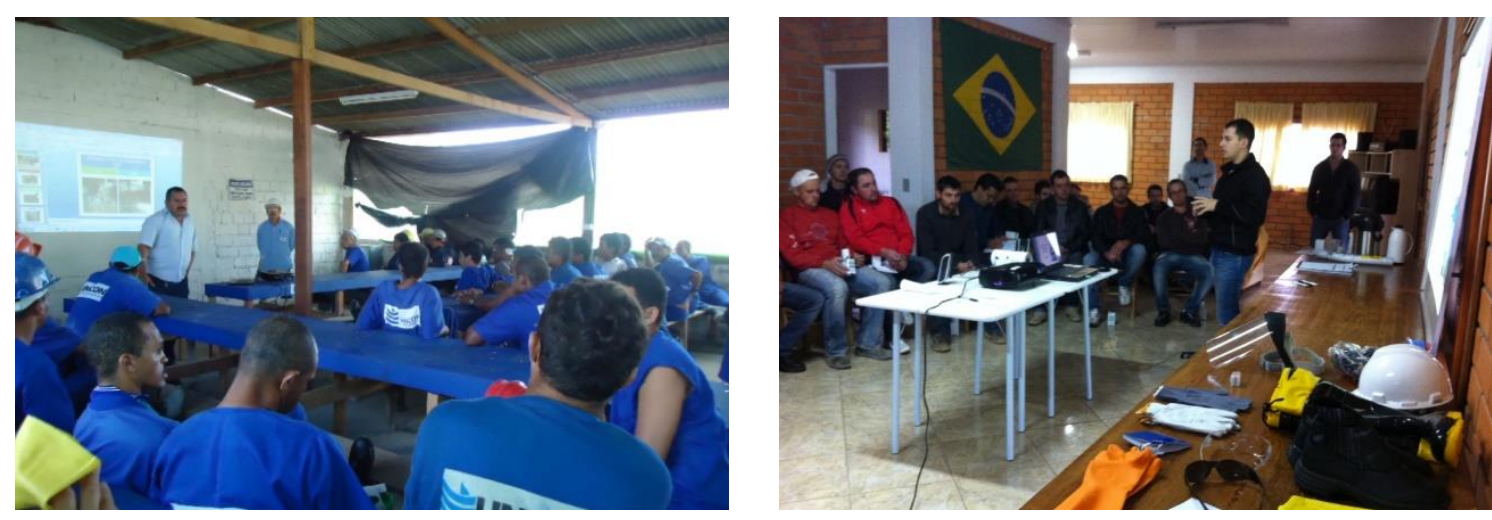

Fonte: MCidades

A inclusão da qualificação como parte dos requerimentos do PBQP-H torna o treinamento uma atividade do contratante do serviço empreitado que será auditada para obtenção de certificação de qualidade. Esta imposição, no entanto, não resolve um impasse frequente: a força de trabalho treinada está vinculada à empresa subempreiteira e pode ser empregada por concorrentes [150]. Com exceção das subempreiteiras especializadas em instalações prediais, o interesse do treinamento por parte do subempreiteiro é baixo, pois é voltado para a política de qualidade de uma empresa com quem tem uma relação contratual temporária. A conexão entre treinamento e certificação igualmente estimula o cumprimento de uma programação formal, suficiente apenas para satisfazer as auditorias de terceira parte com ementas arquivadas e listas de presença assinadas [151].

A suspeita de formalismo não existe para a segunda ressalva do PBQP-H para serviços subempreitados, que é a exigência de "procedimento documentado" do "controle de inspeção". Entre as construtoras certificadas, este procedimento se tornou conhecido como Ficha de Verificação de Serviço - FVS. Como documento de inspeção, a FVS cumpre na ponta final dos serviços de execução de obra a organização de registros e documentos que é primeira exigência de todo sistema de qualidade. Sobre esta exigência formal, ela acumula outra função, esta bem material, de servir como guia de aceitação e aprovação de serviço subempreitado. Assim, para a subempreiteira é impossível separar o atendimento do controle de qualidade da remuneração de seu contrato.

Do ponto de vista da empresa contratante de serviços subempreitados, uma FVS pode ser adaptada a qualquer variação produtiva. Num serviço complexo como

150 É o que Frederick Taylor lamenta no prefácio de "The principles of scientific management": "what we are all looking for, however, is the ready-made, competent man; the man whom some one else has trained".

151 "Nos casos em que as construtoras ofereçam treinamento, por exigência dos seus sistemas de gestão da qualidade, a verdadeira preocupação deve residir em transmitir conhecimentos à mão-de-obra. As subempreiteiras reclamam que muitas vezes têm a impressão de que o foco está no registro do treinamento e não na real capacitação da mãode-obra. Pior do que isso, denunciam, é aquela situação em que o treinamento é registrado sem ser ministrado" (Pereira; Cardoso, 2004: 14). 
o de argamassa de revestimento, é possível prever inspeções de condições de início e fim de trabalho, isto é, da cura do chapisco e posição de andaimes até a limpeza do contrapiso e máquinas. Sobre o serviço realizado, é possível combinar critérios objetivos e mensuráveis, ligados ao projeto de produção da argamassa de revestimento (como espessura e planicidade), com critérios subjetivos mas explícitos, que tratam de manchas e acabamentos [152].

A abrangência e precisão da FVS, no entanto, não deve servir apenas à inspeção, mas sim ao conjunto do sistema de gestão de qualidade. Seu preenchimento, geralmente por estagiários de engenharia civil, segue uma cadeia de responsabilidades que estabelece rotinas e tolerâncias, identifica medidas de correção de não conformidades e retroalimenta os procedimentos de prevenção. Neste sentido, a FVS é tanto o último como o primeiro documento dos ciclos de planejamento, execução, checagem e ajuste de qualidade, o que separa este controle sistemático de uma inspeção tradicional da qualidade. Flávio Picchi faz esta comparação, que aparece com adaptações na tabela T-25:

T-25|Comparação entre controles de qualidade

\begin{tabular}{|c|c|c|}
\hline Aspecto comparado & Inspeção tradicional & Sistema de gestão de qualidade \\
\hline Forma de realização & $\begin{array}{l}\text { Acompanhamento } \\
\text { informal dos serviços }\end{array}$ & $\begin{array}{l}\text { Controle sistematizado, realizado segundo } \\
\text { fichas de verificação, procedimentos e planos } \\
\text { de controle de qualidade }\end{array}$ \\
\hline $\begin{array}{l}\text { Pessoas envolvidas na } \\
\text { avaliação }\end{array}$ & $\begin{array}{l}\text { Mestre de obras e } \\
\text { encarregados }\end{array}$ & $\begin{array}{l}\text { Definidos nos procedimentos, segundo } \\
\text { combinações de inspetores, mestres, } \\
\text { encarregados ou autocontrole dos oficiais }\end{array}$ \\
\hline $\begin{array}{l}\text { Procedimentos de } \\
\text { avaliação }\end{array}$ & Critérios pessoais & $\begin{array}{l}\text { Padronizados e descritos em procedimento de } \\
\text { controle de qualidade }\end{array}$ \\
\hline $\begin{array}{l}\text { Padrões para avaliação } \\
\text { e critérios de aceitação }\end{array}$ & Subjetivos e pessoais & $\begin{array}{l}\text { Objetivos, avaliam características prioritárias e } \\
\text { conforme padrões estabelecidos em normas, } \\
\text { com critérios de aceitação e rejeição claros, } \\
\text { indicando tolerâncias admitidas }\end{array}$ \\
\hline $\begin{array}{l}\text { Momento de realização } \\
\text { e serviços abrangidos }\end{array}$ & $\begin{array}{l}\text { Assistemático, muda de } \\
\text { intensidade conforme } \\
\text { disponibilidade }\end{array}$ & $\begin{array}{l}\text { Sistemático e com rotina pré-estabelecida, } \\
\text { realizado em momentos e sobre serviços } \\
\text { definidos no plano de controle de qualidade }\end{array}$ \\
\hline Papel da gerência & $\begin{array}{l}\text { Dependência total da } \\
\text { competência profissional } \\
\text { e do grau de exigência da } \\
\text { equipe administrativa }\end{array}$ & $\begin{array}{l}\text { Adota controles que garantem a } \\
\text { homogeneidade e previsibilidade de } \\
\text { resultados, reduzindo riscos e desperdícios } \\
\text { dentro de metas e parâmetros da empresa. }\end{array}$ \\
\hline $\begin{array}{l}\text { Reação inicial de } \\
\text { engenheiros e mestres }\end{array}$ & $\begin{array}{l}\text { Aceitação: “construção é } \\
\text { assim mesmo" }\end{array}$ & $\begin{array}{l}\text { Rejeição: "conheço meu trabalho e não preciso } \\
\text { de burocracia ou papelada" [153] }\end{array}$ \\
\hline
\end{tabular}

Fonte: adaptado de Picchi, 1993: 387

152 Observação de uma pesquisa sobre argamassa de revestimento externo: "o controle do serviço foi feito com o auxílio de Fichas de Verificação de Serviço (FVS), sendo verificado o serviço executado diariamente pelo inspetor de qualidade. Nessas fichas foram anotadas eventuais falhas existentes no serviço, com falta de planicidade, falta de prumo etc. Note que as FVSs são importantes ferramentas para controle da qualidade e aceitação de serviço executado por um subempreiteiro" (Shimizu; Barros; Cardoso, 2002: 8).

153 "A engenharia considera que um controle formalizado por uma documentação adequada gera 'burocracia e mais papéis na obra' e, por isso, descartam-no. O problema maior de se ter o controle informal é que as pessoas que os 
Como documento que ao mesmo tempo sustenta uma política de qualidade e remunera o serviço treinado e especializado de subempreitada, a FVS dá uma eficácia à gestão de qualidade que, num canteiro de obras, tende a ser travada pela variabilidade intrínseca do empreendimento de construção. Seu preenchimento diário e constante tem, portanto, esta capacidade de reforçar referenciais normativos tanto nas equipes de engenharia quanto na força de trabalho que elas controlam. Como percebe Sérgio Pereira, o sistema de gestão de qualidade só se torna efetivo para a média e grande empresa de construção quando é efetivo para a micro e pequena empresa subempreiteira.

Uma das exigências dos sistemas de gestão da qualidade com vistas à certificação é a elaboração de procedimentos padronizados dos mais variados processos (produtivos, administrativos, operacionais etc.) desenvolvidos dentro das empresas. A propósito, este inegavelmente é um dos segredos para o alcance de sucesso na implantação dos programas de qualidade nas construtoras - além de registrar a tecnologia e torná-la parte do patrimônio da empresa, esta prática permite que se transmita aos subempreiteiros, de modo claro, as exigências a serem atendidas (Pereira, 2003: 97).

\section{I-15|Inspeção de serviços subempreitados pela construtora Hudson}
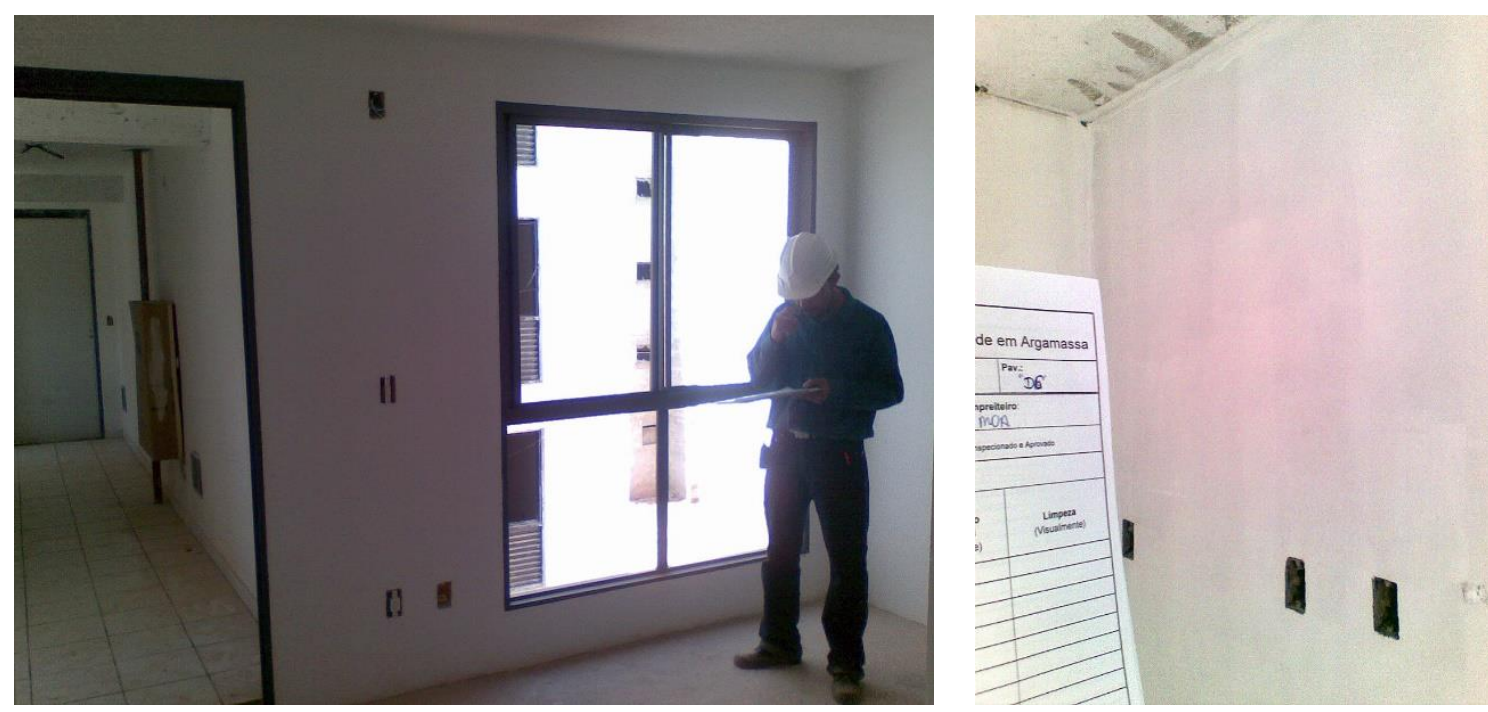

À esquerda, estagiário de engenharia preenchendo FVS de instalações elétricas; à direta, FVS fixada na porta de um apartamento apontando correções para subempreiteira de argamassa de revestimento.

O capítulo anterior mostrou a complexidade dos sistemas de gestão de qualidade, presente tanto em seus requerimentos atuais quanto na evolução histórica de instituições de governo e mercado criadas para implantá-las tanto em indústrias de todo o mundo quanto na construção civil brasileira. A FVS é o ponto de ligação desta complexidade com a organização do canteiro de obras por subempreitada global, de onde emergem após o estabelecimento de requisitos e para onde retornam gerando não só ordens de pagamento como também planilhas de correções e prevenções que realimentam a atividade eternamente cíclica da produção de mercadorias. Estas fichas, que no fim do dia se espalham pelos canteiros de obras nas mãos principalmente de estagiários de engenharia civil, impõem uma submissão às subempreiteiras (e da força de trabalho que ela

praticam não são devidamente capacitadas e treinadas a exercer essa atividade, de grande importância para o processo de racionalização. Por isso, é necessário que a empresa invista nesse processo de capacitação, estabelecendo o quê e como controlar, ou seja, que defina uma metodologia de controle" (Barros, 1998: 45). 
controla) que é impossível de ser obtida pelo aviltamento da remuneração. É a submissão ao controle de qualidade.

A gestão de qualidade que era coerção de governo no programa MCMV se torna finalmente coerção de mercado entre as subempreiteiras.

\section{Concentração de capital}

Uma constante no discurso público de economistas é considerar a concentração de capitais como um fenômeno socialmente positivo, seja por elevar a contradição com outras forças sociais, seja por promover uma maior competitividade nas disputas por mercados nacionais e internacionais, com o consequente aumento de quantidade e qualidade da produção industrial.

Para Marx, a concentração de capital é um fenômeno de aglutinação ligado à própria acumulação, uma desigualdade intrínseca às operações de mercado e que não pode ser controlada na sua expansão mundial. Ele faz uma distinção pouco usada na economia, entre concentração e centralização de capital, em que a última é um acirramento histórico da primeira, pois "é concentração de capitais já constituídos, supressão [Aufhebung] de sua independência individual, expropriação de capitalista por capitalista" (Marx, 2013 [1867]: 701). O que causa este acirramento é a formação de um mercado de crédito, que permite que o crescimento de capitais individuais perca a proporção com o movimento de acumulação produtiva. Com a disposição de financiamento, grandes concentrações de capitais podem surgir em momentos de pequena expansão ou até mesmo de retração econômica, como comprovam diversas fusões e aquisições preferenciais em bolsas de valores.

No fundo, a passagem da concentração para a centralização acontece quando a desigualdade entre capitais ganha dinâmica própria, como acontece com a concentração de renda. Em comum entre ambas está a máxima de que "os capitais maiores derrotam os menores", que Marx explica da seguinte forma:

Com o desenvolvimento do modo de produção capitalista, cresce o volume mínimo de capital individual requerido para conduzir um negócio sob condições normais. Os capitais menores buscam, por isso, as esferas da produção das quais a grande indústria apoderou apenas esporádica ou incompletamente. A concorrência aflora ali na proporção direta da quantidade e na proporção inversa do tamanho dos capitais rivais. Ela termina sempre com a ruina de muitos capitalistas menores, cujos capitais em parte passam às mãos do vencedor, em parte se perdem (...) A centralização complementa a obra da acumulação, colocando os capitalistas industriais em condições de ampliar a escala de suas operações (...) A extensão aumentada de estabelecimentos industriais constitui ponto de partida para uma organização mais abrangente do trabalho coletivo, para um desenvolvimento mais amplo de suas forças motrizes materiais, isto é, para a transformação progressiva de processos de produção isolados e fixados pelo costume em processos de produção socialmente combinados e cientificamente ordenados (Marx, 2013 [1867]: 702-3).

Marx estava pensando na grande fábrica, em que um sistema de máquinas passa a unir sob uma única racionalidade trabalhos parciais. $\mathrm{Na}$ construção habitacional do Brasil de hoje, o capital acumulado na construção habitacional cria cadeias de suprimentos, em que micro e pequenas empresas fornecedoras de 
serviços estão integradas sob a mesma racionalidade e estratégia competitiva das empresas construtoras que planejam e integram subsistemas construtivos. $\mathrm{O}$ capital se concentra, portanto, pelo controle sobre subempreiteiras e sobre as pequenas empresas fornecedoras de insumos e componentes que, juntas, formam a camada de "industrialização sutil" que se apoia sobre a camada (inamovível para as grandes construtoras) dos conglomerados fabricantes de materiais de construção básicos mineral-metálicos. Os capitais pequenos continuam a competir entre si "na proporção inversa do tamanho dos capitais rivais", mas a especialização crescente reforça cada vez mais sua dependência econômica dos capitais concentrados nas empresas "integradoras de sistemas construtivos" [154].

David Harvey faz uma aproximação entre o impulso para a fragmentação da produção e o crescimento da composição orgânica do capital, pela qual o capital fixo associado a insumos e equipamentos predomina sobre o capital variável, associado à força de trabalho. É um impulso em direção a formas mais avançadas de produção, mas que ocorre buscando controlar forças de mercado que são, em si mesmo, incontroláveis por empresas isoladas.

The boundary between the realm of control and the anarchy of the market is set by the size of enterprise (...) To this is opposed the requirement to accelerate the turnover time of capital by fragmenting activity, subcontracting and generating a proliferation in the division of labour. This serves to increase the value composition of capital at the same time as its extends the arena of chaotic and anarchistic exchange relationships at the expense of regulated and controlled production. Between these two forces we can begin to spot the requirement for some equilibrium in organization of production that fixes the degree of vertical integration, size of firm etc. It fixes the boundary between the market and the (relatively) controlled environment within the enterprise (Harvey, 2006 [1982]: 132-6).

Pois é o controle das forças de mercado que torna tão importante que os sistemas de gestão de qualidade sejam coercitivamente generalizados e que sirvam como elemento de coesão de mercado para o capital concentrado em grandes empresas. No caso do programa MCMV, o referencial normativo do PBQP-H cumpre a tarefa de ser "a fronteira entre o reino do controle e a anarquia do mercado". Por um lado dá coerência tecnológica para um mercado restrito de empresas capazes de implantar políticas de qualidade e aprovar empreendimentos junto à Caixa Econômica Federal e, por outro lado, amplia em novas bases a competição entre as empresas construtoras que são capazes apenas de vender a força de trabalho treinada e especializada de seus empregados para os serviços de subempreitada: entre estes capitais menores, restringe a guerra de preços e promove o alinhamento gerencial com a política de qualidade imposta pelo governo federal.

Se o capítulo 5 põe em questão a pertinência do MCMV como programa de habitação social, o mesmo não pode ser dito da sua função como programa de desenvolvimento econômico. Ao se articular com a tecnologia gerencial e organizacional dos sistemas de gestão de qualidade, o MCMV realiza o ideal econômico da concentração de capital na mesma medida que torna as médias e grandes empresas construtoras mais ágeis nos ciclos de retorno de capital ou, no dizer de Luiz Ceotto, "mais cérebro que braço". A relação de produção entre

154 Como visto no capítulo 4, a Pesquisa Anual da Indústria da Construção deixa clara o duplo movimento de acúmulo de capital do setor e sua concentração em poucas empresas. Cf. tabela T-12 e gráfico G-11. 
empresas se estabiliza dentro da atual configuração das forças produtivas no país e atinge uma "equilibrium form of organization consistent with balanced accumulation" (Harvey, 2006 [1982]: 136).

No entanto, resta ainda um passo final neste raciocínio. $\mathrm{O}$ atual equilíbrio de capitais no programa MCMV, por acontecer num mercado em transição produtiva e demográfica como o brasileiro, admite estratégias competitivas díspares das grandes empresas construtoras. A análise de duas empresas construtoras em específico, ambas de capital aberto e ações em valorização constante, ajuda a ilustrar as diferentes estratégias de competição que podem se formar na interação de grandes capitais com a massa de micro e pequenas empresas de subempreitada na construção habitacional.

A primeira empresa construtora é a Cury Construtora e Incorporadora S/ A, que tem atuação relevante no recorte desta pesquisa, isto é, nos empreendimentos para Faixa 1 de renda na região metropolitana de São Paulo, onde repassou à CEF 2.060 unidades habitacionais na Faixa 1 até Agosto de 2013, com outras 1.240 em construção, sempre em terreno adquiridos no município de Mogi das Cruzes (ver tabela T-21). A faixa de renda e a região de atuação já integravam uma estratégia comercial da empresa estabelecida em duas décadas de produção para o "segmento econômico", isto é, moradias comercializadas para as classes de consumo "C" $\mathrm{e}$ "D" [155].

Antes do lançamento do programa MCMV, a construtora Cury já estava capitalizada através de uma "joint venture" realizada em 2007 com a Cyrela Brazil Realty, a gigante da incorporação brasileira que buscava diversificar sua atuação voltada principalmente para alta renda através de uma empresa especializada na habitação para baixa renda. A abertura de capital preservou o controle empresarial da família Cury bem como o importante ativo que é a equipe de obras do engenheiro David Nonno. No balanço financeiro de 2012, a empresa registrou lucro líquido de $\mathrm{R}$ \$ 80 milhões e vendas de R 959 milhões, sendo R \$ 560 milhões em contratações na Faixa 1 do programa MCMV [156].

A especialização da empresa na construção para baixa renda permitiu que o capital da "joint venture" da Cyrela fosse empregado numa experiência construtiva concebida inteiramente para o porte e a padronização da construção

155 Num artigo de publicado no jornal O Estado de S. Paulo, o presidente Fábio Cury afirma que "o público das classes $C$ e $D$ não pode mais ser tratado como nicho, deve sim ser encarado como o verdadeiro mercado imobiliário brasileiro" e, numa análise interessante, considera que a competição neste mercado seria mais acirrada do que nos nichos de renda média e alta, pois na habitação econômica "o maior concorrente das construtoras e imobiliárias é o velho e conhecido 'puxadinho', ou seja, o varejo da construção" (Cury, 2011: 2).

156 Num levantamento recente, Mariana Fix já conseguiu observar o efeito do programa MCMV neste processo de concentração de capitais no setor da construção civil: "As empresas não listadas na Bolsa que participam com expressão do MCMV aparentemente podem ser dividas em: a) incorporadoras atualmente subordinadas a empresas grandes de capital aberto; b) construtoras voltadas para o segmento de 0 a 3 salários minimos, contratadas diretamente com as prefeituras. Algumas delas tiveram aumento expressivo no porte. A Cury, por exemplo, registrou crescimento líquido do lucro de $735 \%$ em 2010, em relação ao ano anterior, impulsionado pelas vendas feitas no programa Minha Casa Minha Vida" (Fix, 2011: 189). Mais recentemente, o presidente Fábio Cury declarou que "os resultados de 2012 se devem à nossa forte cultura de controle de custos e eficiência. Para 2013, continuaremos crescendo com rentabilidade e geração de caixa. Fazer isso ao mesmo tempo que contribuímos para sanar o déficit habitacional do país é a nossa missão" (Cury, 2013: 1). 
para baixa renda, denominada "fábrica de lajes": uma usina de pré-fabricação constituída como uma pessoa jurídica independente [157].

A pré-fabricação da laje tem vantagens sobre a inovação tecnológica adotada por outras grandes empresas construtoras pelo programa MCMV, que é a concretagem integral e "in situ" de paredes e laje de um pavimento, com uso de fôrmas metálicas. $\mathrm{O}$ lançamento do concreto auto-adensável pode ser realizado com rapidez e pouca mão-de-obra, mas não dispensa o tempo de cura nem a incessante ciclo de montagem de fôrma, escoramento, desfôrma e reescoramento.

O aumento da produtividade é obtido pela transferência da força de trabalho do canteiro de obras para a usina de pré-fabricação, operada por uma equipe mínima de armação e instalações elétricas. A usina se torna um fornecedor externo de componentes, que se instala em terreno alugado próximo ao canteiro de obras. Esta mobilidade é conseguida com um equipamento relativamente compacto, em que fôrmas metálicas são afastadas ou unidas rigidamente ao longo de trilhos com passadiços. Afastadas entre si, as formas permitem a montagem na vertical de armaduras e conduítes. Unidas, permitem a concretagem simultânea de até 20 lajes, como se vê na imagem I-16.

\section{I-16|Pré-fabricação de lajes da Cury Construtora S/A}
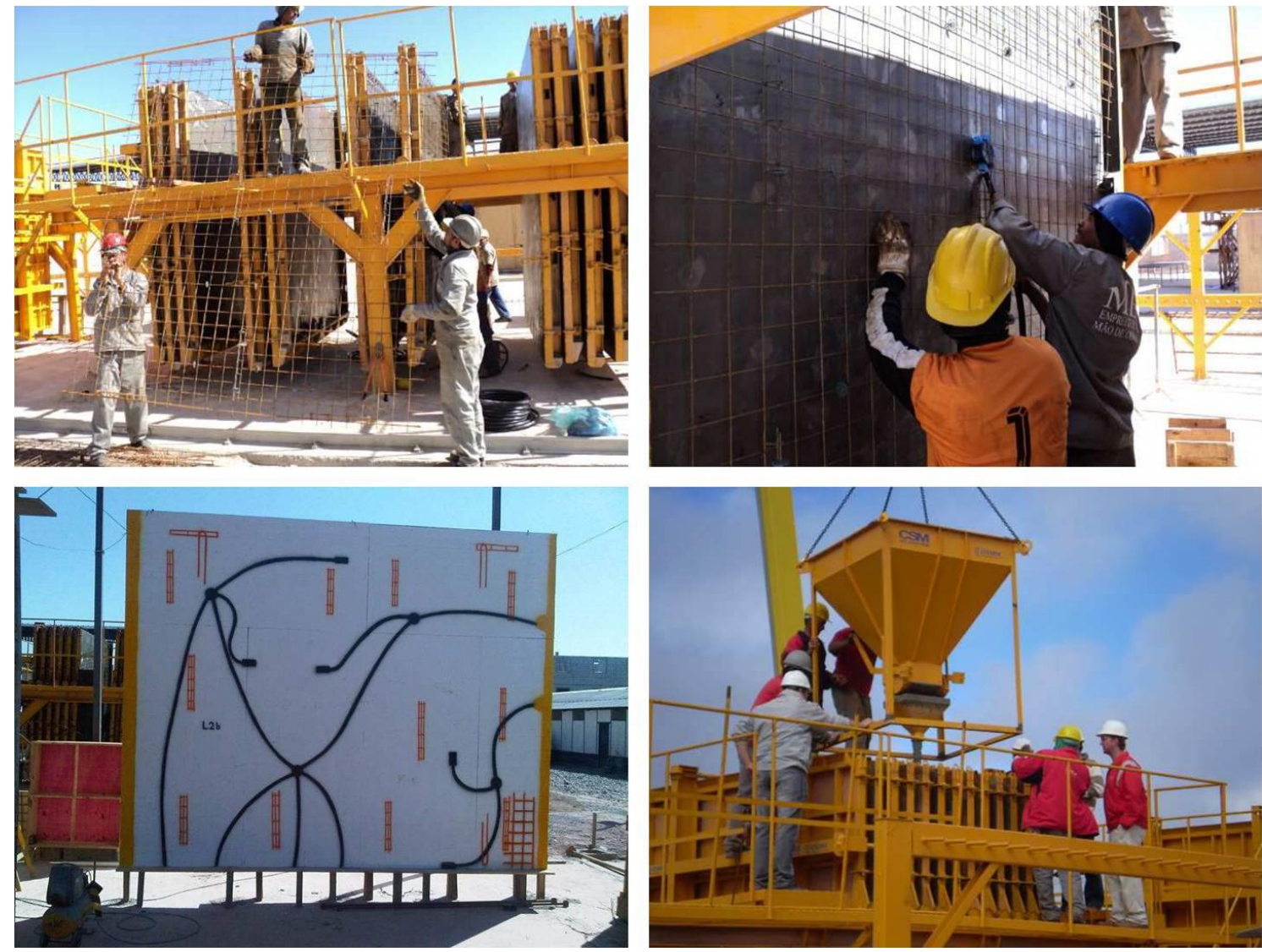

Fonte: Nonno, 2011: 32-44.

157 A tecnologia é adequada ao porte e padronização da tipologia habitacional adotada pela Cury e a imensa maioria das empresas construtoras que atuam pelo MCMV/FAR: o edifício de cinco pavimentos tipo “H”. A sua adequação à segregação urbana é discutida no capítulo 8. 
A transferência das lajes para o canteiro de obras combina a locação de dois veículos, o mais simples sendo uma carreta com braço hidráulico tipo "Munck", o mais especializado um guindaste com patolas, como se vê na imagem I-17.

O assentamento da laje já enrijecida a 21 dias permite que os serviços de alvenaria estrutural prossigam de imediato após o assentamento da laje, bastando fazer a interligação entre as saídas horizontais e os ramais verticais das instalações elétricas, embutidos nos blocos vazados de concreto. No canteiro de obras não há fôrmas ou escoras.

\section{I-17|Transporte das lajes pré-fabricadas na Cury Construtora S/A}
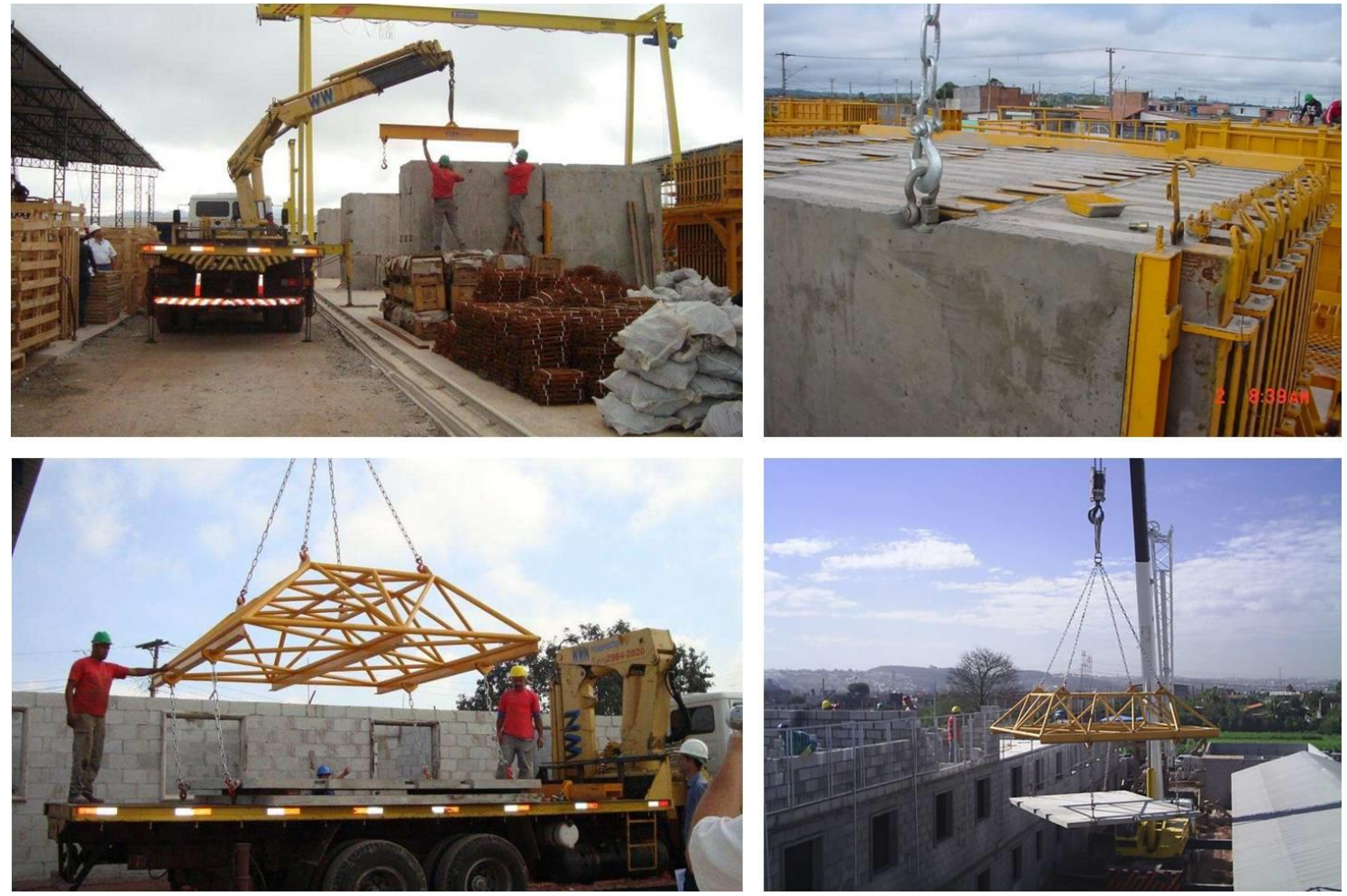

Fonte: Nonno, 2011: 44-60.

Pois bem, após esta tecnologia de pré-fabricação ter sido empregada para construir 2.060 unidades habitacionais em empreendimento para Faixa 1 do programa MCMV, ela deixou de ser usada nas 1.240 unidades habitacionais atualmente em construção para a mesma faixa de renda. $\mathrm{O}$ motivo é duplo. $\mathrm{O}$ primeiro é que a produção de lajes não conseguiu outros clientes e desmobilizar seu capital era mais econômico do que mantê-lo ocioso. O segundo motivo é mais decisivo: a subempreiteira que assumiu serviços de alvenaria estrutural para a Cury Construtora nos empreendimentos do programa MCMV, a Construtora Souza Araújo Ltda, passou de fornecedora de mão-de-obra com baixa qualificação a empresa com serviços especializados e participante do planejamento de obra e especificação de requisitos técnicos da Cury. Nos empreendimentos em construção (denominados "Bambu", "Quadrado" e "Triângulo", no bairro Jardim Aeroporto em Mogi das Cruzes), a subempreiteira Souza Araújo assumiu a construção de lajes com fôrmas prontas e concreto com lançamento mecânico e, com o gerencialmente conjunto com a Cury, sua produtividade passou a ser quase a mesma da "fábrica de lajes". 
A segunda empresa construtora de capital aberto a ser abordada a propósito da estratégia competitiva no programa MCMV é a MRV Engenharia e Participações S/A. É uma das empresas líderes do programa, mas na região metropolitana de São Paulo atua apenas para a "Faixa 2" (renda familiar entre R\$ 1.600 e R\$ 3.275) e “Faixa 3" (renda familiar entre R $\$ 3.275$ e $\mathrm{R} \$ 5.000$ ) e seus empreendimentos, portanto, estão fora do escopo desta pesquisa. O objeto abordado, no entanto, não é diretamente a empresa, mas sim como ela aparece num documento do Ministério Público do Trabalho (MPT) que relaciona seu sucesso no mercado da habitação econômica com a contratação de subempreiteiras que empregam trabalho em condição "análoga à escravidão".

Como a MRV Engenharia e Participações possui certificação PBQP-H Nível A e ISO 9001:2008, o espanto da tese do MPT não é apenas com a união do trabalho escravo com competitividade, mas também com certificação de qualidade. É o mesmo espanto que aparece numa declaração do professor e pesquisador em materiais de construção Vanderley John, que em entrevista comentava a dificuldade em controlar a qualidade da argamassa de revestimento no programa MCMV quando desabafou: "sem contar que há mão de obra escrava na construção. Como é possível discutir qualidade com mão de obra escrava?" (Faria, 2013: 25).

O pressuposto de Vanderley John é que há uma incompatibilidade entre sistemas de gestão de qualidade e "mão-de-obra escrava na construção". A parte final deste capítulo vai argumentar que esta incompatibilidade não existe.

O prenúncio deste argumento é a primeira denúncia de trabalho escravo num canteiro de obras na cidade de São Paulo, em Abril de 2012, quando a Superintendência Regional do Trabalho e Emprego em São Paulo (SRTE/SP) arrombou um alojamento precário na Zona Leste da cidade em que 12 serventes e ajudantes de pedreiro estavam confinados por cobranças de falsas dívidas e retenção ilegal de documentos. $\mathrm{O}$ incidente ganhou repercussão quando se descobriu que os serventes e ajudantes eram intermediados por uma microempresa de subempreitada para trabalharem na ampliação do Hospital Alemão Oswaldo Cruz, empreendimento de uma construtora com prestígio em obras de grande complexidade, a Racional Engenharia Ltda [158].

Segundo reportagem de Bianca Pyl, o subempreiteiro era ex-funcionário da construtora e um relatório do Ministério Público do Trabalho afirmava que "os trabalhadores e o pseudo-empresário eram completamente dependentes economicamente de seu contratante único e exclusivo: a Racional". Em 8 de Maio de 2012, o diretor Marcos Santoro é levado a depor na Comissão de Direitos Humanos da Assembleia Legislativa de São Paulo, onde pede desculpas e lê a seguinte nota: "manteremos nossa postura de sempre atuar para que tais vulnerabilidades sejam mitigadas", antes de terminar com o mantra dos sistemas de gestão de qualidade:

158 Uma figura ainda mais movediça que a subempreitada parece ter participado desta conduta criminosa: o "gato", recrutador de força de trabalho que presta serviços para empresas sem constituir ele mesmo uma pessoa jurídica. Sua remuneração é tanto o pagamento desviado do trabalhador (supostamente para pagar dívidas de transporte ou alojamento) quanto prêmios por parte dos empregadores finais. Recentemente, o presidente do departamento paulista do Sindicato dos Trabalhadores nas Indústrias da Construção Civil (Sintracon), Antonio de Souza Ramalho, declarou que "em alguns casos o engenheiro contratante recebe propina do 'gato' para manter trabalhadores explorados no canteiro" (Bérgamo, 2014: 49). 
"a Racional reavalia sistematicamente todos os seus processos para que eles sigam em melhoria continua" (Pyl, 2012: 1).

O que aparecia assim numa famosa construtora paulista (cujo faturamento ultrapassava um bilhão de reais naquele ano de 2012) era uma submissão violenta da força de trabalho mais comum em empresas rurais de baixa produtividade, como fazendas de pecuária extensiva ou madeireiras irregulares. A caracterização, no entanto, era a mesma e definida como crime no Artigo 149 do Código de Processo Penal: "reduzir alguém a condição análoga à de escravo, quer submetendo-o a trabalhos forçados ou a jornada exaustiva, quer sujeitando-o a condições degradantes de trabalho, quer restringindo, por qualquer meio, sua locomoção em razão de dívida contraída com o empregador ou preposto". No empreendimento da Racional Engenharia Ltda, os trabalhadores eram forçados a trabalhar por causa da retenção de pagamentos e sofriam "restrição de locomoção", pela retenção de documento e cobrança de dívidas forjadas.

\section{I-18|Alojamento de empreendimentos da Racional Engenharia Ltda}
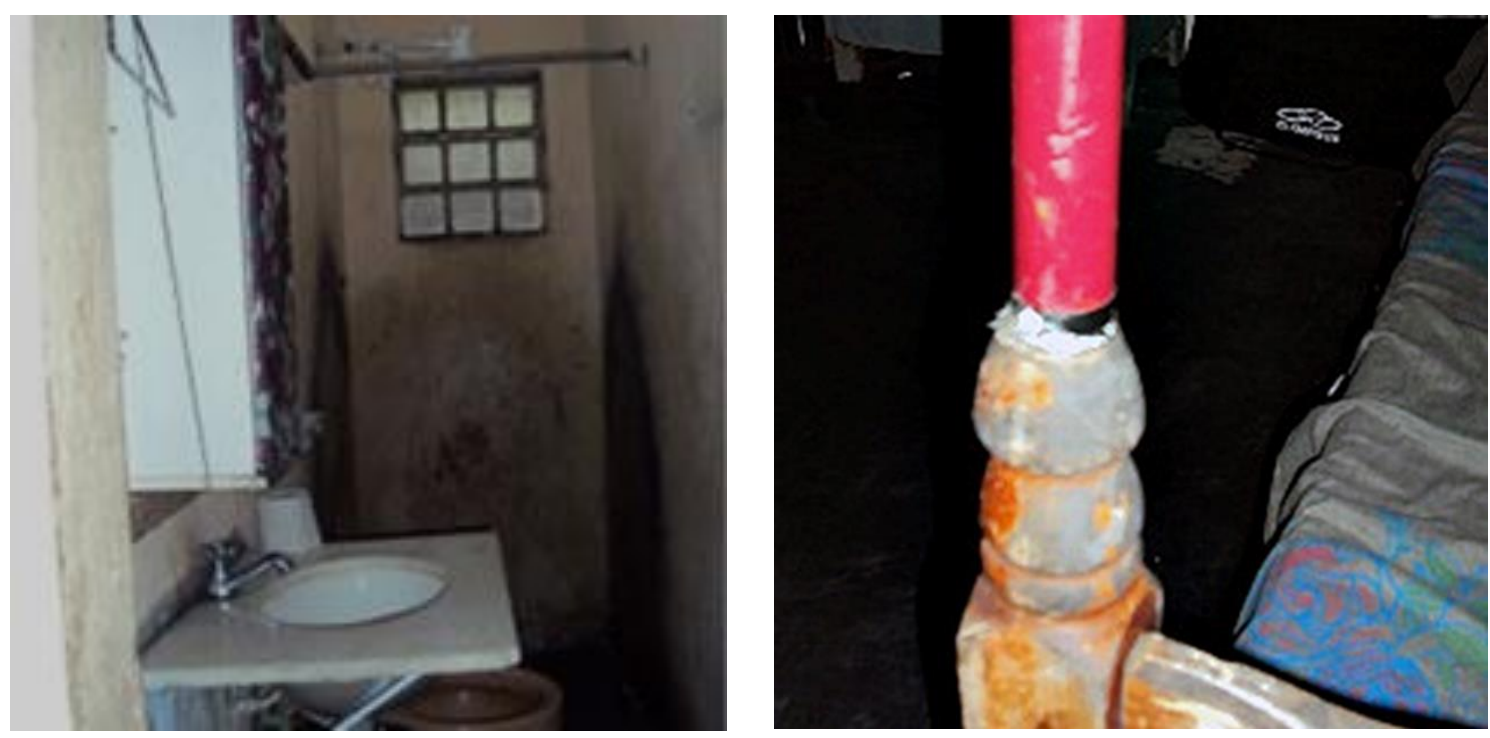

Fonte: Fotos da autuação da SRTE/SP (Pyl, 2012: 1). À esquerda, banheiro compartilhado por 12 pessoas. À direita, estrutura improvisada para beliches.

A identificação de que dormiam e cozinhavam em "condição degradante" também caracterizava o crime de trabalho escravo, o que confirma a força que atualmente possuem os parâmetros de segurança e salubridade fixadas na Norma Regulamentadora 18 (NR-18). Através desta norma impositiva para a construção civil, o Ministério do Trabalho e Emprego põe a serviço de sua consolidada rede de fiscalização critérios objetivos de "condição degradante", válidos tanto para o local de trabalho quanto alojamento e áreas de convivência, onde regulam itens como localização de bebedouros ou espessura de colchões. Nas mãos do Ministério Público do Trabalho, as autuações por infrações à NR18 tornaram a construção civil a atividade produtiva urbana com maior número de casos de trabalho análogo à escravidão: 621 trabalhadores de 24 empresas 
estavam relacionados na última edição de 2013 do Cadastro de Empregadores de Trabalho Análogo à Escravidão (MTE, 2013) [159].

Das condições que tornam um trabalho "análogo à escravidão", uma é difícil de impedir por lei ou regra normativa: a baixa escolaridade. Como estamos no campo da analogia, é possível pensar que a falta de liberdade em latifúndios ou subempreiteiras de construção é da mesma ordem que a falta de autonomia de um trabalhador no uso da língua ou do raciocínio lógico. No Brasil, não há trabalhador reduzido à condição de escravidão que não sofra também de uma desqualificação profissional, não em termos estritos de treinamento e destreza, mas no sentido mais amplo de formação e capacitação [160].

A Comissão Pastoral da Terra (CPT) faz desde 2003 um acompanhamento estatístico das autuações por trabalho análogo à escravidão, obtendo informações sociais dos trabalhadores resgatados pela fiscalização do MTE através do segurodesemprego a que têm direito. As informações sobre a escolaridade destes trabalhadores aparecem na tabela T-26, que destaca em cinza a preponderância, para todos os intervalos estatísticos, do ensino fundamental incompleto entre os trabalhadores resgatados:

T-26| Escolaridade dos trabalhadores em condição análoga à escravidão

\begin{tabular}{l|c|c|c|c|c} 
Escolaridade & \multicolumn{4}{|c}{ Distribuição acumulada a partir de $\mathbf{2 0 0 3}$ (\%) } \\
\hline Não soube informar nível de instrução & $\mathbf{2 0 0 8}$ & $\mathbf{2 0 0 9}$ & $\mathbf{2 0 1 0}$ & $\mathbf{2 0 1 1}$ & $\mathbf{2 0 1 2}$ \\
\hline Analfabeto & 3,6 & 3,7 & 3,8 & 3,4 & 3,0 \\
\hline Abaixo do 5o ano de Ensino Fundamental & 44,5 & 41,6 & 39,6 & 37,7 & 35,3 \\
\hline 5o ano de Ensino Fundamental completado & 34,9 & 35,5 & 35,9 & 37,4 & 38,4 \\
\hline Entre o 6o e o último ano do Ensino Fundamental & 0,0 & 0,0 & 0,0 & 0,4 & 1,4 \\
\hline Ensino Fundamental completo & 11,7 & 13,2 & 14,0 & 14,3 & 14,6 \\
\hline Ensino Médio incompleto & 2,7 & 2,9 & 3,0 & 3,2 & 3,5 \\
\hline Ensino Médio completo & 1,3 & 1,6 & 1,8 & 1,8 & 2,0 \\
\hline Ensino Superior incompleto & 1,3 & 1,5 & 1,7 & 1,7 & 1,8 \\
\hline Ensino Superior completo & 0,0 & 0,0 & 0,0 & 0,1 & 0,1 \\
\hline
\end{tabular}

Fonte: Elaborado pela Comissão Pastoral da Terra com dados da RAIS/MTE (CPT, 2012)

Quando a capacitação intelectual e a formação profissional aparecem entre os temas da Gestão de Produção, os autores enfatizam o dever moral que a educação impõe às empresas construtoras, mas reconhecem também que seu cumprimento não é uma iniciativa necessária para elevar a produção.

É o que observam Sérgio Pereira e Francisco Cardoso a respeito dos empreendimentos de construção nos EUA que operam em regime "open-shop", isto é, que contratam trabalhadores sem realizar acordos com sindicatos

159 O trabalho escravo no Brasil, ainda assim, é um fenômeno rural: dos 12.146 trabalhadores relacionados na listagem final de 2013, somente $1.149(9,4 \%)$ estavam ligados a atividades em meio urbano, enquanto $4.457(41,6 \%)$ eram escravizados por 241 empresas de pecuária. A listagem também dá destaque à madeireiras e produtores de carvão.

160 É preciso especificar a situação brasileira uma vez que o sucesso da indústria exportadora na China se baseia na submissão a regimes de trabalho intoleráveis até mesmo para padrões latino-americanos de trabalhadores com qualificação equivalente ao ensino técnico e superior (Duhigg; Bradsher, 2012) 
profissionais locais e que descartam, assim, a força de trabalho que eles formam e certificam. A principal mão-de-obra utilizada nestes canteiros de obras é imigrante, geralmente clandestina e incapaz de se comunicar em inglês. No entanto, pode ser rapidamente treinada para lidar com os componentes préfabricados que os sindicatos norte-americanos próibem ou tornam desnecessariamente caros:

Continua sendo relativamente comum encontrar operários analfabetos nos canteiros. Esta deficiência traz dificuldades ao processo produtivo, reduzindo a autonomia dos operários - aqueles com pouca escolaridade mostram-se mais dependentes dos encarregados de produção e não conseguem buscar informações por si mesmos. Por outro lado é provável que, equivocadamente, culpa excessiva tenha sido creditada a este fator. A experiência em países como os Estados Unidos indica que é possivel evoluir mesmo empregando-se uma mão-de-obra com limitada educação escolar. Neste sentido as próprias subempreiteiras alegam, por exemplo, que dificilmente são identificadas diferenças de qualidade nos serviços executados por operários com alguma formação e por aqueles que não possuem nenhuma (Pereira; Cardoso, 2004: 12-13).

Em seminário promovido pelo CTE, o mesmo tema da força de trabalho imigrante serve para Fernando Sabbatini apoiar sua tese de que a diferença de produtividade entre empresas construtoras "é função muito mais do projeto e gestão do processo do que da produtividade individual da mão de obra empregada" (Sabbatini, 2008a: 36). Na apresentação oral desta ideia, ele acrescenta:

A gente fica falando sobre a mão-de-obra. Eu morei na Itália e quem construía lá era imigrante, clandestino, não falava italiano e era agricultor no país de origem. E lá se constrói muito bem porque é o processo que garante a qualidade, não é quem está dentro do canteiro (Sabbatini, 2008b).

Ubiraci de Souza traz o raciocínio para o canteiro de obras brasileiro:

Relembro aqui a importância de se abandonarem posturas simplistas e incorretas de considerar que a má produtividade é causada por "nossos operários analfabetos" (...) embora seja sempre válida a ideia de buscar o aprimoramento da formação de nossos trabalhadores (e isto é um dever social dos gestores em qualquer indústria), a melhoria da produtividade deve ser gerenciada com a consciência de que ela depende das características do produto que se quer executar, dos processos adotados e da maior ou menor ocorrência de anormalidades durante a produção (Souza, 2006: 89).

Daí a frustração de Carlos Eduardo Cabanas, diretor da entidade patronal especificamente voltada para a educação técnica da força de trabalho da indústria, o Serviço Nacional de Aprendizagem Industrial - SENAI. Ao tratar da dificuldade em implantar uma certificação para trabalhadores semelhante à certificação de qualidade para empresas, ele comenta:

A qualidade serviu para certificar as construtoras, acertar alguns procedimentos internos, melhorar a qualidade dos materiais, mas a mão-de-obra ficou à margem, foi para o sacrifício. O que outras cadeias produtivas fizeram para envolver e englobar a mão-deobra, a construção não soube fazer (Oliveira, 2008: 48)

Seria mais preciso dizer que a indústria da construção "não soube fazer" apenas o que descobriu que não precisava fazer para obter ganhos de produtividade e qualidade: a capacitação pessoal e profissional de sua força de trabalho. 
Esta discussão preliminar, suscitada pelas condições degradantes vividas por trabalhadores de um empreendimento da construtora Racional Engenharia Ltda dão o contexto necessário para abordar a documentação do Ministério Público do Trabalho que trata da MRV Engenharia e Participações S/A.

A documentação reúne procedimentos de investigação, relatórios de vistoria, autos de infração e sentenças da Justiça do Trabalho e foi protocolada em 02 de Agosto de 2012 como uma "Representação Administrativa" do Ministério Público do Trabalho junto ao Conselho Administrativo de Defesa Econômica Cade (MPT, 2012). Esta Representação é portanto um documento que transita entre duas esferas do direito, originado da Justiça do Trabalho e destinado a um órgão de Direito Econômico responsável por preservar as condições de concorrência de mercado. É uma transição ilustrativa da tese proposta pelo MPT, segundo a qual a MRV Engenharia e Participações S/A realiza uma "supressão maciça e em larga escala de direitos trabalhistas" de tal ordem que ela se constituiria em "infração da ordem econômica", uma vez que concede à empresa "vantagem arbitrária sobre a concorrência (...) que se ajusta à definição de limitar, falsear ou de qualquer forma prejudicar a livre concorrência ou a livre iniciativa" (MPT, 2012: 1-2). $\mathrm{Na}$ Representação, esta tese ganha a seguinte explicação, na característica linguagem adjetivada do ministério público:
A prática de sonegar em larga escala direitos trabalhistas básicos e fundamentais vem sendo cometida de forma sistemática pela MRV há diversos anos, em todas as partes do país onde a empresa esteja presente, com destaque para as seguintes condutas ilícitas: submissão de trabalhadores a condições degradantes, análogas às de escravo; aliciamento de trabalhadores; celebração de terceirizações fraudulentas (...) a MRV valeu-se e continua a se valer de tal significativa vantagem abusiva - custos trabalhistas menores que o da concorrência - para alavancar sua posição no mercado, estratégia na qual a empresa vem obtendo extraordinário sucesso, em prejuízo à ordem econômica e financeira. Ou seja, simultaneamente a uma verdadeira explosão da quantidade de problemas trabalhistas por ela gerados, vem a MRV obtendo sucesso em converter a economia obtida com custos trabalhistas em uma vantagem competitiva, em detrimento aos trabalhadores e à concorrência (MPT, 2012: 2).

A Representação é assinada pelo procurador Rafael de Araújo Gomes, da $15^{\mathrm{a}}$ Região da Justiça do Trabalho (TRT-15). A principal base de acusação que ele usa são documentos oriundos desta jurisdição do interior de São Paulo, todas elas relativas a condutas associadas à redução de trabalho à condição de escravidão (condições degradantes de trabalho, aliciamento de trabalhadores, retenções de pagamento e documentos, entre outras) associadas ao uso de subempreiteiras [161]. A 15 $5^{\text {a }}$ Região tem sedes municipais em Araçatuba, Araraquara, Bauru, Presidente Prudente, Ribeirão Preto, São José do Rio Preto, São José dos Campos e Sorocaba, exatamente a região que tornou a MRV uma das principais construtoras brasileiras [162].

161 Um ano antes, o Procurador da Justiça do Trabalho Élisson Miessa dos Santos dava uma declaração que prenunciava a Representação: "uma mesma obra tem às vezes pedreiros de dezenas de pequenas empreiteiras. O operário nem sabe mais quem é o patrão (...) Há casos como o da construtora MRV, em Franca, onde se achou até operários sem registro em carteira, uma situação mais comum com pequenas empreiteiras" (Coissi, 2011: 2).

162 "Ao contrário da maioria das construtoras do país, que optam pela capital quando decidem investir em São Paulo, a mineira MRV Engenharia e Participações S/A aposta nos municípios do interior paulista. Segundo o diretor 
Como infrações trabalhistas não são incomuns e contratos de subempreitadas são universais na construção habitacional brasileira, mostrar que eles se tornam uma vantagem competitiva para uma única empresa é um desafio jurídico. $O$ procurador Rafael Gomes começa a enfrentá-lo pela descrição de empresas que recorrem a uma infração trabalhista "quando a saúde financeira da empresa se encontra debilitada" (caso em que se dispõe a "recompor tal passivo assim que conseguirem atravessar a fase de turbulência pela qual estão passando") ou "após certa estimativa das vantagens e desvantagens financeiras de se agir desta ou daquela forma" (caso em que "persistem em tal comportamento até serem suficientemente inibidas pelos órgãos de fiscalização" ). Para estes dois tipos de empresas,

A razão do descumprimento não é tanto financeira, estando mais na dificuldade do empresário em organizar seu empreendimento de forma mais eficiente e racionalizar seus processos. De modo que a economia obtida com a supressão de um ou outro direito trabalhista é de pequena monta, insuficiente para proporcionar a essas empresas alguma vantagem concorrencial. Os dois tipos de empresa acima mencionados compõem a esmagadora maioria das empresas brasileiras, que buscam, em maior ou menor grau, honrar suas obrigações trabalhistas, mesmo em face de dificuldades (MPT, 2012: 97).

Em seguida, há a descrição de um "terceiro tipo" de empresa que interessa mais de perto para o caso MRV, pois são "empresas que utilizam a sonegação de direitos como verdadeira ferramenta de gestão, praticando-a de forma sistemática e metódica, inclusive quando a empresa está a experimentar momentos de prosperidade". Apelando à sua experiência profissional, o procurador Rafael Gomes reconhece que mesmo neste caso a prática contumaz da infração trabalhista não implica em competitividade de longo prazo:

Nem todas as empresas desse terceiro tipo, entretanto, conseguem efetivamente converter tal conduta persistentemente ilícita em vantagem econômica frente à concorrência. Pelo contrário, muito poucas conseguem fazê-lo. Com frequência são empresas pessimamente administradas, sendo que a violação em massa é utilizada como tentativa de compensar as deficiências que ela experimenta no embate direto com a concorrência. Ao invés de se modernizarem e de se tornarem mais produtivas, tais empresas optam por permanecer atrasadas, apostando na violação à lei como forma de acompanhar a concorrência, mais eficiente (...) A médio e longo prazo, tais empresas são forçadas a mudar de postura ou fecham as portas.

Para caracterizar a MRV num movimento contrário à esta tendência, tudo o que a Representação do MPT pode fazer é recorrer a fatos e apelar ao "item 2" da Representação, que contém 82 páginas de relatórios, sentenças e autos de infração do TRT-15:

Revela-se assim, no cotejo com o exposto no Item 2 desta representação, que o sucesso recente da $M R V$ não se deu por superior eficiência na exploração da atividade econômica.

\footnotetext{
Executivo Comercial, Eduardo Barretto, 41 das 85 cidades brasileiras em que a empresa atua estão localizadas na região. A menor concorrência e o preço mais reduzido dos terrenos são alguns dos diferenciais encontrados nestes mercados. Barretto destacou que os municípios do interior paulista têm economia bem desenvolvida, elevado indice populacional e uma grande demanda por imóveis (...) O subsídio disponibilizado pelo governo federal, por meio do programa habitacional Minha Casa, Minha Vida, fez com que demanda pela casa própria aumentasse significativamente. 'A facilidade no acesso ao crédito fez com que os imóveis também fossem procurados pelo consumidor do interior, beneficiando os resultados da MRV'"' (Lobato, 2010: 8).
} 
A superioridade demonstrada pela empresa esteve vinculada, preponderantemente, à sua maior capacidade de descumprir a legislação trabalhista (MPT, 2012: 107).

Este fato é confrontado com outro, alardeado pela própria MRV, que é sua ascensão no "ranking" anual das "50 maiores construtoras" brasileiras: em 2012 ela chegava então à $7^{\circ}$ colocação geral e primeira colocação no segmento de edifícios residenciais, quando nem sequer aparecia na listagem antes do lançamento do programa MCMV (CBIC, 2013). O procurador Rafael Gomes também investiga informações do balanço financeiro de 2012 da MRV para apontar que a despesa anual com ações trabalhistas cresceu $892 \%$, mas o valor final, $\mathrm{R} \$ 4,232$ milhões, é pouco mais que um milésimo da receita corrente da empresa, apurada em R \$ 4,015 bilhões em Abril daquele ano.

Ainda assim, o confronto dos fatos resulta apenas na sua justaposição:
Raras são as empresas que, fazendo uma aposta pela supressão em larga escala de direitos trabalhista, obtêm sucesso em tal aposta. A MRV é um exemplo bem acabado de empresa assim, sendo portanto um caso raro na economia brasileira. Fez ela, há vários anos, uma escolha incisiva na ampla sonegação de direitos, e obteve enorme e surpreendente sucesso com isso, passando de coadjuvante a uma das principais protagonistas do cenário da construção civil brasileiro, no mesmo período em que explodiu a quantidade de problemas trabalhistas por ela criados, com crescente gravidade. (MPT, 2012: 99).

Os fatos sem interpretação mostram os limites de uma disciplina jurídica em entender a tecnologia da construção habitacional. $O$ procurador acha "surpreendente" que o domínio que uma grande empresa exerce sobre uma empreiteira possa ao mesmo tempo elevar sua produtividade, domínio que ao longo deste capítulo e do anterior foi analisado como decorrente da principal tecnologia de gestão e organização que conferiu matriz industrial aos empreendimentos do programa MCMV: os sistemas de gestão de qualidade. A principal função destes sistemas é padronizar a diversidade dos empreendimentos e reorganizar o fracionamento das atividades produtivas entre empresas subempreiteiras, cuja submissão econômica passa a seguir o caráter gerencial que é exigido pelo PBQP-H e posto em prática pelos cursos de treinamento e pela sistemática de registro da inspeção, correção e prevenção de qualidade produtiva. Bem aplicado, esta tecnologia organizacional torna produtiva mesmo uma subempreiteira que mantém uma força de trabalho especializada e treinada, mas de baixa ou nenhuma escolaridade e que aceita uma condição de trabalho análoga à escravidão.

A relação deste sistema de gestão de qualidade com a degradação do trabalho não é da ordem da necessidade de mercado (pelo contrário, o procurador diz que o mercado, a longo prazo, pune a infração trabalhista), mas sim da estratégica concorrencial. Esta estratégia pode ser regulada pela moralidade dos gestores, mas seu único limite efetivo é a força da lei, como mostra a ação de fiscalização da Justiça do Trabalho. Ainda assim, a degradação do trabalho que constrangeu a prestigiada Racional Engenharia Ltda (num caso emblemático mesmo que isolado) possui um aspecto constitutivo na escolaridade e formação da mão-deobra brasileira que em nada afeta a Cury Construtora e Incorporadora S/ A e sua busca permanente para implementar tanto centrais de pré-fabricação quanto 
métodos de controle de subempreiteiras em regime de parceria, como a que estabelece com a Construtora Souza Araújo Ltda [163].

Que a MRV Engenharia e Participações S/A tenha incorporado a degradação do trabalho em sua estratégia competitiva é, do ponto de vista desta tecnologia gerencial, apenas um uso imoral e possível da exclusão que a força de trabalho no Brasil sofre dos meios para se formar profissional e politicamente.

Em entrevista recente, o fundador e presidente da MRV, Rubens Menin, alega que a base para o crescimento da empresa é puramente gerencial: "Nossos produtos são todos padronizados. O projeto de Porto Alegre é o mesmo de Recife, Fortaleza ou Brasília. Compramos a mesma cerâmica, as equipes têm o mesmo treinamento. Essa é a verdadeira industrialização da construção" (Reis, 2012: 14). Não há aqui contradição: a padronização produtiva pode controlar tanto a subempreitada do canteiro de obras quanto a produtividade da força de trabalho degradada profissionalmente. Afinal, se a produtividade está ligada a processos que independem do grau de autonomia intelectual do trabalhador, ela independe, no limite, também do grau de sua liberdade pessoal [164].

É o sistema de gestão de qualidade da MRV que transfere para a desqualificação do trabalhador subempreitado a produtividade do que Rubens Menin chama de “a verdadeira industrialização da construção" [165].

$163 \mathrm{O}$ diretor de engenharia Fábio Curi associa explicitamente o controle de qualidade ao controle da legislação trabalhista na empresa fundada por seu pai, Charles Curi, e seu tio, Elias Cury: “A ISO ajuda bastante. No começo, temos a impressão de que o sistema de qualidade exige muito papelada e, no início, é assim mesmo. Mas com o tempo, aprende-se a trabalhar com isso e torna-se uma coisa normal, dá padrão e procedimento, que é muito importante. Temos internamente um gerente da qualidade, com profissionais no campo, que dão instruções aos gerentes das obras, verificam se as fichas técnicas [Fichas de Verificação de Serviço] estão sendo preenchidas e se os procedimentos são seguidos; esse departamento também verifica o atendimento à NR 18, a norma de segurança de trabalho. Essa é uma preocupação nossa" (Rocha, 2012: 13).

164 Da mesma forma, mercadorias de alta tecnologia projetadas pela empresa americana Apple podem ser produzidas em condições de semi-escravidão nas fábricas das províncias chinesas de Chengdu e Shenzhen. Uma reportagem do The New York Times, que não deixa dúvidas sobre as condições degradantes de trabalho nestes locais, traz a seguinte declaração de um gerente da Foxconn Technology: "Apple never cared about anything other than increasing product quality and decreasing production cost (...) Once the deal is set and Foxconn becomes an authorized Apple supplier, Apple will no longer give any attention to worker conditions or anything that is irrelevant to its products" (Duhigg; Barboza, 2012: A1).

165 A tese de doutorado de Lúcia Shimbo observa numa empresa identificada pela sigla ECP uma dualidade semelhante entre racionalização de produção e condição precária de trabalho, que é interpretada da seguinte forma: "Há uma lógica do favor e de uma suposta fidelidade do trabalhador àquele que concede determinado benefício. Isso significa que todo aquele sistema avançado de controle desenvolvido pela ECP requer, na sua base da produção, mecanismo que remontam ao regime de trabalho clássico presente no canteiro brasileiro, já identificado por outros autores desde a década de 1960, permeado por práticas de cunho paternalista" (Shimbo, 2010: 332). A Representação proposta pelo Procuradoria da Justiça do Trabalho contra a MRV qualifica mais o verbo "requer" usado neste trecho: o sistema de gestão da qualidade da MRV "requer" a exploração das subempreiteiras como meio para obter vantagem competitiva no mercado da habitação financiado na Faixa 2 e Faixa 3 do programa MCMV. Os "mecanismos que remontam ao regime de trabalho clássico" dos anos 1960 são apenas instrumentais para a estratégia comercial da MRV, e não essenciais para o "sistema avançado de controle" do trabalho que ela implementa nos canteiros de obras. 
Para concluir a sequência dos eventos, durante a finalização desta pesquisa no final de 2013, a intervenção do Ministério Público do Trabalho caminhava para um acordo judicial com a MRV. A punição mais temida neste meio tempo não era a pena de prisão (uma vez que é difícil um tribunal brasileiro individualizar responsabilidades quando estas recaem sobre empresários), muito menos a multa trabalhista (de valor dezenas de vezes inferior a qualquer despesa administrativa por atraso de obra), mas sim a inclusão no cadastro federal de empregadores que tenham submetido trabalhadores a condições análogas à escravidão, conhecido como "lista suja do trabalho escravo". Gerido e atualizado semestralmente pelo Ministério do Trabalho e Emprego - MTE, o cadastro impossibilita que as empresas nele inscritas tenham acesso a qualquer recurso federal, o que inclui o Fundo de Arrendamento Residencial, que é a mais importante fonte de financiamento do programa MCMV [166].

Em Agosto de 2012 a MRV foi incluída no cadastro de empregadores de trabalho escravo e imediatamente a CEF, signatária do Pacto Nacional pela Erradicação do Trabalho Escravo no Brasil, a descredenciou de suas operações financeiras. Em poucos dias, a ações comercializadas na bolsa de valores de São Paulo (MRV ON e MRVE3) tiveram queda de quase $10 \%$, que só foi revertida em definitivo depois que uma decisão liminar da ministra Eliana Calmon, do Superior Tribunal de Justiça, determinou que a empresa fosse retirada da lista em Janeiro de 2013.

De qualquer forma, a força que contrariou a estratégia competitiva da MRV não se originou do mercado, mas sim do Estado, através dos fiscais do trabalho que inspecionam o cumprimento da NR-18. A estes fiscais a MRV opôs todas as resistências jurídicas e dificuldades no canteiro de obras. Por outro lado, em nenhum momento a MRV precisou constranger ou enganar os auditores de terceira parte, profissionais da empresa certificadora Bureau Veritas que em 2013 inspecionaram o cumprimento do sistema de gestão de qualidade.

Os empreendimentos cumpriam todos os requisitos e referenciais normativos e, como nos anos anteriores, a MRV renovou sem reparos a certificação PBQP-H nível “A” e a certificação ISO 9001: 2008.

166 O corte de financiamento federal é uma punição tão drástica para empresas brasileiras (principalmente rurais) que, após forte atividade de lobby, a Portaria interministerial 2/2011 admitiu a participação de 13 órgãos federais no processo de inclusão no cadastro, entre eles a CEF. 


\section{$8 \mid$ \\ A PERIFERIZAÇÃO DA TECNOLOGIA}

\section{O laboratório da baixa renda}

Uma crítica desde o primeiro momento ao programa MCMV é a de que ele é um programa habitacional apenas de forma secundária: seu objetivo primário é capitalizar a construção civil como setor produtivo e sua natureza, portanto, é de programa de desenvolvimento econômico. As análises discutidas no capítulo 5 que apontam a inadequação deste objetivo econômico com o Plano Nacional de Habitação ou com o perfil do déficit habitacional brasileiro são, no fundo, simples decorrências desta crítica de base ao programa federal.

A conversão de uma política social em econômica, que hoje parece perdurar como uma aliança entre governo federal e empresariado da construção habitacional, era contingencial no lançamento do programa MCMV, em Abril de 2009, elaborado como foi durante o colapso do sistema hipotecário americano (iniciado com a falência do banco Lehman Brothers em 15 de Setembro de 2008), que em poucos meses se tornou uma crise financeira global. Neste tempo de urgência, houve uma reorganização de forças de governo e das interlocuções que estas estabelecem com forças sociais, considerada por um recente estudo do Ipea como uma "ampliação das arenas decisórias das políticas governamentais":

A Casa Civil, sob o comando de Dilma Rousseff, além de suas atribuições normais de coordenação institucional das diversas áreas de governo, passou a assumir, com o Ministério da Fazenda e o Ministério do Planejamento, Orçamento e Gestão (MPOG) um papel mais destacado na gestão das políticas econômicas destinadas a enfrentar a crise de 2008 (...) O programa MCMV representou, politicamente, o deslocamento das prioridades antes acordadas à política habitacional pelo Ministério das Cidades, sob a direção de Olívio Dutra e seus assessores envolvidos com o PlanHab, e a imposição de novas prioridades para a área, determinadas tanto pela necessidade de uma resposta rápida à crise econômica e o papel de destaque assumido pela Casa Civil na gestão das políticas prioritárias do governo, quanto pela pressão do empresariado, prioridades agora melhor contempladas com a mudança de comando no ministério. Em outras palavras, o programa MCMV implicou que a política habitacional passasse a configurar-se como política de cunho predominantemente econômico e não social, ou seja, a necessidade de ativar o mercado passou a se sobrepor ao objetivo de redução do déficit habitacional para trabalhadores de baixa renda (Loureiro; Macário; Guerra, 2013: 17).

Para a construção civil brasileira, a crise financeira de 2008 punha em perigo o acelerado processo de concentração de capital que acontecia desde 2005, através ofertas iniciais de ações e outras operações em bolsa de valores, como fusões e aquisições entre empresas de capital aberto [167].

167 Em sua tese de doutorado, Mariana Fix aborda a formação do "circuito imobiliário" brasileiro, em que o mercado de capitais tem papel central nos últimos estágios e faz uma comparação com o mercado hipotecário americano e a crise financeira mundial de 2008 (Fix, 2011). 
Era o final de um ciclo de expansão financeira que, no subsetor habitacional, tinha se imobilizado num grande estoque de terras urbanas no momento que participações acionárias em todo mundo perdiam valor. Neste momento, o atendimento à urgência do capital da construção precisava da experiência acumulada no Ministério das Cidades:

A participação dos empresários foi importante, mas não explica a configuração do programa MCMV. Dois fatores foram fundamentais para a concepção do programa MCMV: a experiência acumulada em programas que já vinham sendo implementados, como o PAR, e o diagnóstico elaborado no PlanHab, tanto em termos do potencial de consumo quanto de apresentar as modelagens de previsão de demanda, precificação e cálculo de subsídios (Loureiro; Macário; Guerra, 2013: 18).

A demanda modelada e precificada pelo Ministério das Cidades oferecia uma solução à crise financeira que se iniciava, pois dimensionava os efeitos multiplicadores do investimento na construção civil, setor que mobiliza uma longa cadeia de suprimentos e emprega diretamente $7,5 \%$ da população economicamente ativa do país (IBGE, 2013: 171) [168].

Desta forma, o foco do programa MCMV foi desde o primeiro momento a produção e não o produto habitacional. A moradia, principalmente a destinada para baixa renda, nunca deixou de ser tratada nas sucessivas formatações do programa federal como uma externalidade que oscila entre as diretrizes do Ministério das Cidades, o acompanhamento técnico-financeiro da CEF e os interesses clientelistas das prefeituras municipais, tal como mostra a segunda parte deste capítulo.

Nesta primeira parte, a análise recai sobre uma característica essencial do produto habitacional quando construído para famílias de baixa renda, que é a sua aquisição por um "valor máximo" por parte do Fundo de Arrendamento Residencial (FAR), estabelecida conforme critérios regionais que estão reproduzidos na tabela $\mathrm{T}-27$ :

168 Há ainda o que a microeconomia denomina "efeito riqueza", pelo qual a mera condição de morador de uma residência formal e padronizada estimula o consumo de mais serviços e bens. Este estímulo foi reforçado em 2013 pela Lei Federal 12.793, que concede crédito para compra de mobiliário e eletrodomésticos a beneficiários do programa MCMV, através do programa "Minha Casa Melhor". 
T-27|MCMV2 - Regiões dos 10 maiores valores de aquisição de UH

\begin{tabular}{l|c} 
Região da unidade habitacional & $\begin{array}{c}\text { Valor máx. } \\
\text { de aquisição }\end{array}$ \\
\hline Região Metropolitana de São Paulo, Campinas, Baixada Santista e Jundiaí & $\mathrm{R} 76 \mathrm{mil}$ \\
\hline Distrito Federal (não inclui cidades da Região Integrada de Desenvolvimento Econômico) & $\mathrm{R} 76 \mathrm{mil}$ \\
\hline Região Metropolitana do Rio de Janeiro & $\mathrm{R} 75 \mathrm{mil}$ \\
\hline Municípios com mais de 50 mil habitantes no Estado de São Paulo & $\mathrm{R} \$ 70 \mathrm{mil}$ \\
\hline Municípios com mais de 50 mil habitantes no Estado do Rio de Janeiro & $\mathrm{R} 69 \mathrm{mil}$ \\
\hline Região Metropolitana de Belo Horizonte & $\mathrm{R} 65 \mathrm{mil}$ \\
\hline Região Metropolitana de Porto Alegre, Curitiba e Florianópolis & $\mathrm{R} 64 \mathrm{mil}$ \\
\hline Região Metropolitana de Salvador & $\mathrm{R} 64 \mathrm{mil}$ \\
\hline Região Metropolitana de Fortaleza e Recife & $\mathrm{R} 63 \mathrm{mil}$ \\
\hline Região Metropolitana de capitais da Região Norte & $\mathrm{R} 62 \mathrm{mil}$
\end{tabular}

Fonte: Portaria MCidades 168/2013

A variação do teto de valor acontece não por regiões intra-urbanas ou mesmo intra-bairros, como é comum em avaliações de mercado imobiliário, mas por unidades territoriais extensas e heterogêneas que são as regiões metropolitanas ou por agrupamentos abstratos que são as cidades com mais de 50 mil habitantes no Estado de São Paulo e no Estado do Rio de Janeiro. Assim, o teto mais elevado se aplica às moradias construídas em qualquer área urbana da RMSP e, como visto no capítulo 5, pode ser majorado para $\mathrm{R} \$ 96$ mil por um aporte de recursos do Fundo Paulista de Habitação de Interesse Social (FPHIS).

Este valor de teto sempre inclui o valor de terreno, que é expresso através de uma “Opção de Compra e Venda" previamente acordada entre empresa construtora e proprietário. Assim que a CEF, na condição de agente financeiro do programa MCMV, aprovar o valor apresentado, a compra é realizada em nome do FAR. A aprovação do valor se dá meramente por comparação com valores do mercado imobiliário, inflacionado desde o lançamento do programa MCMV, e não envolve qualquer negociação que implique alterações no projeto habitacional associado ao terreno. Isto significa que o ponto inicial que resultou na "opção de compra" fica intocado: o estudo de viabilidade desenvolvido pela empresa construtora, que estabelece o máximo aproveitamento do terreno em termos de unidades habitacionais e sua ponderação de custo positiva ou negativa em termos de escala e logística de construção. Este estudo produz um custo real de edificação e infraestrutura comunitária, cuja diferença em relação ao "valor máximo de aquisição" é a informação básica que uma rede de corretagem de imóveis especializada em empreendimentos da Faixa 1 utiliza na negociação com proprietários de terra urbana de toda RMSP.

Sem a corretagem especializada, interessada tanto em maximizar o custo da terra urbana quanto em viabilizar o empreendimento, não seria possível converter o proprietário de terra urbana em "fornecedor" e "parceiro comercial" da empresa construtora, como aparece nos depoimentos recolhidos por Alberto Guedes, Davi Araújo e Paolo Coti-Zelati para uma pesquisa sobre vínculos comerciais nos empreendimentos do programa MCMV (Guedes; Araújo; Coti-Zelati, 2013). Os seguintes trechos dos depoimentos de diretores das empresas construtoras especializadas em mercado para baixa renda Living Construtora (subsidiária da 
Cyrela Brazil Realty) e Rodobens Negócios Imobiliários deixam evidente a relação de parceria comercial:

Com os donos dos terrenos, temos o relacionamento através da área de terrenos e através dos corretores de terrenos que fazem a aproximação (...) Outro tipo de parceiro importante no nosso negócio são os proprietários de terrenos (...) o proprietário tem que estar apto a fazer o Minha Casa Minha Vida, ele é um fornecedor diferente de terreno (...) Temos os donos de áreas, os proprietários de terrenos, que fornecem a matéria-prima para o nosso negócio. A gente precisa estar junto com eles, né? E aí tem os corretores, que trazem os terrenos para nós. Então tem que ter essa fidelização desses corretores de terrenos (Guedes; Araújo; Coti-Zelati, 2013: 11-12).

O final da negociação, conforme aparece no valor de contrato por unidade habitacional da tabela T-19, T-20 e T-21, sempre resulta numa combinação entre valor de terra urbana e custos de edificação e infraestrutura comunitária que é próximo ou idêntico ao "valor máximo de aquisição" da data vigente de assinatura de contrato [169].

Entre os requisitos que tornam os proprietários de terra urbana "aptos a fazer o programa MCMV" está a regularidade fundiária. Apenas a propriedade descrita e matriculada em cartório de registro de imóveis pode servir como garantia de financiamento na forma de alienação fiduciária, em que a retomada da propriedade, em caso de inadimplência, pode acontecer com um processo administrativo simples. É um parâmetro de natureza financeira que distancia ainda mais os valores da terra urbana de uma função eminentemente social:

Esse parâmetro estendeu-se a todo o programa, inclusive na Faixa 1, em que a fonte de recursos não é onerosa, mas orçamentaria, e os níveis de subsidio chegam a 95\%. Ou seja, uma medida extrema, com molde bancário, foi aplicada a um programa de caráter social. Ao estabelecer um programa com esse formato, o MCMV delimita o mercado formal como seu espaço de atuação, a propriedade privada individual e registrada como único modelo e exclui quaisquer outras formas de acesso a moradia, como locação social ou propriedade coletiva ou cooperativa (Rodrigues, 2013: 136).

Em termos da sociologia urbana francesa, a aquisição a preço fixo da moradia de baixa renda remunera as parcelas monopolizadas da terra urbana e proporciona ao proprietário a "renda de monopólio" que está incorporada na terra "a construir", isto é, urbana mas não edificada. No entanto, sua compra pelo agente financeiro e sua edificação pelo agente promotor do programa MCMV não convertem esta terra numa edificação disponível no mercado imobiliário, pois esta edificação é repassada a famílias cadastradas por órgãos de governo municipais através de um contrato de alienação de dez anos, em que as prestações mensais são quase inteiramente subsidiadas (cf. tabela T-18). Isto significa que nem a empresa construtora nem a CEF obtém na Faixa 1 do

169 Segundo declaração de um coordenador da Caixa Econômica Federal feita para esta pesquisa, " quem faz a negociação da terra sempre sabe quanto custa o empreendimento, quantas unidades serão construídas, quais áreas são excluídas para equipamentos públicos e proteção ambiental, tudo isso é uma negociação aberta entre construtora e proprietários". De qualquer forma, o valor de teto se torna uma meta de valor (ou "conta de chegada") na formatação dos empreendimentos para a Faixa 1 do programa MCMV, confirmando o diagnóstico do Laboratório de Habitação e Assentamentos Humanos da FAU/USP de que "uma consequência negativa do programa é que os subsídios oferecidos tendem a não mais beneficiar a população alvo da política habitacional, pois são drenados para cobrir o aumento especulativo da terra" (Ferreira, 2012: 49). 
programa MCMV o valor associado à localização urbana da unidade habitacional construída, a "renda diferencial" que é a essência do lucro de incorporação [170].

Como nos empreendimentos para Faixa 1 do programa MCMV a renda de monopólio não se converte em renda diferencial, o único valor da terra urbana que é negociado entre proprietários, corretores e construtores é o valor de mínimo suporte geotécnico e fundiário à construção habitacional. Assim, se um terreno em qualquer ponto das regiões metropolitanas ou das cidades médias listadas na tabela T-27 tiver algum valor em virtude de uma localização acessível, socialmente dinâmica ou ambientalmente favorável, este terreno não será usado para empreendimentos na Faixa 1 do programa MCMV [171].

A localização que é desvalorizada (e, assim, desconsiderada) nos empreendimentos da Faixa 1 do programa MCMV volta a ter valor, no entanto, para as linhas de financiamento da Faixa 2 e Faixa 3 do programa federal. Estes financiamentos usam recursos do Fundo de Garantia por Tempo de Serviço (FGTS), que têm uma exigência de retorno financeiro inexistente na aplicação do Fundo de Arrendamento Residencial. Quando oferece moradia para famílias de renda mais elevadas do programa MCMV, o construtor é também incorporador imobiliário e pode vender localização urbana, com a condição de limitar a comercialização a um valor que, na região metropolitana de São Paulo e no final de 2013, estava em R\$ 190 mil (cf. Resolução 702 de 04 de Outubro de 2012 do Conselho Curador do FGTS). Neste caso, a CEF, ao invés de adquirir diretamente uma moradia, subvenciona sua compra pelo morador, no modelo de um financiamento imobiliário convencional, e oferece algumas vantagens únicas de sua regulação institucional, como um seguro financeiro pelo Fundo Garantidor da Habitação Popular (FGHab). O comprador enquadrado na Faixa 2, com renda familiar mensal entre $\mathrm{R} \$ 1.600$ e $\mathrm{R} \$ 3.275$, recebe também subvenção sobre o valor do imóvel e de pagamento de juros do financiamento.

Os pesquisadores de mercado imobiliário Mário Almeida e Fernando Amato contrastam a aquisição da moradia por parte do FAR/Faixa 1 e a subvenção do morador por parte do FGTS/Faixa 2 e 3 através de uma análise de ciclos de investimento no empreendimento e seus riscos associados (Almeida; Amato, 2011). Nas modalidades em que há o prêmio da venda de localização urbana, os investimentos e os riscos tomam a forma do gráfico G-19:

170 "Para produzir duas unidades habitacionais idênticas do ponto de vista do valor de uso, o montante de capital que deve ser empregado pelo empreiteiro é diferente segundo as localizações: para realizar a mesma operação, a soma do preço da produção das mercadorias particulares que a compõe variará; o empreendedor compara, segundo os terrenos, o "preço de custo construção mais equipamentos" como um valor de uso idêntico - a diferença desta grandeza, segundo as localizações, vai ser um primeiro componente da formação do preço no mercado de terrenos" (Topalov, 1979: 69).

171 Esta regra se aplica para os casos em que localização urbana tem valor de mercado. As exceções dependem de instâncias de governo que controlam a função social da propriedade, tais como as mapeadas na cartilha "Como produzir moradia bem localizada com os recursos do programa MCMV", mantida sem aplicação no site do Ministério das Cidades (Rolnik; Bischof; Klintowits; Reis, 2010). 


\begin{tabular}{|c|c|c|c|}
\hline CICLO FORMATAÇÃO & CICLO LANÇAMENTO & CICLO CONSTRUÇÃO & PÓS-IMPLANTAÇÃO \\
\hline $\begin{array}{l}\text { Investimento em } \\
\text { terrenos, projetos e } \\
\text { despesas legais }\end{array}$ & $\begin{array}{l}\text { Investimento em } \\
\text { promoção e marketing }\end{array}$ & $\begin{array}{l}\text { Investimento para } \\
\text { cobrir defasagem de } \\
\text { fluxos de receita de } \\
\text { vendas e de custeio da } \\
\text { construção }\end{array}$ & $\begin{array}{c}\text { Não há novos } \\
\text { investimentos } \\
\text { Ciclo de "Retorno Puro" }\end{array}$ \\
\hline \multicolumn{4}{|c|}{ RISCOS ASSOCIADOS AO INVESTIMENTO } \\
\hline RISCO MODERADO & RISCO ALTO & RISCO BAIXO & RISCO BAIXO \\
\hline
\end{tabular}

Fonte: adaptado de Almeida; Amato, 2011.

Nos empreendimentos oferecidos para a Faixa 2 e Faixa 3 do programa MCMV, o "ciclo de formatação" do investimento comporta risco moderado à medida que usa apenas o terreno como lastro econômico para a aquisição de serviços de projetos e aprovações legais, serviços que são necessários para o empreendimento mas que não aumentam o valor do terreno.

O risco aumenta ainda mais no subsequente "ciclo de lançamento", em que despesas com a estrutura de comercialização e publicidade não têm qualquer lastro, o que torna irrecuperável um fracasso de vendas. Também aumenta o risco a necessidade de venda comprovada de 30\% das unidades habitacionais para incluir um empreendimento no programa MCMV com financiamento pelo FGTS.

No "ciclo de construção", os riscos diminuem porque as variações de custeio da obra estão previstas tanto no planejamento financeiro da incorporação quanto nos contratos de subempreitada. As unidades à venda são um produto que alavanca financiamentos bancários para a obra. No "ciclo pós-implantação" o único risco ao investimento é uma queda brusca de preços que afete unidades habitacionais à venda após a conclusão do empreendimento. Afora esta hipótese, acontece nesta etapa o objetivo maior da incorporação: o "retorno puro" do investimento, pelo qual o dinheiro emerge do empreendimento integralmente como capital, mais-valor soberano e livre das amarras da produção.

A mesma sucessão de ciclos de investimentos, quando aplicada para um empreendimento da Faixa 1 do programa MCMV, toma a forma de menor risco do gráfico G-20.

G-20|MCMV - Ciclos de investimentos para Faixa 1

\begin{tabular}{|c|c|c|c|} 
CICLO FORMATAÇÃO & CICLO LANÇAMENTO & CICLO CONSTRUÇÃO & PÓS-IMPLANTAÇÃO \\
\hline $\begin{array}{c}\text { Investimento em } \\
\text { terrenos e contas pré- } \\
\text { operacionais no formato } \\
\text { do programa }\end{array}$ & $\begin{array}{c}\text { Ciclo inexistente na } \\
\text { Faixa 1 do programa } \\
\text { MCMV }\end{array}$ & $\begin{array}{c}\text { Investimento para } \\
\text { cobrir defasagem de } \\
\text { fluxos de repasse da CEF } \\
\text { e de custeio da } \\
\text { construção }\end{array}$ & $\begin{array}{c}\text { Ciclo Inexistente na } \\
\text { Faixa 1 do programa } \\
\text { MCMV }\end{array}$ \\
RISCO BAIXO & RISCOS ASSOCIADOS AO INVESTIMENTO & SEM RISCO \\
\hline
\end{tabular}

Fonte: adaptado de Almeida e Amato (2011). 
Na produção para baixa renda no programa MCMV, o risco financeiro do "ciclo de formatação" é necessariamente menor que o de um empreendimento convencional porque o terreno é adquirido diretamente pelo FAR, sem onerar o construtor. Custos e exigências de aprovação são igualmente menores e a única despesa significativa do construtor está na produção de projetos conforme a padronização mínima das Portarias do Ministério das Cidades [172].

Como nos empreendimentos da Faixa 1 a aquisição das unidades habitacionais é garantida e até mesmo antecipada pela CEF através do pagamento por medições de obra, o único risco para as empresas construtoras é administrar um capital de giro que normalize o fluxo de caixa e impeça a única ameaça real ao investimento realizado, que são os atrasos de obra. Contribui para o controle de risco o enquadramento das atividades de construção da Faixa 1 no Regime Especial de Tributação (RET), que unifica numa alíquota de $1 \%$ do faturamento do empreendimento os tributos federais PIS, Cofins, Imposto de Renda da Pessoa Jurídica e Contribuição Social sobre o Lucro Líquido (CSLL).

A segurança financeira para produzir moradia na Faixa 1 do programa MCMV tem, no entanto, um apelo limitado para as empresas construtoras, pois o risco que deixam de correr com a eliminação do "ciclo de lançamento" é também o prêmio que deixam de incorporar com a eliminação da venda de localização urbana no "ciclo de pós-implantação". Daí a ambiguidade das avaliações empresariais, que podem reconhecer numa das edições da revista "Construção e Mercado" que "tem empresa que estava dormindo e acordou para fazer Faixa 1, estão até preferindo essa, que não tem risco, do que fazer as outras faixas" (Ferreira, 2013c: 36-37), mas consideram, em declarações feitas para esta pesquisa, que esta faixa de renda "só serve para o dinheiro da gasolina" ou (indicando de forma mais explícita a ideia de baixo rendimento) "é boa para pegar mil e fazer mil e um" [173].

Este equilíbrio entre ausência de risco financeiro e ausência do prêmio fundiário acompanha toda implantação da modalidade de baixa renda no programa MCMV. Nos dados mais atualizados desta pesquisa, fornecidos pelo $9^{\circ}$ Balanço do Programa de Aceleração do Crescimento (CGPAC, 2014), a segunda fase do programa MCMV contratou no triênio 2011, 2012 e 2013 a aquisição em todo país de 1,052 milhão de unidades habitacionais em empreendimentos para a Faixa 1. São números que indicam tanto uma dificuldade em atingir a meta de 1,6 milhão de moradias de baixa renda até o Dezembro de 2014 quanto uma impressionante produção para um país que, desde a fim do BNH em 1986, não conheceu outra forma de provisão habitacional em escala além da autoconstrução popular.

Ainda assim, a segurança contra prejuízos não é insuficiente para motivar a acumulação de capital e, portanto, deve ser buscada fora da esfera estritamente financeira o estímulo que leva as empresas construtoras brasileiras a assumir em três anos a construção de mais de um milhão de unidades habitacionais nas

172 “Como o produto já tem especificações claras e a CEF irá se responsabilizar pela demanda garantida, diminui a necessidade de definir um projeto inovador para conquistar compradores, como acontece em um empreendimento convencional" (Almeida; Amato 2011: 4). A palavra "projeto" é usada aqui como "empreendimento".

173 As declarações foram espontâneas e dadas fora de um roteiro de entrevistas. Em outro contexto, um colega pesquisador ouviu de um diretor da construtora Emccamp Residencial S/A (que apenas recentemente começou a atuar na RMSP) que os repasses da Faixa 1 não passam de "troco de cebola". 
condições de aquisição da Faixa 1 do programa MCMV. Este estímulo foi adiantado para esta pesquisa pela engenheira de qualidade Elaine Martins, que menciona um "laboratório da baixa renda" ao comentar a participação da Construtora e Incorporadora Faleiros Ltda no programa MCMV:

\begin{abstract}
A Faleiros está no MCMV para aprender a fazer baixar renda. Nós vamos aprender e nós vamos amortizar aqui mesmo [no empreendimento Santa Antonieta, em Mogi das Cruzes] o que a gente aprender, porque o empreendimento todo já está vendido para a Caixa (...) Isso aqui é nosso laboratório, é o laboratório da baixa renda, porque aqui a gente tem segurança para trabalhar e para pesquisar.
\end{abstract}

A fala apenas dá expressividade para um raciocínio que deriva, na verdade, dos conteúdos apresentados e discutidos nos capítulos 6 e 7 sobre a tecnologia organizacional dos sistemas de gestão de qualidade. A implantação desta tecnologia tem duas características incontornáveis. A primeira é o custo elevado, que é tanto financeiro, com a contratação de consultorias, treinamentos e empresas certificadoras, quanto em horas-trabalho, decorrentes da alteração de organização, cargos e procedimentos. A segunda característica incontornável é a coerção de governo, que torna obrigatória a adoção do sistema de gestão de qualidade para a operação de construção com recursos públicos federais.

Para empresas que buscam a primeira certificação de qualidade, a segurança do valor máximo de aquisição é, assim, uma segurança necessária, pois a alteração causada pelos sistemas de gestão de qualidade sobre o controle da produção e, principalmente, sobre os serviços subempreitados afeta um fluxo de caixa pequeno e apoiado em poucos empreendimentos.

A tendência de concentração de renda no programa MCMV, por outro lado, torna o "laboratório da baixa renda" ainda mais atraente para as grandes empresas construtoras, que já possuíam certificação de qualidade quando do lançamento do programa federal. Para estas, a tecnologia a experimentar nas seguras condições dos empreendimentos da Faixa 1 amplia os aspectos organizacionais no sentido da gestão de novas tecnologias construtivas. A tecnologia do concreto auto-adensável, discutida no capítulo 4, passou a ser empregada nos empreendimentos de baixa renda em associação com fôrmas de parede e laje, de produção complexa e de alto custo. No entanto, ao final de um empreendimento da Faixa 1 do programa MCMV, o custo destas fôrmas não só está amortizado como também a tecnologia está testada, medida e incorporada aos demais processos construtivos da empresa construtora.

Investimentos de menor visibilidade se beneficiam igualmente da segurança financeira dos empreendimentos de baixa renda. Em declaração para esta pesquisa, um engenheiro da Maxi Engenharia e Construções Ltda considerou a adoção dos veículos Skytrak (também discutida no capítulo 4) como uma experiência em logística de obra que não poderia ser testada fora da Faixa 1 do programa MCMV, pois "o Skytrak muda toda a nossa relação com os subempreiteiros, a gente precisava mudar as estimativas de trabalhadores, frentes de obra, produtividade. Era muito arriscado fazer isso nos outros empreendimentos da empresa".

O resultado mais imediato destas experimentações tecnológicas é obter, num empreendimento isolado, um aumento de produtividade em relação à produtividade média do programa MCMV, isto é, obter um tipo especial de 
ganho de produtividade, que pode ser monopolizado por um único produtor. Este ganho era recorrente na introdução de novas máquinas na primeira industrialização, quando Marx o descreveu como um aspecto temporário da extração de mais-valor relativo, por acontecer durante "um período de transição, em que a indústria mecanizada permanece uma espécie de monopólio, os ganhos são extraordinários, e o capitalista procura explorar ao máximo esse 'primeiro tempo do jovem amor'"' (Marx, 2013 [1867]: 479) [174].

No programa MCMV, o período de transição em que estes ganhos de produtividade são monopolizados nos canteiros de obras da Faixa 1 podem se estender por anos, uma vez que não são ganhos detectados pelo instrumento mais efetivo para generalizar as taxas de produtividade no programa: a tabela do Sistema Nacional de Pesquisa de Custos e Índices da Construção Civil (Sinapi). A forma convencional como as composições de custo do Sinapi representa os processos de trabalho da construção habitacional (exemplificada no capítulo 2) acaba por remunerar todos os empreendimentos do programa MCMV conforme uma produtividade média, que é transmitida para as medições físicas de obra por meio das Planilhas de Levantamento de Serviços (PLS). Desta forma, o programa MCMV remunera apenas composições orçamentárias genéricas, não a produtividade real das empresas construtoras [175].

O ganho de produtividade em relação ao referencial de orçamentação do Sinapi é um resultado imediato da tecnológica organizacional, mas que não fica restrito ao conjunto dos empreendimentos para baixar renda. Pelo contrário, o objetivo principal das grandes empresas construtoras é transferir estes ganhos de produtividade para os empreendimentos das faixas de renda média, em que a tecnologia construtiva incorporada à empresa pode ser combinada com a venda de localizações urbanas.

Esta transferência de tecnologia da baixa renda para as rendas médias tem uma condição básica, que é haver empresas construtoras gerenciando obras tanto na Faixa 1 quanto em outras faixas do programa MCMV. Em 2013, a Fundação Getúlio Vargas (FGV) realizou pesquisa entre 66 empresas construtoras que atuavam naquele ano no programa MCMV, em todo o país. A distribuição das empresas segundo as faixas de renda do programa federal em que possuíam empreendimentos aparece no gráfico G-21:

174 Segundo Rubens Enderle, as últimas palavras citam versos do poema "A canção do sino", de Schieller, versos 78-9: 'Oh, que dure para sempre o frescor, / Do belo tempo do jovem amor! " (Marx, 2013 [1867]: 479).

175 Uma completa revisão das composições de custo da tabela Sinapi foi iniciada em 2013, sob coordenação de Ubiraci de Souza. A revisão vai aferir parâmetros de produtividade de canteiros de obras como os organizados no programa MCMV. Na opinião de José Medaglia, Superintendente Nacional de Assistência Técnica da CEF, “devíamos fazer uma revisão geral, porque há novas técnicas entrando na construção, há diferenças de produtividade, uso de novos equipamentos. Precisamos trazer essa realidade para dentro do sistema" (Ferreira, 2013b: 19). 


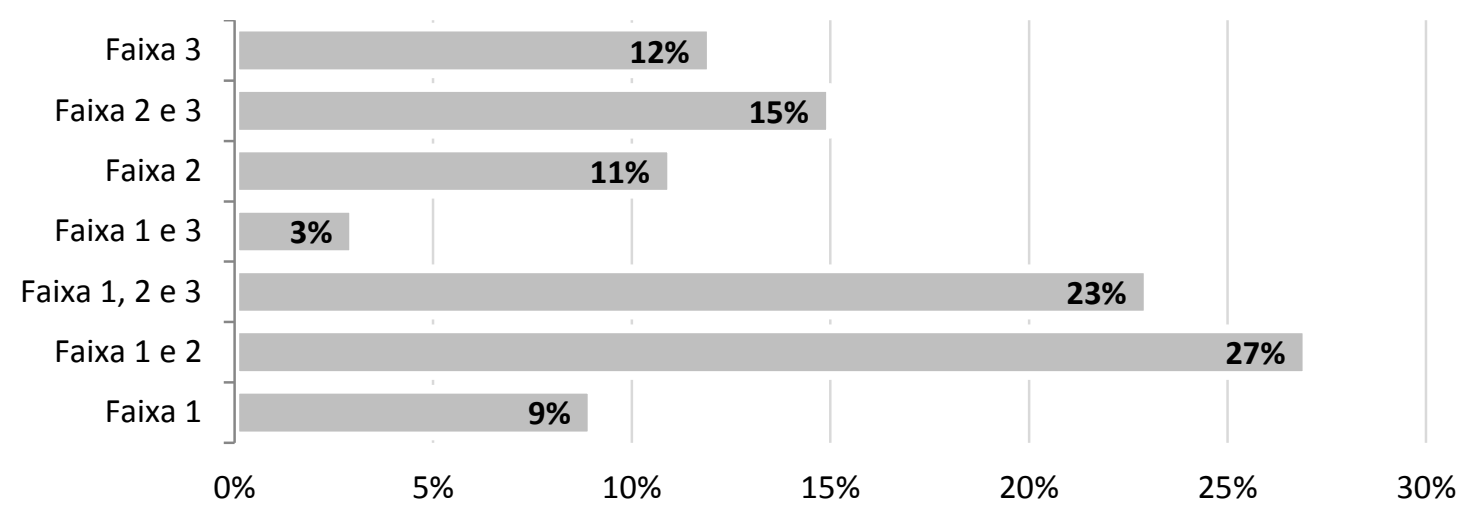

Fonte: FGV, 2013

Pouco mais da metade das empresas construtoras (53\%) combina a atuação em empreendimentos na Faixa 1 com a Faixa 2 e Faixa 3. A publicação da pesquisa pelo Sinduscon/SP omite quais são estas empresas, mas a distribuição torna razoável incluir as grandes construtoras na metade em que aparecem os empreendimentos da Faixa 1, uma vez que são as empresas com maior capacidade financeira para gerenciar diversos empreendimentos simultâneos e com grande quantidade de unidades habitacionais. De qualquer forma, o maisvalor relativo temporariamente obtido por uma empresa na Faixa 1 do programa MCMV é facilmente transferido para os empreendimentos que esta mesma empresa constrói em outras faixas de renda. Como todo monopólio, o domínio tecnológico que uma empresa construtora obtém na segurança da baixa renda está à disposição para ser usado onde mais a sua estratégia comercial exigir [176].

Outro fator que facilita a transferência de tecnologia é a semelhança entre os empreendimentos das diferentes faixas de renda do programa MCMV, que diferem de forma relevante apenas no que diz respeito à localização. É frequente que a tipologia espacial das unidades habitacionais e sua distribuição em blocos seja absolutamente a mesma. Quando há alterações, as mais profundas são o acréscimo de varandas (mas sem acréscimo de área coberta) e coberturas com beirais sobre os edifícios ou em anexos como o centro de medição de energia. $\mathrm{Na}$ implantação condominial, há apenas o aumento de área de estacionamento, na proporção de uma vaga por apartamento.

Portanto, a transferência de tecnologia ocorre entre empreendimentos de uma única empresa construtora que têm poucas diferenças construtivas mas grandes diferenças de localização urbana e na modalidade de risco e rentabilidade em que é financiado pelo programa MCMV.

Uma pesquisa realizada por Gabriel Andrade sobre a incorporação de imóveis financiados pelo programa MCMV acrescenta outra motivação para esta transferência, que é a concorrência mais acirrada na incorporação para famílias

$176 \mathrm{O}$ dado mais difícil de interpretar diz respeito aos $9 \%$ de empresas construtoras que se dedicam unicamente a construir para a Faixa 1 . O mais provável é que seja a contagem de pequenas construtoras que atuam nos financiamentos de "Oferta Pública" para municípios com menos de 50 mil habitantes, incluídos no programa MCMV pela bancada municipalista do Congresso Nacional. Em geral estes empreendimentos são construídos por empresas locais, para as quais a ausência de riscos é estímulo suficiente para executar projetos nesta modalidade, que é exclusiva para baixa renda. 
de renda média do que no mercado imobiliário de alta renda, em que a disputa por localizações de alto valor se dá entre poucas empresas. A pesquisa registra o relato de um corretor de imóveis especializado na Faixa 2 e 3 que confirma o acirramento da competição envolvida neste segmento imobiliário:

Há grande concorrência, e não estou falando de incorporadoras grandes, listadas em bolsa, estou falando de todas as pequenas construtoras presentes em pequenas cidades. Não existem barreiras à entrada. Quanto às despesas de vendas, elas são menores. Não se abre champanhe francês quando alguém fecha uma venda. Nossas vendas são na maior parte das vezes feitas nos plantões da Caixa, onde as pessoas compram os imóveis em uma feira. Lá mesmo a CEF checa a condição de renda e concede o financiamento. Nosso maior esforço comercial é fazer com que os compradores escolham a nossa empresa por já terem visto um empreendimento nosso e confiar na qualidade. Além disso, fazemos propagandas na TVe na internet, mas nada que se compare ao mercado de alta renda (Andrade, 2013: 72).

A "feira" a qual o corretor se refere é o "Feirão da Caixa", evento itinerante em que empresas construtoras e incorporadoras podem disputar compradores subvencionados pela CEF, com renda familiar mensal entre $R \$ 1.600$ e $R \$ 5.000$, respeitados os limites regionais de preço de venda. A elevada competição resultante destas condições de venda (em que o nome "feira" parece apropriado) torna relevante o aumento de controle tecnológico sobre os processos de construção e, neste sentido, é significativo que o relato acima tenha mencionado "confiar na qualidade" como uma distinção de mercado, ao invés da localização urbana. $\mathrm{O}$ "segmento econômico" do mercado imobiliário não lida com a mesma escassez de localizações dos imóveis para alta renda e, com o incremento médio de padrões construtivos, não pode dispensar indefinidamente a busca por ganhos produtivos para seus empreendimentos[177].

I-19| Imagens do "Feirão da Caixa"
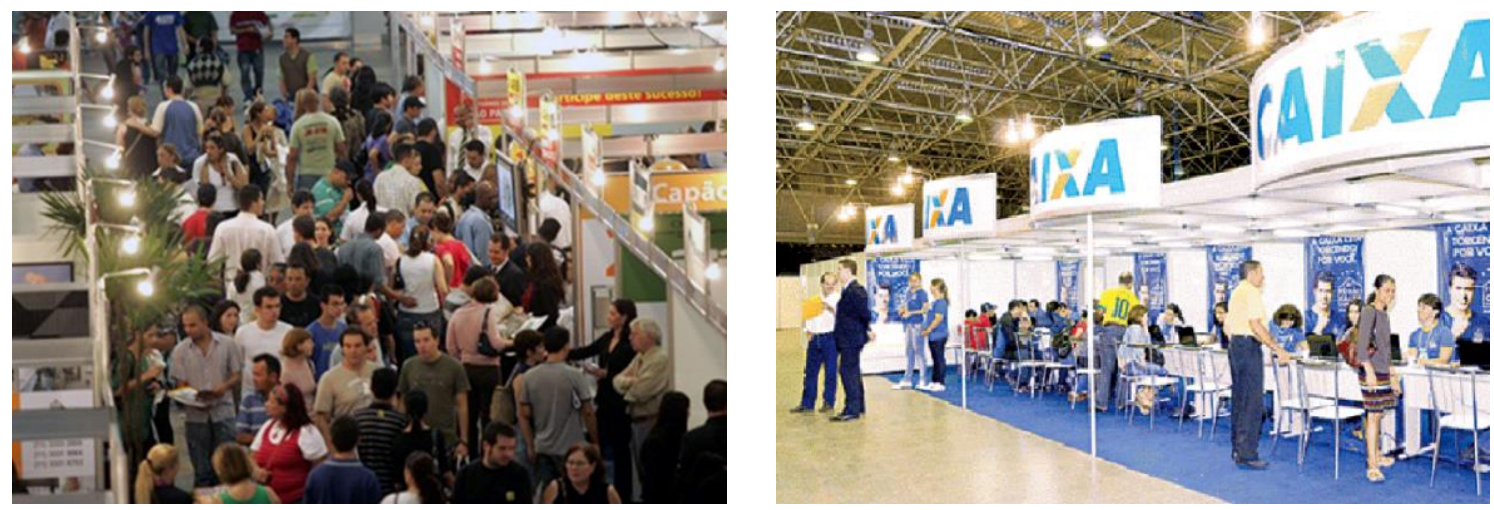

À esquerda, “Feirão" realizado em São Paulo no Expo Center Norte, um dos maiores do país (Paulo Pinto - Agência Estado); à direita, estandes de análise de crédito da CEF (Anna Munhoz - Jornal Mauá)

177 Escrevendo sobre o mercado de alta renda da passagem dos anos 1980-1990, Nilton Vargas percebeu que os ganhos de incorporação imobiliária são "a razão do limitado progresso técnico e organizacional da construção habitacional" uma vez que "os capitais invertidos no subsetor [de construção habitacional] encontram fora da esfera produtiva a melhor maneira de se apropriarem do excedente econômico. E por isso não há necessidade de se imobilizar em máquinas e equipamentos para aumentar a produtividade" (Vargas 1994: 219). Neste caso, o ganho de produtividade é irrelevante e desestimulado diante do ganho fundiário, mas Nilton Vargas está analisando um mercado de menor concorrência e uma época em que o custo de edificação, particularmente da força de trabalho, era igualmente menor. 
Quanto ao conteúdo da transferência de tecnologia dos empreendimentos de baixa renda para os de renda média, ele pode se limitar aos procedimentos controlados pelo sistema de gestão de qualidade ou incluir tecnologias que necessitam de amortização de investimento e alterações substanciais de processos produtivos para serem testadas e controladas. $\mathrm{O}$ exemplo a seguir combina ambas características e é usado mais pela conveniência de ser um componente pré-fabricado da Cury Construtora S/A produzido na "fábrica de lajes" descrita no capítulo 7, uma iniciativa do engenheiro David Nonno bem documentada pela apresentação na $11^{a}$ Conferência Lares (Nonno, 2011).

O componente pré-fabricado - um contramarco de janela em argamassa armada - tem dimensões bem mais modestas do que as demais peças produzidas na "fábrica de lajes", mas cumpre funções igualmente críticas para uma rápida execução de obra. Na tecnologia da alvenaria estrutural, serve como gabarito e suporte estrutural dos vãos de esquadrias e, desta forma, acelera em dois momentos a execução de paredes: ao servir como referência geométrica para o assentamento de blocos junto ao vão e, depois, ao retirar das atividades do bloqueiro a construção de verga e contraverga de janela, que demanda o uso de blocos canaletas, colocação de armadura e lançamento de concreto grout em duas fases intermediadas por atividades de escoramento. Após a conclusão da alvenaria estrutural, a planicidade do contramarco facilita a instalação de esquadria e serve também como arremate nivelado para o revestimento interno.

Para cumprir tantas funções num volume relativamente pequeno, o contramarco exige fôrmas precisas e uma usina de argamassa com grande controle de materiais e procedimentos. Estas condições de produção foram criadas pela construtora Cury na usina financiada pelos empreendimentos "Judiapeba", em Mogi das Cruzes, um dos primeiros e maiores do programa MCMV na região metropolitana de São Paulo (cf. tabela T-20), executado ainda para a antiga faixa de renda de 0 a 3 salários mínimos.

A primeira vez que estes contramarcos foram observados durante a pesquisa (em que ficava evidente sua utilidade) não foi em Mogi das Cruzes, mas num empreendimento da Cury Construtora S/A iniciado na segunda fase do programa MCMV e destinado a comercialização para famílias com renda mensal entre R\$ 1.600 e R 3.725 (Faixa 2), o “Viva Mais Itaquá”, em Itaquaquecetuba. Um dos engenheiros da empresa solicitou que uma entrevista previamente marcada fosse transferida para este local e, como compensação pela mudança, acrescentou: "o empreendimento é idêntico ao da Faixa 1: o apartamento, área de escada, distribuição dos blocos, é tudo igual". O contramarco pré-fabricado também. 

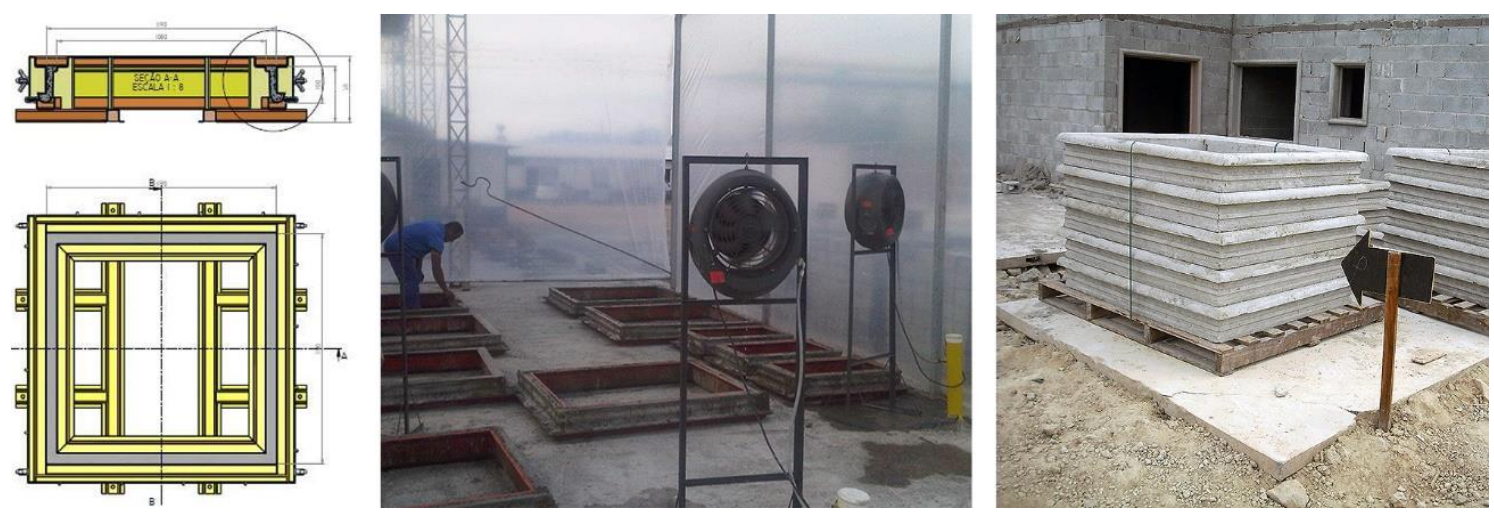

À esquerda, projeto de fôrma de contramarco de argamassa armada e, no centro, cura controlada no empreendimento Judiapeba, para Faixa 1 do programa MCMV (Nonno, 2011: 56); à direita, peças estocadas e instaladas no empreendimento "Viva Mais Itaquá", para Faixa 2 do programa MCMV.

A transferência tecnológica dos empreendimentos de baixa renda para os de renda média não é uma iniciativa isolada de empresários ou governantes, mas um movimento do mercado da construção habitacional que é dos mais racionais, pois é uma transição de capital de um ambiente de negócios de remuneração previsível e estável para outro mais arriscado, mas onde o ciclo de retorno inclui a venda de localizações urbanas para a crescente classe de consumo " $\mathrm{C}$ " $\mathrm{e}$ " $\mathrm{D}$ ". O risco inerente à implantação de uma nova tecnologia, seja ela uma barreira de entrada como os sistemas de gestão de qualidade ou experiências subsidiárias em pré-fabricação ou equipamentos de alto custo, é equilibrado pela segurança do "preço máximo de aquisição" da Faixa 1. Uma vez dominada e amortizada esta tecnologia, ela vai ser replicada como diferencial produtivo no ambiente competitivo das demais faixas de renda, onde verdadeiramente se acumula e se concentra o capital da construção habitacional.

O resultado final é uma continuidade da tecnologia construtiva entre diferentes faixas de renda, mas que ratifica o mercado de localizações e, portanto, reforça a característica final do programa MCMV como promotor da segregação urbana da população de baixa renda.

\section{A segregação aperfeiçoada}

Uma característica da segregação urbana abordada no subcapítulo anterior é que ela nunca acontece em descumprimento ou afrontando o aparato legal e institucional que gere o programa MCMV. Leis, Resoluções e Portarias se sucedem e são todas cumpridas pelos empreendimentos que, entre 2011 e 2013, usaram a tecnologia gerencial e organizacional do PBQP-H e ISO 9001:2008 para acrescentar um milhão de moradias para baixa renda unicamente nas áreas urbanas em que se concentra a população de baixa renda.

Como a segregação urbana prossegue indiferente à regulação institucional do programa MCMV, ela se naturaliza aos olhos de seus gestores de governo e empresariais. Para estes, vai contra a natureza desta segregação transferir uma família pobre para localizações cuja qualidade urbana está precificada para cima 
pelo mercado imobiliário, sendo admissível apenas que ela seja transferida para uma unidade habitacional de produção padronizada e posse formal. Esta dissociação entre moradia e localização se orienta materialmente pelo mercado de terra urbana, mas acredita que os processos de melhoria estão conectados, de forma que a melhoria da moradia provoque a melhoria da localização.

No entanto, a própria melhoria da moradia é limitada, pois o avanço da tecnologia organizacional dos sistemas de gestão de qualidade e sua disseminação como ação de governo transformam o processo produtivo mais do que o produto. Este, por sua vez, perdeu qualquer intencionalidade nas relações entre espaços que lhe são internos e externos. Estas são as relações essenciais da arquitetura e, no programa MCMV, estão ausentes da mesma forma como Lúcia Shimbo descreve em sua tese de doutorado sobre o mercado da "habitação social":

Inicialmente, no meu projeto de doutorado, procurei tratar sobre a produção da arquitetura desde o canteiro de obras, a partir das relações entre os trabalhadores ali presentes e os arquitetos. Ao entrar no canteiro, que foi o ponto de partida da minha pesquisa de campo, percebi que não havia ali arquitetos, tampouco a arquitetura strictu sensu. Não havia, naquela edificação em construção, alguns dos pressupostos básicos do ofício como, por exemplo, a busca pela orientação solar mais adequada; pela implantação em conformidade com o perfil do terreno; pela otimização da circulação interna; pela relação equilibrada entre forma, função e materialidade; e pela análise da inserção urbana do edificio (Shimbo, 2010: 329).

Na presente pesquisa de doutorado, a avaliação é a mesma: não há arquitetos e tampouco arquitetura nos empreendimentos para baixa renda no programa MCMV. Assim como o déficit habitacional legitima o ordenamento economicista do programa (como discutido no capítulo 5), a precariedade da moradia autoconstruída no Brasil legitima a construção de uma unidade habitacional conforme um projeto que é exclusivamente Projeto de Produção.

A definição mais direta deste Projeto de Produção aparece em "O canteiro e o desenho", no capítulo em que Sérgio Ferro trata do "desenho separado" como "desenho de representação do objeto a construir, ordem de serviço" (Ferro, 2006 [1976]: 174). Quando este exercício de poder quer justificar sua separação em relação ao canteiro de obras, ele apela à autonomia da arquitetura e à sua busca exclusiva por noções como "equilíbrio" e "harmonia". Pois bem, no programa MCMV, o Projeto de Produção dispensa este pudor ideológico e mantém o nome "Projeto de Arquitetura" apenas por convenção contratual, pois os únicos valores que carrega são diretamente oriundos da produção empresarial: "construtibilidade" à frente de todos, mas também "redução de operações", "controle de procedimentos", "logística de obra" e, por que não, "qualidade".

A única demanda externa à produção que este projeto precisa seguir são as "especificações mínimas" para empreendimentos financiados pelo FAR, editadas pelo Ministério das Cidades na condição de agente gestor do programa MCMV. Trata-se de uma especificação realmente "mínima": duas tabelas hospedadas no site "www.cidades.gov.br", uma para "casa" (entendida como "edificação residencial unifamiliar de um pavimento") e outra para as tipologias residenciais multifamiliares (ou unifamiliar com mais de um pavimento), que são 
“apartamento, casa sobreposta, village, sobrado". Uma reprodução da parte superior desta última tabela aparece na imagem I-21 [178]:

I-21|MCMV 2 - Especificações mínimas de unidade habitacional

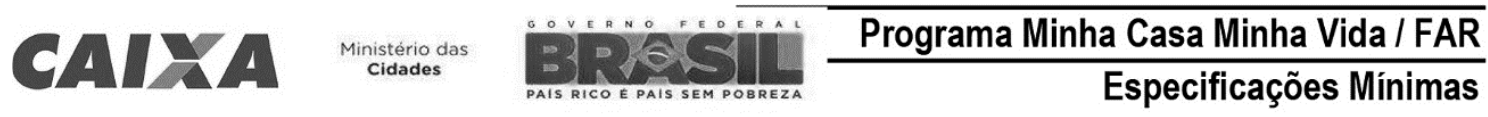

\begin{tabular}{|c|c|}
\hline \multicolumn{2}{|c|}{$\begin{array}{l}\text { Apartamento* / Casa sobreposta* / Village* / Sobrado** (Para contratação com valor máximo de aquisição da unidade de acordo com o item } 7.1 \text { do } \\
\text { Anexo I da Portaria } N^{\circ} 465 \text {, de } 03 \text { de outubro de 2011) }\end{array}$} \\
\hline Projeto & Unidade habitacional com sala / 1 dormitório para casal e 1 dormitório para duas pessoas / cozinha / área de serviço / banheiro. \\
\hline \multicolumn{2}{|c|}{$\begin{array}{l}\text { DIMENSÕES DOS CÔMODOS (Estas especificações não estabelecem área mínima de cômodos, deixando aos projetistas a competência de formatar os ambientes da } \\
\text { habitação segundo o mobiliário previsto, evitando conflitos com legislações estaduais ou municipais que versam sobre dimensões mínimas dos ambientes) }\end{array}$} \\
\hline Dormitório casal & $\begin{array}{l}\text { Quantidade mínima de móveis: } 1 \text { cama }(1,40 \mathrm{~m} \times 1,90 \mathrm{~m}) \text {; } 1 \text { criado-mudo }(0,50 \mathrm{~m} \times 0,50 \mathrm{~m}) \text {; e } 1 \text { guarda-roupa }(1,60 \mathrm{~m} \times 0,50 \mathrm{~m}) \text {. Circulação mínima } \\
\text { entre mobiliário e/ou paredes de } 0,50 \mathrm{~m} \text {. }\end{array}$ \\
\hline Dormitório duas pessoas & $\begin{array}{l}\text { Quantidade mínima de móveis: } 2 \text { camas }(0,80 \mathrm{~m} \times 1,90 \mathrm{~m}) ; 1 \text { criado-mudo }(0,50 \mathrm{~m} \times 0,50 \mathrm{~m}) \text {; e } 1 \text { guarda-roupa }(1,50 \mathrm{~m} \times 0,50 \mathrm{~m}) \text {. Circulação } \\
\text { mínima entre as camas de } 0,80 \mathrm{~m} \text {. Demais circulações minimo de } 0,50 \mathrm{~m} \text {. }\end{array}$ \\
\hline Cozinha & $\begin{array}{l}\text { Largura mínima da cozinha: } 1,80 \mathrm{~m} \text {. Quantidade mínima: pia }(1,20 \mathrm{~m} \times 0,50 \mathrm{~m}) \text {; fogão }(0,55 \mathrm{~m} \times 0,60 \mathrm{~m}) \text {; e geladeira }(0,70 \mathrm{~m} \times 0,70 \mathrm{~m}) \text {. Previsão } \\
\text { para armário sob a pia e gabinete. }\end{array}$ \\
\hline Sala de estar/refeições & $\begin{array}{l}\text { Largura minima sala de estar/refeições: } 2,40 \mathrm{~m} \text {. Quantidade minima de móveis: sofás com número de assentos igual ao número de leitos; mesa para } \\
4 \text { pessoas; e Estante/Armário TV. }\end{array}$ \\
\hline Banheiro & $\begin{array}{l}\text { Largura mínima do banheiro: 1,50 m. Quantidade mínima: } 1 \text { lavatório sem coluna, } 1 \text { vaso sanitário com caixa de descarga acoplada, } 1 \text { box com } \\
\text { ponto para chuveiro - }(0,90 \mathrm{~m} \times 0,95 \mathrm{~m}) \text { com previsão para instalação de barras de apoio e de banco articulado, desnivel máx. } 15 \mathrm{~mm} \text {; Assegurar a } \\
\text { área para transferência ao vaso sanitário e ao box. }\end{array}$ \\
\hline Área de Serviço & Quantidade mínima: 1 tanque $(0,52 \mathrm{~m} \times 0,53 \mathrm{~m})$ e 1 máquina $(0,60 \mathrm{~m} \times 0,65 \mathrm{~m})$. \\
\hline Em Todos os Cômodos & $\begin{array}{l}\text { Espaço livre de obstáculos em frente às portas de no minimo 1,20 m. Deve ser possivel inscrever, em todos os cômodos, o módulo de manobra sen } \\
\text { deslocamento para rotação de } 180^{\circ} \text { definido pela NBR } 9050(1,20 \mathrm{~m} \times 1,50 \mathrm{~m}) \text {, livre de obstáculos. }\end{array}$ \\
\hline \multicolumn{2}{|r|}{ CARACTERISTICAS GERAIS } \\
\hline $\begin{array}{l}\text { Área útil (área interna sem } \\
\text { contar áreas de paredes) }\end{array}$ & $39,00 \mathrm{~m}^{2}$ \\
\hline
\end{tabular}

Fonte: www.cidades.gov.br/images/stories/ArquivosSNH/ArquivosPDF/Especificacoes

A tabela começa pelas especificações referentes a "dimensões dos cômodos", para os quais "não estabelecem área mínima", mas apenas mobiliário e espaços de circulação. O propósito alegado é evitar "conflitos com legislações estaduais ou municipais", o que não impede, no entanto, que a primeira linha das especificações referentes a "características gerais" das unidades habitacionais (no pé da imagem I-21) mostre com precisão de centésimos a área útil mínima de "39,00 $\mathrm{m}^{2}$ ", um dimensionamento que amesquinha qualquer organização dos cômodos listados na mesma tabela. Apenas a especificação que aparece uma linha acima, referente a espaços de manobra de cadeiras de rodas, impede que as unidades habitacionais cheguem a um limiar de área tão baixo [179].

A liberdade para buscar esta área reduzida é mais determinante para o estudo de viabilidade dos empreendimentos do que qualquer uma das 44 especificações que se seguem até o fim da tabela, muitas delas introduzidas com destaque em

178 Segundo relato de um gestor da CEF, um conjunto de requisitos consolidado durante anos pelo banco como um Manual Técnico de Empreendimentos foi abandonado para fins de análise de propostas para o programa MCMV. Esta teria sido uma decisão da gestão do programa com o objetivo de não criar obstáculos aos processos produtivos consolidados de cada empresa construtora.

179 A área útil mínima especificada pelo Ministério das Cidades para uma moradia concebida para quatro pessoas e dois dormitórios não tem equivalente em qualquer país com um histórico significativo em políticas habitacionais. Num estudo comparativo entre o programa MCMV e seu equivalente em Portugal, o programa de "Habitação a Custo Controlado" (HCC), o arquiteto João Branco Pedro aponta que "a área útil mínima estabelecida para os apartamentos do programa MCMV é cerca de $71 \%$ da área útil mínima e $61 \%$ da área útil máxima definida para as habitações do programa HCC (...) Para os padrões europeus, a área útil por morador estabelecida no programa MCMV situa-se próximo do limiar crítico, abaixo do qual tende a aumentar a prevalência de situações patológicas (acidentes, violência, insalubridade, doença) e numa faixa em que a satisfação dos moradores para com a habitação tende a ser negativa" (Branco Pedro, 2012: 127). 
propagandas oficiais na segunda fase do programa MCMV, como piso cerâmico em todo apartamento, esquadrias de $1,5 \mathrm{~m}^{2}$ ou azulejos em meia altura em cozinha e banheiros. O efeito maior não acontece no custo total de edificação, cuja alteração é marginal quando o aumento de área útil se dá pelo aumento de pisos secos em dormitórios e sala, mas sim no menor aproveitamento dos terrenos para a implantação de unidades habitacionais. $\mathrm{O}$ aumento da área privada aumenta a fração ideal do terreno apenas porque as empresas construtoras que atuam no programa MCMV não oferecem outro modelo de densidade habitacional do que o bloco residencial de cinco pavimentos organizado na tradicional tipologia " $\mathrm{H}$ ", em que dois pares simétricos de apartamentos são separados por uma caixa de escada. Esta tipologia construtiva está tão incorporada nos processos produtivos que até mesmo em terrenos em declive e aclive, que poderiam verticalizar a habitação posicionando os acessos coletivos no segundo ou terceiro pavimento dos blocos em " $\mathrm{H}$ ", apenas edifícios de cinco pavimentos são implantados.

Guiados por tipologias convencionais e especificações mínimas, o único desafio atual do Projetos de Produção do programa MCMV é se adaptar a uma nova normatividade técnica da construção habitacional, a da NBR 15.575: 2013 "Desempenho para Edificações Habitacionais", cujo período de "exigibilidade" começou em 19 de Julho de 2013, após treze anos de revisões e prorrogações. Esta norma técnica sistematiza mais de 200 requisitos de habitabilidade e conforto, a maior parte já editados em normas de componentes e materiais, mas que nunca foram reunidos para estabelecer critérios técnicos de desempenho exigíveis de um edifício completo. Os requisitos se agrupam em um capítulo de "requisitos gerais" e outros cinco dedicados a estruturas, pisos, vedações, coberturas e instalações hidrossanitárias, todos eles tratados como "sistemas habitacionais", em que o desempenho é obtido pelo uso combinado e racionalizado de diversos materiais e serviços.

Normas que incidem sobre desempenho técnico de um edifício ao invés de suas partes isoladas são comuns em diversos países e cumprem uma função análoga à da norma de qualidade quando regula gestão de produção ao invés de produtos. É possível assegurar desempenho de uma edificação sem precisar considerar a opção por técnicas ou materiais de construção, o que resolve situações como a descrita por Maria Angélica Covelo Silva, que participou da elaboração da NBR 15.575: "hoje, há muita confusão em torno do que é qualidade. Os próprios Procons cobram marcas, quando deveriam cobrar o desempenho, que é o fundamental" (Rocha, 2013: 11) [180].

No entanto, ao contrário dos sistemas de gestão de qualidade, que foram impostos às empresas construtoras como condição de acesso a recursos públicos

180 Assim como os sistemas de gestão de qualidade iniciam sua disseminação na construção civil brasileira pela habitação de baixa renda, a norma de desempenho habitacional começou a ser elaborada a partir das pesquisas do Instituto de Pesquisas Tecnológicas (IPT) que resultaram no caderno "Critérios Mínimos de Desempenho para Habitações Térreas de Interesse Social", publicação que também forneceu as primeiras contribuições técnicas para o PBQP-H. Vanderley John lembra que a versão inicial da norma se restringia a edifícios de cinco pavimentos "porque, na época em que a norma começou a ser desenvolvida, a CEF só financiava edifícios até cinco pavimentos (...) Essa norma começou como uma norma para baixa renda. Quando ela estava praticamente pronta, o Sinduscon-SP disse que ela não poderia ser cobrada só para baixa renda, porque a baixa renda teria requisitos que a alta não tem" (Faria, 2013: 25). 
federais, uma norma técnica elaborada no âmbito da ABNT só pode ser implantada por consenso de mercado. Uma vez publicada e iniciado o prazo de "exigibilidade", a norma passa a vigorar como parte das obrigações contratuais referentes à capacidade técnica de empresas construtoras. Num país em que qualquer regulação é permitida enquanto não for preciso aplicá-la, o pouco que a NBR 15.752 contém de efetividade foi suficiente para submetê-la a uma revisão que durou mais de uma década [181].

O sentido desta revisão foi anunciado da seguinte forma por Carlos Borges, vicepresidente do Sindicato da Habitação de São Paulo (Secovi-SP) e coordenador da comissão de estudos da norma entre 2004 e 2008:

A revisão trouxe mudanças no sentido de atenuar e simplificar a aplicação, levando-se em conta o estado econômico, técnico e social do Brasil hoje. O desempenho está associado a uma análise de valor que é o custo do desempenho. E não temos condições, hoje, de adotar indices de desempenho iguais a alguns países desenvolvidos (Corsini, 2013: 51).

Entre os requisitos técnicos que foram reduzidos "ao estado econômico, técnico e social do Brasil de hoje", um em especial - a exigência de sombreamento para janelas de dormitórios - implicou não apenas em diminuição de custo, mas também em descarte de parte significativa da arquitetura desenvolvida no país, descarte que é assumido da seguinte forma por Maria Angélica Covelo:

Isso foi retirado porque não existe o hábito de se usar dispositivos de sombreamento, seja um brise, uma persiana, uma veneziana ou qualquer efeito arquitetônico que cause uma sombra no dormitório, pelo receio de que isso se tornasse um custo excessivo. Acho que a retirada desse item foi um prejuízo muito grande (Corsini, 2013: 52).

A redução de especificações técnicas, mesmo quando destroem a própria história da arquitetura brasileira, pode prosseguir até atingir um custo de implantação que as grandes empresas construtoras considerem equilibrado para a continuidade do processo de concentração de capital na construção habitacional brasileira. O alto grau de controle que estas empresas têm sobre sua produção (subempreiteiros incluídos) favorece uma adaptação rápida e de baixo custo aos requisitos de desempenho da NBR 15.572 tal como foram revisados. O mesmo não acontece com construtoras de menor capital, em que qualquer aumento de custo de construção incide sobre um faturamento menor e, portanto, uma menor capacidade de financiamento. Segundo um consultor do Sinduscon-MG, a elevação de custo derivada da exigibilidade da norma de desempenho é mais acentuada nos empreendimentos da Faixa 1 do programa MCMV: "no segmento de baixa renda, que tem menor flexibilidade, o aumento de custo vai ser maior. Alguns dizem que pode haver um encarecimento de 7\% na produção" (Corsini, 2013: 53).

Trata-se de mais um impulso para a concentração de capital na construção habitacional, que Luiz Ceotto, com sua franqueza característica, defende que seja ampliada ao invés de contida pela revisão de especificações:

181 Caso semelhante ocorreu em 2013 com o Código Florestal, que precisou ser abrandado quando as infrações passaram a suspender financiamentos federais. É de se prever, portanto, que o Estatuto das Cidades continuará intocado como legislação exemplar no controle da função social da propriedade enquanto permanecer sem uso por parte dos governos municipais brasileiros. 
A revisão da norma de desempenho está sendo benfeita, mas o pessoal luta para baixar especificação. E a norma de desempenho deve procurar aumentar a especificação, para fazer com que as construtoras que sejam tecnicamente melhores sobrevivam. Existe uma quantidade enorme de construtoras e muitas precisam desaparecer (...) O nosso dever de casa é premiar as melhores construtoras, aumentar a competitividade entre as empresas, fazer com que as empresas possam competir de maneira saudável. Não interessam barreiras de entrada, mas não podemos deixar que, com a melhora do setor, venham aventureiros. É preciso criar barreiras técnicas e de qualidade (Tamaki, 2012: 21).

É possível ainda regular a intensidade com que grandes empresas construtoras se apoderam da produção habitacional no programa MCMV, mas a melhoria da moradia que o programa pode reivindicar não é orientada por qualquer outro ideal que não seja este mesmo processo de concentração de capital.

Os gestores públicos e privados do programa MCMV também acreditam que podem isolar a localização de seus empreendimentos para baixa renda desta lógica de acumulação de capital. Na instituição da segunda fase do programa, em Julho de 2011, esta conviç̧ão parecia orientar os empreendimentos de baixa renda em direção a terras com qualidades urbanas positivas. Esta impressão decorre de um artigo da lei que reeditou o programa (Lei Federal 12.424) redigido em reação às críticas que trataram a primeira legislação como um estímulo com recursos federais à periferização das metrópoles brasileiras [182].

Para responder a estas críticas, a nova legislação acrescenta 99 palavras entre os artigos $5^{\circ}$ e $6^{\circ}$ da lei original, para formar assim o Artigo $5^{\circ}$-A: Art. $5^{\circ}$-A. Para a implantação de empreendimentos no âmbito do PNHU, deverão ser
observados:
I - localização do terreno na malha urbana ou em área de expansão que atenda aos requisitos estabelecidos pelo Poder Executivo federal, observado o respectivo plano diretor, quando existente;
II - adequação ambiental do projeto;
III - infraestrutura básica que inclua vias de acesso, iluminação pública e solução de esgotamento sanitário e de drenagem de águas pluviais e permita ligações domiciliares de abastecimento de água e energia elétrica; e
IV - existência ou compromisso do poder público local de instalação ou de ampliação dos equipamentos e serviços relacionados a educação, saúde, lazer e transporte público.

O que ao longo dos últimos cinco anos tornou o Artigo $5^{\circ}$-A compatível com empreendimentos implantados nas periferias pobres das metrópoles brasileiras foram as sucessivas Portarias do Ministério das Cidades que dispõem sobre "as diretrizes gerais para aquisição e alienação de imóveis", isto é, as regras pelas quais recursos do Fundo de Arrendamento Residencial são utilizados para o repasse da moradia de baixa renda por parte das empresas construtoras.

A primeira regulação do FAR se deu pela Portaria 93, de 24 de Fevereiro de 2010 (assinada pelo ministro Márcio Fortes) e não aborda qualquer controle sobre a localização intra-urbana, pois se limita a publicar no Anexo 1 e Anexo 2 a variação dos valores máximos de aquisição por regiões metropolitanas e grupos de cidades (cf. tabela T-27), além das abstratas metas de produção por Estado. 
A Portaria 325, de 07 de Julho de 2011 (assinada pelo ministro Mário Negromonte) publica três novos anexos: Anexo 3, Anexo 4 e Anexo 5. O Anexo 3 contém a primeira versão da integração do programa MCMV com as obras de urbanização de favelas geridas pelo Programa de Aceleração do Crescimento (PAC). Já o Anexo 4 é de importância central para a localização urbana das moradias financiadas pelo FAR, aspecto tratado em vários itens do seu tema principal, que são as "diretrizes gerais para elaboração dos projetos dos empreendimentos". Basicamente, três incisos do Artigo $5^{\circ}$-A sobre "implantação de empreendimentos" ganham uma nova e mais precisa interpretação neste texto: a inserção em "malha urbana" (item 2.1), o atendimento por "infraestrutura urbana básica" (item 2.2) e proximidade com "equipamentos públicos necessários para $o$ atendimento da demanda gerada" (item 2.4).

O Anexo 4 é breve ao exigir que os empreendimentos sejam "inseridos na malha urbana": basta que esta inserção seja "assim definida pelo Plano Diretor", com a ressalva de que também se admite a classificação de "zona de expansão urbana".

A respeito da infraestrutura urbana, os requisitos do Anexo 4 estão centrados nas redes que devem ser implantadas no interior do empreendimento, na forma de vias de circulação e ligações de energia, água e esgoto condominiais. Do lado de fora deste empreendimento, as exigências são menores. Em primeiro lugar, porque permite "soluções para esgotamento sanitário", um conhecido recurso de linguagem técnica que é usado para desobrigar um empreendimento a ligar a rede condominial de esgoto a uma rede coletora mantida por uma concessão pública. Esta é a rede de infraestrutura urbana que demarca com mais precisão as áreas segregadas para população pobre, pois só pode operar por um controle territorial que nunca foi exercido na cidade informal [183]. Como as redes públicas de abastecimento de água e fornecimento de energia não têm a mesma dificuldade para se prolongarem pela periferia autoconstruída (uma vez que operam por pressão hidráulica e tensão elétrica), o item 2.7.2 do Anexo 4 oferece a possibilidade destas extensões serem executados com recursos do próprio FAR.

A respeito da proximidade com equipamentos e serviços públicos, o item 2.4 do Anexo 4 se limita a exigir uma reserva de área de uso institucional em empreendimentos com mais de mil unidades habitacionais, caso em que a proximidade fica garantida em relação a um futuro edifício, ainda a ser construído, e não a equipamentos e serviços já existentes e consolidados.

A síntese de todas estas exigências sobre a localização dos empreendimentos do FAR é um documento técnico a ser elaborado pela empresa construtora e que é especificado no item 3 do Anexo 4: o "Relatório de diagnóstico da demanda por equipamentos e serviços públicos e urbanos". Antes, o item 2.11.1 avisa que a análise deste documento por parte da Secretaria Nacional de Habitação (SNH) do Ministério das Cidades "pode determinar ajustes na proposta" da empresa construtora. Como todos os empreendimentos implantados nas áreas periféricas da RMSP apresentaram este "relatório de diagnóstico", é preciso supor que a SNH confirmou a proximidade deles com equipamentos e serviços públicos.

183 A universalização do abastecimento de água e sua comparação com a limitada rede de esgotamento sanitário na periferia autoconstruída de São Paulo é um dos temas da dissertação de mestrado de Renata Moreira (Moreira, 2010). 
De qualquer forma, as empresas construtoras sempre podem recorrer às prefeituras dos municípios onde propõem empreendimentos do programa MCMV para que elas façam uso do item 3.3:

Nos casos de inexistência de equipamentos públicos na área mapeada ou nos casos em que os equipamentos não forem capazes de atender a demanda gerada, o poder público local deverá indicar:

a) o endereço da instituição de educação onde as crianças serão atendidas;

b) o número de vagas existentes;

c) o compromisso de fornecimento de meio de transporte para o deslocamento;

d) o endereço da unidade de saúde mais próxima onde as famílias serão atendidas.

No subitem 3.3.1, o Anexo 4 permite ainda que, "nos municípios onde exista sistema de transporte coletivo", o fornecimento de transporte se dê pela "criação de linhas e itinerários para atender a demanda gerada". Desta forma, a regulamentação do Ministério das Cidades inverte todas as exigências sobre localização urbana presentes na lei que reeditou o programa MCMV, pois reconduz cada uma delas às regras fundamentais da expansão periférica: a malha urbana se limita a um zoneamento, a conexão com infraestrutura implica em sua permanente extensão e o acesso a equipamentos públicos se converte num serviço de ônibus.

O Anexo 5, por sua vez, exige que as prefeituras municipais realizem um "Trabalho Social" junto aos futuros moradores dos empreendimentos financiados pelo FAR, uma atividade de tutela que é análoga à edificação que a empresa construtora realiza por lucro, uma vez que busca criar um meio formal de morar no interior da cidade informal.

Assim, ao exigir aulas sobre "educação patrimonial" e formação de condomínios, o Anexo 5 precisa avançar para assuntos disciplinares, tais como "difusão de noções sobre higiene, saúde e doenças individuais e da coletividade" (3.2.1.b1), "estímulo à correta apropriação e uso dos espaços de uso comum" (3.2.1.c1) e "promoção de atitudes e condutas sociais vinculadas ao novo morar" (item 3.2.1.a5). Serviços como este serão executados por convênio e remunerados com $2 \%$ do valor do empreendimento, o que significa que um apartamento contratado a R\$ 96 mil na RMSP requer um desembolso extra de $\mathrm{R} \$ 1.920$ do FAR para o trabalho social junto à família moradora) [184].

Depois que a Portaria 465 de 03 de outubro de 2011 consolidou a redação final de diversos itens, a mais recente atualização das regras do FAR acrescentou o Anexo 6, através da Portaria 168, de 12 de Abril de 2013 (assinada pelo ministro Aguinaldo Ribeiro). É um texto que abandona qualquer ilusão a respeito dos orçamentos municipais e acrescenta recursos do FAR no montante de $6 \%$ do valor dos empreendimentos para "a edificação dos equipamentos de educação, saúde

184 A respeito deste Trabalho Social, duas declarações dadas para esta pesquisa são esclarecedoras. A primeira é de um analista da CEF, que comentava que os empreendimentos do programa MCMV financiados pelo Fundo de Desenvolvimento Social e geridos por entidades de movimentos de moradia (MCMV-E) não demandavam tal serviço: "o FAR está encarecendo em $2 \%$ os empreendimentos para resolver um problema que ele mesmo criou, porque os apartamentos se organizam em condomínios antes mesmo das pessoas saberem que vão para lá (...) Muita ideia boa de projeto foi desperdiçada desse jeito, porque os moradores só podem palpitar depois que a construção acabou". A segunda declaração, mais retórica mas igualmente precisa, foi feita por uma assistente social da prefeitura de Mogi das Cruzes: "este Trabalho Social está todo errado. O governo não tira as pessoas da periferia e, depois, quer tirar a periferia das pessoas". 
e outros complementares à habitação" (item 4.2). A condição mais importante é que a edificação "deverá ocorrer em área situada na poligonal do empreendimento" (item 2.3), seguindo a proporção de uma escola a cada 500 unidades habitacionais e um edifício referente aos "demais equipamentos complementares à habitação" a cada 800 unidades habitacionais, geralmente um posto de saúde ambulatorial.

O Anexo 6 também inova ao estabelecer punições para o descumprimento de acordos por parte de governos municipais, algo frequente quando se trata de viabilizar empreendimentos do programa MCMV: se o equipamento público não estiver em operação 120 dias após a mudança dos moradores, as prefeituras devem devolver ao FAR a totalidade do investimento realizado, "devidamente atualizado pela taxa referencial da Selic" (item 6.1.5). Uma "Declaração Expressa de Ente Público" fechará o compromisso de "dotação orçamentária específica e em valor suficiente para equipar, operar e manter os equipamentos" (item 6.1.1), o que lança uma despesa sobre o orçamento das prefeituras que é de ordem igual ou maior que o valor de edificação da escola ou posto de saúde [185].

O rigor com que o Anexo 6 trata a localização dos empreendimentos do FAR, no fim das contas, apenas leva a um paroxismo o reconhecimento tácito que o Anexo 4 fazia de que a moradia para baixa renda do programa MCMV está segregada da cidade e dos serviços urbanos, pois é preciso refazer na "poligonal do empreendimento" os equipamentos de educação e saúde que todos os gestores do programa sabem não existir no entorno. Esta concepção de gestão pública, em que a localização segue a moradia como um piano é puxado para uma cadeira, decorre do próprio título do Anexo 6, que considera que equipamentos e serviços urbanos são "complementares à habitação". Em nenhum documento institucional do programa MCMV é cogitada uma hipótese inversa para a expansão urbana, em que a habitação seja complementar aos equipamentos e serviços da cidade.

De paroxismo em paroxismo, o resultado final é que o programa MCMV passa a contrariar o próprio plano que deveria realizar, o Plano Nacional de Habitação (PlanHab), cujo pressuposto é abandonar "um modelo de urbanização baseado na expansão horizontal e na ampliação permanente das fronteiras, na subutilização da infraestrutura e da urbanidade já instaladas e na mobilidade centrada na lógica do automóvel particular", um modelo que tem consequências conhecidas:

De um lado, a cidade se expande avançando sobre as áreas rurais e os perímetros urbanos definidos em lei municipal, acomodando de forma arbitrária as áreas que já foram ocupadas e aquelas que serão ocupadas no futuro; de outro lado, os vazios urbanos e imóveis vagos permanecem ociosos por vários anos (...) Um círculo vicioso ocorre quando o preço da terra tem a maior incidência no custo final da habitação; o alto valor em áreas urbanas centrais

185 É um tanto irreal que o Ministério das Cidades queira refrear o ímpeto de uma prefeitura em viabilizar um empreendimento habitacional do programa MCMV, em que dividendos políticos podem ser obtidos sem elevar o endividamento municipal (que muitas vezes está congelado por determinação da Lei de Responsabilidade Fiscal). Além do mais, é fácil se comprometer com um custeio em orçamentos futuros para obter no presente o bônus da edificação sem custo de um equipamento público. 
gera a ocupação da periferia, espalhando a malha urbana, criando vazios e inviabiliza a cidade equipada para a população de baixa renda (MCidades, 2009: 40-1) [186].

O que era renegado como plano de governo antes do programa MCMV é, mesmo assim, confirmado no mercado das localizações, como observado por Mariana Fix e Álvaro Pereira:

A estratégia do empreendedor imobiliário [no programa MCMV] tende a ser aquela de priorizar as áreas de menor preço dentro de cada uma dessas regiões metropolitanas. A consequência é levar os empreendimentos habitacionais, sobretudo os destinados à faixa de renda de 0 a 3 salários mínimos, ao limite das áreas que dispõem de infraestrutura urbana, ou mesmo forçar os municípios a estender essa infraestrutura para áreas cada vez mais distantes, entrando em contradição com as diretrizes e recomendações dos especialistas e da própria política nacional para que as cidades sejam mais compactas e para o cumprimento do dispositivo constitucional da função social da propriedade (Fix; Pereira, 2013: 264).

O último olhar desta pesquisa sobre o programa MCMV, no entanto, não deve se dirigir à gestão do programa em nível nacional, mas sim às prefeituras municipais, para as quais o federalismo brasileiro atribui a gestão do solo urbano como uma gestão local. É um poder fragmentado, mas suficiente para dar uma direção socialmente justa ao programa MCMV e que não foi usado por nenhum dos municípios da região metropolitana de São Paulo.

Por outro lado, é preciso reconhecer que o programa MCMV desestimula a autonomia do município, tratado como foco de inépcia administrativa desde quando adotou um desenho institucional deliberadamente paralelo à gestão de recursos do Fundo Nacional de Habitação de Interesse Social (FNHIS), em que há participação efetiva de governos de cada nível da federação:

A opção em criar um programa que não passasse pela rota do FNHIS foi consciente, em função do diagnóstico de que as prefeituras não tinham condições de implementar o programa MCMV. Dada a experiência anterior com o PAC (voltado a urbanização de favelas), onde se via a dificuldade das prefeituras executarem os recursos, optou-se por um modelo de contratação direta das empresas (Loureiro; Macário; Guerra, 2013: 18).

O modelo de "contratação direta das empresas" não dispensa a participação da prefeitura municipal, mas a desloca para uma posição em que seu interesse em expandir a cidade e aumentar o estoque de habitações para população de baixa renda é satisfeito sem o esforço de planejar e licitar projetos e obras em nível local. Este esforço que deixa de ser realizado é o do "promotor público" da política habitacional, tal como representado esquematicamente no gráfico G-22:

$186 \mathrm{Na}$ apresentação destes mesmo texto, a secretária nacional de habitação, Inês Magalhães, afirma que " 0 lançamento, em abril de 2009, do Programa Minha Casa Minha Vida - PMCMV colocou em curso um conjunto de diretrizes e ações previstas no PlanHab, representado pelos novos patamares de investimentos públicos no setor habitacional (R\$ 34 bilhões até o final do PPA 2008-2011), com impacto direto na alavancagem do setor da construção civil" (MCidades, 2009: 5). Justamente são estes números que fazem com que Nabil Bonduki, um dos principais redatores do PlanHab, seja menos condescendente: "O programa não adota o conjunto das estratégias que o PlanHab julgou indispensável para equacionar o problema habitacional, sobretudo nos eixos que não se relacionavam com os aspectos financeiros; em consequência, aborda-o de maneira incompleta, incorrendo em grandes riscos, ainda mais porque precisa gerar obras rapidamente sem que se tenha preparado para isso" (Bonduki, 2009: 13). 


\section{G-22|Esquema de promoção pública na política habitacional}

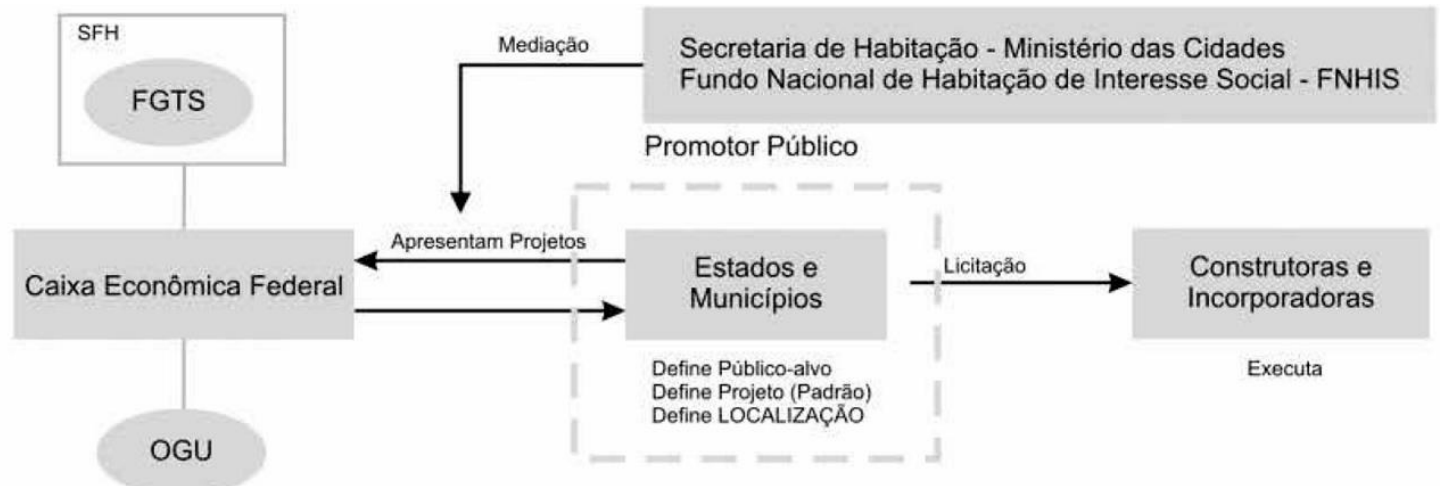

Fonte: Cardoso; Aragão, 2013: 53

O "promotor público", destacado na imagem por uma linha tracejada, tem domínio tanto de projeto quanto da localização do empreendimento, para o qual ele busca recursos de fundos públicos federais geridos pela $\mathrm{CEF}$, sejam eles onerosos, como o FGTS, ou não-onerosos, originados de Orçamento Geral da União, caso em que se inclui o FAR. Na busca destes recursos, há a mediação e a legitimação política e social das estruturas participativas do FNHIS, enquanto que as empresas construtoras aparecem apenas ao fim do processo de financiamento, na licitação pública unicamente para execução de obra.

Também aparece no esquema gráfico a principal dificuldade para a gestão municipal, que é negociar a realização de um mesmo projeto habitacional com duas prestações de serviço de natureza diferente: a intermediação da CEF, que demanda garantias especiais de entes públicos, e, posteriormente, a pressão de mercado das empresas construtoras que concorrem à licitação pública, um processo administrativo complexo e que, se não contar com propostas combinadas, será travado por impugnações e ações judiciais.

Em comparação com esta negociação dupla, a agilidade da "promoção privada" de um programa habitacional está pressuposta pela simples concentração das atividades de proposição, aprovação e execução de um empreendimento numa relação exclusiva entre uma empresa construtora e um banco, a CEF. Estas operações entre agentes privados aparecem esquematicamente no gráfico G-23:

G-23|Esquema de promoção privada na política habitacional

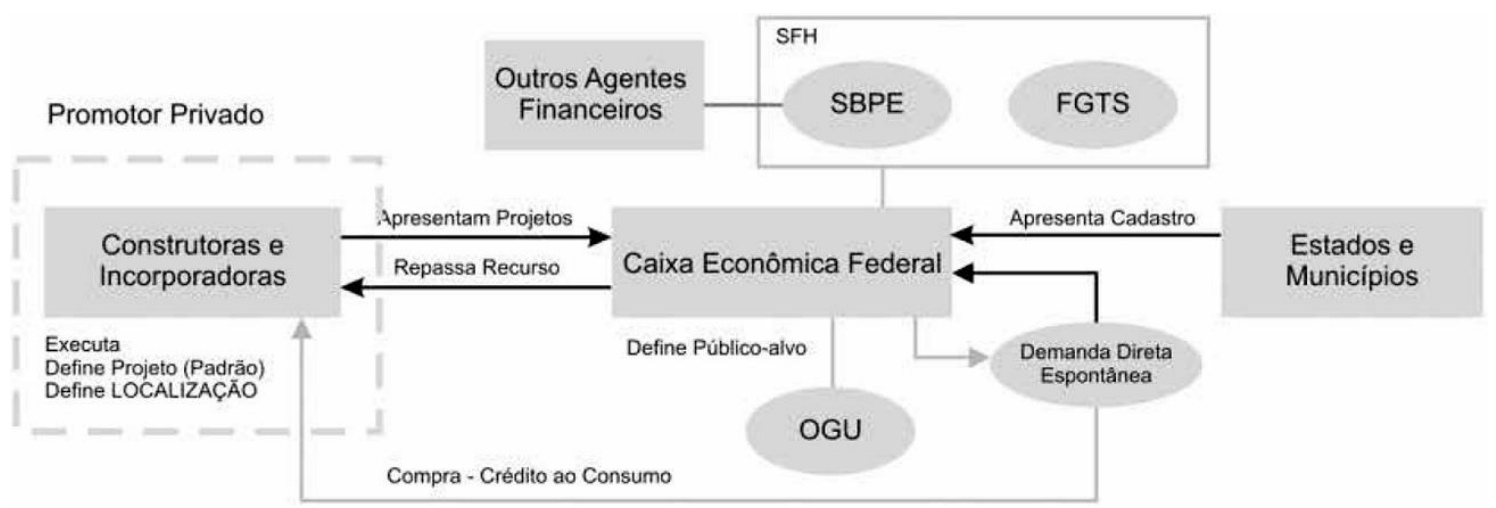

Fonte: Cardoso; Aragão, 2013: 53 
O gráfico elaborado por Adauto Cardoso e Thêmis Aragão inclui os recursos, a demanda direta e as incorporadoras que atuam na produção habitacional para famílias de renda média, na Faixa 2 e Faixa 3. No caso dos empreendimentos para Faixa 1, o único cliente da empresa construtora que é "promotor privado" do programa MCMV, destacado pela linha tracejada, é a CEF, que assume papel central no esquema por fazer tanto a contratação do empreendimento quanto a avaliação do cadastro de moradores, fornecido pela prefeitura municipal. Esta precisa apenas selecionar moradores de baixa renda que são potenciais problemas administrativos, seja por viverem em áreas de risco geotécnico ou em regiões carentes de cabos eleitorais.

A pressão por resultados, a forte legitimidade do programa MCMV, aliados ao despreparo das administrações locais para controlar efetivamente os processos de organização e desenvolvimento do território, fizeram com que as administrações locais se tornassem meros coadjuvantes desse processo, atuando mais no sentido do relaxamento dos controles do que de uma regulação efetiva (Cardoso; Aragão, 2013: 59).

Segundo Pedro Arantes, a promoção privada da habitação no programa MCMV não prolonga o poder sobre a terra urbana que é atribuição das prefeituras, mas o diminui. Equivale portanto a uma abdicação de função pública:

No $M C M V$, quem faz política de terras é o setor privado, como é também ele quem define o local e o padrão de urbanização, a arquitetura, a tecnologia a ser adotada e assim por diante. O estado abdicou de uma política pública de terras e desenvolvimento urbano, abdicou de ter inteligência projetual sobre as cidades e de qualificá-las (Arantes, 2013: 5).

Tangidos pelas disfunções de governo, os futuros moradores têm uma autonomia nula em relação ao projeto e irrelevante em relação à moradia em que devem permanecer por pelo menos dez anos para fazer valer o contrato de arrendamento. Reunidos num cadastro que cria clientelas políticas e organizados apenas em função dos interesses privados da vida em condomínio, não vão obter do empreendimento mais do que o apartamento produzido estritamente conforme as especificações mínimas do programa MCMV e as normas rebaixadas da ABNT. Já a expectativa que podem ter em relação a serviços urbanos de educação, saúde, segurança e transporte precisam ser ainda menores, pois nas novas moradias continuarão a ser a mesma população socialmente segregada nas áreas de baixa renda das metrópoles brasileiras. 


\section{Empreendimentos visitados na RMSP}

Este subcapítulo reúne fotos e informações referentes aos 22 empreendimentos visitados para esta pesquisa, que são a totalidade dos empreendimentos da Faixa 1 do programa MCMV em obras na RMSP no segundo semestre de 2011 e no segundo semestre de 2013.

Quando gerenciados por uma única construtora, os empreendimentos ocupam terrenos adjacentes ou pouco distantes entre si e aparecem na imagem I-22 agrupados sempre que a distância entre eles fosse menor que $1 \mathrm{~km}$, o que corresponde à noção de "poligonal de empreendimento" usada pelo Ministério das Cidades. De qualquer forma, estão distribuídos no mapa todos os empreendimentos listados nas tabelas T-20 e T-21, onde podem ser consultadas as informações completares de bairro e município.

A mancha urbana representada pelo arruamento em branco deixa evidente a localização periférica da Faixa 1 do programa MCMV, não apenas em relação ao espaço conurbado da metrópole como também em relação a cada centralidade municipal, com destaque para Guarulhos, Mogi das Cruzes, o ABCD e, na zona leste de São Paulo, as áreas da Cohab em Guaianazes e Cidade Tiradentes. Considerando que todos estes empreendimentos aplicaram sistemas de gestão de qualidade e procedimentos técnicos de controle de serviços subempreitados, o mapa que aparece na imagem I-22 é também um mapa da periferização da tecnologia organizacional do programa MCMV.

I-22 | MCMV/Faixa 1 - empreendimentos agrupados na RMSP

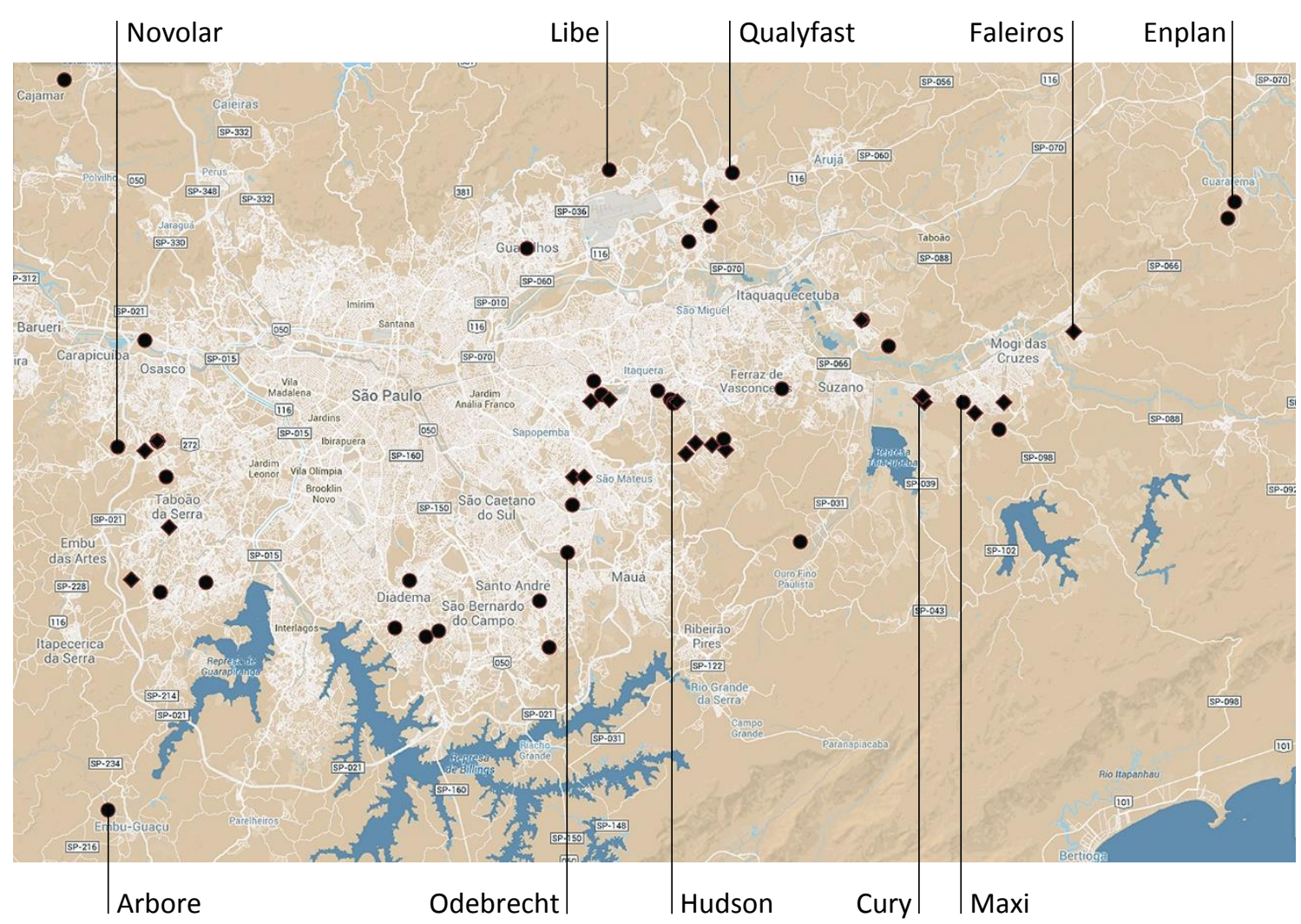

Fonte: elaboração própria com dados da CEF geolocalizados em base Googlemaps. Os pontos em losango indicam empreendimentos concluídos e em círculo, em construção em Junho de 2013. 


\section{I-23 | Construtora e incorporadora Faleiros Itda}
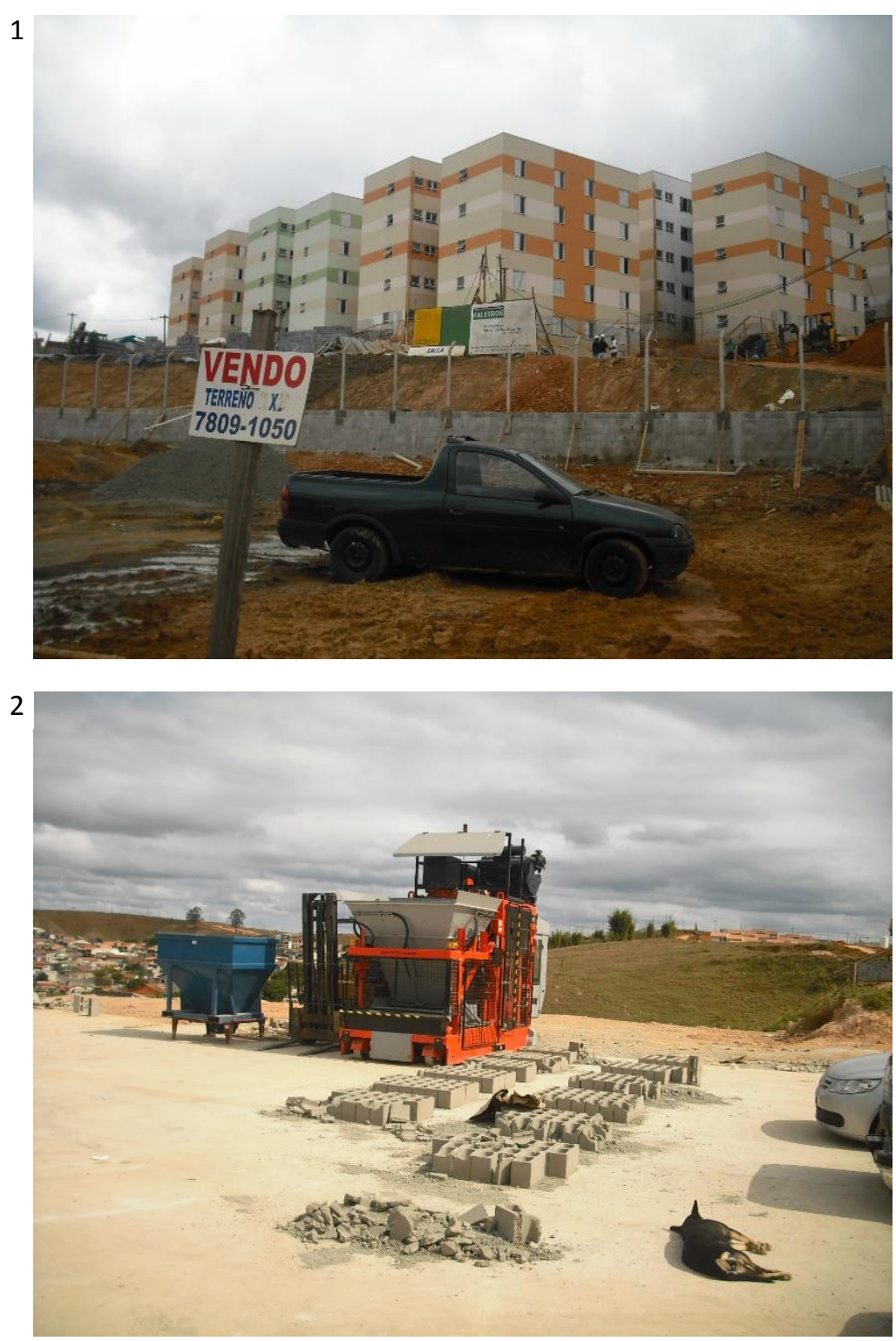

3

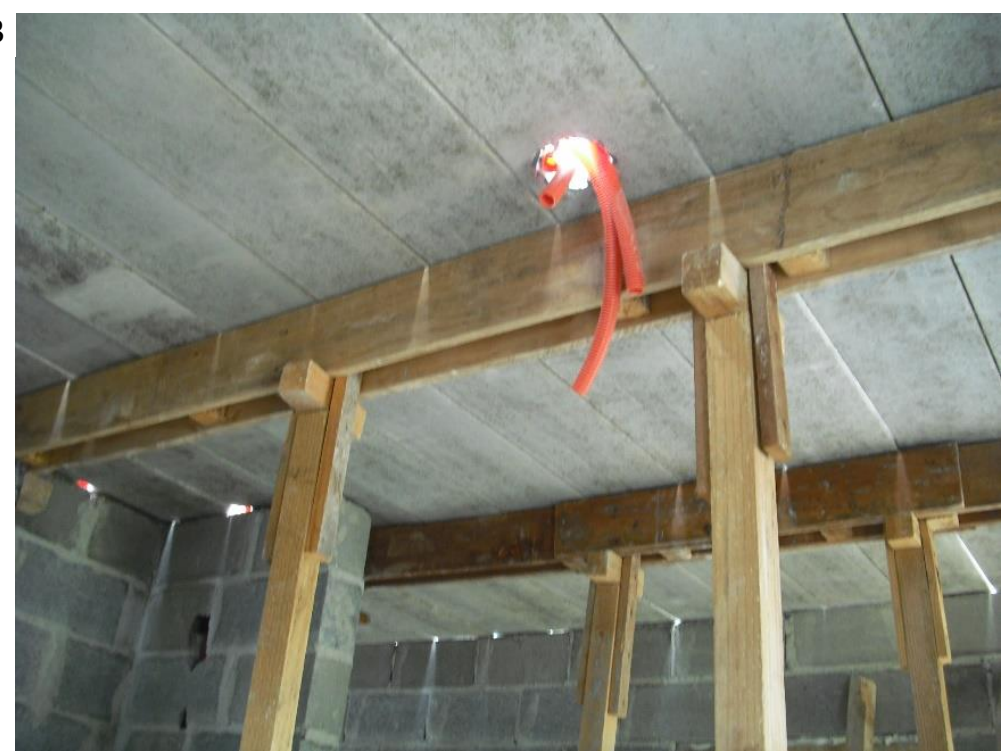

RESIDENCIAL DAS BROMÉLIAS

Av. Ricieri J. Marcatto 2311

Mogi das Cruzes - V. Suíça

$280 \mathrm{UH}$

A construtora concentra os empreendimentos em Mogi das Cruzes e Guarulhos.

Grandes terrenos vazios também são valorizados pela oportunidade de alugar áreas fora do empreendimento como espaços de apoio à obra. Alojamentos, centros de produção ou estocagem são cedidos por proprietários a preços módicos, com a condição de que sejam devolvidos patamarizados e murados. Como no empreendimento visitado, ao final da obra o terreno utilizado como apoio está valorizado e posto à venda [1]

Em outros casos, os terrenos de apoio podem ser usados por empresas fornecedoras, que vão produzir em área contígua à obra, como a que instalou uma máquina compacta de fabricação de blocos estruturais [2]

A construtora Faleiros prioriza a racionalização de técnicas convencionais de construção, como o escoramento de madeira, que, no caso, ganha um desenho de encaixe que facilita a reutilização das peças de maneira simples [3] 


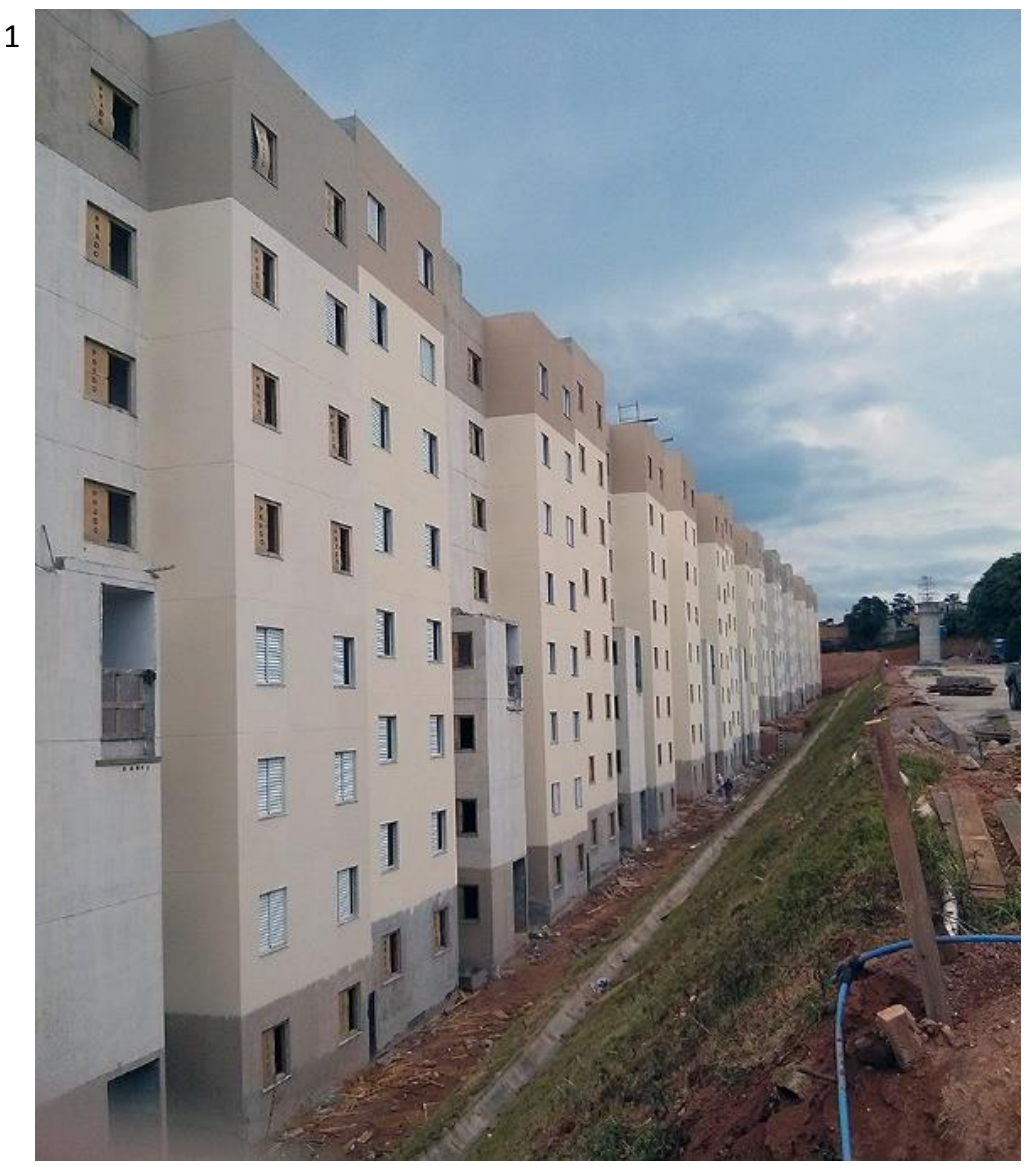

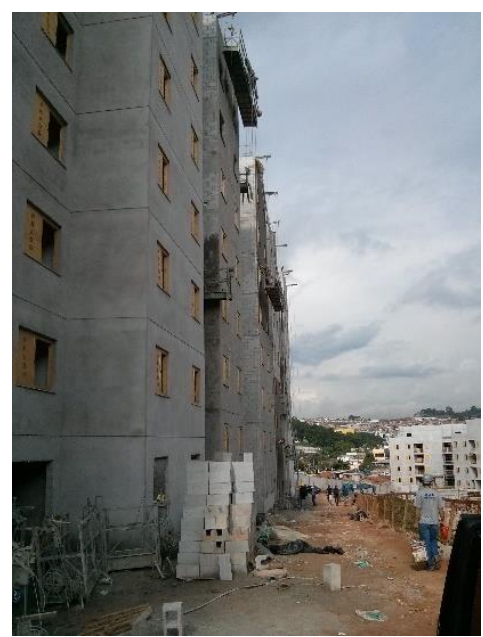

2

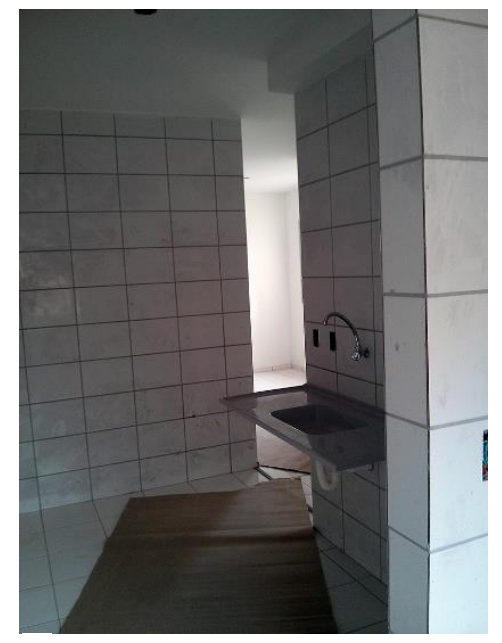

3
RESIDENCIAL GIRASSÓIS, AZALÉIAS, VIOLETAS

Rua Paraguai 23

Carapicuíba - Jd Helena $816 \mathrm{UH}$

A empresa realiza diversas operações em sociedade de propósito específico (SPE) com uma das maiores construtoras do país, a Tecnisa Engenharia $S / A$. A combinação entre diferentes faixas de renda do programa MCMV é uma clara estratégia comercial.

\section{Dos empreendimentos} visitado, este é o único a aproveitar o desnível de terreno para verticalizar os edifícios, que são acessados pelo 4ㅇ pavimento, com centro de medição no pavimento abaixo [1]. Os passadiços foram instalados na semana seguinte à visita.

A foto [2] mostra os balancins para revestimento externo, necessários pela maior altura dos edifícios. O edifício baixo, ao fundo, foi construído para a Faixa 3, em trecho do mesmo terreno, mas de maior acessibilidade. Nas áreas internas, as cerâmicas são moduladas [3]. Com o aumento da densidade habitacional, as áreas de estacionamento abrem grandes espaços entre os renques de edifícios [4].

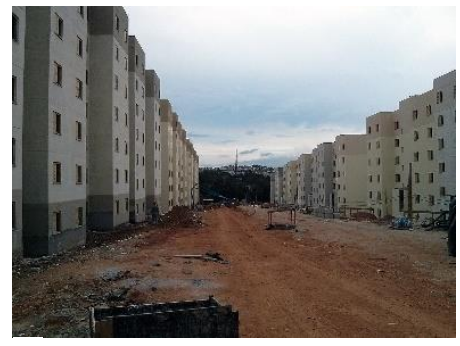

4 

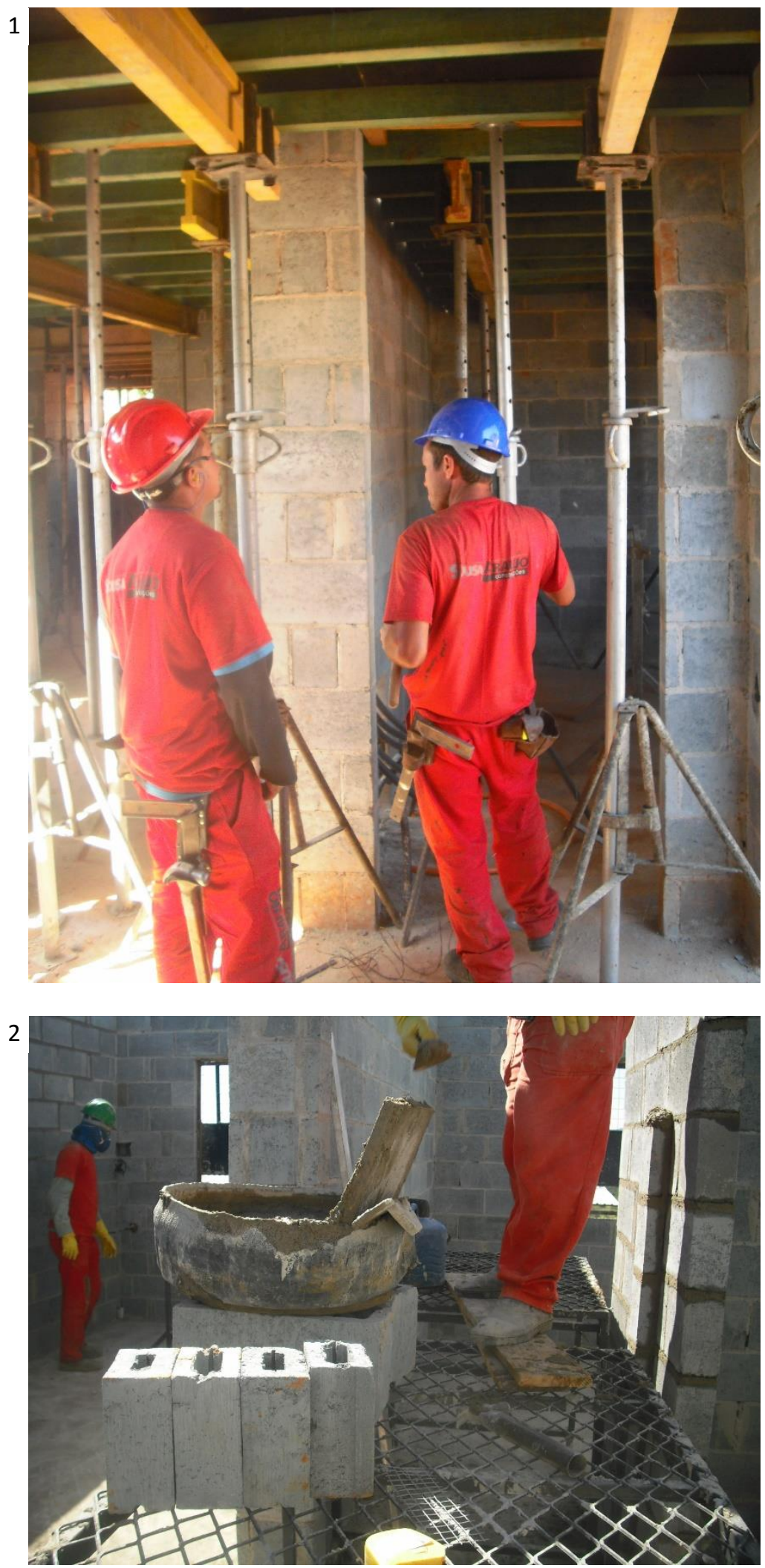

MOGI DAS CRUZES - BAMBU, QUADRADO, TRIÂNGULO Av. Kaoru Hiramatsu s/n Mogi das Cruzes - Jd Aeroporto $1240 \mathrm{UH}$

Os empreendimentos da empresa aparecem em diversos momentos desta pesquisa, com destaque para a "fábrica de lajes" na "poligonal" de Jundiapeba, também em Mogi das Cruzes (imagens I-16 e I-17)

As imagens deste canteiro de obras mais recente mostram equipes da subempreiteira Souza Araújo, cuja qualidade e produtividade na construção de fôrmas de laje dispensou a sua pré-fabricação. A foto [1] mostra os dois únicos carpinteiros de um dos empreendimentos ajustando equipamentos de fôrma e escoramento de tecnologia avançada: chapas vinílicas, vigas e barrotes transpassados pré-fabricados e com compósitos de plástico, dimensionados para os forcados metálicos. As escoras tubulares têm pé de montagem universal. Segundo o carpinteiro, "aqui o martelo não sai do cinto".

$\mathrm{Na}$ frente de alvenaria estrutural [2], o uso da paleta é obrigatório, apenas a tradicional masseira de pneu é tolerada. A obrigação mais difícil era aceita pelos trabalhadores, que é o uso de luva e até de máscara, no caso do ajudante que aparece ao fundo, manipulando sacos de argamassa industrializada. 

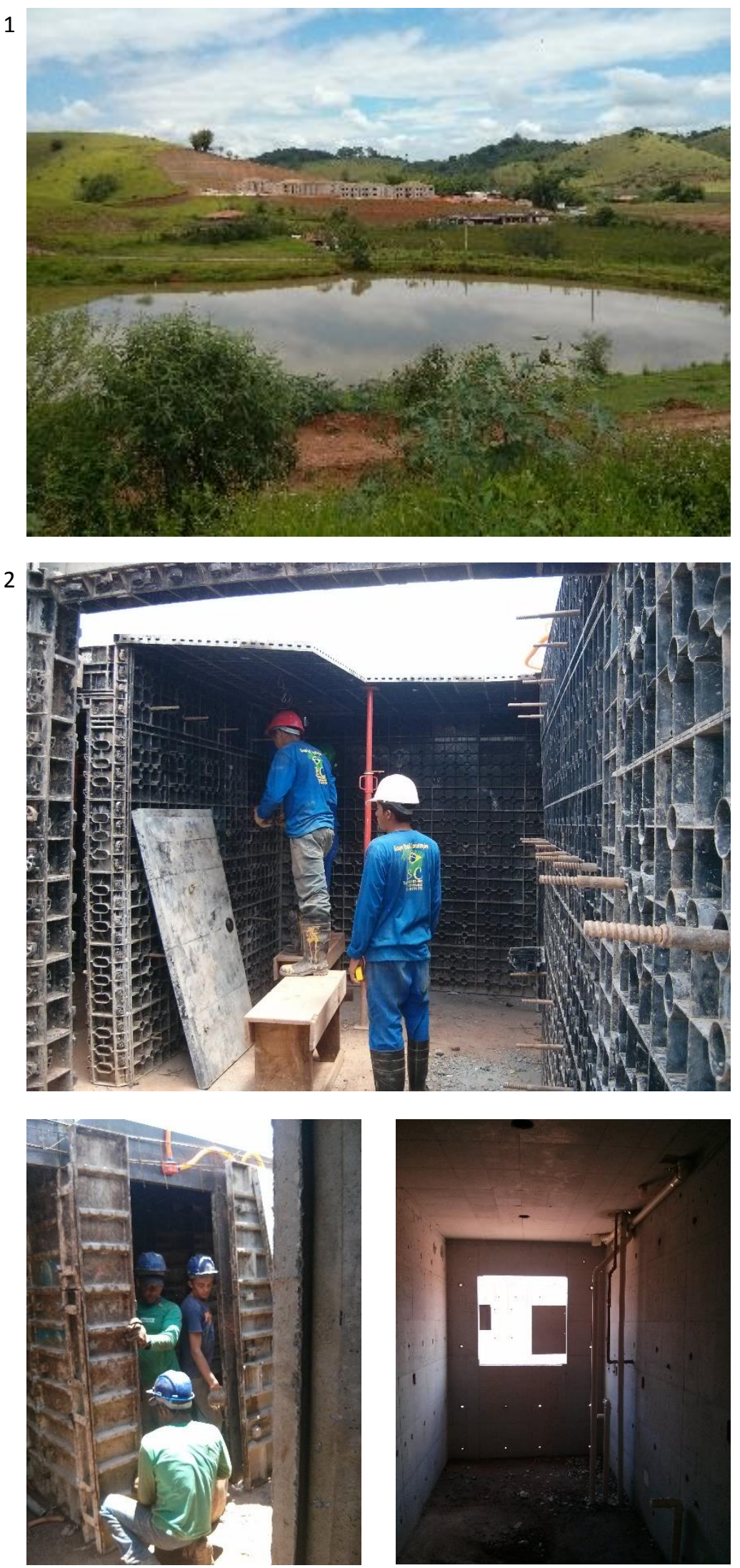

3

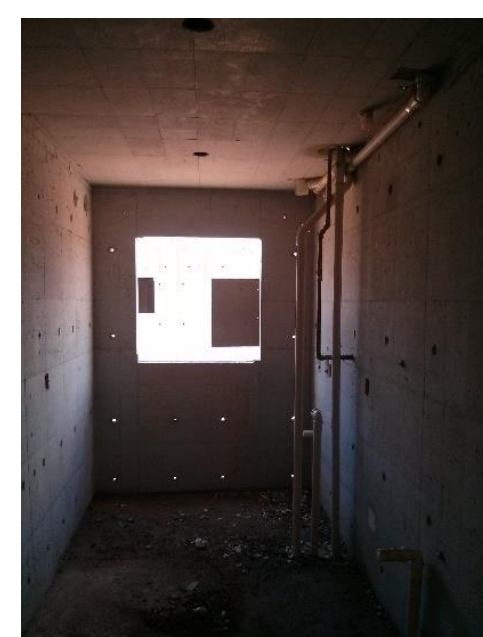

4
RESIDENCIAL PAU D'ALHO Avenida 2 e 3, quadras B-E Guararema - Bairro Nogueira $408 \mathrm{UH}$

Os empreendimentos estão implantados numa franja quase rural deste município limítrofe da RMSP [1]. O isolamento viabilizou grandes movimentações de terra para a construção da tipologia menos densa entre as visitadas por esta pesquisa: casas sobrepostas, em blocos de quatro unidades e dois pavimentos [5]. Como a tecnologia construtiva é a fôrma de parede e laje, a construtora optou por um edifício com menor taxa de aço e fundações simplificadas.

Duas alternativas estavam sendo testadas: fôrmas de PVC [2] e metálica [3], este último com bom acabamento de parede [4]. O sistema mais produtivo entre plástico e metal seria levado para um empreendimento no litoral de São Paulo, o que se revelou uma confirmação do uso da Faixa 1 do programa MCMV como "laboratório da baixa renda".

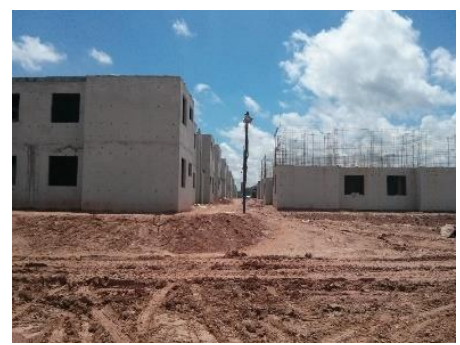

5 


\section{I-27| Libe construtora Itda}
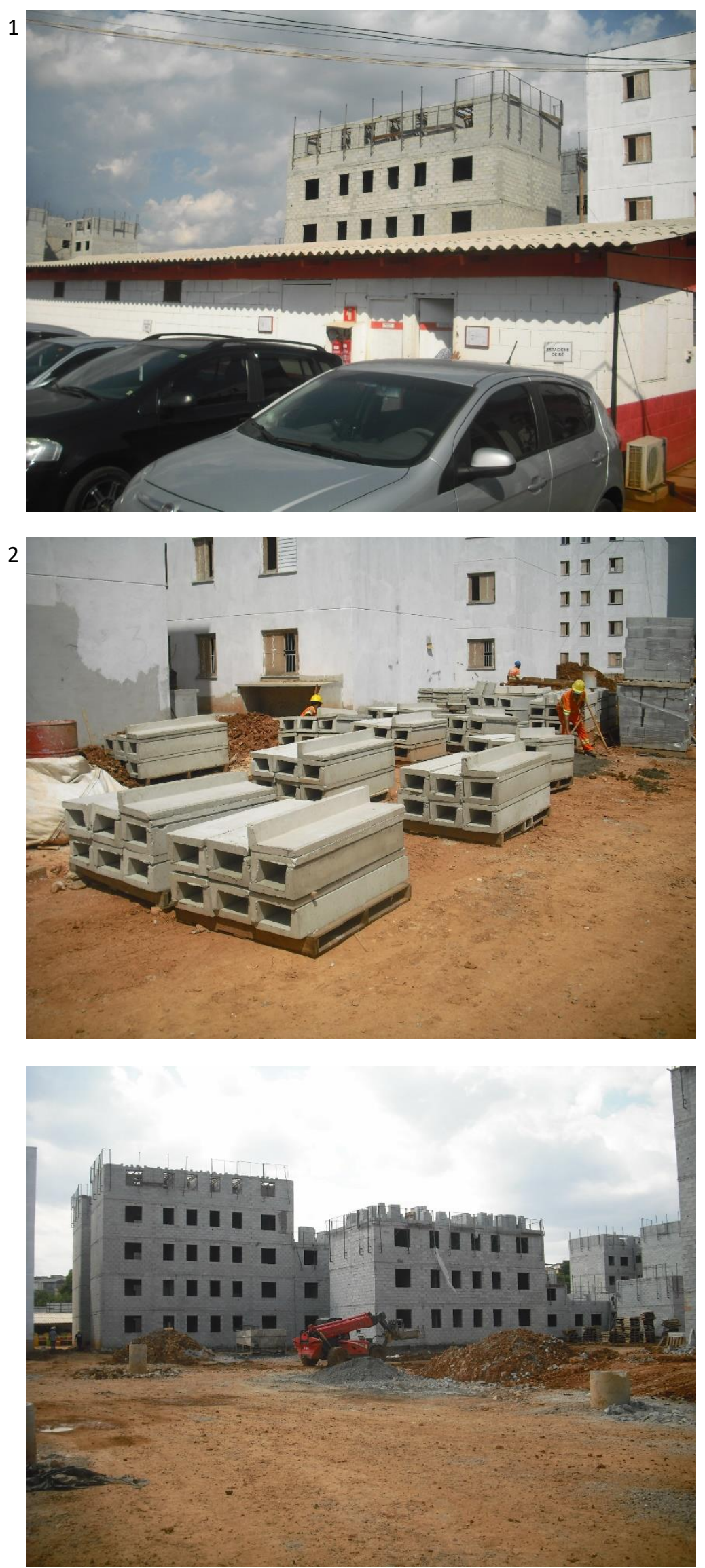

3
RESIDENCIAL LAVRAS

Av. José Brumatti $s / n$

Guarulhos - Bairro das Lavras $1460 \mathrm{UH}$

A construtora mineira Libe assumiu o empreendimento após o abandono da obra por parte de Dib Arquitetura e Incorporação Ltda, empresa que ainda aparece na tabela T21, de Junho de 2013.

A primeira visita deixava evidente a incapacidade desta empresa média em gerenciar a construção das 1.460 unidades habitacionais e a sua substituição comprova o processo de concentração de capital em curso no programa MCMV. A nova construtora remodelou as instalações de canteiro de obras [1] e adotou medidas simples de racionalização construtiva, como peças de escadas préfabricadas [2].

A movimentação de material também foi melhorada, com argamassa comprada em silos mecânicos, concreto grout fornecido por usina e uso mais intenso de veículos Skytrak [3].

A foto [4] mostra a alvenaria estrutural de um dos últimos blocos do empreendimento que ainda precisavam de confirmação técnica a respeito das fundações, executadas pela empresa que não conseguiu continuar a gestão da obra.

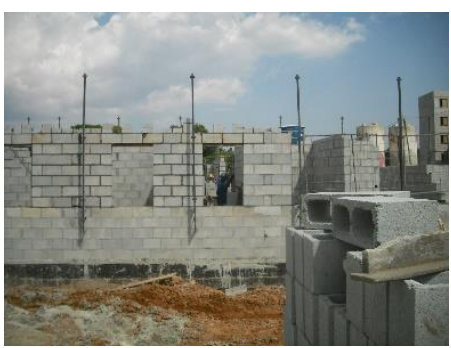

4 

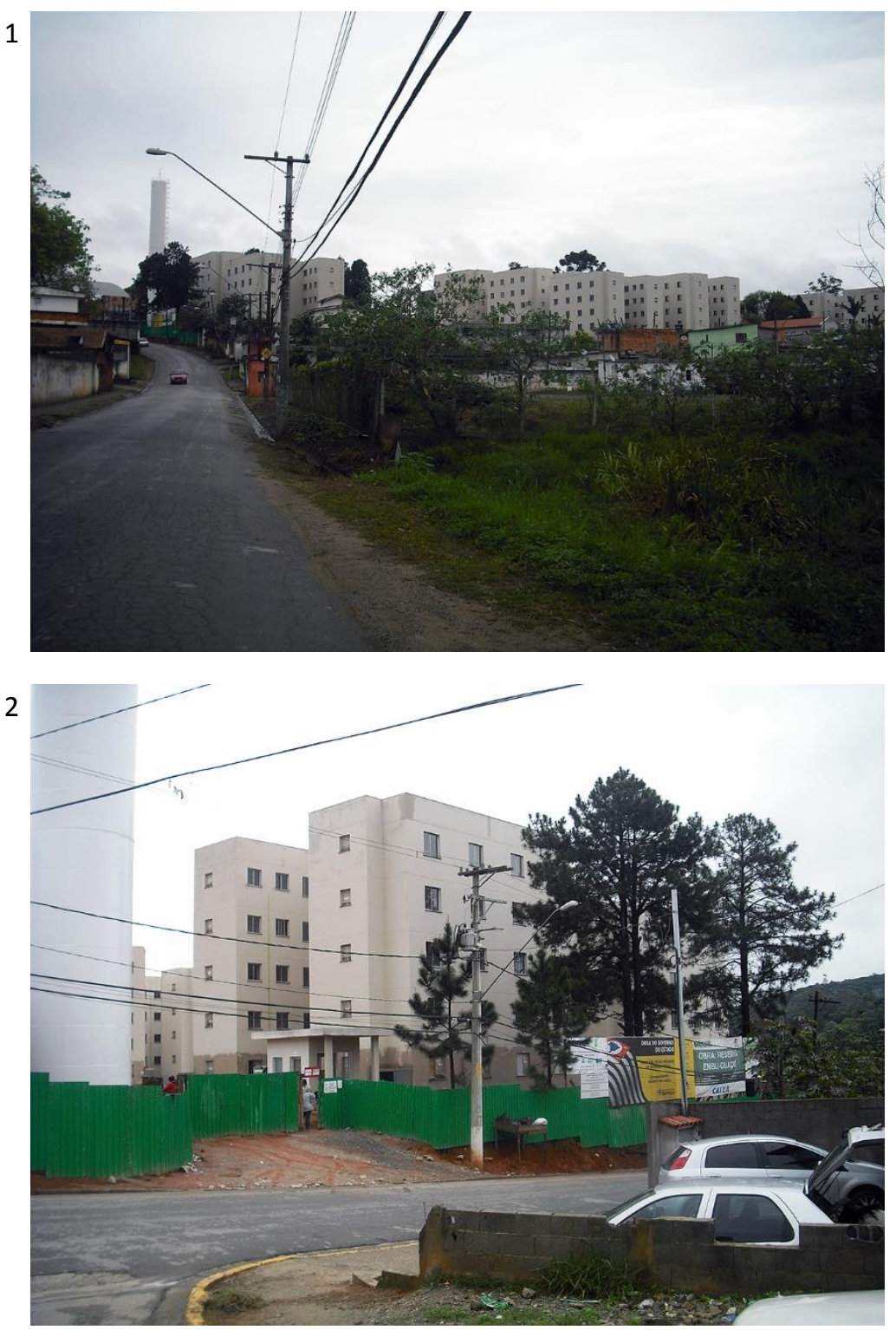

RESERVA EMBU-GUAÇU Av. Dr André Stucchi $s / n$ Embu-Guaçu - Bairro Itararé $360 \mathrm{UH}$

O empreendimento quase concluído destoa dentro de um bairro no limite de EmbuGuaçu, que é pouco denso, com grandes áreas vazias e de ocupação informal [1].

A placa com a bandeira de São Paulo tinha sido colocada recentemente junto às demais, pois identifica a origem da complementação de recursos do Fundo Paulista de HIS [2]. Era a primeira experiência da empresa Arbore Engenharia com a Faixa 1 do programa MCMV e, segundo a engenheira encarregada, Simone Silva, bem avaliada pelos sócios.

A foto [3] mostra a área junto aos escritórios e alojamentos, de boa organização. A pintura dos blocos na altura do térreo só seria realizada após as obras de drenagem e pavimentação.

3

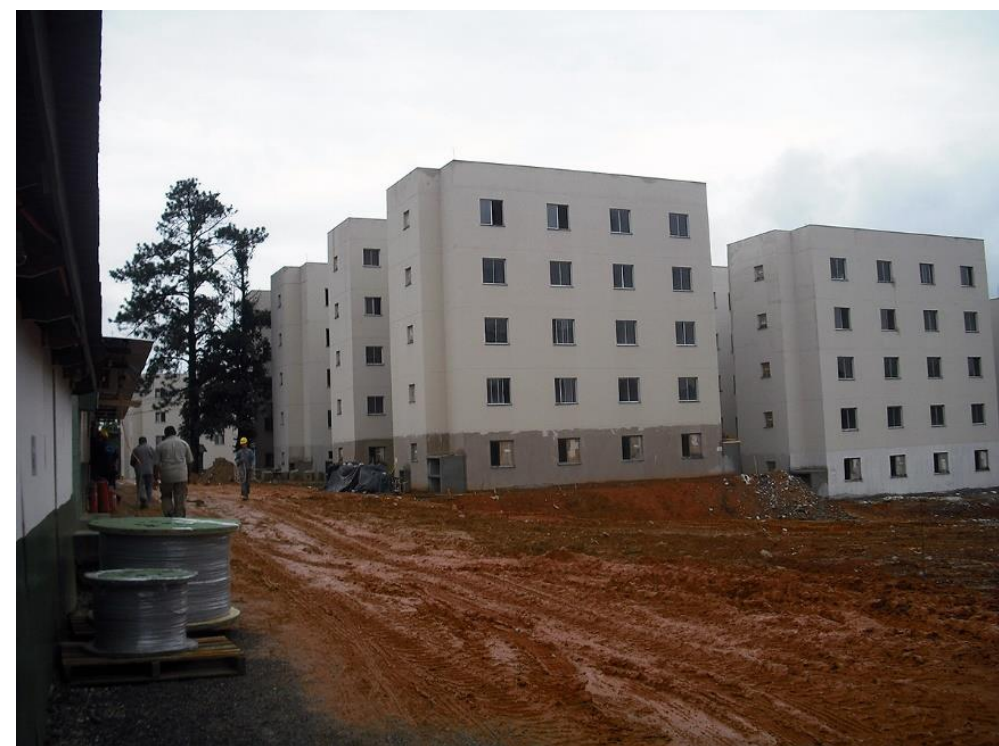



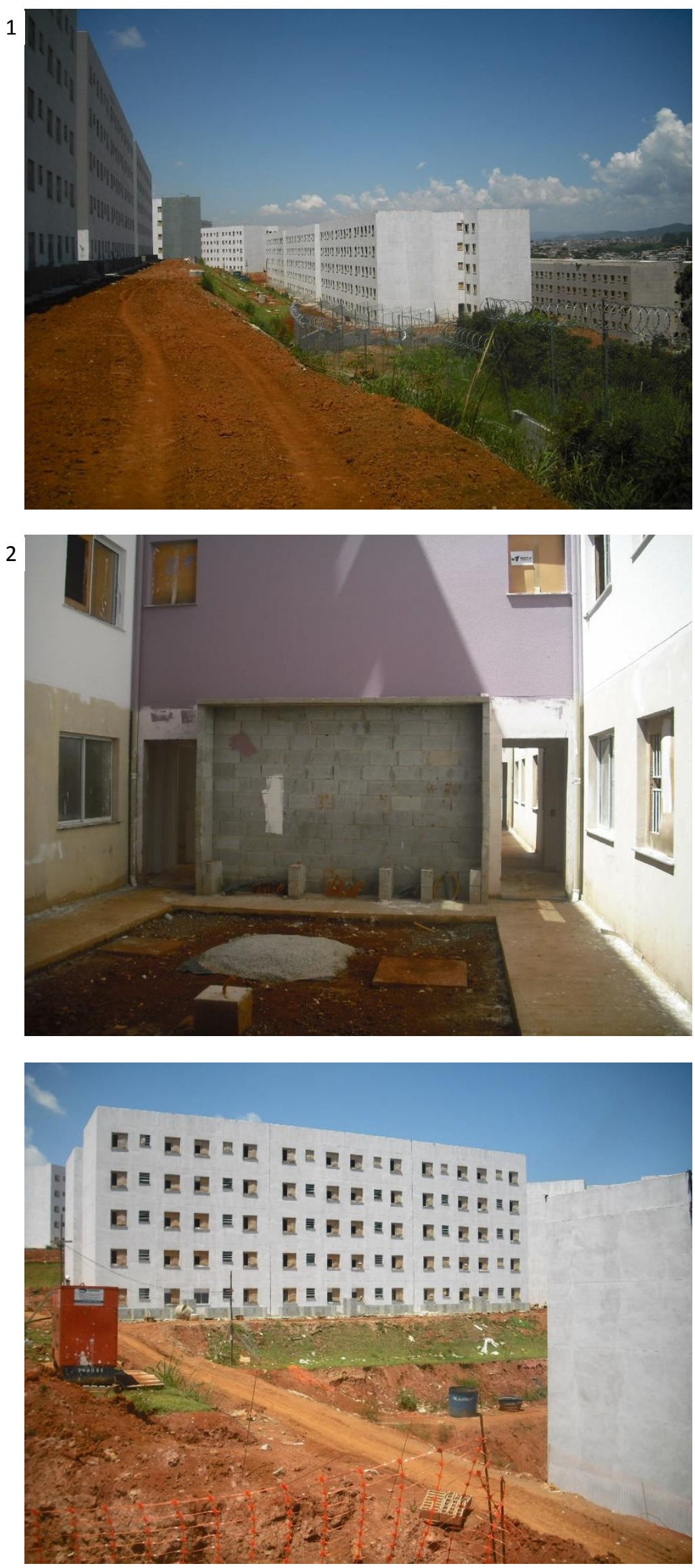

3
CONJUNTO PORTAL FLORA

Rua Tenri s/n

Guarulhos - Bonsucesso

$1500 \mathrm{UH}$

Os condomínios formam um dos maiores conjuntos

habitacionais da Faixa 1 na

RMSP e estão dispostos numa

única encosta em declive.

O conjunto é dominado por renques de 3 blocos de tipologia " $\mathrm{H}$ ", dispostos em patamares paralelos [1]. Do ponto de vista arquitetônico e urbanístico, é o mais pobre dos empreendimentos visitados durante a pesquisa, algo que os testes de pintura acima do centro de medição num dos fossos internos dos renques não conseguiam disfarçar [2].

Mesmo um recurso simples para otimizar a implantação, que é o aproveitamento do acesso em cota para aumentar a quantidade de pavimentos, foi descartado [3].

Na mesma região de Guarulhos, a empresa foi a responsável pela construção de um empreendimento para a modalidade "Entidades" do programa MCMV [4]. O ótimo projeto de arquitetura da assessoria técnica Peabiru comprova que a produção para baixa renda pelo programa MCMV pode produzir um melhor resultado espacial quando a gestão de projeto é realizada por

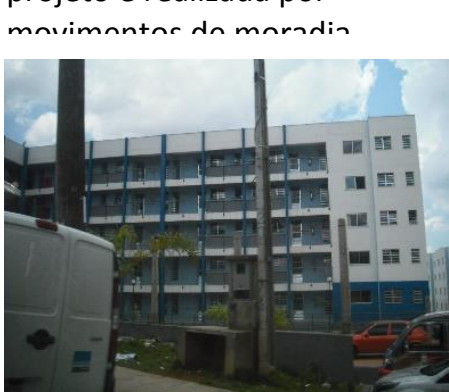

4 


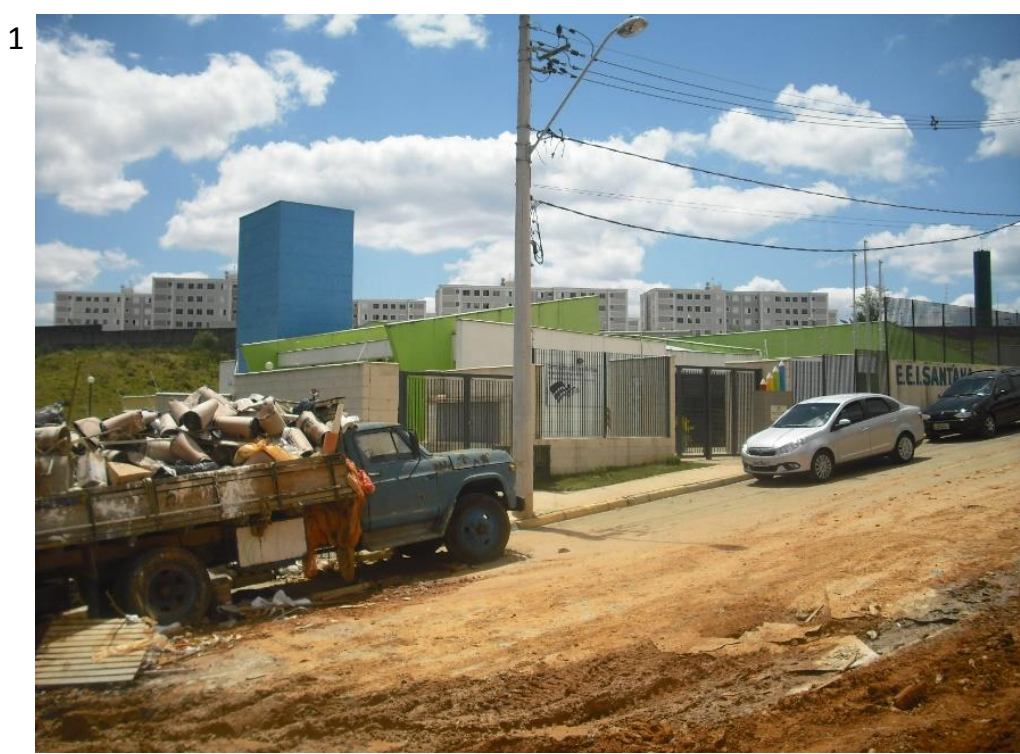

2
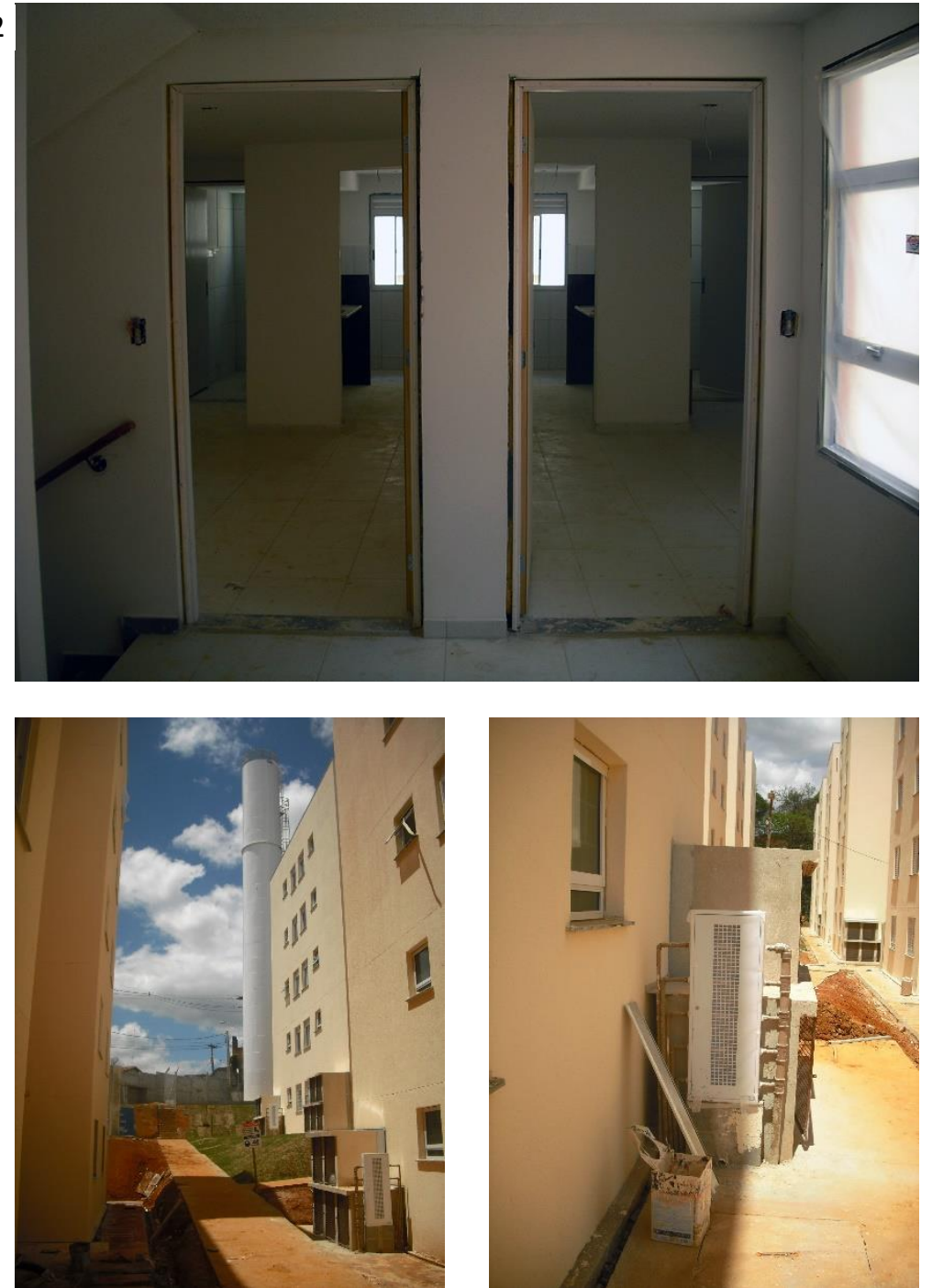

3

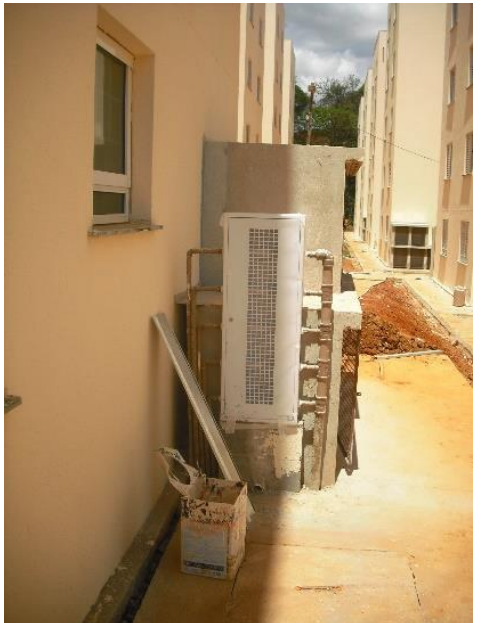

4
CONJUNTO DO BOSQUE I E II

Rua Gramado s/n

Mogi das Cruzes

$400 \mathrm{UH}$

A empresa mantém estrutura societária compartilhada com a construtora e incorporadora Faleiros Itda, embora tenha gestão de obra mais convencional.

O empreendimento integra um bairro dominado por construções recentes do programa MCMV [1], com destaque para condomínios de renda média construídos na parte alta do bairro pela empresa MRV Engenharia S/A. $A$ escola de ensino infantil que aparece em primeiro plano é recém inaugurada e ilustra a necessidade de estender investimentos municipais em áreas de expansão urbana.

A foto [2] mostra o núcleo hidráulico oposto à entrada dos apartamentos, com cozinha, lavanderia e banheiro. Junto a este núcleo estão situadas também uma ao lado da outra as duas portas dos dormitórios. Esta disposição de cômodos, universal no programa MCMV, converte numa grande distribuição a pequena sala, cuja janela sempre se abre defronte à sala oposta na circulação coletiva.

\section{Os blocos estão afastados} apenas 6 metros um do outro [3], mas a tendência a individualizar a gestão do espaço é reforçada pela medição independente de água [4], tal como determinado por regras do 


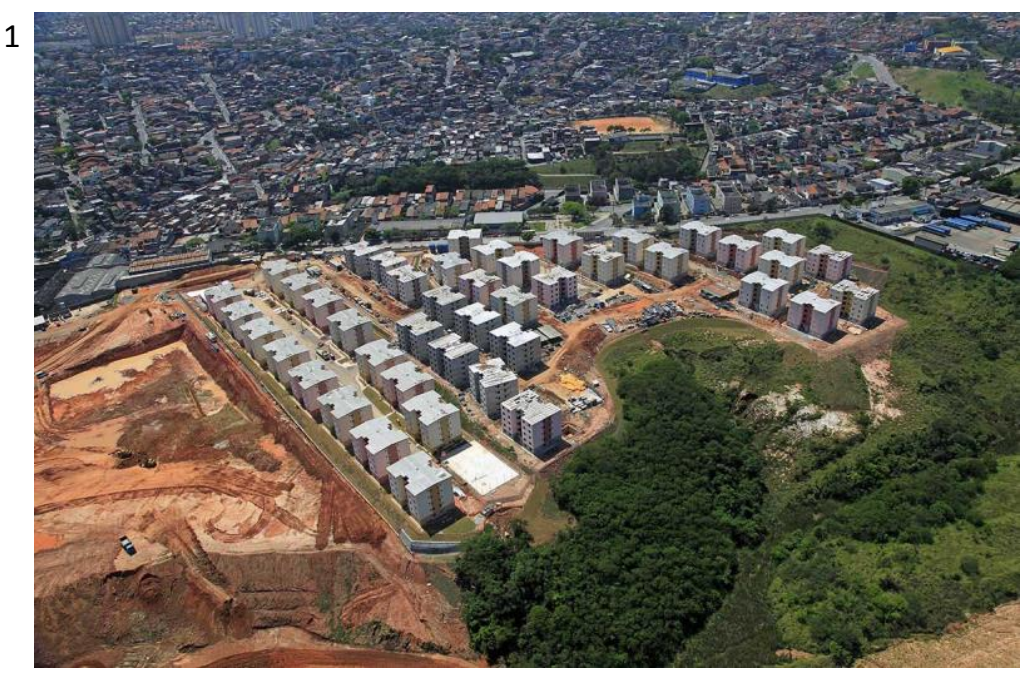

2
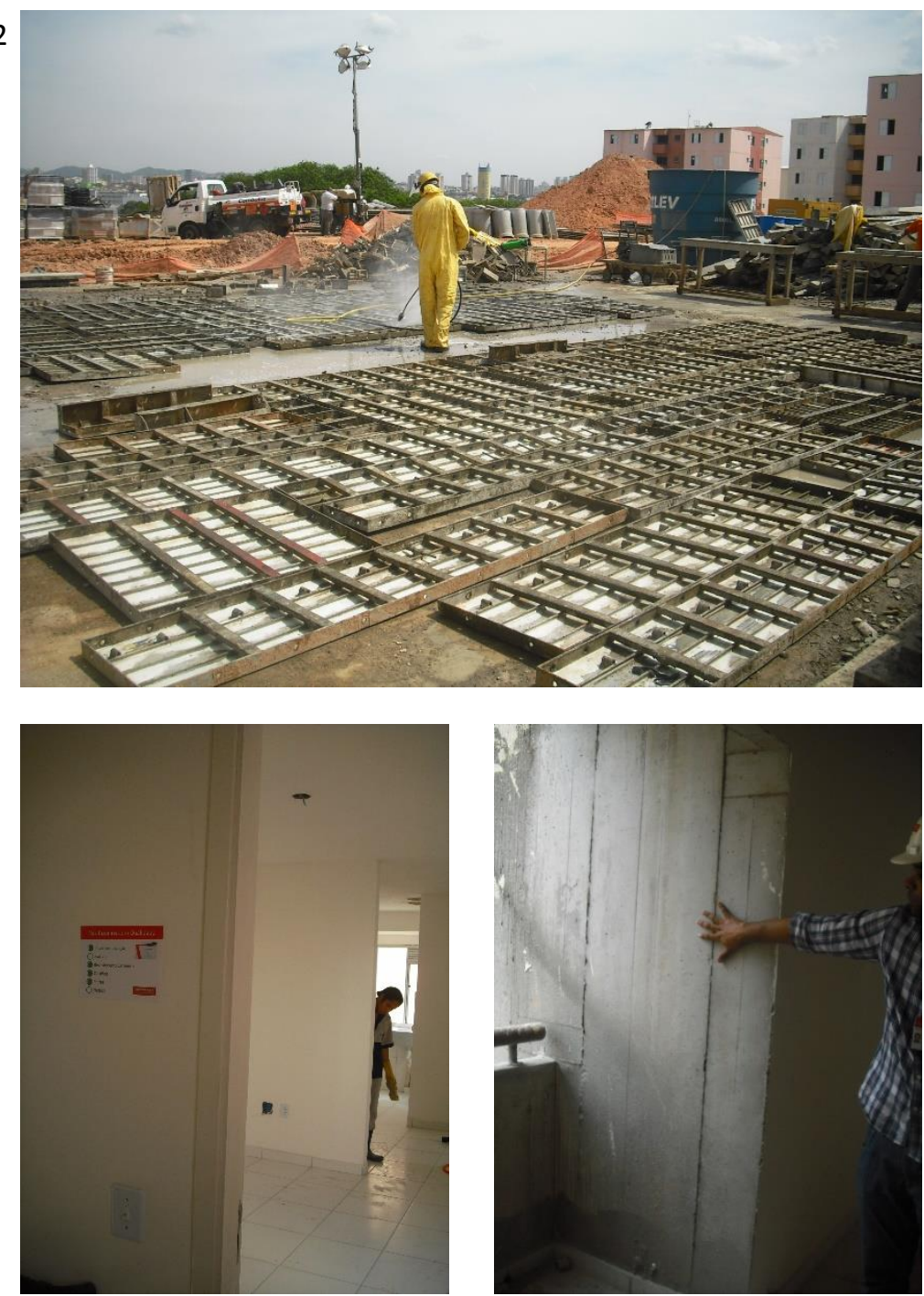

3

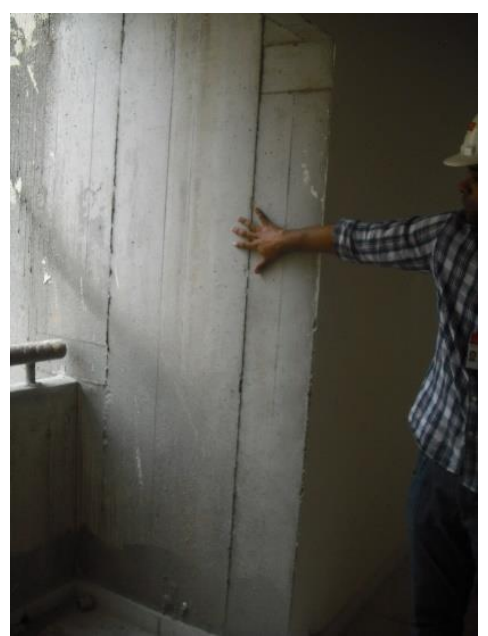

4
COND. GUARATINGUETÁ

Av. Guaratinguetá 1051

Santo André - Jd Alzira Franco $880 \mathrm{UH}$

A foto aérea [1] foi encomendada pela empresa como parte de um registro periódico da produção. Este tipo de controle de obra revela o capital em jogo neste empreendimento, que é de uma empresa subsidiária da Odebrecht OR, uma das maiores empreiteiras do mundo.

A gestão avançada deste canteiro de obras foi discutida no capítulo 4, a propósito do uso do concreto autoadensável em fôrmas de parede e laje (cf. imagens I-10 e I-11, bem como a foto da folha de rosto desta tese). No momento da visita, as últimas fôrmas estavam sendo lavadas [2]. Após a limpeza, foram despachadas para outro empreendimento da Faixa 1, desta vez no Rio de Janeiro, mas o custo das fôrmas de alumínio foi inteiramente amortizado em Santo André.

A limpeza final dos

apartamentos só era liberada após uma rotina de atividades de acabamento listadas numa ficha junto à porta de cada unidade [3]. A primeira atividade aparece nos apartamentos com concretagem recente, que é a raspagem nas áreas de juntas das fôrmas. Após esta raspagem, a parede está pronta para pintura 

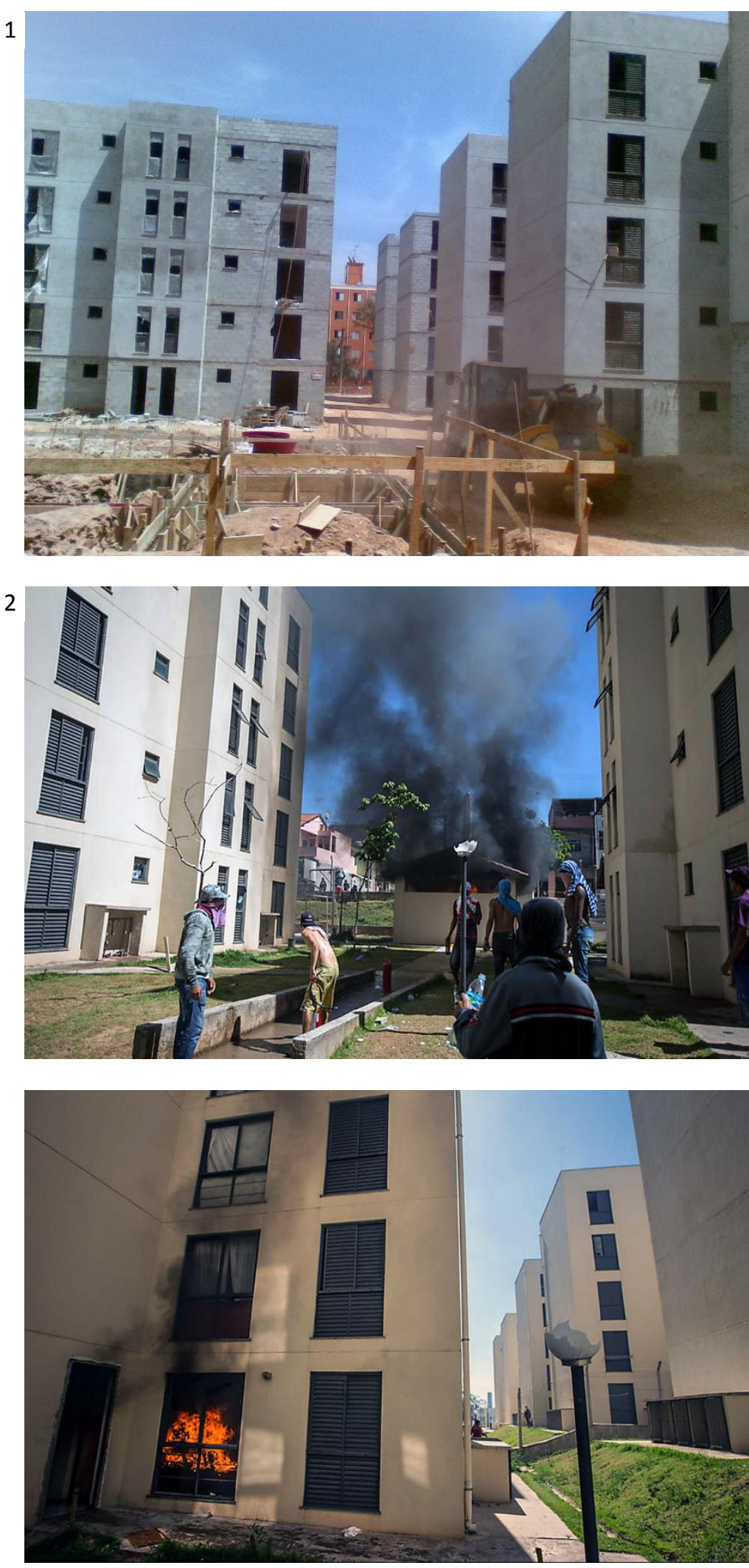

3
COND. CARAGUATATUBA

Rua Domingos Rubino 411

São Paulo - Guaianazes $940 \mathrm{UH}$

Praticamente todos os empreendimentos da Faixa 1 na cidade de São Paulo estão localizados em terrenos da Cohab, principalmente no eixo Itaquera, São Mateus e Cidade Tiradentes. Este, em Guaianazes, foi um dos primeiros visitados por esta pesquisa, em Setembro de 2011 [1]. Ali estava clara a importância de recursos de logística e organização, como o silo de argamassa industrial, o veículo Skytrak e a Ficha de Verificação de Serviço (cf. imagens I-2, I-8 e I-15).

Os quatro condomínios Caraguatatuba ganharam notoriedade nacional no fechamento desta pesquisa, em 20 de Fevereiro de 2014, quando foi executada uma violenta reintegração de posse contra famílias que ocuparam as unidades antes do repasse para a Cohab. O fogo e o vandalismo retratados na imprensa [2][3][4] só serviram para ressaltar o conformismo geral com os limites do programa MCMV.

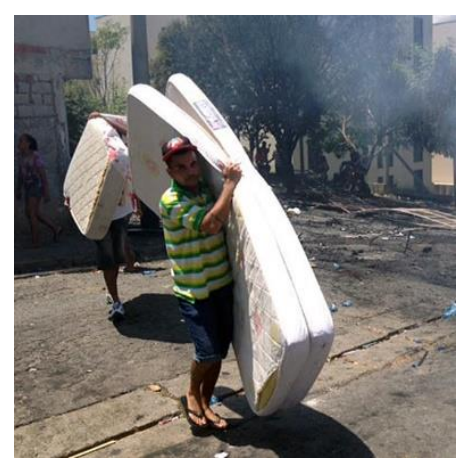

4

Fonte: [2][3] Avener Prado/Folhapress; [4] Rede Globo 


\section{CONCLUSÃO}

$\mathrm{Na}$ altura em que esta pesquisa se conclui, no começo de 2014, o programa MCMV se aproxima da meta final de 3,75 milhões de moradias contratadas. Nenhuma crítica que for lançada contra estas moradias impede a constatação de que integram a mais efetiva ação de governo no campo da habitação social desde o fim dos programas vinculados ao Banco Nacional de Habitação em 1986. É uma efetividade que se mede não apenas pela produção, mas pela alteração institucional e de mercado que criou e que, segundo um dos vice-presidentes da CEF, José Urbano Duarte, vai perdurar:

Não teria sido possível ampliar nessa escala a contratação se não tivesse havido os avanços que tivemos, desde a forma de relacionamento com o setor e toda a cadeia produtiva, incluindo Estados e municípios, a novas regras operacionais (...) O sucesso do programa credencia sua fórmula e é difícil imaginar o mercado sem uma politica e um estímulo dessa natureza (Dias; Castelo, 2013: 4-5).

As conclusões desta pesquisa, entretanto, são de natureza retrospectiva. Buscam entender na atualidade do programa MCMV as condições da construção habitacional que já estavam presentes no Brasil, mesmo que em germe, antes de seu lançamento em Abril de 2009. No "Capital", Marx usa com frequência a noção de "metabolismo" para descrever o trabalho humano e a função produtiva da sociedade. Para seguir dentro do parâmetro das transformações químicas da vida, o programa MCMV poderia assumir um papel mais específico, o de catalisador de materiais pré-existentes da economia e da sociedade brasileira, que é capaz de manter a si mesmo enquanto aumenta e acelera transformações que antes eram apenas potenciais.

O material pré-existente pesquisado ao longo dos capítulos anteriores foi organizado em duas partes. A primeira - "Trabalho e o programa MCMV" - se baseia no canteiro de obras e investiga transformações do trabalho na construção habitacional desde a marcante interpretação de Sérgio Ferro sobre a manufatura. A conversão desta manufatura na força de trabalho agora dominada e criada pelo capital através de programas de treinamento e especialização das operações produtivas foi evidenciada por uma reconstituição tipológica e corroborada por transformações populacionais e de modelos da industrialização da construção. A segunda parte - "Tecnologia e concentração de capital" - se baseia no empreendimento de construção para tratar da tecnologia organizacional dos sistemas de gestão de qualidade, sem a qual o controle da subempreitada não poderia ser conduzido no sentido da concentração de capital no setor produtivo da construção habitacional.

A retomada dos argumentos de cada parte da tese visa formular conclusões sobre o programa MCMV que permitam avaliá-lo para além do reconhecimento de que, hoje, "é difícil imaginar o mercado sem uma política e um estímulo dessa natureza". 
O capítulo 1 - "O fim da manufatura" - é uma contestação de natureza teórica da forma de produção da manufatura como modelo explicativo da construção habitacional e que investiga brechas em textos essenciais de Sérgio Ferro e Michael Ball que permitam interpretar os canteiros de obras do programa MCMV segundo paradigmas da indústria.

A contestação empírica da manufatura aparece no capítulo 2, que recorre à "Argamassa de revestimento como trabalho-tipo" para reconstituir processos de trabalho da construção habitacional reorganizados por sistemas de máquinas flexíveis e novas formas de orçar e remunerar serviços terceirizados. A síntese deste material empírico acontece no capítulo 3, "A destreza do capital", que se utiliza da principal tecnologia construtiva do programa MCMV - a alvenaria estrutural - para mostrar o crescente domínio da gerência do capital sobre a produtividade e treinamento da força de trabalho, domínio que corresponde ao paradigma da industrialização como organização da produção. O trabalho será uma força produtiva associada a sistemas de gestão, não a máquinas.

O controle da força de trabalho é interpretado no capítulo 4, "A população excedente na construção civil", como uma reação ao efeito da transição demográfica brasileira entre os milhões de postos de trabalho deste setor produtivo. A produtividade se eleva para além da elevação da massa salarial de do contingente de trabalhadores da construção, contingente que aparece menor e mais velho nas mais recentes pesquisas demográficas e econômicas.

No capítulo 5 - "A população excedente no programa MCMV" - o trabalho é confrontado com o programa MCMV não pela produção, mas sim pela reprodução de classe, isto é, a população excedente que é o "exército industrial de reserva" será considerada como "déficit habitacional". A legitimação política do programa federal pelo levantamento de carências de moradias não impediu que nesta década o déficit habitacional adquirisse um caráter eminentemente de social, através do fator "ônus excessivo com aluguel".

A segunda parte da pesquisa transita do canteiro de obras para o empreendimento de construção, onde se revela a natureza organizacional da industrialização da construção habitacional. Apesar da transição, a tecnologia empregada no programa MCMV segue o mesmo movimento geral da Parte 1, em que o aperfeiçoamento da produção resulta num consumo deficiente.

O capítulo 6 aborda os "Sistemas de gestão de qualidade" como referência comum da tecnologia organizacional, desde a amplitude global das normas ISO até sua lenta implantação no setor habitacional brasileiro através do SiAC/PBQP$\mathrm{H}$. A vinculação entre os financiamentos do programa MCMV com os sistemas de gestão de qualidade aproxima ainda mais os ciclos de melhoria contínua da gestão empresarial dos ciclos de concorrência e de controle de mercado.

Já o capítulo 7 - "A subempreitada" - aborda a subcontratação de serviços como uma relação de produção da construção habitacional, em que a extração de maisvalor aparece na exploração de capital sobre capital e, portanto, na sua concentração contínua nas médias e grandes empresas construtoras. Elas detêm (com certificados) a tecnologia organizacional com a qual podem exercer o controle produtivo de milhares de subempreiteiras, enquanto estas se integram à cadeia de suprimentos da "industrialização sutil" discutida por Julián Salas e 
Luiz Ceotto, de produção automatizada e flexível. Ao discutir a documentação do Ministério Público do Trabalho que denuncia o uso de trabalho análogo à escravidão por parte de uma das mais atuantes empresas construtoras do programa MCMV, a MRV Engenharia S/A, o capítulo não considera que o caso é uma regressão da gestão de qualidade, mas, pelo contrário e de forma perturbadora, que é sua exacerbação como tecnologia de controle da produção, capaz de elevar a produtividade até mesmo em combinação com uma estratégia de competição baseada na supressão de direitos do trabalho.

Por fim, o oitavo e último capítulo - "A periferização da tecnologia" - analisa a convergência inédita entre a tecnologia organizacional da construção e a mais distintiva característica do programa MCMV, o subsídio quase integral da moradia para baixa renda. O real beneficiário deste subsídio é a empresa construtora que, no centro de um programa público de moradia social, se torna promotor privado de um empreendimento habitacional livre de riscos de incorporação. Nesta modalidade do programa MCMV aparece o "laboratório da baixa renda", ambiente de negócio seguro onde é testado e amortizado todo aperfeiçoamento produtivo permitido pelos sistemas de gestão de qualidade. $\mathrm{O}$ subsídio, que é tutela do morador pelos cadastros municipais e seu trabalho social, é também estímulo para adesão das empresas construtoras a uma tecnologia organizacional que será replicada nas outras modalidades de renda do programa MCMV, potencializando os ganhos com a localização urbana.

$* * *$

As condições de produção da habitação social que estavam dormentes e são catalisadas pelo programa MCMV não são as condições produtivas deixadas pelo BNH há quase trinta anos - uma massa de trabalho manual, pensada como centro da produção habitacional - mas sim a força de trabalho que se reduz e se especializa, uma nova camada no mercado fornecedor de insumos de produção que é automatizada e diversificada, a tecnologia gerencial do sistema de gestão de qualidade (na transição entre o QualiHab e o SiAC) e a integração das subempreiteiras como fornecedoras de serviços especializados em cadeias de suprimentos onde se abre a possibilidade de uma concentração do capital contínua e controlada. São estas novas condições produtivas que dão origem a duas conclusões sobre o programa MCMV: uma diz respeito ao aparato crítico que deve ser utilizado para compreender o estado presente do programa, enquanto outra compreende as implicações sociais de que este estado presente se prolongue no futuro.

Reconhecer que o trabalho e a tecnologia da construção habitacional no Brasil sofreram alterações radicais nos últimos trinta anos é uma posição surpreendentemente rara nos estudos urbanos sobre o programa MCMV, o que diversas vezes impede que críticas importantes e necessárias se beneficiem da análise do canteiro de obras e do empreendimento de construção. Entre vários exemplos disponíveis, um emblemático é a proposta que deu início à linha de pesquisa sobre "O programa MCMV e seus efeitos territoriais" (Cardoso, 2013), 
que retém como base teórica a sociologia urbana de Topalov e faz este "panorama geral das formas de produção da moradia":

Existem limites estruturais para a produção capitalista de moradias, dados pelas características específicas desse bem: seu longo ciclo produtivo, seu alto valor agregado, $e$ a necessidade de terra urbanizada como um insumo fundamental. Essas características estabelecem limites à penetração da lógica da produção capitalista no setor, mantendo um baixo nível de desenvolvimento tecnológico (caráter quase manufatureiro) e um alto grau de utilização de trabalho manual de baixa qualificação (Cardoso; Lago, 2013: 8).

Nesta citação limitada a duas frases, apenas a segunda contém um equívoco, pois de fato existem limites estruturais para a produção capitalista de moradia. No entanto, cabe perguntar: não existiriam em outros setores produtivos outros tantos limites? Não estariam também a agricultura, a imprensa, a indústria aeroespacial ou a de vestuário submetidas "às características específicas" do que produzem? É este truísmo que torna injustificável a segunda frase, em que a construção habitacional permanecerá com baixo desenvolvimento tecnológico, com trabalho manual e desqualificado, devido a um "limite estrutural".

No fundo, o problema deste e outros raciocínios como este é que são apenas raciocínios. A primeira conclusão desta pesquisa de doutorado, derivada da observação e de visitas técnicas a canteiros de obras, de relatos e entrevistas com profissionais da construção, da consulta a documentos primários como orçamentos, cronogramas e relatórios, é uma conclusão empírica e documental em sentido inverso ao do texto citado: no programa MCMV não há "limites à penetração da lógica capitalista".

A segunda conclusão da tese reconhece tanto a transformação do trabalho no canteiro de obras quanto a reorganização dos empreendimentos de construção pela tecnologia organizacional e faz esta avaliação necessária: no programa MCMV, trabalho e tecnologia geram espaços construídos que são socialmente regressivos devido à edificação que segue apenas um projeto de produção para padrões mínimos de desempenho habitacional e à urbanização que segrega famílias pobres em bairros pobres.

O impedimento que esta regressão social prossiga não vai surgir de mais dotações orçamentárias ao FAR, novas portarias do Ministério das Cidades ou revisões de requisitos técnicos do PBQP-H ou da ABNT. Pelo contrário, as regulações que se sucedem reforçam apenas o domínio da produção sobre o programa MCMV: diminuir requisitos, desburocratizar aprovações, reclassificar zoneamentos, subsidiar tecnologia, todas estas iniciativas fazem com que o programa, apesar do nome, dissocie cada vez mais "casa" e "vida".

É inevitável, portanto, a conclusão de que o avanço institucional e tecnológico do programa MCMV não fará nada de novo nas cidades brasileiras se não se associar a um controle político sobre a organização e uso do espaço urbano, pois apenas uma consciência técnica e política da cidade vai interromper a produção contínua por parte do programa MCMV de edifícios cujo único projeto é a replicação urbanizada das áreas de pobreza.

Em Junho de 2013, protestos populares conseguiram aproximar pessoas de diferentes origens e interesses em relação ao espaço público das cidades brasileiras. Talvez apareça desta mobilização uma consciência que é mais 
presente nas revoltas originadas nos conjuntos habitacionais na Europa, fruto de sociedades em que direitos sociais são reconhecidos no espaço urbano e, portanto, onde a política consegue se engajar por uma visão de cidade.

A distância do Brasil em relação a esta consciência não é intransponível, mas ela é mantida pela resistência não da sociedade, mas do Estado em reconhecer conflitos materiais e tomar posição. André Singer considera a recusa ao conflito como característica essencial do que ele chama de "reformismo fraco" das presidências Lula e Dilma Rousseff, os dois principais protagonistas políticos da implementação do programa MCMV:

O reformismo fraco é o projeto adotado pelo bloco no poder. Expansão do mercado interno com integração do subproletariado ao proletariado via emprego (mesmo que precário), consumo e crédito, sem reformas anticapitalistas, e com lenta queda da desigualdade como subproduto, é o que se deve esperar (...) Os governos Lula e Dilma, sustentados pelo subproletariado, buscam equilibrar as classes fundamentais - proletariado e capitalistas -, pois o seu sucesso depende de que nenhuma delas tenha força para impor os próprios desígnios (...) Como fração de classe que não pode se auto-organizar, o subproletariado deposita no Estado, não na sociedade organizada, a esperança de sair da pobreza sem passar por turbulências que poriam em risco o processo de integração (Singer, 2012: 200).

A manutenção deste subproletariado conformado a seu lugar nas cidades e na sociedade brasileira é, por enquanto, o único legado político do programa MCMV. Nele, a segregação urbana dispensa a colaboração da autoconstrução popular: sem causar conflitos sociais, o isolamento espacial da população pobre se torna produto do melhor treinamento da força de trabalho e da melhor tecnologia organizacional que o capital da construção civil consegue reunir na habitação social.

Esta tese de doutorado, que começou com um debate com Sérgio Ferro, termina com um depoimento de seu companheiro do Grupo Arquitetura Nova, Rodrigo Lefèvre. A questão no debate com Sérgio Ferro era apontar que a análise da produção habitacional que era pertinente para a moradia construída pelo BNH não é mais pertinente para a moradia construída pelo programa MCMV. Em outras palavras, mudou o material de que é feita a segregação urbana em um e outro caso. No entanto, numa entrevista concedida a Renato Maia em 1974 (publicada em Maia, 2000), Rodrigo Lefèvre comenta algo que não mudou: a desatenção às perguntas pelo verdadeiro sentido de uma produção habitacional:

Existem outras coisas envolvidas além do problema financeiro de fazer a casa, comprar a casa, fazer alguém ter aquela casa. Existem problemas gravíssimos de como o morador vai usar a casa: que tipo de casa é essa; qual é o conceito de casa para o morador; como essa casa se relaciona com o resto da cidade; que condições o morador tem de realmente continuar mantendo aquelas relações que ele mantinha com a cidade, na nova casa. Todo esse processo foi esquecido. Não se criou nada no sentido de qual orientação dar para o problema da habitação no Brasil. 


\section{REFERÊNCIAS BIBLIOGRÁFICAS}

ABIKO, Alex; CARDOSO, Francisco; MARQUES, Felipe; TIGRE, Paulo (org.) (2005). Setor de construção civil. Série Estudos Setoriais. Brasília: Senai/DN

ABNT - Associação Brasileira de Normas Técnicas (2006). NBR 12.271:2006 - Avaliação de custos unitários de construção para incorporação imobiliária. Rio de Janeiro: ABNT.

AGOPYAN, Vahan (2005). "A construção civil rompendo paradigmas". In: FARIA, Cláudia (org.). Inovação na construção civil. São Paulo: Instituto Uniemp.

ALMEIDA, Mário; AMATO, Fernando (2011). Empreendimentos para Baixa Renda do Programa Minha Casa Minha Vida. Artigo apresentado na $11^{\text {a }}$ Conferência LARES.

ANDRADE, Gabriel (2012). Políticas habitacionais brasileiras - uma avaliação do programa MCMV em suas duas edições. Projeto de Graduação. Rio de Janeiro: EP/UFRJ.

AQUINO, Célia (2011). “Técnica de alvenaria estrutural promete mais eficiência na construção". Estado de Minas, edição de 27MAI11. Belo Horizonte: Diários Associados.

ARANTES, Pedro (2012). Arquitetura na Era Digital-Financeira. São Paulo: Editora 34.

ARANTES, Pedro (2013). “Da (Anti) Reforma Urbana brasileira a um novo ciclo de lutas nas cidades". Correio da Cidadania. Edição de 08 de Novembro. São Paulo: Sociedade para o Progresso da Comunicação Democrática.

ARANTES, Pedro; FIX, Mariana (2009). “Como o governo Lula pretende resolver o problema da habitação". Correio da cidadania. Versão original em mimeo. São Paulo: Sociedade para o Progresso da Comunicação Democrática.

ARENDT, Hannah (1998 [1958]). The human condition. Chicago: Chicago Press.

BALL, Michael (1978). "British housing policy and building industry". Capital and Class, n. 4. Londres: Conference of Socialists Economists.

BALL, Michael (1988). Rebuilding construction. Londres: Routledge.

BALLARD, Glenn; HOWELL, Gregory (2003). Competing construction management paradigms. Conferência em evento da "American Society of Construction Engineering". Honolulu: ASCE.

BARROS, Mércia (1998). “O processo de produção das alvenarias racionalizadas”. In: BARROS, Mércia; SABBATINI, Fernando; MEDEIROS, Jonas (ed.). Seminário de tecnologia e gestão na produção de edifícios: vedações verticais. São Paulo: EP/USP.

BARROS, Mércia; SABBATINI, Fernando (2003). Diretrizes para o processo de projeto para a implantação de tecnologias construtivas racionalizadas na produção de edifícios. Boletim Técnico - BT/PCC, n. 172. São Paulo: EP/USP.

BEARD, Jeffrey; LOULAKES, Michael; WUNDRAM, Edward (2001). Design-Build. Nova York: McGraw-Hill.

BÉRGAMO, Luís. “Trabalho escravo, risco crescente”. Construção e Mercado, ed. 151. São Paulo: Pini.

BOLAFFI, Gabriel (1982). "Habitação e urbanismo: o problema e o falso problema". In: MARICATO, Ermínia (org.). A produção capitalista da casa (e da cidade) no Brasil industrial. São Paulo: Alfa-Ômega. 
BONDUKI, Nabil (1998). Origens da Habitação Social no Brasil (1930-1945). São Paulo: Estação Liberdade.

BONDUKI, Nabil (2009). "Do projeto Moradia ao programa Minha Casa Minha Vida". Teoria e Debate, n. 82. São Paulo: Fundação Perseu Abramo.

BOULOS, Guilherme (2013). “Quando o discurso não convence”. Folha de S. Paulo. Edição de 27DEZ13. São Paulo: Grupo Folha.

BRANCO PEDRO, João (2012). “Exigências de espaço aplicáveis à construção de habitação de interesse social". Revista Pós. São Paulo: FAU/USP

BRANDLI, Luciana (1998). A estratégia de subcontratação e as relações organizacionais na construção civil de Florianópolis. Dissertação de mestrado. Florianópolis: UFSC.

BRANDLI, Luciana; JÜNGLES, Antônio; HEINECK, Luiz (1998). O perfil da mão-deobra subcontratada da indústria da construção civil. Comunicação no Encontro Nacional de Engenharia de Produção. Niterói: Abepro.

BRAVERMAN, Harry (1998 [1974]). Labor and monopoly capital. Nova York: Monthly Review Press

BRUNA, Paulo (1976). Arquitetura, industrialização e desenvolvimento. São Paulo: Perspectiva.

CARDOSO, Adauto; LAGO, Luciana (2013). “O programa Minha Casa Minha Vida e seus efeitos territoriais". In: CARDOSO, Adauto (org.). O Programa Minha Casa Minha Vida e seus efeitos territoriais. Rio de Janeiro: Letra Capital.

CARDOSO, Adauto; ARAGÃO, Thêmis (2013). “Do fim do BNH ao Programa Minha Casa Minha Vida". In: CARDOSO, Adauto (org.). O Programa Minha Casa Minha Vida e seus efeitos territoriais. Rio de Janeiro: Letra Capital.

CARDOSO, Francisco; VIVANCOS, Adriano; JESUS, Cláudia (2001). "The Qualihab experience". In: CASALS, Miguel. CIB W99/TG36 International Conference on Costs and Benefits Related to Quality and Safety and Health in Construction. Barcelona: CIB.

CARDOSO, Francisco (2005). "A dimensão organizacional da construção civil". In: ABIKO, Alex; CARDOSO, Francisco; MARQUES, Felipe; TIGRE, Paulo (org.). Setor da construção civil. Série Estudos Setoriais. Brasília: Senai/DN.

CARDOSO, Francisco (2007). Capacitação e certificação profissional na construção civil. São Paulo: Abramat.

CBIC - Câmara Brasileira da Indústria da Construção (2009). Projeto Inovação Tecnológica. Relatório de evento. São Paulo: CBIC.

CBIC - Câmara Brasileira da Indústria da Construção (2010). "Mais qualidade nas obras do MCMV e PAC". CBIC Hoje, edição de 15 de Abril. Brasília: CBIC

CBIC - Câmara Brasileira da Indústria da Construção (2013). "Classificação das maiores empresas da construção". Banco de dados em "www.cbicdados.com.br".

CEOTTO, Luiz (2005). "A industrialização da construção de edifícios: de passado letárgico para um futuro promissor". In: FARIA, Cláudia (org.). Inovação na construção civil. São Paulo: Instituto Uniemp.

CGPAC - Comitê Gestão do Programa de Aceleração do Crescimento (2014). $9^{\circ}$ Balanço: 2011-2013. Brasília: MPOG.

CHRISTOPHER, Martin (1998). Logistics and supply chain management. Nova Jersey:

Prentice Hall

CICHINELLI, Gisele (2010a). “Alvenaria racional”. Construção e Mercado, n. 109. São Paulo: Pini. 
CICHINELLI, Gisele (2010b). “Acabamento projetado”. Téchne, n. 158. São Paulo: Pini. CLIFFORD, Stephanie (2005). "So many standards to follow, so little payoff. Inc. Magazine, edição de Maio. Nova York: Mansuetto Ventures

CLOUGH, Richard (1986). Construction Contracting. Nova York: J.Wiley \& Sons.

COCITO DE ARAÚJO, Luís; SOUZA, Ubiraci (2001). Produtividade da mão-de-obra na execução de alvenaria. BT/PCC 269. São Paulo: EP/USP.

COISSI, Juliana (2011). “Dossiê da Procuradoria detalha irregularidades de 89 construtoras". Folha de S. Paulo. Caderno Ribeirão. São Paulo: Grupo Folha.

CORIAT, Benjamin (1983). "Le procès de travail de type 'chantier' et sa rationalisation". Ata do colóquio Le travail en chantiers. São Paulo: mimeo (tradução de Jorge Oseki, revisão de João Sette Whitaker Ferreira).

CORIAT, Benjamin (1994). L'Atelier et le chronomètre. Paris : Christian Bourgeois.

CORSINI, Rodnei (2012a). "Produtividade aferida". Guia da Construção, n. 133. São Paulo: Pini.

CORSINI, Rodnei (2012b). "Apagão de operadores". Construção e Mercado, n. 137. São Paulo: Pini.

CORSINI, Rodnei (2013). “Demorou mas chegou”. Construção e Mercado, n. 141. São Paulo: Pini.

COSTA, Rubens (1972). O Sistema Nacional da Habitação e os corretores de imóveis. Rio de Janeiro: BNH

COYLE, John; BARDI, Edward; LANGLEY, John (2003). Management of Business Logistics. Cincinnati: South-Western College Publishing.

CPT - Comissão Pastoral da Terra. Síntese estatística do trabalho escravo. Goiânia: CPT. Documento on-line em "http:/ / www.cptnacional.org.br".

CURY, Fábio (2011). “O verdadeiro mercado”. O Estado de São Paulo. Caderno “Imóveis 1", edição de 14 de Agosto 2011. São Paulo: OESP.

CURY, Fábio (2013). Cury Construtora divulga balanço 2012. Entrevista para Portal VGV publicada em 25 de Abril de 2013. On-line em "www.portalvgv.com.br".

DAI, Jiukun; GOODRUM, Paul; MALONEY, William (2009). “Construction craft workers' perceptions of the factors affecting their productivity". Journal of construction engineering and management, v. 135, n. 3 .

DALGLEISH, Scott (2005). " ISO 9001 Proves Ineffective ". Quality Magazine, edição de Abril. Detroit: BNP Media

DAMÉ, Luiza (2012). "Meta do MCMV2 sobe para 2,4 milhões de casas". O Globo, edição de 12ABR12. Rio de Janeiro: GDA.

DELLA PENA, Cristina; SOUZA, Roberto; MELO, Tula (2012). Tendências no setor de habitação econômica e de interesse social. São Paulo: O Nome da Rosa.

DIAS, Edney; CASTELO, Ana (2013). “O Minha Casa Minha Vida quatro anos depois". Conjuntura da Construção, Ano 11, ed. 1. São Paulo: Sinduscon/SP.

DIETZ, Albert \& CUTLER, Laurence (1971). Industrialized building systems for housing. Cambridge: MIT Press.

DORSEY, Robert (1999). Case studies in building design and construction. Upper Saddle River: Prentice-Hall.

DUHIGG, Charles; BARBOZA, David (2012). "In China, the human costs that are built into an iPad". The New York Times. Edição de 26 de Janeiro, pág. A1. Nova York: NYTC 
DUHIGG, Charles; BRADSHER, Keith (2012). "How the U.S. lost out on iPhone work". The New York Times. Edição de 21 de Janeiro, pág. A1. Nova York: NYTC

EASTMAN, Charles; SACKS, Rafael (2008). "Relative productivity in the AED industries in the United States for on-site and off-site activities". Journal of construction engineering and management, v. 134, n. 7.

ELIEZER, Leister; ALBUQUERQUE, Paulo; NOGUEIRA, Rogério; CARVALHO, David; PASCHOALIM FILHO, João (2003). Utilização de argamassa industrializada para o preenchimento de estaca raiz. Relatório de Pesquisa. Campinas: FEC/Unicamp.

FARAH, Marta (1996). Processo de trabalho na construção habitacional. São Paulo: Annablume.

FARIA, Renato (2007). "Projeto de armaduras". Téchne, ed. 120. São Paulo: Pini.

FARIA, Renato (2013). “Argamassa em foco”. Téchne, ed. 194. São Paulo: Pini.

FELLER, Jacques (2013) “PMG: o vilão das parcerias”. Construção e Mercado, n. 139. São Paulo: Pini.

FERRO, Sérgio (2006 [1969]). “A produção da casa no Brasil”. In: Arquitetura e trabalho livre. São Paulo: Cosac Naify.

FERRO, Sérgio (2006 [1976]). “O canteiro e o desenho". In: Arquitetura e trabalho livre. São Paulo: Cosac Naify.

FERRO, Sérgio (2006 [2003]). “Sobre o canteiro e o desenho". In: Arquitetura e trabalho livre. São Paulo: Cosac Naify.

FERREIRA, Cláudio; GIACOMITTI JR, Martinho (2007). “Avaliação do grau de atendimento das pequenas construtoras de obras civis da cidade de Curitiba aos requisitos do PBQP-H". Da Vinci, v. 4, n. 1.

FERREIRA, João Setti (org.) (2012). Produzir casas ou construir cidades?. São Paulo: LabHab/Fupam.

FERREIRA, Romário (2013a). "Alvenaria Racional”. Guia da Construção, n. 140. São Paulo: Pini.

FERREIRA, Romário (2013b). “Começa a revisão do Sinapi”. Construção e Mercado, n. 141. São Paulo: Pini.

FERREIRA, Romário (2013c). “Dois lados do MCMV". Construção e Mercado, n. 143. São Paulo: Pini.

FGV - Fundação Getúlio Vargas (2012). A produtividade da construção civil brasileira. Brasília: CBIC.

FGV - Fundação Getúlio Vargas (2013). "Pesquisa MCMV". Seminário Minha Casa, Minha Vida e Parcerias. Apresentada pelo vice-presidente do Sinduscon/SP João Robusti em 29 de Março. São Paulo: Sinduscon/SP.

FIX, Mariana (2011). Financeirização e transformações recentes no circuito imobiliário brasileiro. Tese de doutorado. Campinas: IE/Unicamp.

FIX, Mariana; PEREIRA, Álvaro (2013). "A metrópole brasileira nas políticas setoriais". In FURTADO, Bernardo; KRAUSE, Cleandro; FRANÇA, Karla. Território metropolitano, políticas municipais. Brasília: Ipea.

FJP - Fundação João Pinheiro (2011). Déficit habitacional no Brasil 2008. Brasília: MCidades.

FRANCO, Eliete (1995). Ergonomia na construção civil. Dissertação de mestrado. Florianópolis: CETD/UFSC. 
FRANKS, James (1984). Building sub-contract management. Londres: Construction Press FREITAS, Álvaro (2012). Implementar e manter um Sistema de Gestão da Qualidade baseado na norma ISO 9001. Artigo on-line em "www.academiaplatonica.com.br.

FRYER, Barry (1985). The practice of construction management. Londres: Collins FSP - Folha de S. Paulo. "Construção é aposta dos investidores”. Edição 05DEZ11. São Paulo: Grupo Folha.

GARVIN, David (1992). Gerenciando a qualidade. Rio de Janeiro: Qualitymark.

GIRIBOLA, Maryana (2013). "Produtividade na fachada”. Construção Mercado, n. 139. São Paulo: Pini

GODELIER, Maurice (1986). “Trabalho” [Verbete]. Enciclopédia Einaudi: Modo de Produção. Volume 7. Lisboa: Imprensa Nacional.

GOODRUM, Paul; ZHAI, Dong; YASIN, Mohammed (2009). "Relationship between changes in material technology and construction productivity". Journal of construction engineering and management, v. 135, n. 4.

GRANDI, Sonia (1985). Desenvolvimento da indústria da construção no Brasil. Tese de doutorado. São Paulo: FFLCH/USP.

GRUNEBERG, Stephen (2005). "The economics of construction labour". International Council for Research and Innovation in Building and Construction. Artigo para debate. Helsinki: CIB.

GUEDES, Alberto; ARAÚJO, Davi; COTI-ZELATI, Paolo (2013). “Modelo de negócio em empreendimentos habitacionais populares". Anais Simpoi. Comunicação no $16^{\circ}$ Simpósio de Administração da Produção e Logística Internacional. São Paulo: FGV.

GUIA DA CONSTRUÇÃO (2010). Edifício econômico com elevador. Ed. Janeiro n. 102. São Paulo: Pini.

GUIA DA CONSTRUÇÃO (2010). Fôrmas de alumínio. Ed. Janeiro n. 138. São Paulo: Pini.

HAMEL, Gary; PRAHALAD, Coimbatore (1994). Competing for the future. Cambridge: Harvard Business School Press.

HARI, Johann. "Rachaduras no paraíso". Piaui, n.33. Rio de Janeiro: Alvinegra

HARVEY, David (2006 [1982]). Limits to capital. Nova York: Verso.

HARVEY, David (2011). The enigma of capital. Nova York: Oxford

IBGE - Instituto Brasileiro de Geografia e Estatística (2002). Notas metodológicas da Pesquisa Mensal de Emprego. Página eletrônica em "www.ibge.gov.br".

IBGE - Instituto Brasileiro de Geografia e Estatística (2007a). Classificação Nacional de Atividades Econômicas - Versão 2.0. Rio de Janeiro: IBGE.

IBGE - Instituto Brasileiro de Geografia e Estatística (2007b). Relatório metodológico Pesquisa Mensal de Emprego, vol. 23. Rio de Janeiro: IBGE.

IBGE - Instituto Brasileiro de Geografia e Estatística (2012). Pesquisa Anual da Indústria da Construção - 2010. Volume 20. Rio de Janeiro: IBGE.

IBGE - Instituto Brasileiro de Geografia e Estatística (2013). Retrospectiva da Pesquisa Mensal de Emprego. Rio de Janeiro: IBGE.

ISHIWARA, Atsuo (1996). Uma visão do modelo japonês de produtividade. Curitiba: IBQP. ISO - International Standard Organization (2012). ISO 9000 Essentials. Página eletrônica em "http://www.iso.org". 
ISO - International Standard Organization (2013a). Annual Report 2012. Documento online em "http:/ /www.iso.org".

ISO - International Standard Organization (2013b). The ISO Survey of Management System Standard Certifications. Página eletrônica em "http:/ / www.iso.org".

JESUS, Cláudia; CARDOSO, Francisco (2004). Análise crítica da implementação do PSQ: setor de obras do programa Qualihab. BT/PCC 445. São Paulo: EP/USP.

JONES, Gavin; DOUGLAS, Robert; CALDWELL, John; D'SOUZA, Rennie (1997). The Continuing Demographic Transition. Oxford: Clarendon.

KRAUSE, Cleandro; BALBIM, Renato; LIMA NETO, Vicente (2013). Minha Casa Minha Vida, nosso crescimento. Texto para discussão 1853. Rio de Janeiro: IPEA.

LEAL, Ubiratan (2010). “Três não é demais". Construção e Mercado, ed. 109. São Paulo: Pini

LEVI, Primo (2004 [1986]). Os afogados e os sobreviventes. São Paulo: Paz e Terra.

LEVI, Primo (2009 [1978]). A chave estrela. São Paulo: Cia das Letras.

LIBRAIS, Carlus; SOUZA, Ubiraci (2002). Produtividade da mão-de-obra no assentamento de revestimento cerâmico interno de parede. BT/PCC 316. São Paulo: EP/USP.

LIMA NETO, Vicente; FURTADO, Bernardo; KRAUSE, Cleandro (2013). Estimativas do Déficit Habitacional brasileiro (PNAD 2007-2012). Nota Técnica 5. Brasília: Ipea

LINDNER DE OLIVEIRA, Flávio (2006). Argamassa industrializada. Trabalho de Conclusão de Curso. São Paulo: Universidade Anhembi-Morumbi.

LOBATO, Lilian (2010). "MRV aposta no interior de São Paulo". Diário do Comércio. Belo Horizonte: DCEJ.

LOTURCO, Bruno (2008). “Industrialização essencial”. Téchne, n. 137. São Paulo: Pini.

LOTURCO, Bruno; FARIA, Renato (2008). “Vantagens concretas”. Téchne, ed. 140. São Paulo: Pini.

LOUREIRO, Maria; MACÁRIO, Vinícius; GUERRA, Pedro (2013). Democracia, arenas decisórias e políticas públicas. Texto para discussão 1886. Rio de Janeiro: IPEA.

MAGALHÃES, Sérgio (2013). "Minha casa no país do carro zero". O Globo, edição de 27ABR13. Rio de Janeiro: GDA.

MAIA, Renato (2000). "Rodrigo Lefèvre: entrevista". Vitruvius, n. 1, online em "www.vitruvius.com.br". São Paulo: Romano Guerra

MARICATO, Ermínia (1984). Indústria da construção e política habitacional. Tese de Doutorado. São Paulo: FAU/USP.

MARICATO, Ermínia (1988) [org.]. A produção capitalista da casa (e da cidade) no Brasil industrial. São Paulo: Alfa-Ômega.

MARICATO, Ermínia (2009a). “Por um novo enfoque teórico na pesquisa sobre habitação". Cadernos Metrópole, $\mathrm{n}^{\circ}$ 21. Rio de Janeiro: Observatório das Metrópoles.

MARICATO, Ermínia (2009b). “O ‘Minha Casa’ é um avanço, mas segregação urbana fica intocada”. Carta Maior, edição de 27 de Maio. São Paulo: Carta Maior Publicações.

MARICATO, Ermínia (2011). O impasse da política urbana no Brasil. São Paulo: Vozes.

MARCUSE, Peter (2009). "A Critical Approach to the Subprime Mortgage Crisis in the United States". City \& Community, vol. 8, n. 3.

MARX, Karl (2013 [1867]). O capital: Livro I. São Paulo: Boitempo (tradução de Rubens Enderle). 
MARX, Karl (1982 [1859]). Para a crítica da economia política. Lisboa: Editorial Avante (tradução de Barata Moura).

MCIDADES - Ministério das Cidades (2009). Plano Nacional de Habitação - PlanHab. Brasília: MCidades.

MCIDADES - Ministério das Cidades (2012). Sistema de avaliação da conformidade de empresas de serviços e obras da construção - SIAC. Brasília: MCidades.

MENDES, Gustavo (2010). “Mão-de-obra, sempre ela”. Construção Mercado, n. 102. São Paulo: Pini.

MESQUITA, Maria (2006). Subsídios para o planejamento da qualidade em edifícios do segmento hoteleiro. Tese de doutorado. São Paulo: EP/USP.

MOREIRA, Renata (2010). Distribuição de água na região metropolitana de São Paulo. Dissertação de mestrado. São Paulo: FAU/USP.

MORICE, Alain (1992). “Os peões da construção civil em João Pessoa”. Espaço $\mathcal{E}$ Debates, n. 36. São Paulo: Neru.

MOURA, André Drummond (2011). Novas soluções, velhas contradições. São Paulo: Dissertação de Mestrado - FAU/USP.

MOURA FÉ, Ana Lúcia (2013). “Custo da mão-de-obra”. Construção Mercado, n. 138. São Paulo: Pini.

MPT - Ministério Público do Trabalho (2012). Representação para apuração de infração da ordem econômica. Documento protocolado junto ao Conselho Administrativo de Defesa Econômica (Cade) em 02 de Março de 2012. Araraquara: MPT/15a Região. Acessível on-line em "http:/ / pt.scribd.com/ doc/205894629/MPT-Representacao-contra-MRV"

MTE - Ministério do Trabalho e Emprego (2013). Cadastro de Empregadores conforme Portaria interministerial 02/2011. Lista on-line atualizada em 30 de Dezembro de 2013 em "http:// portal.mte.gov.br/trab_escravo"

NASCIMENTO, Denise; TOSTES, Simone (2011). Programa Minha Casa Minha Vida. In: "www.vitruvius.com.br/revistas/read/arquitextos/12.133/3936".

NONNO, David (2011). Projetos - Mogi das Cruzes - Jundiapeba. Apresentação na $11^{\text {a }}$ Conferência Internacional LARES. São Paulo: EP/USP.

OHNUMA, Daniel (2003). Modelo de processos para a gestão de subempreiteiros. Dissertação de mestrado. São Paulo: EP/USP.

OLIVEIRA, Francisco (1976). “A produção dos homens”. Estudos Cebrap, v. 16. São Paulo: Cebrap.

OLIVEIRA, Francisco de (2003 [1972]). Crítica à razão dualista. São Paulo: Boitempo.

OLIVEIRA, Thiago (2008). “Operários à margem”. Construção Mercado, n. 84. São Paulo: Pini.

OSEKI, Jorge (1982). Algumas tendências da construção civil no Brasil. São Paulo: Tese de doutorado - FAU/USP.

PARAVISI, Sandra (2008). Avaliação de sistemas de produção de revestimentos de fachada com aplicação mecânica e manual de argamassa. Dissertação de mestrado. Porto Alegre: PPGEC/UFRGS.

PARAVISI, Sandra; MASUERO, Ângela; BONIN, Luís; ISATTO, Eduardo (2009). "Produção de argamassa com bomba de projeção". Téchne, n. 145. São Paulo: Pini.

PEREIRA, Paulo Cesar (1988). Espaço, técnica e construção. São Paulo: Nobel. 
PEREIRA, Sérgio; DE FILIPPI, Giancarlo; CARDOSO, Francisco (2000). Micro e pequenas empresas fornecedoras de mão-de-obra para construção civil. Apresentação no $2^{\circ}$ Congresso Internacional de Tecnologia e Gestão da Qualidade na Construção Civil. Recife: EP/UFPE.

PEREIRA, Sérgio (2003). Os subempreiteiros, a tecnologia construtiva e a gestão dos recursos humanos nos canteiros de obras de edifícios. Dissertação de mestrado. São Paulo: EP/USP.

PEREIRA, Sérgio; CARDOSO, Francisco (2004). Recomendações de boas práticas na subempreitada de serviços de execução em obras civis. Boletim Técnico - BT/PCC. São Paulo: EP/USP.

PESSÔA, Samuel (2013). "A revolução da oferta de trabalho". Folha de S. Paulo. Edição de 17FEV13. São Paulo: Grupo Folha.

PICCHI, Flávio (1993). Sistema da qualidade: uso em empresas de construção de edifícios. Tese de Doutorado. São Paulo: EP/PCC/USP

PICCINI, Andrea (1999). Cortiços na Cidade. São Paulo: Annablume.

PYL, Bianca (2012). “Trabalhadores de obra da Racional na região da Avenida Paulista são resgatados". Repórter Brasil. On-line em "www.reporterbrasil.org.br".

PRATES, Vinícius (2010). “Crivo da Caixa”. Construção e Mercado, n. 107. São Paulo: Pini.

PRISMA - Revista de soluções construtivas com pré-fabricados de concreto (2003). "Não ponha a mão na massa". Edição n. 8. São Paulo: Mandarim.

PROCHNIK, Victor (1986). O macrocomplexo da construção civil. Rio de Janeiro: Tese de doutorado

REIS, Pâmela (2010). “Os custos do atraso". Construção e Mercado, n. 110. São Paulo: Pini.

REIS, Pâmela (2012). "O maior erro é terceirizar a construção". Construção e Mercado, n. 131. São Paulo: Pini.

REGATTIERE, Carlos; SILVA, Luciano (2003). Ganhos potenciais na utilização da argamassa industrializada. São Paulo: ABAI/EP/USP

RIBEIRO, Luiz Cesar (1996). Dos cortiços aos condomínios de luxo. Rio de Janeiro: Civilização Brasileira.

ROCHA, Ana Paula (2009). "Alvenaria estrutural x estrutura reticulada". Guia da Construção, n. 92. São Paulo: Pini.

ROCHA, Silvério (2011). “Entrevista com Ubiraci Espinelli Lemes de Souza”. Prisma, n. 38. São Paulo: Mandarim.

ROCHA, Silvério (2012). "Construção com o DNA da baixa renda". Prisma, n. 38. São Paulo: Mandarim.

ROCHA, Silvério (2013). “A norma de desempenho vai mudar a cultura da construção brasileira". Prisma, n. 46. São Paulo: Mandarim.

RODRIGUES, Evaniza (2013). A Estratégia Fundiária dos movimentos populares na produção autogestionária da moradia. Dissertação de Mestrado. São Paulo: FAU/USP.

ROLLI, Cláudia; ROMAN, Clara (2013). "Nova lei trava contratação de mensalista". Folha de S. Paulo. Edição de 22MAR11. São Paulo: Grupo Folha.

ROLNIK, Raquel (org.); BISCHOF, Raphael; KLINTOWITS, Danielle; REIS, Joyce (2010). Como produzir moradia bem localizada com recursos do programa minha casa minha vida. Brasília: Ministério das Cidades. 
ROLNIK, Raquel; NAKANO, Kazuo (2009). “As armadilhas do pacote habitacional”. Le Monde Diplomatique, n. 20. São Paulo: Palavra Livre

RONCONI, Reginaldo (1995). Produção de Habitações em regime de mutirão com gerenciamento do usuário. Dissertação de mestrado. São Paulo: FAU/USP

SABBATINI, Fernando (1989). Desenvolvimento de métodos, processos e sistemas construtivos. São Paulo: Tese de Doutorado - EP/USP.

SABBATINI, Fernando (1998). “A industrialização e o Processo de Produção de Vedações”. In: BARROS, Mércia; SABBATINI, Fernando; MEDEIROS, Jonas (ed.). Seminário de tecnologia e gestão na produção de edifícios. São Paulo: EP/USP.

SABBATINI, Fernando (2008a). A contribuição da alvenaria estrutural para a industrialização do processo de produção de HIS. Apresentação em evento. São Paulo: CTE.

SABBATINI, Fernando (2008b). Encontro sobre habitação econômica e industrialização da construção. Gravação em vídeo on-line em “http:/ / www.youtube.com/watch?v=JsCHJMKJ0s\&list=PLB7C39906A20AF435".

SALAS, Julián (2008). “De los sistemas de prefabricación cerrada a la industrialización sutil de la edificación". Informes de la Construcción. V. 60, n. 512.

SANTO AMORE, Caio (2013). Entre o nó e o fato consumado. Tese de doutorado. São Paulo: FAU/USP.

SANTOS, Luiz; MELHADO, Silvio (2003). Diretrizes para elaboração de planos de qualidade em empreendimentos da construção civil. Boletim Técnico - BT/PCC. São Paulo: EP/USP.

SCHWARZ, Roberto (2000 [1977]). Ao Vencedor as Batatas. São Paulo: Editora 34.

SEADE - Fundação Sistema Estadual de Análise de Dados (2010). Necessidades habitacionais no Estado de São Paulo. São Paulo: Seade/CDHU.

SINDUSCON/MG (2007). Custo Unitário Básico. Belo Horizonte: Sinduscon/MG.

SINGER, André (2013). Os sentidos do lulismo. São Paulo: Cia das Letras.

SEDDON, John (2000a). The case against ISO 9000. Londres: Oak Tree Press.

SEDDON, John (2000b). “The 'quality' you can't feel”. The Observer, edição de 19 de Novembro de 2000. Londres: Guardian News and Media.

SHIMBO, Lúcia (2010). Habitação social, habitação de mercado. Tese de Doutorado. São Carlos: EESC/USP.

SHIMIZU, Júlio; BARROS, Mércia Bottura; CARDOSO, Francisco (2002). Análise da gestão da produção de revestimento externo de argamassa. Apresentação no $9^{\circ}$ Simpósio de Engenharia de Produção (Simpep).

SINDUSCON/SP - Sindicato da Indústria da Construção Civil do Estado de São Paulo (2013). Janela, n. 976 (informe publicitário). São Paulo: Sinduscon.

SINGER, André (2012). Os sentidos do lulismo. São Paulo: Cia das Letras.

SLACK, Nigel; CHAMBERS, Stuart; JOHNSTON, Robert (2002). Administração da Produção. São Paulo: Atlas.

SOUZA, Ubiraci (1998). "Produtividade e custos dos sistemas de vedação vertical". Seminário Tecnologia e Gestão de Edifícios. Anal de evento. São Paulo: EP/USP.

SOUZA, Ubiraci; DEANA, Davidson; FARIA, Márcio (2005). "Produção de habitações no mercado da autogestão". In: FARIA, Cláudia (org.). Inovação na construção civil. São Paulo: Instituto Uniemp.

SOUZA, Ubiraci (2006). Como aumentar a eficiência da mão-de-obra. São Paulo: Pini. 
TAMAKI, Luciana; ROCHA, Ana Paula (2010). “Modo econômico". Téchne, n. 165. São Paulo: Pini.

TAMAKI, Luciana (2011a). “Engenheiro de assistência técnica”. Téchne, n. 180. São Paulo: Pini.

TAMAKI, Luciana (2011b). “Mudanças irreversíveis”. Téchne, n. 182. São Paulo: Pini.

TAMAKI, Luciana (2012). “Lições a aprender". Téchne, n. 180. Entrevista com Luís Ceotto. São Paulo: Pini.

TAVARES, Maria (1988). O processo de trabalho na produção da habitação popular. Dissertação de mestrado. São Paulo: EP/USP.

TAYLOR, Frederick (1967 [1911]). The principles of scientific management. Nova York: Norton Library.

TESTA, Carlo (1972). The Industrialization of Building. Nova York: Van Nostrand Reinhold.

TOPALOV, Christian (1979). “Análise do ciclo de reprodução do capital investido na produção da indústria da construção civil". In FORTI, Reginaldo (org.). Marxismo e urbanismo capitalista. São Paulo: Livraria Editora Ciências Humanas.

THOMPSON, Edward Palmer (1978). The poverty of theory and other essays. Londres: Merlin Press.

THOMAS, Randolph; SINHA, Sunil (2002). Are "construction sites and manufacturing facilities the same?" In: UWAKWEH, Ben; MINKARAH, Issam. Construction Innovation and Global Competitiviness. Cincinnatti: CRC Press.

THOMAS, Randolph; YAKOUMIS, Iacovos (1987). “Factor model of construction productivity". Journal of Construction Engineering and Management, v.113, n.4.

VANOSSI, Fábio (2009). “Equação econômica”. Téchne, n.147. Entrevista a Simone Sayegh. São Paulo: Pini.

VARGAS, Nilton (1979). Organização do trabalho e capital. Rio de Janeiro: Coppe/UFRJ

VARGAS, Nilton (1983). "Racionalidade e não-racionalização”. In: FLEURY, Afonso. Organização do Trabalho. São Paulo: Atlas.

VARGAS, Nilton (1992). "Tendências de mudança na indústria da construção". Espaço $\mathcal{E}$ Debates, n.36. São Paulo: Neru.

VILLACRESES, Xavier (1994). Análise estratégica da subcontratação em empresas de construção de pequeno porte. Dissertação de mestrado. Porto Alegre: PPGEC/UFRGS

VILLAS BÔAS, Fábio (2011). “Desafio Motor”. Téchne, n.169. Entrevista a Luciana Tamaki. São Paulo: Pini.

VIVANCOS, Adriano; CARDOSO, Francisco (2001). Estruturas organizacionais de empresas construtoras de edifícios. Boletim Técnico - BT/PCC 306. São Paulo: EP/USP.

WEBER, Max (2006 [1904]). A "objetividade" do conhecimento nas ciências sociais. São Paulo: Ática.

WOMACK, James; JONES, Daniel; ROSS, Daniel (1991). The machine that changed the world. Nova York: Harper.

YONG, Josephine; WILKINSON, Adrian (2002). "The long and winding road: the evolution of quality management". Total Quality Management, v.13, n.1. 